\title{
The rotting heart of Gatineau Park: How and why the Kingsmere-Meech Lake privatopia prevented a national park near Canada's capital
}

\author{
by \\ Michael Christopher Lait
}

A thesis submitted to the Faculty of Graduate and Postdoctoral Affairs

in partial fulfillment of the requirements for the degree of

Doctor of Philosophy in Sociology

in

Department of Sociology and Anthropology,

Faculty of Arts and Social Sciences

Carleton University

Ottawa, Ontario

(C) 2017

Michael Christopher Lait 


\begin{abstract}
First proposed in 1913, Gatineau Park could have been the first national park east of the Rocky Mountains, the first in Quebec, and the first near-urban national park in Canada. Ultimately, the Quebec government proved unwilling to cede territory to the federal government, and the park proposal was shelved. In 1938, the Mackenzie King government responded to a public campaign organized by local cottagers and the Ottawa Ski Club by establishing the "Gatineau Park." Newspapers announced the creation of a national park, and the first expropriations were carried out under this pretense. Gatineau Park is a failed national park.
\end{abstract}

This study shows that federal authorities not only proceeded to establish a park without the consent of the Quebec government, they also failed to consolidate territorial control. My analysis addresses the question of how and why this national park failed, and documents the influence of the Meech Lake Association (MLA) and Kingsmere Property Owners' Association (KPOA) on the park's creation, development, and management. I argue that the park's status as a "mixeduse/ownership area" represents a provisional achievement of these property owners' associations. Further, I argue that the park is a key component of the Kingsmere-Meech Lake privatopia, with the MLA and KPOA exercising territoriality over adjacent park areas.

This study also explores the implications of the lack of legal status for the park's management by the National Capital Commission (NCC). It documents several examples where this fragmented territory seriously hindered NCC park management. It reveals that NCC officials encountered considerable resistance from property owner associations when opening Meech Lake to public use (and Kingsmere Lake remains off-limits). The NCC has also had to expropriate, at great expense, several residential subdivisions and commercial developments.

I offer four recommendations to bring the park's administration closer in line with Canada's national parks: 1) legislated boundaries; 2) consultations with, and consent of the Algonquin; 3) consultations between provincial and federal governments; and, 4) consolidated control of the park's territory. For the latter, the NCC should exercise zoning powers, impose a moratorium on new development, and have right of first refusal over all property sales within park boundaries. 


\section{Acknowledgements}

My most immediate thanks are due to my supervisor, Patricia Ballamingie. Trish has been in my corner from the day we meet and seeking her supervision was easily the best decision I made during my PhD. All her students know how lucky they are to have worked under her supervision. Trish is a great teacher and a wonderful human being. My work has also benefitted immensely from the feedback, patience, and thoughtful advice of my committee members, Bruce Curtis and William Walters. I cannot thank them enough for all their support, help and encouragement. This work has also been improved by feedback received from my thesis examiners, Julia Harrison and Jill Wigle.

I also had the good fortune of getting Gatineau Park activist Jean-Paul Murray to provide feedback on this work, and share valuable information. I look forward to working with him and the Canadian Parks and Wilderness Society (CPAWS) in the future to pressure Parliament into passing Gatineau Park legislation. I'd also like to express thanks to the Executive Director of the Ottawa-Valley chapter of CPAWS, John McDonnell, who hired me years several ago as a research intern to document the history of the chapter's campaign for protective park legislation. That work introduced me to many passionate and intelligent people who have helped orient my research: Sheila Thomson, Theodore 'Ted' Mosquin, Bill Gard, Stephen Knowles, Ian Huggett, Ken Buchan, Scott Findlay, Jim Fraser, Lorna McCrea and Brett Hodnett. This work is dedicated to the memory of Doug Anions, a friend and champion of the park.

I'm grateful for the support of the Department of Sociology \& Anthropology at Carleton University, especially the staff, Paula Whissell, Darlene Moss, and Marlene Brancato, and department/graduate heads, Aaron Doyle and Xiaobei Chen. My sincere thanks to all the students and faculty over the years who have showed interest in my research: Phil Primeau, JeanPhilip Crete, Matt Sanderson, Aaron Henry, Will Nham. My work benefitted from the feedback obtained from peer-reviewers of the Canadian Journal of Urban Research, the Ottawa Studies issue co-edited by Nicholas Scott and Tonya Davidson. This research has also benefitted from comments received after a talk delivered before the Mobilities and Migration reading group: Kara Bisson-Boivin, Ugur Yildiz, Jennifer Matsunaga, Victoria Simmons, Julia Calvert, and Ajay Parasram.

My research would have not been possible without the assistance of the research professionals in the National Capital Commission. I'd especially like to express gratitude to Lindsay Stephenson and Judy Booth for all of their help over the years. The assistance of Marc Robillard at Library Archives Canada was extremely helpful. My thanks to all the archivists and librarians who've aided my research. From 2012 to 2016, this work was financially supported by an Ontario Graduate Scholarship.

I'd like to express my appreciation to my friends who've stayed with me as I plugged away. Thanks to my parents, Ken and Heather, for many hours of entertaining discussion about my research and the great but often-times frustrating city in which we live. They have not heard the end of it! Lastly, I'd like to thank Christina Hovey for her love and companionship, and that of our non-human family, Bruce and Muskwa, who've clocked hundreds of therapy hours pro bono. 
While I have received a substantial amount of assistance in preparing this research, any errors and omissions are mine alone. Finally, this work on Gatineau Park was done on, with, and for unceded and unsurrendered Algonquin territory. 


\section{Table of Contents}

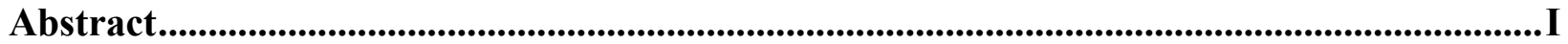

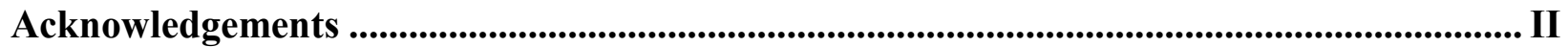

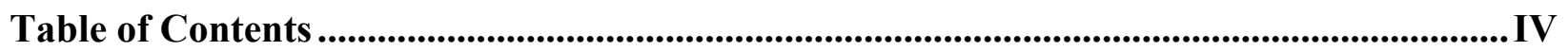

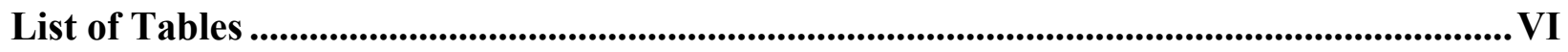

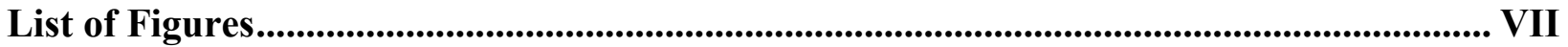

List of Appendices ..................................................................................................................................... VIII

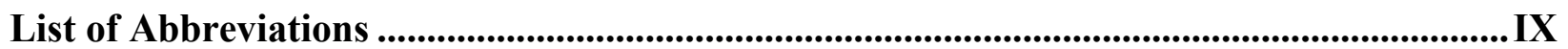

\section{Introduction}

A tempest in a teapot... or a symptom of the rot? .......................................................... 1

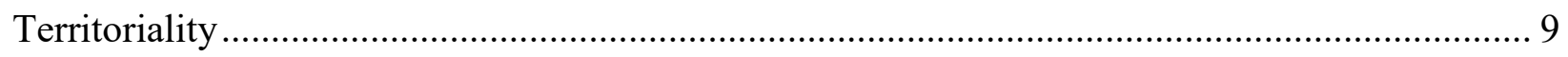

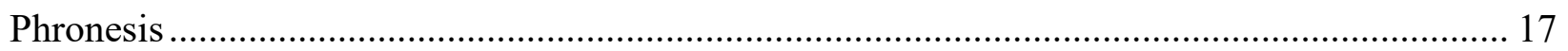

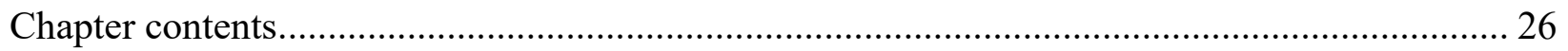

Chapter 1: Territorialities of the federal government

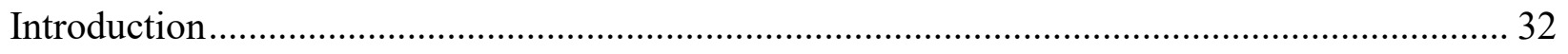

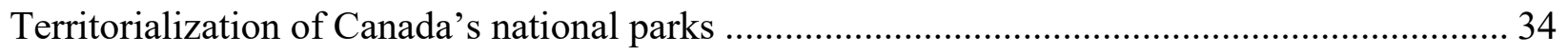

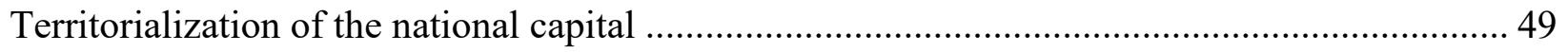

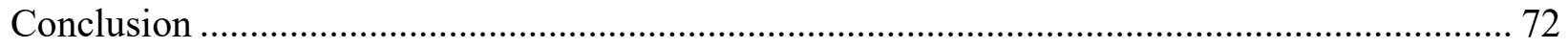

\section{Chapter 2: From Algonquin hunting territory to Ottawa's recreation territory}

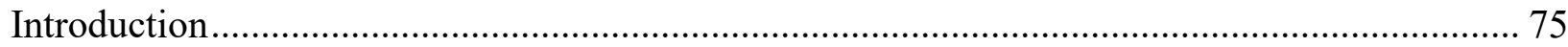

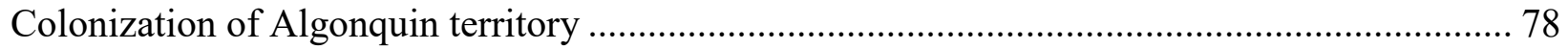

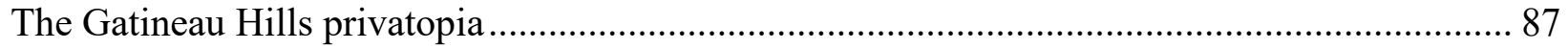

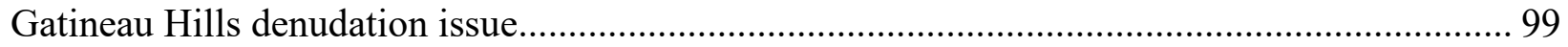

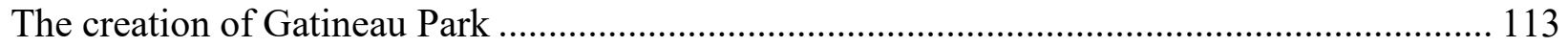

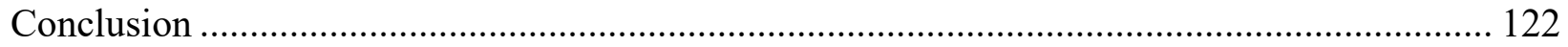

Chapter 3: Territorialization of Gatineau Park

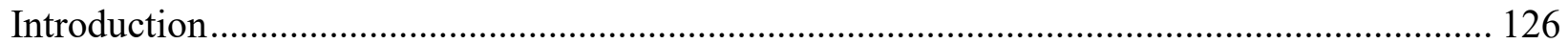

Launch of the parkland acquisition program .................................................................. 129

Territorialization of Philippe Lake and limited accessibility............................................. 141

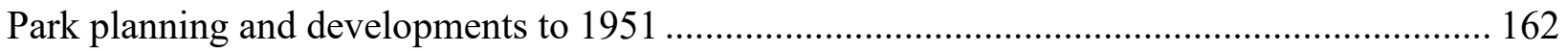

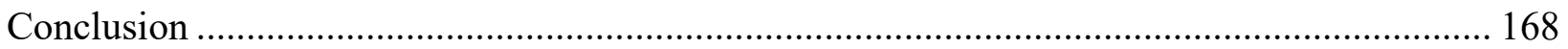




\section{Chapter 4: Controversy sparked over the park's status quo}

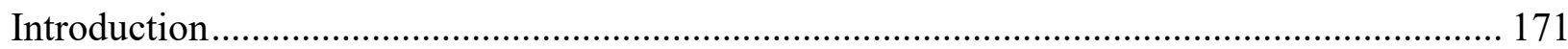

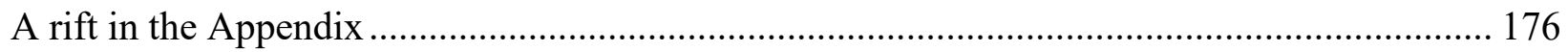

Downfall of the Advisory Committee on Gatineau Park ...................................................... 187

The failures of Sparks' campaign and the Gatineau Parkway ...................................................... 206

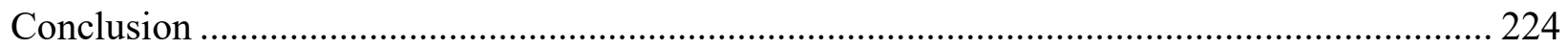

\section{Chapter 5: NCC expropriations in the 1960s}

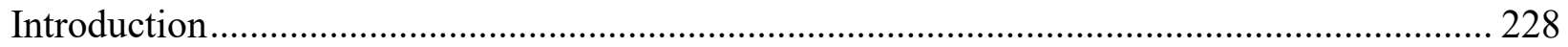

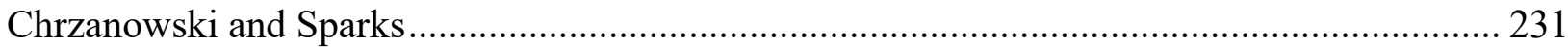

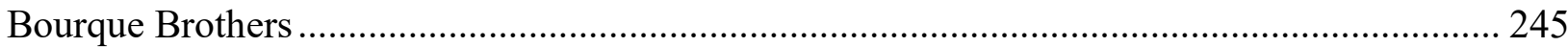

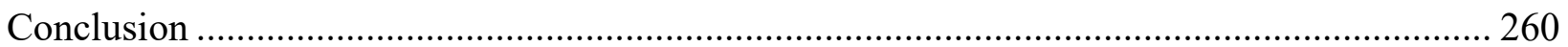

Chapter 6: Meech Lake goes public

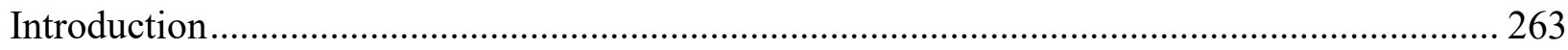

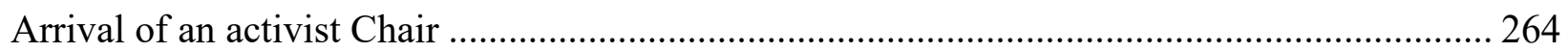

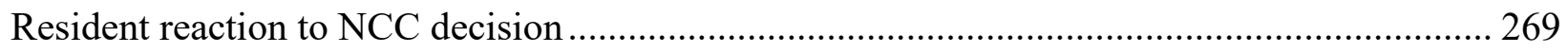

Fullerton's subsequent impact on Gatineau Park and the Outaouais........................................ 288

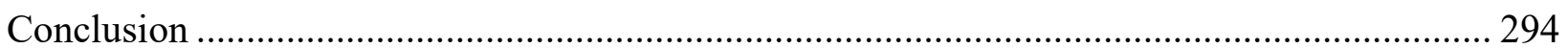

\section{Conclusion}

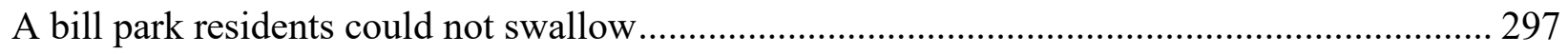

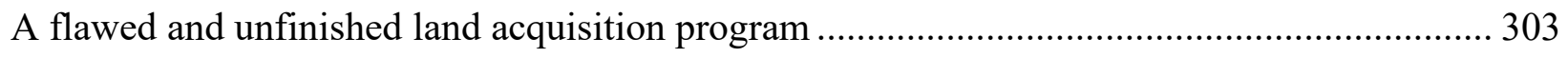

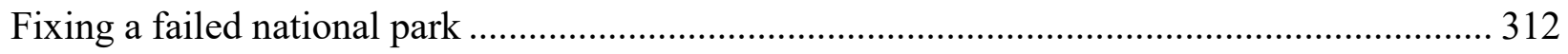

\section{References}

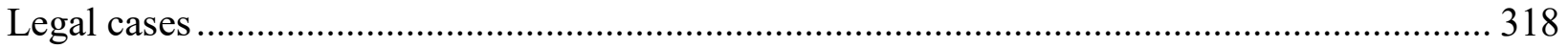

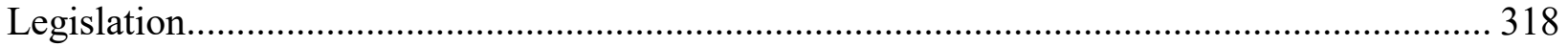

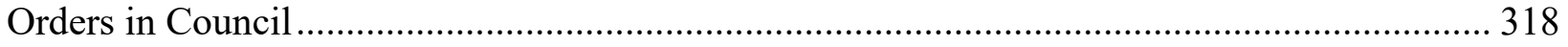

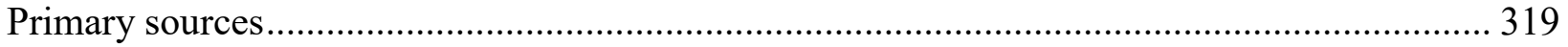

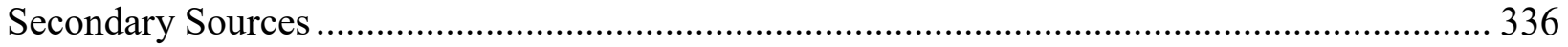




\section{List of Tables}

Table 3.1: Land acquisitions and expenditures on Gatineau Park, 1946-1950...................... 166

Table 4.1: Survey of Meech Lake cottages by R.P. Sparks (1952) ........................................ 182

Table 6.1: Survey of Meech Lake cottages by the NCC (1970) ........................................... 270 


\section{List of Figures}

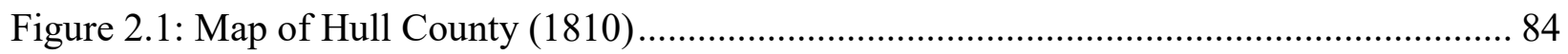

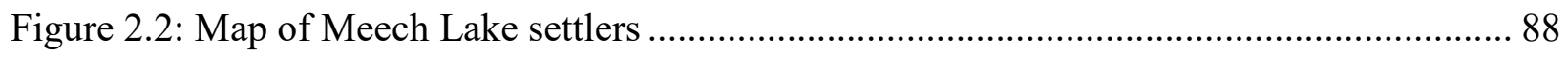

Figure 2.3: Mackenzie King's KPOA membership card .......................................................... 93

Figure 2.4: Letter from KPOA Secretary to Mackenzie King ...................................................... 97

Figure 2.5: Letterhead of the Federal Woodlands Preservation League....................................... 104

Figure 3.1: Cadastral map of woodlot expropriated for Gatineau Park ..................................... 131

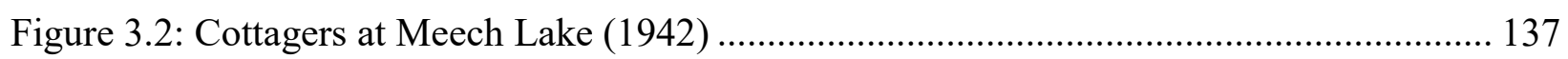

Figure 3.3: Beaver culled in Gatineau Park ......................................................................... 143

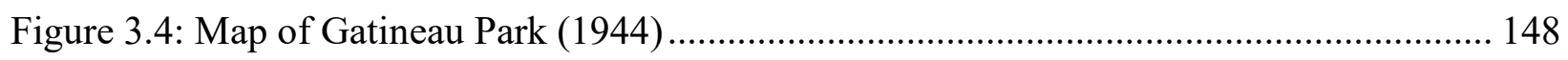

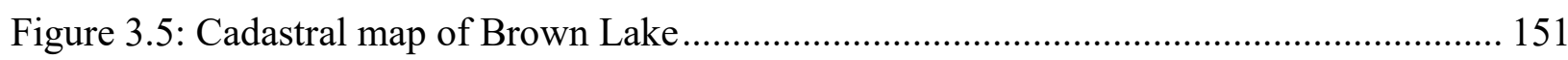

Figure 3.6: Map showing FDC land ownership in Gatineau Park (1946) ................................. 154

Figure 3.7: Cadastral map of privately-owned lands adjacent to Kingsmere Lake (1947) ........ 158

Figure 3.8: Order-in-Council PC 5209 showing Gatineau Park ………………………............ 160

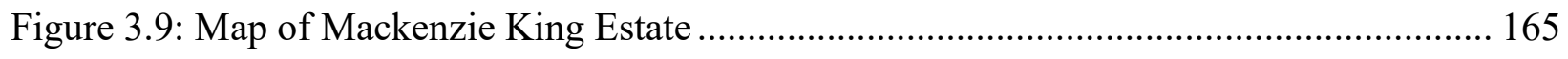

Figure 4.1: Sparks guiding school children in Gatineau Park (1949)....................................... 177

Figure 4.2: Cartoon on Gatineau Parkway construction .............................................................. 194

Figure 4.3: Map of projected Gatineau Parkway system .......................................................... 195

Figure 4.4: Cadastral map of land acquisitions for Gatineau Parkway....................................... 197

Figure 4.5: Gréber and Kennedy examining the Plan for the National Capital .......................... 204

Figure 4.6: Front-page of the Ottawa Journal (12 May 1955) .................................................... 209

Figure 5.1: Cadastral map of Chrzanowski property ................................................................ 233

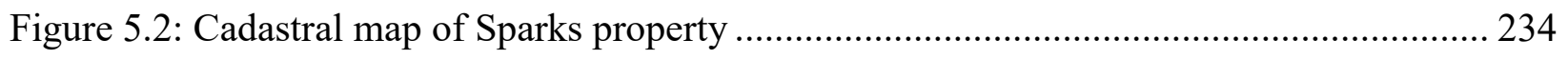

Figure 5.3: Notice of Expropriation sent to Mr. \& Mrs. J. Chrzanowski .................................... 236

Figure 5.4: Cadastral map of Bourque Brothers La Pêche property ............................................ 248

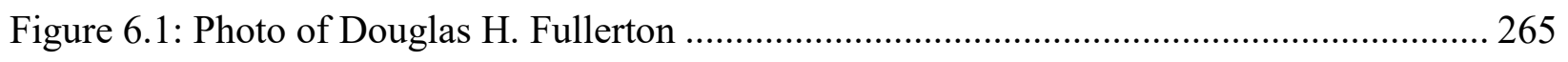

Figure 6.2: Meech Lake resident petition against NCC park facilities....................................... 275

Figure 6.3: Proposed bus bays at Meech Lake (1970) .......................................................... 278

Figure 6.4: Proposed picnic area at Meech Lake (1970) ....................................................... 279

Figure 6.5: Proposed swimming raft at Meech Lake (1970) …………................................... 280

Figure 6.5: Map detail showing provincial Crown lands in Gatineau Park ............................... 291 


\section{List of Appendices}

Appendix A: Gatineau Park land acquisitions, 1938-1978 ..................................................... 342

Appendix B: Access-to-information requests …………………………................................ 343 


\section{List of Abbreviations}

Advisory Committee on Gatineau Park (ACGP)

Boundary Rationalization Exercise (BRE)

Canadian Parks and Wilderness Society (CPAWS)

Canadian Parks and Wilderness Society, Ottawa-Valley chapter (CPAWS-OV)

Chief Executive Officer (CEO)

Collège d'enseignment general et professionnel (CEGEP)

Communauté Régionale de l'Outaouais (CRO)

Department of Public Works (DPW)

Federal District Commission (FDC)

Federal Plan Commission (FPC)

Federal Woodlands Preservation League (FWPL)

Gatineau Park Advisory Committee (GPAC)

Gatineau Park Commission (GPC)

Gatineau Park Protection Committee (GPPC)

Kingsmere Property Owners' Association (KPOA)

Library Archives Canada (LAC)

Meech Lake Association (MLA)

Members of Parliament (MPs)

National Capital Commission (NCC)

National Capital Planning Commission (NCPC)

National Capital Region (NCR)

National Interest Land Mass (NILM)

National and Provincial Parks Association of Canada, Ottawa-Hull chapter (NPPAC-OH)

Ottawa Improvement Commission (OIC)

Ottawa Field-Naturalists' Club (OFNC)

Ottawa Ski Club (OSC)

Peace, order, and good government (p.o.g.g.)

Prince Edward Island (PEI)

Regional Municipality of Ottawa-Carleton (RMOC)

Standing Senate Committee on Energy, the Environment and Natural Resources (SSCEENR) 


\section{Introduction}

There is a question some have posed about why this cannot be a national park. Most people are surprised that Gatineau Park does not have the protections [of a national park] and that Gatineau Park is not actually a park in statute. One of the questions is why is it not a national park. ${ }^{1}$

Paul Dewar (MP - Ottawa Centre), House of Commons, March 2014

\section{A tempest in a teapot... or a symptom of the rot?}

On a July weekend in 2014, a Gatineau Park visitor swam outside the boundaries of Blanchet Beach and into the open waters of Meech Lake. This violation was spotted by Chris Frank, a local resident and President of the Meech Lake Association (MLA). Several days afterwards, the MLA President phoned the park's governing body, the National Capital Commission (NCC), to report the violation. Frank used the opportunity to discuss several other problems that residents were having with park visitors at Blanchet Beach. ${ }^{2}$ He explained that they were often disturbed in the early morning by swimmers who chatted and listened to the radio before going for their swim. The NCC beach, he continued, affected residents through increased traffic volumes. He also expressed concern for the safety of swimmers, as Meech Lake residents travelling (by motorboat) across the lake from the north shore had to avoid visitors who were swimming without a buoy or visible bathing helmet. The MLA President suggested that, to avoid these disturbances and dangers, the NCC should close Blanchet Beach in the mornings.

The NCC official passed President Frank's concerns and suggestions to their superiors. Their telephone conversation was obtained through an access-to-information request to the NCC, which I then shared with a key research participant in the Gatineau Park Protection Committee

\footnotetext{
${ }^{1}$ Dewar, P. 2014, Mar. 7. "National Capital Act." Canada. Parliament. House of Commons Debates. Edited Hansard. $41^{\text {st }}$ Parliament, $2^{\text {nd }}$ Session, pg.3689.

${ }^{2}$ Dorego, P. 2014, July 18. "La saga du lac Meech." Email from P. Dorego to S. McLaughlin and F. Leclerc. NCC ATIP A-2014-00053, pgs.299-300.
} 
(GPPC). The GPPC Secretary, Jean-Paul Murray, informed me that this was not the first time, but the third time that the MLA had tried to restrict public access to Blanchet Beach. In 2003, it requested the closure of the beach in its brief to the NCC during the Gatineau Park Master Plan review. ${ }^{3}$ The MLA repeated this request the following year in a letter to the NCC Chief Executive Officer (CEO), Marcel Beaudry. ${ }^{4}$ The GPPC posted this 2003 MLA letter and the latest request by President Frank on its Facebook page and all over social media. ${ }^{5}$

This revelation caught both the MLA and NCC off guard. Frank wrote on an online message board for local triathletes: "I have no explanation for the content and tone of M. Dorrego's [sic] internal NCC memo; a memo I have just seen and with which I take much exception." ${ }^{\prime 6}$ Despite the evidence proffered by the GPPC, Frank maintained that:

there is no interest or lobby here to close Blanchet Beach to swimmers or anyone else for that matter... When all is said and done this is a mixed use/ownership area. We [Meech Lake residents] respect swimmers and other visitors who use $\mathrm{NCC}$ property and facilities. In turn we hope they will respect our right to the quiet enjoyment of our homes and our accustomed, lawful use of our privatelyowned properties. ${ }^{7}$

Similarly, the NCC defended the MLA against accusations from the GPPC. In a release posted on its website, the NCC sought "to clarify that, if people have seen documents suggesting that the Meech Lake Residents Association has requested the closure of the beaches, this information

\footnotetext{
${ }^{3}$ Meech Lake Association. 2003, Jan. Master Plan Review Gatineau Park. Ottawa: Brief submitted to National Capital Commission, pg.8. Available at https://www.scribd.com/document/255560718/Meech-Lake-AssociationBrief-2003. Last accessed 3 March 2017.

${ }^{4}$ See Boissonneault, S. 2004, Apr. 26. Letter from S. Boissonneault to M. Beaudry. Available at https://www.scribd.com/doc/272305293/L-Association-des-residents-du-lac-Meech-incite-la-CCN-a-fermer-laplage-Blanchet-et-la-mise-a-l-eau-McCloskey. Last accessed 30 Dec. 2016.

${ }^{5}$ Gatineau Park Protection Committee Facebook page available at https://www.facebook.com/gatineauparkprotection/. Last accessed 3 March 2017.

${ }^{6}$ Frank, C. 2015, Feb. 12. Beach at Meech. Available at http://trirudy.com/region/OE/list/index.cfm?listing=3527\#5. Last accessed 30 Dec. 2016.

${ }^{7}$ Ibid.
} 
is incorrect." ${ }^{8}$ Several days later, the NCC, at the request of GPPC Secretary Jean-Paul Murray, removed this "clarification" from its website.

Although this controversy did not result in any substantive change, it should not be dismissed as a tempest in a teapot. Rather it is symptomatic of the competing territorialities in Gatineau Park. Geographer Robert Sack has defined territoriality as "the attempt by an individual or group to affect, influence, or control people, phenomena, and relationships, by delimiting and asserting control over a geographic area." "While MLA President Frank may publicly concede that Meech Lake is a "mixed use/ownership area," park residents, through their property owner associations, have repeatedly attempted to control public access to, and use of park facilities. The territoriality of the MLA and its twin organization, the Kingsmere Property Owners' Association (KPOA) is opposed by the GPPC, which is pressuring the NCC to act on its Gatineau Park Master Plan commitments to acquire and, by implication, eliminate all privately-owned land. ${ }^{10}$ This objective, which has been pursued by the NCC since its inception in 1959, is intended to consolidate NCC control over the park's entire territory. ${ }^{11}$ Not surprisingly, this objective has been denounced by the MLA and KPOA as a violation of park residents' right to private property. Thus, there are competing spatial strategies seeking to control this "mixeduse/ownership area."

\footnotetext{
${ }^{8}$ National Capital Commission. 2015, Feb. 26. Clarification Meech Lake Residents Association. Formerly available at http://www.ncc-ccn.gc.ca/places-to-visit/gatineau-park/news/2015-02-26/clarification-meech-lake-residentsassociation.

${ }^{9}$ Emphasis in original. Sack, R.D. 1986. Human Territoriality: its theory and history. Cambridge: Cambridge University Press, pg.19.

${ }^{10}$ The latest master plan indicates that "...the continuous and gradual acquisition of private properties within Park boundaries ... continues to be the NCC's long-term objective." National Capital Commission. 2005. Gatineau Park Master Plan. Ottawa: NCC, pg.52.

${ }^{11}$ The first official master plan suggested that "in order to open up the Park as a whole to the public and facilitate its management, the National Capital Commission must pursue its program for the acquisition of private properties..." National Capital Commission. 1980. Gatineau Park Master Plan. Ottawa: NCC, pg.60. In the 1990 revision of that master plan, the language was even stronger with the NCC indicating that "private residences fall under the heading of non-conforming uses under Park zoning, and they should be the subject of a long-term acquisition program." National Capital Commission. 1990. Gatineau Park Master Plan. Ottawa: NCC, pg.27.
} 
Meanwhile, as indicated in the epigraph, parliamentarians have recognized that "Gatineau Park" has no legal status, and they have asked why it is not made a national park. As a national park, territorial control would have to be consolidated by the federal government. The position of Gatineau Park as an outlier to Canada's national park system becomes even more puzzling given that, in the events leading up to its formal establishment in 1938, newspapers repeatedly informed the public that the federal government was going to establish a national park, and, as shown below, the first expropriations were even carried out under this pretense. Thus, Gatineau Park was originally intended to be a national park, but I argue that it failed to materialize as such because of the interests and influence of Kingsmere and Meech Lake "residents," at one time "cottagers" for whom this mixed-use/ownership park was created in the first place.

Drawing largely from Sack's analytic framework of territoriality, this phronetic case study of a failed national park addresses three research questions: how - by whom, through what means, and to what ends - was Gatineau Park prevented from becoming a national park? What are the implications of this failure on the park's development and management? What conditions should be met to resolve the ongoing struggles over the park's territory?

I have developed four arguments in response to these research questions. First, I argue that the Park's status as a "mixed-use/ownership area" is a provisional achievement of the property owners' associations, the MLA and KPOA. In an NCC-commissioned study, The Creation and Early Development of Gatineau Park, there is no reference to either of these groups, but that study does allude to how the federal government established the park "with the cooperation of, and sometimes under pressure from, the "greater" bourgeoisie."12 MLA and KPOA members held key positions in the Liberal Party of Canada, and the federal government

\footnotetext{
${ }^{12}$ Gagnon, S., Filion, M., and Tessier, C. 2004. The Creation and Early Development of Gatineau Park: Study on the influence of local interest groups and the sociopolitical context of the Park's creation from 1903 to 1956.

Ottawa: National Capital Commission, pg.24.
} 
(notably, Prime Minister William Lyon Mackenzie King). Further, some of these same people held key positions in, or were "honourary patrons" of, the Federal Woodlands Preservation League (FWPL). In the scholarship on Gatineau Park, this advocacy group is widely credited with convincing King's government to establish the park in order to protect the scenic beauty of the Gatineau Hills from unsustainable lumbering. Notably, the FWPL did not advocate for the creation of a national park, as this implied the elimination of private property. Rather, through the partnership between the FWPL and federal government, specifically the Federal District Commission, Gatineau Park - a mixed-use/ownership area - was created by and for these "bourgeois" cottagers.

Second, following political scientist Evan McKenzie, I argue that the MLA and KPOA are private forms of local governments aspiring to create a "privatopia ... where property rights and property values are the focus of community life; and where homogeneity, exclusiveness, and exclusion are the foundation of social organization." 13 Gatineau Park was integral to the privatopia of "park residents": the federal government not only respected their property rights, but also increased their property values through the protection of scenery and the construction of the Gatineau Parkways. The realization of the Kingsmere-Meech Lake privatopia did not end with the creation of Gatineau Park, as the property associations continued to lobby municipal and provincial governments to improve local roads. And, to prevent the erection of "slum dwellings" and maintain class exclusivity, they drafted municipal by-laws to regulate future development in the cottage country. Further, the MLA and KPOA sought to exclude the general public from their privatopia: in 1942 and 1970, park residents asserted their territoriality in response to FDC/NCC plans to "open” Meech Lake to public use. In 1970, their protests against the establishment of a

\footnotetext{
${ }^{13}$ McKenzie, E. 1994. Privatopia: Homeowner Associations and the Rise of Residential Private Government. New Haven and London: Yale University Press, pg.177.
} 
public beach at Meech Lake proved unsuccessful; however, public access to Kingsmere Lake remains prohibited to this day. Finally, park residents have mounted strong opposition whenever their privatopia has been threatened by proposals for the public ownership of the park. The failure of the national park "ideal" and its replacement by a status quo that allows privatelyowned land is linked to the privatopia in the heart of Gatineau Park.

Third, I argue that the so-called "compromise on shared public-private use" ${ }^{14}$ has greatly hindered the park's development and management by fragmenting the park's territory. Construction of the Gatineau Parkway was stalled and eventually abandoned because Meech Lake property owners refused to sell their lands to the FDC. Then there was the long delay in facilitating public access to Meech Lake. Finally, the NCC has been forced to expropriate several residential subdivisions, leading to lengthy and costly battles in the Federal Court. So, although the park is managed by the NCC as the "National Capital Region's Conservation Park,"15 municipalities have encouraged residential development in the park to increase tax revenues (even though the municipalities receive payments-in-lieu-of-taxes from the FDC/NCC). Taken together, these problems are symptomatic of the park's fragmented territory, as private property falls under the jurisdiction of municipal and provincial governments. Although the NCC could, in principle, exercise zoning powers over, or impose a development moratorium on, privatelyowned lands within the park, NCC officials deny that they have p.o.g.g. (peace, order, and good government) powers. ${ }^{16}$ And the NCC, for reasons unknown, perpetuates the fragmentation of the

\footnotetext{
${ }^{14}$ Gagnon, S., Filion, M., and Tessier, C. 2004. Ibid., pg.24.

${ }^{15}$ See National Capital Commission. 2017. "About Gatineau Park." Ottawa: NCC. Available at http://www.nccccn.gc.ca/places-to-visit/gatineau-park/about-gatineau-park. Last accessed 14 January 2017.

${ }^{16}$ In 1988, all lands within the park boundaries were designated by the federal government to be of "national significance." Consequently, their management falls under Section 91 of the Constitution Act (British North America Act) which provides the federal government with wide ranging powers to ensure peace, order, and good government, known as the p.o.g.g. powers, as confirmed by the Court of the Exchequer and the Supreme Court in the case involving the expropriation of Harold Munro. See Munro v National Capital Commission (1966), S.C.R. 663.
} 
park's territory by claiming, erroneously, that 17\% of lands (approximately 12,500 acres, or 5,058 hectares) are owned by the Quebec Government. ${ }^{17}$ Located in the northwestern section in a checkerboard fashion, Chapter 6 shows that management and control of these Crown lands were transferred to the NCC through a 1973 land exchange agreement with the Quebec government. Given the legal principle of the "indivisibility of the Crown," the transfer of management and control is tantamount to a transfer of ownership. ${ }^{18}$

In addition to documenting how the park's territory is contested and fragmented, this phronetic case study aims to give practical advice concerning what should be done to remedy this failed national park. Fourth, I argue that the following "sound conditions" must be met to ensure the park's territorial integrity, while accounting for its socio-historical context:

- Legislated boundaries: The only statutory instrument delimiting the park boundaries is a 1960 Order-in-Council. However, in 1997-1998, the NCC severed lands from the park that had been developed, including a residential subdivision. National parks have legislated boundaries, such that Parliament must approve the removal of lands.

- Consent of the Algonquin First Nations: The park area is situated in unceded Algonquin territory. When establishing new national parks, Parks Canada routinely consults affected Aboriginal people to obtain their consent. Gatineau Park should be no exception to this practice. As the park's boundaries and legal status are planned, the Algonquin must be consulted and give their approval. I take consultation to be substantive and meaningful not tokenistic engagement,

\footnotetext{
${ }^{17}$ See National Capital Commission. 2005. Master Plan for Gatineau Park. Ottawa: NCC, pg.75.

${ }^{18}$ Mundell, D.W. 1960. "Legal Nature of Federal and Provincial Executive Governments: Some Comments on Transactions Between Them.” Osgoode Hall Law Journal, 2(1): 56-75, pg.71.
} 
where the Algonquin have strong representation and a decisive voice on all issues that concern them. ${ }^{19}$

- Provincial-federal consultations: Unlike other national parks in eastern Canada, Gatineau Park was established in 1938 without the express consent of the Quebec government. Premier Duplessis publicly condemned expropriations by the federal government for the purposes of capital beautification projects as a violation of the province's territorial integrity. In 1973, the Quebec government agreed to transfer provincial crown lands to the NCC so long as they were used for park purposes, implying provincial agreement with the general park concept (it also agreed to issue no mining exploration permits and declared the area a game reserve). To ensure continued cooperation, provincial authorities should be consulted before the NCC can approve boundary changes and park management plans.

- Consolidated control: As per the decision in Munro $v$ NCC, the administration of the National Capital Region (NCR) is an issue of national concern and falls under Section 91 of the Constitution Act which gives the NCC powers of peace, order, and good government (p.o.g.g.). Thus, the NCC can consolidate control over the park's territory through zoning powers and a development moratorium on privately-owned lands within the park. But, in the face of opposition from park

\footnotetext{
${ }^{19}$ An early advocate of participatory planning, Sherry Arnstein, characterized "public consultation" as a tokenistic planning exercise, unless and until it is accompanied by meaningful negotiations among all stakeholders. Whenever non-government groups can and do influence outcomes in political decision-making processes, Arnstein considers this "citizen power" as famously delineated in her article "A Ladder of Citizen Participation" in the Journal of the American Planning Association (JAIP); see Arnstein, S. 1969. "A Ladder of Citizen Participation." JAIP, 35(4): 216-224. As this study concerns the park's history and politics, it does not address the important question of how Gatineau Park consultations should be conducted. Nonetheless, I refer the interested reader to Marcus B. Lane's excellent review of "consultation" in planning theory: see Lane, M.B. 2005. "Public Participation in Planning: an intellectual history." Australian Geographer, 36(4): 283-299. Although provincial planning legislation makes little reference to Indigenous people, planning scholars are pressuring for greater recognition of Indigenous rights as well as past injustices tied to settler colonialism, like Canada's Residential School System and systemic land dispossession. See recent essays on this topic in the edited collection by Walker, R., Jojola, T. and Natcher, D. 2013. Reclaiming Indigenous Planning. Montreal \& Kingston: McGill-Queen's University Press.
} 
residents at Kingsmere and Meech Lakes, the NCC denies that it has the powers. Further, the NCC should be given right of first refusal on all property sales and subdivisions in the park. Once territorial control is consolidated and the threat of urban-type development is eliminated, Gatineau Park can be managed with the maintenance and restoration of ecological integrity as priorities. In other words, it can be administered as a national park.

The discussion will now turn to Sack's conception of territoriality as it provides the theoretical lens for the subsequent analysis. As Sack's work on territoriality is now several decades old, scholars, like geographer David Delaney and sociologist Andrea Mubi Brighenti, have offered some important criticisms and advanced alternative approaches. Having reviewed these, I maintain that for the purpose of understanding political territories such as national parks, Sack's conception of territoriality remains relevant and useful. The second section addresses the methodological approach of phronesis which guides my research. Following this, I elaborate my reading strategy for territoriality as well as data collection methods (archival research, access-toinformation requests, and document sharing). The introduction concludes with a brief overview of the chapter contents.

\section{Territoriality}

Sack's seminal Human Territoriality was a critical response to previous conceptions that view territoriality as the defense of an area, and an innate behavior found in both human and nonhuman animals. Sack rejects this biological determinism. He argues that human territoriality can be distinguished from its animal counterpart in that "[i]t [territoriality] takes an act of will and 
involves multiple levels of reasons and meanings. ${ }^{" 20}$ Sack's conception emphasizes the intentionality and creativity implicated in the exercise of human territoriality, which he understands as "a strategy [used] to establish different degrees of access to people, things, and relationships. ${ }^{21}$ Sack notes that, because territoriality is dependent on the intentionality of the controlling agent, it is something that can be turned on and off. Similarly, territoriality must be continually enacted for it to be effective. As Sack puts it, "territories require constant effort to establish and maintain." 22 On this view, territories represent the, more or less, successful outcome of territoriality, and this process is encapsulated by the term "territorialization."

Sack positions "[t]erritoriality as squarely within two geographical traditions: social geography and historical geography." ${ }^{23} \mathrm{He}$ frames his overall project on territoriality as "theory," one that aims to grasp the "internal logic of territoriality." ${ }^{24}$ Of course, the status of territoriality as "theory" holds certain connotations, and Sack insists that what he is advancing is neither a predictive nor mechanistic theory, but a series of general and abstract open-ended propositions concerning the potential "tendencies" and "combinations" of territoriality; the tendencies and combinations at a particular site must always be analyzed empirically. ${ }^{25}$ Despite Sack's qualifications, prevalent assumptions about "theory" render its use problematic (and Sack perpetuates this by rejecting consideration of values). In light of this, geographer David Delaney suggests approaching Sack's work on territoriality as an analytical framework, for it offers "a sort of field guide or 'How to' for seeing the effects or consequences of territorial operations."26 This study documents the effects of a fragmented territory, documenting the effects of privately-

\footnotetext{
${ }^{20}$ Sack, R.D. 1986. Ibid., pg.26.

${ }^{21}$ Ibid., pg. 20.

22 Ibid., pg. 19.

${ }^{23}$ Ibid., pg. 2

${ }^{24}$ Ibid., pg. 28.

${ }^{25}$ Ibid., pg.3.

${ }^{26}$ Delaney, D. 2005. Territory: A short introduction. Malden MA: Blackwell Publishing, pg.76.
} 
owned lands on the park's governing bodies, the Federal District Commission and National Capital Commission.

Sack identifies three core tendencies of territoriality. First, it involves classification by area, rather than classification by kind or type. Sack gives the example of a parent keeping their child out of the kitchen while food is being cooked. Instead of being another room in the house, the kitchen is turned "on" as a territory by the parent, one that children must keep out of when food is cooking. Sack contends that this example shows the core tendencies of territoriality. Instead of having to enumerate the different types of people, things, and relationships to which one may or may not have access to, classification by area, he argues, is a more efficient means of controlling access. ${ }^{27}$ Second, territoriality offers the advantage of simple communication "because it requires only one kind of maker or sign - the boundary." 28 Besides communicating territorial limits, boundary markers also make statements about ownership and conditions of access such as, for instance, the ubiquitous "Private Property: No Trespassing” sign. Third, territoriality requires enforcement. Differential access to an area can be enforced through spatial forms such as a fence, wall, or other barriers that restrict mobility (an important concept related to territoriality, one that will be unpacked below). Territorial enforcement also assumes nonspatial forms, such as overt violence or legal punishment. Returning to the "Private Property" sign, the message underneath typically reads "Violators will be prosecuted." As the threat of legal punishment indicates, territoriality can also be efficient in that enforcement does not always require the physical presence of the controller within the territory. ${ }^{29}$ So the parent doesn't have to be in the kitchen to keep their child out of the room when cooking is taking place, but they can

\footnotetext{
${ }^{27}$ Sack, R.D. 1986. Ibid., pg.32.

${ }^{28}$ Ibid., pg.32.

${ }^{29}$ Sack, R.D. 1986. Ibid., pg.20.
} 
instead use a marker to indicate when children must stay out, and threats of punishment can be communicated, verbally or written on the marker (e.g., "you will be grounded for two weeks"). Following the discussion of classification, communication, and enforcement, Sack's Human Territoriality proceeds to identify seven other "tendencies" of territoriality, and fourteen "primary combinations" of these tendencies. Rather than detailing them all of the tendencies and combinations, Sack's analytical framework is applied in the next two chapters. Chapter 2 covers the territorialization of Canada's national parks system as well as the territorialization of the national capital "region" by the federal government; and Chapter 3 turns to the territorialization of Gatineau Park. From examining these instances of territorialization, I argue that, on the one hand, the federal government has very limited powers over lands it does not own. Thus, Parks Canada requires full title vested in the national parks, meaning that, with only a few exceptions, ${ }^{30}$ privately-owned lands are prohibited in Canada's national parks system. On the other hand, the federal government has opted not to establish a federal district in the capital, such that the National Capital Region encompasses two major cities in two provinces (Ottawa, Ontario and Gatineau, Quebec). It is within this "jurisdictional swamp" that federal authorities established “Gatineau Park" as a mixed-use/ownership area.

For the moment, I wish to turn to the criticisms of Sack's work on territoriality, and will then discuss Brighenti's more advanced "relational" approach to territory. David Delaney argues that Human Territoriality - published over three decades ago - "remains unsurpassed,"31 but finds that discussion of "politics in any robust sense is virtually absent." 32 Delaney is surprised

\footnotetext{
${ }^{30}$ There are privately-owned lands in the form of railway rights of way in Banff, Jasper, Yoho, etc. Further, the townsite of Yoho has privately owned lands. McNamee, K. 2002. "From Wild Places to Endangered Spaces." In Dearden, P. and Rollins, R., eds., Parks and Protected Areas in Canada, 2nd edition. Oxford: Oxford University Press, pg.32.

${ }^{31}$ Delaney, D. 2005. Ibid., pg.70.

${ }^{32}$ Ibid., pg. 71 .
} 
by this, ${ }^{33}$ because Sack understands territoriality as an exercise of power, and even goes so far as to claim that "[t]erritoriality is the primary spatial form power takes." ${ }^{34}$ But Sack's conception clearly privileges "the controller" although, to be fair, Sack does recognize that territoriality has "normative implications" such that, depending on the perspective taken, "[a]n effect of territoriality may be considered by some as good, or neutral, or bad." 35 Still, Delaney maintains that "[t]here is very little interest [in Sack's Human Territoriality] in either what it is like to be on the receiving end of attempts to control or how the dynamics of resistance or evasion affect territorializing processes." 36

Delaney's second, related criticism of Human Territorialiy is that Sack gives a "bloodless account," one which downplays the role of violence and fear in modern forms of territoriality, particularly state sovereignty and private property. ${ }^{37}$ On this note, some scholars question the etymology of territory, which is commonly assumed to be derived from the Latin territori-um (the land around a town). They have suggested that there are associations with terrere (to frighten) and territorium which refers to "a place from which people are warned off." 38 Following Delaney's criticisms, empirical analyses of territoriality must not only strive for a more symmetrical account of the intentionality and agency of both the controller and controlled, but they must also avoid sanitizing the violence and emotional suffering that territoriality often inflicts on the latter: the controlled, the governed, and the subjected. This phronetic study of territoriality in Gatineau Park reveals the conflicts involving government expropriations, and those subjected (or not) to the expropriations, "good" and "bad" actors alike.

\footnotetext{
${ }^{33}$ Brighenti offers the opposite view, writing that Sack "frames the question of territory as inherently political." Brighenti, A.M. 2006. "On Territory as Relationship and Law as Territory." Canadian Journal of Law and Society, 21(2): 65-86, pg.69.

${ }^{34}$ Sack, R.D. 1986. Ibid., pg.26.

${ }^{35}$ Ibid., pg. 30.

${ }^{36}$ Delaney, D. 2005. Ibid., pg.98.

${ }^{37}$ Ibid., pg.99.

${ }^{38}$ Oxford English Dictionary cited in Hindess, B. 2006. “Terrortory.” Alternatives, 31: 243-257, pg.244.
} 
Sack's analytical framework is not only apolitical but also ahistorical. His conception has been criticized for "treating territory and territoriality as historically transcendent processes..." 39 The core tendencies of territoriality (classification, communication, enforcement), Sack admits, "can be found in all societies, but they, in turn, generate further potential effects that can be equally important but which occur only in particular historical contexts." 40 One of the most significant effects of territoriality is the production of "territory." In The Birth of Territory, Professor Stuart Elden has shown the notion of political territories to be a relatively recent invention. ${ }^{41}$ Moreover, boundary drawing is predicated on the ability to render space calculable and measurable, that is, the geometric conception of three-dimensional space which emerged during the scientific revolution of the sixteenth and seventeenth centuries. ${ }^{42}$ Elden draws attention to the practices and techniques that political authorities use to measure land and control terrain, terms which are related to, but ultimately distinct from, territory. ${ }^{43}$ The cadastral map, Torrens system of land titling, and property registry are among the techniques used to measure and standardize land as a political-economic commodity. ${ }^{44}$ Hedges, fences, and border checkpoints are techniques for the control of terrain, which Elden takes to be a military-strategic concept. ${ }^{45}$ Territorialization is therefore not reducible to territoriality as a spatial strategy. Rather, the production of territory involves the combination of practices, techniques, and institutions.

\footnotetext{
${ }^{39}$ Murphy, A.B. 2012. "Entente territorial: Sack and Raffestin on territoriality.” Environment and Planning D: Society and Space, 30: 159-172, pg.166.

${ }^{40}$ Sack, R.D. 1986. Ibid., pg.22.

${ }^{41}$ Elden, S. 2013. The Birth of Territory. Chicago: University of Chicago Press.

42 Elden, S. 2010. "Land, terrain, territory." Progress in Human Geography, 34(6): 799-817, pg.811. Although Sack does show how the European territorial claims in the New World were rooted in an abstract and geometrical concept of space, he fails to acknowledge that the concept of territory has a history.

${ }^{43}$ Elden, S. 2013. Ibid., pg.9.

${ }^{44}$ Scott, J.C. 1998. Seeing Like a State: How Certain Schemes to Improve the Human Condition Have Failed. New Haven and London: Yale University Press, pg.36.

${ }^{45}$ On hedges, see Blomley, N. 2007. "Making Private Property: Enclosure, Common Right and the Work of Hedges." Rural History, 18(1): 1-21. On border checkpoints, see Paasi, A. 1999. "Boundaries as Social Processes: Territoriality in the World of Flows.” In Newman, D., ed., Boundaries, Territory and Postmodernity. London: Frank Cass Publishers.
} 
Accordingly, "territory should be examined not as an actual state space, but as the powerful, metaphysical effect of practices that make such spaces appear to exist." 46

Political scientist Alexander Murphy takes the criticism of Sack's ahistoricism one step further, as his analytical framework uncritically adopts the territorial ideal of the sovereign state system which originated with the Peace of Westphalia. The "modernist" territorial ideal divides the earth's surface into discrete and autonomous territories, each of which has a legitimate sovereign ruler. ${ }^{47}$ One of the problems with this, and unrecognized by Sack, is that territory often has competing "controllers," and that there can be "overlapping territorial entities." 48 This is referred to as the "vertical dimension of territory." As Elden notes, "territory is a volume rather than an area ..."49 While analyses must be attuned to this verticality and mindful of the assumptions embedded in Sack's analytical framework, there is still value in his conception of territoriality. As Murphy points out, "we live in a world that is so dominated by modernist territorial ideas and practices that studying how those ideas and practices play out is a legitimate (and much needed) realm of inquiry in its own right.",50

The final criticism of Sack's analytical framework is that territoriality, the control of a delimited area, is only one of the functions of territory. Brighenti maintains that Sack's notion leads to a "sociological reductionism." ${ }^{, 51}$ He then advances a "radical conception of territory" which approaches the production of territory as a "form of social relations." 52 As such, while the control and defense functions of territory remain important, territorialization is also implicated,

\footnotetext{
46 Painter, J. 2010. "Rethinking territory.” Antipode, 42(5): 1090-1118, pg.1116.

${ }^{47}$ Murphy, A.B. 1996. "The sovereign state system as political-territorial ideal: historical and contemporary considerations.” In Biersteker, T.J., and Weber, C., eds., State sovereignty as social construct. Cambridge: Cambridge University Press, pg.87.

${ }^{48}$ Delaney, D. 2005. Ibid., pg. 13.

${ }^{49}$ Elden, S. 2009. Terror and Territory: The Spatial Extent of Sovereignty. Minneapolis: University of Minnesota Press, pg. 12.

${ }^{50}$ Murphy, A.B. 2012. Ibid., pg.167.

${ }^{51}$ Brighenti, A.M. 2006. Ibid., pg.70.

${ }^{52}$ Ibid., pg.65, 76.
} 
inter alia, in identity formation and the naturalization of ownership. Brighenti’s relational approach to territory goes further, encouraging analysts to explore the expressive and affective dimensions of territory as they, respectively, express a particular "milieu," within them through the "spread of moods, attitudes, desires, beliefs, etc." 54 Having advocated for a more capacious, relational approach to territory, ${ }^{55}$ Brighenti proposes "territorology" as a problem-driven "sociology (science of the socius) of territorial acts, movements and relations." Territorology serves as an important reminder that territoriality is only one aspect of territory. Certainly, there are expressive and affective dimensions to Gatineau Park. For instance, historian Alisa Apostle has shown how national park culture and ideals of pristine nature were repeatedly expressed in the events leading up to the creation of Gatineau Park. ${ }^{57}$ Another aspect of territoriality that warrants further consideration are possible linkages to the "new mobilities paradigm," 58 associated with sociologists John Urry, Mimi Sheller, and Tim Cresswell, among others. ${ }^{59}$ Sociologists working from this paradigm challenge the view of national parks - and territories in general - as fixed or immobile entities. Instead, they would open the black box of travel in parks and protected areas, and ask how human and non-human movement occurs within, around, and through them. In the case of Gatineau Park, movement has been facilitated, to different areas, and at different times, through the construction of parkway to the Kingsmere-

${ }^{53}$ Ibid., pg. 64 .

${ }_{55}^{54}$ Ibid., pg. 65.

${ }^{55}$ The geographer Claude Raffestin similarly views territory through "a relational problematic," and explicitly acknowledges that "Brighenti comes to conclusions quite near my own." Raffestin, C. 2012. "Space, territory, and territoriality." Environment and Planning D: Society and Space, 30:121-141, pg.127. Raffestin's approach has been contrasted with Sack's conceptualization of territoriality, see Murphy, A.B. 2012. Ibid.

${ }^{56}$ Brighenti, A.M. 2010. Ibid., pg.68

${ }^{57}$ Apostle, A. 1997. The View From The Hill: National Park Culture and Gatineau Park. Kingston: Queen's University (unpublished MA thesis).

${ }^{58}$ Philip Steinberg offers one of the most sustained engagements of territoriality and mobility lenses in his historical analysis of modernist European cartographic representation of the world's oceans. See Steinberg, P.E. 2009.

"Sovereignty, Territory, and the Mapping of Mobility: A View from the Outside." Annals of the Association of American Geographers, 99(3): 467-495.

${ }^{59}$ Sheller, M. and Urry, J. 2006. "The new mobilities paradigm." Environment and Planning A, 38: 207-226; see also Cresswell, T. 2010. "Towards a politics of mobility." Environment and Planning D, 28: 17-31. 
Meech Lake privatopia, and, later, the extension of Highway A5 to the park's more distant public facilities at Philippe and La Pêche lakes.

Although Brighenti's conception of territory as a form of social relations invites a more capacious analysis, I argue that Sack's analytical framework continues to be relevant and useful for understanding how and why Gatineau Park became a contested and fragmented territory, in other words, a mixed-use/ownership park. An empirical analysis of the competing territorialities will be instructive for the ongoing campaign for legislation, which could potentially result in the park's territorial reconfiguration. Understanding how different territorialities have impacted the development and management of the park is not only of interest to parliamentarians, but also of interest to the Gatineau Park Protection Committee and to the National Capital Commission (NCC), the park's governing body. Of course, having noted the criticisms of Sack's approach, I must be mindful to account for the perspectives and experiences of "the controlled," to avoid sanitizing territoriality, to observe the vertical dimensions of the park's territory, and to recognize, as far as possible, the range of affects tied to territorialization. Further, it must be acknowledged that Sack's conception reflects the sovereign territorial ideal. These caveats, however, do not preclude the utility and relevance of Sack's conception of territoriality as a spatial strategy that attempts to control a delimited area.

\section{Phronesis}

In advancing a "theory" of territoriality, Sack deliberately avoids questions of values. According to Sack, "the theory itself will not present procedures by which one can judge whether an action is, on its own merits, good or bad."60 This non-committal position is intended to give his conception of territoriality "an intellectual 'space' of its own," but Sack then goes on to suggest

${ }^{60}$ Sack, R.D. 1986. Ibid., pg.31. 
that "the theory can be reconnected to specific historical cases and to theories of power." 61 This section elaborates on sociologist Bent Flyvbjerg's “phronesis," a problem-driven methodology that advances both an analytics of power and procedures to render value judgements about a particular case.

Just as Sack was responding to limitations in previous conceptions of territoriality, phronesis was Flyvbjerg's reaction to the prevailing assumption that the social sciences should be modeled on the natural and physical sciences. His point of departure is an acknowledgement that the social sciences cannot yield generalizable, context-independent propositions for which the hard sciences are celebrated. The inability of the social sciences to make statements beyond a specific socio-historical context would indeed be a limitation if, like the hard sciences, they were only prepared to remain descriptive and analytical. Drawing on the Aristotelian distinction between episteme (know why), techne (know how), and phronesis (practical wisdom), Flyvbjerg positions the social sciences as applied phronesis, that is, concerned with ethical questions. ${ }^{62}$ Social scientists must use their in-depth knowledge of a given situation, and then explicitly engage with questions of values and interests. For Flyvbjerg, the social scientist occupies the role of a "virtuoso social actor,"63 one who can make value judgements "about what it would be good to do in given circumstances." 64 When expanding on Flyvbjerg's phronetic social science, the following discussion will make links between this methodological approach and my case study of territoriality in Gatineau Park.

\footnotetext{
61 Ibid.

${ }^{62}$ Flyvbjerg, B. 2001. Making Social Science Matter: Why social inquiry fails and how it can succeed again. Cambridge: Cambridge University Press, pg.56.

${ }^{63}$ Flyvbjerg, B. 2004. "Phronetic Planning Research: Theoretical and Methodological Reflections." Planning Theory \& Practice, 5(3): 283-306, pg.284.

${ }^{64}$ Schram, S. 2012. "Phronetic social science: an idea whose time has come." In Flyvbjerg, B., Landman, T. and Schram, S., eds., Real Social Science: Applied Phronesis. Cambridge: Cambridge University Press, pg. 15.
} 
The overarching aim of phronetic social science is for the researcher's value judgements about goals and means to be both relevant and useful to the participants involved in the study. Flyvbjerg identifies two criteria to facilitate this. First, phronetic social science must be "problem-driven," meaning that it proceeds from the problems identified by the actors themselves. ${ }^{65}$ My research began with the Ottawa-Valley chapter of the Canadian Parks and Wilderness Society (CPAWS-OV). Since 1970, this conservation group has been campaigning for legislation to address the park's myriad management problems. My research on the history and politics of the park brought me into contact with the Gatineau Park Protection Committee (GPPC) which has also been campaigning for protective legislation - often, but not always, alongside CPAWS-OV. Although both groups agree on the park's problems, they hold different views about which problems are the most serious, and differ on the best means of addressing the park's problems. For CPAWS-OV, the greatest problem rests with the park's governing body: the National Capital Commission (NCC) can change its policy behind closed doors. CPAWS-OV has learnt that there is nothing requiring the NCC to adhere to, or even implement its own policy, which, as per the latest master plan, is to maintain the park's ecological integrity. Legislation would not only mandate this as the park's foremost management priority, but would also provide parliamentary oversight over the park's management as well as any future policy changes. While the GPPC recognizes this as critical problem of the park's management, and endorses legislation as the appropriate solution, it views the park's fragmented territory as the most pressing problem as privately-owned lands have repeatedly undermined NCC management and threatened the park's ecological integrity. Whereas the GPPC wants legislation to mandate the NCC with the acquisition of remaining privately-owned land in the park, and giving the federal agency right of first refusal over property sales, CPAWS-OV has backed away from these so-called "radical"

\footnotetext{
${ }^{65}$ Flyvbjerg, B. 2001. Ibid., pg. 156.
} 
proposals given the adverse effects it would have on park residents (some of whom are CPAWS members). Phronetic social science is ideally suited for problematic situations involving different values and interests, and so it is adopted for the purposes of this case study.

Flyvbjerg's second criteria to ensure the researcher's value judgements are relevant and useful to participants is that phronetic research must a dialogical process. Research findings must be shared with participants and, in turn, shaped by them through their feedback. ${ }^{66}$ As I have indicated already, access-to-information results have been shared. The GPPC Secretary, Mr. Murray, has supplied useful data that assisted with the preparation of this study. While the present study focuses on the problem of the park's fragmented and contested territory, I have recently published a journal article that traces both the history of CPAWS-OV and the problem of reversals in NCC policy. ${ }^{67}$

With these two criteria in place, Flyvbjerg offers the following "value-rational questions" to guide the phronetic research process:

(1) Where are we going?

(2) Who gains and who loses, and by which mechanisms of power?

(3) Is this development desirable?

(4) What, if anything, should we do about it? ${ }^{68}$

The "we" refers to the researcher and the participants. Given the tendency of the social sciences to study conflicts, and that the phronetic researcher cannot claim to be a neutral observer, Flyvbjerg recognizes that the "we" typically implies a "they." ${ }^{69}$ In focusing on the problems tied to the park's territory, I have clearly aligned myself with the GPPC which takes the position that the NCC should acquire and ultimately phase out privately-owned lands. Ironically, the GPPC

\footnotetext{
66 Ibid.

${ }^{67}$ Lait, M. 2016. "Preserving Ottawa's metropolitan nature: How the 1970 Gatineau Park planning controversy transformed the National Capital Commission and its Conservation Park." Canadian Journal of Urban Research, 25(1): 63-79.

${ }^{68}$ Flyvbjerg, B. 2004. Ibid., pgs.289-290.

${ }^{69}$ Ibid.
} 
position is identical to that taken by the NCC in its Gatineau Park master plans. Nevertheless, the GPPC has come into conflict with park residents, in particular the Meech Lake Association (MLA), a group that turns out to be central to the creation and administration of Gatineau Park. Neither "we" nor "they" are without precedent: the Park's founding father (and resident living on Meech Lake Road) Roderick Percy Sparks also dealt with an angry response from other residents when, in the mid-1950s, he proposed eliminating privately-owned lands at Kingsmere and Meech Lakes. Past and present conflicts between park residents and proponents of public ownership are, I argue, symptoms of this failed national park. Thus, "we" are trying to bring Gatineau Park closer in line with Canada's national parks, while "they" are trying to maintain the park's status quo as a mixed-use/ownership area.

The second question - "who gains and who loses, and by which mechanisms of power" reflects the importance of power relations to phronetic social science. Flyvbjerg draws from philosopher Michel Foucault's "analytics of power relations." ${ }^{, 70}$ Foucault's relational approach rejects the "sovereign" view of power as a repressive force wielded by political institutions. Rather, Foucault insists that power relations are open ended and multi-directional. Power can be positive, and it can be exercised from below, such as with the property owner associations, and from above, i.e., the provincial and federal governments. ${ }^{71}$ Foucault is interested in "how" power is exercised, and with what practical and material effects. ${ }^{72}$ In pursuing the question of "how" power is exercised, Foucault's analytical approach considers the practices and techniques through which relations are affected, as well as the rationalities directing the exercise of power.

\footnotetext{
${ }^{70}$ Flyvbjerg, B. 2001. Ibid., pg.119.

${ }^{71}$ Foucault, M. 1983. “The Subject and Power.” In Dreyfus, H.L. and Rabinow, P., Michel Foucault: Beyond Structuralism and Hermeneutics, $2^{\text {nd }}$ edition. Chicago: University of Chicago Press, pg.216.

${ }^{72}$ Flyvbjerg, B. 2001. Ibid., pg.119.
} 
Knowing how power is exercised and to what effect(s), Flyvbjerg's third and fourth questions address, respectively, the desirability and possibility of change within a given sociohistorical context. In this way, phronetic social science avoids relativism, which holds that there are no criteria with which to evaluate a problematic situation. But it also avoids foundationalism, which claims that there are universal values. Flyvbjerg insists that phronetic social science is engaged in "contextualism or situational ethics." ${ }^{, 73}$ With an understanding of power relations and the perspectives of the actors involved in a problem, the researcher can make context-dependent value judgements about "what can be done" and "what ought to be done." These prescriptive judgements about means and goals must not be regarded as authoritative; rather, value judgements are interpretative and provisional. ${ }^{74}$ Indeed, they must be shared with participants in order to make research into a dialogic process, as participants propose modifications. In this way, phronetic social science offers, as one proponent put it, "an important research supplement to the kind of knowledge that comes from an intimate familiarity with practice in contextualized settings." 75

As a strategy that attempts to control a geographical area, territoriality is an exercise of power that produces differential effects (e.g., restricting access for some and/or increasing mobility for others), hierarchies, and inequalities. This case study of Gatineau Park illustrates such differential impacts well, as the federal government expropriated lands for the purposes of establishing a national park, but the territoriality of Kingsmere and Meech Lake residents prevented the realization of a national park. Moreover, the federal government built parkways to the privatopia but never extended those parkways to public facilities at Philippe Lake because of the resistance of Meech Lake landowners. The framing of this study as a case of a failed national

\footnotetext{
${ }^{73}$ Flyvbjerg, B. 2004. Ibid., pg.291.

${ }^{74}$ Ibid., pg.300.

${ }^{75}$ Schram, S. 2012. Ibid., pg. 19.
} 
park makes my position on the desirability of change self-evident. In addition to revealing how and why park residents benefitted from preventing the realization of a national park, this study documents the losses incurred by those affected by the land acquisition program, perhaps one of the largest undertaken by the federal government in Quebec.

Based on Flyvbjerg's typology of case studies, ${ }^{76}$ I would define this study of a failed national park as an atypical and critical case. Since Parks Canada has consolidated control over the national parks, it does not have to negotiate with property owner associations, nor does it have to expropriate residential subdivisions that are approved by municipal governments. In the United States, however, many national parks have privately-owned lands within their boundaries, and the National Park Service frequently deals with the same management crises documented in this study. So, Gatineau Park is atypical in the Canadian context, but not internationally. This study also offers a critical case: it underscores the strategic importance of the territorial configuration of Canada's national parks, where the problem of divided control has been effectively avoided through the exclusion of privately-owned lands. It is in this national context that Gatineau Park is a failed national park.

For this research, I have read documents intending to find evidence of both the exercise of territoriality and of power more broadly. This "evidence" is not simply found and then (re)presented, but is subject to a creative and interpretive process. Further, I have offered recommendations that can help resolve the park's territorial conflicts, while taking into account Algonquin territoriality and Quebec's territorial integrity. Many of these recommendations legislated boundaries, consultation with Algonquin and provincial governments, and consolidated control - were arrived at through an examination of the territorialization of

\footnotetext{
${ }^{76}$ Flyvbjerg, B. 2006. "Five Misunderstandings About Case-Study Research." Qualitative Inquiry, 12(2): 219-245, pg.229.
} 
Canada's national parks. For my purposes, the requests made to the federal government by property owner associations and advocacy groups have been especially worthy of mention, because, as in the case of requests by the MLA to restrict use of Blanchet Beach, they frequently involve strategies to "affect, influence, and control" specific park areas, or sometimes the entire park territory. The federal government also makes important statements concerning the park's territory, which appear in park master plans and public documents such as NCC Annual Reports. In this way, I can compare the exercise and effects of the territorialities of governments, park residents, and public advocacy groups.

While public documents are important, most of the data for this research has been obtained through archival research, document sharing, access-to-information requests, and visits to the NCC headquarters and Federal Court, both located in Ottawa. The archived files of the NCC and its predecessor, the Federal District Commission, were obtained from Library and Archives Canada (LAC). The documents of the latter have been examined in previous studies of the park's early history, ${ }^{77}$ but Gagnon, Filion, and Tessier conceded that "the piecing together of Gatineau Park's creation calls for further research in vast document collections..."78 Of course, these historical studies did not approach these materials through the lens of territoriality. But the absence of any reference to either the Meech Lake Association or Kingsmere Property Owner's Association remains a glaring omission, as if these groups played no role in the park's history. Thus, I consulted the FDC files on Gatineau Park with an interest in correspondences and documents from these property owner associations. ${ }^{79}$ I also examined archived files of the

\footnotetext{
77 See Apostle, A. 1997. Ibid.; Lanzon, Q. 2014. From the Ground Up: The Alpine and Cross-Country Sportscapes of Gatineau Park, 1910-1967. Ottawa: Carleton University (unpublished MA thesis).

${ }^{78}$ Gagnon, S., Filion, M., and Tessier, C. 2004. Ibid., pg.24.

${ }^{79}$ Research Group (RG) 34, file number 190, vols.1-20, as well as RG34 file numbers 190-A through 190-H (and 190-N, 'Roads in Gatineau Parks', 2 vols.). Files RG34.190-C 'Gatineau Park - Expropriation of Lands' and RG34.190-G 'Advisory Committee on Gatineau Park' were especially important for reconstructing the land acquisition program.
} 
Department of Forestry files on the Federal Woodlands Preservation League, which disclosed the role of the MLA in the League's formation. ${ }^{80}$

The NCC has archived files specifically on Kingsmere and Meech Lake which provided further evidence of the territoriality exercised by park residents. Through access-to-information requests to the NCC and LAC, I have also examined NCC folders on Gatineau Park planning, land acquisitions, and expropriations. Recent correspondences between the property owner associations and the NCC were obtained through the access-to-information requests, which included the controversial staff email discussed above. The GPPC and CPAWS-OV have shared minutes of meetings, memorandums, newspaper clippings, and other documents related to their campaign for Gatineau Park legislation. Instructive comparisons are frequently made in this material between the (mis)management of Gatineau Park and Canada's national parks.

As sociologists Kevin Walby and Alex Luscombe rightfully point out, access-toinformation requests are "under-used in social research." 81 They contend that access-toinformation requests yield valuable data in a "raw format" that is especially credible and trustworthy. They write: “Compared to documents designed for public consumption, ATI/FOI [access-to-information/freedom-of-information] records are not necessarily shaped by the spin and rhetoric of public relations specialists." 82 One of the advantages of this data collection method is that it can be made accessible for subsequent researchers since access-to-information requests have numbers to identify them with. Appendix B provides the details of my requests to the NCC and LAC, such that this data can be requested by anyone who may be interested.

\footnotetext{
${ }^{80}$ RG39.69 files 49170 and 49171 (1935 Lower Gatineau Valley Woodlands Survey), RG39.25 file 49136 (Federal Woodlands Preservation League).

81 Walby, K. and Luscombe, A. 2016. "Criteria for quality in qualitative research and use of freedom of information requests in the social sciences." Qualitative Research, 1-17, pg.3.

${ }^{82}$ Ibid., pg. 8.
} 


\section{Chapter contents}

As a point of departure, Chapter 1 describes the territorialization of the federal government, with respect to both the national parks system and the national capital. It is shown that, by virtue of the Constitution Act, the government has no control over privately-owned lands. Thus, national parks have adopted the "perfectly sensible" policy of having full title prior to assuming control of a newly-established national park. ${ }^{83}$ Historically, the provinces have undertaken the land acquisition programs, often employing expropriation whenever property owners refused to sell. Chapter 1 examines the territorialization of the national parks system as local residents were expropriated in the creation of the Atlantic Provinces and later the first national parks in Quebec, where the provincial government there acted swiftly and decisively in the dislocation of residents affected by the creation of Forillon national park. The extreme exercise of territoriality is then contrasted with the lack of territoriality exercised by the fathers of Confederation, who opted not to establish a federal district in Canada's capital. Had they created a federal district in Ottawa, the creation of a national park in the Gatineau Hills would have been much easier (as detailed in Chapter 1).

One of the arguments that park residents ingeniously use to justify their special privilege of residing within the park is that their community predates the park. Chapter 2 describes the changing territorialities in the Gatineau Hills, as they were once the traditional hunting territories of the Algonquin. As with the rest of the so-called National Capital Region, which is nothing more than an area of operation for the NCC and its predecessors, Gatineau Park is situated on unceded Algonquin land. Thus, the future territorialization should consider the views of the

\footnotetext{
${ }^{83}$ Bankes, N.D. 1986. "Constitutional Problems Related to the Creation and Administration of Canada's National Parks.” In Saunders, J.O., ed., Managing Natural Resources in a Federal State. Toronto: Carswell.
} 
Algonquin on whether, and if so how, the park area should be transformed into a national park. Perhaps the Algonquin, who were forcibly displaced from the Ottawa River watershed, would agree that the federal government has made a complete mess of the park project, and that it does not go far enough in exercising territoriality over the last remaining park residents?

Chapter 2 documents the first colonists who unsuccessfully tried to eke out a living as farmers in the unfertile soils of the Gatineau Hills. Over time, these pioneer farming families have been replaced by cottagers. Chapter 2 then describes the formation of the property owner associations, which are the practical means through which cottagers at Kingsmere and Meech Lakes mobilized to pressure the federal government into establishing 'Gatineau Park'. As shown, cottagers were the crème-de-la-crème of Ottawa's political and economic elites. Unlike previous studies, I trace the creation of Gatineau Park to the Meech Lake Association and, in the process, undermine the existing scholarship, which attributes the park's formation to Ottawa Ski Club. As it turns out, the OSC was a side-line supporter of the MLA, which established the Federal Woodlands Preservation League. As is well known, the FWPL pressured the federal government by having it first conduct a survey and then by having it approve funds for the Federal District Commission to proceed with the land acquisitions (for what the newspapers frequently reported as a national park; elsewhere, newspapers informed readers of the imminent construction of the “Gatineau Parkway”).

Chapter 3 describes the territorialization of Gatineau Park as the FDC began purchasing and expropriating privately-owned lands to form an initial nucleus around the Kingsmere-Meech Lake privatopia. The territorialization extended to Philippe Lake, as the FDC established the park's first public beach there. Following World War II, when the FDC resumed the land acquisition program, it tried to acquire lands around Brown Lake, but met with resistance from a 
property owners' association which asked to remain within the "national park: as had those at Kingsmere, Harrington and Meech Lakes. With the master planning of the entire capital region then underway, the FDC set up the Advisory Committee on Gatineau Park (ACGP) to determine the park's future expansion and long-term development. The President of the Federal Woodlands Preservation League, Roderick Percy Sparks, was elected the ACGP Chairman. Though Sparks was a park resident, living on his property at Meech Lake Road, the Advisory Committee viewed privately-owned lands as inimical to the park's expansion and administration. In 1948, the ACGP recommended the acquisition of remaining privately-owned lands around Philippe Lake as well as Kingsmere Lake, knowing that Prime Minister Mackenzie King had an estate there. The FDC acted on one recommendation, but not on the other. For several decades, the park's sole public facilities were located at Philippe Lake, the only lake fully controlled by the FDC.

The ACGP Chairman believed that Gatineau Park would become the "best of its kind in the world," its kind being a near-urban national park. Chapter 4 examines Sparks' attempt as ACGP Chairman to get the FDC to adopt a "rational" land acquisition policy. Having studied the experiences of national park administrators in the United States, Sparks knew of the dangers of mixed public-private ownership, as privately-owned lands could be subdivided and the federal government cannot prevent undesirable development. With other park residents on the ACGP, Sparks could not get consensus among Advisory Committee members concerning the issue of how privately-owned lands should be acquired (but there was a consensus that the park should, eventually, be brought under public ownership). Sparks knew that there were "powerful forces" at work behind the scenes, with the MLA and KPOA jealously protecting the territorial integrity of the Kingsmere-Meech Lake privatopia. Nevertheless, he argued that there should be a time limit imposed on remaining land acquisitions, with the FDC expropriating if owners refused to 
sell. Chapter 4 then details Sparks' fall-out with the FDC as the ACGP Chairman held contrarian views on expropriations. No longer involved in park planning, Sparks valiantly pressed on, publishing his criticisms of FDC park administration in local newspapers and appearing before the joint-parliamentary committee setup to reform the FDC. But, ultimately, the park's founding father was unsuccessful in pressing the FDC/NCC to pursue a cogent land acquisition policy; indeed, Sparks' efforts backfired as park residents, by lobbying municipal and provincial governments, forced the FDC/NCC to renounce the use of expropriation for park purposes. Cottagers played Quebec's “territory question” to their advantage: the FDC was cowed into taking a piecemeal approach to the Gatineau Park land acquisition program, as it announced that it would only buy properties on a willing-seller basis. The Kingsmere-Meech Lake privatopia was thus assured of its longevity, though the FDC did make several purchases in the area.

At the same time, the FDC was building the Gatineau Parkway to the privatopia (and, ostensibly, to provide access for skiers at Camp Fortune and park visitors at Philippe Lake). Sparks sounded the alarm that land values were going to become astronomical. Ironically, as shown in Chapter 5, when the FDC was replaced by the NCC (coincidentally just after Sparks had passed away), the Sparks property was expropriated by the NCC in response to the prospect of increased land values, although NCC officials would later justify the expropriations based on rumored subdivision and ski developments. Chapter 5 also documents the expropriation of an even larger subdivision at La Pêche Lake. The limits of NCC control over park areas was becoming increasingly self-evident, and the NCC lacked the necessary funds to proceed with some expropriations. Fortunately, the Bourque Brothers' expropriation at La Pêche Lake was carried out, otherwise, in addition to the subdivision, there might have been a private hotel and marina at the park's largest lake. 
At the end of the 1960s, the NCC still had to secure complete control as there were approximately 12,000 acres of provincial Crown lands in the La Pêche area. It had yet to open facilities at Meech Lake even though it owned most of the lands around the lake. The park's status quo as a mixed-use/ownership area had given park officials many headaches. Along with the planning consultants hired to prepare a master plan for the park, NCC officials recommended to the newly-appointed Chairman, Douglas Fullerton, the expropriation of remaining privatelyowned lands at Kingsmere and Meech Lakes, which was designated as the park's "Active Recreation Area." Chapter 6 describes the territorialization of Gatineau Park during Fullerton's tenure; though he did not completely overturn the park's status quo, this so-called "activist" NCC Chairman decided to open public facilities at Meech Lake. Chapter 6 examines the visceral response of park residents who petitioned the federal government, criticized the NCC in the local media, lobbied parliamentarians, and even sought legal advice. Chapter 6 unpacks their desperate attempt to prevent the NCC from using the privatopia as a public park, the very reason that "Gatineau Park" was established in the first place.

This was the last challenge to the park's status quo, one which remains firmly entrenched to this day, perhaps more so now than ever. Park residents have always been from Ottawa's political and economic elite - and the mega mansions in the heart of the park attest to this fact. Just as this Introduction drew from a recent example of the territoriality of park residents at Meech Lake, so the Conclusion begins with a discussion of the MLA and KPOA undermining Senator Spivak's Bill S-210, An Act to Amend the National Capital Act (Creation and Protection of Gatineau Park). To accelerate the Gatineau Park land acquisition program, Senator Spivak drafted the bill with a "right of first refusal" clause, requiring park residents to offer their property to the NCC first, before putting it for sale on the open market. Believing that right of 
first refusal would reduce property values, the MLA and KPOA both rejected Bill S-210 because it would hurt their investment. Nevertheless, park residents insist that they receive no special treatment and claim they co-operate with the NCC in the stewardship of Gatineau Park. As with every Canadian homeowner, their rights to private property should be respected by the federal government.

Along with the Gatineau Park Protection Committee, I take the opposite view. "They" have received special treatment, and "we" are arguing that right of first refusal is a fair compromise in view of the fact that, long ago, the federal government should have carried out a blanket expropriation so that Canada's capital would have its national park. Instead "we" - the Canadian public - have a mixed-use/ownership area cluttered with McMansions and inadequate public facilities, in other words, a failed national park. 


\section{Chapter 1: Territorialities of the federal government}

...sorting out territories simultaneously sorts out governing authorities. ${ }^{84}$

\section{Introduction}

The "sorting out" of territories within nation states, or internal territorialization, has been given "scant attention" by sociologists despite its central role in shaping state-society relations. ${ }^{85}$ As legal theorist Mariana Valverde explains, once the question of territory (where) is sorted, the answers to the other jurisdictional questions (who, what, how) "seem to follow automatically." 86 As such, the domestic territories of nation states have frequently been sorted out in founding constitutions. ${ }^{87}$ Canada's Constitution Act of 1867 not only recognized the territories of the original provinces (Ontario, Quebec, Nova Scotia, and New Brunswick), but also gave the federal government authority to establish new ones and, with the consent of a provincial legislature, modify provincial boundaries. ${ }^{88}$ Although the provincial governments were given authority over most public lands, natural resources, and private property, Section 91(1A) of the Constitution Act vests the federal government with the authority to legislate for "The Public Debt and Property." This authority is a proprietary right, meaning that "[ $\mathrm{t}]$ he loss of property will result in a loss of jurisdiction." ${ }^{\prime 99}$ The presence of federal public property, also known as federal

\footnotetext{
${ }^{84}$ Valverde, M. 2009. "Jurisdiction and Scale: Legal "Technicalities” as Resources for Theory." Social and Legal Studies, 18(2): 139-157, pg.144.

${ }^{85}$ Vandergeest, P. and Peluso, N.L. 2001. "Territorialization and State Power in Thailand.” In Blomley, N., Delaney, D. and Ford, R.T., eds., The Legal Geographies Reader: Law, Power, and Space. Oxford: Blackwell Publishers Ltd, pg. 177.

${ }^{86}$ Valverde, M. 2009. Ibid., pg.144.

${ }^{87}$ For a discussion of how territory was sorted in the United States Constitution, see Sack, R.D. 1986. Ibid., pgs.148149.

${ }^{88}$ The Constitution Act, 1871, 34-35 Vict., c.28 (U.K.).

${ }^{89}$ Bankes, N.D. 1986. "Constitutional Problems Related to the Creation and Administration of Canada's National Parks.” In Saunders, J.O., ed., Managing Natural Resources in a Federal State. Toronto: Carswell, pg.215.
} 
Crown land, does not create an enclave within the province. ${ }^{90}$ Unless there are federal laws in place, provincial laws still apply to federal Crown land (but, as per the doctrine of paramountcy, the federal government can pass laws to exclude the application of provincial laws on federal public property). ${ }^{91}$ Even though the Constitution Act predates the invention of national parks, constitutional scholar Nigel Bankes points out that Section 91(1A) is the precondition for the establishment of Canada's national parks. ${ }^{92}$

By outlining the territorialization of Canada's national parks and its national capital, this chapter contextualizes the creation of Gatineau Park, a mixed-use/ownership area, which will be described in the next chapter. On the one hand, the federal government, as per Section 91(1A), consolidated territorial control over its national parks so they were firmly within its jurisdiction. As shown in the first section, this required the federal government to obtain full title to all lands within the park boundaries, such that there are no privately-owned or provincial Crown lands within the national parks. For the national capital, on the other hand, the federal government refrained from exercising territoriality. Indeed, there is only one substantive reference to the capital in the Constitution Act, namely, Section 16 which declares that "[u]ntil the Queen otherwise directs, the Seat of Government of Canada shall be Ottawa."93 Thus, the capital and its environs are administered by municipal governments, which are, in turn, under the jurisdiction of provincial governments. The second section reveals how, in a sense, the capital's territory was never sorted out. It examines the complications that arose from the divided control of the capital, and describes the federal government response and the controversy that swirled around the establishment of a "federal district."

\footnotetext{
${ }^{90}$ Gibson, D. 1976. "The 'Federal Enclave' Fallacy in Canadian Constitutional Law." Alberta Law Review, 76: 167178.

${ }^{91}$ Bankes, N.D. 1986. Ibid., pg.215fn.

${ }^{92}$ Ibid., pg. 213.

${ }^{93}$ The Constitution Act, 1871, 34-35 Vict., c.28 (U.K.).
} 
Taken together, the extremes of federal territoriality - either total control or no control made the establishment of a national park adjacent to the national capital quite difficult, but not impossible. Both sections detail the failed proposals and attempts for a national park in the Gatineau Hills put forward by the public and federal government.

\section{Territorialization of Canada's national parks}

The world's first national park, Yellowstone (established 1872) made national parks synonymous with "pristine wilderness" where permanent human settlement was excluded from national park territories. ${ }^{94}$ Following Sack's analytic grid, national parks reflect the tendency of territoriality "to create the idea of a socially emptiable space."95 Political geographers Dilsaver and Wyckoff find it unfortunate that the "Yellowstone model" spread internationally as it proved to be the exception to the rule: the majority of national parks were established in previously settled areas, with park boundaries either drawn to exclude existing settlements or superimposed over them. ${ }^{96}$ On account of the Yellowstone model, the establishment of national parks has frequently entailed the forcible removal of entire communities. ${ }^{97}$ From the perspective of displaced Aboriginals and settlers, national parks offer examples of malevolent territoriality. But, for those advocating for the creation of national parks, it is benign territoriality deemed necessary for the preservation of natural landscapes and wildlife habitats.

\footnotetext{
${ }^{94}$ Lowry, W.R. 1998. Preserving Public Lands for the Future: The Politics of Intergenerational Goods. Washington, D.C.: Georgetown University Press, pg.21.

95 Sack, R.D. 1986. Ibid., pg.33.

${ }^{96}$ Dilsaver, L.M. and Wyckoff, W. 2005. "The Political Geography of National Parks.” Pacific Historical Review, 74(2): 237-266, pg.248.

${ }^{97}$ Dilsaver, L.M. 2004. Cumberland Island National Seashore: A History of Conservation Conflict. Charlottesville: University of Virginia Press, pgs.111-136; Hemmat, S.A. 1986. "Parks, people, and private property: The National Park Service and Eminent Domain.” Environmental Law, 16: 935-961; Perdue, C. and Martin-Perdue, N.J. 1980. "Appalachian Fables and Facts: A Case Study of the Shenandoah National Parks Removals." Appalachian Journal, 7(1-2): 84-104; Rudin, R. 2011. "The First French-Canadian National Parks: Kouchibouguac and Forillon in History and Memory." Journal of the Canadian Historical Association, 22(1): 161-200; Sandlos, J. 2005. "Federal Spaces, Local Conflicts: National Parks and the Exclusionary Politics of the Conservation Movement in Ontario, 19001935." Journal of the Canadian Historical Association, 16: 293-318.
} 
Canada's first national parks, known as the Rocky Mountain National Parks, were similar to Yellowstone in that they were carved from unsettled, federal property. Unlike Yellowstone, the Rocky Mountain parks did not embrace the preservationist ideal of pristine wilderness. ${ }^{98}$ As historian Robert Craig Brown explains of the early formative period of national parks in Canada, “the term 'wilderness' was scarcely used in discussion of parks policy and then only to suggest a primitive condition demanding 'improvement' in order to 'make a park'."99 The non-compliance with the Yellowstone model was questioned by Samuel Burdett, Liberal M.P. for Hastings East (Ontario): "What I understand by a national park is a territory set apart exclusively for the public, a territory free from settlers, free from corporations, free from monopolists of all kinds."100 Instead of preservation, Canada's national parks were intended to grow the national economy by way of tourism and resource exploitation. ${ }^{101}$ This was accomplished through "a system of partnership between the state and private enterprise." 102 Historian Leslie Bella argues that Banff National Park was established:

... not to preserve a landscape, but to centralize control of that landscape in the hands of the railroads. That control was used to reduce competition in the parks, and to restrict access to the mountains. Businesses that might be patronized by the working class were not sufficiently aesthetic. Access to the mountains was provided instead to upper- and middle-income tourists willing to pay substantial sums for a sanitized view of the mountains. ${ }^{103}$

Alongside the resorts and hotels built and operated by the railway companies, the government administered townsites where it promoted the development of private businesses and cottages

\footnotetext{
${ }^{98}$ Dubasak, M. 1990. Wilderness Preservation: A Cross-Cultural Comparison of Canada and the United States. New York: Garland Publishing, pg.23; see also Foster, J. 1978. Working for Wildlife: The Beginning of Preservation in Canada. Toronto: University of Toronto Press, pg.25.

${ }^{99}$ Brown, R.C. 1969. "The Doctrine of Usefulness: Natural Resource and National Park Policy in Canada, 18871914.” In Nelson, J.G., ed., Canadian Parks in Perspective. Montreal: Harvest House Ltd., pg.58.

${ }^{100}$ Burdett, S.B.1887, May 3. "Banff National Park." Canada. Parliament. House of Commons. Edited Hansard, 5051(1), 6th Parliament, 1st session, pg.241.

${ }^{101}$ Bella, L. 1987. Parks for Profit. Montreal: Harvest House Ltd.

102 Brown, R.C. 1969. Ibid., pg.49.

${ }^{103}$ Bella, L. 1987. Ibid., pg.24.
} 
through nominal, renewable, long-term leases. Thus, the federal government assumed the roles of municipal government and landlord, an arrangement that ensured control of townsite development, but also meant that overall operating costs far exceeded the revenues collected from rentals. $^{104}$

The Rocky Mountains Park Act of 1887 declared Canada's first national park to be "a public park and pleasure ground for the benefit, advantage and enjoyment of the people of Canada." 105 While this appears democratic as it implies universal access, the scholarship has demonstrated that Banff and the other Rocky Mountain parks were, in fact, "playgrounds" for the elites. ${ }^{106}$ Parliamentarians even made it explicit that they wanted to keep out "the doubtful class of people." ${ }^{107}$ In the House of Commons, Prime Minister John A. Macdonald argued that cottage lots should only be "leased out to people of wealth, who will erect handsome buildings on them." 108 Similarly, Aboriginals were also excluded from the national parks through regulations prohibiting subsistence hunting, even though park authorities actively encouraged "sport hunting." ${ }^{109}$ Contrary to the formal legislation, then, this differential access indicated the tendency of territoriality "to create inequalities." 110 The territoriality of Canada's national parks perpetuated the class inequalities and colonialism found in the broader socio-historical context.

\footnotetext{
${ }^{104}$ Scace, R.C. 1969. "Banff Townsite: An historical geographical view of urban development in a Canadian national park." In Nelson, J.G., ed., Canadian Parks in Perspective. Montreal: Harvest House Ltd., pg.193. ${ }^{105}$ Parliament of Canada. 1887. Rocky Mountains Park Act. 50-51 Victoria, Chap. 32. Revised Statutes of Canada. ${ }^{106}$ MacEachern, A.A. 2001. Natural Selections: National Parks in Atlantic Canada, 1935-1970. Montreal: McGillQueen's University Press, pg.6; see also Sandlos, J. 2008. "Not Wanted in the Boundary: The Expulsion of the Keeseekoowenin Ojibway Band from Riding Mountain National Park." The Canadian Historical Review, 89(2): 189-221, pg.193; and Kopas, P. 2007. Taking the Air: Ideas and Change in Canada's National Parks. Vancouver: UBC Press, pg.28.

${ }^{107}$ Mitchell, P. 1887, Apr. 29. "Banff National Park." Canada. Parliament. House of Commons. Edited Hansard, 5051(1), 6th Parliament, $1^{\text {st }}$ session, pg.194.

${ }_{108}$ MacDonald, J.A. 1887, May 3. "Banff National Park." Canada. Parliament. House of Commons. Edited Hansard, 50-51(1), $6^{\text {th }}$ Parliament, $1^{\text {st }}$ session, pg.245.

${ }^{109}$ Binnema, T. and Niemi, M. 2006. "“'Let the Line Be Drawn Now': Wilderness, Conservation, and the Exclusion of Aboriginal People from Banff National Park in Canada." Environmental History, 11: 724-750; see also Sandlos, J. 2008. Ibid.

${ }^{110}$ Sack, R.D. 1983. Ibid., pg.63.
} 
In 1911, the federal government passed the Dominion Forest Reserves and Parks Act which centralized control of Canada's national parks with the Dominion Parks Branch (herein Parks Branch), the very first government agency in the world dedicated to administering the national parks as a "system." Shortly following the passage of the 1911 Act, an Order-in-Council significantly reduced the size of the national parks (approximately 800,000-hectares). ${ }^{111}$ There were growing concerns within the federal government that park authorities could not properly supervise and control such vast territories. ${ }^{112}$ With citizen groups and railway companies protesting the reductions, the "boundary issue" was among the first addressed by the Parks Branch, and it was ultimately successful in convincing the federal government to, more or less, reinstate the original park boundaries. ${ }^{113}$

There were two other problems that the first and longest-serving Commissioner of the Parks Branch, James Harkin, was simultaneously trying to address. First, as all the parks were in the west, the so-called national parks system was not representative. The eastern provinces derived no benefit from the national parks even though they contributed to them. Second, Harkin was aware of the class inequalities tied to the inaccessibility of the distant Rocky Mountain parks. He strongly believed that all Canadians should have access to the "humanitarian" national parks for healthful recreation. ${ }^{114}$ In the 1910 s, however, travelling to the national parks was timeconsuming and expensive; automobility was reserved for the elites, ${ }^{115}$ while the masses of "middle-class" visitors arrived at the national parks by train.

In November 1912, Harkin was presented with a solution to these related problems when the famous Canadian geologist, John Macoun, proposed establishing "Connaught National Park"

\footnotetext{
111 Privy Council of Canada. 1911, June 8. PC 1338.

${ }^{112}$ Foster, J. 1978. Ibid., pg.81.

113 Ibid., pg.85.

${ }^{114}$ Bella, L. 1987. Ibid., pg.62.

115 Sachs, W. 1992. For the Love of the Automobile. California: University of California Press, pg.10.
} 
in the Gatineau Hills. Macoun's proposal was submitted to the Editors of the Ottawa Citizen who had called for a national monument in recognition of the honour accorded to Canada when Prince Arthur, the Duke of Connaught, was appointed Governor General - Canada was the first colony to have a member of the royal family occupy a central leadership role. Macoun's letter to the Editor of the Ottawa Citizen is quoted here in full:

Your editorial note referring to the naming of insignificant places and things for our Governors-General suggests to me that if Canadians wish to have a lasting memorial of H.R.H the Duke of Connaught nothing could be more appropriate than the setting aside as a national park of that practically uninhabited region of hills, lakes and streams which lies between the Gatineau and the Colonge rivers from Chelsea north and west. As the merchantable timber has practically all been taken off this area and there is little agricultural land the cost of expropriating 50,000 or even 100,000 acres would not be great, and as a game preserve and a national park it could from its accessibility and natural advantages be made the greatest and most attractive national park in [North] America. Some such scheme as this might very well be taken up by those who are advocating the federal district and the extension of the work of the [Ottawa] improvement commission to the north side of Ottawa. ${ }^{116}$

The reference in Macoun's letter to the idea of a federal district is taken up in next section on federal territoriality in the national capital. For the moment, it is worth nothing that the scholarly literature on Gatineau Park has overlooked Macoun's national park proposal. ${ }^{117}$ This is surprising given the responses to his letter: first, there were additional letters to the Editor endorsing the proposal and highlighting the park's potential economic and recreational benefits; ${ }^{118}$ and, second, Macoun's letter and the ensuing public discussion of it caught the attention of Parks Branch officials. Thus, in December 1913, Commissioner Harkin submitted a four-page memorandum to his superiors in the Department of Interior providing the rationale for

\footnotetext{
116 Macoun, J.M. 1912, Nov. 7. "National Park As Memorial." Ottawa Citizen.

117 The NCC-commissioned study moved from the 1903 Todd Report to the 1915 Holt Plan without any mention of either the proposals from Macoun and Harkin. See Gagnon, S., Filion, M., and Tessier, C. 2004. Ibid., pgs.11-12.

118 Seton, E.T. 1912, Nov. 26. "National Park would be asset to Canada." Ottawa Citizen; see also Macrae, J.A. 1912, Dec. 1. “Commends National Park Idea.” Ottawa Citizen.
} 
the establishment of "Gatineau Park." ${ }^{119}$ Commissioner Harkin's submission attached newspaper clippings on Connaught Park, including Macoun's original letter to the Ottawa Citizen.

Harkin positioned Gatineau Park as a solution to the unrepresentativeness and class exclusivity of the national parks system. Had it been established, Gatineau Park would have marked the beginning of the eastward expansion of the national park system. It would have been the first national park east of the Rocky Mountains, and the first in the Province of Quebec. Located in the Gatineau Hills adjacent to the cities of Hull and Ottawa, the park would have been easily accessible, even to those outside the emergent automobility system. Harkin wrote: “Today there is an agitation amongst all classes for preservation of park lands in the vicinity of cities to prevent speculators taking up all available land to the detriment of the community." ${ }^{120}$ While insisting on park preservation, Harkin envisioned a planned townsite in Gatineau as in Banff, where the federal government would offer residents renewable, long-term leases at nominal rents. Given the closer proximity of the Gatineau Park townsite to Ottawa-Hull, Harkin expected that there would be thousands more residents, necessitating the construction of hospitals, schools, lecture halls, and camps for the "extremely poor."121 Through this near urban national park, the Parks Branch would thus be providing a remedy to "the slum conditions of our cities ... [as] people would dwell in the country and be transported each morning to the factories, offices and stores within the city areas." 122

\footnotetext{
${ }^{119}$ MacEachern cautions about attributing credit to Commissioner Harkin, as he relied upon his Dominion Parks Branch staff to prepare policy, especially during his early years in office when he was unfamiliar with national parks. MacEachern, A.A. 2001. Ibid., pg.2.

${ }^{120}$ Harkin, J.B. 1913, Dec. 3. Memorandum re: Gatineau Park. Ottawa: Dominion Parks Branch. pg.1.

${ }^{121}$ Ibid., pg.3.

122 Ibid., pg. 2.
} 
The four-page memorandum has not only been overlooked by the Gatineau Park scholarship, but also in studies of Canada's national parks system, ${ }^{123}$ including Commissioner Harkin's exhaustive biography. ${ }^{124}$ But, even though it was shelved, the Gatineau Park memorandum contained an alternative conception to the future of national park system. That is, Harkin did not intend Gatineau Park to be unique. He wanted it to be a prototype: the first in a series of near urban national parks. Thus, Commissioner Harkin proposed to "[c]reate in the wilderness near each centre of population a National Park which will always be preserved for the people for all time, and in which game and vegetation will be protected."125 Harkin's enthusiasm for the prospect of near urban national parks could not be contained for " $[\mathrm{t}]$ he adoption of such a scheme in relation to the Dominion Parks it is suggested would carry Canada into the forefront of civilization in respect to the care of the health and virility of the people." ${ }^{126}$ He urged immediate action as property values would escalate from land acquisitions by private interests. ${ }^{127}$ With the approval of the Interior Department, Harkin wrote a short, subdued letter to Charles Devlin, Minister of Colonization, Mines and Fisheries asking "whether the Government of the Province of Quebec would be willing to co-operate in the materialization of such a scheme... ${ }^{128}$ Despite assurances that provincial authorities would consider the DPB proposal, ${ }^{129}$ Minister Devlin died of a heart attack before he could reply to Harkin.

Harkin's proposal for near urban parks would have brought the national parks system to Canada's cities, resolving the problem of inaccessibility/class exclusivity. As it turns out,

\footnotetext{
123 There is one exception, but the significance of Harkin's proposal as an alternative conception of national parks was not brought out. See Lothian, W.F. 1987. A Brief History of Canada's National Parks. Ottawa: Environment Canada, pg. 132.

${ }^{124}$ Hart, E.J. 2010. J.B. Harkin: Father of Canada's National Parks. Edmonton: University of Alberta Press.

${ }^{125}$ Harkin, J.B. 1913, Dec. 3. Ibid., pg. 3.

${ }^{126}$ Ibid., pgs.3-4.

127 Ibid., pg.3.

${ }^{128}$ Harkin, J.B. 1913, Dec. 23. Letter from J.B. Harkin to C. Devlin. Obtained from Jean-Paul Murray.

${ }^{129}$ Dufault, S. 1914, Jan. 3. Letter from S. Dufault to J.B. Harkin. Obtained from Jean-Paul Murray.
} 
Canada's cities had to be brought to the national parks through an ambitious program of highway construction. One of the first actions taken by the Dominion Parks Branch was to lift the ban on automobiles that had been imposed in deference to the interests of the railroad companies. ${ }^{130}$ The Parks Branch soon built roads to and in Banff and the other Rocky Mountain parks, absorbing most of its budget in the process. But the Parks Branch justified the costs as necessary to overcoming the inaccessibility problem: "In the past it has been a matter of regret that situated as they were, the parks could not serve all the people of Canada. With the coming of good roads and the low priced automobile, they are within easy reach of practically half the country."131 Funds for road and highway construction projects were often promised in an attempt to interest provincial governments in the establishment of national parks. In 1922, the federal government proposed a small national park, 400 to 800 hectares in size (1000 to 2000 miles) in Quebec, situated midway on a highway between Ottawa and Montreal. ${ }^{132}$ In exchange for the transfer of provincial Crown lands, the federal government was "prepared to assist with the highway." 133 As before, the Quebec government did not respond to this national park proposal for, as Harkin now recognized, "Quebec of course is very sensitive in matters of [territorial] autonomy and might suspect ulterior motives where there are none." ${ }^{134}$ But, to provide a successful example, the establishment of Prince Albert National Park in Saskatchewan 1927 - the last to be unilaterally created by the federal government through an Order-in-Council - came with the realized promise

\footnotetext{
${ }^{130}$ Bella, L. 1987. Ibid., pg.62.

${ }^{131}$ Dominion Parks Branch. 1918. Annual Report. Ottawa: Department of the Interior, pg.6.

132 The proposal for Laurier National Park, located east of the Gatineau River, was submitted to the Canadian National Parks Branch by Thomas Adams, Town Planning Advisor to the federal government. Adams rejected the Gatineau Hills for national park purposes: "The stretch of the Gatineau between Hull and Wakefield, and even beyond, may be regarded as more or less exploited for private purposes. It would be as well to leave it in this condition, especially having regard to the fact that other lands of an equally attractive character, and not in use, are available for park purposes." Adams, T. Proposal to develop Laurier National Park. Ottawa: Canadian National Parks Branch. Document obtained from Jean-Paul Murray.

${ }^{133}$ Harkin, J.B. 1922, Oct. 22. Memorandum to W.W. Cory. Document obtained from Jean-Paul Murray.

${ }^{134}$ Ibid.
} 
from the Mackenzie King government to build a road leading to the Waskesiu townsite. ${ }^{135}$

Clearly, the national parks were intimately linked with the mid-twentieth century proliferation of automobility, with its corollary of "seamless [car] travel” which, as sociologist John Urry explained, "unbundled territorialities of home, work, business and leisure that were historically closely integrated."136

As roads became instrumental in promoting recreation and tourism in the national parks, the Parks Branch increasingly regarded resource extraction as incompatible with these same purposes, namely, the preservation of the national parks. Parks Branch officials found that they could exercise little control over lumbering and mining operations in the national parks, which impaired scenery and damaged wildlife habitats. For the Parks Branch, the resources within park territories were perceived as "inviolable." The principle of inviolability, as it became known, was first invoked by the Parks Branch in response to the claim by the Irrigation Branch over water rights in national parks, and an application by a hydroelectric company to dam Spray Lakes in Banff. ${ }^{137}$ Commissioner Harkin rejected both on the grounds that national parks belonged to, and were managed for all Canadians such that "they should not be developed for the benefit of any one section of the country or of private interests." ${ }^{\prime 38}$ The principle of inviolability was enshrined in the National Parks Act of 1930. That the general purpose of the national parks had changed since 1911 becomes clear as the 1930 Act makes no reference to "advantage" and reads: "The National Parks are hereby dedicated to the people of Canada for their benefit, education and enjoyment ... and the National Parks shall be maintained and made use of so as to leave them

\footnotetext{
135 Waiser, B. 2011. "A Case of Special Privilege and Fancied Right”: The Shack Tent Controversy in Prince Albert National Park". In Campbell, C.E., ed., A Century of Parks Canada, 1911-2011. Calgary: University of Calgary Press, pg.105; see also Bella, L. 1987. Ibid., pg.76.

136 Urry, J. 2007. Mobilities. Cambridge, UK: Polity Press, pg.120.

137 Taylor, C.J. 1990. "Legislating nature: The National Parks Act of 1930.” In Lorimer, M., M'Gonigle, M., Revéret, J., and Ross, S., eds., To see ourselves / to save ourselves: Ecology and Culture in Canada. Montreal: Association for Canadian Studies, pg.131.

${ }^{138}$ Dominion Parks Branch. 1920-1921. Annual Report. Ottawa: Department of the Interior, pg.14.
} 
unimpaired for the enjoyment of future generations." ${ }^{139}$ As the National Parks Act excluded resource extraction, park boundaries were often redrawn by Parliament to exclude lands for the resource industry. ${ }^{140}$

Also, in 1930, the federal government passed legislation that transferred the control of natural resources to Alberta, Saskatchewan, and Manitoba such that national parks could no longer be unilaterally created in these newly-established provinces. Incidentally, the federal government modified the boundaries of the Rocky Mountain Park to exclude Spray Lakes and Kananaskis watersheds as well as the areas of Canmore and Exshaw. ${ }^{141}$ But, with what remained of the national parks, the Natural Resource Transfer Agreements ensured that the park territories came under the exclusive jurisdiction of the federal government, in perpetuity.

The federal government recognized the lingering problem of the unrepresentativeness of the national park system, and indicated that it wanted to "nationalize" the system with a national park in every province. ${ }^{142}$ One impediment to the nationalization of the system was the absence of a "national park standard" to determine the suitability of an area. Although Harkin had once wanted national parks adjacent to every major Canadian city, he later wrote that "[a]reas deemed suitable for a National Park must possess scenic beauty and recreational qualities of a character so outstanding and unusual as to be properly classified National rather than merely local." ${ }^{143}$ As observed by national park historian Alan MacEachern, "[s]ince 1885 the Canadian national park system had developed with a single idea of what was suitable national park land. Staff in the Parks Branch were indoctrinated with the belief that a park's beauty demanded virgin territory,

\footnotetext{
139 The National Parks Act, 1930, 20-21 George V, c.33.

${ }^{140}$ Bankes, N.D. 1986. Ibid., pg.233fn.

${ }^{141}$ McNamee, K. 2002. Ibid., pg.32.

${ }^{142}$ MacEachern, A.A. 2001. Ibid., pg.42; MacEachern points out that there is no evidence to suggest that the Parks Branch pursued this goal. Ibid., pg.80.

${ }^{143}$ Cited in Taylor, C.J. 1990. Ibid., pg. 133.
} 
huge parcels of land, and mountains."144 Although Gatineau Park did not have virgin mountains, it does possess sufficient quantities and beautiful wooded hillsides. The Gatineau Hills were ripe to become a national park, a territory which, following Brighenti's relational approach, can be understood as imparting "Canadian" environmental values to park visitors, who experience the beauty of "typical" Canadian scenery, that is, in the forested hillsides which are "characteristic" of the vast Canadian Shield landscape.

The eastward expansion of the national park system finally took off during the Great Depression, at the urging of the Atlantic provinces which wanted federal investment in road building and unemployment relief projects. The 36,700-hectare Cape Breton Islands national park was established in 1936, and it was followed a year later by the 1800-hectare Prince Edward Island (PEI) national park. ${ }^{145}$ The Maritime national parks did not offer the scenic landscapes and pristine wilderness characteristic of the Rocky Mountain parks. Rather they promised accessible seashore recreation to the masses, overcoming the earlier mobility problems of the Rocky Mountain Parks. The federal-provincial negotiations for PEI national park were undertaken without the involvement of the National Parks Bureau (and Harkin retired in November 1936). ${ }^{146}$ Historian Alan MacEachern's Natural Selections examines the establishment of these Maritime national parks, as boundaries were superimposed over several communities, and arbitrarily drawn to exclude others. ${ }^{147}$ MacEachern's study indicates that many, if not most, residents were surprised to find out that their lands were going to be expropriated by the provincial government for the purposes of establishing the parks. In Cape Breton, there was some discussion among affected residents about mounting a resistance

\footnotetext{
${ }^{144}$ MacEachern, A.A. 2001. Ibid., pg.45.

145 Bella, L. 1987. Ibid., pg.132.

${ }^{146}$ MacEachern, A.A. 2001. Ibid., pg.53.

${ }^{147}$ Ibid., pg.54.
} 
campaign, but the expropriations were, as MacEachern points out, "docile affairs." 148 Once the National Parks Bureau assumed control of the area, park authorities expressed their displeasure at those communities which were allowed to remain, given the likely demand for schools, hospitals and other amenities from park residents. ${ }^{149}$ Although the expropriations for the PEI National Park were not as extensive, they were fiercely contested, especially as the offers of compensation from the provincial government were non-negotiable - thus property owners had no legal recourse. ${ }^{150}$ Despite the expropriations eliciting protest among residents and landowners, there was widespared public support in PEI for the newly establish national park, not only for the recreation and tourism opportunities it provided, but also for the federal funds that came it. ${ }^{151}$ Following World War II, the expansion of the national park system was slow, with the establishment of Fundy in New Brunswick (1948) and Terra Nova in Newfoundland (1957). The same approach was taken in both parks. First, federal-provincial agreements were concluded. These agreements were followed by the provinces assuming the costs and responsibility for land acquisitions; and, third, the process was completed by the transfer of lands to the federal government - all without much protest from expropriated owners. This national park creation process would change in the late 1960s when Parks Canada, under the direction of Minister of Northern Affairs and Indians, Jean Chrétien, renewed the goal for a representative national park system. Quebec was the sole province without a national park, and Chrétien, the Liberal MP for St. Maurice (Quebec), reached an agreement with Gabriel Loubier, Minister of Tourism, Fish and Game for the Government of Quebec to establish two or three national parks, with the province transferring provincial Crown land to the federal government on 99-year renewal leases

\footnotetext{
148 Ibid., pg. 19.

149 Ibid., pg.55.

${ }^{150}$ Ibid., pg.88.

151 Ibid., pg.91.
} 
(with the Quebec government promising to continue administering the area as a conservation park if control ever reverts to it). ${ }^{152}$ This unprecedented compromise not only respected Quebec's territorial integrity but also gave the province a "special status" in Canada's national park system. ${ }^{153}$ But, according to Bankes, the lease agreement is legally unenforceable as it fetters the provincial executive and contravenes the National Parks Act, which dedicates the national parks to all Canadians for all time. ${ }^{154}$

Nevertheless, soon after the agreement between Ministers Chrétien and Loubier, Forillon National Park was established in 1970, with the provincial government having to expropriate five-hundred property owners before (temporarily) transferring lands for national park purposes. Of those, one-hundred expropriates took the provincial government to court, which, as historian Rudin notes, "lambasted a bureaucracy that had arbitrarily ignored its own long-standing rules regarding compensation in cases of expropriations prompted by road construction, disregarded norms for the payment of interest, and neglected to consider what costs would be incurred by expropriates trying to attain a level of comfort comparable to what they had had before their removal." 155 The Quebec government settled the cases out of court, with the total cost of compensation almost double the original estimate of $\$ 5.3$-million. ${ }^{156}$ As part of an effort by the Bureau d'Aménagement de l'Est-du-Québec to concentrate the region's population in urban areas, the Forillon expropriates were "deported" to selected towns. ${ }^{157}$ The national parks in Quebec were very much off limits to the original residents that they displaced.

\footnotetext{
${ }^{152}$ Lothian, W.F. 1987. Ibid., pg.134.

${ }^{153}$ Rudin, R. 2011. Ibid., pg.169.

154 Bankes, N.D. 1986. Ibid, pg.225.

155 Ibid., pg. 174.

${ }^{156}$ Rudin, R. 2011. Ibid., pg. 175.

${ }^{157}$ Ibid., pg. 172.
} 
In 1969, the establishment of Kouchibouguac in New Brunswick led to even fiercer resistance as it entailed "the destruction of eight long-standing communities." ${ }^{158}$ The provincial government expropriated 236 households (a community of 1,227 people), ${ }^{159}$ with compensation costs reaching nearly triple the original estimated amount. ${ }^{160}$ While most expropriates cooperated, a small group of dispossessed Acadians, led by Jackie Vautour, tried to close down Kouchibouguac Park by ransacking the Parks Canada offices. In response to this outbreak of violence, the federal and provincial governments commissioned a special inquiry, which recommended increased compensation and recommended that affected residents be allowed to undertake commercial fishing and clam-digging. ${ }^{161}$ In 1979, Parks Canada amended its policy to prohibit the expropriation of privately-owned lands in the establishment of national parks (and this policy was enshrined in law with the amendment of the National Parks Act in 2000). ${ }^{162}$ However, constitutional scholar Bankes argues that this policy change is "moot since Parks Canada requires the provincial authority to expropriate prior to the transfer to the federal Crown." ${ }^{163}$ Still, the new approach to national park creation was reflected in federal-provincial agreement for the Grasslands National Park in Saskatchewan, with the provincial government negotiating purchase of third-party interests, and both governments sharing in the land acquisition costs. ${ }^{164}$

This section has traced, in broad strokes, the territorialization of Canada's national parks. While policy changes have been made with respect to how parks are established, one feature has remained in place from the outset. That is, as per Section 91(1A) of the Constitution Act, the

\footnotetext{
${ }^{158}$ Ibid., pg. 178.

${ }^{159}$ Ibid., pg. 178 .

${ }^{160}$ Ibid., pg. 181.

${ }^{161}$ McNamee, K. 2002. Ibid., pg.39.

162 Ibid.

${ }^{163}$ Bankes, N.D. 1986. Ibid., pg.217.

${ }^{164}$ Ibid., pg.226.
} 
federal government must have full title to all lands within the park boundaries. Land ownership gives the federal government jurisdiction over park territories. Even though national parks are not federal enclaves in the host provinces, the admission of privately-owned lands would add vertical dimensions to the park territory, as the federal government does not have jurisdiction over privately-owned lands which are under the control of provincial governments. Given this, Bankes argues that "the Parks Canada policy of not alienating the fee simple within a park, even within a town such as Banff, is eminently sensible."165

This section also described the first proposal for a national park in the Gatineau Hills, emphasizing its significance as an alternative conception of how the national parks system could have been expanded. Commissioner Harkin proposed Gatineau Park as the prototype in a system of near-urban national parks with regulated townsites. Having identified the Gatineau Hills as an area suitable for a national park, the Parks Branch approached its provincial counterparts. But this was as far as the national park proposal went. ${ }^{166}$ Had Gatineau Park been implemented at this time (1913), the expansion of the national parks system could have been otherwise. Instead, Harkin is credited, for better or worse, with bringing Canadian cities to the national parks through the construction of highways built in and to the "autoparks." National parks became an important federal institution participating in the spread of automobility through the construction of infrastructure as well as celebration of car culture. Federal investment towards road and highway construction also became a tactic used by officials to entice provincial governments to

\footnotetext{
${ }^{165}$ Ibid., pg. 215.

${ }^{166}$ Legal scholar Nation identifies the eight stages of federal-provincial negotiations for national parks as follows: "(1) the identification of areas of interest; (2) informal discussion between bureaucrats of Parks Canada and the relevant provincial departments dealing with parks; (3) ministerial consent at the provincial and federal level, leading to (4) more negotiation and a memorandum of intention; (5) public consultation; (6) a formal agreement to create a park; (7) the acquisition of title and all interests in the land by the provincial government, and the transfer [262] of them to the federal government; and (8) legal inclusion of the land in the national park system, thus making it subject to the provisions of the National Parks Act." Nation, R.E. 1983. "The Acquisition of National Parkland: A Challenge for the Future." Dalhousie Law Journal, 7: 260-296, pgs.261-262.
} 
establish national parks. After all, provincial authorities were, understandably, reluctant to bear the costs of acquiring lands and transferring natural resources to the federal government for park purposes. As shown above, when the Quebec government was approached for Laurier National Park (east of the Gatineau River) with promises of federal funds for a highway between Montreal and Ottawa, it was concerned with protecting the province's territorial integrity. Despite the reticence of provincial authorities, the next chapter documents the unilateral establishment of “Gatineau Park in 1938, as part of federal government plans for Canada’s capital.

\section{Territorialization of the national capital}

In 1858, Queen Victoria famously chose Ottawa, a frontier lumber town with divisions along ethnic and religious lines, as the Provincial Capital of the United Canadas. The Queen's Choice resolved the decades-old "the seat of government question," a controversial political struggle that, in the end, necessitated royal arbitration. Given that the history of the seat of government question has already been well documented elsewhere, it need not be repeated here. ${ }^{167}$

As the provincial capital, Ottawa held jurisdiction over the City of Ottawa, meaning that the provincial government could exercise control over the municipal government. Similarly, the provincial government had jurisdiction over the adjacent City of Hull. Under this arrangement, the Ottawa River was only a geographic boundary, not a political one. But, all of this changed with Canadian Confederation

It is unclear whether the "fathers of Confederation" considered establishing a federal territory for the capital, commonly referred to as a "federal district" following the precedent set

\footnotetext{
${ }^{167}$ Knight, D.B. 1991. Choosing Canada's Capital: Conflict Resolution in a Parliamentary System. Ottawa: Carleton University Press; see also Eggleston, W. 1961. The Queen's Choice. Ottawa: National Capital Commission.
} 
by the United States in the establishment of the District of Columbia in $1790 .{ }^{168}$ Within Washington's federal district, federal authorities would have jurisdiction over municipal government. This arrangement provides the federal government with considerable influence over the planning and development of the capital and its environs. At the time of Confederation, only the delegate from New Brunswick, John Hamilton Gray, seemed aware of the unique set of problems associated with Ottawa's new-found status as Canada's national capital, such as increased demands on municipal services and higher property values. ${ }^{169}$ John Hamilton Gray clearly endorsed the exercise of federal territoriality over the capital and its surrounding area, including parts of Quebec. He wrote:

The City of Ottawa, with a certain area around it, should be created a Federal District; the laws for its future government (not interfering with private rights, or the city's present municipal privileges without adequate consideration) should be passed by the Dominion Parliament, and carried out by officers responsible to the Dominion Government, and through it to the people of the whole Dominion; or by a territorial arrangement, as in the District of Columbia, the legislatures of Ontario and Quebec ceding such portion of territory on both sides of the river as would make the District thoroughly unprovincial, and stipulating such terms in the cession as would preserve existing rights and interests. ${ }^{170}$

Besides Gray, Confederation delegates did not see the need for a federal district. Rather they found the area of Parliament Hill more than sufficient accommodation for the "seat of government." And, owing to the "sluggish" growth of the federal government, this area remained sufficient, such that federal-municipal arrangements in Ottawa did not significantly change during the 1870 s and 1880 s. ${ }^{171}$

\footnotetext{
${ }^{168}$ Rowat, D.C. 1973. "Ottawa” in Rowat D.C., ed., The government of federal capitals. Toronto: University of Toronto Press, pg. 317

${ }^{169}$ Gray, J.H. 1872. Confederation: The Political and Parliamentary History of Canada. Toronto: Copp Clark, pg.108.

${ }_{170}$ Ibid., pg. 110.

${ }^{171}$ Taylor, J.H. 1989. “City form and capital culture: remaking Ottawa.” Planning Perspectives, 4: 79-105, pg.88.
} 
Thus, the Constitution Act transformed Ottawa into "a federal capital located within a provincial municipality, and the latter took its orders, not from Parliament Hill, but from Queen's Park, 275 miles away, and from a jurisdiction separate and autonomous and independent in broad respects from the central federal government." ${ }^{172}$ Although the fathers of Confederation were not prepared to override the jurisdiction of the City of Ottawa, they were also not prepared to require the federal government to pay municipal taxes: the Constitution Act exempted all federal Crown lands from municipal taxes in Ottawa and elsewhere.

The economic depression between 1875 and 1895 forestalled the issue of lost municipal taxes. However, the expansion of the federal government into Ottawa's central business district deprived the cash-strapped City of Ottawa of considerable revenue. In 1896, City Council set up a special committee to study arrangements of other federal capitals in the British Empire, and found that municipal governments were typically compensated by the federal government for lost tax revenues and expenditures on municipal services. ${ }^{173}$ Based on these findings, the City of Ottawa, in 1897, petitioned the newly elected Laurier government for payments-in-lieu-of-taxes, which the municipality estimated to be \$14-million. ${ }^{174}$

In addition to the pressure from the City of Ottawa, the Governor General Lord Aberdeen and his wife, Lady Aberdeen (Ishbel Grordon), urged Prime Minister Laurier to act on his earlier election promise to make Ottawa "the Washington of the North." ${ }^{175}$ Since the Queen's choice of provincial capital in 1858, successive Governors Generals had looked unfavorably upon Ottawa, which remained very much an unsightly and disorderly lumber town until the early twentieth

\footnotetext{
172 Eggleston, W. 1961. Ibid., pg.144.

${ }^{173}$ Carter, A.C. 2001. Planning a "Capital Worthy of the Nation": The federal district controversy and the planning of the Canadian capital. Kingston: Queen's University (unpublished MA thesis), pg.103.

${ }^{174}$ Rowat, D.C. 1973. Ibid., pg.318.

${ }^{175}$ Gordon, D.L.A. 2001. "From Noblesse Oblige to Nationalism: Elite Involvement in Planning Canada's Capital." Journal of Urban History, 28(1): 3-34, pgs.10-11.
} 
century. ${ }^{176}$ "Happily,” wrote Lady Aberdeen, “Ottawa does not mean Canada, nor does it represent Canada." "177

The Laurier government responded to municipal concerns and vice-regal pressures by introducing an Act Respecting the City of Ottawa of $1899 .{ }^{178}$ In the House of Commons, the idea of a federal district, which seemed implied by Laurier's earlier election promise, was raised, but the Finance Minister, W.S. Fielding, rejected a federal district outright:

... the proposal to make Ottawa in reality the Washington of the North, in the literal sense of the expression, would give satisfaction neither to Parliament nor the city. To Parliament it would be objectionable because it cost too much; to the citizens of Ottawa it would be objectionable because it would deprive them of the rights of representation which they now possess. ${ }^{179}$

Parliamentarians were not moved by the pleas of the City of Ottawa for lost taxes. ${ }^{180}$ Rather, they maintained that any funds given to Ottawa should be used only for national, not local, purposes.

To this end, the Act established the Ottawa Improvement Commission (OIC) with a mandate towards the beautification of Canada's capital through "the acquisition, maintenance and improvement of public parks, squares, streets, avenues, drives, or thoroughfares, and the erection of public buildings in the said city or in the vicinity thereof." ${ }^{181}$ In order to carry out this beautification mandate, the Act gave the OIC an annual budget of $\$ 60,000$, and powers of expropriation in Ottawa. The executive decision-making body of the OIC, the Commission, consisted of four Commissioners; apart from the Mayor of Ottawa, Commissioners were unpaid Cabinet appointments. The inevitable result was that the first OIC Chairman, Sir Henry Bate, and

\footnotetext{
176 Ibid.

${ }^{177}$ Gordon, I. 1960. The Canadian Journal of Lady Aberdeen. Toronto: Champlain Society, pg.194.

178 An Act Respecting the City of Ottawa, 1899, 62-63 Vict. c.10.

${ }^{179}$ Fielding, W.S. 1899, Aug. 2. "Grant to the City of Ottawa." Canada. Parliament. House of Commons. Edited Hansard, $8^{\text {th }}$ Parliament, $4^{\text {th }}$ Session, Vol.3, pg.9187.

180 This position was relaxed in 1910 when the federal government began paying an annual grant directly to the City of Ottawa. Carter, A.C. 2001. Ibid., pg.121.

${ }^{181}$ An Act Respecting the City of Ottawa, 1899, 62-63 Vict. c.10.
} 
Commissioners were almost always supporters of the Liberal Party of Canada. ${ }^{182}$ The volunteer staff of the OIC was drawn from the federal government. Despite its small volunteer staff, the early work of the Commission was widely praised, as the OIC cleared industry from the banks of the Rideau Canal and constructed a "scenic driveway" along it (driveways for the enjoyment of the handful of car-owners in the early twentieth century capital). But it quickly became apparent that OIC improvements would remain piecemeal and cosmetic, that is, confined to small parks and driveways.

In 1903, the OIC hired the landscape architect Frederick G. Todd, who produced a preliminary report for a regional park and parkway system. The very first recommendation in the Todd report was to create two nature reserves, one along the Gatineau River and the other surrounding Meech Lake. ${ }^{183}$ Both would be made accessible by a parkway extending from Hull. Todd wrote glowingly of the benefits of these nature reserves: "Not only will those reserves be of inestimable value to future generations as an example of the original forest, but they will also provide a place where nature may still be enjoyed, unmarred by contact with humanity." 184 This seems to suggest that there would be no settlements in the nature reserves. Todd, then Canada's only practicing landscape architect, does not explicitly address the cottage community at Meech Lake. His report does, however, urge an immediate start on land acquisitions given that the costs of land would become prohibitive, with Todd projecting that, in fifty years, Ottawa's urban area will have expanded five times, He wrote: "Will it at that time be possible to secure within reasonable distance of the city large areas of untamed forest which can be set aside forever for the enjoyment of people who wish to get away for a day from the crowded city, who wish to

\footnotetext{
182 Gordon, D.L.E. 2015. Ibid., pg. 114.

183 Todd suggested that the lake could provide an alternative supply of drinking water for Ottawa. Todd, F.G. 1903. Preliminary Report to the Ottawa Improvement Commission. Ottawa: Ottawa Improvement Commission, pg.8. ${ }^{184}$ Ibid., pg. 2.
} 
wander in the woods, where the wildest birds are at home, and where nature's mossy carpet is still luxuriant and unworn?"185

Neither the Meech Lake nor Gatineau River reserves were established. Indeed, despite the positive reception of the Todd report by the OIC and local newspapers, its recommendations were never seriously considered, and the OIC proceeded, largely without Todd's assistance, with relatively minor improvements to Ottawa's parks and parkways system. ${ }^{186}$ As noted by historian Wilfred Eggleston, "[t]he Ottawa Improvement Commission was handicapped by insufficient funds, restricted powers, and possibly, by lack of imagination. As it was not created as a townplanning body, and in any event lacked the authority in that field, its remedies were bound to be superficial rather than basic." ${ }^{\prime 187}$ In 1905, Ottawa City Council, perhaps sensing the limitations of the OIC, set up a special committee to approach federal officials about establishing "a certain area, including the City of Ottawa, as a territory to be conducted along similar lines as the city of Washington and to gather all the information which they may deem advisable in the matter." 188 Though nothing came of this meeting, the City of Ottawa, during the 1907 elections, held a plebiscite on creating a federal district: voters narrowly defeated the proposal with 4,431 opposed and 3,630 in favor of a federal district. ${ }^{189}$

In 1910, the ongoing works of the OIC and its failure to act on the Todd Report were publicly criticized by prominent architects, town planners, and even the Governor General Earl Grey. In response, the Laurier government increased OIC funding from $\$ 60,000$ to $\$ 100,000$, but critics of the OIC did not relent. They pressured the newly elected Prime Minister, Sir Robert

\footnotetext{
185 Ibid., pgs.9-10.

${ }^{186}$ Planning historian David Gordon discusses Todd's poor treatment by the OIC as disputes arose over his pay and the OIC adopted park plans prepared by its own engineer rather than the landscape architect. Gordon, D.L.A. 2002. "Frederick G. Todd and the Origins of the Park System in Canada's Capital." Journal of Planning History, 1(1): 2957, pg.40.

${ }^{187}$ Eggleston, W. 1961. Ibid., pg.166.

${ }^{188}$ Carter, A.C. 2001. Ibid., pg.112.

189 Ibid.
} 
Borden, to suspend OIC operations, and to consider establishing a federal district for the national capital. ${ }^{190}$ Borden was approached by the Royal Architects Institute of Canada to undertake a comprehensive plan for Ottawa. Following their meeting, Opposition Leader Wilfrid Laurier defended the work carried out by the OIC. Referencing the Todd Report, Laurier maintained that “it is not accurate to say ... that the commission proceeded without any plan prepared in advance."191 There was mounting pressure on the Borden government to establish a federal district. Notably, in the City of Ottawa election in 1913, a second plebiscite was held on establishing a federal district, one governed by a committee of elected and appointed officials. Ottawa voters approved this plebiscite with 7,335 voting in favor, and only 2,942 against a federal district ruled by municipal and federal officials. ${ }^{192}$

In response to the growing pressure for a federal district and a comprehensive plan, and since the OIC remained too closely tied the Liberal Party, Prime Minister Borden established an independent Federal Plan Commission (FPC). The FPC was loaded, in turn, with supporters of the Conservative Party of Canada, including Chairman Herbert Holt, a Montreal business tycoon. The FPC included the Mayors of Ottawa and Hull. This was the first time that the federal government recognized the north side of the Ottawa River as part of the national capital, a decision that was well received, at least initially, by Hull officials. ${ }^{193}$ It was agreed among municipal and federal governments that the latter would cover half the cost of the master plan, with each municipality paying a quarter of the total cost. As we shall see, because of the federal district controversy, the City of Hull left the FPC and abandoned its obligations to pay.

\footnotetext{
${ }^{190}$ Gordon, D.L.A. 2001. Ibid., pg.13.

${ }^{191}$ Laurier, W. 1912, Jan. 10. "Ottawa Improvement Commission.” Canada. Parliament. House of Commons. Edited Hansard, 103(1) $12^{\text {th }}$ Parliament, $1^{\text {st }}$ session, pg.977.

192 The confidence of voters in the abilities of municipal authorities was low owing to major typhoid outbreaks in 1911 and 1912 from contaminated water supply. Carter, A.C. 2001. Ibid., pgs.111-3. On the typhoid outbreaks, see Lloyd, S. 1979. "The Ottawa typhoid epidemics of 1911 and 1912: A case study of disease as a catalyst for urban reform." Urban History Review, 8(1): 66-89.

193 Ibid., pg. 117.
} 
The first recommendation of the FPC, or the Holt Plan as it is sometimes known, was to establish a federal district: "We are of the firm opinion that the future improvements in the area about the Capital at Ottawa and Hull should not be attempted without first establishing a federal district and securing for the Federal authority some control of local government." ${ }^{194}$ While this recommendation was well received by Ottawa politicians and residents, it prompted the City of Hull to sever all ties with the FPC. Hull even refused to pay its share of costs, prompting an unsuccessful legal challenge by the federal government. ${ }^{195}$ Planning historian Aidan Carter has convincingly argued that the federal district proposal was denounced by Hull since "many francophones believed that it was essential that their communities retain their political sovereignty in order to safeguard their cultural integrity." 196 With the exit of Hull from the FPC, the question of whether the Quebec government would cede territory for a federal district became a non-starter. Given this thorny issue, the Borden government remained non-committal about its stance on a federal district. ${ }^{197}$

Had the federal district been restricted to Ontario, this exercise of territoriality would have been perceived as benevolent by most residents. But, on the Quebec side, the creation of a federal district was viewed as a malevolent exercise of territoriality. So perhaps it is not surprising that the Borden government, for its part, was disinclined to the proposed federal district which would require an amendment to the Constitution Act (and as indicated below, there were other priorities for it to attend to).

\footnotetext{
${ }^{194}$ Federal Plan Commission for Ottawa and Hull. 1916. Report of the Federal Plan Commission on a General Plan for the Cities of Ottawa and Hull. Ottawa: FPC, pg.22.

195 The federal government took the case against the City of Hull to the Supreme Court of Canada. Despite the Court's condemnation of Hull's actions, the federal government lost the case on technical grounds. The City of Ottawa paid Hull's share of the costs for the Holt Report. Carter, A.C. 2001. Ibid, pg.117.

196 Ibid., pg.. 118.

197 Ibid., pg. 115.
} 
The second recommendation of the Holt Plan was to create a 30,000 to 40,000-hectare national park in the Gatineau Hills. Echoing Todd's thinking and Macoun's 1912 proposal for Connaught Park, ${ }^{198}$ the recommendation in the Holt Plan is quoted here at length as it reveals an increasingly archaic conception of a national park (that is, the Dominion Parks Branch had banned hunting and resource extraction was less and less tolerated):

One of the attractions of Ottawa is to be found in the slopes on the north side of the river which stretch away to sky line of distant forest-clad mountains. Nature, which has not made this tract of land fertile, has made it beautiful. Much of it is still covered with forest. Since it has little commercial value, it could be acquired at slight cost and a great tract of it, consisting of 75,000 or 100,000 acres, should be secured as a national park. Here, at the very door of the capital, should be preserved, for all time, a great area in the state of nature. It would include lakes and hills. The owners of land, who now occupy it, simple farmer or hunter folk for the most part, need be little disturbed, and could be employed as game and timber wardens. Such a park would have scientific value, both in respect to forestry and wild life. Its growth of timber might even be made profitable. The Gatineau River, a part of which would be included in the park, flows through one of the best regions for wild game in North America and, under proper restrictions, the park would offer excellent sport for rod and gun. But, above all, it would have priceless value for those who live in or visit Ottawa. Within half an hour they could pass from the bustle of the capital to the seclusion of the forest. Side by side would be seen the beauty of the city, which man has created, and that of nature as it has been for countless ages. It is not proposed that this park should be included in the federal district to be formed, and the carrying out of this proposal need not wait upon other plans for the capital. ${ }^{199}$

The main weakness of this proposal rests with the position regarding private landowners, who "need be little disturbed." As indicated in the last section, the Canadian government must eliminate private lands to consolidate control over any park territory. And, in the context of the national capital, the federal government would most effectively assert territoriality by placing the park within the federal district, as Macoun and Harkin had suggested earlier. Clearly, when putting forward this park proposal, capital planners had not sufficiently examined national park.

\footnotetext{
198 The Holt Plan has been mistakenly identified as the first to propose a national park in the Gatineau Hills: Gordon, D.LA. 2002. Ibid., pg.44.

${ }^{199}$ Federal Plan Commission. 1915. Report of the Federal Plan Commission on a General Plan for the Cities of Ottawa and Hull. Ottawa: Federal planning Commission, pg. 26-27.
} 
The Holt Report was also released at a very inopportune time, coinciding with the outbreak of World War I, and the destruction of Parliament by fire in 1916. Moreover, the Holt Report was severely criticized by the Town Planning Advisor to the federal government, Thomas Adams, and Ottawa-based town planner, Noulan Cauchon, who had prepared the base plan and contour map used by the Federal Plan Commission. ${ }^{200}$ The Holt Report was shelved and the Federal Plan Commission disbanded. Only the Ottawa Improvement Commission lingered on, with the federal government providing periodic funding increases to the OIC towards the maintenance of an expanding parks and parkways system; still, no major projects or plans were ever carried out by the OIC, which, by the 1920 s, was experiencing institutional drift.

Notably, in 1922, Noulan Cauchon, then Chairman of the Ottawa Town Planning Commission published an article, "A federal district for Ottawa," in the Journal of the Town Planning Institute of Canada. Cauchon proposed in the article a "Federal District Commission" composed of a "small body of experts" to oversee the management of those "public services" voluntarily transferred to it by the municipal governments of Ottawa and Hull. ${ }^{201}$ Cauchon's Federal District Commission would function as a regional planning authority, with the municipalities retaining responsibility for the provision of some services. Clearly, this proposal for a federal district differed markedly from the District of Columbia in the United States, where the federal government had exclusive control over the capital territory. Eventually, in 1927, the Mackenzie King government re-constituted the OIC; King created the Federal District Commission (FDC), but this new organization was not the quasi-federal district that the OTPC Chairman Cauchon had proposed five years earlier.

\footnotetext{
${ }^{200}$ Carter, A.C. 2001. Ibid., pg.119. For Adams' influence on town planning in Canada, see Simpson, M. 1982. "Thomas Adams in Canada, 1914-1930." Urban History Review, 11(2): 1-16; for Cauchon, see Gordon, D.L.A. 2008. “'Agitating people's brains': Noulan Cauchon and the City Scientific in Canada's capital." Planning Perspectives, 23: 349-379.

${ }^{201}$ Cauchon, N. 1922. “A federal district for Ottawa." Journal of the Town Planning Institute of Canada, 1(9): 3-6.
} 
Nevertheless, King's FDC was Canada's first regional planning authority, with an additional $\$ 100,000$ in funding (for an annual budget of $\$ 250,000$ ) and a paid, professional staff. When introducing the Federal District Commission Act, the Prime Minister indicated that this was more a rearrangement than a substantial institutional reconfiguration: "The purpose of the bill ... is to extend somewhat the powers of the present Ottawa Improvement Commission by enlarging the area over which it will be authorized to carry on its work, increasing the amount of money at its disposal, and changing its name to conform more accurately with the intent and purpose of the commission. ${ }^{202}$ But the Federal District Commission continued to be a misnomer, as a federal district had not in fact been created. Although FDC operations extended over a broader area, the 1927 FDC Act did not actually establish a territory which the federal government had control. There was a bounded area, but the FDC, like the OIC, could not assert territoriality over lands it did not own. During the debate of the FDC Act, the Liberal MP for Toronto Centre, Horatio Hocken insisted on a federal district following the "splendid precedent" of Washington: "If we are going to make the city of Ottawa, a great capital, attractive in all its physical features, the way to go about the matter is to appoint a commission now to take over the city. Let this government manage and govern it." ${ }^{203}$ But the specter of Anglophone dominance prompted Joseph-Éloi Fontaine, the Liberal MP for Hull, to defend the political sovereignty of Hull: "On behalf of my constituents I am absolutely opposed to the City of Hull becoming part of a federal district, because it would despoil us of our cherished rights." ${ }^{204}$ So long as an actual federal district was left in abeyance, Fontaine supported the FDC, especially the prospect of

\footnotetext{
${ }^{202}$ King, W.L.M. 1927, Apr. 6. "Federal District Commission.” Canada. Parliament. House of Commons. Edited Hansard. $16^{\text {th }}$ Parliament, ${ }^{\text {st }}$ Session, Vol.2, pg. 1975.

${ }^{203}$ Hocken, H. 1927, Apr. 6. "Federal District Commission.” Canada. Parliament. House of Commons. Edited Hansard, 16th Parliament, 1st Session, Vol.2, pg.1980.

${ }^{204}$ Fontaine, J. 1927, Apr. 6. "Federal District Commission." Canada. Parliament. House of Commons. Edited Hansard, 16th Parliament, 1st Session, Vol.2, pg.1980.
} 
federal investment in his constituency. Fontaine's opposition did not deter Mackenzie King: in 1928, the Prime Minister advocated for a federal district before the House of Commons, whatever the constitutional reforms that may be required to enact it. ${ }^{205}$

While the Federal District Commission Act extended the scope of FDC operations, it did not give the FDC the power to expropriate lands in Quebec. A subsequent amendment to the Act in 1928, however, granted this power to the FDC such that it could expropriate private property "without the co-operation by the provincial legislature." 206 Incidentally, I found no record that this new expropriation power was debated in the House of Commons during discussion of the amendment of the FDC Act. Surely, this amendment would have been opposed by MPs from Quebec. In the absence of a federal district, this expropriation power was critical for the Gatineau Park land acquisition program which, as documented in the next Chapter, was initiated in 1938. For the moment, it is important to turn to the ongoing debate over a federal district and the subsequent institutional rearrangement of the FDC.

Before the outbreak of World War II, Prime Minister King recruited the French town planner, Jacques Gréber, to visit Ottawa and prepare a comprehensive plan for Canada's national capital. $^{207}$ Gréber famously rejected the need for a federal district, seeing federal-municipal cooperation as sufficient for enacting a comprehensive plan. ${ }^{208}$ Professor Rowat astutely notes, “Gréber, of course, had not lived under a federal system of government and was not fully conversant with the difficulties of divided jurisdiction." 209 With the onset of World War II, Gréber's work was suspended. During the war, the federal government expanded considerably,

\footnotetext{
${ }^{205}$ King, W.L.M. 1927, Apr. 24. "Federal District Commission.” Canada. Parliament. House of Commons. Edited Hansard. $16^{\text {th }}$ Parliament, $2^{\text {nd }}$ Session, Vol.2, pg.2320.

${ }^{206}$ Edwards, S.W. 1937, Mar. 19. Letter from W.S. Edwards to H.R. Cram. RG34 Vol265.190(2).

${ }^{207}$ Gordon, D.L.A. 2002. "William Lyon Mackenzie King, planning advocate.” Planning Perspectives, 17: 97-122, pg. 110 .

${ }^{208}$ Eggleston, W. 1961. Ibid., pg.184.

${ }^{209}$ Rowat, D.C. 1974. “The Proposal For a Federal Capital Territory For Canada's Capital.” In Fullerton, D., Canada's Capital: How Should it be Governed? Ottawa: Information Canada, pg.397.
} 
with numerous permanent and 'temporary' buildings were erected throughout war-time Ottawa, which was now a decidedly government town as opposed to its beginnings as a lumber town. The growing federal presence took a heavy toll on the municipal government, not only in the form of lost taxes, but also in the provision of municipal services to federal buildings.

In response to the complaints from the City of Ottawa, a joint committee of the Senate and House of Commons was set up to work out "better fiscal terms." 210 During the committee hearings, the Chairman of the FDC, Frederic Bronson, argued that the creation of a federal district was "inescapable." ${ }^{211}$ But, the idea of a federal district was, once again, condemned by Quebec officials. ${ }^{212}$ Ultimately, the joint-parliamentary committee agreed that "it is clear that with the growth of Canada and the corresponding expansion of its governmental activities, the administrative problems arising between the City of Ottawa and the Federal Government will become more complex and more difficult of settlement than they are now." 213 However, the joint-parliamentary committee was not prepared to endorse the federal district option; in its final report, it suggested, instead, that a committee of experts be convened "to study the plans and working of federal capital districts in other countries." ${ }^{214}$ Further, the joint-parliamentary committee recognized the misnomer of the FDC, and suggested its name be changed "to include the idea of a National Capital."215

Following World War II, Prime Minister King resumed planning of the national capital, a project which he dedicated to those who had died during the War, but which he also considered

\footnotetext{
${ }^{210}$ Eggleston, W. 1961 Ibid.., pg.177. The City of Ottawa argued before the joint-parliamentary committee that it should annually receive $\$ 1.60$-million to offset lost taxes, but the committee recommended that the annual grant be increased from $\$ 100,000$ to $\$ 300,000$.

${ }^{211}$ Cited in Eggleston, W. 1961. Ibid., pg.182.

${ }^{212}$ Gordon, D.L.A. 2001. "Weaving a Modern Plan for Canada's Capital: Jacques Gréber and the 1950 Plan for the National Capital Region." Urban History Review, 29(2): 43-61, pg.60.

${ }^{213}$ Cited in Eggleston, W. 1961. Ibid.., pg.183.

${ }^{214}$ Cited in Ibid.

${ }^{215}$ Canada. Parliament. Joint Committee of the House and Senate on Relations between the Federal Government and the City of Ottawa. 1944, Aug. 1. Final Report of the Committee. Ottawa: King's Printer, pg.172.
} 
"a personal legacy."216 First, an Order-in-Council defined a 2,330 square kilometer (900 square mile) area as the "National Capital District." 217 Again, this "district" is not a territory, but an area of operation for the FDC. Second, an Order-in-Council established the National Capital Planning Committee (NCPC) to advise the FDC concerning federally-owned lands, and to prepare a master plan for the long-term development of the National Capital District. ${ }^{218}$ Gréber was recalled from France and appointed as consultant to the NCPC, which included representatives from the FDC, the Department of Public Works, and various municipal governments. Third, in 1946, the Federal District Commission Act was amended to, inter alia, raise the annual grant for the Commission from $\$ 200,000$ to $\$ 300,000$, and to provide $\$ 3$-million "for the purchase of land or the carrying out of schemes of improvements requiring a larger outlay than is available from the actual annual income of the Commission." ${ }^{219}$ As detailed in Chapter 3, the \$3-million consolidated fund enabled the rapid expansion of Gatineau Park, with the land acquisition program carried out by the FDC under the direction of an Advisory Committee on Gatineau Park, chaired by the park's founding father, Roderick Percy Sparks.

According to planning historian Aidan Carter, ${ }^{220}$ a front-page editorial opposing the increase in FDC powers prompted Prime Minister King to abandon his public advocacy of a federal district. ${ }^{221}$ Meanwhile, Gréber continued to maintain that federal-municipal co-operation

\footnotetext{
${ }^{216}$ Gordon, D.L.A. 2002. Ibid., pg.97.

${ }^{217}$ Privy Council of Canada. 1945, Aug. 16. PC 5634; see also Federal District Commission. 1947. Annual Report. Ottawa: King's Printer, pg. 4.

218 Privy Council of Canada. 1946, Apr. 18. PC 1266; see also Federal District Commission. 1947. Ibid., pg.4.

${ }^{219}$ Federal District Commission. 1947. Ibid., pg.3.

${ }^{220}$ Carter, A.C. 2001. Ibid., pg. 159

${ }^{221}$ In advance of forming the 1944 joint-parliamentary committee, for instance, King told the House of Commons "... some years ago I made the suggestion, which others have also made, that some day the capital of Canada might become a federal district to be administered by a commission, in a manner similar to the capital at Washington ... If feel that just now, if there is to be any immediate consideration of the planning of greater Ottawa as a city or as a capital, that planning ought to have in mind all possibilities of the development of this capital. I have often hoped that if the capital were to become a federal district, that district would extend far enough to include a very large area on the other side of the river as well as the Ottawa are." The "very large area" in Quebec to which King alludes is
} 
was all that was needed to implement the major recommendations of the 1950 Plan for the National Capital (popularly known as the Gréber Plan), which included the expansion and protection of Gatineau Park, the creation of Greenbelts around Ottawa and Hull, the relocation of railways and industry, the construction of a regional road and parkway network, the decentralization of federal office complexes, etc. As Professor Rowat explained, "the problem of what would happen if these governments did not co-operate was never squarely faced. The fact is that the Federal District Commission had no power to enforce any part of the plan that did not affect federally owned territory." 222 Carter was less forgiving in his assessment as "[a]n increasing amount of federal money was at stake in the planning of the capital, and given that a good deal of time and energy had been devoted to the preparation of a comprehensive plan for the region, it really seems rather inexplicable that the official government line continued to be that the various levels of government should somehow muddle their way through the task of planning the capital." 223

The problem of federal-municipal non-cooperation was not immediately apparent, as the City of Ottawa formed the Ottawa Area Planning Board which not only adhered to, but also tried to implement, the zoning scheme laid out in the Gréber Plan. ${ }^{224}$ The townships of Nepean and Carleton refused to set aside lands for the Greenbelt (and it appears that the question of the Greenbelt around Hull was never seriously considered by the FDC). The inability to get a start on Ottawa's Greenbelt through municipal-federal co-operation prompted the appointment of another joint committee of the Senate and House of Commons, this one established specifically

almost certainly Gatineau Park. King, W.L.M. 1944, Apr. 21. “City of Ottawa Agreement.” Canada. Parliament. House of Commons. Edited Hansard. 19 ${ }^{\text {th }}$ Parliament, $5^{\text {th }}$ Session, Vol.3, pg.2237.

222 Rowat, D.C. 1973. Ibid., pg.321.

${ }^{223}$ Carter, A.C. 2001. Ibid., pg. 185.

${ }^{224}$ Rowat, D.C. 1973. Ibid., pg.321. 
"to review and report upon the progress and programs of the Federal District Commission in developing and implementing the Plan for the National Capital."225

Whereas former FDC Chairman Bronson had indicated that a federal district was an absolute necessity, and thus only a matter of time before the idea was realized, then FDC Chairman Major-General Howard Kennedy, a Kingsmere cottager (see Chapter 4), insisted that there was never going to be a federal district. Chairman Kennedy explained to the committee: "I do not believe that such a body can, or will, be created here and would consider it a disaster for FDC to take over such matters as police, education, health, fire protection or even in broad outline the engineering services of any or all of the municipalities in the national capital area."226 Interestingly, Senator John J. Connolly, a Meech Lake resident and opponent of proposals for public ownership of Gatineau Park (see Chapter 4), took the opposite view: "The ideal situation, if the Federal District Commission is to accomplish the purpose for which it is established, would be to have an area there in which the jurisdiction over all these things would be in the hands of the FDC. That is the Washington arrangement, but I take it the municipalities in the area resist the idea of divesting themselves of their autonomy." 227 Another notable witness before the 1956 joint-parliamentary committee was the Auditor General of Canada, Watson Sellar, who indicated that the FDC has no "official status," and that, through an amendment to the Constitution Act, it should be given the authority to act on behalf of the provinces in the administration of the national capital and its environs. ${ }^{228}$ The joint-parliamentary committee did not ultimately act on this advice, of amending the . The National Capital Act did, however,

\footnotetext{
${ }^{225}$ Eggleston, W. 1961. Ibid., pg.203.

${ }^{226}$ Kennedy, H. 1956, June 28. Joint Committee of the Senate and House of Commons on the Federal District Commission, Vol.19. Ottawa: Queen's Printer, pg.922.

${ }^{227}$ Cited in Eggleston, W. 1961. Ibid., pg.213-214.

${ }^{228}$ Cited in Ibid., pg.215.
} 
establish an organization with the capacity to dispose of lands in the on behalf of the national interest, as confirmed by the Supreme Court decision in Munro v. NCC.

The FDC, for its part, submitted a 100-page "brief” to the joint-parliamentary committee, recommending several amendments to the FDC Act. The FDC wanted the power to (re)define the boundaries of the National Capital District (and to have those boundaries described in the $A c t$ ). Further, it sought to enhance its powers of expropriation, namely, "without first having to obtain the refusal of owners." ${ }^{229}$ For property acquisitions over $\$ 5,000$, the FDC had to request approval from the Governor in Council; it requested that the minimum be raised to $\$ 50,000.230$ Most of the other FDC recommendations would provide it with greater flexibility for land acquisitions and disposals. Incidentally, with the Township of Nepean refusing to co-operate in the zoning of the Greenbelt, the FDC was authorized to proceed with the land acquisition program for Ottawa's Greenbelt, and, by the end of 1958, the FDC had already assumed control of $20 \%$ of the overal area $(37,500$ acres $) .{ }^{231}$ Indeed, the joint-parliamentary committee urged that "federal policy be exercised as far as possible through the ownership and use of property."232 To this end, it concurred with the FDC that more substantial funding was needed to implement the Gréber Plan. Even though the joint-parliamentary committee did recognize the jurisdictional problems tied to the divided control of the National Capital District, its final report did not

\footnotetext{
${ }^{229}$ Federal District Commission. 1956, Mar. Brief. Ottawa: Submitted to the Joint Committee of the Senate and House of Commons appointed to review and report upon the progress and programs of the Federal District Commission in developing and implementing the Plan for the National Capital of Canada, pg.95. This suggestion was realized in the National Capital Act, Section 13(1), which provided: "The Commission may, with the approval of the Governor in Council, take or acquire lands for the purpose of this Act without the consent of the owner..." ${ }^{230}$ Ibid., pg. 95 .

${ }^{231}$ Federal District Commission. 1958. Annual Report. Ottawa: Queen's Printer, pg.5.

${ }^{232}$ Joint Committee of the Senate and House of Commons on the Federal District Commission, Vol.19. Ottawa: Queen's Printer, pgs.1049-1050.
} 
address the federal district question. Rather, the joint-committee insisted: "For the resolution of these conflicts, co-operation between the three levels of government is essential." ${ }^{233}$

Following the recommendations of the joint-parliamentary committee, the St. Laurent government introduced Bill 417, An Act Respecting the Development and Improvement of the National Capital Region, in the House of Commons. With the defeat of the St. Laurent government in the June 1957 federal elections, Bill 417 died. ${ }^{234}$ The newly-elected Conservative minority government of John Diefenbaker, however, supported the continued implementation of the Gréber Plan. It reintroduced legislation based on Bill 417 in the summer of 1958, and the National Capital Act was proclaimed in 1959.

The institutional rearrangement of the FDC was a familiar one. Besides an increase in funding and staff, as well as a larger area in which to operate, the reconstituted organization, the National Capital Commission (NCC), was neither provided with new jurisdictional powers, nor given a territory to govern. While the joint-parliamentary committee emphasized the importance of co-operation, local representation was removed from the NCC Executive Board. Due to the exclusion of local Mayors and the ongoing expropriations carried out for the Greenbelt and Gatineau Park (see Chapter 5), the NCC gained a reputation as a remote, unaccountable, and autocratic body. In 1965, Harold Munro, a farmer whose lands were expropriated by the NCC for Greenbelt purposes, challenged the right of the federal government to expropriate property for beautification purposes. Munro argued that his farm fell under the exclusive jurisdiction of the provincial legislature. The Court of the Exchequer and the Supreme Court ruled that NCC expropriations were legitimate, and NCC authority over lands in the national capital region fell under the peace, order, and good government clause of the Constitution Act.

\footnotetext{
${ }^{233}$ Ibid., pg. 1055.

${ }^{234}$ Gyton, G. 1999. Ibid., pg.47.
} 
In 1966, the Quebec government extended the scope of the Dorion Commission to include an examination of how the NCC affected the territorial integrity of Quebec (the Dorion Commission was originally set up to look at provincial boundaries, especially with Labrador). ${ }^{235}$ Following this, in 1967, the Pearson government initiated talks with the Ontario and Quebec premiers to examine the possibility of a "Tripartite Commission" with representatives from the three governments collectively adminsitering the National Capital Region. The creation of a federal district was ruled out from the outset of the Tripartite talks. ${ }^{236}$ During the negotiations, the Quebec government proposed, based on the recommendation of the Dorion Commission (1968), the abolition of the NCC, and that all federal Crown lands in Quebec be unconditionally transferred, without cost, back to the provincial governments. ${ }^{237}$ Further, the Government of Quebec wanted the provinces to have veto powers over any federal decisions affecting provincial territory. The NCC Chairman who was involved in these inter-governmental talks, Douglas H. Fullerton, neatly summed up the position of the provincial government on: "The 'territorial' question. [In view of provincial authorities] Quebec's boundaries are regarded as sacred, not even (or perhaps most of all) to be breached by the intrusion of a federal capital."238 Incidentally, the Tripartite talks were broken off by federal officials, who were unwilling to enter an arrangement where the federal government would have even less control over the future development of the capital. ${ }^{239}$ Moreover, the Province of Ontario rejected the idea of a tripartite intergovernmental agency. As one of the negotiators involved in the broken-off talks, Claude Morin, explained: “elle [Ontario] admit le bien-fondé de plusieurs des positions québécoises,

\footnotetext{
235 Fullerton, D.H. 1978. The Dangerous Delusion: Quebec's Independence Obsession. Toronto: McClelland and Stewart, pg. 122.

${ }^{236}$ Fullerton, D.H. 1978. Ibid.

${ }^{237}$ The Commission on the Integrity of the Territory of Québec. "A summary of the postulates and recommendations." In Fullerton, D.H. 1974. The Capital of Canada: How Should It Be Governed? Ottawa. Information Canada, pgs.255-256.

${ }^{238}$ Fullerton, D.H. 1978. Ibid., pg. 123.

${ }^{239}$ Ibid.
} 
mais n'était ailleurs prête à laisser s'établir un mécanisme intergouvernemental qui risquait d'amoindrir sa part traditionnelle des dépenses fédérale dans la region." 240

Fullerton observed that the governance of Canada's capital region was an "increasingly confused and tangled web of jurisdictions..."241 The former NCC Chairman characterized the National Capital Region as a "jurisdictional swamp." 242 Indeed, the possibility of coordinated intergovernmental planning of the NCR had become more remote by the 1970s, with both provinces introducing regional governments, namely, the Regional Municipality of Ottawa Carleton (RMOC, established 1968) and the Communauté Régionale de l'Outaouais (CRO, established 1970). Fullerton's study, commissioned by Prime Minister Pierre Trudeau, infamously conceived of a "supra-regional council," with half the council members elected by local residents and the other half appointed by federal and provincial governments. ${ }^{243}$ Fullerton's proposal for a supra-regional council met with the disapproval of most municipal and regional politicians. ${ }^{244}$ Meanwhile, the vertical dimensions of the capital region were suffocating the planning role of the NCC: its 1974 plan Tomorrow's Capital: An invitation to dialogue made proposals concerning regional development and growth that directly contradicted those found in drafts of the RMOC and CRO regional plans. According to planning historian Professor David Gordon, “Tomorrow's Capital became simply a footnote marking the point at which the NCC's regional planning power evaporated."245

With the added complexity brought by "upper-tier" municipal governments (RMOC and CRO), and mounting criticisms of the NCC, the Trudeau government appointed another joint-

\footnotetext{
${ }^{240}$ Cited in Cimon, J. Le Dossier Outaouais: réflexions d'un urbaniste. Quebec: Éditions du Pélican, pg.24.

${ }^{241}$ Fullerton, D.H. 1978. Ibid., pg.155.

242 Ibid., pg. 124.

${ }^{243}$ Fullerton, D.H. cited in Taylor, J. 1989. Ibid., pg.196.

${ }^{244}$ Fullerton, D.H. 1978. Ibid., pg.157; see also Gordon, D.L.E. 2015. Ibid., pg.272.

245 Ibid., pg. 274.
} 
parliamentary committee to study the governance of the National Capital Region. As one NCC historian observed, "there was a distinct sense of déjà vu about the proceedings." 246 The hearings of the joint-parliamentary committee provided a platform for the municipal, provincial, and, now, regional governments to bemoan the continued existence of the NCC. Notably, the NCC followed its predecessor in not advocating for a federal district. Unlike the 1956 jointparliamentary committee, the 1975-1976 iteration was not "fruitful.",247 That is, the jointcommittee did not release a final report with recommendations leading to new legislation. ${ }^{248}$ Despite the proposals and criticisms, NCC reform was left in abeyance.

Having implemented the Gréber Plan, with the sole exception of the expansion and protection of Gatineau Park, the NCC struggled to find a purpose as it continued to muddle through a tangled jurisdictional swamp. Added to this, the economic recession of the early $1980 \mathrm{~s}$ prompted a Cabinet-directed moratorium on NCC land acquisitions (see Conclusion for the effects of the moratorium on Gatineau Park as the NCC was forced to expropriate residential subdivisions).

Following the election of the Mulroney government, a comprehensive review of federal expenditures was launched. The Nielsen Task Force - named after Deputy Prime Minister Eric Nielsen - saw that the NCC was aimless for "the Gréber Plan has been substantially completed, and the National Capital Commission is an agency in search of a new master plan." ${ }^{249}$ The Nielsen Task Force went on to recognize that the NCC role was less concerned with planning, and more involved with property management, as the Crown corporation owned 48,200 hectares

\footnotetext{
${ }^{246}$ Gyton, G. 1999. Ibid., pg.81.

${ }^{247}$ Fullerton, D.H. 1978. Ibid., pg. 156.

248 The federal government probably suspended the special committee because of the election of the Parti Quebecois. If Quebec's territorial question was a thorny one during negotiations between Liberal federal and Liberal provincial governments, it would have been Parti Quebecois. As the NCC indicated in its annual report: "In November 1976, the province of Quebec elected a government whose policies include fairly radical implications for the capital of Canada." National Capital Commission. 1976. Annual Report. Ottawa: Queen's Printer, pg.9.

249 Task Force on Program Review. 1986. Real Property. Ottawa: Ministry of Supply and Services Canada, pg.250.
} 
$(119,105$ acres $)$, or $10 \%$ of total area of the NCR, with an estimated value of $\$ 350$-million. ${ }^{250}$

The Nielsen Task Force found considerable "overlap and duplication" between the NCC and the capital region's second largest property owner, the Department of Public Works (DPW).

Wanting to reduce the annual $\$ 100$-million NCC budget by $25 \%$, the Task Force recommended merging the architectural, engineering, real estate, and maintenance services of the NCC with the DPW. ${ }^{251}$ While acknowledging that the NCC should remain the federal agency responsible for the planning of the National Capital Region, the Task Force also recommended an in-depth review of the entire NCC property portfolio with the "NCC to transfer ownership of all property that is not central to the NCC mission such as roads, bridges, bicycle paths, to the relevant municipalities." 252 Finally, the Task Force suggested that custody and control of "symbolic" federal properties (i.e., Parliament, the official residences) should be transferred from the DPW to the NCC (and this was carried out in the summer of 1986). While the Task Force elicited, according to one insider, "general paranoia" within the NCC, ${ }^{253}$ "the results," as NCC historian Gyton has observed, "were generally positive for the NCC.",254

Under Chairmwoman Jean Pigott, the NCC adopted "a new mandate ... which contains three basic principles 1) Making the Capital Canada's Meeting Place; 2) Using the Capital to Communicate Canada to Canadians; and 3) Safeguarding and Preserving the Capital for future generations." ${ }^{255}$ Although the merger with DPW was never carried out, the in-depth review of the property portfolio was undertaken, leading to the designation of certain lands as National Interest

\footnotetext{
${ }^{250}$ Ibid.

251 Ibid., pg.52.

252 Ibid., pg.262.

253 Jones, L.M. 1987. The Role and Rationale of the National Capital Commission: A Critical Analysis. Ottawa: Carleton University (unpublished Honours thesis), pg.25

${ }^{254}$ Gyton, G. 1999. A Place for Canadians: The Story of the National Capital Commission. Ottawa: National Capital Commission, pg.94.

${ }^{255}$ National Capital Commission. 1988, Jan. Plan for Canada's Capital: A Federal Land Use Plan. Ottawa: NCC, pg.i.
} 
Land Mass (NILM). As Gyton explains, "[t]he idea was that non-NILM lands (expensive to own and irrelevant to any real "Capital" purpose) could be disposed of without damaging the NCC's ability to build a great Capital for Canadians. ${ }^{256}$ Ottawa's Greenbelt and Gatineau Park were classified as NILM, requiring the NCC to protect them "on behalf of all Canadians." ${ }^{257}$ As the NCC explained, NILM classification “meant, firstly, to keep NILM lands already in NCC ownership and acquire and consolidate non-federal lands identified as part of the NILM."258 When the Treasury Board approved NILM designation, it also lifted the moratorium on NCC land acquisitions so that it could consolidate ownership of Gatineau Park. ${ }^{259}$ Despite NILM status, the NCC, under Chairman Marcel Beaudry, conducted the Gatineau Park Boundary Rationalization Exercise in the mid-1990s which severed land from the park's territory, whilst claiming to add Meech Creek Valley (but the NCC never obtain a new Order-in-Council such that the 1960 boundaries are, technically, the only ones in recognized in law).

In 2006, the newly-elected government of Stephen Harper commissioned an expert panel to review the NCC mandate. The Mandate Review panel's report diagnosed several problems with the NCC such as "undue secrecy and lack of transparency" and "the sale of public assets in response to financial pressures created by underfunding." 260 The Mandate Review did not propose remedies to the problems arising from the national capital's “overlapping levels of government and intermingled jurisdictions. ${ }^{261}$ Moreover, the Harper government's attempts to amend the National Capital Act on the basis of the Mandate Review ultimately proved unsuccessful. Thus, the NCC continues to pursue the "symbolic" mandate it adopted in the mid-

\footnotetext{
${ }^{256}$ Gyton, G. 1999. Ibid., pg.94.

${ }^{257}$ National Capital Commission. 1988, Jan. Ibid., pg.iii.

${ }^{258}$ National Capital Commission. 2006, Sept. About National Capital Commission Lands. Ottawa: NCC, pg.4.

${ }^{259}$ Gatineau Park Task Force. 1989, May. Acquisition Plan: Gatineau Park Private Properties. Ottawa: NCC. Document obtained from Jean-Paul Murray.

${ }^{260}$ Paquet, G. Farber, B.L., and Benoit, G. 2006, Dec. The National Capital Commission: Charting a new course. Ottawa: NCC Mandate Review, pg.5.

261 Ibid., pg.9.
} 
1980s. Professor Gilles Paquet, Chairman of the Mandate Review, warned that the NCC has become a "timid operator." ${ }^{262}$ While recognizing that a federal district is the best solution for capital planning, Professor Paquet concedes that it is unfeasible given Quebec's concern with protecting its territorial integrity. He recently wrote: "They [provincial authorities] want no federal encroachment on their territory one inch." ${ }^{263}$ But the federal government has encroached on Quebec's territorial integrity - at least $361 \mathrm{~km}^{2}$ of it! Chapter 3 describes how the Mackenzie King government successfully evaded the "territorial question" when establishing the Park.

\section{Conclusion}

At the time of Confederation, the federal government was not envisioned as territorial controller, not even in the federal capital of Ottawa. Section 91(1A) authorizes the federal government to legislate for the public property. Even though "property" is defined broadly in Section 91(1A), the legislation provides the federal government with only a proprietary right, meaning the loss of property results in a loss of jurisdiction. This chapter has described two contrasting responses to this limited constitutional authority in the territorialization of Canada's national parks and national capital.

As shown in the first section, the federal government must ensure that it has full title to all lands within the national parks. This policy, deemed by one constitutional scholar as “eminently sensible," has complicated federal-provincial negotiations when establishing national parks; historically, the provinces have been expected to extinguish third party interests and transfer resources. When Gatineau Park was established in 1938, two national parks had been established through provincial land acquisition programs involving purchase and expropriation

\footnotetext{
${ }^{262}$ Cited in Adam, M. 2012, Jan. 3. "“Timid' NCC could become irrelevant, scholar warns." Ottawa Citizen.

263 Paquet cited in Ibid.
} 
of privately-owned lands. As historian MacEachern has documented, the expropriations for the Maritime national parks created during the Great Depression met with relatively little resistance.

The precedent had been set; ultimately, it would not be followed in the creation of, and land acquisition for, Gatineau Park. Of course, the crucial question is why, especially since the Dominion Parks Branch, as early as 1913, identified the Gatineau Hills as suitable area for national park status, an area possessing qualities - wildlife, Canadian landscapes, aesthetic beauty, etc. - worthy of being a national park and, by implication, a protected territory. Part of the answer of why Gatineau Park never became a national park rests with the protection of Quebec's territorial integrity by the provincial government. But "Gatineau Park" was established without the consent, let alone co-operation, of provincial authorities. The creation of Gatineau Park represents the successful exercise of federal territoriality around the Quebec government. To rectify this injustice, a federal-provincial agreement should be negotiated, especially as the $\mathrm{NCC}$, for whatever reason, continues to create confusion over the ownership of provincial Crown lands in the park's northwest sector near La Pêche Lake.

National parks constitute one extreme of federal territoriality, where jurisdiction and control are consolidated through complete federal ownership of national park territories. Though national parks are not federal enclaves within the provinces, the verticality of these territories is compressed through the elimination of privately-owned land and provincial Crown lands. The opposite is the case in Canada's National Capital Region, where the federal government has refrained from asserting territoriality. The Fathers of Confederation had the long-established precedent of a federal district in Washington D.C. to turn to, but the Constitution Act does not address the role of the federal government vis-à-vis Canada's national capital. As detailed in the second section, numerous conflicts arose between municipal and federal governments over 
compensation for municipal services and lost tax revenues from the expanding federal presence. There were repeated calls for a federal district in Ottawa, but the response of the federal government was to establish a comparatively weak Ottawa Improvement Commission, which began acquiring lands towards the capital's "beautification."

Apart from an expanded area of operation, budget, and staff, the NCC is not substantively different from its institutional predecessors. Several joint-parliamentary committees and proposed legislation have not significantly altered the position of the federal government for, simply put, it does not have a territory to govern. As this Chapter has indicated, the capital's territory has never been sorted out. Meanwhile, with the addition of new levels of government, planning in the "jurisdictional swamp" has become more complicated - indeed, treacherous. Over time, the possibility of a federal district has become more remote, largely due to Quebec's "territorial question," which, as the chapters that follow suggest, was violated through the establishment and enlargement of Gatineau Park. The next chapter shows that the park was not the outcome of earlier proposals for a national park in the Gatineau Hills. Rather, the creation of Gatineau Park was the territorial expression of cottagers' interests, those living in the Kingsmere-Meech Lake privatopia. 


\section{Chapter 2: From Algonquin hunting territory to Ottawa's recreation territory}

Here is the classic example of the hinterland being overshadowed by the metropolis. $^{264}$

\section{Introduction}

Although there are several monographs that provide comprehensive histories of Canada's national capital, there has yet to be a comprehensive history of Gatineau Park. In the former, the park receives only a passing mention, sometimes addressing the main events - the formation of the Federal Woodlands Preservation League, the 1935 Lower Gatineau Woodlands Survey Report by the Department of Interior prepared at the League's request, and further pressure from the League on the federal government - which led to its establishment in 1938 when Parliament approved $\$ 100,000$ for the initial land acquisitions. ${ }^{265}$ The few historical studies on Gatineau Park have similarly focused their attention on its early formative period. ${ }^{266}$ A standard narrative has since emerged that "[ $\mathrm{t}]$ he Federal Woodlands Preservation League was born out of the concerted efforts of the Ottawa Ski Club, among others. ${ }^{267}$ As noted in the introduction, previous accounts of the park's early history have neglected to mention the role and influence of the property owner associations at Meech and Kingsmere Lakes. ${ }^{268}$ It is as if these groups do not exist, and "park residents" would probably like it to remain this way.

\footnotetext{
${ }^{264}$ Creelman, J. 1978. Man and the land: A short history of Gatineau Park. Ottawa: National Capital Commission, pg. 1.

${ }^{265}$ Eggleston, W. 1961. Ibid., pg.271; Gordon, D.LA. 2015. Ibid., pg.180; Gyton, G. 1999. Ibid., pg.42.

${ }^{266}$ Historian Lanzon also recognized that "[ $\left.\mathrm{t}\right]$ here is a dearth of literature on Gatineau Park...” Lanzon, Q. 2014.

Ibid., pg.4.

${ }^{267}$ Emphasis added. Fletcher, K. 2004. Historical Walks: The Gatineau Park Story, 3rd Edition. Markham, ON: Fitzhenry \& Whiteside Limited, pg.61.

${ }^{268}$ I refer to the following: Fletcher, K. 2004. Ibid.; Apostle, A. 1997. Ibid.; Gagnon, S., Filion, M., and Tessier, C. 2004. Ibid. Citing much of this literature, Lanzon perpetuated this explanation in his MA thesis. He wrote: "In 1934, the OSC efforts led to the creation of a Federal Woodlands Preservation League." Lanzon, Q. 2014. Ibid., pg.48.
} 
This chapter shows that the Meech Lake Association was the driving force behind the establishment of the FWPL, which was, in turn, instrumental in pressuring the government to prevent the "denudation" (i.e., clear-cutting) of the forested hillsides adjacent to Ottawa. Whereas previous plans and proposals for the capital had called for a national park in the Gatineau Hills, the League did not advocate for this option, as it implied the elimination of privately-owned lands at Kingsmere and Meech Lakes. Nevertheless, as documented below, the newspaper reading public was repeatedly told that the national capital was going to get a national park and, as shown in the next chapter, the first expropriations were carried out under this pretense. "Gatineau Park" was - and still is - a failed national park, promoted in the public/national interest but directly benefitting private/local residents at Kingsmere and Meech Lakes. The park was integral to their privatopia as it, ironically, eliminated private ownership and exploitation of the forested hillsides. The park's creation was an exercise in territoriality that involved behind-the-scenes negotiations with the federal government to ensure that it was not made into a national park.

Park residents are not the only people that the existing historical scholarship on Gatineau Park ignores. While the property owner associations, in response to proposals for the park's public ownership, often invoke the fact that the cottage communities at Kingsmere and Meech Lakes predate the creation of Gatineau Park, it is situated on unceded Algonquin territory. Through the lens of territoriality, this chapter begins by addressing the colonization of the Algonquin by white settlers in the 1800s. This involved, among other things, the institution of private property.

The second section traces the changing human geography of the Gatineau Hills which, for almost half a century, were exploited for agricultural and industrial purposes. Following the 
decision to make Ottawa into the capital, the forested hillsides became a countryside retreat for politicians and civil servants seeking a summer escape from lumbertown Ottawa. In the 1920s, cottagers established the Kingsmere Property Owners' Association and Meech Lake Association to beautify and improve their communities. In addition to pursuing benign ends, the KPOA and MLA functioned as private local governments that sought to maintain privacy, class exclusivity, and racial homogeneity of the cottage communities.

The third section traces the role of the MLA in the formation of the FWPL and its first lobbying efforts for federal government intervention on the Gatineau Hills “denudation issue." The League's first achievement was to have the federal government survey the forest cover of the area to determine the extent of clear cutting. The fourth section recounts the events following the re-election of Prime Minister Mackenzie King in 1935. The NCC-commissioned study concluded that this "was not a 'creation' in the strictest sense, for which we can provide the date of founding and the name of the founder, whether an individual or a group..."269 However, my account shows that Parliament approved funds for land acquisition on 1 July 1938. And this vote came in response to the mounting pressures of the FWPL on the Mackenzie King government, especially from the League President, Roderick Percy Sparks, who lived on a year-round basis in his home off Meech Lake Road. Sparks is widely credited as the park's "founding father."270 Unlike other cottagers-turned-park residents, Sparks came to view privately-owned lands within Gatineau Park as inimical to the park's public purposes. Chapters 3 and 4 document Sparks' role in the park's planning and development as Chairman of the Advisory Committee on Gatineau Park. Ultimately, Sparks was unsuccessful in convincing the Federal District Commission to

\footnotetext{
${ }^{269}$ Gagnon, S., Filion, M., and Tessier, C. 2004. Ibid., pg.24.

${ }^{270}$ Murray, J.P. 2003. “Roderick Percy Sparks: Gatineau Park's Forgotten Founder.” Up the Gatineau!, Vol. 30: 1216.
} 
manage Gatineau Park as if it were a national park, so that it would exercise territoriality over all the park's residents.

\section{Colonization of Algonquin territory}

Since 600 A.D., the Anishnabek or Algonkin nation, later called "Algonquin" by French and British settlers, inhabited the entire Ottawa River watershed. ${ }^{271}$ Prior to European contact, the Algonquin were semi-nomadic hunters who periodically engaged in subsistence agriculture.

They were also animists who "believed that everything surrounding them - or almost everything - possessed a soul: water, earth, animals, thunder and even fabricated objects. Accordingly, they placed great importance on maintaining harmonious relations with the forces of nature..."272

Thus, unlike European invaders, the Algonquin did not see nature as something that could be owned or possessed by an individual. ${ }^{273}$ Rather, they were similar to many Indigenous people in North America, having their own legal order, one that was "rooted in place and in the ontologies of care (or, as Leanne Simpson calls the basis of Indigenous nationhood, 'ecologies of intimacy').",274

The Algonquin exercised territoriality in the form of patrilineal family hunting territories.

At the onset of British rule in 1760, a soldier recounted:

These [Algonquin] Indians had left their village before the surrender of Montreal, and I was the first Englishman they had seen. In conversation with my men, I learned that the Algonquins of the Lake des Deux Montagnes claim all the lands on the Outaouais, as far as Lake Nipisingue; and that these lands are subdivided,

\footnotetext{
${ }^{271}$ Cellard, A. 1997. "Kichesippi: the Great River of the Algonquins (1600-1650).” In Gaffield, C., ed., History of the Outaouais. Quebec: University of Laval Press, pg.69.

272 Ibid., pg. 77.

${ }^{273}$ Evans, P.M.O. 1988. A Tale of Two Chelseas. Ottawa: Les Editions J. Oscar Lemieux, pg.3.

${ }^{274}$ Pasternak, S. 2014. "Jurisdiction and Settler Colonialism: Where Do Laws Meet?" Canadian Journal of Law and Society, 29(2): 145-161, pg.160.
} 
between their several families, upon whom they have devolved by inheritance. I was also informed that they are exceedingly strict as to the rights of property. ${ }^{275}$

The boundaries of the family hunting territories were delimited by geographic features such as rivers, lakes, swamps, forests, etc. ${ }^{276}$ Family hunting territories were fixed for generations, and, as families grew, further territorial subdivisions were carried out. ${ }^{277}$ This reflects Sack's point about the tendency of territoriality towards multiplication. ${ }^{278}$ The territorial configuration of the Algonquin helped regulate the supply of game, as families kept an account of the animal resources within their respective territories. ${ }^{279}$ Whenever the game was depleted in a territory, the family would have to obtain permission to temporarily hunt in the adjacent territories. ${ }^{280}$ Trespassing to hunt in another family hunting territory was strictly forbidden (there was still freedom of movement among Algonquin families). The punishment for trespass, according to Speck, a Canadian state official carrying out ethnographic research on the Algonquin in the early twentieth century, was meted out by an elder from the victim family, which typically involved conjuring against their health, but occasionally resulted in death. ${ }^{281}$

Territoriality was thus central to the organization of Algonquin social relations, as it shaped interactions among families and regulated their access to game. Following Sack's analytic grid, Algonquin territoriality is an example of "the social definition of territory."282 Familial relations defined and enforced the boundaries of hunting territories. This is worth noting

\footnotetext{
${ }^{275}$ Alexander Henry cited in Cellard, A., and Pelletier, G. 1997. “The Ottawa River: 1650-1792.” In Gaffield, C., ed., History of the Outaouais. Quebec: University of Laval Press, pg.88.

${ }^{276}$ Speck, F.G. 1915. "Family Hunting Territories and Social Life of Various Algonkian Bands of the Ottawa Valley." Geological Survey Memoir, 70(8). Ottawa: Government Printing Bureau, pg.4.

277 Ibid., pg.5.

278 Sack, R.D. 1986. Ibid., pg.34.

${ }^{279}$ Speck, F.G. 1915. Ibid., pg.5.

${ }^{280}$ Ibid.

${ }^{281}$ Ibid., pg.4.

282 Sack, R.D. 1986. Ibid., pg.37.
} 
as white settlers later imposed "a territorial definition of social relations."283 Property ownership became the basis to making claims over a particular geographic area, and all property owners had the same legally enforceable rights. Settler and Algonquin territorialities were diametrically opposed. As shown below, the Algonquin knew that it was imperative to have their land ownership recognized by the colonial government, which "inaugurated" a legal order that envisioned jurisdiction space as a, and proceeded from the doctrine of discovery for so-called "uninhabited lands." 284 Not coincidentally, it was Philemon Wright, the first loyalist settler, who "discovered" the virgin pine forests of the Ottawa River Valley, and who invoked title not only to claim ownership but also to harvest the rich timber resources.

Before turning to the emergence of settler colonialism, it is important to note that the Algonquin occupation of the Ottawa River watershed was interrupted for over half a century following their defeat in the Iroquois Wars of the late 1640s. ${ }^{285}$ Having retreated to the French missions, the Algonquin population was further devastated by disease and alcoholism. ${ }^{286}$ It was during this period when the Ottawas nation - after whom the river and city are named - engaged in the French fur trade along the Ottawa River. ${ }^{287}$ Following the British conquest of New France, many Algonquin families returned to their traditional hunting grounds. ${ }^{288}$

In 1763, the British Crown issued a Royal Proclamation in response to the Pontiac's War, which was triggered by the British following their victory in the Seven Years War with France. King George III's explicit intention was to define jurisdictions and territorial boundaries between First Nations and the Crown. The 1763 Proclamation reinforces the integrity of Algonquin

\footnotetext{
283 Ibid.

${ }^{284}$ Pasternak, S. 2014. Ibid., pg. 160.

${ }^{285}$ Hessel, P. 1993. The Algonkins of the Ottawa Valley: An Historical Outline. Arnprior, ON: Kichesippi Books, pg. 68 .

${ }^{286}$ Ibid., pgs.63-67.

${ }^{287}$ Ibid., pg.62.

${ }^{288}$ Ibid., pg.68.
} 
territory by reserving all unceded lands from white settlement. ${ }^{289}$ However, Shiri Pasternak, an Algonquin scholar, argues that the Royal Proclamation embedded the racist and imperialist doctrine of “discovery,” which declared British North America “our Dominions, and Territories." 290 The doctrine of discovery had a direct impact on the semi-nomadic Algonquin because the British regarded all uninhabited lands as terra nullius, such that "already inhabited nations [like the Algonquin] were simply legally deemed to be uninhabited if the people were not Christian, not agricultural, not commercial, not "sufficiently evolved' or simply in the way."291 Pasternak notes the Proclamation was not only the advent of "Indian owned" land but made it illegal for Indigenous people to sell lands to third parties unless it was first ceded to the Crown; when considered overall, the 1763 Proclamation was a significant step in the consolidation of the British common law system, which recognized the legitimacy of only one source of authority over the land. ${ }^{292}$ In response to the Proclamation, some 2,000 Indigenous chiefs met with colonial officials, and they concluded the Treaty of Niagara of 1764 which, according to Pasternak, "reflected the deeper, mutual, and diplomatic commitments made between the Crown and Indigenous nations." ${ }^{293}$ It was in the context of ongoing nation-to-nation negotiations that, in July 1772, the Algonquin formally submitted their claim to the entire Ottawa River watershed to the Crown. They reserved a 3,439,827 hectare area (8.5 million acres), and indicated to the Government of Quebec that they were prepared to use force, if necessary, to remove settlers from their territory. Then, in 1773, the British Crown issued another Royal Proclamation, signed by Sir Guy Carleton, which reads that aboriginals "shall not, under any pretense whatever, be

\footnotetext{
289 Ibid., pg.69

${ }^{290}$ Pasternak, S. 2014. Ibid., pg.160.

${ }^{291}$ Culhane, D. 1998. The Pleasure of the Crown: Anthropology, Law and First Nations. Vancouver: Talon Books, pg.48.

${ }^{292}$ Pasternak, S. 2014. Ibid., pg. 156.

${ }^{293}$ Ibid., pg. 157.
} 
deprived of the lands claimed..."294 Even if colonial officials had yet to formally acknowledge Algonquin claims, it may have appeared that the British Crown was going to respect their territorial possessions.

Nation-to-nation relations between the British Crown and Algonquin were quickly undermined following the Constitutional Act of 1791, which divided Quebec into two provinces, Upper and Lower Canada (respectively, Ontario and Quebec). In 1792, the administrator of Lower Canada, Alured Clarke, proclaimed all lands along the United States border as open to settlement by Americans willing to take an oath of allegiance to the British Crown. ${ }^{295}$ And, following two reconnaissance expeditions to the Ottawa River valley, Philemon Wright, a successful farmer from Massachusetts, led his and four other families to establish Hull in 1800 (see Figure 2.1). Although Wright fought with the revolutionaries during the American War of Independence, he pledged allegiance to the British Crown and received, in turn, land and timber rights along the Ottawa River from the Government of Lower Canada. ${ }^{296}$ Wright's ambition was to create a self-sufficient agrarian community of "independent farmers," but, as pointed out by historian Bruce Elliott, "these aims were abandoned by the residents so they could make a living.,"297 That is, although Wright was not initially interested in exploiting the timber of the Ottawa River and Gatineau River valleys, Hull's founding father “is usually credited with launching single-handedly the region's development in the forest economy."298

As recounted by historian Chad Gaffield, the Algonquin immediately recognized Wright's settlement as a threat to their territorial integrity, and two chiefs met with him in

\footnotetext{
${ }^{294}$ Hessel, P. 1993. Ibid., pg. 69; see also Cellard, A., and Pelletier, G. 1997. Ibid., pgs.88-89.

${ }^{295}$ Elliott, B.S. 1979. “"'The Famous Township of Hull”: Image and Aspirations of a Pioneer Quebec Community." Histoire Sociale/Social History, 12(24): 339-367, pg.341.

296 Ibid.

297 Ibid., pg.339.

${ }^{298}$ Gaffield, C. 1997a. "Land, Family, and the Origins of Colonization.” In Gaffield, C., ed., History of the Outaouais. Quebec: University of Laval Press, pg. 121.
} 
Wrightsville. The chiefs insisted that the Algonquin had been "in the peaceable and quiet possession of these lands for generations past." ${ }^{299}$ They complained that the ongoing forest cutting and clearing was driving away their game, and questioned the authority under which Wright was "cutting down their wood and taking possession of their land." ${ }^{300}$ Wright responded that the Government of Lower Canada had given him title to the lands. But the Algonquin did not recognize Wright's ownership claim, and rented islands on the Ottawa River to white settlers on 99-year leases - much to Wright's consternation. ${ }^{301}$ Nevertheless, to maintain good relations with the Algonquin chiefs, Wright paid them \$30, and subsequently gave them tribute on an annual basis. ${ }^{302}$ There is evidence that Wright's efforts were somewhat successful for he became known among the Algonquin as "the white chief." 303 As Algonquin scholar Paula Sherman points out, such gifts were not bribes, as settlers like Wright saw them, but were "diplomatic protocols" significant in the conduct of nation-to-nation dialogue. ${ }^{304}$

With the expansion of settlement in the Ottawa River valley, Algonquin leaders continued to lodge protests with colonial administrators against illegitimate white settlement and re-assert territoriality over the watershed. ${ }^{305}$ The colonial government continued to ignore them. To make matters worse, in 1822, the Missisaugas and Chippewas surrendered Algonquin territory in Upper Canada with the Williams Treaty; colonial officials negotiating the treaty were informed that these bands did not have the authority to surrender another First Nation's

\footnotetext{
${ }^{299}$ Ibid., pg. 124

300 Ibid.

${ }^{301}$ Gaffield, C. 1997b. “A Territory Transformed 1791-1886.” In Gaffield, C., ed., History of the Outaouais. Quebec: University of Laval Press, pg. 146.

${ }^{302}$ Gaffield, C. 1997a. Ibid., pg.124; see also Hughson, J.W. and Bond, C.J. 1987. Hurling Down the Pine. $3^{\text {rd }}$ edition. Chelsea, Quebec: The Historical Society of the Gatineau, pg.4.

${ }^{303}$ Evans, P.M.O. 1988. Ibid., pg.3.

${ }^{304}$ Sherman, P. 1998. "Review of Elusive Empires: Constructing Colonialism in the Ohio Valley, $1673-1800$ by Eric Hinderaker." American Indian Quarterly, 22(4): 547-548, pg.547.

${ }^{305}$ Gaffield, C. 1997b. Ibid., pg.146.
} 
territory. ${ }^{306}$ Historian Peter Hessel has found an 1837 Order-in-Council that acknowledged the presence of the Algonquin "and their claim to a vast territory, although it denied them the right to grant land leases or to sell land they owned."307

Figure 2.1: Map of Hull County (1810)

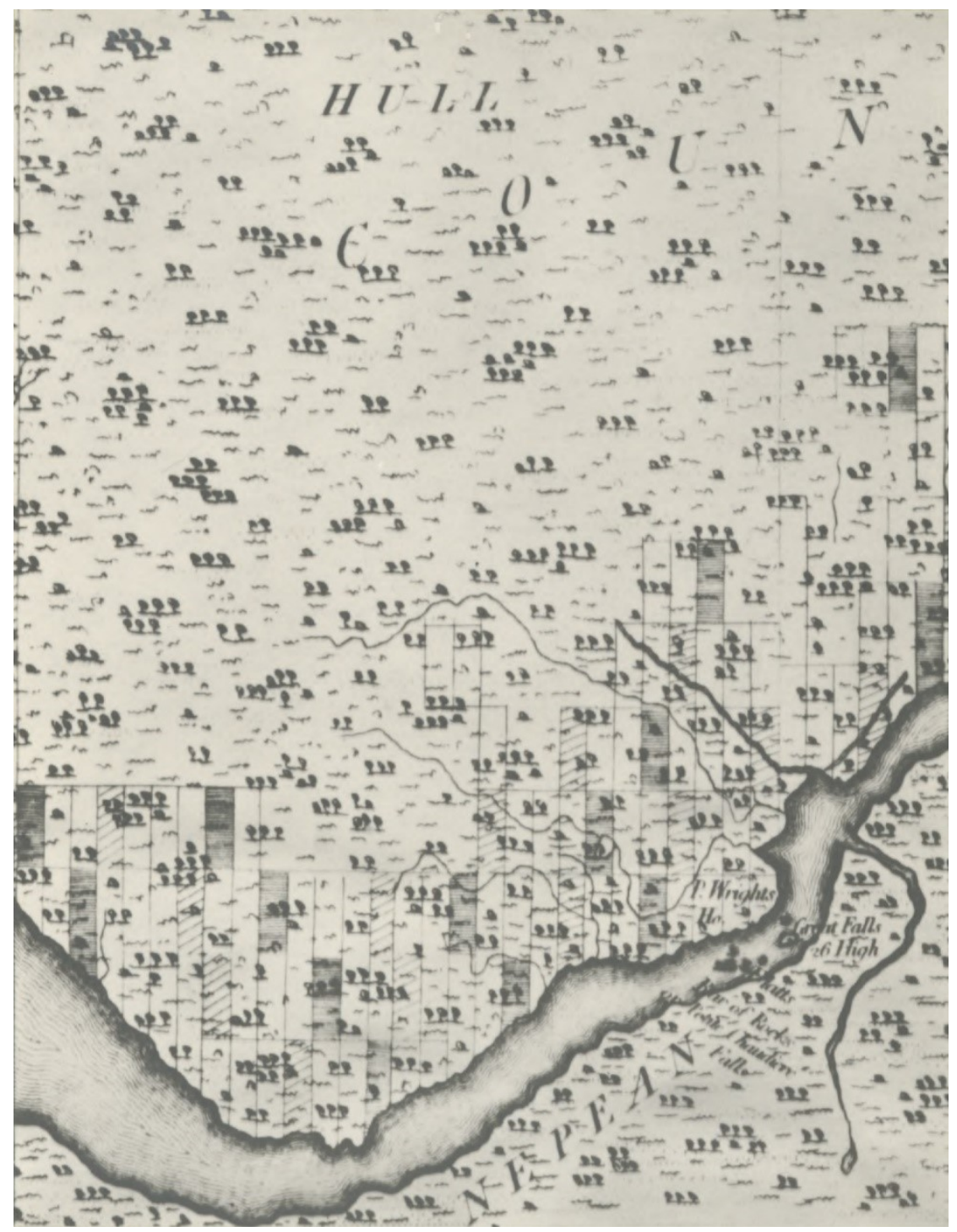

Source: MG26 J10 Vol.25

Beyond this limited recognition, however, the colonial government did not act on the territorial claims of the Algonquin. So, the Algonquin, rather than continuing this futile exercise

\footnotetext{
${ }^{306}$ Hessel, P. 1993. Ibid., pg.69; see also Hodgins, B.W. and Cannon, K.A. 1997. Ibid., pg.57.

${ }^{307}$ Hessel, P. 1993. Ibid., pg.70.
} 
of territoriality over an increasingly settled area, petitioned colonial authorities for compensation. In the Act of Union of 1840, however, the newly-established Provincial Government abdicated any responsibility for the Algonquin. ${ }^{308}$ As was the case with the French during the fur trade, the colonial government simply "forgot the Algonquins."309 It not only ignored the Algonquin territory and their demands for compensation, but it also systematically erased their presence. Indeed, "[i]n the first comprehensive census, taken in 1852, only five Algonquins were listed despite the actual presence of perhaps several thousand in the region." 310 And yet, in 1857, a Crown Lands Agent forwarded the petition of five Algonquin families - the Agent referring to them as "squatters" - to the government which requested that it set aside 632 hectares $(1,561$ acres) near Golden Lake, Ontario for a reserve, one which remains to this day. ${ }^{311}$ Hessel underscores the irony of the creation of this Algonquin reserve: "Thus, after an absence of about 200 years, the descendants of the Kichesippirini, Weskarini and other Algonkin bands returned to the Ottawa Valley officially, as 'beneficiaries of grants." 312

With the exception of historian June Creelman, previous studies of Gatineau Park overlook the fact that the park is situated on unceded and unsurrendered Algonquin territory. Creelman notes that, while game was abundant in the Gatineau Hills, the Algonquin probably did not carry out much hunting there. She explains that "[ $\mathrm{t}]$ his is likely due to the fact that the park is fairly inaccessible both by land and water." 313 The National Capital Commission (NCC), in its 2012-2013 Annual Report, indicated that it would "develop a study on indigenous heritage associated with the park." ${ }^{314}$ Further, the NCC wanted to "[i]ntegrate Algonquin First Nation

\footnotetext{
308 Ibid., pg. 71.

${ }^{309}$ Cellard, A., and Pelletier, G. 1997. Ibid., pg. 89.

${ }^{310}$ Gaffield, C. 1997b. Ibid., pg. 108.

${ }^{311}$ Hessel, P. 1993. Ibid., pg.85; see also Hodgins, B.W. and Cannon, K.A. 1997. Ibid., pg.57.

${ }^{312}$ Hessel, P. 1993. Ibid., pg.85.

${ }^{313}$ Creelman, J. 1978. Ibid, pg. 6.

${ }^{314}$ National Capital Commission. 2012-2013. Annual Report. Ottawa: NCC, pg.38.
} 
participation through the development of a process for identifying cultural resources important to the presence of Anishinabe in the land that is now Gatineau Park." 315 While the heritage study is listed among "upcoming plans,"316 the NCC has already made some changes as Wolf Trail has been re-named "Mahingan" (Algonkin for wolf), and a birch-bark canoe with explanatory notes has been placed in the Sparks Hall at the Gatineau Park visitor centre in Old Chelsea.

Meanwhile, for their part, the Algonquin have recently re-asserted their territoriality over the Ottawa River watershed, and have entered into negotiations with the provincial governments for compensation. ${ }^{317}$ Clearly, in the context of the recent report of the Truth and Reconciliation Commission, ${ }^{318}$ and the ongoing nation-to-nation treaty negotiations which could see large swaths of land in the National Capital Region returned to Algonquin First Nations, any future discussions concerning the reconfiguration of Gatineau Park must not only include, but also obtain the consent of, the Algonquin people. It would be interesting to know what they think of this failed national park and the privatopia within it, where public use is discouraged and, to a certain extent, prohibited. Algonquin scholar Shiri Pasternak would enjoin "us" - the Canadian public interested in the park's future - to "flip the colonial terms of recognition that currently condition settler sovereignty in Canada." 319 This would necessitate seeing that there is more than one legal order that could define and regulate the park territory.

\footnotetext{
${ }^{315}$ National Capital Commission. 2012. Cultural Heritage Plan: Public Consultation. Ottawa: NCC, pg.31.

316 National Capital Commission. 2017. “Gatineau Park Master Plan.” Available at http://www.nccccn.gc.ca/planning/master-plans/gatineau-park-master-plan. Last accessed 24 January 2017.

317 Tasker, J.P. 2016, Oct. 18. "Historic land deal with Algonquin peoples signed by federal, Ontario governments." CBC News. Available at http://www.cbc.ca/newspolitics/ottawa-ontario-algonquin-agreement-in-principle1.3809876. Last accessed 19 October 2016; Johnstone, H. 2016, Dec. 8. "Quebec Algonquins file title claim to downtown Ottawa." CBC News. Available at http://www.cbc.ca/news/canada/ottawa/quebec-algonquins-title-claimottawa-1.3888427. Last accessed 24 January 2017.

318 The final report of the Truth and Reconciliation Commission of Canada is available here: http://www.trc.ca/websites/trcinstitution/index.php?p=890. Last accessed 18 May 2017.

${ }^{319}$ Pasternak, S. 2014. Ibid., pg.160.
} 


\section{The Gatineau Hills privatopia}

In 1806, the Government of Lower Canada completed the township surveys of both Hull and Eardley Townships, which were parceled into 81-hectare (200-acres) rectangles (see Figure 2.2). Beginning in the 1820s, American, Irish, and Scottish immigrants began settling in the Gatineau Hills (the first French Canadian settler, Ovide Bélanger, established Ste-Cécile-de-Masham in $1837,{ }^{320}$ but most Francophones arrived in the Gatineau Hills after the mid-1850s). ${ }^{321}$ One of the first settlers in the Gatineau Hills was an American, Reverend Asa Meech, after whom the lake adjacent to his lands was named. Similarly, Kingsmere Lake was once known as Jeffs Lake after the first settler who lived there. Harrington Lake was the misspelled name used by Anglophones after the first family, the Hetheringtons, who lived and farmed by the lake, but Francophones insist that the lake is named after the Mousseau family. ${ }^{322}$ Philemon Wright, in his capacity as Crown Lands Agent for the Government of Lower Canada, was responsible for issuing land grants. Like Wright, the first settlers in the Gatineau Hills intended to establish themselves as independent farmers. Thus, land grants required the settler, within a certain time limit, to build a residence and clear trees from a minimum area in preparation for the farming of cash crops. ${ }^{323}$ But the rocky and thin soils of the Gatineau Hills, which Wright was well aware of, ${ }^{324}$ made basic subsistence farming difficult. This situation prompted many families, such as the Hetheringtons and Mousseaus, to abandon farming around the turn of the century. ${ }^{325}$

\footnotetext{
${ }^{320}$ Creelman, J. 1978. Ibid., pg.8.

${ }^{321}$ Parson, H.E. 1975. "The Rise and Fall of Farming in a Marginal Area: The Gatineau Valley, Quebec." Cahiers de géographie du Québec, 19(48): 573-582, pg.576.

322 Lait, M. 2016. "A lake with two names: The Harrington Lake (Lac Mousseau) Toponymy Controversy." Up the Gatineau!, 42: 39-52; see also Redford, M. "The Hetherington Farm.” Up the Gatineau!, 19: 31-35.

${ }^{323}$ Evans, P.M.O. 1988. Ibid., pg.3.

${ }^{324}$ Describing the Gatineau Hills, Wright wrote: "the country is very mountainous, rocky and broken and in general unfit for the purposes of agriculture." Cited in Parson, H.E. 1975. Ibid, pg.575.

${ }^{325}$ Creelman, 1978. Ibid., pg.9; see also Thomson, S.C. 1965. Recollections of Early Days in the Gatineau Hills, Part II. Ottawa: Unpublished document, pg.178.
} 


\section{Figure 2.2: Map of Meech Lake settlers}

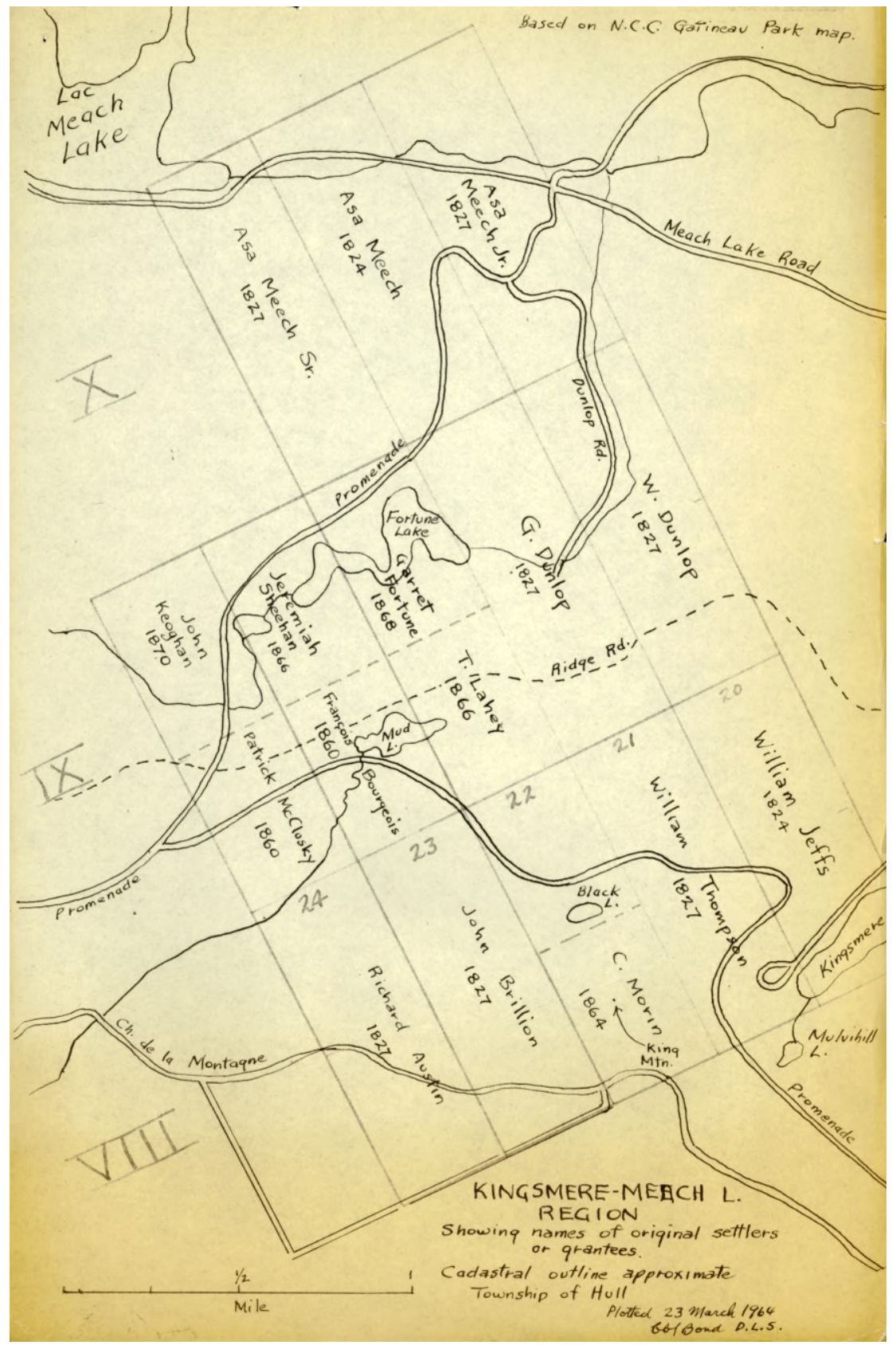

Source: ATI 2014-0607 280.22 PT2 Vol.39.

Economically, the Gatineau Hills were more significant for their timber and mining resources ${ }^{326}$ The lumber industry did not penetrate deeply into the current park area; there were sawmills at Meech, Harrington, and La Pêche Lakes, but these operated on a cottage industry

\footnotetext{
${ }^{326}$ On the latter, see Graham, S. 2009. "The Mines of Gatineau Park.” The Gatineau Park Chronicle. Ottawa: NCC.
} 
scale, mainly to supply the needs of local residents. ${ }^{327}$ The export-oriented forest economy was concentrated along the Gatineau River, where logs were easily transported. ${ }^{328}$ The towns of Chelsea and Wakefield developed as stopping points for lumbermen travelling by horseback. ${ }^{329}$

Shortly following Confederation in 1868, the Gatineau Hills took on a new role as a summer retreat for politicians and civil servants from Ottawa. According to Dominion Archivist, Gustave Lanctôt, the 1870s marked a "new era" for the Gatineau Hills with the arrival of the summer cottagers who purchased land and built cottages. ${ }^{330}$ Those of more moderate financial means "summered" at one of the hotels in Chelsea or at the boarding homes on Kingsmere and Meech Lakes. ${ }^{331}$ Between 1870 and 1872, William James Tilley, a public servant in the Department of Railways and Canals, built the first cottage at Meech Lake. Through the purchase of two additional farms, Tilley eventually expanded his Meech Lake estate to 140 acres. ${ }^{332} \mathrm{He}$ came to have such a close association with the lake that he was buried there (but his remains were later exhumed by his family). ${ }^{333}$

In 1875, Colonel John Stoughton Denis, a deputy minister in the Department of Interior, became the first cottager at Kingsmere Lake (then known as Jeffs Lake). ${ }^{334}$ Shortly following this, Sir John Bourniot, chief clerk of the House of Commons, purchased the Jeffs farm house

\footnotetext{
${ }^{327}$ Messier, D. 2009. “Gatineau Hills Forest Industry 1800 to 1938: Myth or reality?” The Gatineau Park Chronicle. Ottawa: NCC, pgs.2-3.

${ }^{328}$ For the history of lumber industry on the Gatineau River, see Hughson, J.W. and Bond, C.J. 1987. Ibid.

${ }^{329}$ Evans, P.M.O. 1988. Ibid., pg.21.

${ }^{330}$ Lanctôt, G. 1936. Kingsmere in Chronology. Ottawa: Dominion Archives of Canada, pg.2.

${ }^{331}$ Mahoney, E. 1999. "Summer Hotels of the Gatineau." Up the Gatineau!, Vol.25. Available at: http://www.gvhs.ca/publications/utga-summer-hotels.html. Last accessed 5 July 2016.

332 Fletcher, K. 2004. Ibid., pg.44; Martin, J.C.G. 1999. 'In Memory Of' Chelsea's Historic Cemeteries: Community institutions from pioneer times to the present. Ottawa: University of Ottawa (unpublished MA thesis), pg. 38; see also Evans, P.M.O. “Cottage at Meech Lake.” Gatineau Valley Historical Society. Available at http://www.gvhs.ca/digital/lowdown/evans/display.php?row=0\&search=279. Last accessed 20 April 2016.

${ }_{333}$ Martin, J.C.G. 1999. Ibid.

334 von Baeyer, E. 1990. Garden of Dreams: Kingsmere and Mackenzie King. Toronto and Oxford: Dundurn Press, pg.45.
} 
and most of the farmer's lands. ${ }^{335}$ Every summer after Parliament adjourned, the Bourniot family moved their belongings (including a piano and parts of their library) by stage coach to their cottage at Kingsmere Lake. ${ }^{336}$ This reflects the inaccessibility of the Gatineau Hills prior to the introduction of the railroad in the 1890s. In 1880, Dennis, Bourniot, and other cottagers changed Jeffs Lake's name to Kingsmere when their fledgling cottage community needed a post office. ${ }^{337}$ As historian Edwinna von Baeyer notes, the name change was "[i]nspired by the English lakes Grassmere and Windermere." ${ }^{338}$ The remaining farmers in the Gatineau Hills supplied food and labour to the growing summer cottage communities at Kingsmere and Meech Lakes. ${ }^{339}$

Cottages were, at first, simple and rustic structures. According to local historian Ernie Mahoney, "[m]ost cottages were somewhat primitive, with wood stoves for cooking and heating and a hand pump on the kitchen sink (for the more upscale premises) or the pump in the yard of the farmer from whom you bought the land for the cottage." ${ }^{340}$ But cottages became more elaborate over time, and some were made into permanent, year round residences. ${ }^{341}$ Having first bicycled to the Gatineau Hills in 1900, William Lyon Mackenzie King -Kingsmere's most famous cottager - was immediately drawn to the wilderness of the Gatineau Hills, which was similar to the Muskoka Lake cottage country which he had experienced during his early adulthood. ${ }^{342}$ The following year, the future Prime Minister contemplated purchasing a Kingsmere lot from a local farmer for $\$ 200 .{ }^{343}$ King wrote in his diary, "this is a valuable

\footnotetext{
${ }^{335}$ Fletcher, K. 2004. Ibid., pg.45; see also von Baeyer, E. 1990. Ibid., pg.45.

336 Bourniot, A. 1963, Oct. 8. Some Personal Recollections and Historic Facts about Kingsmere. Ottawa: Paper presented to the Gatineau Valley Historical Society, pg.4.

337 Ibid.

${ }^{338}$ von Baeyer, E. 1990. Ibid., pg.46.

339 Ibid.; see also Thomson, S. 1965. Ibid., pg. 125.

${ }^{340}$ Mahoney, E. 1999. Ibid.

${ }^{341}$ von Baeyer, E. 1990. Ibid., pg.46.

342 Ibid., pgs.36-38.

${ }^{343}$ Ibid., pg.28; see also Henderson, G.F. 1993. "Mackenzie King's First Visit to Kingsmere.” Up the Gatineau!, 19: 8-11.
} 
summer locality and few places near Ottawa compare with it." ${ }^{344}$ In 1903, he purchased a one hectare (2.9 acre) lot from Isabelle Bourniot and built his first cottage, "Kingswood." At a cost of $\$ 29,650$, King's Kingsmere estate grew to 201 hectares (497 acres), ${ }^{345}$ and included five residences and the famous stone ruins. As indicated in his will, Kingsmere was King's "real home;" 346 as such, he was very concerned about privacy. ${ }^{347}$ As shown in the next section, King's concern for privacy and fear of criticism over improving his Kingsmere estate inhibited him from approving proposals to establish Gatineau Park.

The most famous Meech Lake cottager was Thomas "Carbide” Willson, who, in 1904, rented a cottage. ${ }^{348}$ In 1906, Willson began acquiring waterfront property, eventually owning half a mile of Meech Lake. By 1909, his estate had grown to 460 acres and included Little Meech Lake and the start of Meech Creek. ${ }^{349}$ His summer estate - for it was not a cottage - had two furnaces, seven fireplaces, and eleven bedrooms. ${ }^{350}$ The home and adjacent buildings were designed by an Ottawa architect. Interestingly, the "millionaire" Willson was also Ottawa's very first car-owner: "Cars were by 1910 one of the toys in which Willson interested himself." In fact, he owned Ottawa's first three cars, but he could not drive them. Rather, he hired a chauffeur! ${ }^{351}$ Still, Willson is to be credited with linking automobility to the Gatineau Hills. Subsequently, other political and economic elites from Ottawa did the same, perpetuating car travel between these places, not only in terms of physical movement over the ground, but also at a conceptual level. To an increasing extent, elites thought (and, as shown below, complained) about the road

\footnotetext{
344 Cited in von Baeyer, E. 1990. Ibid., pg.28.

345 Ibid., pg.95.

${ }^{346}$ King, W.LM.K. 1950, Feb.28. Last will and testament of William Lyon Mackenzie King. MG26.J17(1).

347 As King explains, "I have purchased, by degrees, adjoining properties in order to secure privacy and to enlarge my own holdings." King, W.L.M. No date. Memorandum, Re: Country Residence. MG26.J10 Vol.28(13).

348 The nickname "Carbide" derives from Willson's sale of his U.S. patents for crystallizing calcium carbide to Union Carbide. Roberts, M. 1976. “Carbide Willson - 1850-1915.” Up the Gatineau!, 2: 16-22, pgs.16-17.

${ }^{349}$ Ibid., pg.19.; see also Fletcher, K. 2004. Ibid., pgs.36-37.

${ }^{350}$ Ibid.

${ }^{351}$ Roberts, M. 1976. Ibid., pg.21.
} 
conditions leading up to Ottawa's cottage country. Through the property owner associations, they also acted on these beliefs, and were incredibly successful with obtaining local road improvements through the co-operation of all levels of government.

But Willson, the inventor and industrialist, was not content to simply live in the Gatineau Hills; rather, he was intent on working there. In 1911, Willson repurposed the dam on Meech Creek and also built an electricity generating station and the world's first phosphoric acid condensation plant, used to produce fertilizer. The effects of his industrial operations on Meech Lake cottagers are recounted by local historian Marion Roberts: "No sooner did his experiments commence than [sic] the summer residents at the Lake were up in arms. One day their boat houses would be six feet under water, then they would be six feet from the water." 352 Willson's Meech Lake estate was sold to the Archibald J. Freiman, the wealthy and influential owner of one of Ottawa's most successful department stores. ${ }^{353}$ While Willson and King were among the most famous cottagers, the majority of cottagers came from Ottawa's political and economic elite. As a result, the "cottages" in the Gatineau Hills reflected the wealth, status, and mobility of their owners. ${ }^{354}$

\footnotetext{
352 Roberts, M. 1976. Ibid., pgs.21-22.

${ }^{353}$ Fletcher, K. 2004. Ibid., pg.39.

${ }^{354}$ Notable individuals residing in the Gatineau Hills cottage country from the political and economic elite included lumber barons like J.R. Booth, who owned a large estate at Kingsmere Lake, one that was eventually acquired by the government for the purposes of Gatineau Park. However, the Booth estate was destroyed by a mysterious fire. Colonel Edwards, who sold his Harrington Lake estate to the federal government for park purposes (and the Edwards estate became the official summer residence of Canada's Prime Minister), was also from a wealthy and well-connected family closely associated with Ottawa's all-important lumber industry. Another early cottager was the industrialist and entrepreneur Ambrose O'Brien (after whom O'Brien beech is named). O'Brien built the Kincora Lodge on a promontory at Meech Lake. As shown in Chapter 2, O'Brien was a charter member of the Federal Woodlands Preservation League, the citizen's group credited with pressuring the federal government to protect the wooded hillsides surrounding the national capital. As recounted by an NCC historian, "Ambrose O'Brien and his father were instrumental in establishing the National Hockey League and the legendary Montreal Canadiens hockey team. Thus, the most beautiful panoramas of the Gatineau Hills were divided primarily among members of Ottawa's high society." The NCC historian acknowledged that "[it] was primarily the cottagers who imposed a recreational function on the area of present-day Gatineau Park..." Messier, D. 2007. "Fresh Air Seekers." Gatineau Park Chronicles. Available at: http://www.gvhs.ca/digital/gatineau-park/chronicles/fresh.html. Last accessed 18 May 2017.
} 
After World War I, the Gatineau Hills became popular as Ottawa's "winter playground." Accessibility for the masses improved through the introduction of public transit, i.e., buses. Alongside of this improved mobility was the construction of new recreation facilities. In 1919, the Ottawa Ski Club (OSC) purchased 127 hectares (315 acres) of land near Fortune and Pink Lakes. ${ }^{355}$ The Club built lodges and members re-purposed mining and logging roads for ski trails in what became known as the "Kingsmere-Camp Fortune area." Through its development of an extensive trail network, the OSC "transformed agricultural space into recreational territory."356 But it was not alone. A rival ski organization from Ottawa, the Cliffside Club, purchased lands and repurposed a farmer's lodge near Fairy Lake. ${ }^{357}$ On winter weekends, the Ottawa ski clubs attracted thousands of trail skiers into the "recreational territory" of the Gatineau Hills. The ski clubs also took an active interest in improving local roads and public transportation.

Figure 2.3: Mackenzie King's KPOA membership card

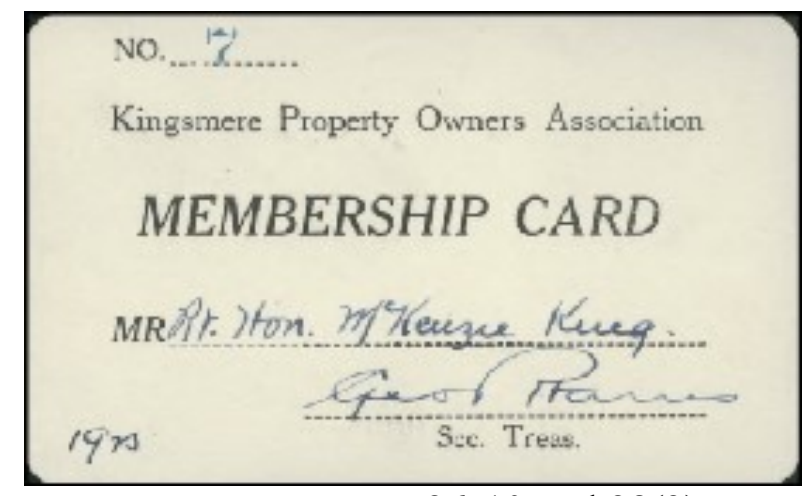

Source: LAC MG26J10 Vol.28(3)

Indeed, the Ottawa Ski Club was a paying member of the Kingsmere Property Owners' Association (KPOA), which was established in October $1924 .{ }^{358}$ Having endorsed the

\footnotetext{
${ }^{355}$ Lanzon, Q. 2014. Ibid., pg.30.

356 Ibid., pg. 37.

${ }^{357}$ See Charles Hodgson's video on the history of the Cliffside Ski Club and its Keogan Lodge: https://www.youtube.com/watch? $v=y N 9 Y p K m 2 R R 4$

${ }^{358}$ Originally known as the Kingsmere Property Holders Association.
} 
organization of the KPOA "very heartily," 359 Prime Minister Mackenzie King was made the honorary President (see Figure 2.3). ${ }^{360}$ The purposes behind the formation of the KPOA were recorded by its Secretary, George Harris: "For the good of all; For the betterment of Kingsmere; For the beautifying of the community." ${ }^{361}$ Had the KPOA only been intent on improving local roads, posting better signage, maintaining building standards, and preventing the pollution of Kingsmere Lake, this property owners' association would perhaps be laudable. But, as Ideas and Schemes of the Kingsmere Property Holders Association reveals, cottagers also desired to "see that only Property holders or their guests fish in the Lake."362 More tellingly, the KPOA sought “[t]o stop all undesirable ones from bathing in the Lake." ${ }^{363}$ And finally, under "Improvements," the KPOA proposed "[t]o protect all Property holders from picnickers, poachers, and undesirables." 364 The question of how the KPOA would protect cottagers is not addressed in the Ideas and Schemes document. However, it did indicate one means of keeping out undesirables, by giving KPOA the authority to oversee all property sales and property rentals at Kingsmere. Fortunately, Kingsmere cottagers did not relinquish their property rights to the KPOA.

The KPOA was clearly intended for the good of all - property owners. In other words, the KPOA was intended for the good of some, but this necessitated the exclusion of others. Exactly who those "undesirables" were soon became apparent. In 1925, KPOA Secretary Harris sounded the alarm to Mackenzie King "that another Jew has taken a Cottage at Kingsmere. This is the third this year..."365 Harris suggested that any further land purchases by Jews "would be very harmful to the Community [sic]" and wrote to the Prime Minister in an attempt to "seal our

\footnotetext{
${ }^{359}$ King, W.L.M. 1924, Dec. 8. Letter from W.L.M. King to G.P. Harris. MG26J10 Vol.28(3).

${ }^{360}$ Kingsmere Property Holders Association. 1925, Jan. 15. Memorandum. MG26J10 Vol.28(3).

${ }^{361}$ Harris, G.P. 1924, Oct. 22. Letter from G.P. Harris to W.L.M. King. MG26J10 Vol.28(3).

362 Kingsmere Property Holders Association. 1925. Ideas and Schemes of the Kingsmere Property Holders Association. MG26J10 Vol.28(3), pg.1.

${ }^{363}$ Ibid.

${ }^{364}$ Ibid., pg.3

${ }^{365}$ Harris, G.P. 1925, June 25. Letter from G.P. Harris to W.L.M. King. MG26J10 Vol.28(3).
} 
end [of the lake] up" by purchasing the adjoining Cameron property and dividing it between themselves. ${ }^{366}$ Although Harris' letter did not receive a reply, King sadly shared the antiSemitism of other Kingsmere cottagers. Thus, his diary entry of 11 April 1927 reads that "the greatest danger and menace is a sale to Jews, who have a desire to get in at Kingsmere and who would ruin the whole place." 367 King even acted on his racist beliefs. Following another addition of land to his Kingsmere estate, he wrote "...if I had not purchased the properties, they might have been secured by Jews or other undesirables." ${ }^{368}$

Jews were not the only undesirables that the KPOA sought to protect Kingsmere from. Thus, in May 1927, the KPOA Secretary learned that Dr. Charles Saunders was going to sell his Kingsmere lands to the Joan of Arc Institute, a Roman Catholic organization that provided residence for young girls and women (see Figure 2.4) ${ }^{369}$ Harris explained to King that the Institute intended to erect "several small buildings...for the purpose of housing Ladies of the Institution who need a rest... This I think would be detrimental to Kingsmere."370 King was asked by the KPOA Secretary to try to persuade Dr. Saunders not to sell his property to the Institute. But, as pointed out by historian Edwinna von Baeyer, "King wisely did not interfere, perhaps because the founder of the Institute, Sister Marie de St. Thomas d'Aquinas, was King's friend." ${ }^{371}$ Instead, Dr. Saunders proceeded with the sale, much to Secretary Harris'

\footnotetext{
366 Ibid.

${ }^{367}$ Cited in von Baeyer, E. 1990. Ibid., pg.95.

${ }^{368}$ Ibid., pg.61. On King's anti-Semitism, von Baeyer observed that "it was perhaps more insidious than overt prejudice." She references another of King's diary entry on 9 August 1936: "My own view is there are good as well as bad Jews and it is wrong to indict, a nation or a race." Irrespective of King's "balanced" view, it is worth remembering, as von Baeyer does, that "[h]is government's nonaction ... during World War II toward the plight of European Jews was shameful episode in modern Canadian history." Ibid.

${ }^{369}$ Ibid., pg. 62.

370 Ibid.

${ }^{371}$ Von Baeyer, E. 1990. Ibid., pg.63.
} 
disappointment. Notably, Harris, having been unsuccessful in moving King to action, tried to raise funds to purchase Dr. Saunders' property with other Kingsmere residents. ${ }^{372}$

On the surface, the KPOA was established for benign ends of local beautification. But it was also a means of asserting territoriality over Kingsmere Lake, as cottagers sought to maintain their privacy, class exclusivity, and racial homogeneity by denying access and use of the lake to "undesirables," which included Jews, French Canadians, and the general population at large. Ultimately, the KPOA had no formal powers as it was a voluntary association. As shown above, this could have been otherwise: the KPOA suggested that all property sales and leases be submitted to it for approval. If Kingsmere residents had conceded to this restriction on their property rights, the KPOA would have been a private form of local government: it would have been able to prevent Jews and the Joan of Arc Institute from purchasing property in the area that is, the ineffective exercise of a malevolent territoriality.

${ }^{372}$ Harris, G.P. 1927, June 9. Letter from G.P. Harris to W.L.M. King. MG26J10 Vol.28(3). 
Figure 2.4: Letter from KPOA Secretary to Mackenzie King

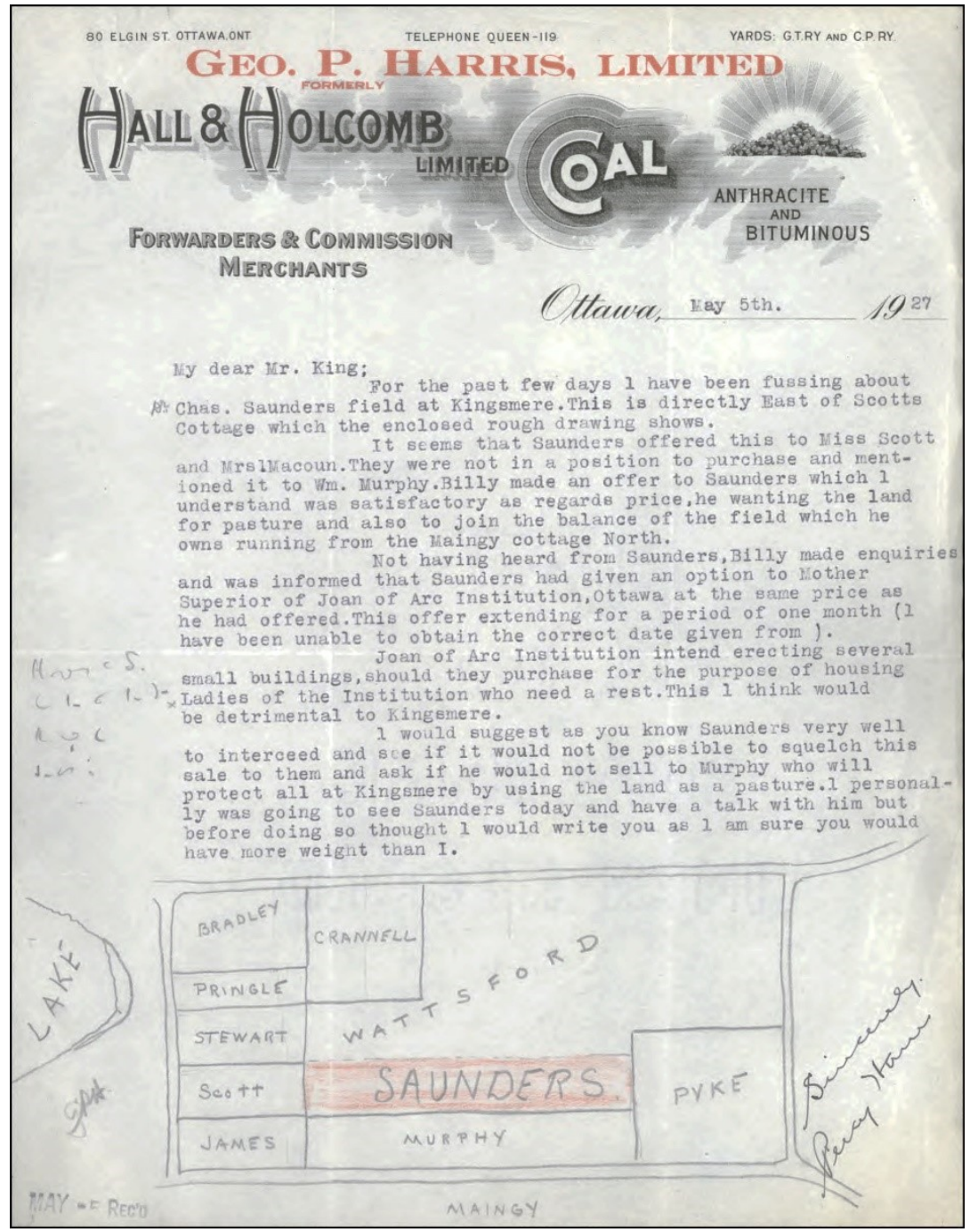

Source: Library and Archives Canada MG26J10 Vol.28(3).

Mackenzie King's file on the KPOA ends in 1927, as there is no record that he paid his \$5 membership dues that year. Perhaps King did not want to become involved in the politics surrounding land ownership at Kingsmere Lake. But King's disassociation from the KPOA could have also been the result of his emerging view that the forests of the Gatineau Hills should be protected as a national park for the benefit of all Canadians (and not just cottagers in the Kingsmere-Meech Lake privatopia). The implications of this idea were expressed in a May 1926 diary entry which reads: "It breaks one's heart, the way the forests roundabout are being thinned 
out and cut down. Were I a wealthy man I would purchase them outright. Had I a majority in parliament, I would expropriate them for the State." ${ }^{373}$ Like many others, the Prime Minister recognized the scenic beauty of the Gatineau Hills and their proximity to the national capital as necessitating intervention by the federal government, specifically in the creation of a national park. While King was concerned about the loss of privacy resulting from the national park, he intended to - and ultimately did - bequeath his Kingsmere estate to the Canadian people. Thus, King did not share the same concern with expropriation as other Kingsmere cottagers.

In April 1927, King's clear desire to establish a national park in the Gatineau Hills was tangentially announced in the House of Commons during the debate on the Federal District Act:

I have seen some mention in the press that this bill would include provision for a national park. That is an idea entirely separate; it has nothing to do with the present measure at all. I want to make that clear. I should like to say, however, that I do think a national park in the vicinity of Ottawa is something that is very much in the public interest, and that provision should be made for it at once, but that has nothing to do with this particular measure. ${ }^{374}$

A shrewd and cautious politician, the Prime Minister probably anticipated the criticism of this proposal, which came the following day from Conservative MP John Edwards:

I do not wish to inject anything of a controversial character, but I may say I have heard that certain persons are interested in the other side of the [Ottawa] river through having summer homes there. Is it the idea to make beautiful driveways up to the homes of these persons, some of whom sit in this House and have summer residences on the other side of the river? ${ }^{375}$

To which King immediately replied:

I have a summer home at Kingsmere, twelve miles from here. I say to my hon. Friend that if the commission were to attempt to spend any money out of this appropriation for improving any part of a driveway approaching my residence, I

\footnotetext{
${ }^{373}$ King, W.L.M. 1926, May 23. Diary of William Lyon Mackenzie King. Item 9882. Available at: http://www.baclac.gc.ca/eng/discover/politics-government/prime-ministers/william-lyon-mackenzieking/pages/item.aspx?IdNumber=9882\&. Last accessed 28 March 2016.

${ }^{374}$ King, W.L.M. 1927, Apr. 6. "Federal District Commission" Canada. Parliament. House of Commons Debates. Edited Hansard. $16^{\text {th }}$ Parliament, $1^{\text {st }}$ Session, Vol.2, pg.1978.

${ }^{375}$ Edwards, J. 1927, Apr. 6. "Federal District Commission" Canada. Parliament. House of Commons Debates.

Edited Hansard. 16th Parliament, 1st Session, Vol.2, pg.1978.
} 
would strongly oppose the attempt. The [Ottawa Improvement] commission itself made the suggestion of a federal district including Hull. I had no thought of the other side of the river being included when I was approached by the commission to allow its work to be given this larger scope. I hardly thought an insinuation such as the hon. Member has made would be voiced, and if he has in mind any other member than myself perhaps he would name him and so give him an opportunity of replying. ${ }^{376}$

This suggestion of a conflict-of-interest prevented King from following through on the national park proposal during his term in office, despite rumors to the contrary. ${ }^{377}$ The Liberal Party lost the 1930 federal election, but King continued, as Leader of the Opposition, to advocate for the protection of the forests in the Gatineau Hills. As shown in the next section, this would not be accomplished through the creation of a national park, as King first envisaged. Another property owner association would ensure that the federal government intervened on terms that were amenable to cottagers at Kingsmere and Meech Lakes. While a national park was never established, a parkway to Kingsmere was eventually built, confirming Edwards' suspicions about the link between the Federal District Commission and the cottage communities in the Gatineau Hills. Indeed, several senior FDC officials owned land in the park.

\section{Gatineau Hills denudation issue}

Incorporated in 1926, the Meech Lake Association (MLA) had as its mandate: "the promotion of good roads and stationing posters at dangerous places; safeguarding of the lake levels and the improvement of the general appearance of the lake; protection, conservation and improvement of fishing in the lake; fostering of sports during the summer; the protection of all property holders

\footnotetext{
${ }^{376}$ King, W.L.M. 1927, Apr. 6. Ibid.

377 Ottawa Ski Club. 1929, Mar. 13. Ottawa Ski Club News. No. 10, pg.1. Available at: http:/www.gvhs.ca/digital/gatineau-park/osc/1929-03-13.pdf. Last accessed 28 Mar. 2016.; see also Dickson, J.R. 1929, Dec. 4. Memorandum re: Invasion of Blister Rust in the Gatineau - Kingsmere - Meech Lake country. RG39 Vol.25.49136; and Ottawa Ski Club. 1929, Dec, 3. Resolution re: Outbreak of the White Pine Blister Rust in the Gatineau-Kingsmere - Meech Lake Country. RG39 Vol.25.49136.
} 
from poachers and undesirables; the fostering of a community spirit, etc." ${ }^{378}$ Thus, the MLA was very similar to its counterpart at Kingsmere Lake pursuing "benign" ends of local improvement (improving automobility), but also pursuing malignant exclusionary purposes. Among the undesirables that the MLA would seek to exclude were woodlot owners who put their financial needs ahead of the scenic beauty of the Gatineau Hills.

As indicated by Mackenzie King's diary entry cited above, woodlots were being cut during the 1920s, but the Great Depression intensified cutting through the expansion of fuelwood market, as wood was a cheaper heating source than coal and oil. Herbert Marshall, President of the Ottawa Ski Club, summed up the situation:

The economic depression of the early 30s with its toll of unemployment, and low prices for agricultural products, induced some who owned plots in the Gatineau area to exploit their resources to the utmost. The consequence was wholesale cutting in some areas. One region of the Merry-Go-Round trail is named "Desolation Valley" which is suggestive of its condition at the time of its making. The cutting of timber for firewood was on such a scale that the landscape could be well described as an "Abomination of Desolation." 379

During the Great Depression, fuelwood dealers from Ottawa and Hull paid farmers and other property owners in the Gatineau Hills to cut their wood. The modus operandi of fuelwood dealers was maximum exploitation of both laborers and resources. Fuelwood dealers contracted workers at $\$ 1.00$ per cord of wood, and sold cords at $\$ 6.00$ each. On average, workers cut a cord per day, and earned between $\$ 5$ and $\$ 6$ a week. Although this wage was exploitatively low, laborers considered it preferable to going on relief. ${ }^{380}$ The consequences of this exploitative approach were noted by a forester with the federal government: “[ $t]$ he wood dealers' only interest is in the extraction of the timber crop and it is accordingly to his advantage to take

\footnotetext{
${ }^{378}$ No Author. 1926, July 12. "Annual Meeting of Meech Lake Assn.” Ottawa Citizen.

${ }^{379}$ Marshall, H. 1973. History of the Ottawa Ski Club. Ottawa: Self-published, pgs.111-112.

${ }^{380}$ Cameron, D.R. 1935, May 28. Memorandum. RG39 Vol.25.49136, pg.2.
} 
everything which is marketable. After such an operation all the farmer has left is a completely devastated area not worth to him the cost of taxes." "381

Cottagers and skiers sought ways to prevent further "denudation" of the Gatineau Hills. In September 1933, Harry Baldwin, a member of the Meech Lake Association and the former personal secretary of Mackenzie King, indicated that the Capital District Conservation Association was about to have its inaugural meeting. ${ }^{382}$ The MLA asked J.R. Dickson, a fellow cottager and an official in the Forest Service of the Department of Interior, to contact provincial authorities to determine if there were any laws or regulations that could stop clear cutting near roads and lakes or, at the very least, require selective cutting. ${ }^{383}$ Dickson wrote provincial counterparts: "[t]his matter, as you will readily perceive, is one which very closely touches the financial (real estate) interests and personal enjoyment of the great body of summer residents who own homes in these localities." 384 Thus, for cottagers, preserving scenic values was tied to preserving their property values, since cottages surrounded by forests sold for more than those situated amongst denuded hillsides.

While waiting for the replies from provincial foresters, Dickson interviewed George Bleakney, a lawyer practicing in Quebec and Tenaga cottager, who informed him "that there is at present no provision or machinery in Quebec law or procedure for controlling the cutting of cordwood on private lands, regardless of the object sought by such control." 385 Provincial officials confirmed that the Quebec government had no jurisdiction over cutting on private lands. While expressing a "deep interest in ... the preservation of the scenery in the lower Gatineau

\footnotetext{
381 Ibid.

382 Baldwin, H. 1933, Sept. 16. Letter from H. Baldwin to J.R. Dickson. RG39 Vol.25.49136.

${ }^{383}$ Dickson, J.R. 1933, Sept. 14. Letter from J.R. Dickson to A. Bedard. RG39 Vol.25.49136.

${ }^{384}$ Dickson, J.R. 1933, Sept. 19. Letter from J.R. Dickson to the L.A. David. RG39 Vol.25.49136.

${ }^{385}$ Cited in Dickson, J.R. 1933, Sept. 27. Interim report on question of controlling the cutting of cordwood, etc., on private lands in Quebec, having in view the preservation of scenery bordering lakes and highways, in summer resort districts. RG39 Vol.25.49136.
} 
Valley ... [and recognizing] the growing importance of summer resorts in this province and their resulting wealth for the surrounding communities and the public at large," Quebec's chief forester indicated that "the territory in the Hull township has all been alienated since quite a long time, probably most of it before 1884 , hence it escapes more or less our ruling." ${ }^{386}$

Alongside these behind-the-scenes negotiations, the Ottawa Ski Club (OSC) acted on the denudation issue by purchasing woodlots in its recreational territory, that is, the Camp FortuneKingsmere area. In December 1933, the OSC founded a Forest Preservation Society which raised funds towards the purchase of adjacent woodlots. ${ }^{387}$ But OSC members knew that this was only a stop-gap measure. In a letter to the editor of the Ottawa Ski Club News, the President of the Forest Preservation Society, George McHugh, called for " $[\mathrm{t}]$ he expropriation by the Federal Government of the entire ridge lying northwest of Old Chelsea ... as a National Park for the use of all citizens for all time." 388

Meanwhile, having reached a dead-end with provincial authorities, Meech Lake residents once again turned their attention to creating a new citizen's group dedicated to addressing the denudation issue. In February 1934, Baldwin wrote Dickson: "I am now trying to interest the [Ottawa] Ski Club in the organization of an Arboreal Beauty Conservation Society and shall be glad to hear from you whenever you can spare time to advise me concerning the very pressing and neglected problem." ${ }^{389}$ Several months later, Baldwin updated Dickson: "You may be interested to hear that at the annual meeting of the Meech's [sic] Lake Association held a few weeks ago I was authorized as chairman of a special committee to bring about the creation of an association dedicated solely and specifically to the work of preserving trees in and about the

\footnotetext{
386 Piche, G.C. 1933, Nov. 27. Letter from G.C. Piche to J.R. Dickson. RG39 Vol.25.49136.

${ }^{387}$ Lanzon, Q. 2014. Ibid. pg.47.

${ }^{388}$ McHugh, G. 1933, Dec 1. "Letter to the Editor." Ottawa Ski Club News, Vol.1. Available from: http:/gvhs.ca/digital/gatineau-park/osc/1933-12-01.pdf. Last accessed 28 Mar. 2016.

${ }^{389}$ Baldwin, H. 1934, Feb. 5. Letter from H. Baldwin to J.R. Dickson. RG39 Vol.25.49136.
} 
capital." ${ }^{390}$ Baldwin's letters confirm that the Meech Lake Association was the impetus behind the establishment of the Federal Woodlands Preservation League (see Figure 2.5), which held its first meeting on 26 October 1934. As noted above, previous scholarship suggested that the Ottawa Ski Club was the driving force behind the League, which has the effect of diverting attention away from the link between preservation of scenic beauty and property values.

The attribution of the League's creation to the Ottawa Ski Club (OSC) becomes even more puzzling given the fact that its leadership was almost entirely composed of cottagers from Kingsmere and Meech Lakes. Baldwin was elected President, while Roderick Percy Sparks, an Ottawa businessman who lived along Meech Lake Road, was elected Vice-President. Other charter members and area cottagers included Lawrence Freiman (Meech Lake) and Duncan K. MacTavish (Kingsmere). Prime Minister Bennett, who was a Kingsmere cottager, and the Leader of the Opposition, Mackenzie King, were among the League's patrons. Like most residents of the Kingsmere-Meech Lake privatopia, the FWPL membership was drawn from Ottawa's political and economic elite (see Figure 2.5).

${ }^{390}$ Baldwin, H. 1934, Aug. 17. Letter from H. Baldwin to J.R. Dickson. RG39 Vol.25.49136. 
Figure 2.5: Letterhead of the Federal Woodlands Preservation League

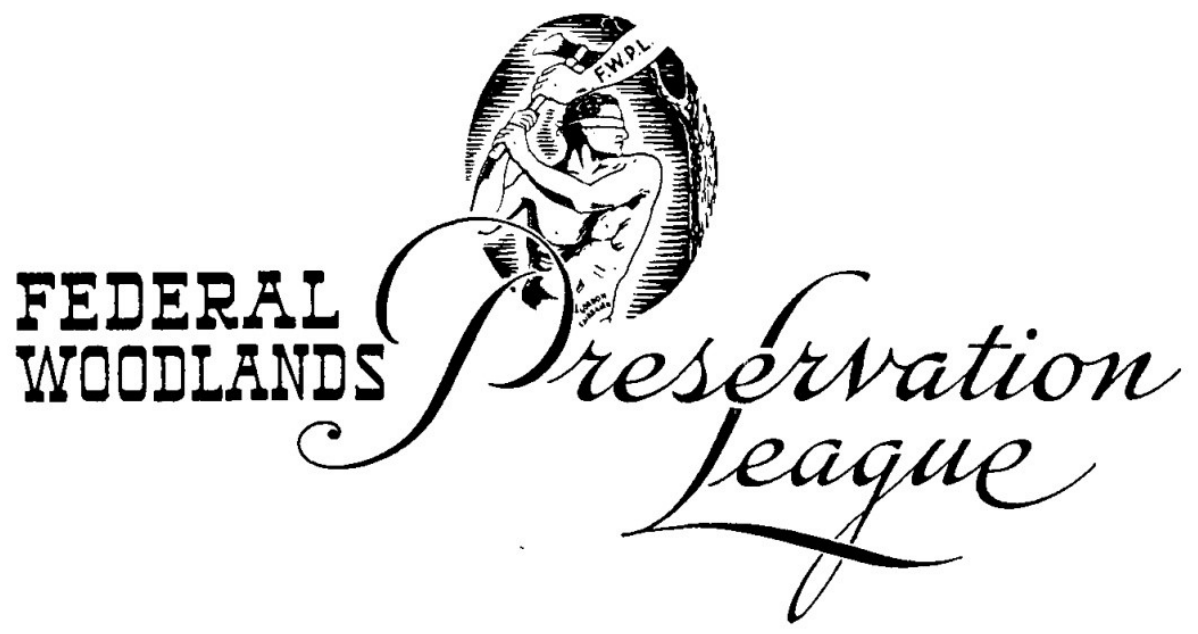

HONORARY PATRONS

His Excellency The Governor General and

Her Royal Highness, Princess Alice, Countess of Athlone

PATRONS

Rr. Hon. R. B. BenNetT

Mayor of Ottawa

P. D. Ross, Ess.
Rr. Hon. W. L. Mackenzie King MAYOR OF HUlL

Hon. Alphonse Fotrnier

Source: RG39 Vol.25.49136

The League's information pamphlet explained that, over the course of another winter, 1,000 acres of forest would be lost "in the Kingsmere-Meech Lake District alone."391 The League outlined what it knew about the denudation issue, namely, that there was "no legislation" to prevent "wholesale cutting" on privately-owned woodlots. It acknowledged that woodlots provide "an important, though uncertain and soon to be exhausted, source of income to many owners ... [and that] [i]t is unreasonable to expect the owner to forgo this income in order to

${ }^{391}$ The FWPL information pamphlet is available in RG39 Vol.25.49136. 
preserve for all Canadians the wooded setting of the Capital." 392 The goals of the FWPL were laid out in the information pamphlet as follows:

1. To attract to its membership all those who are interested in the problem of preserving and protecting the beauty of the woodlands within a radius of twentyfive miles of Ottawa, and more especially such woodlands as contribute to the beauty of the prospect of or from the rivers, lakes, hills and highways immediately surrounding the Capital of Canada;

2. To collect and collate facts, figures and plans concerning the problems, and study and discuss them so as to be qualified;

3. To formulate a policy of woodlands preservation, and

4. To initiate, support, and encourage social action as the results of the League's research may indicate as being practical. ${ }^{393}$

The first goal implied that the League had a larger focus than the forests of the Gatineau Hills but, as pointed out by Baldwin's letter and confirmed by subsequent FWPL actions, this was not the case. Even though the creation of a national park would have effectively resolved the denudation issue and preserved the forested hillsides for all Canadians, a national park would have proven contrary to cottagers' interest as it entailed the elimination of privately-owned land. The League sought other options, those that would be limited to restricting the woodlot owner. Its pamphlet asked: "WILL YOU HELP US devise a plan which will at once benefit the owner of the woodlands and save the scenery?"394

To this end, the League partnered with the Federal District Commission (FDC), and even acquired permission from the FDC to use the designation "Federal" in its name. ${ }^{395}$ League Vice President Sparks headed the Research Committee, which obtained cadastral and road maps of the Gatineau Hills from the provincial government, and the list of property owners from the

\footnotetext{
392 Ibid.

393 Ibid.

394 Ibid.

${ }^{395}$ Bronson, F.E. 1935, Nov. 4. Letter from F.E. Bronson to D.K. MacTavish. RG34 Vol.265.190(1).
} 
Municipality of West Hull. The League supplied these data to the FDC. Following this, Sparks wrote the Minister of the Department of Interior, T.G. Murphy, requesting assistance with a "general survey of just what the problem is." ${ }^{396}$ Sparks was assured by Minister Murphy of the full cooperation of the Dominion Forest Service: “...in the broader work of the League I think we should be able to help materially for once the preliminary data [sic] is assembled it seems entirely probable that it will be necessary to use foresters in securing data with respect to timber, and also in formulating plans for conservation in use thereof." 397 As indicated below, the Department of Interior did follow through on this promise with the 1935 Lower Gatineau

\section{Woodlands Survey.}

In addition to these early data collection efforts, the League aligned public opinion to its cause through local newspapers. ${ }^{398}$ Charles A. Bowman, a charter member of the FWPL, was an Editor with the Ottawa Citizen. Bowman ensured that the newspaper reading public was kept informed about the denudation issue. An early Citizen article, one of many, explained that " $[\mathrm{t}] \mathrm{he}$ cutting of trees on the Gatineau Hills, until the whole countryside is denuded, will stand as an accusing record against conditions at this time in Canada."399 The Citizen not only targeted the clear cutting, but also decried the "wage slavery in the woods." "400 It promoted the new FWPL as “a responsible national organization with a Dominion charter issued by the Secretary of State."

In May 1935, the League held its first public meeting at the prestigious Chateau Laurier. Photographs of clear cut areas were put on display and the information booklet was distributed. Mackenzie King introduced the meeting: "It is difficult to overestimate the importance of

\footnotetext{
396 Sparks, R.P. 1935, Apr. 3. Letter from R.P. Sparks to T.G. Murphy. RG39 Vol.25.49136.

${ }^{397}$ Murphy, T.G. 1935, Apr. 26. Letter from T.G. Murphy to R.P. Sparks. RG39 Vol.379.49170.

398 No author. 1934, Dec. 15. "Form Organization With Aim of Preserving the Woodlands." Ottawa Citizen.

${ }^{399}$ No author. 1935, Jan. 12. "The Hillsides will accuse.” Ottawa Citizen; see also No author. 1934, Dec. 15. "Woodlands Around Ottawa." The Evening Citizen.

${ }^{400}$ No author. 1935, Jan. 12. Ibid.

${ }^{401}$ Ibid.
} 
preserving for Ottawa the natural beauty of its surroundings. If facts concerning the destruction of woodlands as described tonight were brought home to the public, I am certain the organization would have everywhere good support."402 Following King's introduction, speeches were given by the FWPL President and Vice President. As if President Baldwin were preemptively countering criticisms that the League was only interested in protecting property values, he insisted that the League's goals were in the public interest: "It was not a question of Summer residents owning cottages in the Gatineau working for something in which they were directly interested. Although Summer residents had a direct interest in the preservation of woodlands, it was a question of general public interest and all should lend their full support."403

Two weeks after the League's public meeting, the Opposition Leader brought the Gatineau Hills denudation issue up for debate in the House of Commons. King repeated the League's main arguments:

Many acres of beautiful woodland adjacent to the rivers or to the highways have been ruthlessly destroyed. I say ruthlessly, because they have been cut for a mere pittance, the owners receiving very little, and some unemployed men who have done the cutting with a very small amount of pay. There is an obligation on the federal government to have regard not merely for Ottawa to-day as the capital city, but to the capital of Canada for years and generations to come. ${ }^{404}$

This passionate appeal was followed by a practical proposal: that the Prime Minister call a meeting between the Province of Quebec and federal government to study remedial measures. But Prime Minister Bennett indicated that the federal government had no jurisdiction over cutting on private lands, which, through the British North America Act, fell under the jurisdiction of the provincial government. King reminded Bennett of the recommendation for a national park in the Gatineau Hills as put forward in the Holt Plan of 1916, a Conservative Party initiative. The

\footnotetext{
${ }^{402}$ Cited in No author. 1935, May 9. "Urge Protection Woodland Beauty in Ottawa Area." Ottawa Journal.

${ }^{403}$ Cited in Ibid.

${ }^{404}$ King, W.L.M. 1935, May 27. “Public Works Program.” Parliament. Canada. House of Commons Debates. Edited Hansard. $17^{\text {th }}$ Parliament, $6^{\text {th }}$ Session, Vol.3. pg.3047.
} 
Prime Minister responded by putting the Opposition Leader on the defensive: why had King not acted on the national park proposal during his nine years in office? ${ }^{405}$ To which King replied, somewhat disingenuously given his 1926 diary entry about how indiscriminate cutting "breaks one's heart": "It has been only within the last two years that what has been happening along the roadsides, the river banks and the lake shores has taken place, and it is for that reason that I am saying to my right hon. friend that I am sure another winter will work a degree of devastation that will be completely irreparable." ${ }^{\prime 06}$ Out of this exchange, Prime Minister Bennett agreed to discuss the issue with the Chairman of the Federal District Commission.

Three days later, FWPL members met with FDC officials to discuss potential solutions to the denudation issue. FWPL President Baldwin explained that the League "had gone as far as it could with the resources available." 407 Through its Research Committee, the League obtained data concerning the "30,000 acres requiring control." $" 408$ It was time, Baldwin argued, for either the FDC or Forestry Branch of the Department of the Interior "to assume responsibility," adding that "[h]e didn't think it would be necessary to expropriate the lands but to endeavour to get agreements by owners not to sell to 'cut and run' wood contractors." ${ }^{409}$ Notably, as the discussion turned to the economic value of woodlots, the FDC Chairman, W.E. Matthews, "questioned what would be the effect of depriving labour of this market." ${ }^{410}$ Chairman Matthews named two committees, one directed towards further data collection on privately-owned lands that needed to be acquired, and the other towards project financing, with the FWPL President estimating that payments to woodlot owners and land acquisitions would require about " $\$ 10,000$

\footnotetext{
405 Ibid.

406 Bennett, R.B. 1935, May 27. "Public Works Program.” Parliament. Canada. House of Commons Debates. Edited Hansard. 17th Parliament, 6th Session, Vol.3. pg.3047.

${ }^{407}$ Federal District Commission 1935, May 30. Meeting Re: Gatineau Woodlands. RG.34 Vol.265.190(1).

${ }^{408}$ Ibid.

409 Ibid.

${ }^{410}$ Ibid.
} 
a year in perpetuity." 411 Following the meeting, President Baldwin gratefully acknowledged the "practical sympathy" of the FDC in a letter to Chairman Matthews: "Those of us who have had the privilege of assisting in the genesis of the idea of preserving what we with optimist presumption called the federal woodlands, are relieved beyond measure that our lusty infant has now fair prospect of adoption, to say nothing of illustrious godparents."412

The FDC Chairman was not the only one to question the economic impact that the League's proposals would have. At a Conservative Party meeting in Hull, Aimé Guertin, MLA, “strongly denounced” Mackenzie King's earlier remarks in the House of Commons. He asked:

What are the remedies that Hon. W.L. Mackenzie King proposes, to give employment to the hundreds of local residents who now earn their living with the cutting of wood in the district? He had not announced them yet. Hull workingmen are starving and farmers of the district are financially embarrassed, but we must put a stop to the cutting of wood in the district or else the scenery of Kingsmere will disappear. ${ }^{413}$

And, when the Government of Quebec was approached by the FDC to co-operate in the preparation of a survey of the forest cover in the Gatineau Hills, Premier Taschereau, who was a member of the FWPL, ${ }^{414}$ replied: "We quite realize that such [clear-cutting] practices are prejudicial from a touristic point of view to the aesthetic appearance of that section of our Province. We must, however, call your attention to the fact that the lands on which such practices have been resorted to, being private lands, we could not very well intervene otherwise than through a campaign of education and preservation." 415 The Quebec Premier added that Hull

\footnotetext{
411 Ibid.

${ }^{412}$ Baldwin, H. 1935, May 31. Letter from H. Baldwin to W.E. Matthews. RG34 Vol.265.190(1).

${ }^{413}$ No author. 1935, June 13. "Liberal Leader's Proposal Scorned by Aimé Guertin.” Ottawa Citizen.

414 Taschereau, L.A. 1935, Mar. 21. Letter from L.A. Taschereau to H. Baldwin. RG39 Vol.25.49136; see also No author. 1935, Dec. 17. "Ottawa May Become Winter Sports Centre of America Predicts Charles A. Bowman." Ottawa Citizen.

${ }^{415}$ Taschereau, L.A. 1935, June 27. Letter from L.A. Taschereau to W.E. Matthews. RG34 Vol.265.190(1).
} 
foresters would offer their services and co-operate in supplying data on land ownership, and this assistance was subsequently obtained. ${ }^{416}$

The non-committal response from the Quebec government did not deter the federal government from proceeding with the survey of the Gatineau Hills. With the FDC "acting in a consulting capacity, ${ }^{417}$ the Department of Interior not only provided staff and equipment, but also assumed the full costs of the survey. ${ }^{418}$ During the summer of 1935 , the Department's Forestry Service, with the assistance of the Aerial Surveys Branch, surveyed woodcutting and forest cover around Kingsmere and Meech Lake. ${ }^{419}$ Surveyors were given permission to camp on Sparks' property on Meech Lake Road. ${ }^{420}$ The FDC kept both the FWPL and Mackenzie King updated on the surveyors' progress. ${ }^{421}$ Local newspapers were also informed of the preparation of the survey, and were enthusiastic about the first steps being taken: "The day will come - The Journal hopes it will not be long delayed - when the whole Gatineau region will be turned into a national park. In the meantime there is much that can be done to preserve the forest of the district, to guard against the disfigurement of its wonderful scenic beauties; and it is good to see the Government address itself to the task." ${ }^{422}$

\footnotetext{
${ }^{416}$ Cram, H.R. 1935, July 19. Memorandum, re: Property survey of Gatineau Hills woodland adjacent to Ottawa. RG34 Vol. 265.190(1); see also Matthews, W.E. 1935, Oct. 29. Letter from W.E. Matthews to W.L.M. King. RG34 Vol.265.190(1).

${ }^{417}$ Cram, H.R. 1935, Aug. 1. Letter from H.R. Cram to W.L.M. King. RG34 Vol.265.190(1).

418 Ibid.

${ }^{419}$ Murphy, T.G. 1935, July 30. Letter from T.G. Murphy to W.E. Matthews. RG34 Vol.265.190(1).

${ }^{420}$ Robertson, W.M 1935, Oct. 18. Interim Report Re: The Lower Gatineau Woodlands Survey. Ottawa: Department of Interior. RG34 Vol.265.190(1). Before Sparks' struggles against the park's status quo were known, historian Apostle took Sparks' accommodation of the government surveyors as evidence that he wanted "to seize the property of his neighbours." Apostle, A. 1997. Ibid., pg.80. As shown in the chapters that follow, Sparks advocated for the public ownership of Gatineau Park.

${ }^{421}$ Cram, H.R. 1935, July 31. Letter from H.R. Cram to H. Baldwin. RG34 Vol. 265.190(1); Cram, H.R. 1935, Aug. 1. Letter from H.R. Cram to W.L.M. King. RG34 Vol.265.190(1).

${ }^{422}$ No author. 1935, Aug. 19. "Preserving the Gatineau." Ottawa Journal. See also No author. 1935, Aug. 16. "Murphy Sends Party of Seven to Inspect Field." Ottawa Citizen; No author. 1935, Nov. 27. "Minister of Interior Welcomes Suggestions: Deplores Stripping of Hills in Ottawa District and Elsewhere.” Ottawa Journal; No author. 1935, Nov. 27. "Hope To Secure Co-operation In Preserving Gatineau Area." Ottawa Citizen; and No author. 1935, Nov. 28. "Gatineau Woodlands Survey." Ottawa Citizen.
} 


\section{In December 1935, the Lower Gatineau Woodlands Survey: Interim Report was}

submitted to the FDC. Surveyors identified the extent of the denudation and proposed remedial measures: "Within the past five years wood has replaced coal as a fuel to a considerable extent, with a consequent expansion of the fuelwood market. Owing to their easy accessibility from the markets of Hull and Ottawa, the woodlands of the Lower Gatineau region have been subjected to greatly increased cutting activities." 423 The surveyors found that, in the previous 20 years, 40 percent of the 6,215 -hectate area (15,360 acres) had been either completely or partially cut over. ${ }^{424}$ The crux of the denudation issue rested with farmers affected by the Great Depression: they sold woodlots to fuelwood dealers who, as mentioned above, contracted workers at exploitatively low wages, directing them to cut indiscriminately so as to maximize profits. ${ }^{425}$ Contrary to the claims of the FWPL that 1,000 acres would be cut in a single winter, surveyors estimated that the annual average cut was 224 acres. ${ }^{426}$ They did not consider this amount of cutting to be excessive: "from the purely forestry standpoint no serious criticism can be directed against the practice of the owners in clear cutting. ${ }^{427}$ Indeed, the Gatineau Hills were unusually productive in terms of tree growth, such that cut areas would regenerate relatively quickly. But the surveyors conceded that indiscriminate and irregular cutting was enough to impair the scenic values coveted by "those who wish a more intimate association with the woods..." 428 The effects of clear-cutting on scenic values became more pronounced as "operations have extended up the valleys to the hill tops." 429

\footnotetext{
${ }^{423}$ Robertson, W.M 1935, Oct. 18. Ibid., pg.1.

${ }^{424}$ Ibid., pg.8.

${ }^{425}$ Ibid., pg.6.

${ }^{426}$ Ibid., pg.7.

${ }^{427}$ Ibid., pg. 10 .

${ }^{428}$ Ibid.

${ }^{429}$ Ibid., pg.8.
} 
Surveyors considered eight remedial measures to address the denudation issue. Space does not permit a full discussion of these measures, ${ }^{430}$ so I will only focus on those that involve the exercise of territoriality, that is, the attempt to control the surveyed area and the conduct of existing owners. Under the "Protective Strip Method," the federal government would purchase land - 3 chains wide (198 feet or 60 meters) - on both sides of every highway; the protective strip method would be comparatively inexpensive, but would not prevent cutting beyond the highways in areas that were still highly visible. ${ }^{431}$ On the opposite end of the cost spectrum is the "National Park Method" wherein the federal government would acquire, whether through purchase or expropriation, the entire area, and more: "Compared with the average sized national park the lands covered by this report are quite small in extent, and to be a success, additional areas would have to be secured." ${ }^{432}$ In addition to prohibitive land acquisition costs, surveyors cautioned "that following the announcement of such policy there would be a rush of owners to remove as much timber as possible before disposing of the land." ${ }^{433}$ Between these two methods is the "Land Purchase Method." Since the surveyors recommended this remedial measure to address the denudation issue, their description is quoted here in full:

This would involve purchase, parcel by parcel, of land necessary for [the] protection of scenic values with the object of ultimately securing all the lands suitable for inclusion in a federal district. Under such a scheme only such areas as

\footnotetext{
430 The "Education Method" would require foresters to inform woodlot owners about selective cutting methods, that is, how much mature timber could be cut on an annual basis without depleting the supply. The advantage of education is its relatively inexpensive cost. But, it would take several years for the results to be noticeable, if at all as some woodlot owners would still engage in indiscriminate cutting for short term profits, particularly during the Great Depression. The "Bonus Method" would pay woodlot owners for the additional cost of operating following a selective cutting system determined and supervised by a forester. Although the cost would not be very great, surveyors recognized that "there is the possibility of complications and dissatisfaction amongst owners, and a cumbersome machinery would have to be set up to provide proper supervision." The "Stumpage and Ground Rental Method" would have the federal government cut timber on a selective basis, and compensate woodlot owners. But the cost of compensation to woodlot owners would be comparable to the methods involving land purchases. Finally, the "Provincial Legislation Method" would, as its name implies, have the provincial government pass legislation requiring owners "to cut their woodlands under the direction and control of forest officers." Ibid., pgs.12-15.

${ }^{431}$ Ibid., pg. 13.

${ }^{432}$ Ibid., pg. 15.

${ }^{433}$ Ibid.
} 
bare merchantable timber and are immediately required for scenic purposes would be purchased immediately. Additional areas would be purchased when conditions were favourable or as the timber approached maturity. Such a method would tend to curb unrestricted cutting, since cutting by the owner would exclude the lands from the present purchase plan. Management of the areas purchased for the removal of timber under [this] selection system would provide financial returns as a partial offset to carrying charges. ${ }^{434}$

A subsequent memorandum from the surveyors indicated that 6,220 acres should be purchased immediately at an estimated cost of $\$ 108,290$, or approximately $\$ 17.40$ per acre. ${ }^{435}$ In order to prevent land speculation, the survey was kept confidential. It was, however, shared with those League members who had instigated it. ${ }^{436}$

The newly re-elected Mackenzie King government was in possession of a survey of denudation in the Gatineau Hills, and a recommended approach for addressing it. ${ }^{437}$ Given King's involvement in, and support of the FWPL, the beginning of a land acquisition program whether for a national park or for woodlands protection - seemed imminent. As shown in the next section, the Prime Minister had reservations which needed to be overcome. And, while King continued to view the proposals for Gatineau Park as a national park, the recommendation made in the Lower Gatineau Woodlands Survey was carried out, almost to a tee as the federal government proceeded to assemble the park territory on a parcel-by-parcel basis (albeit with several major and controversial expropriations documented in the following chapters).

\section{The creation of Gatineau Park}

In the years between the re-election of Prime Minister King (October 1935) and the creation of Gatineau Park (July 1938), local newspapers continued to publish alarmist articles about the

\footnotetext{
${ }^{434}$ Ibid., pgs.14-15.

435 Cameron, D.R. 1936, Apr. 17. Memorandum. RG34 Vol. 265.190(1).

${ }^{436}$ Cameron, D.R. 1935, Dec. 11. Letter from D.R. Cameron to J.M. Wardle. RG39 Vol.69.49171.

${ }^{437}$ Cram, H.R. 1935, Dec. 17. Letter from H.R. Cram to T.A. Crerar. RG39 Vol.69.49171.
} 
denudation issue, and to demand intervention from the federal government. The establishment of a national park was frequently advocated as the solution to the denudation issue. A common component to national park proposals in this period was the construction of a new highway, and the proposed Gatineau Park was not an exception. So, when the Ottawa Citizen interviewed six Members of Parliament (MPs), it was to get their views on "the proposal for the creation of a national park in the Gatineau Hills round Ottawa and the construction of a modern highway rendering this great scenic district more accessible to the thousands of Canadians and tourists who annually visit the Capital." ${ }^{438}$ As it was the Great Depression, the highway would be built as part of an unemployment relief program. The proposal for a national park and highway received unanimous support from the multi-partisan group of MPs that were interviewed by the Citizen.

The calls for a national park in the Gatineau Hills were probably unnerving for cottagers at Kingsmere and Meech Lakes. In July 1936, the Meech Lake Association (MLA) unanimously passed a resolution reiterating the need to resolve the denudation issue, and pressuring the government to acquire lands:

Whereas the indiscriminate cutting of fuel wood continues on the hillsides adjoining Meech Lake, and

Whereas this wholesale and indiscriminate destruction of woodlands is destroying the natural beauty of this area, and

Whereas the use of heavy trucks in drawing out this wood is very injurious to the highways, and

Whereas large numbers of men could be employed in improving this area from a forestry standpoint rather than destroying it,

This Association respectfully suggests that the Federal Government should acquire the mountainous sections of this area so as to preserve it as part of a general scheme for the beautification of the Capital of Canada. ${ }^{439}$

\footnotetext{
${ }^{438}$ Hume, J.A. 1936, June 20. "Prominent Members of House Endorse Scheme for Park in Gatineau." Ottawa Citizen.

${ }^{439}$ Gill, A. 1936, July 14. Letter from G.A. Gill to W.E. Matthews. RG34 Vol.265.190(1).
} 
Copies of the MLA resolution were sent to the Department of Interior, Federal District

Commission, and Prime Minister Mackenzie King.

At the same time, the President of the Ottawa Ski Club, and Charter member of the

FWPL, Charles Mortureux, also applied pressure directly on Prime Minister King. President

Mortureux's letter explained to King in letter that:

... The Ottawa Ski Club has done what it could by way of purchasing threatened stands of timber, but our resources are now exhausted.

Knowing your interest in the trees and hills which should belong to the Capital of Canada, we hope that the excellent survey made during the last administration may enable the present government to arrest the destruction of the Woodlands, at least those of the immediate environs of Ottawa. ${ }^{440}$

Clearly, the pressure was mounting on the Prime Minister to do something about the denudation of the Gatineau Hills, but he deferred to the Minister of Interior, T.A. Crerar. ${ }^{441}$ As confirmed below, King dithered on the denudation issue because of concerns over the loss of privacy and earlier accusations of a conflict of interest.

Historian Alisa Apostle has already observed the ambiguity of the solutions put forward as " $[\mathrm{t}]$ he Gatineau preservation plan was sometimes endorsed as a national park project, and other times as a highway or parkway drive through the country." ${ }^{442}$ Local newspapers increasingly advocated for "a national memorial parkway...into the lovely hill country north of Ottawa"443 That same Ottawa Citizen article, probably written by Ottawa Citizen editor and FWPL member, Charles Bowman, added that the parkway "would help ensure the preservation

\footnotetext{
${ }^{440}$ Mortureux, C.E. 1936, June 12. Letter from C.E. Mortureux to W.L..M King. RG34 Vol.265.190(1). Mortureux's letter was forwarded to the Department of Interior, which replied that "the matter is complicated by questions of jurisdiction and the fact that the lands involved are all under private ownership..." Crerar, T.A. 1936, June 26. Letter from T.A. Crerar to C.E. Mortureux. RG34 Vol.265.190(1).

${ }^{441}$ Henry, H.R.L. 1936, June 18. Letter from H.R.L. Henry to C.E. Mortureux. RG34 Vol.265.190(1).

${ }^{442}$ Apostle, A. 1997. Ibid., pg.73.

${ }^{443}$ No author. 1936, Apr. 25. "Federal Parkway Work." Ottawa Citizen.
} 
of the woodlands as a Canadian place of beauty and a joy forever." 444 But Bowman did not indicate how the parkway would, in actuality, preserve the Gatineau Hills (thus it was assumed that the lands adjacent to the parkway would be acquired and preserved). In a subsequent article, the Citizen Editor (this time identifying his authorship) sketched the route of the proposed parkway which would extend from the Champlain Bridge "past Kingsmere to Meech Lake, around by Philippe Lake to Wakefield." ${ }^{445}$ King's worries about accusation of a conflict of interest by his political opponents must have been reaffirmed when Bowman projected that "the national memorial parkway would go past the summer home of Premier Mackenzie King."446 Bowman's article also touches on the territoriality of Kingsmere cottagers:

The lake is virtually surrounded by the cottages of summer residents. It used to be possible to picnic by the lake shore, but the wayfarer may no longer dip a tea kettle in the lake without a guilty feeling of trespassing in someone's front garden. Perhaps the day may come when the public, on good behavior, will be again permitted to sit by the lakeside, even in the seclusion of the silver birches so carefully preserved through the years since the present prime minister of Canada as a young civil servant in the Department of Labor - first built himself a summer cabin in the woods. ${ }^{447}$

Newspaper articles calling for the preservation of Gatineau Hills continued, urging long-overdue action: “...under the pressure of routine business from day to day, one government after another has passed by without taking the necessary steps to establish the national park in the neighboring hills."448 The Gatineau national park/parkway was positioned as a much-needed unemployment relief project with widespread public support. ${ }^{449}$

In August 1936, the Federal District Commission approached the National Employment Commission about the possibility of "a National Parkway in the Gatineau district adjacent to

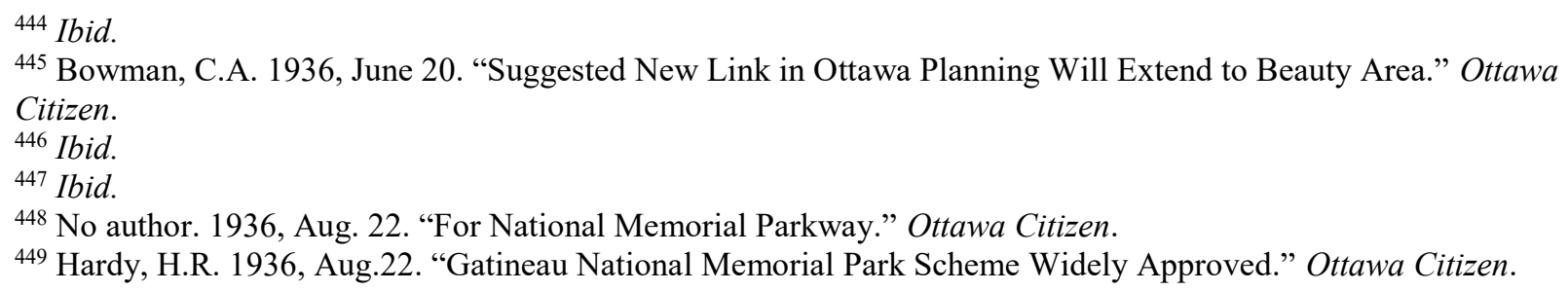


Ottawa as an unemployment project." The proposed relief project would employ 200 workers, and would cost $\$ 380,000$ to build a looped parkway from Champlain to Masham, for a total of 60 miles $(97 \mathrm{~km})$ of new roads. Of course, there was no mention - either by Bronson or in local newspapers - of park facilities, or of the fact that the parkway would be of immense benefit to the existing cottage communities at Kingsmere and Meech Lakes. Rather, in the formal proposal, Bronson outlined how construction of the parkway would be carried out during the summer. During the winter, he added, the workforce could be employed for forestry operations on the first 12,000 acres of parkland purchased by the FDC, at a cost of $\$ 120,000$ (or $\$ 10$ per acre). The total estimated cost of the parkway, unemployment relief program, and initial purchases for the 12,000 -acre park amounted to $\$ 756,000 .^{450}$

Eventually, the park area would encompass between 75,000 to 100,000 acres $(30,351$ to 40,468 hectares), as additional lands were purchased and put under FDC control. ${ }^{451}$ Interestingly, FDC Vice-Chairman Bronson's submission suggested that "[a]ny expropriation of lands by the Commission in this area will, it seems, require the co-operation of the Province of Quebec."452 But scribbled in the margin notes: "No FDC [Federal District Commission] act ensures this."453 The 1928 amendment to the FDC Act that gave the FDC powers of expropriation in Quebec without the co-operation of the provincial legislature - was so secretive that even high-ranking officials were not aware of it.

FDC archived files do not contain the response from the National Employment Commission concerning the parkway unemployment relief project. Nevertheless, NCC historian Dennis Messier suggests that it was the precursor to the establishment of Gatineau Park. Harry

\footnotetext{
${ }^{450}$ Ibid., pg.3.

${ }^{451}$ Bronson, F.E. 1936, Aug. 24. Letter from F.E. Bronson to A.B. Purvis, Re: Proposed development of a National Parkway in the Gatineau district adjacent to Ottawa as an unemployment project. RG34 Vol.265.190(1), pg.6.

452 Ibid.

${ }^{453}$ Ibid.
} 
Baldwin, the President of the Federal Woodlands Preservation League (and long-time friend of Mackenzie King) had been appointed to the National Employment Commission "and participated in drafting the plan to create Gatineau Park." ${ }^{454}$ Messier underscores Baldwin's involvement in pushing for the parkway unemployment relief project: "He was insistent with the Prime Minister that this opportunity should not be missed. It was not until he was convinced that King was finally resolved to take action, in late 1937, that he passed on the role of League president to Roderick Percy Sparks." ${ }^{455}$ As shown below, Messier misrepresents the timing of the events leading up to the park's formal establishment, and downplays the role of the new League President in persuading a reluctant Prime Minister to "finally" take action.

Moreover, there is nothing to suggest that Mackenzie King agreed with the costly parkway unemployment relief program put forward by the FDC. Federal officials may have discussed the program with the provincial government in the fall of $1936,{ }^{456}$ but it is unclear what the newly-elected Quebec Premier, Maurice Duplessis, thought of it. The Quebec Premier did approve $\$ 125,000$ in provincial funds to improve and widen the existing Gatineau highway. ${ }^{457}$ Further, it was rumored that Duplessis wanted the provincial government to establish a national park in the Gatineau Hills. ${ }^{458}$ While the provincial government appeared to want to act independently from the federal government, the federal MP for Wright constituency, Quebec, strongly endorsed the FDC parkway proposal. ${ }^{459}$ And, of course, local newspapers continued

\footnotetext{
454 Messier, D. 2007. "Harry Baldwin.” The Gatineau Park Chronicle. Ottawa: NCC, pg.3.

${ }^{455}$ Ibid.

${ }^{456}$ No author. 1936, Sept. 16. "For Gatineau National Parkway." Ottawa Citizen.

${ }^{457}$ No author. 1936, Sept. 26. "Gatineau Highway Improvement.” Ottawa Citizen.

${ }^{458}$ No author. 1936, Dec. 9. "Gatineau Park and Hull Court-house Plans Remembered.” Ottawa Citizen. And, in March 1937, a Union nationale MLA tried to put the request for a national park in the Gatineau county before the provincial legislature. No author. 1937, Mar. 24. “Asks National Park In Gatineau County.” Ottawa Citizen.

${ }^{459}$ Cram, H.R. 1937, Mar. 16. Memorandum. RG34 Vol.265.190(1).
} 
publishing articles endorsing parkway construction. ${ }^{460}$ With this momentum, the FDC submitted, in March 1937, the Gatineau parkway proposal to the Minister of Finance, Charles Dunning, requesting $\$ 100,000$ in the fiscal year $1937-1938$ to purchase 12,000 -acres of land needed for the parkway. ${ }^{461}$ FDC Chairman Bronson included a memorandum affirming that the FDC had "the necessary powers to expropriate lands in the Province of Quebec, as elsewhere, without cooperation by the provincial legislature. ${ }^{242}$ Duncan MacTavish of the Federal Woodlands Preservation League wrote letters in support of the FDC parkway proposal to Finance Minister Dunning and the Minister of Mines and Resources, T.A. Crerar. ${ }^{463}$ Ultimately, the FDC parkway proposal did not receive a positive response from either of these Cabinet Ministers. ${ }^{464}$

As mentioned, there was an important leadership change in the Federal Woodlands Preservation League. In October 1937, Harry Baldwin resigned as League President, indicating that he "regretted that the objects of the league had not been fulfilled under his presidency." 465 Vice President Sparks was then elected President. With the League's approval, President Sparks met with Minister Dunning to (re)negotiate the parkway proposal that had been submitted earlier by the FDC to the Department of Finance. Sparks convinced Minister Dunning that land acquisition, not parkway construction, was the most immediate concern regarding the denudation of the Gatineau Hills. ${ }^{466}$ Following Dunning's instruction, Sparks then met with the Federal District Commission, and had it modify and resubmit its proposal to the Finance Department.

\footnotetext{
${ }^{460}$ No author. 1936, Nov. 13. "J.C. McCuaig Tells of Plans for New Gatineau Highway." Ottawa Citizen; No author. 1936, Nov. 24. "The Woodlands North of Ottawa." Ottawa Citizen; No author. 1936, Nov. 26. "Interest in Gatineau Parkway." Ottawa Citizen; No author. 1937, Jan. 7. "Work for War Veterans.” Ottawa Citizen.

${ }^{461}$ Bronson, F.E. 1937, Mar. 5. Letter from F.E. Bronson to C.A. Dunning, Re: Proposed development of a National Parkway in the Gatineau Valley adjacent to Ottawa. RG34 Vol.265.190(1).

462 Bronson, F.E. 1937, Mar. 5. Letter from F.E. Bronson to C.A. Dunning, Re: Powers of Expropriation in the Province of Quebec. RG34 Vol.265.190(1).

${ }^{463}$ MacTavish, D. 1937, Mar. 6. Letter from D. MacTavish to T.A. Crerar. RG34 Vol.265.190(2).

464 Jackson, C.W. 1937, Mar.23. Letter from C.W. Jackson to F.E. Bronson. RG34 Vol.265.190(2).

${ }^{465}$ No author. 1937, Oct. 11. "Urge Immediate Action to Preserve Gatineau's Hillsides." Ottawa Citizen.

${ }^{466}$ Sparks, R.P. 1937, Dec. 13. Memorandum Re: Activities of the Federal Woodlands Preservation League. Document obtained from Jean-Paul Murray.
} 
Thus, the FDC requested $\$ 200,000$ ( $\$ 100,000$ in the first year) from the Department of Finance towards the purchase of 12,000 acres and preliminary engineering surveys for a "National Parkway."467

Upon receipt of the revised FDC proposal, the Finance Minister sought the approval of the Prime Minister. King's journal entry is quoted here in full as it reveals why he had not addressed the denudation issue since his re-election in October 1935:

I had a short talk with Dunning who seemed pleased with his Toronto visit, and who spoke to me about the Improvement Commission's [sic] desire to go on with preserving some of the Gatineau wood toward Meech Lake for National Park purposes, etc. He wanted to know what I wished to have done. I told him that the matter had stood over last year because of my feeling that people might think I was seeking to improve property around Kingsmere. I have come to the conclusion this year that I should not let possible misunderstanding of my ownership at Kingsmere stand in the way of a much-needed preservation of the forest. I told him I wished them to go ahead with the work, though personally it meant less in the way of seclusion for myself on the way to and from Kingsmere to have even the Meech Lake district open to tourists. I believe that we owe it to the Capital of Canada to save that part of its environment. I think he will agree to the $\$ 100,000$ being appropriated for that purpose. ${ }^{468}$

So, contrary to the views of the NCC historian Messier that Sparks was a mere "figurehead," 469 the new FWPL President was the catalyst to the chain of events that culminated in the Prime Minister's approval of the revised FDC proposal. But King still had a national park in mind, as was confirmed by a subsequent journal entry: "This morning, on opening the paper, I saw a reference Sparks had given at a dinner regarding property at Meech Lake, being taken for a

\footnotetext{
${ }^{467}$ Bronson, F.E. 1937, Dec. 15. Letter from F.E. Bronson to C.A. Dunning. RG34 Vol.265.190(2).

${ }^{468}$ King, W.L.M. 1937, Dec. 20. Diary entry. Library Archives Canada, Item 18593. pg.1148. Available from http:/www.bac-lac.gc.ca/eng/discover/politics-government/prime-ministers/william-lyon-mackenzieking/Pages/item.aspx?IdNumber=18593\&. Last accessed 24 Jan. 2017.

${ }^{469}$ Messier, D. 2007. "Roderick Percy Sparks." The Gatineau Park Chronicle. Ottawa: NCC, pg.4. Messier's entry on Sparks provides the most superficial detail on the remainder of Sparks' role in the Gatineau Park, quoted here in full: "from 1947 to 1954, he [Sparks] served as chairman of the Advisory Committee on Gatineau Park. In this capacity, as part of the capital planning committee established by Mackenzie King and led by the Federal District Commission, he co-signed one of the first planning documents for the Park." Ibid. Thus, the NCC historian overlooks Sparks' controversial attempt to change the FDC land management policy
} 
national park. I told Dunning, the other day, I hoped he would allow it to be done." ${ }^{270}$ Local newspapers also informed readers that the establishment of a national park in the Gatineau Hills was imminent. ${ }^{471}$ The Ottawa Journal wrote:

Officers of the Federal Woodlands Preservation League have hopes that at the coming session, Parliament will set aside the small sum of money necessary for the initial step in the creation of a national park in the Gatineau. It is to be hoped their optimism is warranted. The Prime Minister at least does not need to be convinced of the wisdom of such a step, because he knows from personal observation how serious are the inroads of the wood-cutters in this lovely area at the door of the Capital. ${ }^{472}$

But, as per the FDC request, Parliament was voting on $\$ 100,000$ in federal funds " $[\mathrm{t}]$ o provide for acquisition of land and surveys in connection with the national parkways in the Gatineau Valley adjacent to Ottawa." ${ }^{473}$ Once again, local newspapers moved back and forth between reporting on a national park and “... a national memorial parkway..."474

On July 1, 1938, Parliament approved \$100,000 “as an initial vote to purchase the more important woodlands from the point of view of forest conservation and to provide funds for surveys to determine the feasibility and cost of constructing a scenic driveway through the park and connecting with the present terminus of the driveway system at the Aylmer road." 475 Unlike Canada's national parks, Parliament did not pass legislation to set out the purposes and boundaries of Gatineau Park. Rather, as the Federal District Commission explained in its Annual Report, Gatineau Park was to simply become "a large natural park of some 20,000 acres in the

\footnotetext{
${ }^{470}$ King, W.L.M. 1938, Jan 19. Diary entry. Library Archives Canada, Item 18704, pg. 68. Available from http:/www.bac-lac.gc.ca/eng/discover/politics-government/prime-ministers/william-lyon-mackenzieking/Pages/item.aspx?IdNumber=18704\&. Last accessed 24 Jan. 2017.

${ }^{471}$ No author. 1937, Dec. 27. "Urging Purchase of 12,000 Acres In Gatineau.” Ottawa Journal; No author. 1938, Jan. 19. "National Park In Meech Lake Area Probable. Ottawa Citizen; No author. 1937, Dec. 27. "Urging Purchase of 12,000 Acres In Gatineau." Ottawa Journal.

472 No author. 1937, Dec. 28. "A Good Time to Start on a Gatineau Park.” Ottawa Journal.

473 No author. 1938, Feb. 4. "Provision In Estimates for Gatineau Park." Ottawa Citizen.

${ }^{474}$ No author. 1938, Feb. 4. "Gatineau National Park At Last Taking Shape." Ottawa Citizen; see also No author. 1938, Feb. 25. "Support Proposal of National Park." Ottawa Citizen; No author. 1938, Feb. 4. "For National Memorial Parkway." Ottawa Citizen; see also No author. 1938, Feb. 4. "100-Mile Scenic Gatineau Parkway To Realize Long-Mooted Project." Ottawa Journal.

${ }^{475}$ Federal District Commission. 1938-1939. Annual Report. Ottawa: King's Printer, pg. 6.
} 
Gatineau hills adjacent to Meech, Harrington, and Philippe lakes, fifteen miles northwest of Ottawa. ${ }^{" 476}$ Had the confusion over the park's status been restricted to the newspaper reading public, my argument about a failed national park would be unconvincing. However, the next chapter details how the FDC expropriated landowners under the pretense of establishing a national park, and how the Meech Lake Association tactically referred to Gatineau as a national park in an attempt to convince municipal and provincial authorities to enact development bylaws and improve local roads.

\section{Conclusion}

This chapter has documented the territorialities of two significant and overlooked groups in the scholarship on Gatineau Park: the Algonquin and cottagers at Kingsmere and Meech Lakes. Gatineau Park is situated on unceded Algonquin territory, which consists of the entire Ottawa River watershed. Prior to European contact, the semi-nomadic Algonquin had subdivided their lands into family hunting territories. Algonquin territoriality regulated interactions among families and helped ensure a steady supply of game. It was an example of the social definition of territory as kinship determined the area in which one lived. The first section described how the territorial integrity of the Algonquin was undermined by white colonists, and the various failed attempts by Algonquin leaders to assert their territoriality and, later, demand compensation from the colonial government. Although the extent to which the Algonquin occupied the Gatineau Hills remains unclear, it is significant enough to warrant consideration by the park's current governing body, which has indicated that the Algonquin will be consulted when identifying “cultural resources" and "indigenous heritage." Moreover, the Algonquin themselves are re-

\footnotetext{
${ }^{476}$ Ibid.; see also No author. 1938, June 30. "House Approves Start on new Gatineau Park: Item of $\$ 100,000$ Passed." Ottawa Citizen.
} 
asserting territoriality in a contemporary context, once again demanding compensation for the illegal occupation of their lands. Considering this, I argue that the Algonquin must be involved in any discussions about the territorial reconfiguration of Gatineau Park as a national park. The legitimacy of any changes to Gatineau Park's legal status rests on obtaining the consent of the Algonquin, who might agree that it should be administered along the lines of a national park.

The second section turned to the territorialization of the Gatineau Hills, as township boundaries were surveyed and the first land grants were issued to immigrant families. For several decades, the "pioneer" families of the Gatineau Hills - after whom lakes, roads, and other topographical features were named - tried to make a living as farmers producing cash crops. But the rocky and thin soils of the Gatineau Hills were not conducive to agriculture. Rather, the area was much better suited to mining and lumbering, but neither expanded beyond a cottage industry scale. The 1870 s signaled a "new era" for the Gatineau Hills, which increasingly became the "recreational territory" of Ottawa residents with increasing accessibility of the area, first through the railroad and then through automobility. First, political and economic elites began purchasing lands and building cottages, while most "summered" at one of the hotels in Chelsea or the lodges at Kingsmere and Meech Lakes. After World War I, the Gatineau Hills became a summer and winter playground, when the Ottawa Ski Club purchased lands at Camp Fortune. With the increasing popularity of the Gatineau Hills came a growing number of "undesirables." The Kingsmere Property Owners' Association and Meech Lake Association functioned as private forms of local government, seeking to "beautify" the area as well as control access to the lakes. To maintain class exclusivity and racial homogeneity, the KPOA wanted the power to review all property sales and rentals. Though it never obtained this, KPOA members tried to pool their 
financial resources to stop Jews from purchasing Kingsmere property. The KPOA and MLA were seeking to make the Gatineau Hills into a privatopia for elite cottagers.

The third and fourth sections further demonstrated how, through the property owner associations, cottagers exercised territoriality beyond their property limits to control adjacent land owners. To be more specific, cottagers wanted to prevent economically depressed farmers from cutting their woodlots. In addition to destroying the scenic beauty of the area, clear-cut woodlots decreased property values. As indicated in the third section, preservation of scenic beauty and land values were motivating factors for the Meech Lake Association to establish a separate organization, the Federal Woodlands Preservation League, which, on behalf of all Canadians, advocated for the preservation of the Gatineau Hills adjacent to the national capital. The League's well-documented campaign pressured the federal government, not only to recognize the significance of the denuded hillsides, but also to conduct a survey of the clearcutting and recommend remedial measures. The 1935 Lower Gatineau Woodlands Survey found that cutting in the area was not severe from a forestry standpoint, but conceded that it impaired scenic values. After reviewing several remedial measures, including the possibility of establishing a national park, the surveyors recommended the "Land Purchase Method" to preserve scenic values without requiring a large initial expenditure.

Though Mackenzie King was a vocal supporter of the FWPL while he was the Leader of the Opposition, the fourth section examined why there was almost a three-year delay between his re-election as Prime Minister and the establishment of Gatineau Park. King was reticent because he had been accused of a conflict of interest associated with the federal government building a parkway to Kingsmere. Further, he was worried about a loss of privacy. Finally, there was the fact that the Gatineau Hills were under the jurisdiction of the Quebec government which had 
repeatedly told its federal counterpart that it would not intervene on the rights of private land owners. The fourth section traced the behind-the-scenes negotiations between the FWPL President, Percy Sparks, and the Minister of Finance, Charles Dunning, as they refined earlier proposals that included a costly parkway built by relief workers. King was far less interested in a parkway to Kingsmere, but he did want to establish a national park. And, when approached by Dunning, the Prime Minister believed that he was approving a national park. But, as shown in the next chapter, "Gatineau Park" was closer to a "federal woodlands" than a national park or "national parkway." Whatever the case, farmers lost their woodlots because of the Gatineau Park, while cottagers kept their privatopia in the middle of it. The immediate effects of this territorialization on both groups, the municipalities where the park is located, and federalprovincial relations are examined in Chapter 3. 


\section{Chapter 3: Territorialization of Gatineau Park}

We park the car at the foot of the hill. It is perfectly safe here. There is no time limit. And no one to enforce it if there were. That is the point of the whole story. For miles to the west and to the north, intersected by trails more or less clearly defined, the woods extend. Negotiating a slope and entering the bush we come face to face with a sign. THIS PARK IS YOURS.

\section{W.J. Hurlow, letter to the Ottawa Citizen, September 1940}

I find that these expropriations smell dictatorship for miles and are totally anti democratic. This, for a project that could be placed in the category of luxuries. Oh! if it was for a matter where public interest would really be concerned, as for example a telephone line, an electric power house or even a road, I would approve such expropriations provided that the expropriated parties receive an adequate compensation.

I know different parties that possess hundreds of acres right in the center of the Park involved, close to Meech and Mousseau [Harrington] Lakes and who have not yet been expropriated. ${ }^{477}$

Marcel B. Bonnier, letter to MP, January 1947

\section{Introduction}

Despite repeated calls for a national park adjacent to Canada's capital, this chapter documents the territorialization of a "mixed-use/ownership area" influenced by the privatopia at Kingsmere and Meech Lake. As indicated in Chapter 1, the territorialization of Canada's national parks requires the federal government to acquire full title to all lands within park boundaries. As per Section 91(1A) of the Constitution Act, the federal government needs this proprietorship to legislate and control the park territory. Given the prevalence of privately-owned and provincial public lands in most areas, the creation of a national park also necessitates a federal-provincial agreement. Historically, it is the responsibility of the provincial government to undertake land

${ }^{477}$ Bonnier, M.C. 1947, Jan. 20. Letter from M.B. Bonnier to L.J. Raymond. RG34 Vol.267.190(13). 
acquisitions in advance of transferring full title to the federal government which then develops and administers park facilities.

This chapter documents the territorialization of Gatineau Park from its inception (1938) to the first master plan (1952). This territorialization, I argue, had several shortcomings. First, the Federal District Commission (FDC) did not draw park boundaries. Initially, it acquired a central nucleus of lands around Kingsmere and Meech Lakes, and then proceeded to add surrounding land in a piece-meal fashion. The park's boundaries were not determined until after the Second World War, and they were not codified until a 1960 Order-in-Council, just after the National Capital Commission (NCC) assumed control of the park. Second, even though FDC officials approached the Quebec government in February 1940 about establishing a national park in the Gatineau Hills, ${ }^{478}$ the federal government never obtained the approval of the provincial government, meaning that the creation and enlargement of "Gatineau Park" violated Quebec's territorial integrity. Third, the FDC expropriated lands under the pretense of establishing a national park. Ignoring the fact that there was no federal-provincial agreement, ${ }^{479}$ the FDC might have succeeded in establishing a national park had its land acquisition program been superimposed over the entire park territory. As shown below, some privately-owned lands were expropriated, while others were left undisturbed. The park's status as a mixed-use/ownership area benefitted the privatopia at Kingsmere and Meech Lakes, but also resulted in the removal of cottages at Philippe and La Pêche Lakes. The latter are located farther away than the lakes in the so-called "heart of the park."

This chapter begins by describing the launch of the land acquisition program, as the FDC expropriated farmers and woodlot owners to prevent further cutting in the Gatineau Hills. The

\footnotetext{
${ }^{478}$ No author. 1940, Feb. 1. "FDC Officials, Quebec Cabinet, Talk Park Plans." Ottawa Citizen; see also No author. 1940, Feb. 1. "La province dottée d'un parc national sans qu'il lui coûte un seul sou." Quebec Evening-Journal. 479 in 1973, the Quebec government transferred provincial Crown lands for park purposes)
} 
first section also shows how the Meech Lake Association (MLA), having succeeded in protecting the woodlands surrounding its cottage community, took further steps to control development in the area through the enactment of a municipal bylaw. Following this assertion of territoriality, cottagers-turned-park residents lobbied provincial and municipal governments, with the support of the FDC, for improvements to local roads which were experiencing heavier traffic from the "new national park."

The World War II period has been overlooked in the scholarship on Gatineau Park because the FDC suspended the land acquisition program. However, in 1941, the FDC began developing the park's first public facilities at Philippe Lake. In response to this development, the MLA exercised territoriality by protesting rumored plans for public facilities at Meech Lake. In addition to describing these related events, the second section documents the frustrations of park visitors who were sometimes denied access to Kingsmere, Meech, and Pink Lakes. Following the War, the Federal Woodlands Preservation League was reactivated. League President Percy Sparks submitted a plan proposing to enlarge the park territory, and to improve its accessibility through the construction of the Gatineau Parkway. Given Sparks' foundational role in the park's establishment, he was then elected Chairman of the Advisory Committee on Gatineau Park (ACGP) by its members. This section examines the post-war territorialization of Gatineau Park, which was coordinated, in large part, by the ACGP. On its recommendation, FDC consolidated ownership by expropriating remaining property-owners at Philippe Lake. The ACGP went one step further, proposing the expropriation of privately-owned lands at Kingsmere Lake, but the FDC did not act on this recommendation. The territoriality of park residents limited public 
access to what was supposed to be the most "democratic national park," owing to its proximity to the cities of Ottawa and Hull. ${ }^{480}$

The third section describes the first report of the Advisory Committee as well as FDC acquisitions of the Mackenzie King, Bronson, and Edwards estates. Following the expropriation of Philippe Lake residents, ACGP Chairman Sparks pushed harder for the public ownership of the park, and frequently referred to making Gatineau Park into a national park. But other members of the advisory committee, especially Meech Lake resident, Senator John J. Connolly, did not share this view. The next chapter describes the internal divisions within the ACGP over the park's status as a mixed-use/ownership area, which boiled over in the first master plan. Due to Sparks' "radical" views, the FDC scrapped the ACGP. But Sparks was not prepared to give up on the national park ideal, and, in the mid-1950s, made the FDC's Gatineau Park land acquisition program a public issue.

\section{Launch of the parkland acquisition program}

Even before Parliament had formally approved funds, the Federal District Commission began preparations for the land acquisition program. As indicated in the last chapter, in 1934, the Federal Woodlands Preservation League had obtained data on property ownership from the provincial and municipal authorities ahead of the Lower Gatineau Woodlands Survey (1935). Thus, the FDC had to update this data through the Gatineau Registry Office. ${ }^{481}$ As with the Lower Gatineau Woodlands Survey, the FDC enlisted the co-operation of the Department of Mines and Resources which, in addition to providing aerial surveys of the Gatineau Hills, loaned

\footnotetext{
${ }^{480}$ See No author. 1949, Apr. 12. "Gatineau Park: A Great Achievement.” Ottawa Journal.

${ }^{481}$ Cram, H.R. 1938, Mar. 25. Letter from Letter H.R. Cram to L.J. Raymond. RG34 Vol.265.190(2); see also Cram, H.R. 1938, Feb. 23. Letter H.R. Cram to L.J. Raymond. RG34 Vol.265.190(2).
} 
the services of a land surveyor, surveying instruments, camp equipment, and two trucks. ${ }^{482}$ The FDC hired E.S. Richards, "timber cruiser and land valuator," 483 to survey woodlots slated for acquisition and interview owners.

In late May 1938, Richards, who would go on to become the first Gatineau Park Superintendent, began his survey of the area covered by the Lower Gatineau Woodlands Survey. He found that "[p]ractically all of these lots have been either logged since that time or are in the process of being cut over now." ${ }^{484}$ When carrying out interviews with owners, Richards noted that local residents and farmers "do not leap to quick decisions." 485 They were asking: "How will we obtain our fuelwood when the Government takes over lands?" 486 He indicated that the "inability to satisfactorily answer this question is a big hindrance to buying lands directly." 487 As it was the Great Depression, residents and farmers depended on the woodlots to provide for their basic needs. Recognizing this, Richards concluded that expropriation was necessary: “After giving the matter much thought I do not believe that it will be feasible to make individual arrangements." 488 The FDC accepted Richards' view, and no attempt was made to negotiate values with property owners. Thus, besides the preparatory work, the first concrete step in the parkland acquisition program consisted of an expropriation order. ${ }^{489}$

\footnotetext{
${ }^{482}$ For aerial surveys and other requests, see McLeish, J.W. 1938, May 7. Letter from J.W. McLeish to A.K. Hay. RG34 Vol.268.190(2) and Bronson, F.E. 1938, May 14. Letter from F.E. Bronson to C. Camsell, re: Gatineau Parkway Project. RG34 Vol.265.190(2).

${ }^{483}$ Federal District Commission. 1938, Sept. 20. Minutes of Meeting. RG34 Vol.269-A-2(1).

${ }^{484}$ Richards, E.S. 1938, June 13. Memorandum, re: Purchase of Gatineau lands for proposed park. RG34 Vol.265.190(2).

${ }^{485}$ Richards, E.S. 1938, July 9. Memorandum, re: Purchase of Woodlands. RG34 Vol.265.190(2).

${ }^{486}$ Richards, E.S. 1938, Aug. 2. Memorandum, re: Acquisition of Forest Lands, Lower Gatineau Region. RG34 Vol.265.190(2).

${ }^{487}$ Ibid.

488 Ibid.

489 There is a historical amnesia within the park's current body, the National Capital Commission, about Gatineau Park land acquisitions. This is how it recounts the parkland acquisitions: "By 1939 a total of 6,500 hectares had been purchased. ... Land was [subsequently] acquired by negotiated purchase, rather than by expropriation, over a 40 year period." Emphasis added. National Capital Commission. 1985. A Very Special Mandate: The Story of the National Capital Commission. Ottawa: NCC, pg.34.
} 
Figure 3.1: Cadastral map of woodlot expropriated for Gatineau Park

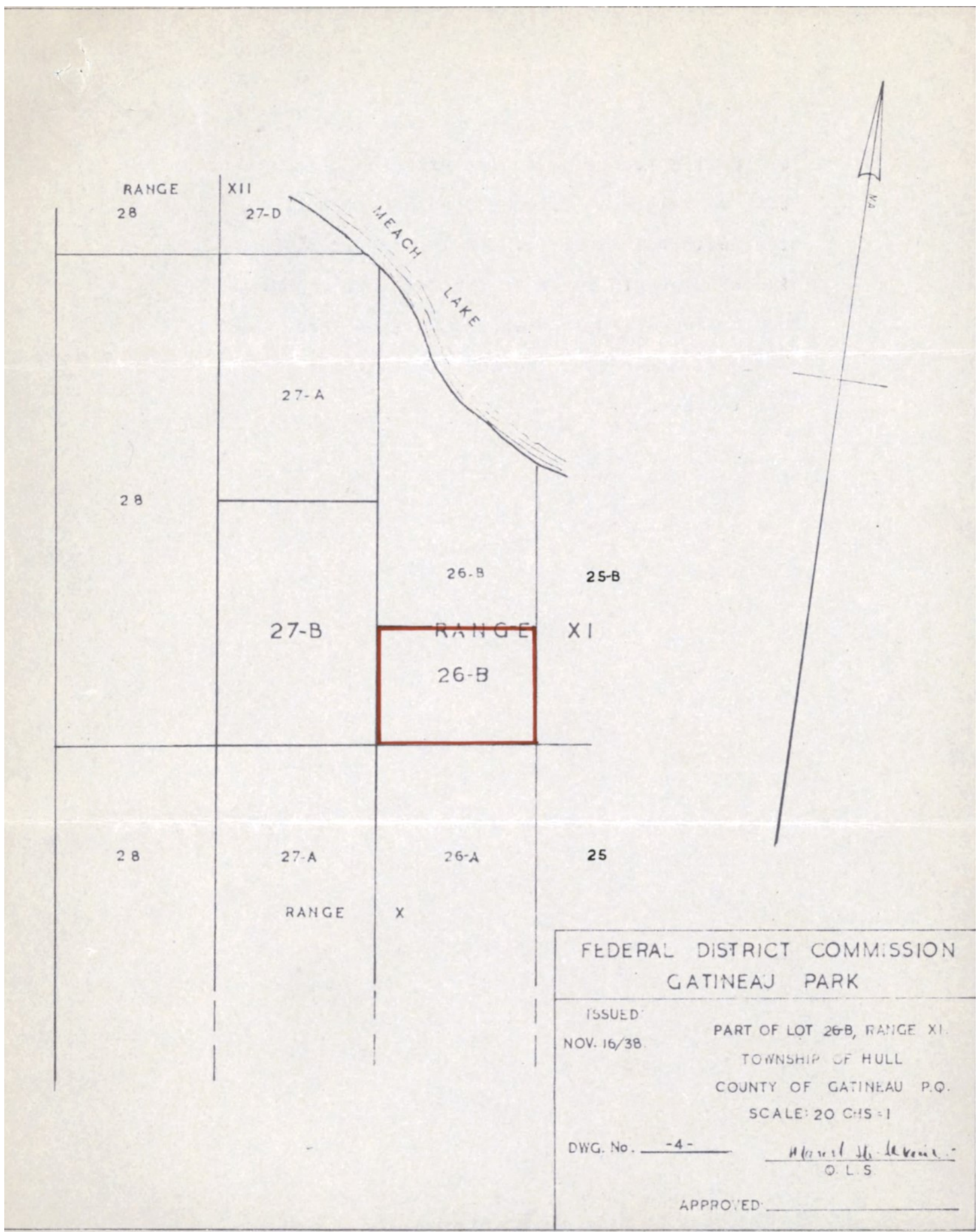

Source: RG34 Vol.269.190-C(1) 
The FDC obtained permission to expropriate lands in the Gatineau Hills through three Orders-in-Council; PC 2476 approved \$80,000 for the acquisition of 5,900 acres. ${ }^{490}$ The notice of expropriation read: "As you are doubtless aware, forest lands are now being acquired by the Federal District Commission, Ottawa, in the Gatineau district for the purpose of creating a national park [sic]. Among other lands it has been decided to include [1].... township of West Hull, containing [2]... acres, more or less, of which, it is understood, you are the owner."491 Government officials also misled farmers and other landowners by claiming that the FDC was "making a national park." ${ }^{\prime 92}$ In the fall of 1938, the FDC purchased 1,546 hectares $(3,281$ acres), and expropriated 913 hectares (2,258 acres). ${ }^{493}$ Expropriation notices were sent to 111 property owners, and five cases were taken to the Exchequer Court. ${ }^{494}$

An aggrieved Mulvihill family wrote to their neighbor, Prime Minister Mackenzie King, about the inadequate compensation (\$550) offered by the FDC for their 20 hectares (50 acres). ${ }^{495}$ Richard Mulvihill informed King that the expropriation had deprived his family of work opportunities for:

\footnotetext{
${ }^{490}$ Orders-in-Council PC 2193 (1938, Sept. 8), PC 2476 (1938, Oct. 4), and PC 2477 (1938, Oct. 4). Copies can be found in RG34 Vol.265.190(3).

${ }^{491}$ Federal District Commission. 1938, Oct. 21. Notice of Expropriation. RG34 Vol.265.190(3).

${ }^{492}$ Cram, H.R. 1938, Oct. 21. Letter from H.R. Cram to F. Mulvihill. RG34 Vol.269.190-C(1); Cram, H.R. 1938, Oct.29. Letter from H.R. Cram to W. Ryan. RG34 Vol.265.190(3); Richards, E.S. 1939, Mar. 6. Letter from E.S. Richards to L. Depuis. RG34 Vol.266.190(5); Cram, H.R. 1941, Mar. 7. Letter from H.R. Cram to J.A.C. Champion. RG34 Vol.266.190(8).

${ }^{493}$ Federal District Commission. 1938-1939. Annual Report. Ottawa: King's Printer, pg.6.

${ }^{494}$ Federal District Commission. 1939-1940. Annual Report. Ottawa: King's Printer, pg.7; see also Cram, H.R. 1944, Mar. 28. Letter from H.R. Cram to W.F. Lothian. RG34 Vol.267.190(11).

${ }^{495}$ Mrs. Mulvhill pleaded with the Prime Minister, invoking her longevity as an area resident. She wrote: "The Federal District Commission has put a price on it, to give us $\$ 550$ which is far far from the price we wish to accept. Furthermore forbidding us to have any more interference with the property. Now this property has been in our name for a number of years I would think more than 60 years so you know what that means to us to be offered a mean amount of $\$ 550$ and especially with a lake on it and so much wood also pine. I write to ask you what step I can take so surely we are not going to lose our property we value so much. We need money we are not wealthy. We would like to educate our children but are not able to do so. If you will kindly answer this I will be greatly obliged. This property I refer to is in from Booths Hill it is known as the Leahy property and now belongs to my sister and myself." Mulvihill, R. and Leahy, M. 1938, Dec. 31. Letter from. R. Mulvihill and M. Leahy to W.L.M. King. RG34 Vol.265.190(3).
} 
... 3 boys and myself. We do now know what they [Federal District Commission] mean to do. They have offered us a price which we cannot accept. It is ideal park grounds, and we are satisfied to part with it for some, but must get a price for it. It's not only for the present time it gives us a living but for years to come. I value it at $\$ 50000.00[!]$.

We would like to get work from the Commission but so far we do not know what they mean to do. We lost our crop last year with the hail storm and cannot afford to remain idle. We are all willing to work four of us if there is something to do. ${ }^{496}$

The Mulvihill family was among the five expropriation cases disputed in the Exchequer Court of Canada, which increased the compensation paid by the FDC to $\$ 1,150 .{ }^{497}$

In addition to affecting families, farmers, and woodlot owners, the first expropriations adversely impacted the Township of West Hull, much in the way that Conservative MLA, Aimé Guertin, had anticipated: by prohibiting wood cutting, the exercise of federal territoriality resulted in a loss of employment for residents and, by implication, loss for the municipality. As soon as the parkland acquisition program began, West Hull raised its concerns with the FDC:

Economic conditions in this municipality have reached a state of emergency which calls for immediate action to avoid distress and practical starvation threatening a considerable portion of the population. These conditions have been brought about by the destruction of crops by hail, and aggravated greatly by the fact that a large area of wooded land has been expropriated by the Federal Government where employment of wood cutters had been in the past a means of livlihood [sic] for numbers of heads of families who are in great distress to-day. ${ }^{498}$

Following this complaint, the FDC established a \$30,000 unemployment relief project, which lasted four months and was organized and supervised by the Ministry of Labour. ${ }^{499}$ At its peak, 280 workers were employed, “...men of Hull, Deschenes, and other districts in the province of Quebec who with their families are in need of immediate financial assistance." ${ }^{500}$ In addition to clearing trails and putting up signage for the newly-established park, the relief project built the 4-

\footnotetext{
${ }^{496}$ Mulvihill, R. 1939, Jan. 3. Letter from R. Mulvihill to W.L.M. King. RG34 Vol.265.190(3).

${ }^{497}$ No author. 1939. Feb. 1. "Judgements Fix Price of Land for Gatineau Parkway." Ottawa Citizen.

${ }^{498}$ Municipality of West Hull. 1939, Jan. 3. Letter from Secretary Treasurer to F.E. Bronson. RG34 Vol.265.190(3).

${ }^{499}$ Federal District Commission. 1938-1939. Ibid., pg.7.

${ }^{500}$ Cram, H.R. 1939, Feb. 4. Letter from H.R. Cram to W.C. Ronson. RG34 Vol.270.190(D1).
} 
kilometre Dunlop Road that connected Meech Lake Road with the Ottawa Ski Club's Camp Fortune, greatly enhancing the accessibility of the ski club. ${ }^{501}$

Around the time that Dunlop Road was built, Gatineau Park Superintendent Richards approached the private not-for-profit ski club about forming a partnership. ${ }^{502}$ The trail network in the Gatineau Park converged on Camp Fortune. As pointed out by Richards, this made "it difficult for the general public to stay off the land owned by the ski club."503 The FDC Chairman, F.E. Bronson, proposed that the OSC transfer ownership of its Camp Fortune property - but not the lodges - to the FDC, in exchange for federal investments in ski tows, lodges, and other facilties required by the Club. Although OSC trails and a ski jump were already located on parklands owned by the FDC, Chairman Bronson's offer as "it [the Club] was convinced that to lose the ownership of the land would eventually mean the disintegration of the Ski Club."504

While there was opposition to the FDC land acquisitions, there was also continued support for the expansion of Gatineau Park. Claiming that the expropriations for "Gatineau National Park" "505 were not "in the least encroaching on Quebec's provincial jurisdiction," 506 the Ottawa Citizen urged that "[ $\mathrm{t}]$ here should be provision in next year's estimates to carry on this work for the general advantage of Canada." ${ }^{, 507}$ With the start of the parkland acquisitions, the President of the Federal Woodlands Preservation League, Roderick Percy Sparks, was

\footnotetext{
${ }^{501}$ No author. 1939, Feb. 7. "Make Progress Improving Road To Camp Fortune." Ottawa Journal; See also No author. 1939, Mar. 3. "Workmen Making Progress on New Parkland." Ottawa Journal; and No author. 1939, June 23. "Gatineau Parkway Progress." Ottawa Citizen.

${ }^{502}$ Richards, E.S. 1939, Feb. 16. Letter from E.S Richards to J.C Leslie. RG34 Vol.265.190(3).

${ }^{503}$ Richards, E.S. 1940, Jan. 24. Memorandum, re: 1. Building by the Ottawa Ski Club of a ski tow part of which may be on land owned by the commission, 2. Free use by non-members of the Ottawa Ski Club trails at all times in the year. RG34 Vol. 266.190(6).

${ }^{504}$ Advisory Committee on Gatineau Park. 1952, May. Report on Master Plan for the Development of the Gatineau Park. Ottawa: Federal District Commission, pg.11.

${ }^{505}$ No author. 1939, Jan. 3. "In the Gatineau Hills." Ottawa Citizen.

${ }^{506}$ No author. 1938, Nov. 15. "The Gatineau National Parkway." Ottawa Citizen.

${ }^{507}$ Ibid.
} 
“immensely pleased." ${ }^{508}$ But the FWPL President continued to apply pressure on federal officials, with letters to the Finance Minister and FDC Chairman advocating for the park's further expansion to prevent further denudation in the Gatineau Hills:

May I again express the view that no other country in the world would allow these beautiful hillsides so close to the National Capital to be ruthlessly stripped of their beauty to produce fuel wood. The members of the League, while thanking you sincerely for what has already been done, would strongly urge that this work be continued.

This undertaking, when initiated, had the support of representatives of all parties in the House of Commons, and I feel sure that should a further amount be included in next year's estimates, that support would be continued. ${ }^{509}$

Sparks' request was endorsed by FDC Chairman Bronson. ${ }^{510}$ In the 1939-1940 federal budget, another $\$ 100,000$ was approved to acquire lands for Gatineau Park. ${ }^{511}$ Through Order-in-Council PC1662, the got permission to acquire 13,000 acres for $\$ 95,000 .^{512}$ In the $1939-1940$ fiscal year, land acquisitions resulted in an addition of 3,507 hectares to Gatineau Park, bringing its overall size to 4,844 hectares. Before the outbreak of World War II, the FDC had spent $\$ 107,761.94$ on acquisitions and $\$ 6,124$ on legal costs, mostly to deal with the expropriations. ${ }^{513}$

As shown in Figure 3.1, land acquisitions were made around the cottage communities at Kingsmere and Meech Lakes. As President Sparks told local newspapers, "the land being bought by the Federal District Commission is not farm land, or summer cottages, but rough wooded hillside mostly." ${ }^{14}$ With several FDC officials owning property within the park, namely, Chairman Frederic Bronson and Commissioners Duncan MacTavish and Stanley Lewis (Mayor of Ottawa), it should not be surprising that park residents were confident about their long-term

\footnotetext{
${ }^{508}$ No author 1938, Oct. 11. "National Parkway in Gatineau Beginning to Take Shape." Ottawa Journal.

${ }^{509}$ Sparks, R.P. 1938, Dec. 28. Letter from R.P. Sparks to C.A. Dunning. RG34 Vol.265.190(3).

${ }^{510}$ Bronson, F.E. 1939, Jan. 9. Letter from F.E. Bronson to W.L.M King. RG34 Vol.165.190(3).

${ }^{511}$ Cram, H.R. 1939, June 15. Letter from H.R. Cram to W.C. Ronson. RG34 Vol.266.190(4).

512 Privy Council of Canada. 1939, June 29. P.C. 1662. RG34 Vol.268.190(5).

${ }^{513}$ Federal District Commission. 1939-1940. Ibid., pg.7.

${ }^{514}$ No author 1938, Oct. 11. Ibid.
} 
residency in the park. Indeed, the FDC Secretary, Haldane Cram, in response to a question about public fishing rights in the park, indicated "that Kingsmere and Meech Lakes are not included within the present boundaries of the Gatineau Park of the Federal District Commission." ${ }^{515}$ His letter went on to add: "Regarding fishing rights in these two lakes, I have been informed that in connection with Kingsmere Lake these are held privately by the adjoining landowners, while Meech Lake is open to the public in this respect." ${ }^{516}$ As indicated in the last chapter, the public could not dip a tea kettle in Kingsmere, let alone fish in it.

Confident in its future residency, the Meech Lake Association, passed a resolution, in August 1939, seeking to regulate future the development of its privatopia in the newlyestablished "national park":

Whereas the summer colony of Meech Lake has now grown to the stage where it is desirable that some control should be exercised on the type of cottage to be erected in the future, and

Whereas it is to the common advtage [sic] of the municipality of West Hull and to the Federal District Commission administering the Gatineau National Park [sic] that the Meech Lake district should be developed as a desirable summer colony and hence, the erection of jerry-built cottages for rental, and the natural sequence, undesirable tenants, discouraged,

Be it therefore resolved that the municipality of West Hull be requested to pass a By-law requiring a building permit from the West Hull Council before any future building operations are carried on, and that

The Federal District Commission be requested to do whatever may be in their power to assist the Meech Lake Association in its endeavours to improve the Meech Lake district as a desirable summer colony. ${ }^{517}$

\footnotetext{
${ }^{515}$ Cram, H.R. 1940, Mar. 8. Letter from H.R. Cram to M. Yuill. RG34 Vol.266.190(6).

${ }^{516}$ Ibid.

${ }^{517}$ Dodge, C.M. 1939, Aug. 18. Letter from C.M. Dodge to S. Lewis. RG34 Vol.266.190(5).
} 
Figure 3.2: Cottagers at Meech Lake (1942)

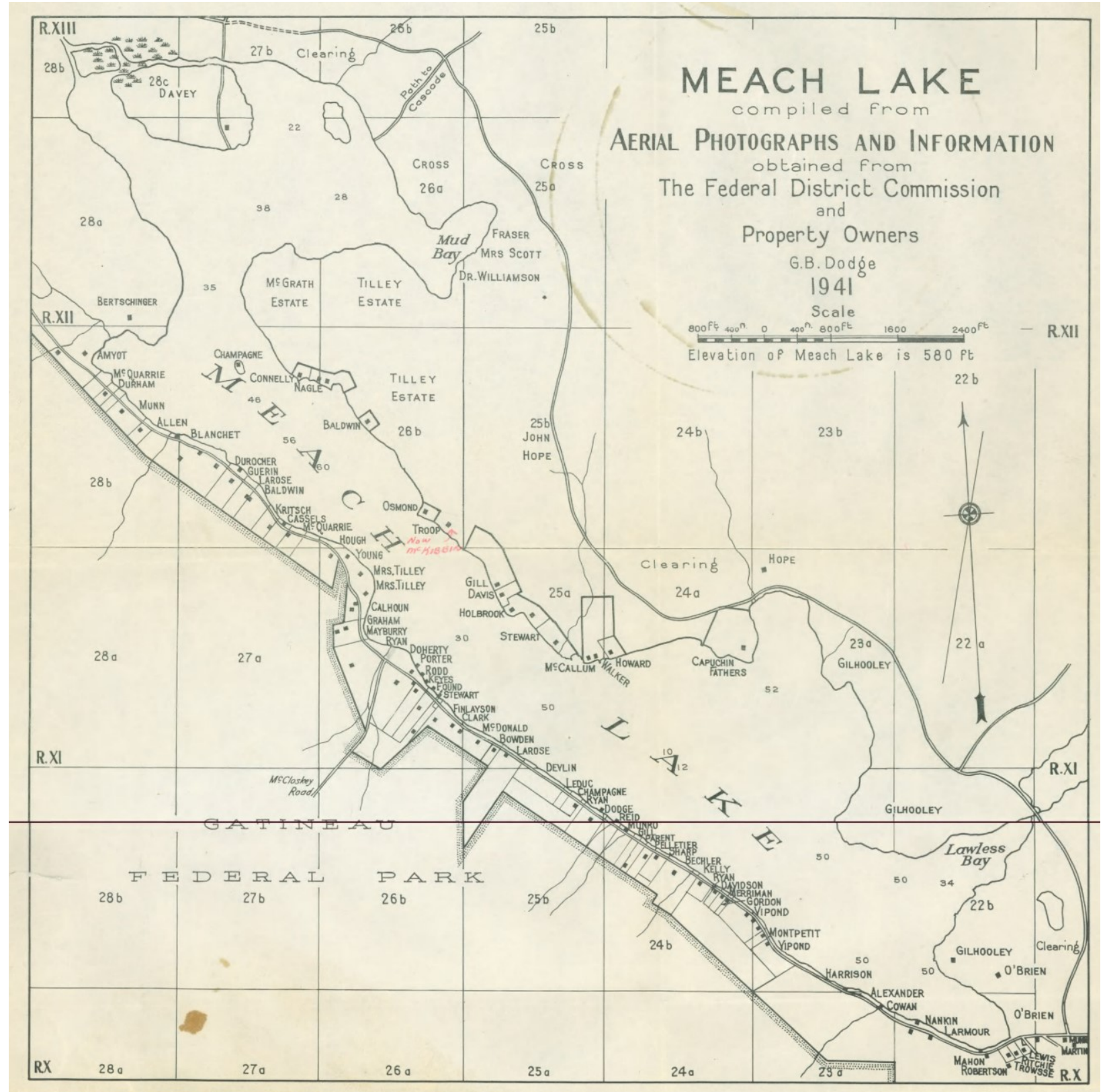

Source: RG34 Vol.273.190-N(1)

A draft municipal bylaw was included with the MLA resolution. The proposed bylaw would require municipal permits for any new buildings within 1000 feet of Meech Lake. The preamble offers the justification for the bylaw as "the District of Meech Lake in the Municipality of West Hull adjoins lands which the Federal District Commission are developing as a National Park [sic] and it is desirable for the general welfare and improvement of the said Meech Lake District in 
the said Municipality and in the interests of the inhabitants thereof to preserve the natural beauty and ensure a sanitary condition of the said district." 518 Through the bylaw, the MLA would indirectly but nevertheless effectively influence future development in the Meech Lake area; this was an exercise of territoriality in the interests of park residents. The MLA did, however, invoke the "public interest" when asking provincial highway authorities to pave Meech Lake Road. ${ }^{519}$ As pointed out by MLA Secretary Connolly, the four-mile gravel road was experiencing heavier traffic since it was "one of the entrances to the national park established by the Federal District Commission." ${ }^{520}$ In a letter to provincial authorities, Connolly argued that "unless the highway approach to the park is in satisfactory condition, the general public will not patronize the park." 521 The Meech Lake Association enlisted the Commission and municipal authorities to also pressure provincial road authorities. ${ }^{522}$ Despite this support, the MLA was unsuccessful in its attempt to have Meech Lake Road surfaced, which remained a difficult road for cars to travel on.

As an indication of the level of co-operation between the FDC and MLA, the Gatineau Park Superintendent extensively revised and substantially expanded the MLA draft bylaw. Superintendent Richards extended the area covered by the bylaw to include 1000-feet from Meech Lake, Meech Lake Road, Kingstree Road, and "[o]ne thousand feed from the centre line(s) of any other road(s) which exists or shall exist in that portion of Hull township lying south of the Meech Lake Road." ${ }^{, 523}$ Richards altered the bylaw so that FDC approval would be required before the municipality could issue building permits. Further, the application of the bylaw was

\footnotetext{
${ }_{518}$ Meech Lake Association. 1939, Aug. Draft Building By-law for the Meech Lake District. RG34 Vol.266.190(5).

${ }^{519}$ Meech Lake Association. 1940, Nov. 28. Minutes of Executive Meeting. RG34 Vol.266.190(8).

${ }^{520}$ Connolly, J.J. 1942, Jan. 18. Letter from J.J. Connolly to T.D. Bouchard. RG34 Vol.266.190(9).

${ }^{521}$ Ibid.

522 Dodge, G.B. 1941, July 14. Letter from G.B. Dodge to H.R. Cram. RG34 Vol.266.190(9); see also Cram, H.R. 1941, Aug.9. Letter from H.R. Cram to A. Bergeron. RG34 Vol.266.190(9); and Municipality of West Hull. 1942, Apr. 7. Resolution of Municipality of West Hull. RG34 Vol.266.190(9).

${ }^{523}$ Richards, E.S. 1939, Sept. 16. Draft Building By-law for the Meech Lake and Kingsmere District by the Municipality of West Hull under authority of article 392A of the Municipal Code of Quebec. RG34 Vol.266.190(5).
} 
extended to controlling businesses at Kingsmere and Meech Lakes requiring a municipal permit for every kind of business besides farming. ${ }^{524}$ Richards also pointed out that, as per Article 392A of the Quebec Municipal Code, municipal governments only obtained the authority to zone private property once their population reached 20,000. Thus, an amendment to the Municipal Code was needed for the Municipality of West Hull to enact the bylaw.

The MLA subsequently altered the draft by-law so that responsibility for approving new buildings came under the exclusive jurisdiction of the Municipality of West Hull. This latter change proved unacceptable to the FDC. As pointed out by the Secretary Cram, "this draft bylaw creates an absurd position in that the commission, the ranking organization respecting beautification matters, would be required to defer officially to a country municipality for the right to carry out developments on its property particularly with respect to buildings." 525 The subsequent version of the bylaw exempted FDC lands. The Municipality of West Hull, for its part, amended the bylaw to cover its entire territory. ${ }^{526}$

But, as pointed out above, the municipality did not have the legal authority to pass such a comprehensive bylaw. Rather an amendment to the Quebec Municipal Code was needed, and the provincial government was only willing to do this through a private members' bill, at a cost of $\$ 500$ to the municipality. At the behest of the MLA and Municipality of West Hull, ${ }^{527}$ FDC Chairman Bronson asked the Quebec government to support the legislative amendment, and that it waive the $\$ 500$ cost to the municipality. ${ }^{528}$ But the cash-strapped municipality ultimately paid the costs and, in June 1940, the amendment was passed in the Quebec legislature. The purpose of

\footnotetext{
524 Ibid.

${ }^{525}$ Cram, H.R. 1939, Nov. 20. Memorandum to F.E. Bronson, re: Meech Lake Association Building Bylaw. RG34 Vol.266.190(5); see also Cram, H.R. 1939, Nov. 27. Letter from H.R. Cram to A.J. Pelletier. RG34 Vol.266.190(5). ${ }^{526}$ Municipality of West Hull. 1940, June 3. By-Law 147. RG34 Vol.266.190(7).

${ }^{527}$ Church, C.H. 1940, Apr. 9. Letter from C.H. Church to H.R. Cram. RG34 Vol.266.190(6); Connolly, J.J. 1940, Mar. 5. Letter from J.J. Connolly to H.R. Cram. RG34 Vol.266.190(6).

${ }^{528}$ Bronson, F.E. 1940, Apr. 18. Letter from F.E. Bronson to O. Drouin. RG34 Vol.266.190(6).
} 
Bill No. 64, An Act to amend the Municipal Code, was "to give every village corporation and to every local corporation the territory whereof adjoins a national park the special power to regulate constructions that section 392A now gives to municipalities adjoining a city of twenty thousand souls. ${ }^{, 529}$ Of course, Gatineau Park was not - and is not - technically a national park, but such an inconvenient technicality did not deter the Municipality of West Hull. Following the amendment, it passed Bylaw No. 147. ${ }^{530}$ After negotiating the approval of federal and provincial authorities, the municipality could now control development on behalf of the Kingsmere-Meech Lake privatopia. As MLA Secretary, John J. Connolly, remarked of the event, "this was a most unusual accomplishment for a local community association...It demonstrates what can be done by people who have an interest in such matters. It also demonstrates government ownership and control may not be the only method of assisting to preserve beauty." 531

To control future development, however, the municipal bylaw was a necessary but not sufficient condition. Lacking financial resources, the Municipality of West Hull failed to enforce it, such that "unsightly structures" and "undesirable tenants" continued to frustrate park residents, such as Prime Minister Mackenzie King, ${ }^{532}$ and FDC officials. ${ }^{533}$ The MLA called for the enforcement of the bylaw, and for better co-operation between federal and municipal authorities to ensure its proper enforcement. ${ }^{534}$ But the MLA had, perhaps, done as much as it could. As shown in the next section, this was not the final expression of territoriality by park residents, who would successfully oppose public access to their privatopia in the park.

\footnotetext{
${ }^{529}$ Legislative Assembly of Quebec. 1940, June 17. Bill No.64 An Act to amend the Municipal Code. Quebec: King's Printer. MG.26J10 Vol.27.

${ }^{530}$ Bronson, F.E. 1943, Aug. 18. Letter from F.E. Bronson to W.J. Turnbull. RG34 Vol.266.190(10).

${ }^{531}$ Connolly, J.J. 1952, May. Ibid., pg.23.

532 Turnbull, W.J. 1943, Aug. 12. Letter from W.J. Turnbull to F.E. Bronson. RG34 Vol.266.190(10).

${ }^{533}$ Bronson, F.E. 1943, Aug. 18. Ibid.

${ }^{534}$ Connolly, J.J. 1952, May. Ibid., pg.23.
} 


\section{Territorialization of Philippe Lake and limited accessibility}

The scholarship on Gatineau Park glosses over the World War II period. Even with the onset of War, however, the Federal District Commission continued to expand, maintain, and even develop its new park, albeit on a much-reduced scale. Officially, the FDC suspended the land acquisition program during the War. In 1940-1941, the FDC spent, based on agreements entered the previous year, $\$ 33,829.80$ to acquire another 2,242 acres of land. ${ }^{535}$ In $1941-1942$, the Commission reduced its land acquisitions: it spent $\$ 5,693$ to acquire 1,589 acres. ${ }^{536}$ There were no further expenditures on land acquisitions during the War. So, while the land acquisition program was suspended, eventually, the FDC added 3,800 acres to the park during the War, bringing its territory to 15,800 acres of a projected 25,000 acres. ${ }^{537}$ In total, the FDC paid $\$ 152,600$ (or $\$ 9.60$ per acre) on the land acquisitions. ${ }^{538}$

Alongside of this, the FDC annually spent, on average, $\$ 16,480$ on park administration throughout the War. This amount includes staff salaries and park improvements. Gatineau Park Superintendent Richards and a small staff were employed to enforce FDC policy; they were given the same enforcement powers as police officers, game wardens, and fire rangers. ${ }^{539}$ Work crews were hired on a seasonal basis to carry out a "limited" amount of trail cutting, ${ }^{540}$ and make "some" improvements to the park's trail network. ${ }^{541}$ Beaver, having become extinct in the Gatineau Hills during the French fur trade, were re-introduced to the park through the co-

\footnotetext{
${ }^{535}$ Federal District Commission. 1940-1941. Annual Report. Ottawa: King's Printer, pg.5.

${ }^{536}$ Federal District Commission. 1941-1942. Annual Report. Ottawa: King's Printer, pg.4.

${ }^{537}$ Federal District Commission. 1942-1943. Annual Report. Ottawa: King's Printer, pg.2; see also Federal District Commission. 1945-1946. Annual Report. Ottawa: King's Printer, pg.4.

${ }^{538}$ Cram, H.R. 1942, Feb. 12. Letter from H.R. Cram to L.A. Richard. RG34 Vol.266.190(9).

539 Ibid.

${ }^{540}$ Federal District Commission. 1939-1940. Ibid., pg.4.

${ }^{541}$ Federal District Commission. 1940-1941. Ibid., pg.5.
} 
operation of provincial authorities. ${ }^{542}$ Owing to an absence of predators, the beaver population proliferated, much to the consternation of farmers adjacent to the park whose fields were flooded. ${ }^{543}$ Throughout the War, the roads leading into the park were plowed during the winter, with the municipality and Ottawa Ski Club reimbursing the FDC for service costs. FDC expenditures on park administration were denounced by the Department of Finance: "these undertakings are unnecessary and wasteful in wartime..." ${ }^{, 54}$ FDC Chairman Bronson defended the FDC expenditures on the park, stressing the "healthful recreation" which the it provided, not only to the general public, but also to members of the armed forces. ${ }^{545}$

Although not mentioned by Bronson in his reply to the Department of Finance, the FDC had, in 1941, established the park's very first public facilities, with a public beach and camp-site on the south-west shore of Philippe Lake. ${ }^{546}$ The northern half of the lake was occupied by cottagers at the time, such as the Heggtveit family, who had built their first cottage during the Great Depression using stones from the site and rejected lumber. ${ }^{547}$ As the furthest in the "Chain of Three Lakes," Philippe Lake was the last to have a cottage community occupy its shores. With Meech Lake "outside” of Gatineau Park and the entirety of Harrington Lake surrounded by privately-owned lands, that is, the estate of Colonel C.M. Edwards, Philippe Lake was the only remaining lake to be developed by the FDC. However, the road leading up to the lake was

\footnotetext{
542 Ibid.; see also Cram, H.R. 1940, Aug. 2. Letter from H.R. Cram to L.A. Richard, re: Beaver for FDC Gatineau Park. RG34 Vol.266.190(7).

${ }^{543}$ County of Gatineau. 1953, June 10. Resolution No.23 of the meeting of the Corporation of the County of Gatineau. RG34 Vol.268(17); see also Cram, H.R. 1957, Aug. 19. The Tale of the Beaver in Gatineau Park. RG34 Vol.268.190(A1); and, for a spirited defense of the beaver, see Habgood, H.M. 1953, July 27. "Beaver In Gatineau Park." Ottawa Citizen.

${ }^{544}$ Ronson, W.C. 1942, July 27. Letter from W.C. Ronson to H.R. Cram. RG34 Vol.266.190(10).

${ }^{545}$ Bronson, F.E. 1942, July 31. Letter from F.E. Bronson to W.C. Ronson. RG34 Vol.266.190(10). Gatineau Park was also used by the armed forces for training purposes, see Cram, H.R. 1942, Jan. 16. Letter from H.R. Cram to W.W. Slack. RG34 Vol.266.190(10).

${ }^{546}$ No author. 1941, Feb. 26. "Creating Breach and Camp-Site Near Wakefield.” Ottawa Citizen.

547 As recounted by Ruth Heggtveit, the family had "lived on porridge and trout from the lake." Heggtveit, R. no date. "History of the ruins at Lac Philippe." Unpublished document obtained from Bill McGee.
} 
"practically impassable." ${ }^{548}$ So, before the public facilities were opened, the FDC tried to convince provincial highway authorities to improve the road leading to Philippe Lake, but it met with little to no success. ${ }^{549}$ Whereas Meech Lake cottagers wanted the road leading to their cottage community improved for "Gatineau National Park," clearly the prerogative for the park was road improvements to Philippe Lake.

Figure 3.3: Beaver culled in Gatineau Park

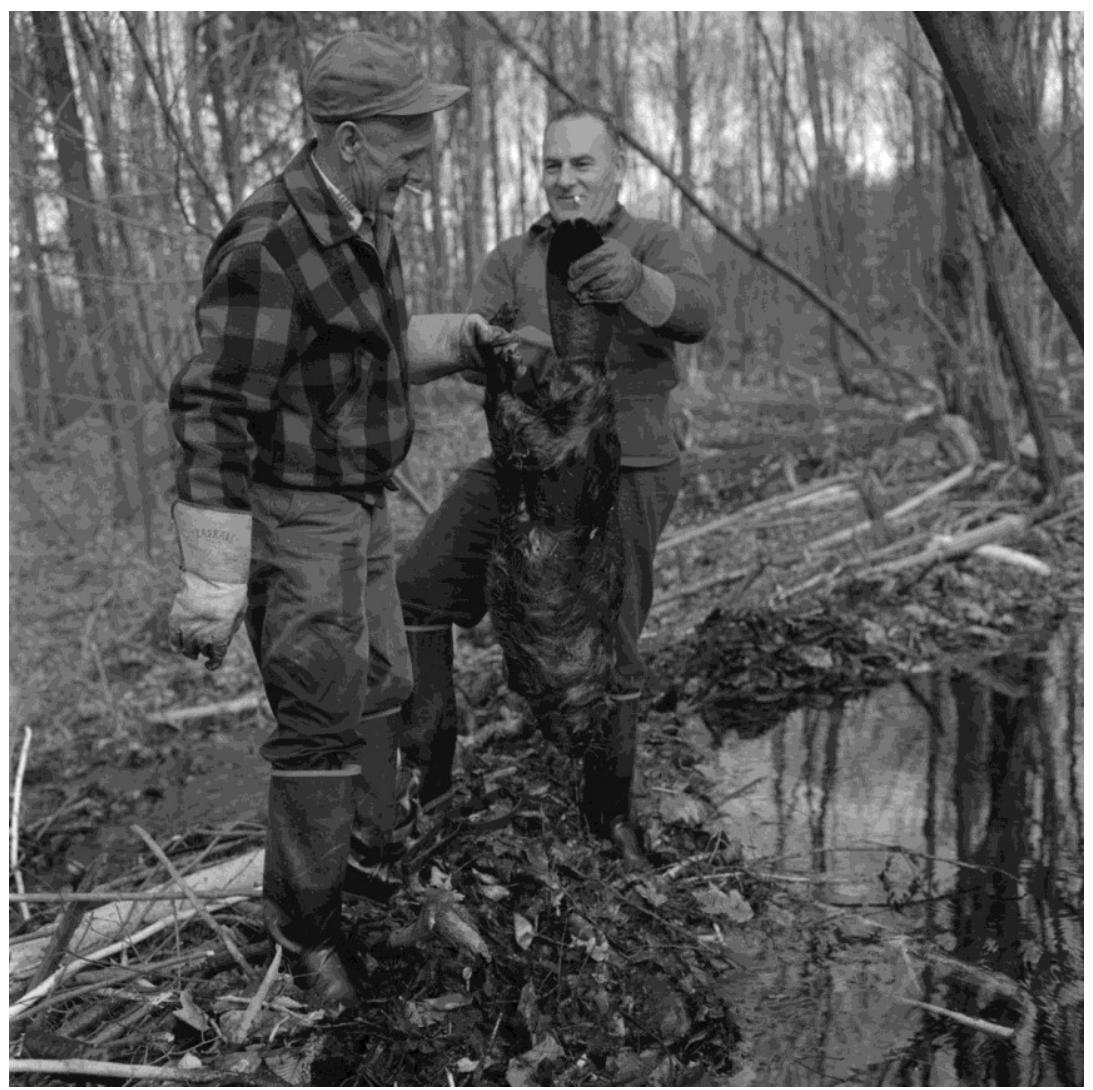

Source: Library Archives Canada E011160345

\footnotetext{
${ }^{548}$ Cram, H.R. 1940, Oct. 28. Letter from H.R. Cram to E. Gohier. RG34 Vol.266.190(8). This problem persisted after the War. As noted in 1947 by the Ottawa Journal, one "[s]tumbling-block in the way of wider public use of the Park, officials admitted today, is the road running from Meech to Philip's [sic] Lake. The stretch of this road running for some five miles along the east shore of Harrington Lake, centre body of water in the three-lake chain, is impassable for automobiles." No author. 1947, Feb. 5. "Choosing Sites in Development of Gatineau Park." Ottawa Journal.

${ }^{549}$ See Cram, H.R. 1940, Oct. 28. Ibid.; and Cram, H.R. 1941, July 29. Letter from H.R. Cram to E. Gohier. RG34 Vol.266.190(9); and Cram, H.R. 1944, Feb. 4. Letter from H.R. Cram to E. Gohier. RG34 Vol.267.190(11). Though it is unclear the extent of the repairs to the road, a positive response can be found in the reply from the Quebec's chief highway official; see Gohier, E. 1944, Feb. 10. Letter from E. Gohier to H.R. Cram. RG34 Vol.267.190(11). But as pointed out in the footnote above, passage on the road leading to Philippe Lake remained difficult even after the War.
} 
From the outset, the beach and camp-site at Philippe Lake proved immensely popular. In its first year, the new public facilities received 4,000 visitors. ${ }^{550}$ Following the war, Philippe Lake would receive 4,000 visitors in a single day, with overcrowding becoming such a serious issue that park officials had to sometimes turn visitors away. ${ }^{551}$ The new public facilities at Philippe Lake did not receive a warm welcome from the Meech Lake Association. The MLA protested rumored plans that the FDC was going to open Meech Lake to the public. As recounted by the Ottawa Citizen:

Officials of the Federal District Commission today spiked a rumor to the effect that they were to establish a public swimming beach at Meech Lake. The commission has no property on the lake and is not buying any, it was said [by FDC officials].

The commission first heard the rumor when a delegation from the association of Meech Lake residents waited on the commission to protest against the establishing of a public beach. The delegation was assured nothing along these lines was being done. The commission a year ago did some work at Philippe Lake, the second lake above Meech and public swimming is permitted there. ${ }^{552}$

In fact, there is no plan for Meech Lake among FDC archived files. It is also notable that there is no documentation of this meeting between the MLA and FDC. As shown in Chapter 6, Meech Lake was not opened to park visitors until 1970, and the MLA strongly protested this decision. In the meantime, the lack of public access to the park was, for one visitor, an "intolerable state of affairs.” In 1947, Arthur Alsvold wrote the FDC Chairman:

Now that Meech Lake property owners association has succeeded in barring all from the lake but themselves, I thought Pinks lake [sic] might be a substitute and decided to drive up there for a swim yesterday. Several hundred yards from the

\footnotetext{
${ }^{550}$ Richards, E.S. 1942, Feb. 11. Memorandum, re: Visitors to Gatineau Park. RG34 Vol.266.190(9).

${ }^{551}$ In 1955, the FDC reported that "Lac Philippe, where crowds of about three to four thousand are common, had an estimated 10,000 people on Sunday in July." Federal District Commission. 1955. Annual Report. Ottawa: Queen's Printer, pg.5. To be sure, there was skepticism expressed as to the official visitor figures. Thus, a Citizen reporter who was toured around the park by Superintendent Richards explained: "The only means of checking the people in the park is by counting the cars in the scattered parking spaces. The number of 50,000 within the past year cannot be accurate, yet is revealing enough of the attractions of the country." Hardy, A.T. 1942, Oct. 12. "Gatineau Park Trails." Ottawa Citizen.

552 No author. 1941, Oct. 14. "Not Establishing Public Beach At Meech Lake.” Ottawa Citizen.
} 
lake I was confronted by a formidable array of signs reading: "Journeys End, Private Property, No Trespassing, Trespassers will be prosecuted. This means you." For prudence's sake I left the car there and proceeded the last piece on foot only to see more signs such as "Final notice, Trespassers will be prosecuted, this means you.

The obnoxious property owners appear to be a farmer and a miner. The farm is a frightful eyesore and in an extreme state of decay. It could no doubt be expropriated for a trifle. If there is no money for this, there is room for the road to by-pass the farm. It would be less than 100 yard [sic] and a couple of dozen loads of gravel would do it.

It may be that it is the miner that has put up the signs. He has a small shack by the beach and there are signs around, about no trespassing as blasting is going on. I could find no signs of operations nearby though.

There is also another new shack built on the North Shore further up and while there I heard a violent commotion going on. It was evidently the owner of the shack who was trying to prevent some people from going in swimming. ${ }^{553}$

Behind-the-scenes, however, there was an initiative to improve public access. After the War, the Federal Woodlands Preservation League was reactivated by President Roderick Percy Sparks. ${ }^{554}$ Although its mandate had seemingly been fulfilled with the park's creation, President Sparks saw that it still had a role to play: "The saving of the woodlands is not enough in itself. If the public is to receive the benefits which accrue from the public ownership of large wooded areas, it must be made possible for the public to reach such areas, and facilities must be provided for its convenience and pleasure." 555 To this end, Sparks prepared a report, Enlargement and Development of the Gatineau Park, which he submitted to the FWPL at its September 1945 meeting. ${ }^{556}$ The FWPL report was then submitted, unchanged, to the FDC.

Sparks' report recognized the "unsatisfactory" condition of the highway from Old Chelsea to Masham, by means of which the park's only facilities at Philippe Lake were accessed.

\footnotetext{
553 Alsvold, A. 1947, Aug. 8. Letter from A. Alsvold to F.E. Bronson. RG34 Vol.267.190 (13).

554 Sparks, R.P. 1944, Feb. 16. Letter from R.P. Sparks to D.R. Cameron. RG39 Vol.25.49136.

${ }^{555}$ Federal Woodlands Preservation League. 1945, Oct. Report on the Enlargement and Development of the Gatineau Park. Ottawa: Submitted to the Federal District Commission. RG34 Vol.267.190(11), pg.7.

${ }^{556}$ Sutherland, J. 1945, Sept. 21. Letter from J. Sutherland to D.R. Cameron. RG39 Vol.25.49136.
} 
It suggested approaching provincial highway authorities about constructing a two-lane paved highway "from, say Old Chelsea, through to the south end of Philippe Lake to the east side of Meech and Harrington Lakes." ${ }^{557}$ It also urged the FDC to build a new parkway from the Champlain Bridge to the entrance of Gatineau Park. ${ }^{558}$ Unlike subsequent proposals and the realization of the Gatineau Parkway in the mid-1950s, the 1945 FWPL report did not want roads built in the "mountainous sections of the Park... This should be preserved in all its natural beauty." "559 Through the parkway and highway proposals, this "National Park" would be widely accessible to the public. Sparks' 1945 report echoes the 1913 memorandum by Dominion Parks Branch Commissioner Harkin: "Most of the National Parks in Canada are not available to people of low or medium income. The Gatineau Park, being close to large centres of population would offer all the natural beauties, spiritual values, and healthful recreation of the outdoors, which generally speaking are only available to a privileged few, who can afford to visit our National Parks. ${ }^{, 560}$ This statement reflects how, in the immediate post-War period, automobility was becoming more widely available to an emergent "middle class."

While the FDC would be amenable to proposals for a parkway and highway, Sparks' report contained a radical proposal that the federal government did not prove ready to accept, namely, the formation of a five-member Gatineau Park Commission (GPC) to administer the park. GPC membership would include the FDC Chairman, a representative from the Dominion Parks Branch, and "three independent citizens who will have the time to devote to such a project, and the business experience and vision necessary to make a success of the development of what

\footnotetext{
${ }^{557}$ Federal Woodlands Preservation League. 1945, Oct. Ibid., pg.2.

558 Ibid.

559 Ibid., pg.3.

${ }^{560}$ Ibid., pg. 7.
} 
might in time be one of the finest natural parks in the world." ${ }^{, 561}$ Business experience was necessary as the GPC would issue bonds of $\$ 500,000$ (with an annual interest of $3.5 \%$, or \$22,500). ${ }^{562}$ This money would be used to enlarge the park territory and to develop public facilities. The FWPL estimated that another $\$ 400,000$ would acquire 35,000 acres, bringing the park's overall size to 50,000 acres. ${ }^{563}$ The park would completely take in the Chain of Three Lakes and twenty smaller lakes (interestingly, it did not mention La Pêche Lake, the largest lake in the current park).

The GPC would ensure that the park project was "self-liquidating" with income generated through selective woodcutting and land sales. Of course, having deprived farmers and residents of the ability to cut wood, the FWPL was aware that government sales of fuelwood might be found objectionable by those who had their woodlots expropriated. But the report insisted that there was an "obligation" on the part of the federal government to continue to supply Ottawa and Hull with fuelwood, with the FWPL anticipating minimum revenues of $\$ 15,000$ per year. ${ }^{564}$ As for land sales, the GPC would allow private cottages "the design and location of which would strictly be controlled by the Park Commission." 565 The report wanted to ensure that lake shorelines were publicly accessible such that cottages were located at least 400 feet away. ${ }^{566}$ As President Sparks had approached the railway companies about building a resort hotel before the park was established, the hotel proposal was reiterated in the 1945 report, with the GPC leasing an area between Meech and Harrington Lakes to a railway company for $\$ 5,000$ per year. ${ }^{567}$ Income would also be derived from the operation of ski tows, concessions, and

\footnotetext{
561 Ibid., pg. 3.

562 Ibid.

${ }^{563}$ Ibid., pg.1; Federal District Commission. 1942-1943. Ibid., pg.2.

${ }^{564}$ Federal Woodlands Preservation League. 1945, Oct., pg.3.

${ }^{565}$ Ibid., pg. 4.

${ }^{566}$ Ibid., pg.3.

567 Ibid., pg.5.
} 
camp-sites. While the FWPL insisted that "natural attractions" would be free, it did concede that even a $\$ 0.10$ contribution from each of the park's 200,000 visitors "would have provided an amount almost sufficient to pay the interest and sinking fund on a $\$ 500,000$ bond issue." 568

Figure 3.4: Map of Gatineau Park (1944)

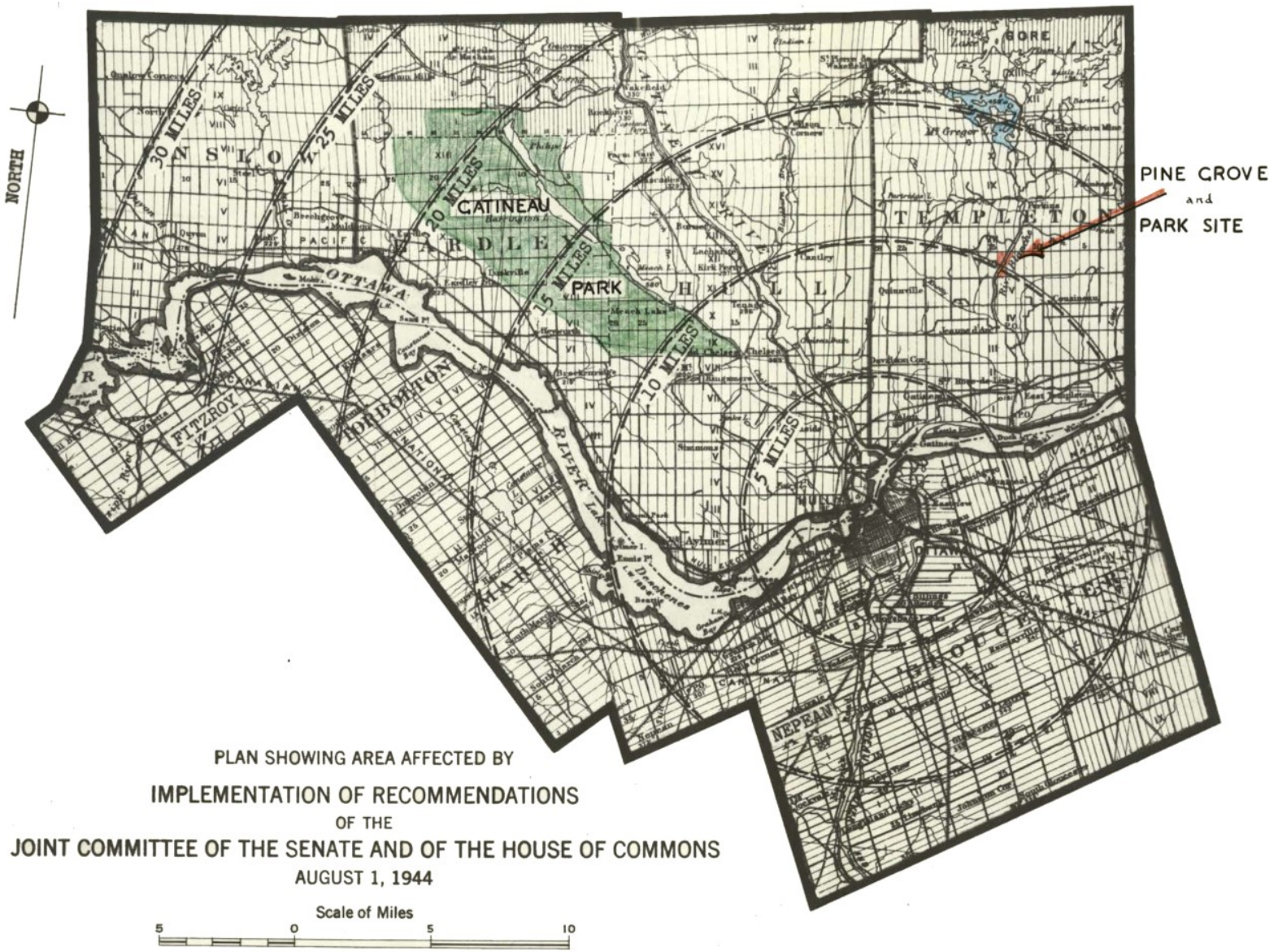

Source: RG34 Vol.267.190(14)

In the FDC archived files, there is no indication of the reception of the 1945 FWPL

Report. But Chairman Bronson was clearly sympathetic. With the FWPL President, Bronson appeared before the Senate Standing Committee on Tourist Traffic. Copies of the FWPL report were given to Senators. Bronson urged the park's expansion to 50,000 acres, and told the

${ }^{568}$ Ibid., pg. 7. 
committee that the $\$ 400,000$ cost would be "a drop in the bucket 20 years from now. If it is purchased and developed as we have been developing the area we now manage, Ottawa will have a hinterland such as no capital in the world has." ${ }^{569}$ As the FWPL Report seemed to allow for privately-owned lands within the park but also insisted on public use of lake shorelines to 400 feet, Senator Crerar asked President Sparks about residences at Meech Lake. ${ }^{570}$ As the Ottawa Journal put it, "Sparks said there was no intention on the part of the League to ask that cottageowners on Meech Lake be interfered with in any way. The FDC, he suggested, would purchase lands surrounding the cottage area but not the cottages themselves." 571 The Senate Committee, for its part, "was impressed with the case presented [by Sparks and Bronson], particularly the view that if additional land was to be acquired it should be done now before allowing it to pass into the possession of private parties. It was argued that this park in its close proximity to the Capital, would do much to increase tourist flow from the United States."

It did not take long for the FDC to reinitiate the parkland acquisition program. In November 1946, having been unable to negotiate purchase at \$10 per acre, the FDC expropriated 1,300 acres from ten owners. ${ }^{573}$ The expropriation included Lot 1A, Range 13, Township of Eardley, which completely surrounded Brown Lake and had a number of cottages on it (see Figure 3.5). The notices of expropriation were followed by a petition signed by the seven members of the Brown Lake Association. Having been informed that the expropriation was carried out for establishing a national park, the petition read:

\footnotetext{
${ }^{569}$ No author. 1946, June 27. "Would Extend Gatineau Park To 50,000 Acres." Ottawa Journal.

${ }^{570}$ Despite my best efforts (and those of a persistent librarian), I have not been able to locate the Senate Committee proceedings for the day of Bronson and Sparks' testimony.

${ }^{571}$ Ibid.

572 Buchanan, W.A., 1946. Report of the Standing Committee on Tourist Traffic. Ottawa: Senate of Canada. RG34 Vol.267.190(12).

${ }^{573}$ Federal District Commission. 1946, Oct. 11. Meeting Resolution. Ottawa. RG34 Vol.270.190-C(4); Privy Council of Canada. 1946, Dec. 5. PC 4382. RG34 Vol.270.190-C(4).
} 
Though we welcome the idea of the area being added to the National Park, we do not wish to part with our respective property, developed after much effort and at great expense. Therefore, we humbly petition the Federal District Commission that we be left in complete ownership of our properties as was done in the case of those located within the Park Area comprising Kingsmere, Meech and Philippe Lakes.

We are of the opinion it is in the best interest of the Federal District Commission to retain as owners those who have developed and beautified areas and will continue to do so, so long as they remain owners. ${ }^{574}$

The FDC subsequently backtracked from the expropriation, opening discussion with the Brown Lake Association about the conditions under which the expropriation would be lifted, which included right-of-first-refusal on property sales, no commercial developments, and FDC approval of new structures or alterations to existing ones. ${ }^{575}$

As indicated in Chapter 1, following World War II, Prime Minister Mackenzie King undertook an ambitious planning and development program for the national capital, one that was dedicated to those Canadians who had lost their lives fighting in the War. French planner Jacques Gréber was appointed consultant to the National Capital Planning Committee, which had the responsibility of preparing a long-term master plan for the National Capital District. Among Gréber's earliest ideas was for a huge monument in Gatineau Park, overlooking the capital.

The dedication of the National Capital Plan to the memory of the soldiers who have given their lives during the Second World War needs to be materialized to appeal more completely to the public.

We found a very fortunate site for this materialization at the end of the Mountain (elevation 525 feet), right above the connecting point of Mountain Road and Old Chelsea Road. A large terrace could be created to overlook the whole city and the back wall of this terrace formed by the rock of the Mountain lends itself for a simple and natural monument reminding us of the efforts and sacrifices given by the nine provinces of Canada during the Second World War.

\footnotetext{
574 Tetu, A.E., Brown, H., Harris, W.R., et al. 1946, Dec. 10. Petition by cottage-owners on Brown Lake. RG34 Vol.270.190-C(4).

${ }^{575}$ Cram, H.R. 1947, Jan. 13. Letter from H.R. Cram to A.E. Tetu. RG34 Vol.270.190-C(4).
} 
A memorial room could be provided inside the monument with a plan of the region engraved on marble. An outlook at the top, reachable by steps inside the monument and walks on both sides, would show from the elevation of 600 feet a still more extended view of the region. ${ }^{576}$

\section{Figure 3.5: Cadastral map of Brown Lake}

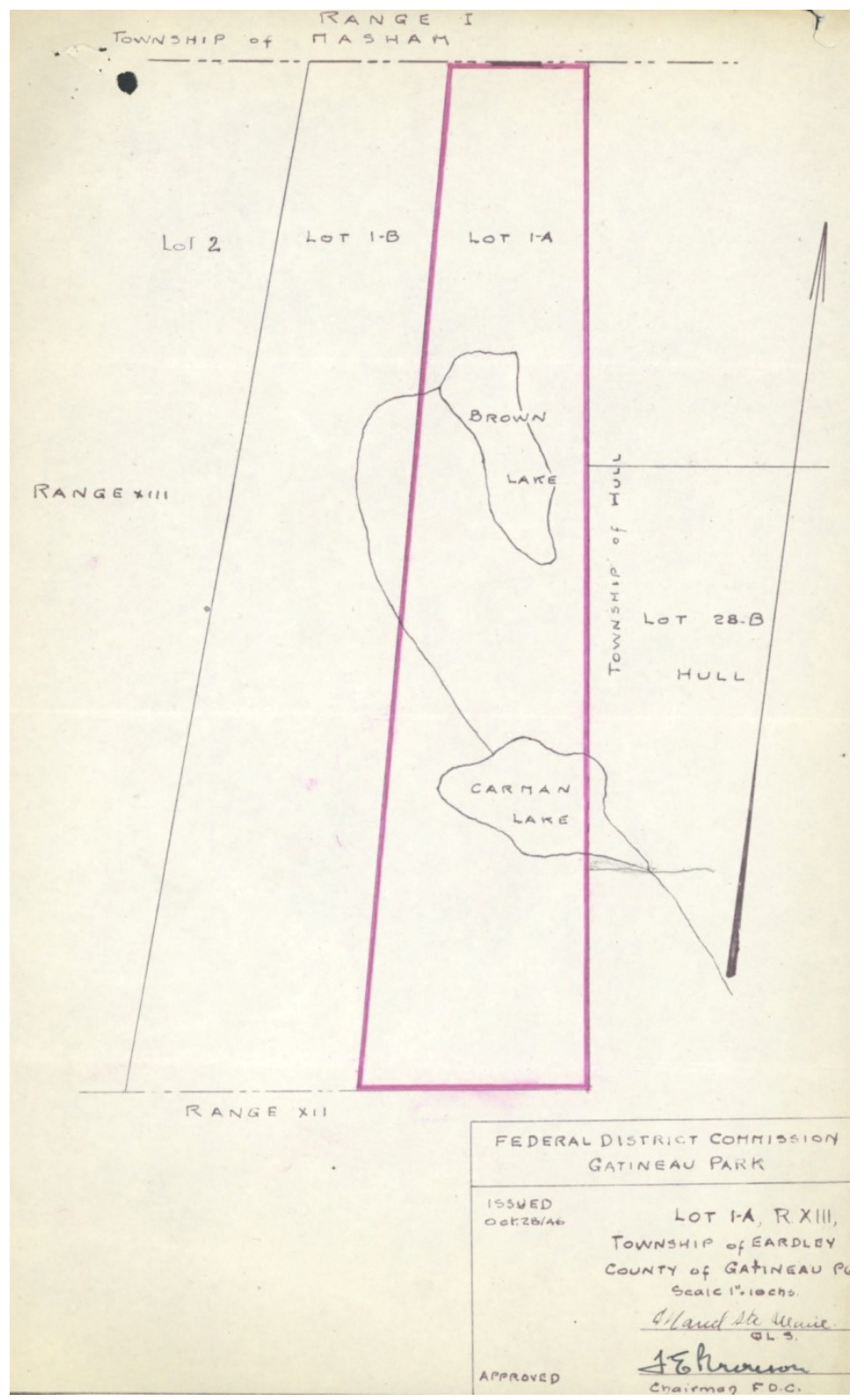

Source: LAC RG34 Vol.270.190-C(4)

\footnotetext{
${ }^{576}$ National Capital Planning Committee. 1947, May 15. Summary of Verbal report by Jacques Gréber Consultant City Planner to the Committee. RG34 Vol.281.211-D(1), pg.7.
} 
As part of this monument proposal, the first NCP report recommended the construction of a parkway and the acquisition of lands "[f]rom Aylmer Road to Fairy Lake, and to the ridge of the Gatineau Park." ${ }^{, 77}$ Despite Gréber's enthusiasm for the idea, the Gatineau Park war memorial never materialized. ${ }^{578}$ It was opposed by Prime Minister King and war veterans; the existing memorial in downtown Ottawa was rededicated to those who had fallen in both World Wars. ${ }^{579}$

Nevertheless, the FDC followed through on the NCPC recommendation to acquire lands south of Gatineau Park. ${ }^{580}$ It obtained Order-in-Council approval to spend $\$ 200,000$ on the acquisition 6,500 acres "by direct negotiation or, if necessary, by expropriation." 581 The extension of the park was once again resisted. On behalf of a Luskville farmer whose 50-acre woodlot was expropriated by the FDC, ${ }^{582}$ Marcel Bonnier told his Hull MP, Léon Raymond, that "he [Henri Papineau] does not want to sell, absolutely not, and he needs this lot for his professional utility." ${ }^{583}$ Bonnier indicated that FDC forms were only in English, and he questioned whether "this law does not violate the liberty of the farmers of my district who, between ourselves, are more and more dissatisfied of the manner in which they are treated by the officers of the Federal District Commission." ${ }^{, 584}$ As indicated in the epigraph, the treatment of farmers led Bonnier to condemn the entire Gatineau Park project as unjust, given that the FDC did not expropriate privately-owned lands at Meech and Harrington Lakes. In response to the

\footnotetext{
${ }^{577}$ National Capital Planning Committee. 1946, Mar. 19. First Report on Operations. RG34 Vol.291.211-D(1).

${ }^{578}$ Gréber, J. 1956, June 12. Letter from J. Gréber to H. Kennedy. RG34 Vol.281.211-D(2), pg.3.

${ }^{579}$ Gordon, D. 2001. Ibid., pg.54.

${ }^{580}$ Cram, H.R. 1947, Jan. 13. Letter from H.R. Cram to A.D.P. Heeney. RG34 Vol.267.190(13).

${ }^{581}$ Privy Council of Canada. 1947, Mar. 25. PC 1093. RG34 Vol.267.190(13).

582 The FDC lawyer wrote Papineau that he needed to immediately cease cutting wood on his property as " $[\mathrm{t}] \mathrm{he}$ timber that you cut actually belongs to the Federal District Commission. However, on account of the fact that you had not been officially informed of this expropriation, the Commission will not insist to take possession of said wood. The value of same will however be deducted from the value of the land." Ste-Marie, P. 1947, Jan. 11. Letter from P. Ste-Marie to H. Papineau. RG34 Vol.267.190(13).

${ }^{583}$ Bonnier, M.C. 1947, Jan. 15. Letter from M.B. Bonnier to L.J. Raymond. RG34 Vol.267.190(13).

${ }^{584}$ Ibid.; The FDC conceded that the English-only forms as "admittedly insufficient" and prepared forms in French. It did, however, claim that land agents were always accompanied by a French speaking park ranger. Cram, H.R. 1947, Feb. 18. Letter from H.R. Cram to L.J. Raymond. RG34 Vol.267.190(13).
} 
accusation that the FDC was privileging park residents, the FDC Secretary - who in another letter had said that Meech Lake was outside the park limits - elusively informed the Hull MP that " $[\mathrm{t}]$ he Commission is incorporating within Gatineau Park such lands that lie within definite limits that have been carefully considered and approved by it. All lands within these limits will eventually be acquired." 585 What Cram failed to mention was that the park's limits had yet to be determined.

The 22,000-acre park had no long-term plan and unclear boundaries (see Figure 3.6). The wide mandate assigned to the National Capital Planning Committee prevented it from giving Gatineau Park much attention, particularly with respect to its day-to-day management and emerging issues. Rather, the NCPC consultant, Jacques Gréber, focused on the routing of the Gatineau Parkway, which, by this time, had clearly been established as the central component of the park project (see Figure 4.3). Through automobility, the park would be "democratized."

In March 1947, the FDC established a volunteer, five-member Advisory Committee on Gatineau Park (ACGP). While this was not the Gatineau Park Commission envisioned by the 1945 FWPL report, Percy Sparks was elected Chairman. As its name implied, the role of the Advisory Committee was to provide the FDC with advice concerning the park's planning, development, and management. This advice was to be submitted to Secretary Cram on a strictly confidential basis, and passed to the FDC Executive for a final decision. Nevertheless, as Chairman Bronson explained in Sparks' letter of appointment as member, "it goes without saying that the Commission would give great weight and consideration to the advice of men whom it had itself chosen to act in that capacity." 586

\footnotetext{
585 Ibid.

${ }^{586}$ Bronson, F.E. 1947, Mar 21. Letter from F.E. Bronson to R.P. Sparks. RG34 Vol.272.190-G(1).
} 
Figure 3.6: Map showing FDC land ownership in Gatineau Park (1946)

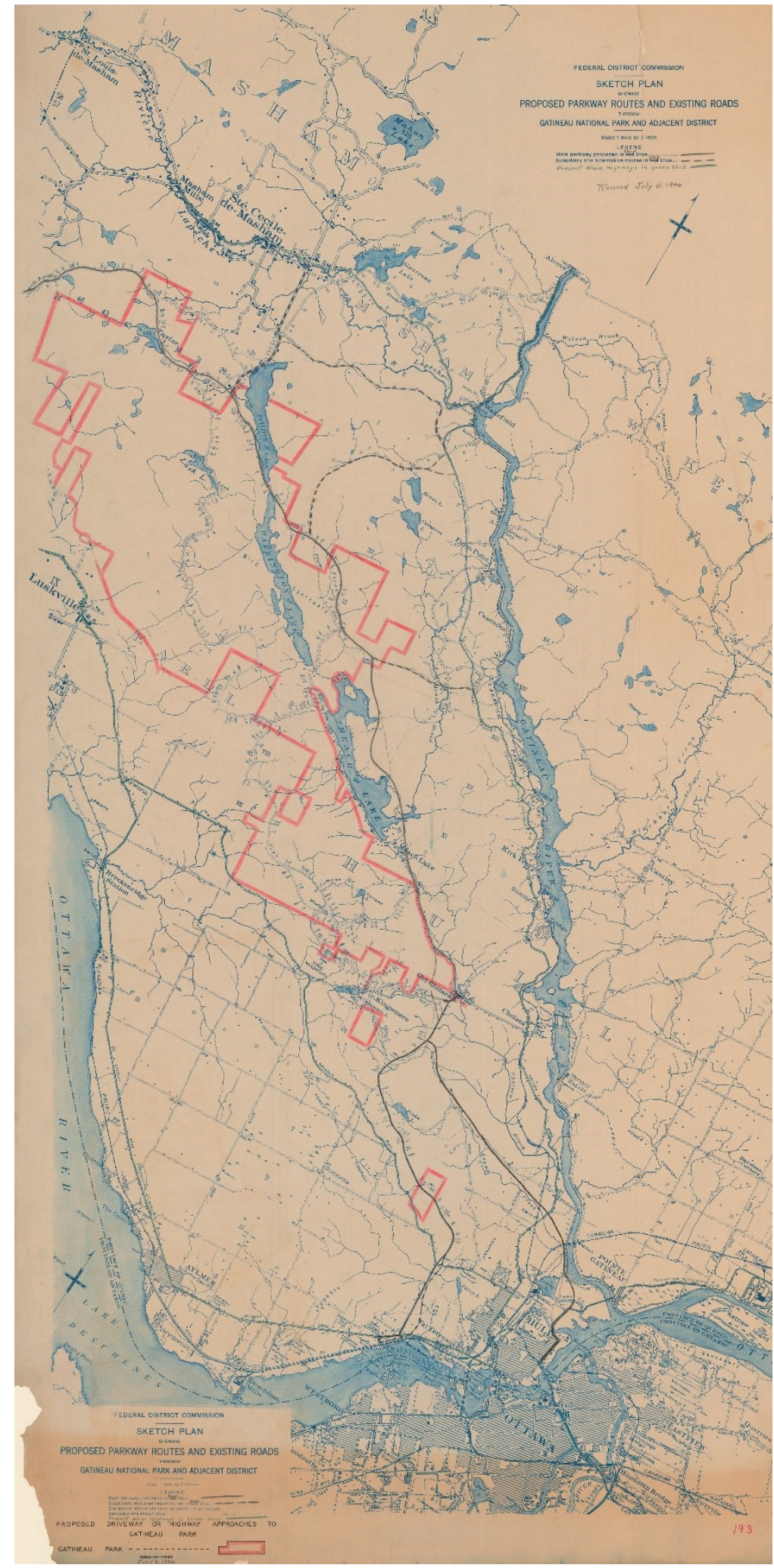

Source: RG34M 81203/53, item 251 
The Advisory Committee was "composed of persons living within or near the park for at least part of the year and those who are interested in and active participants in the development of skiing and other activities within its area." ${ }^{287}$ The "other activity" to which Bronson referred was "cottaging" in the park. In addition to Chairman Sparks, Secretary John J. Connolly (who was the Secretary of the Meech Lake Association), and Major General Daniel Spry were park residents. The two remaining members, Herbert Marshall and S. Bernier, were members of the Ottawa Ski Club (OSC); Marshall was the OSC President. Though rifts among members of the Advisory Committee on the issue of private lands were not apparent, this account shows that they stalled the park's very first planning process, preventing the Advisory Committee from fulfilling its most important task: the preparation of a master plan for Gatineau Park.

In May 1947, the ACGP held its first meeting. The very first 'matter for consideration' was "[t]he ultimate boundaries of the Park." ${ }^{588}$ ACGP members subsequently toured the park area to determine which lands were owned by the FDC. In June 1947, the ACGP visited Philippe Lake:

It was found that the Commission was the owner of practically the entire shore line of this lake with the exception of certain lots at the north end...

It should be pointed out that unlike Meech Lake, Lac Philippe is not a thickly settled area. It is located reasonably close to the City of Ottawa and the Committee feels that it would be desirable to preserve the facilities which it offers and the beauty which is there, for park purposes.

At the present time construction has begun on some new buildings of what appears to be an inferior type and in a place which the Committee feels would be detrimental to the ultimate development of the lake within the park. For this reason the Committee would like to make a firm strong recommendation to the Federal District Commission that the lands detailed above be expropriated by the Committee forthwith. ${ }^{589}$

\footnotetext{
587 Ibid.

${ }^{588}$ Advisory Committee on Gatineau Park. 1947, May 9. Matters for consideration of Gatineau Park Committee. RG.34 Vol.272.190-G(1).

${ }^{589}$ Connolly, J.J. 1947, June 10. Letter from J.J. Connolly to F.E. Bronson. RG34 Vol.272.190-G(1).
} 
In November 1947, perhaps having heard rumors either of the ACGP recommendation to expropriate the remaining privately-owned lands around the lake or the forthcoming delimitation of the park's boundaries, the Lac Philippe Cottagers' Association was formed. It asked that FDC officials attend their next meeting "to give us an outline on the expansion of Gatineau Park as proposed for Lac Philippe. ${ }^{, 590}$ Coincidentally, the FDC approved the expropriation on the very same day that it received this request from the Lac Philippe Cottagers' Association. ${ }^{591}$ Nevertheless, the Gatineau Park Superintendent and ACGP Chairman proceeded to meet with residents. Although no minutes of the meeting were kept, Sparks later recounted the meeting with cottagers in a 1952 memorandum to the Advisory Committee: "At first there was strong objection and indignation. A meeting was held, but, when the situation was fully explained, agreement was reached with 100 percent of the owners." ${ }^{592}$ Sparks' assessment of the meeting does not reflect the actual outcome, as five out of twenty-four owners were "holding out for highest prices." 593 For the Heggtveits, the expropriation "was a very sad event." 594 This family of Norwegian immigrants lost their cottages on account of the expansion of the park's territory.

Shortly after the ACGP visit to Philippe Lake, it obtained Gréber's parkway plans for the proposed war monument. In a 25-point letter written and co-signed by the ACGP Chairman and Secretary, they understood that the proposed parkway:

...creates an entirely new situation both in respect to the future development of this area [Kingsmere Lake] and the establishment of land values ... A decision should be reached immediately as to what land adjacent to Kingsmere and land abutting Kingsmere Road should be taken over by the Commission. After much consideration, your Committee recommends that notice of expropriation should be given to all owners of land within this area. This recommendation is made, keeping in mind the statement of policy made at a meeting between the Chairman

\footnotetext{
${ }^{590}$ Merrell, W.J. 1947, Nov. 12. Letter from W.J. Merrell to H.R. Cram. RG34 Vol.267.190(13).

${ }^{591}$ Federal District Commission. 1947, Nov. 12. Federal District Commission Resolution. RG34 Vol.267.190(13).

${ }^{592}$ Sparks, R.P. 1952, July. Memorandum to Advisory Committee on Gatineau Park. RG34 Vol.272.190-G(1).

${ }^{593}$ Cram, H.R. 1948, Oct. 6. Letter from H.R. Cram to L.J. Raymond. RG34 Vol.267.190(14).

${ }^{594}$ Heggtveit, R. no date. Ibid.
} 
of this Committee and your Commission to the effect that it was the policy of the Commission to purchase land and resell it at higher prices if circumstances justify such action. ${ }^{595}$

The recommendation to acquire Kingsmere Lake would involve the expropriation of 600 acres, worth an estimated $\$ 500,000 .{ }^{596}$ The Advisory Committee was adamant that, if Kingsmere residents remained in place (see Figure 3.7), the proposed Gatineau Parkway would provide them with "huge windfall profits..." 597 This outcome, the committee added, would leave the FDC "open to the severest criticism." 598 As it turns out, this criticism would come from Sparks (see Chapter 4), whose lands were posthumously expropriated on account of increased values from the opening of the Gatineau Parkway! (see the plight of Sparks' children in Chapter 5)

As indicated in the passage above, the Advisory Committee suggested that, once the Kingsmere area had been acquired by the FDC, it could later be resold for a "large profit." 599 Drawing comparisons with Ottawa's prestigious Rockcliffe Park community with its embassies and mansions, the Advisory Committee maintained that:

...[a] carefully planned area in this beautiful setting overlooking the capital, largely confined to the homes of the representatives of the growing number of foreign countries now represented at Ottawa, would be a feature of great interest to tourists and others who might visit the capital and we suggest would be an important part of the general plan in connection with the development of Ottawa as a great Capital City. ${ }^{600}$

While there was some reluctance on the part of the advisory committee to recommend this realestate proposition to the FDC, it maintained that additional parkland could be purchased with the profits. In this way, Gatineau Park would be a "self-liquidating proposition."601

\footnotetext{
${ }^{595}$ Sparks, R.P. and Connolly, J.J. 1947, July 26. Letter from R.P Sparks and J.J. Connolly to Federal District Commission. RG34 Vol.272.190-G(1), pg.1.

${ }^{596}$ Ibid., pg. 3 .

${ }^{597}$ Ibid., pg. 2.

${ }^{598}$ Ibid.

${ }^{599}$ Ibid.

${ }^{600}$ Sparks, R.P. 1947, July 26. Letter from R.P Sparks to J.J. Connolly. RG34 Vol.272.190-G(1).

${ }^{601}$ Ibid.
} 
Figure 3.7: Cadastral map of privately-owned lands adjacent to Kingsmere Lake (1947)

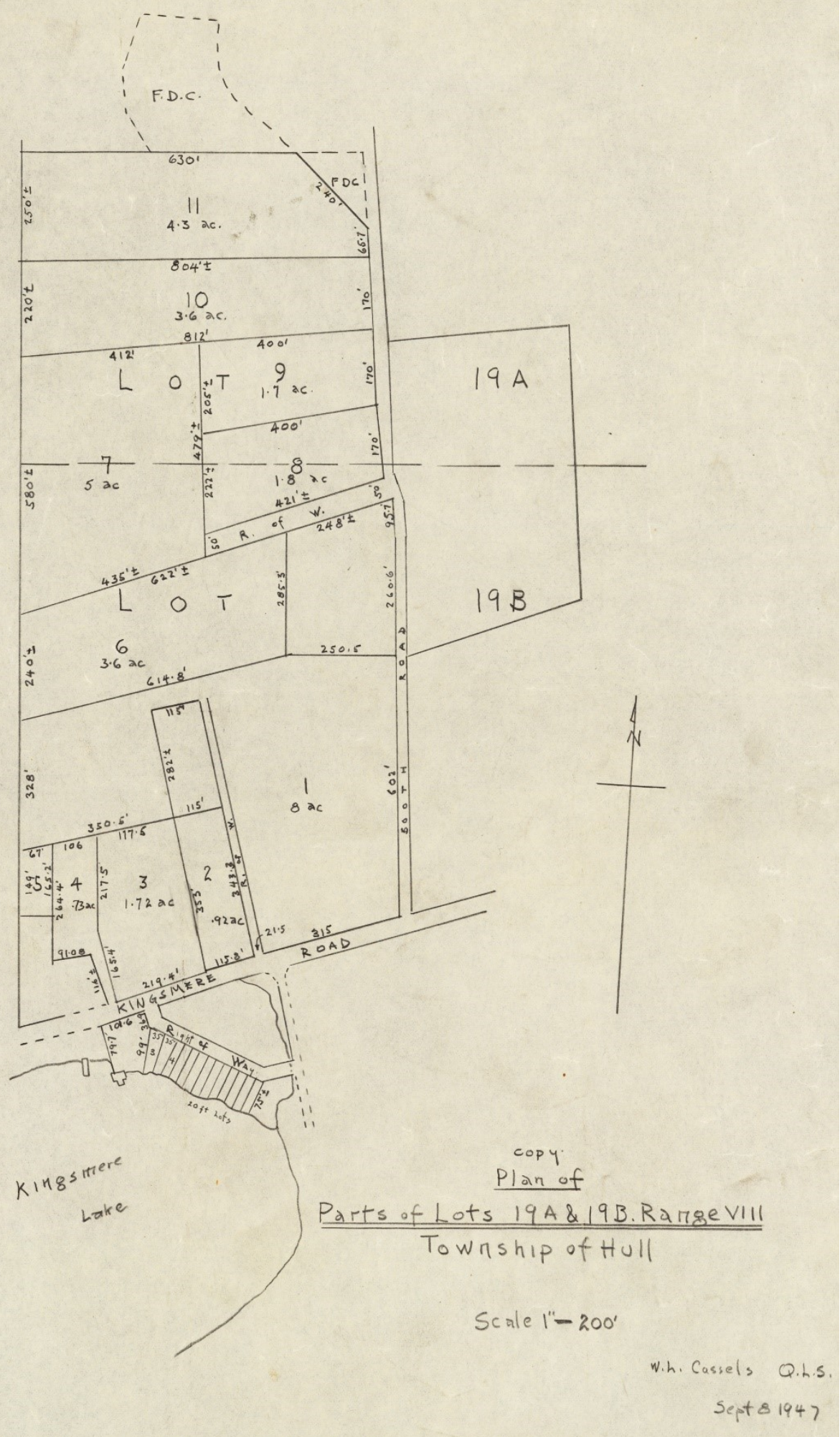

Source: RG34M 81023/53 item 262. 
The Advisory Committee was aware, of course, that its recommendation to expropriate Kingsmere residents included the estate owned by Prime Minister Mackenzie King. In a letter to the FDC Chairman Bronson, Sparks wrote: "While we recommend that notice of expropriation be given to "all owners" of property in this area, I know that it has been rumoured that the Prime Minister may leave his property to the State as part of the Park ... If such were the case of course the problem would solve itself." 602 Bronson knew that the "rumor" was in fact true, and, as discussed in the next section, King bequeathed his Kingsmere estate to the Canadian people.

There is no record of the FDC response to this recommendation, but it would be reiterated by the Advisory Committee in subsequent communications. ${ }^{603}$ The implicit disagreement would become apparent as the FDC took steps to delimit the boundaries of Gatineau Park. In November 1947, the following resolution was passed at the Executive meeting of the FDC:

Whereas it is considered advisable that Gatineau Park be enlarged to include Lac La Piche [sic], Harrington Lake and other desirable topographical conformations within its limits.

Therefore Be It Resolved that the approval of the Governor-in-Council be sought under the provisions of Section 13 of the Federal District Commission Act to acquire the property outline in red on the attached plan by direct negotiation, or if necessary, by expropriation. ${ }^{604}$

This formalization of boundaries highlights the important difference between the front-stage and back-stage representations of the park. On maps distributed to the public, Gatineau Park was represented as a contiguous wedge-shaped area. The Order-in-Council (see Figure 3.8) that authorized the FDC to proceed with the Gatineau Park land acquisition program, however,

\footnotetext{
${ }^{602}$ Sparks, R.P. 1947, July 25. Letter from R.P. Sparks to F.E. Bronson. RG34 Vol.272.190-G(1).

${ }^{603}$ Sparks, R.P. 1947, Dec. 23. Letter from R.P. Sparks to F.E. Bronson. RG34 Vol.272.190-G(1), pg.5.

${ }^{604}$ Federal District Commission. 1947, Nov. 12. Resolution. RG34 Vol.267.190(13).
} 
excluded the shoreline of Meech Lake and the entirety of Kingsmere Lake. ${ }^{605}$ In effect, the Kingsmere-Meech Lake privatopia was an enclave within the park's territory, but this was not public knowledge.

Figure 3.8: Order-in-Council PC 5209 showing Gatineau Park

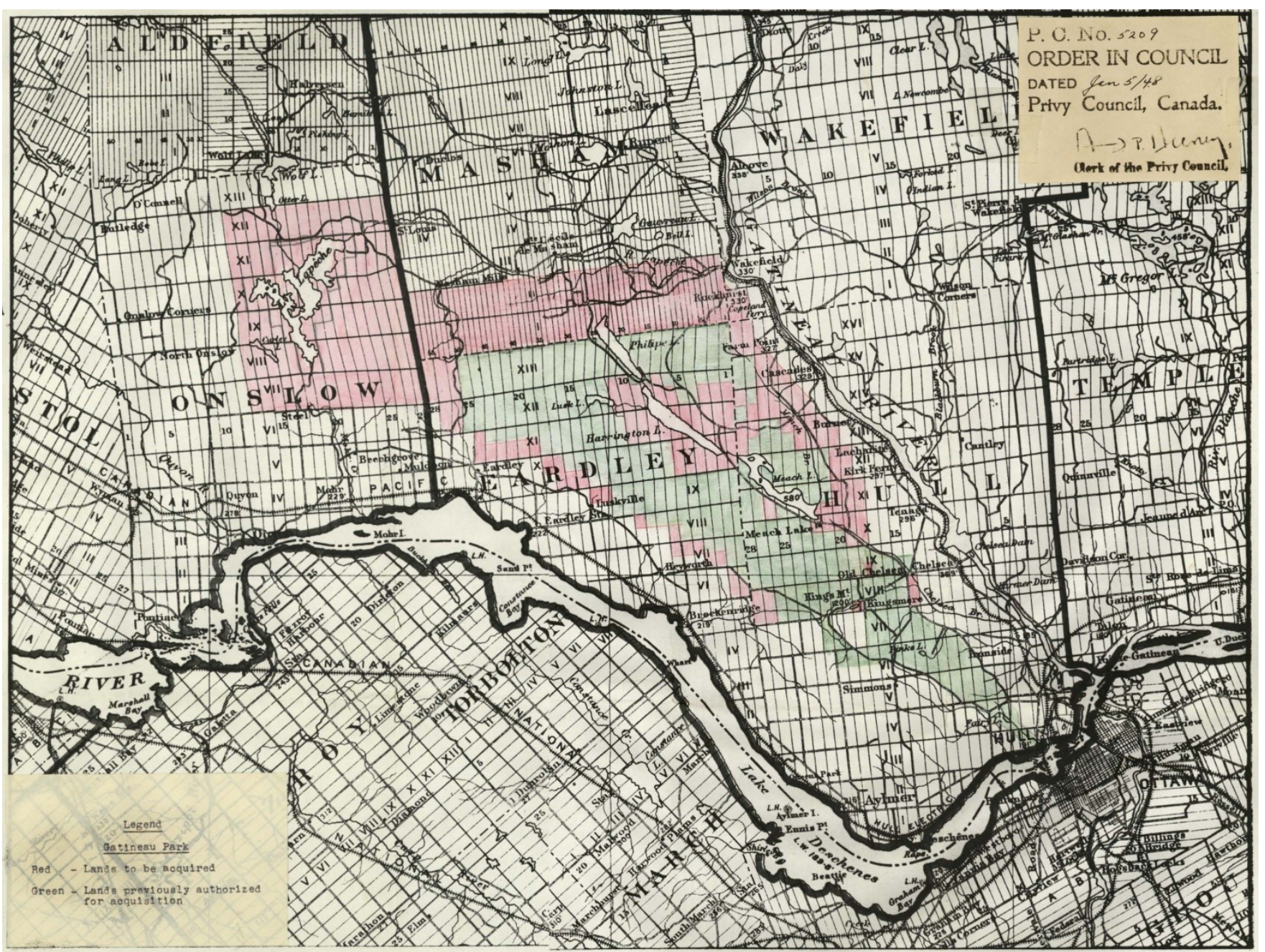

Source: Privy Council of Canada. 1948, Jan. 5. PC 5209. RG34 Vol.267.190(13). Note: Meech Lake shoreline and Kingsmere lots are not shaded

And it is unclear whether park residents were aware that the park boundaries had been drawn around them. In September 1948, Kingsmere residents approached the FDC to "enter into an agreement with them to refrain from expropriating their land providing that they undertake to

${ }^{605}$ Privy Council of Canada. 1948, Jan. 5. PC 5209. RG34 Vol.267.190(13). 
set up certain building restrictions on their property." 606 The building restrictions would not just apply to Kingsmere Lake but also to the surrounding area; further, the restrictions would apply to both local residents and the FDC. The Kingsmere Property Owners' Association (KPOA) proposal was an exercise of territoriality which not only prohibited public access to the lake area, but also severely curtailed FDC powers. Thus, under the proposed restrictions, the FDC, in addition to agreeing not to expropriate residents, "shall not construct, permit (so far as it can control the same) or carry on any public parking place, picnic ground, play ground, swimming or boating or other public recreation or amusement place." ${ }^{607}$ And KPOA territoriality extended to the territory of Gatineau Park as "[ $\mathrm{t}]$ he Commission shall take all reasonable steps to prevent its facilities outside the district shown in Schedule 'A' from constituting a nuisance to the [Kingsmere] Owners." ${ }^{\prime 60}$ The KPOA went even further in its final suggestion, essentially having the FDC act against its own interests:

In the event of any Owner having occasion to request a fiat to sue the Crown in respect of any act or omission of the Commission, the Commission shall, in every case, regardless of its conception of the merits of such request, recommend the granting, by the Crown, of such permission to sue, but shall not have any obligation to see that such recommendation is accepted by the Crown. ${ }^{609}$

Instead of dismissing this audacious request out-of-hand, the FDC took it seriously and obtained a legal opinion. ${ }^{610}$ The law firm of Clark, Robertson, Macdonald \& [J.J.] Connolly replied: "It is our opinion upon reading the Federal District Commission Act that you cannot validly enter into any such contract or undertaking limiting the powers conferred on your Commission by

\footnotetext{
${ }^{606}$ Macdonald, A. 1948, Oct. 12. Letter from A. Macdonald to FDC, Re: Kingsmere. RG34 Vol.267.190(14).

${ }^{607}$ Kingsmere Property Owners' Association. 1948. Kingsmere Building Restrictions Proposal. RG34 Vol.267.190(14).

${ }^{608}$ Ibid.

609 Ibid.

${ }^{610}$ Cram, H.R. 1948, Sept. 30. Letter from H.R. Cram to A. Macdonald. RG34 Vol.267.190(14).
} 
Parliament." ${ }^{611}$ Clearly, a formal agreement could never be made between the FDC and Kingsmere residents to keep park visitors outside of the area.

Ironically, even though Kingsmere Lake remained off limits to park visitors, it was the most publicly accessible area of the park, that is, accessibility went beyond the private use of the automobile. As pointed out by one visitor, "[u]nlike the other parts of the federal park which can only be reached by one's moto-car, Kingsmere can be reached by most people. You may cycle, there is a regular service of motor-buses and in the Spring you will find around Old Chelsea and Kingsmere more people than in any other part of the Laurentians."612 Nevertheless, with such strong assertions of territoriality by Kingsmere residents, the FDC proved willing to keep park visitors away from the area, even though it owned part of the shoreline. When the FDC was provided with an "unofficial application," the FDC asked the Advisory Committee whether "it might prove advantageous to the Commission if the Kingsmere owner's association were to exercise supervisory control over the use of the land adjoining Kingsmere Lake including the Commission's lands." ${ }^{\prime 613}$ Given that the ACGP wanted the FDC to have full control over the Kingsmere Lake area, the FDC should probably have anticipated the negative response to the KPOA proposal from the Advisory Committee. ${ }^{614}$

\section{Park planning and developments to 1951}

By 1949, the park had unofficial boundaries and a parkway plan, but it was still without a longterm master plan. The need for a plan became even more pressing as outgoing Prime Minister

\footnotetext{
${ }^{611}$ Macdonald, A. 1948, Oct. 12. Ibid.

612 Saint-Jacques, H. 1948, Jan. 23. Letter from H. Saint-Jacques to F.E. Bronson. RG34 Vol.267.190(13).

${ }^{613}$ Cram, H.R. 1949, July 15. Letter from H.R. Cram to R.P. Sparks. RG34 Vol.272.190-G(1).

${ }^{614}$ Sparks, R.P. 1949, July 29. Letter from R.P. Sparks to H.R. Cram. RG34 Vol.272.190-G(1).
} 
Mackenzie King asked for a plan in advance of appropriating funds for the park. ${ }^{615}$ Following this, in April 1949, the new Prime Minister Louis St. Laurent informed the House of Commons that the federal government had budgeted $\$ 7,050,000$ for land acquisitions and developments, ${ }^{616}$ with local newspapers reporting on the projected expenditures for "Gatineau National Park.",617 The Advisory Committee on Gatineau Park, for its part, had long recognized the need for a plan, ${ }^{618}$ and it had the 1945 report of Federal Woodlands Preservation League - what one researcher has described as the "mother of all Gatineau Park master plans" - to draw inspiration from (and it did). But there remained a thorn in the side of the Advisory Committee.

Despite the consensus among committee members about expropriating privately-owned lands around Kingsmere Lake, a rift emerged over whether the same policy should be carried out at Meech Lake. The first evidence of this rift appeared when the FDC asked for advice from the Advisory Committee concerning "the establishment of a dining room and dance hall on the McDonald property on Meech Lake." ${ }^{619}$ Though the Advisory Committee recommended against the proposed commercial development, Chairman Sparks informed the FDC Secretary of its inability to give advice on a general policy for Meech Lake:

The whole question of what the policy of the Commission should be in regard to the Meech Lake area has been discussed by your Committee on several occasions but as you know, no report has ever been made. It is the intention of the Committee to consider this matter at their next meeting after which a recommendation will be made in regard to the future policy which might be adopted in respect to this area. Considerable new building is going on around Meech Lake and the Committee feels that a long term policy should now be

\footnotetext{
${ }^{615}$ Richards, E.S. 1949, Feb. 14. Letter from E.S. Richards to E. Handy. RG34 Vol.267.190(14).

${ }^{616}$ St. Laurent, L. 1949, Apr. 8. "National Capital Plan.” Canada. Parliament. House of Commons. Edited Hansard. $20^{\text {th }}$ Parliament, $5^{\text {th }}$ Session, Vol.3, pg.2468.

${ }^{617}$ No author. 1949, Apr. 8. "\$7,000,000 On Gatineau.” Ottawa Citizen; No author. 1949, Apr. 9. “Government to Spend \$7,000,000 On Gatineau Park Expropriations.” Ottawa Journal; No author. 1949, June 11. "Gatineau National Park Will Be Extended To 60,000 Acres." The Evening Citizen; No author. 1949, June 11. "New Acreage Expected To Be 60,000." Ottawa Citizen.

${ }^{618}$ Sparks, R.P. 1947, Dec. 23. Ibid., pg.5.

${ }^{619}$ Of course, the FDC could not prevent this development on privately-owned land. Sparks, R.P. 1948 , May 11. Letter from R.P. Sparks to J.E. Blackburn. RG34 Vol.272.190-G(1).
} 
adopted, and are prepared to make recommendations as soon as the matter has been given some further study. ${ }^{620}$

But, by the time of the General Report on Gatineau Park (1949), the Advisory Committee had not reached a consensus on Meech Lake. Indeed, the Report carefully avoided reference to Meech Lake, and privately-owned lands more generally: "the matter will be dealt with in a future report." 621

The General Report, deemed a "long-term plan," recycled many of the proposals from the 1945 FWPL report. ${ }^{622}$ On the one hand, it emphasized preservation, such that "nothing is done which would mar its natural beauty." 623 On the other hand, it suggested a looped parkway that cut through the middle of the park, and pressed the FDC, once again, to acquire Kingsmere Lake, and then resell the lands to private buyers at a profit. It also suggested that the FDC purchase lands adjacent to the park for this purpose, claiming "that a profit of not less than one million dollars could be made within the next ten years, as a result of well organized planning to develop these and other properties as building sites." ${ }^{624}$ It is unclear why the Advisory Committee was so insistent on ensuring that the park was self-liquidating since the federal government, through Mackenzie King, had allocated such a generous budget for parkland acqusiitions.

\footnotetext{
${ }^{620}$ Sparks, R.P. 1948, May 11. Letter from R.P. Sparks to H.R. Cram. RG34 Vol.272.190-G(1).

${ }^{621}$ Advisory Committee on Gatineau Park. 1949, May 16. General Report. Ottawa: Federal District Commission, pg. 11 .

${ }^{622}$ Ibid., pg.2. Thus, the 1949 General Report repeated proposals for a railway hotel, nature museum, and natural amphitheatre. Many if not most these development recommendations were, in turn, adopted in the 1952 Report on a Master Plan for Gatineau Park.

${ }^{623}$ Ibid., pg.5.

${ }^{624}$ Ibid., pg. 10.
} 
Figure 3.9: Map of Mackenzie King Estate

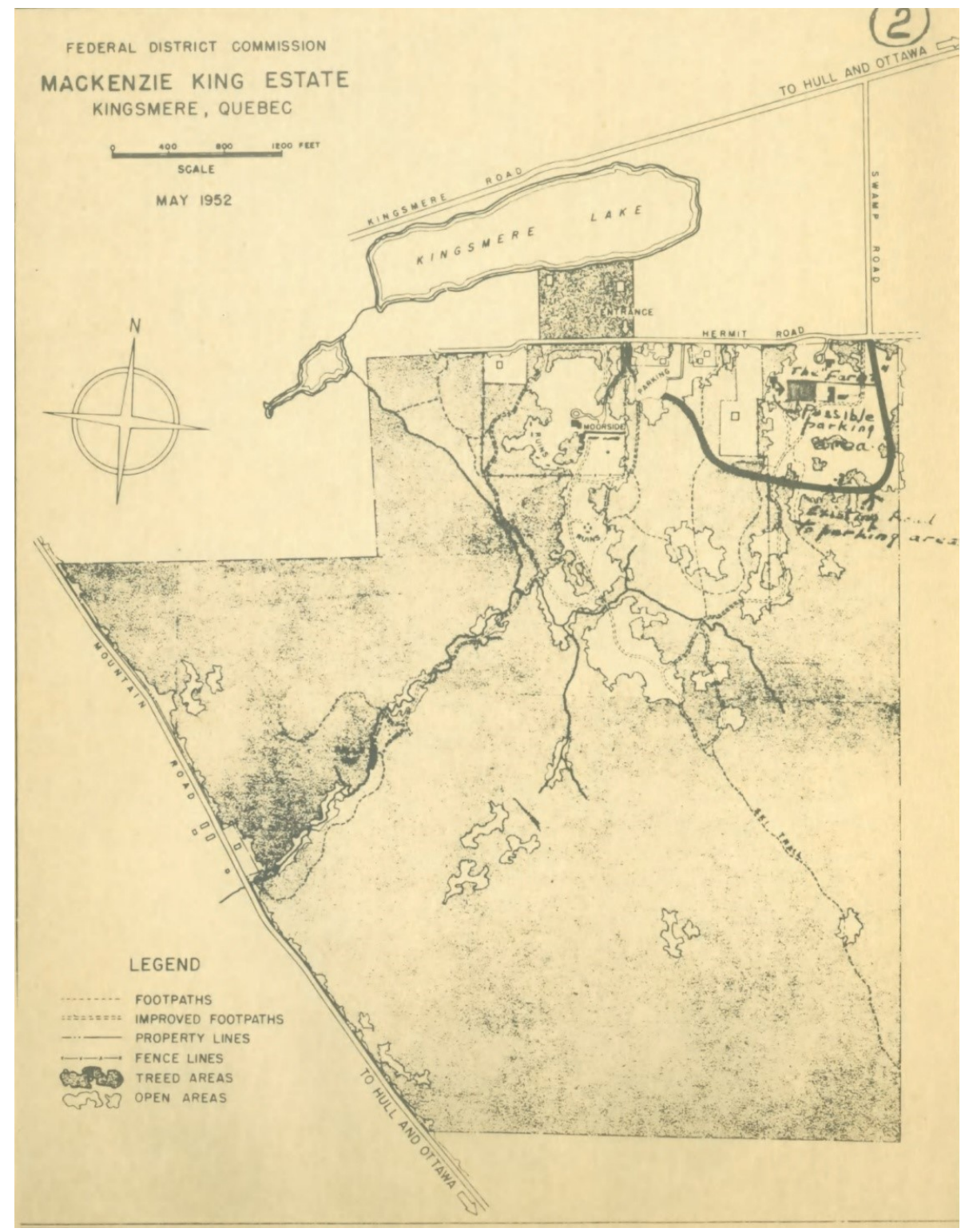

Source: RG34 Vol.274.190-O(3)

On 22 July 1950, Mackenzie King died, at the age of 75. The final act of generosity by the former Prime Minister was to bequeath his entire 600-acre Kingsmere estate to the Canadian people as part of Gatineau Park (see Figure 3.9) ${ }^{625}$ King was therefore not alive when the National Capital Planning Committee published the Plan for the National Capital. Known as the

\footnotetext{
${ }^{625}$ King also willed that the Farm be made into the official summer residence of future Prime Ministers. A wealthy lumber baron, Lieutenant-Colonel Cameron Macpherson Edwards had built the only residence on Mousseau Lake, and FDC officials favored it as the official summer residence of the prime minister.
} 
“Gréber Plan,” it only made general recommendations as to the protection and expansion of Gatineau Park to 83,000 acres. The Gréber Plan deferred to the Advisory Committee for specific park developments, citing the "most complete and interesting report in which all the aspects of the development and life of the park are dealt with." ${ }^{626}$ As documented in the next chapter, Gréber was called upon by the FDC to weigh in on the on the issue of privately-owned lands in Gatineau Park following the May 1952 Report on a Master Plan for Gatineau Park that was submitted by the Advisory Committee.

Table 3.1: Land acquisitions and expenditures on Gatineau Park, 1946-1950

\begin{tabular}{|c|c|c|c|c|c|}
\hline Year & 1946-1947 & 1947-1948 & 1948-1949 & $1949-1950$ & Total \\
\hline $\begin{array}{l}\text { Number of Acres of } \\
\text { Land Acquired }\end{array}$ & $1,787.90$ & $2,282.97$ & $3,993.29$ & 969.65 & $9,033.81$ \\
\hline $\begin{array}{l}\text { Amount Expended } \\
\text { on Property }\end{array}$ & $22,437.00$ & $55,364.63$ & $288,065.25$ & $50,547.84$ & $416,414.72$ \\
\hline $\begin{array}{l}\text { Total Expended on } \\
\text { Maintenance }\end{array}$ & $36,639.01$ & $30,128.60$ & $47,192.30$ & $51,123.50$ & $165,073.42$ \\
\hline $\begin{array}{l}\text { Gatineau Snow } \\
\text { Plowing }\end{array}$ & $2,493.45$ & $3,272.01$ & $1,994.02$ & $1,050.96$ & $8,761.34$ \\
\hline
\end{tabular}

Source: RG34 Vol.267.190(14)

While the question of privately-owned land was put off, the FDC land acquisition program continued at an accelerated pace (see Table 3.1 and Appendix A). In 1949, the park territory was expanded to include La Pêche Lake through the purchase of 510 acres for $\$ 30,000 .{ }^{627}$ In 1951, the FDC purchased the 4,800 acres Edwards-Herridge lands at Harrington Lake for $\$ 232,000 .^{628}$ The Ottawa Journal regarded this acquisition as "one of the most significant developments of this great Summer and Winter playground....Until these two estates, some 18 miles north of Ottawa, were part of Gatineau Park, the Federal District Commission was

\footnotetext{
${ }^{626}$ National Capital Planning Committee. 1950. Plan for the National Capital. Ottawa: King's Printer, pg.248.

${ }^{627}$ No author. 1949, June 11. Ibid.

${ }^{628}$ No author. 1951, Apr. 12. "Big Step in Park Planning." Ottawa Citizen.
} 
not in a position to plan for the park as a whole..." ${ }^{29}$ Thus, the second and third lakes in the Chain of Three Lakes were now completely under FDC control, reinforcing the need for an acquisition policy on Kingsmere and Meech Lakes.

With the growth in the park's territory, the municipalities adjacent to the park were deprived of more and more tax revenues given that federal lands were, at the time, exempt from paying property taxes as per the Constitution Act. The loss of productive farmland and tax revenues had been recurrent complaints levied against the FDC as soon as it resumed the parkland acquisition program in the post-War period. Thus, one concerned municipal official wrote Léon Raymond, MP for Hull: "I submit that this park is now large enough - we need the producing farmers more than the Park." ${ }^{630}$ Having met with concerned municipal officials, Advisory Committee Chairman Sparks initially thought the losses represented "a very small sum and I think they realized they are worrying needlessly." 631 However, Sparks changed his mind on the issue, and the Advisory Committee convinced the FDC to seek an amendment to the Federal District Commission Act, so that it could institute grants-in-lieu-of-taxes for the municipalities affected by Gatineau Park. ${ }^{632}$ The amendment allowed the FDC to compensate the six municipalities and eleven school boards affected by Gatineau Park. ${ }^{633}$ Thus, in 1951, the FDC paid $\$ 5,359.76$ payments-in-lieu-of-taxes. Despite the claim by the FDC that the payments "have been most favorably received,"634 the affected municipalities still routinely complained that the amount of compensation was inadequate.

\footnotetext{
${ }^{629}$ No author. 1951, Apr. 14. “A Great Recreation Ground.” Ottawa Journal.

${ }^{630}$ Geggie, H.J.G. 1948, Jan. 14. Letter from H.J.G Geggie to L. Raymond. RG34 Vol.272.190-G(1).

${ }^{631}$ Sparks, R.P. 1948, Jan. 29. Letter from R.P. Sparks to H.R. Cram. RG34 Vol.272.190-G(1).

${ }^{632}$ See Sparks, R.P. 1951, Apr. 13. Letter from R.P. Sparks to F.E. Bronson. RG34 Vol.272.190-G(2); see also Sparks, R.P. 1951, Apr. 17. Letter from R.P. Sparks to H. Marshall. RG34 Vol.272.190-G(2).

${ }^{633}$ Federal District Commission. 1951. Annual Report. Ottawa: King's Printer, pg. 17.

${ }^{634}$ Ibid., pg.4.
} 


\section{Conclusion}

This chapter documented the park's territorialization from 1939 to 1951 . The park territory was expanded from an initial nucleus around Kingsmere and Meech Lakes, with FDC officials then projecting an overall size of only 20,000 acres. ${ }^{635}$ By the end of 1951 , the park territory covered 32,269 acres; it encompassed the Chain of Three Lakes and had been extended to La Pêche Lake. The land acquisitions encountered resistance from the farmers and local residents whose lands were expropriated to establish a "national park." And municipalities were adversely affected not only by lost tax revenues but also from lost employment with lumbering prohibited within the park. But the costs borne by the expropriates and municipalities were justified by the FDC because Gatineau Park was for the benefit all Canadians. The FDC was indeed proud of the fact that Gatineau Park had "the largest attendance of any Federal natural park in Canada." 636 Notably, in its Annual Report, the FDC never referred to Gatineau Park as a national park.

So, on the one hand, FDC expropriations were carried out under the pretense of a national park, and local newspapers reinforced that the FDC was establishing a national park in the Gatineau Hills. On the other hand, this chapter highlighted the unevenness of the parkland acquisition program, as privately-owned lands around Kingsmere and Meech Lakes were left undisturbed, while residents at Philippe Lake were expropriated to expand the park's only public facilities. Were this a national park, the FDC would have had to acquire all privately-owned lands within the park boundaries. But it was a "federal natural park" and, behind-the-scenes, the FDC had drawn the park boundaries to exclude the Kingsmere-Meech Lake privatopia. Further, a national park requires the agreement of the host province; even though FDC officials approached the Quebec government about the national park in the Gatineau Hills, they never

\footnotetext{
${ }^{635}$ Federal District Commission. 1939-1940. Ibid., pg.7.

${ }^{636}$ Federal District Commission. 1948. Annual Report. Ottawa: King’s Printer, pg.10.
} 
reached an agreement. This opened the door to the later condemnation of FDC expropriations by Premier Duplessis. After 1948, the FDC would no longer expropriate for park purposes. In total, the FDC had, between 1938 and 1948, expropriated 3,301 acers of land. ${ }^{637}$

Unlike Canada's national parks, territoriality in Gatineau Park is not confined to the federal government. This chapter also described the exercise of territoriality by the Meech Lake Association and Kingsmere Property Owners' Association as they tried to regulate future development and limit public access to their privatopia. The FDC supported the MLA in the passage of a comprehensive municipal bylaw, which required an amendment to the Quebec Municipal Code and was never enforced by the Municipality of West Hull. And the FDC sought out legal advice when the KPOA attempted to restrict its powers of expropriation and ownership. Thus, the FDC co-operated with these property owner associations even as they asserted territoriality over adjacent areas, i.e., the MLA protest against rumored plans for a beach on Meech Lake. Further, the FDC received warnings from the Advisory Committee that property values would increase in Gatineau Park, especially with the completion of the Gatineau Parkway (and, as documented in the next chapter, the FDC built parkways in the vicinity of Kingsmere).

Even though the Advisory Committee recommended the expropriation of Kingsmere Lake, it did not follow through on this logic with respect to Meech Lake. This chapter examined the first signs of the rift within the ACGP as opinion was divided on the issue of privately-owned lands in the park. As shown in the following chapter, Chairman Sparks came out against the park's status quo as a mixed-use/ownership area, insisting that Gatineau Park should be administered as a national park for the benefit of all Canadians. The ACGP Secretary Connolly, who was also the MLA Secretary, maintained that residents were responsible park stewards and

${ }^{637}$ Richards, E.S. 1953, Oct. 29. List of Land Expropriated and Forming Part of Gatineau Park. RG34 Vol.270C(4). 
that, historically, the Gatineau Hills had provided generations of families with a much-needed escape from Ottawa. 


\section{Chapter 4: Controversy sparked over the park's status quo}

Thousands of maps have been issued by the FDC [Federal District Commission] showing that all these properties at Kingsmere and Meech Lake are within the designated boundaries of Gatineau Park. All of the property owners in that area have a direct financial interest in the plans of the Commission and under no circumstances should their situation be regarded as a matter of public relations. In fact it is no reflection on them to say that their interest may be in direct conflict with the public interest. ${ }^{638}$

Roderick Percy Sparks, Gatineau Park founder and architect Before a joint-parliamentary committee in June 1956

\section{Introduction}

As shown in the last chapter, the park's territorialization by the Federal District Commission (FDC) did not involve the superimposition of boundaries over an entire area, but proceeded by way of piecemeal acquisitions through negotiated purchase or, only if necessary, expropriation. The FDC began by acquiring a nucleus of lands around Kingsmere and Meech Lakes, with notices of expropriation informing property owners that the FDC was establishing a national park. In 1948, the FDC brought Philippe Lake fully into the park territory by expropriating 40 residents. But this was the last major expropriation, as Premier Maurice Duplessis challenged the authority of the FDC to expropriate lands in Quebec for the purposes of capital beautification. Thus, the land acquisition proceeded by way of negotiated purchase. In 1949, the park territory was expanded to include land around La Pêche Lake. In the years following, Mackenzie King bequeathed his 600-acre Kingsmere estate as a public park, and the FDC purchased the 4,300acre Edwards estate, thereby consolidating its ownership and control of Harrington Lake.

\footnotetext{
${ }^{638}$ Sparks, R.P. 1956, June 26. "Land Policy in Gatineau Park." Canada. Parliament. Joint Committee of the Senate and the House of Commons on the Federal District Commission. Minutes of Proceedings and Evidence, Vol.18, pg.842.
} 
The last chapter revealed that the park was created by and for "park residents," those living in the Kingsmere-Meech Lake privatopia. Through their property owner associations, park residents exercise territoriality. Through an amendment to the Quebec Municipal Code by the provincial legislature, the Meech Lake Association had a municipal bylaw enacted to regulate future development, requiring a minimum standard be met such that only the well-to-do could build residences at the Lake. Further, the MLA and Kingsmere Property Owners' Association (KPOA) tried to restrict public use of both lakes. The MLA even protested rumored FDC plans for a public beach, while the KPOA tried to enter an agreement with the FDC to prevent it from establishing any park facilities at Kingsmere Lake. Thus, the MLA and KPOA were intent on keeping park visitors from the Kingsmere-Meech Lake privatopia even though surrounding lands (i.e., the wooded hillsides) had been acquired under the pretense of national park purposes.

As Sack's analytic grid points out, territoriality is something that can be turned on and off. But, in the case of Gatineau Park, such a binary is complicated, particularly with respect to the Kingsmere-Meech Lake privatopia. The Order-in-Council that authorized the FDC to acquire lands for the park excluded it. And this chapter shows that FDC was ambiguous about whether it was intent on eliminating privately-owned land at Kingsmere and Meech Lakes. As pointed out in the epigraph, the FDC did not suggest that Kingsmere and Meech Lakes were excluded from the park territory; behind the scenes, however, it was reluctant to exercise territoriality there. And, had the FDC decided to carry out the blanket acquisition necessary to turn Gatineau Park into a national park, park residents (many of whom were lawyers) would have probably challenged the expropriations in the Exchequer Court. Then there was the fact that many federal government officials, including the FDC leadership, owned property in the park's privatopia. 
Just as much of the park territory was a mixture of public and private land, so its administration was a mixture of public and private interests. In other words, it is a failed national park.

In 1951, a Kingsmere resident and lawyer, Duncan MacTavish, was appointed as the FDC Chairman. As documented in Chapter 2, MacTavish was formerly the Secretary of the Federal Woodlands Preservation League (FWPL), the lobby group set up by the Meech Lake Association and led by future park residents to pressure the federal government into acquiring lands in order to resolve the Gatineau Hills denudation issue. The FDC noted of MacTavish: "His great love of the outdoors made the development of Gatineau Park of particular interest to him.. ${ }^{\circ 39}$ Unfortunately, it is unclear whether MacTavish was for or against the public ownership of Gatineau Park. In May 1950, while he was a Commissioner, MacTavish urged the FDC to expropriate, if necessary, "the development along the road between Old Chelsea and Kingsmere... It is obvious that if this [private development] is to go unchecked, a very unattractive situation will be created and its correction will be extremely expensive." ${ }^{640}$ But, in that same letter, Commissioner MacTavish suggested that the Gatineau Park Superintendent discuss a possible ski tow and concessionary near Meech Lake with a private developer. ${ }^{641}$ Later, as FDC Chairman, MacTavish contemplated "acquiring property for Gatineau Park by restricted covenants rather than by complete acquisition, particularly with respect to populated areas."642 While the use of restricted covenants may have had the effect of making park residents more willing to sell to the FDC, the terms of sale would have probably restricted the FDC from establishing public facilities on newly acquired lands.

\footnotetext{
${ }^{639}$ Federal District Commission. 1952. Annual Report. Ottawa: King's Printer, pg.29.

${ }^{640}$ MacTavish, D.K. 1950, May 15. Letter from D.K. MacTavish to H.R. Cram. RG34 Vol.267.190(14).

${ }^{641}$ Ibid.

${ }^{642}$ Cram, H.R. 1952, Feb. 5. Memorandum, re: Gatineau Park. RG34 Vol.267.190(15).
} 
Regardless of his position, Chairman MacTavish was confronted with the issue of the FDC policy on privately-owned lands in Gatineau Park. This chapter describes how the insider dispute over this divisive issue was turned into a public controversy. The first section uncovers the spectrum of opinion among members of the Advisory Committee on Gatineau Park which is on full display in the Appendix of its 1952 Report on a Master Plan for Gatineau Park. Members Herbert Marshall (Ottawa Ski Club President) and John J. Connolly (MLA Secretary) argued that the park should remain a mixed-use/ownership area - the status quo be maintained. They believed that park residents contributed to preserving the natural beauty of the landscape. The Advisory Committee Chairman Sparks and member General E.L.M Burns, both park residents, were in favor of the public ownership of the park, and, in their submissions to the Appendix, correctly foresaw the problems that private lands would create for park officials. But Sparks and Burns held opposite views as to how the FDC should consolidate territorial control, with Sparks advocating expropriation while Burns wanted negotiated purchase. For its part, the FDC, having received the Report and its inflammatory Appendix, did not alter its policy of acquiring parklands on a willing seller basis. The FDC did, however, become more determined to acquire lands at Kingsmere and Meech Lakes (on a willing seller basis). In late 1952, MacTavish assumed the Presidency of the Liberal Party of Canada. He was succeeded by another Kingsmere resident, Major General Howard Kennedy, who remained the FDC Chairman until the institutional reform of the FDC in 1958 (and, as shown in the next chapter, continued to exercise influence as a Commissioner of the National Capital Commission).

As the FDC began acquiring property at Meech Lake, the Meech Lake Association sought reassurances from the FDC that it would not expropriate. The second section details how the FDC, under Chairman Kennedy, responded with a public statement on its Gatineau Park land 
acquisition policy which renounced expropriation except to facilitate parkway construction. Notably, the policy statement did not indicate whether it was the intention of the FDC to acquire remaining privately-owned land. The second section then details Kennedy's campaign to have Chairman Sparks removed from the Advisory Committee for his stance on FDC expropriations to consolidate the park's fragmented territory. Following Sparks' departure, there was no further activity from the ACGP.

The third section documents Sparks' unwillingness to abandon his campaign to bring about the public ownership of Gatineau Park through a "rational" acquisition policy, one that involved a blanket expropriation. Knowing that a joint-parliamentary committee was going to be set up to investigate FDC progress in implementing the 1950 Plan for the National Capital, Sparks took it upon himself to prepare a brief, detailing the problems with private lands and the influence of the Kingsmere-Meech Lake privatopia and its residents. Before presenting his brief to the joint-parliamentary committee, Sparks published excerpts of it in the Ottawa Journal. Of course, Meech Lake residents defended themselves from Sparks' charges of “eyesores.” Although Sparks' brief went into detail about the long-term consequences of allowing privatelyowned lands in Gatineau Park, he failed to convince the joint-parliamentary committee to recommend the elimination of privately-owned lands from the park - or, put more positively, the public ownership of Gatineau Park. Rather, the joint-parliamentary committee congratulated the FDC on its wise policy. Throughout the institutional reform of the FDC, Chairman Kennedy ensured the continuity in the Gatineau Park land acquisition policy.

When considered overall, Sparks' failure was the park's failure. Before the institutional reform had taken place, the FDC could not acquire the lands necessary to extend the Gatineau Parkway to Philippe Lake, the park's main public facility. Even though stated policy was to 
expropriate for parkway purposes, the FDC decided to develop the parkway around the Kingsmere-Meech Lake privatopia. The third section concludes by describing how, despite some preliminary work, the extension of the parkway to Philippe Lake was eventually abandoned, such that the parkway system was only half completed. Not coincidentally, the park's current governing body, the National Capital Commission (NCC), refers to the Kingsmere-Meech Lake area as the Parkway Sector, revealing the strong connection between automobility and exclusivity in this privatopia. The following two chapters further describe the long term consequences of privately-owned lands in the park. Much as Sparks predicted, the NCC expropriated property to prevent the development of ski resorts and cottage subdivisions, while park residents resisted NCC plans to establish public facilities at Meech Lake.

\section{A rift in the Appendix}

From the outset, the Advisory Committee on Gatineau Park (ACGP) was tasked with giving the FDC recommendations on what areas should be included in the park territory. On the advice of the Advisory Committee, the park territory was expanded to include La Pêche Lake, and the FDC consolidated ownership at Philippe Lake. The Advisory Committee also suggested, as part of its plan to make Gatineau Park into a self-liquidating real-estate operation, that the FDC expropriate privately-owned lands at Kingsmere Lake. The FDC did not carry out this recommendation. Notably, the Advisory Committee was silent on the question of whether the FDC should acquire privately-owned lands at Meech Lake. The expropriation of Philippe Lake residents was justified, in part, on the basis that Meech Lake was "a thickly settled area."643 Further, the Advisory Committee contended that Meech and Harrington Lakes were unsuitable

\footnotetext{
${ }^{643}$ Connolly, J. 1947, June 10. Ibid.
} 
for public facilities: "The shores ... are mostly rocky. There are small sandy areas on both but not suitable as public bathing beaches." ${ }^{644}$ While the other lakes might have, indeed, been more suitable, the question of whether the FDC should acquire property at Meech Lake remained. As Chairman Sparks explained to the FDC Secretary in May 1948, this question was often discussed by the Advisory Committee but needed further study. ${ }^{645}$ The 1949 General Report of the advisory committee failed to address the acquisition of Meech Lake, and promised that a recommended policy on privately-owned lands would be addressed in "a future report." Unfortunately, the minutes of ACGP meetings are not filed in the FDC archived documents, but the question clearly vexed the committee.

\section{Figure 4.1: Sparks guiding school children in Gatineau Park (1949)}

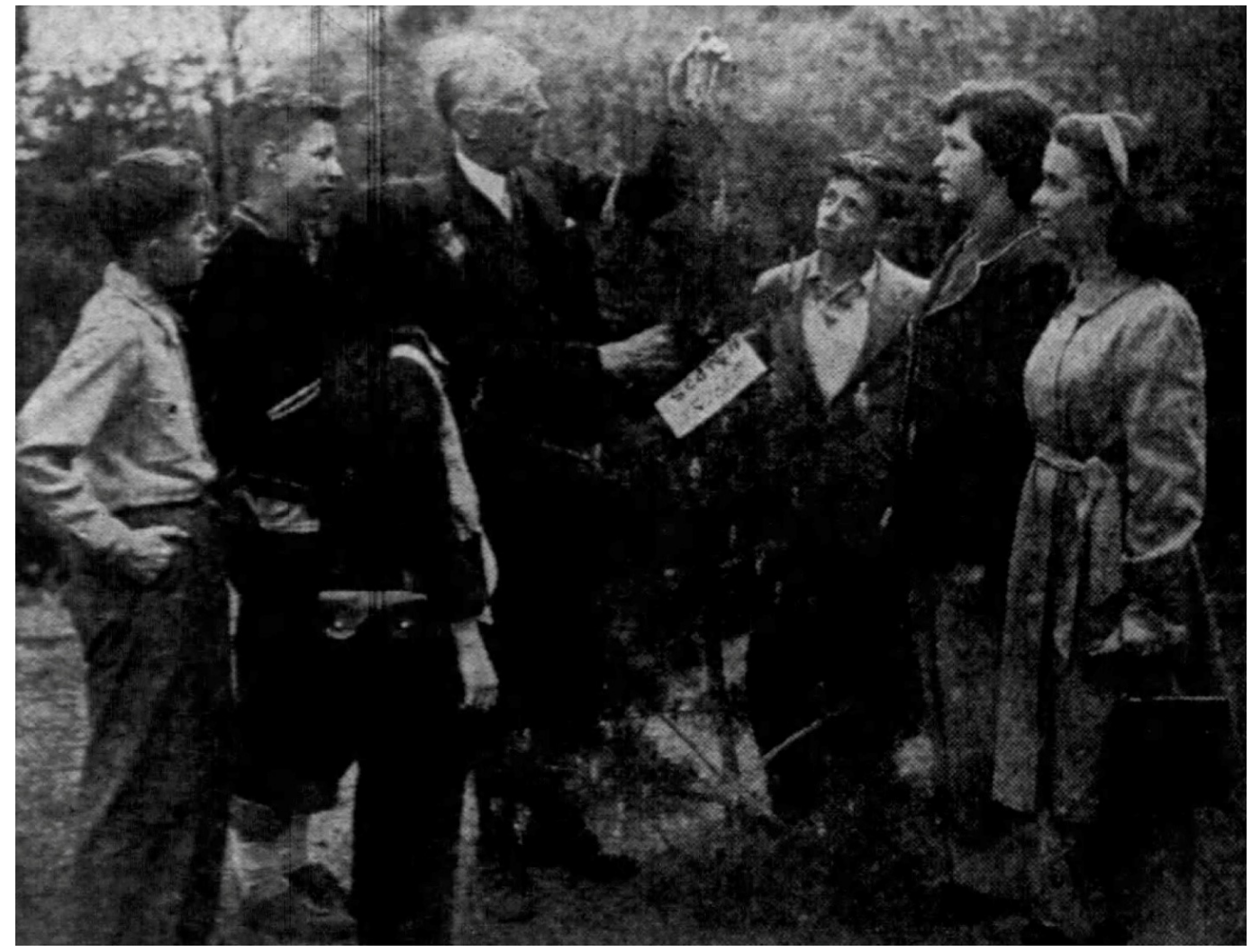

Source: Ottawa Journal, 27 May 1949

\footnotetext{
${ }^{644}$ Sparks, R.P. 1947, Dec. 23. Ibid., pg.1.

${ }^{645}$ Sparks, R.P. 1948, May 11. Ibid.

${ }^{646}$ Advisory Committee on Gatineau Park. 1949, May 16. Ibid.
} 
In 1951, the FDC tasked the Advisory Committee with the preparation of "a Master Plan as a guide for the expansion of the Park..." ${ }^{647}$ In May 1952, the ACGP submitted the Report on $a$ Master Plan for Gatineau Park. The confusing title is worth noting, for the document is a comprehensive long-term master plan masquerading as a report. The long list of recommendations from the 1949 General Report is recycled (these were, in turn, recycled from the 1945 Report of the Federal Woodlands Preservation League). And the most significant recommendation implemented by the FDC was the start on parkway planning, discussed in the next section. But the thorny issue of privately-owned lands at Kingsmere and Meech Lakes precluded the Advisory Committee from submitting a master plan. Ultimately, the committee did not fulfill its role in guiding the park's expansion. This was largely because several committee members rejected the idea of consolidating territorial control with the FDC. The rift in the committee was finally exposed in the Appendix to its 1952 Report.

The most entrenched supporter of the park's status quo as a mixed-use/ownership area was Secretary Connolly. Existing public facilities at Philippe and La Pêche Lakes, he contended, were adequate and could accommodate increased public use. Further, Kingsmere, Meech, and Harrington Lakes were unsuitable for public beaches, but were ideal for summer cottages. Connolly argued that it is no coincidence that "this area west of the Gatineau River has been a summer resort district for citizens of Ottawa for many years." ${ }^{\prime 648}$ He went on to add:

This been one of the very desirable features of life in Ottawa. Unlike the case in Toronto and Montreal, citizens of Ottawa of moderate means have been able to have summer places within commuting distance of their work. This has provided them and for their children for generations and the beauty of the countryside has not been damaged thereby. ${ }^{649}$

\footnotetext{
${ }^{647}$ Federal District Commission. 1951. Ibid., pg.18.

${ }^{648}$ Ibid.

${ }^{649}$ Ibid.
} 
As the Secretary of the Meech Lake Association, Connolly had a leading role in the enactment of the municipal building bylaw which, in principle, regulated development in the KingsmereMeech Lake privatopia. For Connolly, the MLA's role in this proved that residents were responsible stewards of Gatineau Park. While conceding that undesirable new developments had occurred despite the bylaw (and he urged the FDC to take steps to strengthen and enforce the municipal bylaw), other residences "add tremendously to the attractiveness of the landscape and give great additional value to the district." ${ }^{650}$ Thus, "[t]here would seem to be no reason why the three Lakes in question should ever be returned to a state of nature in a country like Canada which contains so many lakes where nature will never be disturbed."651

Those who advocated for complete public ownership of Gatineau Park, according to Connolly, failed to appreciate the role played by "the Community Associations established or to be established ... The purpose of these Associations is to try and develop among the residents a concern for the preservation of the natural beauty of the locality by voluntary effort." $" 652$ Through trilateral co-operation between the MLA, FDC, and Municipality of West Hull, Connolly argued that the park would be preserved: residents would not subdivide their property, and any and all new developments would meet the "standard set by the Commission..."653 In response to claims that the Gatineau Parkway would provide "windfall profits" to adjacent park residents, Connolly confidently wrote: "I am firmly of the opinion that few, if any people, in the areas discussed herein, will see their property values increased through any new roads which might be built by

\footnotetext{
${ }^{650}$ Ibid.

${ }^{651}$ Ibid.

${ }^{652}$ Ibid.

${ }^{653}$ Ibid.
} 
the commission." ${ }^{654}$ In his view, the park benefitted more from the stewardship of park residents, such that the FDC should only purchase properties as they come on the market.

Connolly's stance on maintaining the park's status quo as a mixed-use/ownership area was reinforced by Herbert Marshall, then President of the Ottawa Ski Club. As the last chapter documented, the OSC rejected the FDC proposal to transfer Camp Fortune to the park territory, in exchange for considerable federal investment in skiing facilities. A corporate property-owner, the OSC was a member of the Kingsmere Property Owners' Association, and President Marshall's submission to the 1952 ACGP was confirmation that it generally supported park residents. Thus, Marshall's submission maintained private residences at Kingsmere and Meech Lakes "are not painful to aesthetic sensibilities ... To remove them would be a meticulous striving after additional aesthetic values." ${ }^{655}$ While understanding the importance of those values, the OSC President emphasized the park's recreational vocation, and even proposed a golf course. Marshall conceded that some ugly cabins had already been erected along Kingsmere Road, and he expressed concern that Kingsmere could even "become a slum area." ${ }^{656}$ So, while Marshall agreed with Connolly with setting standards and regulations on future building in the KingsmereMeech Lake privatopia, the Ski Club President went one step further than the cottager by insisting that the FDC should "[s]ecure the right to expropriate property within the Park area." 657 Marshall concluded that: "no irrevocable decision should be made now which would stir up opposition on the part of a large number of people and which the future development of the Park may show to be quite unnecessary." ${ }^{\prime 658}$ The existing FDC policy of purchasing lands as they

\footnotetext{
${ }^{654} \mathrm{Ibid}$.

${ }^{655}$ Marshall, H. 1952, May. "Private Ownership of Property in Gatineau Park.” In Advisory Committee on Gatineau Park. Report on Master Plan for the Development of Gatineau Park. Ottawa: Federal District Commission, pgs.2425.

${ }^{656}$ Ibid.

${ }^{657} \mathrm{Ibid}$.

${ }^{658}$ Ibid.
} 
come on the market should be continued. Marshall did not offer his view on whether privatelyowned lands should eventually be eliminated.

However, this was the view taken by the memoranda submitted by the remaining committee members. General E.L.M. Burns, a Kingsmere resident appointed to the Advisory Committee on the suggestion of Chairman Sparks, ${ }^{659}$ saw the need to eliminate privately-owned lands because "such property will, in the long run, cause many inconveniences to the public and in the administration of the Park for the public benefit." ${ }^{960}$ But General Burns recommended that the acquisition of privately-owned lands within the park should only be carried out incrementally and strategically, with the FDC prioritizing large parcels of vacant lands. Park residents might be encouraged to "sell their lands subject to their retaining rights of occupancy at nominal rentals for the period of their lifetime." ${ }^{661}$ And, if the FDC could not purchase property deemed essential for park purposes, Burns argued that it should "obtain powers of expropriation by agreement with the Provincial Government."662

Chairman Sparks found the incremental approach to be inadequate because it meant that privately-owned lands would continue to exist in the park almost indefinitely. His submission elaborated on the problem of divided control, citing the experience of national parks in the United States where privately-owned lands "present grave problems of administration and protection." ${ }^{663}$ While Connolly and Marshall believed that municipal bylaws could regulate

\footnotetext{
${ }^{659}$ Sparks, R.P. 1949, Mar. 22. Letter from R.P. Sparks to H.R. Cram. RG34 Vol.272.190-G(1).

${ }^{660}$ Burns, E.L.M. 1952, May. "Private Ownership of Property in Gatineau Park." In Advisory Committee on Gatineau Park. Report on Master Plan for the Development of Gatineau Park. Ottawa: Federal District Commission, pg. 23.

661 Ibid.

${ }^{662}$ Ibid.

${ }^{663}$ Newton B. Drury cited in Sparks, R.P. 1952, May. "Private Ownership of Property in Gatineau Park.” In Advisory Committee on Gatineau Park. Report on Master Plan for the Development of Gatineau Park. Ottawa: Federal District Commission, pg.22.
} 
future building and land uses within the park, Sparks believed that this would have the effect of homogenizing the class composition of park residents:

I think it is generally agree that a great many of these structures should be removed as they are wholly out of keeping with a national park. It is a fact, however, that the type and condition of these buildings in a general way would reflect the income groups to which they belong. I do not think it is possible or desirable to remove only the buildings owned by people in the lower income group and leave the property of the well-to-do where they are. The removal of the poorer type of buildings would greatly enhance the value of the few buildings of the better type which would remain and I do not think that the Commission can be a party to windfall profits of this character to a select few. ${ }^{664}$

And, whereas Connolly and Marshall viewed the existing residences as complementing the park's natural beauty, Sparks conducted a survey of the Meech Lake (see Table 4.1) and found the majority "[d]ecidedly ugly and might properly be described as eye-sores." ${ }^{665}$ Sparks was emphatic that the FDC acquire Meech Lake since "[i]t is the most scenic [lake] and the one which if its shores were open to the public, would be the most used. It is the very heart of the whole park project and yet the Commission does not own one foot of its shoreline." ${ }^{666}$ Lack of ownership would also hinder the construction of the Gatineau Parkway; if it had to be routed to avoid privately-owned lands, it would be costlier to build and provide less in the way of scenic values.

Table 4.1: Survey of Meech Lake cottages by R.P. Sparks (1952)

No. of buildings Description

60 Decidedly ugly and might properly be described as eye-sores

23 Respectable but certainly not attractive

6 Attractive summer cottages in good locations

23 Garages, all ugly, and badly located

40 Boathouses, all ugly

12 Combination boathouses and garages, worse still

Source: Sparks, R.P. 1952, May. Ibid., pg.21

\footnotetext{
${ }^{664}$ Sparks, R.P. 1952, May. Ibid., pg.21.

${ }^{665}$ Ibid.

${ }^{666} \mathrm{Ibid}$, , pg.21.
} 
The ACGP Chairman was adamant that the "national interest" should come before the private interests of residents and, to a certain extent, skiers. To this end, Sparks insisted that the FDC should consolidate ownership and, by implication, control of this "National Park." In his memorandum, Sparks frequently referred to Gatineau Park as a national park, and even obliquely criticized the federal government when he wrote that:

It would have been better if, when the decision was made to create a National Park in this area, a policy had been adopted to prevent new buildings on the area which it was proposed to take over. However, this was not done and some building has been continued on land which it was known would be ultimately required for park purposes. Even if a decision had been made when the Gréber Report was finally accepted, there would have been substantial savings.

I am convinced that when the time comes to fully develop this magnificent project, it will be found that no proper planning is possible if the park area is cluttered up with privately owned land and buildings. ${ }^{667}$

To bring Gatineau Park closer in line with Canada's national parks, Sparks recommended that the FDC "adopt the policy of no privately-owned land within the park boundaries." 668 Knowing that land values were going to increase to astronomical levels following the construction of the parkway, he suggested the imposition of a 10-year time-frame within which the FDC would take over all remaining privately-owned lands, with the expropriation of those property owners who refused to sell by the deadline.

While the Appendix revealed that there was a spectrum of opinion, the Report had earlier indicated that " $[\mathrm{t}]$ he majority of the Committee have come to the conclusion that ultimately all private property within the park should be acquired by the Commission." 669 Still, the Advisory Committee could not agree on the means through which the FDC would consolidate ownership of the park territory. Following the submission of the Report, Chairman Sparks implored the

\footnotetext{
${ }^{667}$ Emphasis added. Ibid., pg.22.

${ }^{668}$ Ibid., pg. 22.

${ }^{669}$ Advisory Committee on Gatineau Park. 1952, May. Ibid., pg.12.
} 
Advisory Committee members to render a final decision on "whether or to what extent privately owned land is to be allowed within the Gatineau Park area. This problem interjects itself into nearly every aspect in the planning and development of the Park." ${ }^{970} \mathrm{He}$ added: "I am convinced that we cannot draft a worthwhile Master Plan until this decision is made." ${ }^{671}$ Despite Sparks’ attempts, the Advisory Committee never reached a compromise on this issue.

Two-hundred copies of the 1952 ACGP Report were circulated to FDC officials, members of the National Capital Planning Committee, and other government officials such as the mayors of Hull and Ottawa. ${ }^{672}$ Even as the report was under consideration, the FDC began acquiring remaining privately-owned lands through negotiated purchase. In September 1952, the Gatineau Park Superintendent obtained options to purchase several properties at Kingsmere and Meech Lakes. As Richards explained of the latter, "they are for vacant building sites, or for rather old cottages that are offered cheap. Options were taken in the belief that it would be to the Commission's advantage to gradually acquire parts of the shore line of Meech Lake when such can be obtained through voluntary sale at prices favourable to the Federal District Commission." 673 The Advisory Committee was consulted about acquiring the Kingsmere properties as they were located adjacent to the Mackenzie King estate; Chairman Sparks was emphatic that the FDC proceed with purchasing the Kingsmere properties. ${ }^{674}$

In September 1952, Secretary Cram prepared a brief, Gatineau Park Land Acquisition Policy. Having worked for the FDC since the park's inception, Secretary Cram had an intimate understanding of the parkland acquisition policy, and its impact on the park's development.

\footnotetext{
${ }^{670}$ Sparks, R.P. 1952, July. Ibid.

671 Ibid.

${ }^{672}$ Cram, H.R. 1952, June 11. Letter from H.R. Cram to multiple recipients. RG34 Vol.267.190(16).

${ }^{673}$ Richards, E.S. 1952, Sept. 10. Gatineau Options for Consideration Federal District Commission Meeting. RG34 Vol.269.190-B(2).

${ }^{674}$ Sparks, R.P. 1952, Sept. 10. Letter from R.P. Sparks to H.R. Cram. RG34 Vol.272.190-G(1).
} 
The Federal District Commission in 1936 recommended as the initial step in forming Gatineau Park the purchase of some 12,000 acres in the Kingsmere, Old Chelsea and Meech Lake area, where wood cutting was then largely centered. Consideration was given to the method of securing the control needed to protect the forest cover and to make lands freely usable by the general public in the park to be formed. It was decided that land purchasing was the best way to secure the complete control desired, and this policy was adopted and has since been consistently followed by the Commission in subsequent enlargements of the Park. The Federal Government concurred. ${ }^{675}$

Still grappling with the different options presented by the Advisory Committee, the FDC Executive sought out the opinion of Jacques Gréber, consultant of the National Capital Planning Committee. ${ }^{676}$

As indicated earlier, the 1950 Plan for the National Capital Region, prepared by the NCPC under Gréber's direction, treated Gatineau Park in relatively broad terms, calling for its protection, enlargement, and the construction of the Gatineau Parkway. As mentioned, the 1950 Gréber Plan deferred to the expertise of the Advisory Committee on Gatineau Park, and Gréber repeated this move in his 1952 Report on Gatineau Park. Nevertheless, the preeminent planner had been given an opportunity to elaborate on what he considered "really the essential feature of the whole plan of the National Capital of Canada." ${ }^{677}$ He recognized the park's intrinsic importance: "Its natural structure, the infinite variety of its beauty and the attractive possibilities of such a Park, are far beyond the needs of an ordinary city park at the service of the population of neighbouring cities." ${ }^{678}$ Although in agreement with Herbert Marshall that the issue of privately-owned lands in Gatineau Park "cannot be solved by a drastic and immediate regulation," Gréber adhered to the "principle" that the park "should be ultimately prohibited to

\footnotetext{
${ }^{675}$ Cram, H.R. 1952, Sept. 10. Memorandum, re: Gatineau Park Land Acquisition Policy. RG34 Vol.267.190(16).

${ }^{676}$ Cram, H.R. 1952, Aug. 28. Letter from H.R. Cram to J. Gréber. RG34 Vol.266.190(16).

${ }^{677}$ Gréber, J. 1952. Oct. 20. Report on Gatineau Park. Paris: Submitted to Federal District Commission, pg.2.

${ }^{678}$ Ibid., pg. 2.
} 
private ownership." ${ }^{\prime 679}$ To that end, he endorsed the policy of negotiated purchase, with expropriation as a last resort.

Nevertheless, Gréber shared Sparks' diagnosis of the problem, referring to the "hellish disorder" at Kingsmere and Meech Lakes. Further, he was in complete agreement with the Advisory Committee Chairman about the acquisition policy that should be adopted for the centre of the park:

Speaking now of really objectionable structures, either due to their location or by their shabby appearance, there is no other solution except elimination, and what has been successfully obtained around Lac Philippe, seems to be possible on the western side of Meech Lake. It is obvious that such elimination cannot be obtained at once, as a certain number of those objectionable buildings will necessitate long and desirable negotiations.

The fact that their establishment was tolerated and that families of residents of Ottawa are enjoying there, summer cottages and boat houses, must be handled with a certain diplomacy. Otherwise, the Federal District Commission might be criticized for maintaining country houses of wealthy people and expropriating summer cottages of people of low income, in spite of being fully justified for so doing for the sake of esthetics. ${ }^{680}$

Gréber concluded: "At any rate, Meech Lake, as very well stated by Mr. Sparks, is the largest and nearest lake to the Capital and must be gradually freed of all obstacles to a fully organized public enjoyment." ${ }^{681}$ Although Meech Lake was the essential part of Gatineau Park, which is, in turn, the essential feature of Canada's national capital plan, public facilities would not be established there until 1970 (see Chapter 6: Meech Lake goes public).

Still, the FDC did modify its land acquisition policy to include purchasing property around Kingsmere and Meech Lakes. As the FDC explained in its Annual Report, it had adopted, on the recommendation of Gréber and the National Capital Planning Committee, the

\footnotetext{
679 Ibid., pg.5.

${ }^{680}$ Gréber, J. 1952. Oct. 20. Ibid., pg.6.

${ }^{681}$ Ibid.
} 
1952 Advisory Committee Report “in principle." ${ }^{62}$ Meanwhile, the majority of the park's territory remained inaccessible to the general public. To remedy this, the FDC set up a Parkway Subcommittee for Gatineau Park (a subcommittee of the Advisory Committee on Gatineau Park). ${ }^{683}$ The ACGP Chairman Sparks was appointed a member of the Parkway Subcommittee, which was chaired by a road engineer, Howard Hyman. The activities and report of the Parkway Subcommittee are elaborated in the next section.

\section{Downfall of the Advisory Committee on Gatineau Park}

Although the 1952 Report on a Master Plan for Gatineau Park was treated confidentially, park residents, perhaps through Connolly, MacTavish, Sparks, etc., were "aware that the Federal District Commission, in its plans for the Gatineau Park, has an interest in developments in the Meech Lake area." ${ }^{984}$ In April 1953, the Meech Lake Association, on behalf of 150 families, submitted a memorandum to the FDC. As shown below, this memorandum set off a chain of events which culminated in Sparks' removal from the Advisory Committee, and its dissolution.

The MLA informed the FDC that it took "vigorous issue" with the "[p]roposals [which] have been made from time to time that all private property in the area should be eliminated at once." ${ }^{\prime 65}$ It then conceded that "there are unsightly developments. These should be removed as quickly as possible. But there are many places, in full view of the public, which add to the beauty of the area very greatly. These should not be eliminated. They give life and beauty to the

\footnotetext{
${ }^{682}$ Federal District Commission. 1954. Annual Report. Ottawa: Queen's Printer, pg.11.

${ }^{683}$ Gatineau Parkway Sub-committee. 1952, Nov. 21. Minutes of Meeting. RG34 Vol.190-G-2-1(1).

${ }^{684}$ Worden, A.R. 1953, Apr. 9. Letter from A.R. Worden to H.R. Cram. RG34 Vol.268.190(17).

${ }^{685}$ Meech Lake Association. 1953, Apr. 9. Memorandum to Federal District Commission. RG34 Vol.268.190(17), pg. 2 .
} 
countryside." ${ }^{\prime 66}$ This reflects the class exclusivity of the MLA: they might represent 150 "wellto-do" families, but they do not represent those families residing in unsightly developments. Added to this, the MLA did not want Meech Lake opened to Gatineau Park visitors. As with Connolly's submission to the 1952 Report, the MLA maintained that the lake's rocky and steep shores as well as a lack of beach areas along its shoreline render it unsuitable for public use. Based on this evaluation, the MLA predicted that "[i]f all private property was eliminated, there would be no public use made of the lake sufficient to compensate for the loss of private use which would ensue." ${ }^{687}$ Also, there were far more suitable lakes for public facilities, such as Harrington and Philippe Lakes. To deter FDC from its new policy of acquiring property in the KingsmereMeech Lake privatopia, the MLA cited the prohibitive cost, estimating privately-owned land to be worth \$2-million. ${ }^{688}$

But the MLA memorandum does not rely on this negative argument alone, namely, that the new FDC acquisition policy does more harm than good. Rather, it insisted on the positive effects of the park's status quo as a mixed-use/ownership area. Once again echoing Connolly's submission to the 1952 Report, the MLA referred to its pivotal role in the enactment of the municipal building bylaw as an example of its interest in preserving "the natural beauty, not only of Meech Lake, but as well of the entire municipality." ${ }^{689}$ Like Connolly, it conceded that the bylaw had, through no fault of the MLA, never been enforced. To this end, the MLA suggested that FDC park officials inspect the Meech Lake area "to report on violations and on situations which call for improvement." ${ }^{\prime 690}$ Further, the MLA promised its co-operation with the FDC in

\footnotetext{
${ }^{686}$ Ibid., pg.2.

${ }^{687}$ Ibid.

${ }^{688}$ Ibid., pg.3.

${ }^{689}$ Ibid., pg.2.

${ }^{690}$ Ibid.
} 
ensuring building and aesthetic standards were met, and asked for its assistance in molding

existing structures to conform with these standards.

On the south shore along the existing road there is some overcrowding, some unsightly cottages and unsightly boathouses. We believe that much could be accomplished to correct this situation through voluntary effort within the Meech Lake Association. However, the Association needs advice. If the FDC could delegate one of its officials to go over the ground with officials of the Association, a plan could be formulated to approach a standard set by the FDC. Discussion could cover the purchase by the FDC of certain available lands and buildings. Some cottages are now for sale. The building of others which might be a blight upon the scenery might be prevented. Landscaping and tree cutting should be discussed. Even a programme of painting buildings could be considered. The amalgamation or elimination of boathouses it appears, might well be desirable in some places. ${ }^{691}$

It took the FDC almost three months to respond to the MLA request. FDC officials knew that they needed to consult with the Advisory Committee on Gatineau Park on the matter, but were reticent to do so. In June 1953, the MLA memorandum was brought to the attention of the ACGP. The FDC Secretary casually wrote Chairman Sparks: "This memorandum may be of interest to you, and the Commission will be pleased to have your comments..." ${ }^{692}$ Sparks took the MLA memorandum as an opportunity to meet with the property-owner association, as had been done before with the Lac Philippe Cottagers' Association. Sparks would have probably informed the MLA that, in the development of Gatineau Park, public and national interests must override private interests. The ACGP Chairman was prevented from meeting with the MLA. ${ }^{693}$ Indeed, an anxious Gatineau Park Superintendent Richards urged the FDC that "this be not allowed." 694 Perhaps Richards recalled the previous meeting that he and the ACGP Chairman had with Philippe Lake residents, which Sparks portrayed as an unqualified success. Richards

\footnotetext{
${ }^{691} \mathrm{Ibid}$.

${ }^{692}$ Cram, H.R. 1953, June 17. Letter from H.R. Cram to R.P. Sparks. RG34 Vol.268.190(17).

${ }^{693}$ Sparks' response letter was not stored in the FDC archived files.

${ }^{694}$ Richards, E.S. 1953, July 6. Memorandum dated 9th April 1953 from the Meech Lake Association. RG34 Vol.268.190(17).
} 
was evidently concerned about the outcome of the proposed meeting with the MLA. He cautioned the FDC:

Mr. Sparks is responsible to no one and a hornet's nest will be stirred up. Things should be left just as they are, with the Federal District Commission buying up these lake side properties at a fair price as they become available. Within the last year eleven purchases have been made. There are still some 70 properties on the south west side of Meech Lake and 18 on the north east. Within five years a very different situation will exist if the present and proper policy is continued. ${ }^{695}$

The park superintendent then gave his views about the MLA memorandum. He rejected the claim that Meech Lake was unsuitable for public use, and that the loss of private use would not be compensated for by public use. And Richards rejected the MLA request for assistance:

I strongly recommend that a letter be sent the Meech Lake Association regretting that the Federal District Commission personnel is not available due to increased responsibilities caused through implementing the Capital Plan. Otherwise the Commission will work against its own interests. ${ }^{696}$

Richards' recommendation was accepted by the FDC, and Secretary Cram wrote both the MLA President and ACGP Chairman to inform them of its decision not to hold a meeting, or to co-operate with the MLA. Cram explained to Sparks that

while the suggestions by the Association had some merit, and it [the Commission] appreciated the efforts of the Meech Lake people in preparing bylaws, it did not feel that officials or personnel connected with the Federal District Commission should discuss this memorandum with the Association. It was felt that were such done, the Commission might find itself engaged in a policy of improving the properties of Meech Lake owners which it will be ultimately purchasing, thereby increasing the price. ${ }^{697}$

Obviously, Sparks was not going to assist the MLA in improving privately-owned lands, such that the FDC Secretary was evading the real reason the FDC did not want him to meet with park residents. The MLA President was similarly told that "the Commission commends the steps

\footnotetext{
${ }^{695}$ Ibid.

${ }^{696}$ Richards, E.S. 1953, July 6. Ibid.

${ }^{697}$ Cram, H.R. 1953, July 29. Letter from H.R. Cram to R.P. Sparks. RG34 Vol.268.190(17).
} 
which your Association had taken in the past as being of value to the whole Gatineau [Park?]

development." 698 Cram's letter to the MLA President continued:

The Commission, however, did not feel that it could make its personnel available in the way suggested in the memorandum as arising from the intensive development of the Park, such employees are not available, and also it was considered that the enforcement of the zoning bylaws was the responsibility of the municipality and/or the residents.

With respect to the suggestion that the FDC eliminate all private property in the area at once, we might assure you that this is not the policy of the Commission. The Commission is buying and will continue to buy property in the Meech Lake area as it becomes available for sale at reasonable and proper prices. However, it was never the intention of the Commission to eliminate all private property now. ${ }^{699}$

Early in October 1953, the FDC drafted two versions of its Policy on Land Ownership within Gatineau Park. Citing the policy of national park administrators in Canada and the United States as support, the unused draft indicates that "ultimately private ownership of land within Gatineau Park should cease."700 It then reiterates the FDC policy of purchasing property at reasonable prices as it becomes available on the market. Acknowledging that, by following this, it could take "50 years or more" to bring the park territory completely within the public domain, the unused draft concludes by indicating the FDC will expropriate "[o]nly in the case where some important development in the park is blocked by privately owned lands, such as for example the construction of the main driveway... which step would be considered in the public interest."

In the draft version that was published by the FDC, complete public ownership of Gatineau Park was not advanced as an objective. Further, although the expropriation policy is the

\footnotetext{
${ }^{698}$ Cram, H.R. 1953, July 29. Letter from H.R. Cram to A.R. Worden. RG34 Vol.268.190(17).

${ }^{699}$ Ibid.

${ }^{700}$ Federal District Commission. 1953, Oct. 7. Policy on land ownership within Gatineau Park (unused draft). RG34 Vol.268.190(17).

${ }^{701}$ Ibid.
} 
same as the unused draft, it is worded differently, such that the FDC is made to appear as never having expropriated for park purposes. As shown in the last chapter, the FDC expropriated 3,301 acres, and expropriated residents at Philippe Lake to consolidate ownership there. ${ }^{702}$ The full, official statement reads:

The Federal District Commission realizing that there is some uncertainty in the minds of property owners within the Gatineau Park area as to the attitude of the Commission toward purchase of private property, wishes to place on record its policy toward acquirement of land within the area. No effort has been made or will be made to expropriate property in Gatineau Park except in cases where such property is required to facilitate the construction of parkways. There is no intention of altering this practice.

On the other hand the Commission has purchased and will continue to purchase any property within the Park area which is available at a price which it considers reasonable. Municipalities will be adequately compensated for loss of tax revenue because of acquirement of property by the Commission.

In view of the fact that the shoreline of many of the lakes, such as Meech Lake and Kingsmere, within the Park area are privately owned, it is proposed to maintain Harrington Lake, the shoreline of which is wholly owned by the Commission, in its natural state. ${ }^{703}$

At the October meeting of the FDC Executive, this policy statement was adopted. The ACGP

Chairman was not informed of the decision by the FDC, but only found out about it through the

local newspapers which reported on the FDC meeting. ${ }^{704}$ Sparks' response is quoted in full:

I notice in both of last evening's papers a statement of policy by the Commission in respect to Gatineau Park. Sometimes these newspaper reports are somewhat garbled or condensed and sometimes they do not give a clear picture of what is proposed.

This raises a couple of questions in my mind. The Commission apparently are only going to buy properties which are offered for sale. Did they discuss the question of more building in the area by owners of property who decide not to sell to the Commission?

\footnotetext{
${ }^{702}$ Richards, E.S. 1953, Oct. 29. Ibid.

${ }^{703}$ Federal District Commission. 1953, Oct. 7. Policy on land ownership within Gatineau Park. RG34 Vol.268.190(17).

${ }^{704}$ No author. 1953, Oct. 20. "FDC Sets Expropriation Plans for Gatineau Park." Ottawa Citizen; see also No author. 1953, Oct. 20. "Council to Study FDC Request Building Permit Be Held Up." Ottawa Journal.
} 
There is a rather cryptic reference to the shorelines of Meech Lake and Kingsmere. Does this mean that regardless of the appearance of structures near these two lakes they are not to be touched and that more of the same type can be built?

Finally, is this a permanent policy for all time or a tentative policy subject to change if expropriation proceedings are facilitated?

If you could give me this information I would be very grateful. ${ }^{705}$

Sparks never received a response to his questions. Instead, he only received a copy of the official policy. ${ }^{706}$ A copy of the FDC land acquisition policy was also sent to the MLA. ${ }^{707}$

Even though it was now public knowledge that the FDC would not - and did not! expropriate for park purposes, Redmond Quain, a Kingsmere resident and lawyer, still launched a campaign against the powers of the FDC to expropriate for park purposes in Quebec. Quain suggested that the recent public statement by the FDC "was more to lull public uneasiness than to indicate clearly the Commission's intentions."708 The evidence suggests that Quain had spoken with ACGP Chairman Sparks, who had expressed his personal views to Quain about what the FDC ought to do, namely, "that all private homes in Gatineau Park limits be taken over by the Government." 709 The Lower Gatineau Chamber of Commerce appointed Quain as Chairman of a special committee "to inquire into the constitution and activities of the Federal District Commission, to protect property owners and public bodies in the Gatineau area."710 Through Quain's efforts, the municipality of West Hull was preparing “a resolution objecting to the expropriation of private homes in the area." 711 As a last resort Quain was even prepared to ask Union nationale Premier Maurice Duplessis to intervene on the FDC, knowing that Duplessis

\footnotetext{
${ }^{705}$ Sparks, R.P. 1953, Oct. 21. Letter from R.P. Sparks to H.R. Cram. RG34 Vol.272.190-G(2).

706 Sparks, R.P. 1956, June 26. Ibid., pg.837.

${ }^{707}$ Cram, H.R. 1953, Oct. 28. Letter from H.R. Cram to W. Duffet. RG34 Vol.268.190(17).

${ }^{708}$ No author. 1953, Oct. 24. "Uneasiness Expressed Over FDC Land Grabs in Gatineau." Ottawa Citizen.

${ }^{709}$ Ibid.

${ }^{710}$ No author. 1953, Oct. 24. "Battle Shapes Up Over FDC Power.” Ottawa Journal.

${ }^{711}$ Ibid.
} 
had, in December 1948, stated that the provincial government would issue a legal challenge against any expropriations by the federal government for capital beautification purposes. ${ }^{712}$ Quain, a self-identified member of the Liberal Party of Canada, was quoted as saying: "there seems no way of getting protection except by going to Mr. Duplessis."713

\section{Figure 4.2: Cartoon on Gatineau Parkway construction}

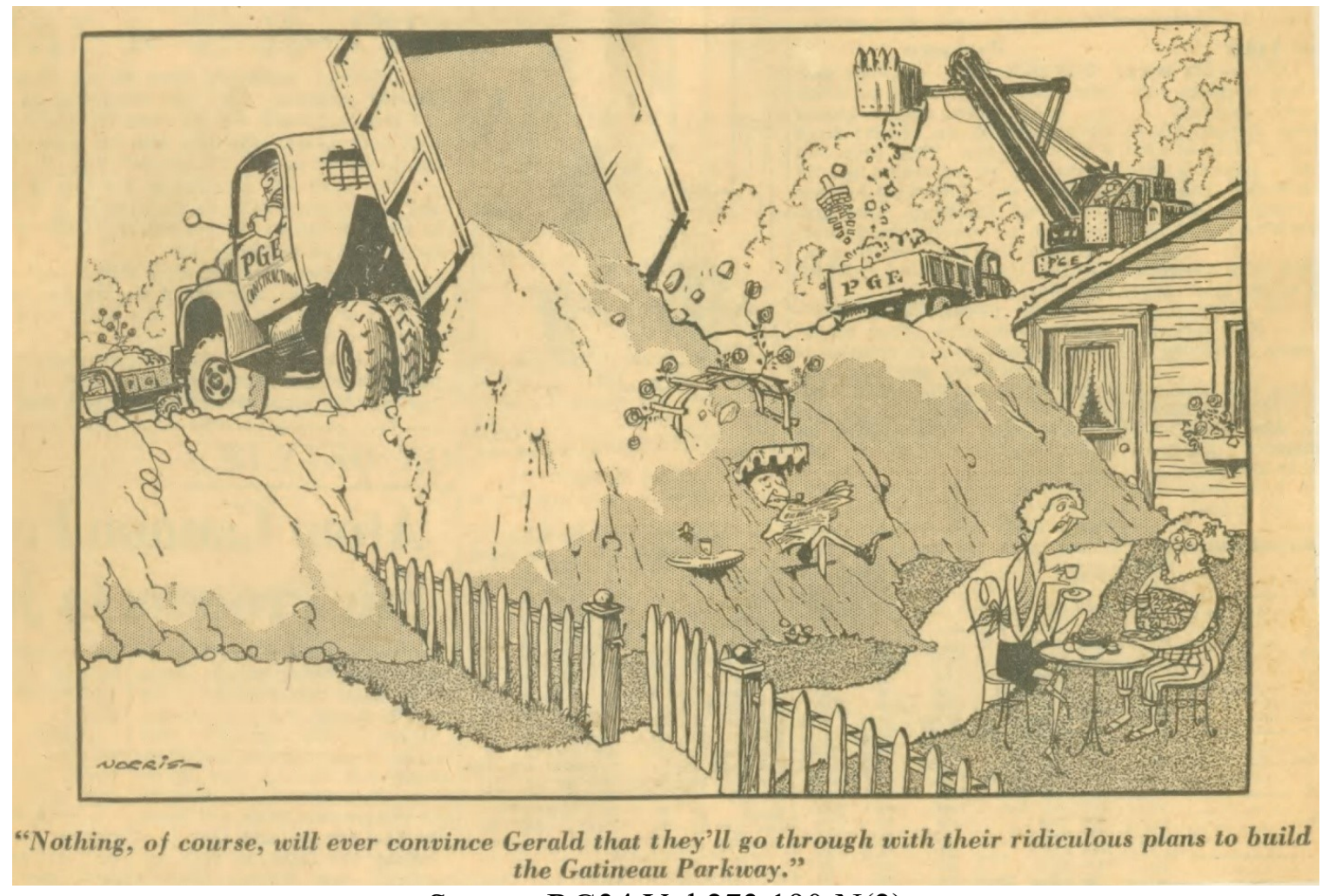

Source: RG34 Vol.273.190-N(2)

As Quain was stirring up opposition in Quebec, the Gatineau Parkway Subcommittee submitted its first report in December 1953. Members of the Parkway Subcommittee had travelled around the Appalachian Mountains for eight-days and examined the scenic parkways of the United States National Park Service in Virginia, North Carolina, and Tennessee. ${ }^{714}$

Subcommittee Chairman Hyman's letter hinted at the differences that had emerged within the

\footnotetext{
712 Ibid.

713 Ibid.

${ }^{714}$ Hyman, H. 1953. Letter from H. Hyman to R.P. Sparks. RG34 Vol.272.190-G2(1).
} 
subcommittee: "Reconciliation of the various viewpoints on the many subjects covered was not simple." ${ }^{715}$ Nevertheless, Hyman added that the parkway report, which prioritized scenic beauty over practical utility, was "a factual recommendation, by a disinterested group, with a conception of National character in mind..."

Figure 4.3: Map of projected Gatineau Parkway system

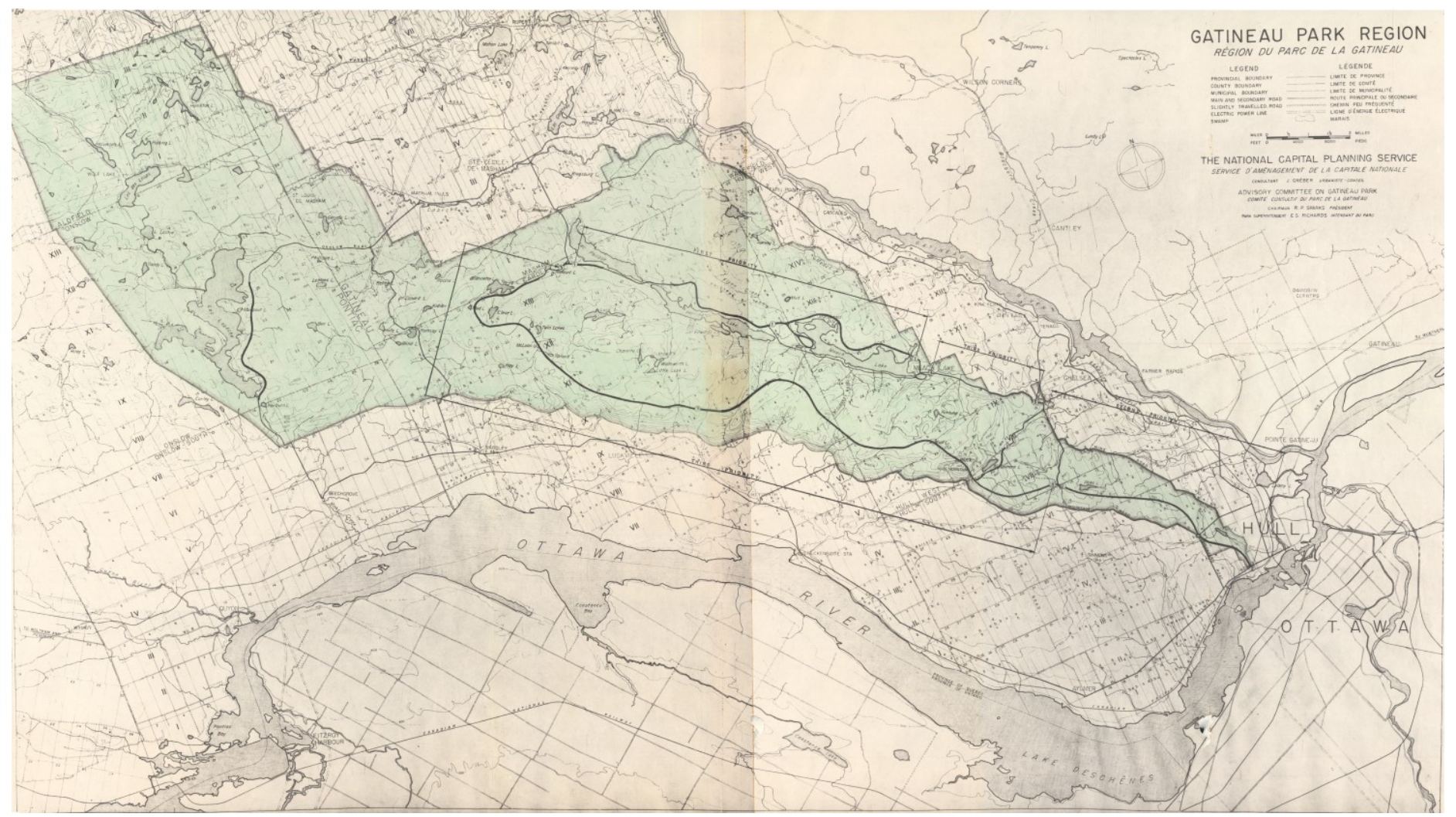

Source: Library Archives Canada Freiman Family fonds 756/23181, item 15

The General Report of the Gatineau Parkway Subcommittee reiterated much of what ACGP Chairman Sparks had already said about privately-owned lands in Gatineau Park. Members of the subcommittee discussed the problems of divided ownership and control with 
national park administrators in the United States. ${ }^{717}$ The Parkway Report detailed the problems with having privately-owned lands within the park's territory:

Private ownership will involve: complicated boundaries, making the game warden's job difficult; increased expenditure for grade separations and access roads; construction of unsightly parallel service roads, unreasonable fencing costs; elimination of some of the finest sites from public use.

Private ownership will bring uncontrolled subdivision of land, with the probability of jerry-built houses, neon signs, plastic palaces, amusement parks, stock car speedways, questionable "Tourist Accommodations." Subdivision means greatly increased population which leads to organization of pressure groups to request increased services, scheduled bus lines, additional winter ploughing, and many special privileges. Pressure groups inevitably create difficult situations between park authorities and the administrations of the municipalities and the province. Private ownership will be accompanied by disregard for park laws, and vandalism. Weekend visitors will be frustrated when coming across private holdings. Owners will resent infiltration and will resist the construction of Park developments near their boundaries. Fire hazards and fire protection costs will be greater. Dogs cannot be controlled. Conservation of wild life will be hampered. ${ }^{718}$

With the Ottawa Ski Club and property-owner associations at Kingsmere and Meech Lakes, Gatineau Park was perhaps more susceptible than most national parks to "pressure groups." Thus, the Parkway Subcommittee was emphatic that the FDC acquire all remaining privatelyowned lands as soon as possible for "[e]very mile of the Parkway which is built increases the value towards which it reaches. Delay can provide no gain.",719

Though the Parkway Subcommittee began studies of specific areas, these studies were suspended for Kingsmere and Meech Lakes because of the "unsettled question of land ownership in the lower end of the Park." ${ }^{720}$ In February 1954, during a joint-meeting of the Advisory Committee and Parkway Subcommittee, Herbert Marshall (President of the Ottawa Ski Club) objected to the Parkway Report for its position on privately-owned lands. The ACGP Chairman

\footnotetext{
${ }^{717}$ Ibid.

${ }^{718}$ Gatineau Parkway Subcommittee. 1953, Dec. General Report. Ottawa: Federal District Commission, pg. 18.

719 Ibid., pg. 19.

${ }^{720}$ Sparks, R.P. 1954, Feb. 25. Letter from R.P. Sparks to H. Kennedy. RG34 Vol.272.190-G2(1).
} 
noted that "[ $\mathrm{t}]$ he objector thought that if the Report should be made public these references [to eliminating private property] would provoke further controversy over a question which is already an issue and for this reason would reduce the educational and promotional value of a really excellent report." ${ }^{721}$ It is also notable that the ACGP Secretary, John Connolly, was absent from the joint-meeting such that, despite the objection raised, the General Report met with unanimous approval. ${ }^{722}$ Had Connolly been at the meeting, this would have probably not been the case.

Figure 4.4: Cadastral map of land acquisitions for Gatineau Parkway

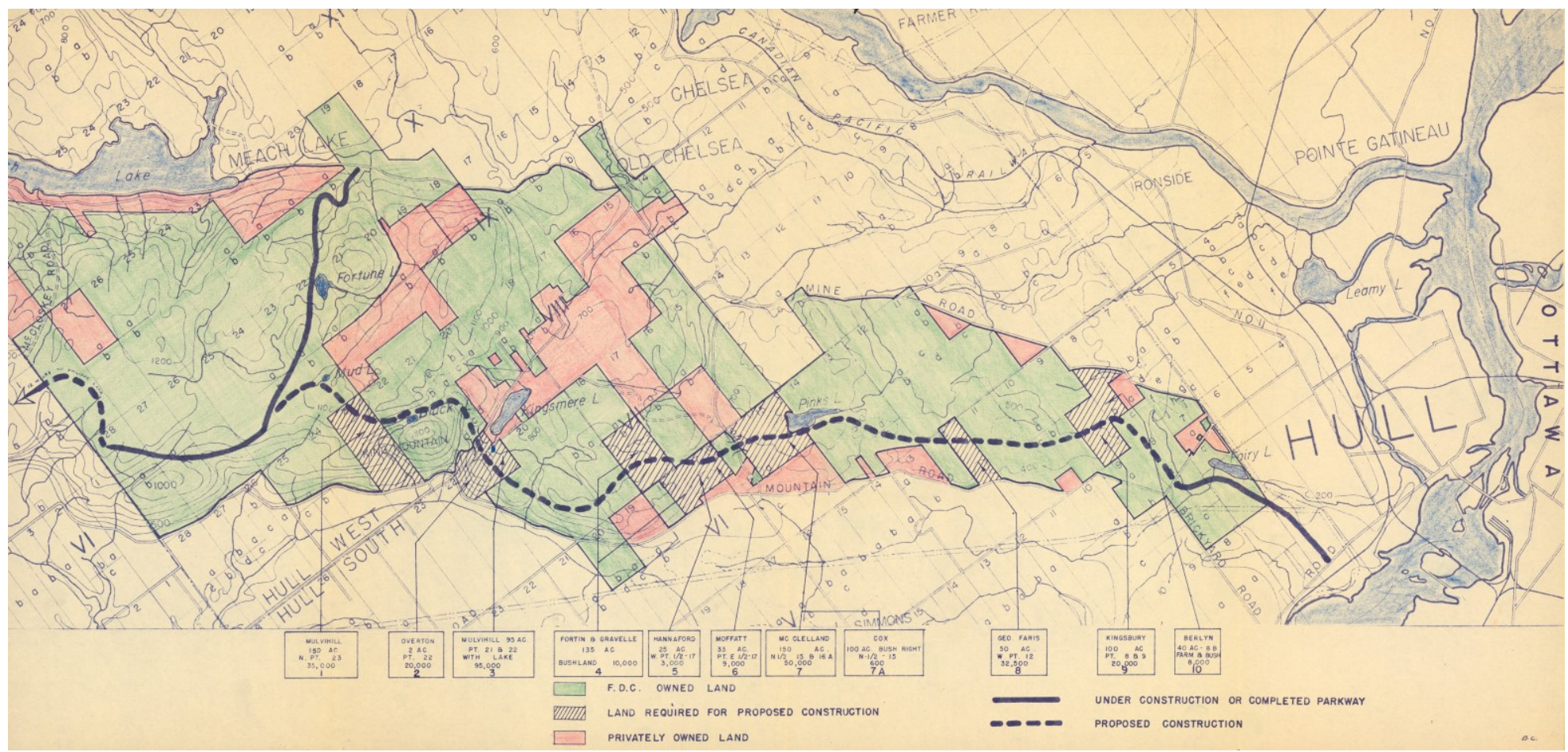

Source: Library Archives Canada Freiman Family fonds 756/23183, item 18

The Parkway Report was prepared while construction of the first stage of the Gatineau Parkway was underway, specifically the first 2-mile stretch of parkway from Aylmer Road at Val Tetreau to Gamelin Street (Mountain Road) adjacent to Kingsmere Lake (see Figure 4.4.). ${ }^{723}$ FDC surveyors were sent to the Kingsmere-Meech Lake area as the parkway was going to be

\footnotetext{
${ }^{721}$ Ibid.

722 Ibid.

${ }^{723}$ Federal District Commission. 1954. Ibid., pg.30.
} 
extended "along the Valley of the Three Lakes to the north end of Lac Philippe."724 Acting on behalf of a Meech Lake resident, Quain threatened to charge surveyors with trespass. ${ }^{725}$ The FDC was also encountering problems in the Kingsmere-Meech Lake area with purchasing lands for the parkway right-of-way. As indicated by the FDC in its 1954 Annual Report: "Due to some difficulty in acquiring necessary land, the extension of the Gatineau Parkway north of Boulevard Gamelin (sic) was not possible this year." ${ }^{26}$ As shown in the next section, the FDC would never acquire the right-of-way, such that the parkway loop around the Valley of the Three Lakes was never realized (see Figure 4.3). Thus, even though its policy was to expropriate for parkway purposes, the FDC did not exercise territoriality in the Kingsmere-Meech Lake privatopia, even for the parkway. This was perhaps due partly to the growing opposition in Quebec, mobilized by Quain, over the expansion of Gatineau Park by the FDC.

On 19 January 1954, a delegation from the Township of Masham met with FDC officials to discuss restricting Gatineau Park boundaries, increasing FDC payments-in-lieu-of-taxes, making retroactive payments-in-lieu-of-taxes, and preparing a future master plan with input from municipal government officials. ${ }^{727}$ Shortly following its meeting with the Masham delegation, the FDC was blasted in the media for wanting to impose a Federal District on Quebec, even though the 1950 Plan for the National Capital (the Gréber Plan) did not call for one. Aimé Guertin, the former Conservative MLA for Hull, submitted a brief to the Tremblay Commission, Quebec's government inquiry on constitutional problems. ${ }^{728}$ Guertin wanted more compensation

\footnotetext{
${ }^{724}$ Ibid., pg. 24.

${ }^{725}$ Quain wrote: "We are instructed by Dr. J. Murray who owns property at Meech Lake to protest against the trespassing upon his property by your engineers or surveyors who have gone upon his property without his consent and have actually placed stakes on it. ..." Quain, R. 1954, Oct. 15. Letter from R. Quain to Federal District Commission. RG34 Vol.273.190-N.

${ }^{726}$ Federal District Commission. 1954. Ibid., pg.30.

${ }^{727}$ Federal District Commission. 1954, Jan. 25. Memorandum, re: Township of Masham and Gatineau Park. RG34 Vol.190.268(17).

${ }^{728}$ No author. 1954, Jan. 29. “Oppose Federal District.” Ottawa Citizen.
} 
for Quebec municipalities, especially Masham, where the FDC was "systematically tearing away thousands of acres of good land from generations of farmers who found in the plow their only means of existence." ${ }^{729}$ Guertin also repeated the argument made earlier by the Masham delegation, that revenues from potential residents were lost through Gatineau Park. No doubt aware that the Plan for the National Capital did not call for a federal district, Guertin nevertheless argued: "We feel justified in offering resistance to implementation of the National Capital Plan because we fear that Hull and district will be ripe for conquest or systematic absorption at the hands of the Federal District Commission." 730

Despite the growing opposition to the FDC and Gatineau Park in Quebec, ACGP Chairman Sparks continued in his attempts to influence the FDC land acquisition policy through insider channels. In early February 1954, Sparks wrote FDC Chairman Kennedy indicating his disappointment with the public statement about expropriations, and requesting a meeting. Sparks saw the policy of non-expropriation as a tactical mistake, since the FDC experience with land acquisitions for the Gatineau Parkway had already clearly demonstrated that property owners could not be expected to sell at reasonable prices. Another tactical mistake, according to Sparks, was that parkway planning was taking place in advance of acquiring the right-of-way. He wrote:

I am convinced that this whole park scheme will be wrecked unless you obtain powers of expropriation and exercise these powers. The other alternative is tremendous expenditure of money for the benefit of a few land owners, some of whose property is almost worthless without the parkway. It should be noted that most of this property is in the hands of people who can afford to wait when they see fortunes in sight as a result of FDC policy. ${ }^{731}$

The FDC Chairman did not hold the one-on-one meeting with Sparks; instead, Sparks' letter was forwarded by Kennedy to the FDC Executive "to test the feelings of the members as to

\footnotetext{
${ }^{729}$ No author. 1954, Jan. 30. "Fraud Charge in Tremblay Study of FDC." Ottawa Citizen.

${ }^{730}$ Sykes, A.R. 1954, Jan. 29. "Say Property Owners Terrified.” Ottawa Journal.

${ }^{731}$ Sparks, R.P. 1954, Feb. 5. Letter from R.P. Sparks to H. Kennedy. Cited in Sparks, R.P. 1956, June 26. Ibid., pg.840.
} 
their attitude on expropriations." ${ }^{, 732}$ The results of this test were then communicated back to Sparks:

With thirteen members present, (a fully representative gathering) the feeling was unanimously in favour of a continuance of the present policy of non-expropriation except as a last resort in eliminating missing links in the chain of properties necessary for the Parkway system. The Commission is still firmly convinced that the vast bulk of the property required for the Parkway may be obtained without resorting to expropriation, a practice which has been, and is, bitterly assailed by an extremely vocal group of residents of the Gatineau area. It is felt that the evil result on public relations would much overbalance any gain which would accrue from a programme of expropriation.

Some distress was evident that you, as Chairman of the Advisory Committee on Gatineau Park, should continue to advocate expropriation on a considerable scale despite the policy of the Commission as expressed to the public. It has proved embarrassing to several members of the Federal District Commission, including myself, quoting the policy of the Commission to critics like Redmond Quain, to have their reply that it is hard to accept our statements that no expropriations are contemplated in the face of the views that you, as Chairman of our Advisory Committee, continue to express.

The Commission has asked me to convey to you its feelings in the matter and to ask you, in discussing the matter with the public, to make it clear that your views on expropriation are diametrically opposed to the unanimous views of the members of the Commission. I am sure that, despite the obvious gap which exists between your thoughts concerning expropriation and those of the Commission members, you will see the necessity for its request. ${ }^{733}$

In a subsequent letter, Sparks defended his record as Advisory Committee Chairman, claiming "never since I have been appointed as a member of this Committee have I made any public statement of any kind in regard to policy or plans for Gatineau Park."734 Sparks' letter acknowledged that he had discussed his views on land ownership in the park with Quain, but this was before the FDC had publicly issued its policy. ${ }^{735}$ In any event, as a result of the Appendix to the 1952 ACGP Report, Sparks maintained that his views were well known to those interested in

\footnotetext{
${ }^{732}$ Kennedy, H. 1954, Feb. 18. Letter from H. Kennedy to R.P. Sparks. RG34 Vol.272.190-G(2).

${ }^{733}$ Ibid.

${ }^{734}$ Emphasis added. Sparks, R.P. 1954, Mar. 1. Letter from R.P. Sparks to H. Kennedy. Cited in Sparks, R.P. 1956, June 26. Ibid., pg.843.

${ }^{735}$ Sparks, R.P. 1956, June 26. Ibid., pg.833.
} 
Gatineau Park. Sparks concluded by noting that his position has since remained unchanged: "The more I think of the matter the more I am convinced that the opinions which I expressed in our Report of May 1952 are still valid but I have no desire to embarrass the Commission in connection with the controversy which is now being carried on, on expropriation." 736

There was further exchange of personal correspondence between Sparks and Kennedy, with numerous corrections on the part of the FDC Chairman. Thus, Kennedy corrected his earlier remark: "It would have been more accurate for me to have said 'to private citizens', rather than, 'to the public', as I am well aware that you have not spoken to groups on the matter."737 But Chairman Kennedy would, once again, express concerns about public relations, indicating that "[w]e [the Commission] would have been involved in a losing battle with the municipalities and associations involved, as well as with the Quebec Government, if we had not been able to come back with a complete rebuttal of his [Aimé Guertin's] charges concerning expropriation."738 Kennedy reiterated his belief that the Commission would be embarrassed "to have you, the Chairman of our Park Committee, advocating expropriation, even privately." ${ }^{\text {,739 }}$

In April 1954, Kennedy met with Sparks for two hours to discuss "not only the question of expropriation but the whole question of the development of Gatineau Park." ${ }^{, 740}$ Following the meeting, Sparks wrote to members of the Advisory Committee:

I explained to General Kennedy that the impression left with me by his letters was that I was 'persona non grata' with the Commission on account of my views on expropriation and perhaps my resignation would be welcomed by the Commission. I pointed out to him that this would not be necessary as our Committee was appointed on a yearly basis and our tenure of office expired on

\footnotetext{
${ }^{736}$ Sparks, R.P. 1954, Mar. 1. Ibid.

${ }^{737}$ Kennedy, H. 1954, Mar. 12. Letter from H. Kennedy to R.P. Sparks. Cited in Sparks, R.P. 1956, June 26. Ibid., pg.844.

${ }_{738}$ Ibid.

${ }^{739}$ Ibid.

${ }^{740}$ Sparks, R.P. 1956, June 26. Ibid., pg.845.
} 
March 31st. If the Commission wished to reappoint the Committee they could simply eliminate my name as a member.

[... ] I told him that I wasn't prepared to resign voluntarily without an opportunity of placing my views before the Commission. This he said he would arrange at some time in the near future. Whether the whole committee will be invited to meet the Commission again I do not know, although I would prefer it so and will so advise General Kennedy.

My reason for carrying out this correspondence personally is that I certainly cannot speak for the whole committee. ${ }^{741}$

Even though Sparks' views posed a threat to the Kingsmere-Meech privatopia, the interests of park residents were, in the end, protected by FDC Chairman Kennedy, who invited Sparks, not the entire Advisory Committee as had been requested by Sparks, to address the August 1954 meeting of the FDC Executive. ${ }^{742}$

Having given a presentation to the Executive on the Park's historical development, and then argued that the entire project would fail unless privately-owned lands were removed, Chairman Kennedy and FDC Commissioner Caron, then Mayor of Hull, launched a smear campaign against Sparks. That is, following Sparks' presentation, the FDC Chairman "bitterly opposed expropriation proceedings and said that as a property owner at Kingsmere he would fight in court any attempt to expropriate his property." ${ }^{, 743}$ According to Sparks, the FDC Chairman had:

repeated this statement 3 or 4 times, that he would take the matter to the courts rather than give up his property. He was supported in this statement by one member of the FDC. The other members present offered no objection to the Chairman's statement, and from this it might be assumed that they would support him in taking court action to prevent expropriation. ${ }^{744}$

\footnotetext{
${ }^{741}$ Sparks, R.P. 1954, Apr. 23. Letter from R.P. Sparks to members of the Advisory Committee on Gatineau Park. Cited in Sparks, R.P. 1956, June 26. Ibid., pg.844.

${ }^{742}$ Kennedy, H. 1956, June 28. Ibid., pg.928.

${ }^{743}$ Sparks, R.P. 1956, June 26. Ibid., pg. 845.

${ }^{744}$ Ibid.
} 
To be sure, this is only one side of the story. In Kennedy's testimony before the 1956 joint-parliamentary committee, he admitted engaging Sparks over the latter's proposals for expropriations and developing Kingsmere into a diplomatic community. As recounted by Kennedy: "At the meeting of the FDC when Mr. Sparks was accorded a hearing I informed him that if a proposal such as he advocated was undertaken, I would urge all property owners to resist it." 745 Surely, it would be a compromising situation for the FDC Chairman to actively encourage resistance against an official government policy, but Kennedy was clearly prepared to side with the park residents on this issue. As Kennedy put it: "I consider that if there is to be a settlement at Kingsmere then the present property owners have even a better moral and legal right to the property than a colony of foreign diplomats." 746

While Sparks had probably anticipated Chairman Kennedy`s opposition, he was caught off guard when Kennedy and Commissioner Caron accused him of being "the cause of difficulties with the municipalities." ${ }^{, 747}$ As Sparks wrote in his last letter to Kennedy: "I was so astounded at this statement that I made no reply to it [at the meeting] as it is a long story."748 To counter this “completely unfair statement," Sparks' letter to Kennedy revisited his role as Advisory Committee Chairman as, in 1951, he urged the FDC to institute payments-in-lieu-oftaxes for the municipalities affected by the park's territorial occupation. In his letter, Sparks enclosed correspondence with the FDC reflecting the extent of his involvement as, previously, "the Commission had ignored the claims of the municipalities."749 Thus, Sparks had ample evidence to demonstrate that he was, in fact, "a friend of the municipalities." ${ }^{\text {750 }}$ And it was

\footnotetext{
${ }^{745}$ Kennedy, H. 1956, June 28. Ibid., pg.928.

${ }^{746}$ Ibid.

${ }^{747}$ Sparks, R.P. 1954, Sept. 14. Letter from R.P. Sparks to H. Kennedy. RG34 Vol.272.190-G(2).

748 Ibid.

749 Ibid.

${ }^{750}$ Ibid.
} 
Sparks' opinion that Kennedy made this erroneous claim because of “...the fact that I, among many others, am opposed to any privately-owned land remaining in Gatineau Park. I think I am within the truth when I say that everyone who has studied this project agrees with me, except the property owners in the park whose opinion of course is prejudiced by their own financial interest."

Figure 4.5: Gréber and Kennedy examining the Plan for the National Capital

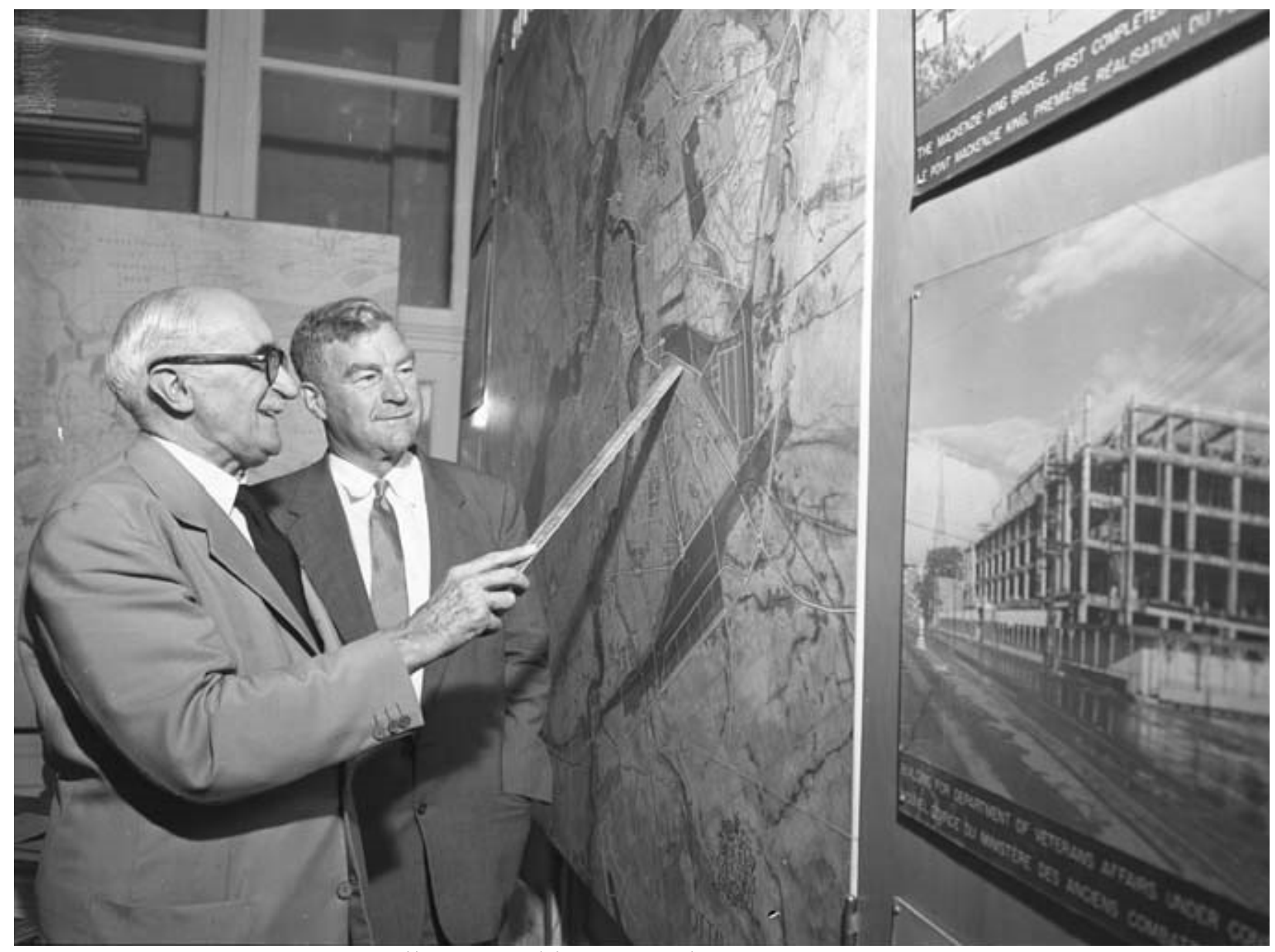

Source: Library Archives Canada, Image CA033455-W

Note: Jacques Gréber situated at front-left and Howard Kennedy at rear-right

In addition to having his professional integrity cast into doubt at the meeting, Sparks' personal integrity - as a Meech Lake Road resident - would be put into question. Thus, after the meeting, Sparks wrote Kennedy that he was 
...also rather surprised that Mayor Caron and yourself have joined the smear campaign which has been going on for a couple of years. The form it generally takes is that people owning property in the area circulate the story with variations that - "if Sparks' property was to be taken away from him he would not be so anxious to see all private property within the park taken over."751

Sparks defended himself at the meeting, indicating that, if his proposals for the Gatineau Parkway were carried out by the FDC, "I will probably suffer greater financial loss than any of the property owners in the whole 90,000 acres which will constitute Gatineau Park." ${ }^{\text {752 }}$ Sparks concluded his letter to Kennedy by asking that "you and Mayor Caron will discontinue your association with this campaign which has gone on now for some years." ${ }^{753} \mathrm{He}$ also requested that the letter be brought to the attention of Commissioners. Thus, following the October 1954 meeting of the FDC Executive, Secretary Cram wrote Sparks:

During discussion on this item it was pointed out that at no time were any of the comments of the meeting which you attended meant to be derogatory or personal.

The Federal District Commission is interested in the development of Gatineau Park and is doing its upmost to proceed with this work. Your co-operation in this project has been greatly appreciated. ${ }^{754}$

Without doubt, Sparks' subsequent actions were not be appreciated by the FDC, as his criticisms of the FDC land acquisition policy were made public knowledge.

Following the August 1954 meeting of the FDC Executive, Sparks was referred to as the "former" Advisory Committee Chairman. ${ }^{755}$ As indicated above, Sparks did not have to tender his resignation as the ACGP appointments were not renewed by the FDC. This situation even prompted the resignation of one member, Wilfrid D'Amour, who believed that "the work of the

\footnotetext{
751 Ibid.

752 Ibid.

${ }^{753}$ Ibid.

${ }^{754}$ Cram, H.R. 1954, Oct. 26. Letter from H.R. Cram to R.P. Sparks. RG34 Vol.272.190-G(2).

${ }^{755}$ Federal District Commission. 1956, May 16. Minutes of Executive Meeting. R1181-0-2-E.
} 
committee is completed."756 Although the 1952 Report was supposed to be followed by a master plan, the Advisory Committee never reached a consensus on the issue of privately-owned lands at Meech Lake. Thus, the committee failed to finalize a park master plan. And, following the August 1954 Executive meeting, the FDC contemplated a "New Committee on Gatineau Park to be set up by the National Planning Committee." ${ }^{, 757}$ But this replacement for the ACGP never materialized.

\section{The failures of Sparks' campaign and the Gatineau Parkway}

In the 1955 Speech from the Throne, the government called for the establishment of a jointcommittee of the Senate and House of Commons to review progress on the implementation of the Plan for the National Capital (popularly known as the Gréber Plan). The joint-parliamentary committee had been struck because Ontario municipalities (Nepean, Gloucester) were failing to co-operate with the FDC in the creation of Ottawa's Greenbelt. These rural municipalities refused to implement zoning bylaws to prevent development on future Greenbelt lands.

After Sparks' fall-out with the FDC, his energies were directed towards the preparation of a memorandum for the joint-parliamentary committee, outlining his extensive involvement with the FDC since the very beginning of the park project and his position on the parkland acquisition program. Sparks had the memorandum ready by May 1955, but heavy workloads led to the postponement of the joint-parliamentary committee. ${ }^{758}$ This delay prompted Sparks to submit his memorandum to the Ottawa Journal (see Figure 4.6), with a copy also sent to the FDC. ${ }^{759}$

\footnotetext{
756 D'Amour, J.W. 1954, May 21. Letter from J.W. D’Amour to H.R. Cram. RG34 Vol.272-G(2).

${ }^{757}$ Federal District Commission. 1955, Jan. 10. Minutes of Executive Meeting. R1181-0-2-E.

758 Sykes, A.R. 1955, May 12. "FDC Land Policy Assailed." Ottawa Journal.

759 Sparks, R.P. 1955, May 15. Letter from R.P. Sparks to H.R. Cram. RG34 Vol.190.268(19).
} 
In the 21 May 1955 issue of the Journal, Sparks, without referring to the KingsmereMeech Lake privatopia by name, denounced how "[ $t$ ]hey [the Federal District Commission] have allowed the selfishness of a comparatively few land owners to interfere with the proper development of this project." ${ }^{, 760}$ The full, front-page article recounted how "[a]s Chairman of the Advisory Committee on Gatineau Park, he [Sparks] has repeatedly urged both Gen. Kennedy and former chairmen to use powers of expropriation of lands so that the 80,000 -acre park will not be cut into bits and pieces of privately and publicly-owned land." ${ }^{, 761}$ It provided a summation of Sparks' forthcoming brief:

1. "Certain influential people" [i.e., Kingsmere and Meech Lake residents] have been holding up the Gatineau Park plan by their anti-expropriation attitude.

2. Failure of the FDC to institute expropriation proceedings in Gatineau Park has added and is adding additional expense of hundreds of thousands of dollars to the cost of the new Parkway from Fairy Lake to the Laurentian Hills.

3. The FDC has turned the lower end of Gatineau Park into "a paradise for speculators."

4. The FDC has ignored Quebec Premier Duplessis in its planning of Gatineau Park, thus bringing the project into the realm of politics.

\section{Full-Time Job}

Apart from these main charges, Mr. Sparks contends that the office of the Chairman of the FDC should be a full-time job and paid accordingly. ${ }^{762}$

Four days later, the Journal published the FDC response to Sparks' initial media blast.

Readers were thus informed that "the commission prefers to acquire land by negotiation and purchase [in Quebec], rather than to use extraordinary power to take property away from families which have held it unquestioned for half or three-quarters of a century."763 Another factor preventing the FDC from sharing Sparks' view was Premier Duplessis who “expressed doubts as

\footnotetext{
${ }^{760}$ Sykes, A.R. 1955, May 12. Ibid.

761 Ibid.

762 Ibid.

${ }^{763}$ No author 1955, May 16. "Despite Policy Battle Gatineau Park Goes Ahead.” Ottawa Journal.
} 
to whether even the Federal Government has the right to expropriate lands for park purposes." 764 Finally, the FDC challenged Sparks' invocation of national park policy on private lands: "In many cases sites of the national parks were virtually ready-made for the purpose, and the acquisition of privately-owned lands for park purposes involved few of the complex legal and planning problems which face the Federal District Commission in Gatineau." ${ }^{765}$ Despite these complexities, the Gatineau Park project was successful, according to the FDC, as it had turned "waste land into a centre of scenic beauty ... to the credit of the park superintendent and staff of the Federal District Commission, the Government of Canada, and not least to Mr. R.P. Sparks, one of its sponsors."766

The Journal published an even more elaborate rebuttal of Sparks' brief the following day, with the Commission reaffirming its policy that "no effort has been made [sic] or will be made to expropriate property in Gatineau Park except in the construction of driveways or other essential works. $" 767$ As shown above, this statement is mistaken as the FDC expropriated thousands of acres in the process of expanding the park. The newspaper-reading public, however, was probably not aware of this. As in the previous Journal article, the FDC first paid its respects to its opponent, the "former Chair of the one-time Advisory Committee on Gatineau Park." Thus, the first of its ten points, reads: "The Federal District Commission recognizes the great services Mr. Sparks had performed in the creation of Gatineau Park and compliments him on his foresight and the continued interest he has taken in the development of Gatineau Park since its inception."768 Sparks' brief, however, "does not fairly represent the situation." ${ }^{769}$ It did not, for

\footnotetext{
${ }^{764}$ Ibid.

765 Ibid.

766 Ibid.

${ }^{767}$ No author. 1955, May 17. “Gatineau Park Policy Unchanged.” Ottawa Journal.

768 Ibid.

${ }^{769}$ Ibid.
} 
instance, include data on the land acquisition program. Thus, the FDC pointed out that, since 1951 , another 17,387 acres had been added to the park, at a cost of $\$ 1,072,479$. Overall, 60 percent of total lands had been acquired $(44,000$ of a projected 75,000$)$ at a total cost of approximately $\$ 2,060,000$. For the Commission, these data revealed that it had a definite parkland acquisition policy; further, this policy had been effective, acquiring $60 \%$ of the total park area in only twelve years of operation (exclusive of the Second World War period).

Figure 4.6: Front-page of the Ottawa Journal (12 May 1955)
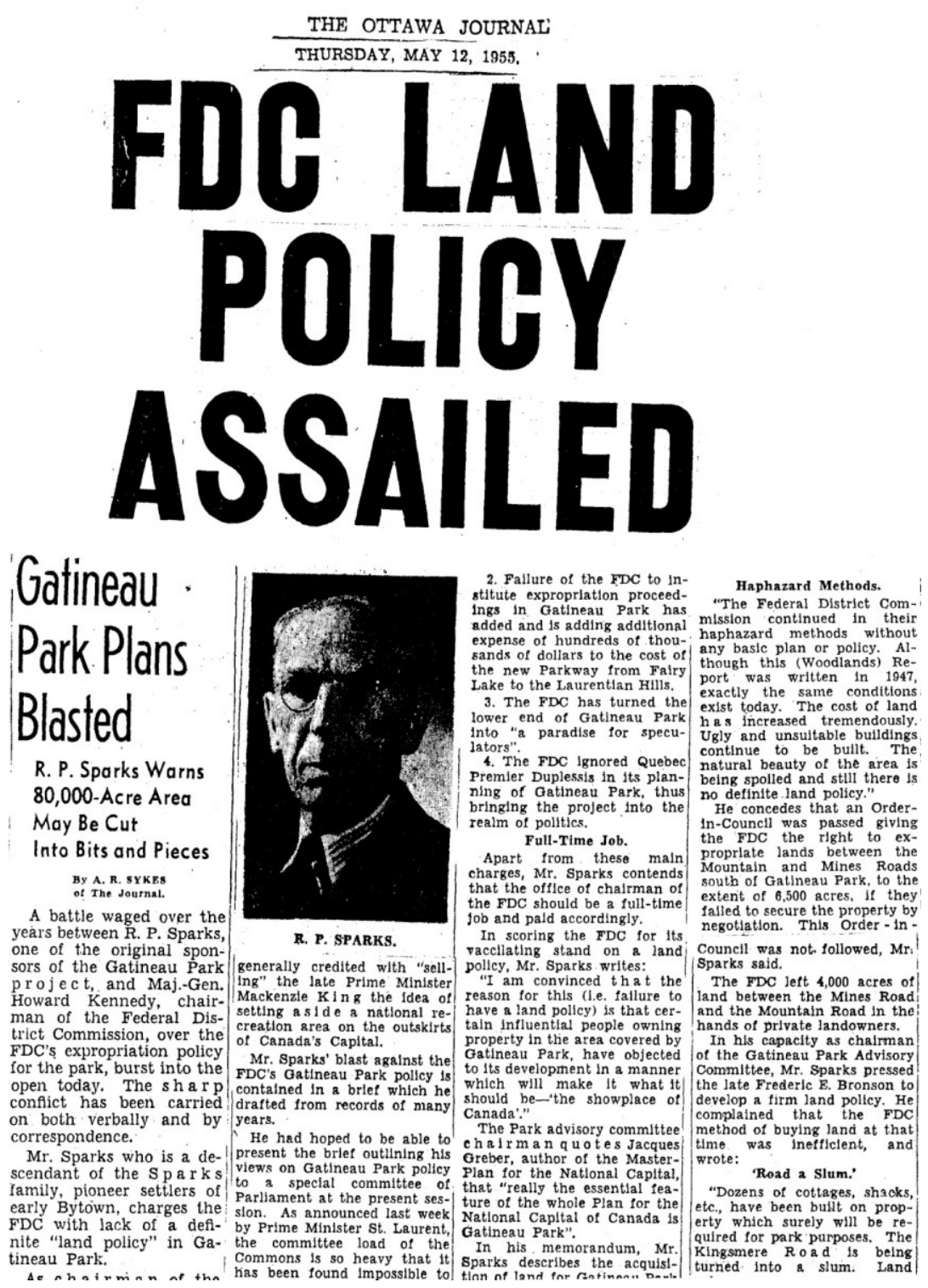
Sparks" charges about land speculation were also dismissed: "the Commission is not aware that there has been any rush to speculate in properties within the park area as a result of its activities. Furthermore, the Commission has not and does not propose to meet exorbitant offers for properties within the area of its activities." $" 770$ The article then provides an example wherein the FDC refused to purchase a Kingsmere property valued at $\$ 30,000$ an acre. Was this not an example of land speculation? Sparks' prediction about rapidly increasing property values was also confirmed as the FDC had tried to purchase Kingsmere properties ahead of the construction of the Gatineau Parkway. The values of Kingsmere properties had risen to $\$ 3,000$ per acre. ${ }^{771}$ It should perhaps not be surprising that, in 1955, the FDC would once again report that "[d]ue to some difficulty in acquiring the necessary land, extension of Gatineau Parkway north of Boulevard Gamelin (sic) is not yet possible.",772

Having been delayed by a year, the joint-parliamentary committee was convened in March 1956. Before turning to Sparks' appearance before the joint-parliamentary committee, there are no less than five important preceding events to cover: a Masham delegation proposing a luxury hotel at Philippe Lake; the FDC submitting its brief to the joint-parliamentary committee; Meech Lake residents criticizing Sparks' views of the built environment; the Capuchin Brothers, on behalf of all Meech Lake residents, seeking assurance from the FDC of their long-term residency; and the Ottawa Ski Club President's submission to the joint-parliamentary committee.

First, earlier in March 1956, the Chamber of Commerce from Ste. Cecile de Masham sent a delegation to the FDC headquarters in Ottawa to propose a luxury hotel development at Philippe Lake. The hotel would have been the first of its kind in the Gatineau region, and would be administered on lands that would be transferred from the FDC to the Chamber of Commerce.

\footnotetext{
${ }^{770}$ Ibid.

${ }^{771}$ Carrolly, C.J.G. 1955, May 27. Letter from C.J.G. Carrolly to E.S. Richards. RG34 Vol.268.190(A1)-1.

${ }^{772}$ Federal District Commission. 1955. Ibid., pg.25.
} 
The Masham delegation believed that the \$2-million hotel would provide the boon needed by local businesses, and would allay the negative financial consequences which federal acquisitions for Gatineau Park had imposed on the municipality and local lumber industry. The Chamber made no mention of possible conflicts between hotel users and park visitors, nor did it suggest removing the public facilities already established at the lake. Rather, Masham authorities wanted the hotel to complement existing facilities, just as the construction of the Gatineau Parkway would, in turn, complement the hotel which would service "visitors to our country and of our federal government. It would be a place for picnics or for conventions or for national or international meetings." ${ }^{, 773}$ In addition to the new hotel offering accommodation and convention space, the Masham delegation proposed boating, fishing, swimming, and winter sports on Philippe Lake. The hotel facility would include tennis courts and a swimming pool, which "would save the visitors of the hotel being inconvenienced by the public on the beach of the lake, that is to say would not change the facilities already planned for a large public beach."774 The proposal for a hotel at Philippe Lake received the support of the Metropolitan Council of Western Quebec. ${ }^{775}$ The FDC did not agree to the hotel proposal as it involved the transfer of park lands to a municipality for the purposes of a private development. Interestingly, the documents related to the Masham proposal were the last ones deposited in the folder on the Advisory Committee on Gatineau Park. But, of course, there was no Advisory Committee to give the FDC advice.

Second, early in April 1956, the FDC submitted its 100-page brief to the jointparliamentary committee. The main recommendations of this brief were covered in Chapter 1. As mentioned, many of these recommendations - for greater funds, personnel, powers of

\footnotetext{
${ }^{773}$ Chamber of Commerce of Sainte-Cécile de Masham. 1956, Mar. 7. Untitled document. RG34 Vol.272.190-G(2).

774 Ibid.

${ }^{775}$ Metropolitan Council of Western Quebec. 1956, Mar. 14. Resolution. RG34 Vol.272.190-G(2).
} 
expropriation in Ontario and Quebec, etc. - were endorsed by the joint-parliamentary committee and later inscribed in the National Capital Act. The brief describes the park territory: "Its main sections are the Kingsmere area, including the Mackenzie King Estate; the Valley of the Three Lakes - Meech, Harrington and Philippe - and the western section comprising the Lac Lapêche area. ... The objective is to develop its facilities for the use and enjoyment of the public..."776 Although there is no reference in the FDC brief to the problem of divided control arising from privately-owned lands around Kingsmere and Meech Lakes, it does recognize that privatelyowned lands have the stalled the construction of the Gatineau Parkway: "The Commission has not been successful in acquiring the necessary land for the right of way for the easterly branch of the parkway loop from the Kingsmere-Old Chelsea area around the east side of Meech Lake to Lac Philippe. The owners either refuse to sell to are asking prohibitive prices." "777 The Ottawa Journal, having noted that Senators Connolly and Justice Minister Stuart Garson were both Meech Lake residents, reported on how, in the FDC brief, the resistance of property owners had forced the FDC to delay the extension of the parkway to Philippe Lake, which, it should be recalled, were the park's only public facilities at the time. ${ }^{778}$ The Ottawa Citizen interviewed an FDC official who confirmed that neither Senator Connolly nor Justice Minister Garson were among the Meech Lake property owners holding up the parkway construction. ${ }^{779}$

Third, Meech Lake residents responded to Sparks' forthcoming brief by criticizing him in local newspapers. Having seen the results of Sparks' survey, one resident, Corliss Keyes, arrived at the opposite conclusion: 80 of the 100 cottages were attractive. ${ }^{780}$ Another resident retorted:

\footnotetext{
${ }^{776}$ Federal District Commission. 1956, Mar. Ibid., pg.28.

777 Ibid., pg.31.

${ }^{778}$ Jackson, R. 1956, Apr. 7. "Fight Over Gatineau Park Land: Cottage Owners Refuse to Sell for Scenic Drive." Ottawa Journal.

${ }^{779}$ No author. 1956, Apr. 9. "Meech Lake Cottagers Resent Sparks Charges.” Ottawa Citizen.

${ }^{780}$ Ibid.
} 
“Mr. Sparks' garage on the driveway to the lake is a real eyesore." ${ }^{781}$ The Ottawa Citizen subsequently went to Meech Lake to corroborate resident opinions of cottages on the lake.

Yesterday a Citizen reporter and cameraman toured the disputed summer resort area to attempt to locate the "eyesores" but came away with samples of "eye appeal."

Very few of the buildings there could be regarded as "ugly" and "eyesores." Granted some were in need of minor repair and painting, but The Citizen found that the great majority of the cottages were, basically, attributes to the locality. ${ }^{782}$

Fourth, the Monastery of the Capuchin Fathers at Meech Lake sought "guarantees" from the FDC, not only on behalf of themselves, but also the other 283 property owners at the lake. ${ }^{783}$ The Capuchin Fathers informed the FDC that their Chapel had become "inadequate and decrepit." 784 Prior to investing the $\$ 20,000$ to $\$ 25,000$ required for a new, more spacious chapel, the Capuchin Fathers asked for the following guarantees, in writing, from the FDC, for a period of 15 to 20 years:

1) That substantial expropriation or one on a large scale, of private properties, will not be resorted to as regards the private properties of Meech Lake - which would deprive our chapel of attendance by the public;

2) That Meech Lake, according to plans of the Federal District Commission, will not become during that period of time a site or a place so easily accessible to the public at large to such an extent that it would be undesirable for us to remain there. $^{785}$

If these guarantees could not be provided, the Capuchin Brothers indicated that they would negotiate the sale of their property, which they had owned since 1901 . This would be done, however, with "deep regrets."786 They added:

\footnotetext{
781 Ibid.

${ }^{782}$ No author. 1956, Apr. 12. "Lots of Eye Appeal but Few Eyesores at Meech Lake." Ottawa Citizen.

${ }^{783}$ Monastery of the Capuchin Fathers. 1956, May 7. Letter from the Monastery of the Capuchin Fathers to the Federal District Commission, pg.1.

${ }^{784}$ Ibid.

785 Ibid.

${ }^{786}$ Ibid.
} 
We would regret it if the Federal District Commission should detect in the present request any form of opposition to the projects which it contemplates in [page 2] the public interest, and for the development of our national capital. We do not wish to ignore those points of view, and we have not, ourselves, any objection in principle to the realization of the projected roadway now under construction which may take place, affording the public all the pleasure possible without being in the least bothersome to the private interests of the residents of Meech Lake.

It is only because it has seemed to us that the Commission had not adopted definite or unchangeable measures for the utilisation of Meech Lake that we have taken the liberty to express our sentiment and wishes in the matter before undertaking the costly construction of a Chapel for the performance of religious services for a very large part of the residents of Meech Lake.

We would request the Federal District Commission kindly to accept our request in the spirit which we had in mind, that of a close co-operation in the conciliation of public and private interests, and to accept the assurance of our highest consideration. $^{787}$

The guarantees sought by the Capuchin Fathers would not be provided by the FDC, ${ }^{788}$ and their chapel property was purchased by the National Capital Commission in 1968.

Fifth, Herbert Marshall, President of the Ottawa Ski Club (OSC) and former member of the Advisory Committee on Gatineau Park, testified before the joint-parliamentary committee ahead of Sparks. President Marshall wanted to give the views of the OSC on Gatineau Park "in which, of course, it is vitally interested." ${ }^{, 789}$ Marshall began by outlining the OSC investment and ownership in the park. With 3,600 members, the OSC had invested some $\$ 50,000$ to purchase 400 acres of land at Camp Fortune; further, the OSC had built four ski lodges, maintained eight ski hills serviced by seven ski tows, and established two ski jumps. ${ }^{790}$ As detailed in the last Chapter, the FDC approached the OSC about forming a partnership, but the OSC refused to transfer its land (not lodges) in exchange for federal capital investment in skiing facilities. As

\footnotetext{
${ }^{787}$ Ibid., pgs.1-2.

${ }^{788}$ Blanchard, J.H. 1956, May 7. Letter from J.H. Blanchard to J.E. Handy. RG34 Vol.268.190(20); see also Handy, J.E. 1956, May 31. Letter from J.E. Handy to Rev. Marie-Antoine. RG34 Vol.268.190(20).

${ }^{789}$ Marshall, H. 1956, May 31. "Ottawa Ski Club.” In Canada. Joint Committee of the Senate and the House of Commons on the Federal District Commission. Minutes of Proceedings and Evidence, 10, pg.469.

${ }^{790}$ Ibid., pg.470.
} 
Marshall explained, "members are convinced that to lose the ownership of the land would eventually mean the disintegration of the Ski Club."791 Nevertheless, President Marshall insisted that the OSC and FDC enjoyed "happy" relations. The only recommendation to the jointparliamentary committee was to "speed up" the parkway construction program, thus improving the park's accessibility. ${ }^{792}$ Marshall further specified the recommendation: "In particular, the Ottawa Ski Club requests that immediate attention be given to the improvement of the short road from Dunlop's on the Meech Lake Road to the parking lot at Alexander Hill.",793

Notably, in the follow-up questions, Marshall was asked whether the OSC would have any objection to making Gatineau Park into a National Park administered by the National Parks Branch. To which Marshall replied: "Oh, it [the OSC] is very much in favour of that, and thinks that this is the only way in which we can really develop the magnificent Gatineau area."794 Aware of what the national park proposal entailed for privately-owned land, Senator Connolly, a member of the joint-parliamentary committee, set the OSC President back onto the right course:

Senator Connolly: I do not want to have Mr. Marshall change his answer, but I wonder whether he understood Senator Reid's question. The purport of his question was this: do you think that jurisdiction over Gatineau park should be removed from the Federal District Commission and be put under the national parks branch?

[page 472] Marshall: Oh, I am very sorry-I did misunderstand.

Senator Reid: See how it all gets twisted!

Senator Connolly: Don't change your answer unless you want to.

The witness: I do want to change my answer-very much. We work very closely with the Federal District Commission and we want to see the park developed by them. ${ }^{795}$

\footnotetext{
${ }^{791}$ Ibid., pg.471.

${ }^{792}$ Ibid.

${ }^{793}$ Ibid.

${ }^{794}$ Ibid., pg.471.

${ }^{795}$ Ibid.
} 
The changes required to transform Gatineau Park into a National Park would have unwelcome consequences for property owners in the park, like the OSC. The MP for Gatineau, Rodolphe Leduc, then expressed his "hope [that] they would not be in trouble with the federal government even if this area became a national park." ${ }^{, 796}$ Were committee members contemplating national park status for Gatineau Park?

On 26 June 1956, Percy Sparks, the founding father of Gatineau Park and former Chairman of the Advisory Committee on Gatineau Park, appeared before the joint-parliamentary committee on the FDC. Sparks' 25-page brief, Land Policy in Gatineau Park, was read verbatim to the committee. After 22 years of voluntary service on the park project, Sparks' appearance as a witness before the committee would be his last attempt to transform the park's status as a mixed-use/ownership area into a national park for, in 1959, Sparks passed away at the age of 79.

The central argument in Sparks' brief is that the FDC never had a land acquisition policy. He went over the implementation of the land acquisition program, describing the initial outcome of this exercise of territoriality by the federal government:

Sometimes a substantial area of privately owned land would be surrounded wholly or partly by land owned by the Commission. In other cases, the Commission would own a section of the area which was partly or wholly surrounding by private land. The area owned by the Federal District Commission at the beginning of the war could hardly be described as a public park, because privately and publicly owned land was hopelessly mixed. ${ }^{797}$

Sparks argued that, while blanket acquisition would involve a larger initial outlay, piecemeal acquisitions would cost more in the long run, as land values increased, particularly with the construction of the Gatineau Parkway and other road improvements. The FDC ignored this advice and continued "its haphazard methods without any basic plan or policy." 798 In anticipation

\footnotetext{
796 Ibid., pg.472.

${ }^{797}$ Sparks, R.P. 1956, June 26. Ibid., pg.833.

${ }^{798}$ Ibid., pg.834.
} 
of the Gatineau Parkway, it was even given the authority to acquire all lands, by negotiation or, if necessary, expropriation, in the southern section of the park, but, of course, the FDC did not acquire the 6,500 acres of privately-owned lands. ${ }^{799}$

Even following the formation of the ACGP, however, "nothing was done." 800 In 1950 , Sparks was close to resigning from the ACGP. He wrote to then FDC Chairman Bronson, "the FDC has no plan or policy with regard to this project." ${ }^{801}$ As this biting letter is not found in the FDC files, it is quoted here at length:

You have several times told me that all you intend to do at the present time is buy land, but a look at the map, and a visit to the area will demonstrate clearly that you have no co-ordinated plan even of buying property. Dozens of cottages, shacks, etc., have been built on property which surely will be required for park purposes. This is still going on. The Kingsmere Road is being turned into a slum. Your failure to anticipate the needs of this project has already cost hundreds of thousands of dollars. Land values are being established by building of a few shacks and cottages in vacant areas which will require not only that you buy the buildings but you have permitted higher land values to be established. ${ }^{802}$

Sparks was asked by Bronson to remain on as ACGP Chairman. With the FDC projecting the expansion of Gatineau Park to 60,000 acres, the majority opinion of the Advisory Committee, from the outset, was that privately-owned lands within the park boundaries should be acquired. Only Senator Connolly, a Meech Lake resident, thought otherwise. Sparks points out that, in making the argument to retain privately-owned lands at Kingsmere and Meech Lakes, Connolly made no reference to the significance that Gatineau Park holds for the 1950 Gréber Plan. ${ }^{803}$

Sparks' brief details the controversy around FDC powers of expropriation in Quebec that was sparked by Kingsmere resident Redmond Quain, citing the subsequent release of the FDC Policy on Land Ownership within Gatineau Park which announced that, with the exception of

\footnotetext{
${ }^{799}$ Ibid.

${ }^{800}$ Ibid., pg.835.

${ }^{801}$ Ibid.

${ }^{802}$ Ibid.

${ }^{803}$ Ibid., pg.836.
} 
lands needed for the parkway, "[n]o effort has been made or will be made to expropriate property in Gatineau Park." ${ }^{\prime 04}$ Sparks then recounts the FDC expropriations at the very beginning of the Gatineau Park land acquisition program. The exorbitant demands of property owners were overcome because the FDC had established land values through negotiated purchase. Following this, the FDC, on the recommendation of the Advisory Committee, expropriated 40 residents at Philippe Lake to prevent further private development. Sparks juxtaposes the treatment of Philippe Lake residents with those in the Kingsmere-Meech Lake privatopia, which is not only much closer to Hull and Ottawa, but is also, for Sparks (and Gréber), more important to the overall park project.

Some of the people at Philippe Lake felt at the time, and still feel, that they were discriminated against, and that the reason why properties at Kingsmere and Meech Lake were not expropriated at that time was that there were people living in these localities who had great influence with the FDC. I am inclined to agree that they were right. ${ }^{805}$

The second problem with the FDC's public statement of policy on Gatineau Park was its claim that Kingsmere Lake was entirely privately-owned. Sparks pointed out that the Mackenzie King Estate, which the FDC owns, abuts the lake. However, the cottages near the lake had been rented out, turning the Mackenzie King estate into a "real estate proposition" when the former Prime Minister bequeathed his lands as a public park (and also intending it to serve as the official summer residence of the Prime Minister). According to Sparks, the FDC "wanted to keep the public from the lake shore which would please other owners of lake shore property. On the gate leading to these rented houses a large sign reads: 'No Picnics Please' which, in effect means 'no

\footnotetext{
${ }^{804}$ Ibid., pg.837.

${ }^{805}$ Ibid., pg. 838 .
} 
admittance' thus shutting off from the public use what is definitely the most attractive part of the King estate." 806

Having shown the inaccuracies of the FDC statement, Sparks turned to its overall inadequacy as it meant that privately-owned lands could remain within the park indefinitely. Sparks warned the joint-parliamentary committee: "There is danger that if the present policy of the FDC is followed this area will develop into a sort of glorified amusement park with everything from tent shows to souvenir stands ... If privately owned land is permitted the FDC completely loses control of the area." 807 In other words, without public ownership, Gatineau Park was not an FDC territory; rather ownership and control were divided among the FDC, municipal governments, and property owners. The park's status as a mixed-use/ownership area betrayed its potential significance as the "the finest thing of its kind in the world." 808 That is, the finest nearurban national park. This was Sparks' vision for Gatineau Park, and he pointed to how international visitors were taken to Old Chelsea, which he considered a "shabby locality." 809 His brief concluded by condemning the federal agency responsible for the park: "Although the FDC has been working for 20 years on this park area, and have spent millions of dollars, Canadians should not feel that they have to be ashamed of what they have to offer to visitors in this magnificent park land, adjacent to the National Capital. The policy of the FDC is to retain all this ugliness and disorder." ${ }^{810}$ But, Sparks recognized that there "are very powerful forces, that would like to make something second-rate and shabby. The land owners want to make fortunes and I think they are succeeding." 811

\footnotetext{
${ }^{806}$ Ibid., pg.839.

${ }^{807}$ Ibid., pg.854.

${ }^{808}$ Ibid., pg.863.

${ }^{809}$ Ibid., pg.855.

${ }^{810}$ Ibid.

${ }^{811}$ Ibid.
} 
Following Sparks, FDC Chairman Kennedy would subsequently appear before the jointparliamentary committee to offer a rebuttal of Sparks' recommendations, with the exception of his recommendation to remunerate the position of the FDC Chairman. Without making explicit what he meant by "objective," Kennedy insisted that the FDC held the same objective for the park as Sparks, that is, acquisition of all privately-owned lands within its boundaries. However, the FDC and Sparks did part ways on the means through which this objective was to be achieved: "we propose to carry it out over a couple of decades rather than over a couple of months." 812 Kennedy argued that the blanket expropriation option endorsed by Sparks would be costlier that piecemeal acquisitions, as the expropriations would add legal fees and an additional $10 \%$ to the appraised value of the lands. ${ }^{813}$ Kennedy denied Sparks' claims that the construction of the Gatineau Park or other park developments would inflate land values, lead to land speculation, or encourage a construction boom. In any event, the FDC Chairman contended that funds were needed "for more urgent projects such as the railway [relocation] project." the funds were available for parkland acquisitions, Kennedy maintained that the FDC would encounter stiff resistance, not only from park residents, but also from Quebec Premier Duplessis, who challenged the right of the FDC to expropriate for park purposes. Kennedy clarified that “[a]s a matter of fact Mr. Duplessis is very friendly to the Gatineau park idea, but is jealous of provincial autonomy." 815

As mentioned above, the joint-parliamentary committee recommended sweeping institutional reform of the FDC. It did not, however, recommend any changes to the Gatineau Park land acquisition program. The final report that the joint-parliamentary committee submitted

\footnotetext{
${ }^{812}$ Kennedy, H. 1956, June 28. Ibid., pg.928.

${ }^{813}$ Ibid., pg.927.

${ }^{814}$ Ibid.

${ }^{815}$ Ibid.
} 
must have disappointed an aging Sparks. With Senator Connolly and Hull MP Caron among its members, the joint-parliamentary committee made no reference to the criticisms leveled by the park's founding father. Rather, the report of the joint-parliamentary committee reads: "We think that the policy applied to Gatineau Park by the Federal District Commission has been wise and we say so bearing in mind the onerous financial implications involved in the development of the National Capital Plan within the urban sections of the National Capital area." ${ }^{816}$ Sparks' final attempt at altering FDC land acquisition policy had failed. And, to add insult to injury, the FDC started paying Chairman Kennedy a $\$ 7,500$ honorarium.${ }^{817}$ Even though the joint parliamentary committee submitted its final report in August 1956, the federal government passed legislation to reform the FDC three years later. To be specific, the Louis St. Laurent government tabled legislation, but it died with the 1957 federal election. ${ }^{818}$ Reflecting the bipartisan support for the implementation of the Gréber Plan, the newly elected Diefenbaker government passed the National Capital Act.

In the interim, in 1956, the FDC completed, at a cost of $\$ 900,000$, the Fortune Lake Parkway. This was the first 5-mile $(8 \mathrm{~km})$ stretch of the projected 50-mile scenic parkway system. The Fortune Lake Parkway extended from Meech Lake Road to the Champlain Lookout. ${ }^{819}$ Construction of the 10 -mile $(16 \mathrm{~km})$ Kingsmere-Pink Lake section of the parkway linking Gamelin Street with the Fortune Lake Parkway was expected to begin early the following year. ${ }^{820}$ But the FDC subsequently reported that "[p]rogress on this project had been held up due to the difficulty of acquiring land at reasonable prices; also construction is carried out only to the

\footnotetext{
816 Joint Committee on the Federal District Commission. 1956, Aug. 1. "Second and Final Report." Canada. Parliament. House of Commons. Edited Journals. 22 ${ }^{\text {nd }}$ Parliament, $3^{\text {rd }}$ Session, Vol.100(141), pg.980.

${ }^{817}$ Federal District Commission. 1957. Annual Report. Ottawa: Queen’s Printer, pg.30.

818 Ibid., pg.5.

${ }^{819}$ Federal District Commission. 1956. Ibid., pg.28.

${ }^{820}$ Ibid., pg.44.
} 
extent that monies become available for this purpose." 821 President Redmond Quain of the Kingsmere Property Owners Association pressed, on behalf of area residents, for direct access to the FDC parkway from municipal roads. Quain told the FDC Chairman: "Such a move might assist the Commission to get from time to time the concessions that it will need from the representatives of property owners in the Municipal Council." ${ }^{822}$ And shortly before the new section of the parkway was opened, the FDC erected a sign prohibiting through-traffic along Meech Lake Road, much to the delight of the Meech Lake Association. ${ }^{823}$ The motoring public, attracted to the park by the new parkways, was not to travel into the heart of the park. Rather, automobility was restricted to residents of the privatopia. In October 1959, Prime Minister Diefenbaker was on hand at the opening of the Kingsmere-Pink Lake section. ${ }^{824}$ Former FDC Chairman Kennedy spoke at the opening ceremonies:

... this new Parkway is not just another road, it is the result of vision and perseverance. It was more than twenty years ago that the Commission commenced the acquisition of land over which the Parkway passes. Three years ago the first link from Meech Lake Road to Champlain Lookout was opened. It is hoped that during the next decade, other sections of Gatineau Parkway will be completed. ${ }^{825}$

But only one section of the Gatineau Parkway was subsequently built. In October 1961, the 5.2mile $(8.3 \mathrm{~km})$ Old Chelsea section was opened, linking Dunlop Road with the Kingsmere section of the parkway (and the Kingsmere Property Owners' Association probably welcomed this). ${ }^{826}$

The 13.5-mile $(21.7 \mathrm{~km})$ section of the Gatineau Parkway that extended to the park's only public facilities at Philippe Lake was never begun. The FDC Annual Report for 1957 described the situation: "The Commission has not acquired the necessary land for the proposed

\footnotetext{
${ }^{821}$ Federal District Commission. 1957. Ibid., pg.14.

${ }^{822}$ Quain, R. 1957, June 11. Letter from Redmond Quain to H. Kennedy. RG34 Vol.273.190-N4.

${ }^{823}$ McElroy, M.H. 1957, Apr. 11. Letter from M.H. McElroy to FDC RG34 Vol.268.190(A1); see also Duffett, W.E. 1957, July 8. Letter from W.E. Duffett to R.E. Edey. RG34 Vol.273.190-N4.

${ }^{824}$ National Capital Commission. 1959. Annual Report. Ottawa: Queen’s Printer, pg.13.

${ }^{825}$ Ibid.

${ }^{826}$ National Capital Commission. 1961-1962. Annual Report. Ottawa: Queen’s Printer, pg.13.
} 
construction of the easterly branch of the parkway to Lac Philippe." ${ }^{827}$ Earlier in that very Report the FDC had indicated that the public facilities at Philippe Lake "were inadequate to cope with the large number of visitors to the area. For that reason, the Commission decided to enlarge existing parking areas, to improve the roadways and to add to the bathing and picnic facilities." ${ }^{828}$ In 1958, the FDC surveyed the parkway route and began clearing operations. ${ }^{829}$ Tellingly, there was no update on land acquisitions.

Following the reorganization of the FDC as the National Capital Commission (NCC), the parkway system would be revisited by the Gatineau Park Advisory Committee (GPAC). Initially, the new Advisory Committee confirmed that "it would be advisable to work towards the construction of a main parkway through the centre of the park to Lac Philippe." ${ }^{830}$ Following this, surveys were carried out for alternate routes to Philippe Lake. ${ }^{831}$ Another 1.5 miles $(2.4 \mathrm{~km})$ of forest was cleared in the McKinstry Mountain Section. ${ }^{832}$ When the NCC undertook the preparation of a Gatineau Park master plan in the mid-1960s, the idea of a scenic parkway had lost favor among GPAC members: "Originally, in the atmosphere of post-war boom, it was planned to extend the Parkway along the Escarpment to opposite Grand View, so it could circle back around Lac Philippe. In the more recent climate of economic retrenchment, the Parkway has come to be thought of as a luxury, or else a public-works program for slack employment periods." ${ }^{833}$ When NCC planners abandoned the parkway extension in the 1967 Development

\footnotetext{
${ }^{827}$ Federal District Commission. 1957. Ibid., pg.30.

${ }^{828}$ Ibid., pg. 14.

${ }^{829}$ Federal District Commission. 1958. Ibid., pg.59.

${ }^{830}$ Gatineau Park Advisory Committee. 1960, July 8. Minutes of Meeting. RG34 280.22 Vol.1. The Advisory Committee later suggested "that before this work was undertaken, the Chairman of the NCC should get the Prime Minister's view point concerning this matter, as unless the road location is carefully made, it could mean construction in the vicinity of the Prime Minister's official summer home on Harrington Lake." Gatineau Park Advisory Committee. 1961, Mar. 27. Minutes of Meeting. RG34 280.22 Vol.1.

${ }^{831}$ National Capital Commission. 1961-1962. Annual Report. Ottawa: Queen's Printer, pg.13.

${ }^{832}$ Ibid., pg. 15.

${ }^{833}$ Morse, E.W. 1967, Dec. 6. Letter from E.W. Morse to D. Audet. RG34 280.22 Vol.3.
} 
Concept, the GPAC endorsed this decision: "The Ridge, because of its rugged and forbidding character is useless for any purpose other than to be preserved as a wilderness core." 834 Thus, the Gatineau Parkway was never extended to the facilities at Philippe Lake. Rather, the KingsmereMeech Lake privatopia and Camp Fortune are located in what is now referred to as the Parkway Sector of Gatineau Park. As there were no major public facilities at Meech Lake until 1970, the Gatineau Parkway served park residents more than park visitors. Just as Gatineau Park, a failed national park, was established by and for residents of this privatopia, so the parkway catered to this elite automobility, not only in terms of improving "seamless" access by car, but also through escalating property values.

\section{Conclusion}

After Quebec Premier Duplessis challenged the FDC right to expropriate for park purposes in 1948, the FDC Gatineau Park land acquisition program proceeded by way of negotiated purchase. Between 1952 and 1958, the Federal District Commission purchased an additional 20,000 acres, bringing the park's overall size to 57,000 acres. ${ }^{835}$ As this chapter has shown, the Chairman of the Advisory Committee on Gatineau Park (ACGP), Sparks, argued that this piecemeal approach to parkland acquisitions did not constitute a policy at all. In the Appendix to the 1952 ACGP Report on a Master Plan for Gatineau Park, Sparks proposed to impose a time limit for the blanket acquisition of all remaining privately-owned land within the park. This approach, he argued, did constitute a rational policy as it provided a calculated means to an end. While this approach might involve a larger initial expenditure than piecemeal acquisitions, Sparks argued that it was cheaper in the long run. Further, what was the cost of not having

\footnotetext{
${ }^{834}$ Gatineau Park Advisory Committee. 1968, Jan. Memorandum to Executive Committee. RG34 280.22 Vol.3.

${ }^{835}$ Federal District Commission. 1958. Ibid., pg.39.
} 
control over privately-owned lands? Having canvassed the experience of national park administrators in the United States, Sparks knew of the threats posed by privately-owned lands in unsightly buildings, residential subdivisions, and commercial developments, and conflicts between private owners and park visitors.

This chapter documented Sparks' attempts to convince the FDC and federal government to adopt a land acquisition policy, and to back it up by giving the FDC powers of expropriation. Though the Advisory Committee did not reach an agreement on how the FDC should acquire remaining privately-owned lands, its 1952 Report did indicate that there was a consensus on the desirability of eventually eliminating privately-owned lands. Sure enough, following the 1952 Report, the FDC began purchasing lands along the Meech Lake shoreline. Thus, FDC territoriality had been turned "on," and this move threatened Meech Lake residents. In 1953, the Meech Lake Association submitted a memorandum seeking assurances from the FDC that it would not expropriate, and requesting the co-operation of FDC officials in enforcing the building standards set out in the municipal bylaw enacted earlier. Advisory Committee Chairman Sparks took the MLA memorandum as an opportunity to meet with the MLA to explain that national and public interests must take precedence in the park's planning and development. Even though the Advisory Chairman had met with Philippe Lake residents prior to their expropriation, Sparks was prevented from meeting with the MLA. The FDC also did not agree to send park officials to meet with MLA representatives.

Park residents' fears over expropriation were soon allayed when the FDC published its first policy statement on Gatineau Park land acquisitions. Its statement - one of two drafted confirmed the policy of negotiated purchase, with expropriation used only for parkway construction. But the published statement did not indicate whether the FDC intended to acquire 
all remaining privately-owned lands. Moreover, the public statement did not prevent controversy around FDC expropriation powers in Quebec. Having spoken with the ACGP Chairman, Redmond Quain, a Kingsmere resident and lawyer, claimed that the FDC statement concealed its true intentions. As this controversy was unfolding, the Gatineau Parkway Advisory Subcommittee reinforced Sparks' earlier calls for public ownership of the park. In its December 1953 Report, the Parkway Subcommittee warned the FDC that privately-owned lands would not only increase parkway costs, but would also delay parkway construction. Despite this, the FDC Chairman, Major-General Howard Kennedy, was unwilling to expropriate, even for the parkway purposes. And, with the prospect of further controversy around Sparks' views on the necessity of expropriation powers, Kennedy forced Sparks from his position as ACGP Chairman. Following Sparks' removal, the Advisory Committee ceased meeting. It never produced a master plan even though the Report on a Master Plan for Gatineau Park had all the makings of one.

The third section described Sparks' final attempt to challenge the park's status quo as a mixed-use/ownership area. Through the local newspapers, he made the issue of privately-owned lands in Gatineau Park public for the first time. Of course, Meech Lake residents resented Sparks' claims of unsightly buildings. Through the Capuchin Brothers, they tried, once again, to get assurances from the FDC as to their long-term residency. Following the public controversy, Sparks appeared before the joint-parliamentary committee set up to examine FDC progress on the implementation of the Gréber Plan. As one of its main recommendation was the enlargement and protection of Gatineau Park, Sparks pointed out how the FDC policy of negotiated acquisition without recourse to expropriation, while ostensibly intended to pacify the Government of Quebec, left the park unprotected, as the FDC could not exercise any control over privately-owned land. Sparks argued before the joint-parliamentary committee that allowing 
private lands at Kingsmere and Meech Lakes not only financially benefitted park residents, but was also unjust to those who had been expropriated at Philippe Lake. But, with Senator Connolly and MP Alexis Caron (who had participated with Kennedy in the smear campaign against Sparks) as members, the joint-parliamentary committee supported the park's status quo. Its final report made no recommendations concerning the FDC land acquisition policy, as if the problems with privately-owned lands did not even exist. Sparks had failed to convince the FDC and federal government that the entire project would be ruined unless the park was brought under public ownership as in the national parks.

Indeed, the most important park development, the Gatineau Parkway, was thwarted by divided ownership. Even though the FDC was supposed to expropriate for parkway purposes, it never acquired the lands necessary to extend the parkway to Philippe Lake, where the park's public facilities were located. Instead the FDC built only half of the Gatineau, which was thus concentrated in the Kingsmere-Meech Lake privatopia, where there were no public facilities (only Camp Fortune owned by the Ottawa Ski Club). As Sparks predicted, land values increased and park residents benefitted from improved access and increased property values. This was not the last of Sparks' predictions concerning privately-owned lands to come true; as shown in the next chapter, proposals for a ski chalet, marina, hotel, subdivisions threatened to turn Gatineau Park into a "glorified amusement park." Unlike its institutional predecessor, the National Capital Commission did have to expropriate, both reactively and proactively. 


\section{Chapter 5: NCC expropriations in the 1960s}

It would be difficult to maintain that the federal government has not the right for its specific purposes to expropriate in the Province of Quebec, but that the federal government has the right to expropriate in Quebec to establish a Capital or to embellish it, and that the federal government becomes owner of a large territory in our Province to this end, the Union nationale is not in accord.

...We hold dearly to the integrity of the territory like the sight of our eyes because it is the duty of every Government of Quebec not to sell or dispose of its territory. ${ }^{836}$

Daniel Johnson (Premier of Quebec), Legislative Assembly, May 1967

\section{Introduction}

The National Capital Act of 1959 reconstituted the Federal District Commission (FDC) as the National Capital Commission (NCC). Compared with its predecessor, the NCC had greater funding and a larger area of operation, the 1,800-square mile National Capital Region (NCR). This was not a territory over which the NCC had jurisdiction. Rather, the NCC, like the FDC, only controlled those lands that it owned. As indicated in Chapter 1, the idea of a federal district, that is, a territory over which the federal government exercised control, was unpopular, and not only in Quebec, but also in Ontario. Despite this, the NCC was given powers of expropriation in both provinces so that it could acquire the lands it required, whether for Gatineau Park, the Gatineau Parkway, or the Greenbelt around Ottawa.

Even though Gatineau Park was the largest and most important territory controlled by the FDC/NCC, it was only mentioned once in the entire National Capital Act. To be specific, Section 15(3) permitted the NCC to pay grants in lieu of taxes to the municipalities "situated in

\footnotetext{
${ }^{836}$ Author's translation. Johnson, D. 1967, May 10. “Motion de M. Roy Fournier.” Quebec. Legislative Assembly. Debates of the Legislative Assembly. Edited Hansard. $28^{\text {th }}$ Legislature, 1st Session, pg.2834-2835.
} 
Gatineau Park." Thus, the National Capital Act did not define the park boundaries, nor did it provide the NCC with a specific administrative mandate, e.g., park protection and expansion. Nevertheless, the Diefenbaker government passed Order-in-Council 1960-579, dated 29 April 1960, which authorized the NCC to purchase lands "within the wide shaded line ... indicating the Gatineau Park boundary." 837 Without an accompanying cadastral description, OIC 1960-579 was not a very precise definition of the park boundary. Perhaps it was for this reason that the FDC/NCC employed work crews to cut down a twenty-food-wide swath of forest along the park's perimeter, to serve as both a boundary marker and "fire-break." ${ }^{, 838}$

Order-in-Council 1960-579 ensured continuity between the FDC and NCC in the Gatineau Park land acquisition program, such that lands would only be acquired on a willing seller basis. An early meeting of the reconstituted Gatineau Park Advisory Committee (GPAC) recommended that the NCC adopt the same land acquisition policy as its predecessor, specifically that "[n]o effort will be made to expropriate property in Gatineau Park except in cases where such property is required to facilitate the construction of driveways, other essential works or where necessary to protect present Commission developments." 839 Finally, to further reinforce the acquisition policy continuity, Major-General Howard Kennedy was appointed as a member of the GPAC. ${ }^{840}$ As indicated in the last chapter, Kennedy was a Kingsmere resident intent on maintaining the park's status quo as a mixed-use/ownership area.

When the NCC assumed control of the park in 1959, the land acquisition program was 78.7\%. complete (see Appendix A). To be specific, the park had been expanded to 59,000 acres

\footnotetext{
${ }^{837}$ Privy Council of Canada. 1960, Apr. 29. PC 1960-579.

${ }^{838}$ Federal District Commission. 1958. Ibid., pg.6; see also National Capital Commission. 1959-1960. Ibid., pg.28; National Capital Commission. 1960-1961. Ibid., pg.38.

${ }^{839}$ Gatineau Park Advisory Committee. 1960, Dec. 7. Minutes of Meeting. RG34 Vol.280.22(1).

${ }^{840}$ Kennedy, H. 1960, Nov. 17. Letter from H. Kennedy to J.M. Wardle. RG34 Vol.280.22(1).
} 
of a projected 75,000 acres. ${ }^{841}$ The NCC continued to acquire large parcels of inexpensive vacant lands, particularly around La Pêche Lake. But, the acquisition of Kingsmere and Meech Lakes was not a high priority for the NCC. ${ }^{842}$ Rather, in 1961, the NCC entered negotiations with the Government of Quebec to exchange 12,500 acres of provincial Crown lands adjacent to La Pêche Lake for parklands immediately adjacent to Hull; these former NCC parklands would then be used for the purposes of an educational complex. ${ }^{843}$ Through the land exchange, the park's territory would be increased to 88,000 acres. But, as revealed in the epigraph and detailed in section two, the federal-provincial negotiations were suspended with the election of the Union nationale party, which resolutely opposed ceding any Quebec territory to the federal government. As shown in the next chapter, the land exchange negotiations were resumed in 1970 and, under NCC Chairman Fullerton and Hull MLA Oswald Parent, successfully concluded in 1973.

This chapter describes NCC expropriations in Gatineau Park during the 1960s. These expropriations confirmed the prescience of the earlier warnings of the park's recently deceased founder, Roderick Percy Sparks, namely, that land values would increase and that privatelyowned lands threaten to undermine the park project with residential subdivisions and commercial developments. Ironically, Sparks' children were among the expropriated property owners along Meech Lake Road. The NCC carried out these expropriations not only in response to rising land values resulting from parkway construction but also because Sparks' children were, allegedly, contemplating a cottage subdivision and motel. This section recounts the resistance campaign mounted by Sparks' children, as they allied with Redmond Quain, the Kingsmere resident and lawyer whose earlier campaign against the Federal District Commission in Gatineau Park was

\footnotetext{
${ }^{841}$ National Capital Commission. 1959. Ibid., pg.29.

${ }^{842}$ Gatineau Park Advisory Committee. 1961, Mar. 7. Minutes of Meeting. RG34 Vol.280.22(1).

${ }^{843}$ Gatineau Park Advisory Committee. 1961, May 23. Meeting with Mr. Oswald Parent, MPP, in Quebec City. RG34 Vol.280.22(1).
} 
documented in the previous chapter. Quain pressured the Municipality of West Hull to petition the Quebec Government. Premier Lesage forced the NCC to suspend its ongoing expropriations in Quebec, which went beyond Gatineau Park. Following a federal Cabinet decision, the NCC was given permission to resume the expropriations.

This controversy was just the beginning of the difficulties for the NCC caused by privately-owned lands in Gatineau Park. In 1966, NCC plans for La Pêche Lake were nearly undermined when real estate developers acquired 571 acres abutting the lake. The Bourque Brothers" "Domaine du Lac La Pêche" included a cottage subdivision, marina, and hotel. These urban-type developments would have compromised the wilderness character of La Pêche Lake. Like Sparks' children, the Bourque Brothers protested NCC compensation offer, and took the government to the Exchequer Court. Gatineau Park expropriations were becoming so numerous and costly that the NCC had to abandon the expropriation of privately-owned land adjacent to the Mackenzie King estate, even though the NCC knew that the owner was preparing to subdivide their property. The flaws in the piecemeal approach had been exposed and taken advantage of, but the NCC, like its predecessor, remained committed its land acquisition "policy" of negotiated purchase on a willing seller basis.

\section{Chrzanowski and Sparks}

In 1960, as construction of the Old Chelsea section of the Gatineau Parkway was just getting underway, NCC officials recognized that land values were going to be greatly inflated along Meech Lake Road. Gatineau Park Superintendent, R.E. Edey, wanted to purchase properties 
(totaling 2,425 acres) from 18 different owners at an estimated value of \$2-million. ${ }^{844}$ But, in 1961, the Treasury Board refused additional expenditures on Gatineau Park land acquisitions "pending submission by the Commission of a programme statement dealing with plans for the Park's future and operation." ${ }^{845}$ Thus, the properties could not be acquired before the public opening of the parkway in Old Chelsea. Although the NCC eventually obtained purchase agreements with most owners, it had to expropriate seven owners along Meech Lake Road given that "the appraisal value and asking price were too far apart for the Commission to even consider a reasonable offer." 846 But, as shown below, the NCC would not negotiate in good faith with Sparks' children.

Located in the "Chair Lift Area," the Meech Lake Road properties inherited by children Sparks' children were described by Superintendent Edey as follows:

8) R.P. Sparks - Part Lot 17A, Range 9, Township of Hull, containing 62.9 acres. Part of this lot is presently being leased to the Ottawa Ski Club as a parking area to serve the new ski developed areas on NCC property south of the Meech Lake Road. Mr. Sparks has ideas of constructing a motel and over-night cabins to be made available to skiers during the winter season.

He is quite reluctant to even think of selling his property, as he recently moved from the City and taken up year-round residence in the house bequeathed to him by his late father.

9) Mrs. J. Chrzanowski - Part Lot 18A, Range 9, Township of Hull, containing 15 acres. Mrs. Chrzanowski is the daughter of L.R. Sparks [sic] and was left this property by her father. Part of this land is also used by the Ottawa Ski Club as a parking lot to serve the ski area. She also plans to build a year-round residence on this lot during the spring of 1961. She is very reluctant to sell. ${ }^{847}$

\footnotetext{
${ }^{844}$ Edey, R.E. 1960, Dec. 7. Information on properties within the bounds of Gatineau Park that should be acquired at this time in order that values will not increase due to the opening of the Old Chelsea section of the Gatineau Parkway. RG34 280.22 Vol. 1; see also Gatineau Park Advisory Committee. 1961, Mar. 7. Ibid.

${ }^{845}$ Gatineau Park Advisory Committee. 1961, Mar. 7 Ibid.

${ }^{846}$ Gatineau Park Advisory Committee. 1960, Dec. 7. Ibid.

${ }^{847}$ Edey, R.E. 1960, Dec. 7. Ibid.
} 
Of course, the original motive was to acquire the lands in advance of the public opening of the Old Chelsea section of the Gatineau Parkway. But, with that section of the parkway now opened, the second motive took precedence as the Gatineau Park Superintendent claimed to be aware of the plans of Sparks' children, whose properties were almost entirely surrounded by the park.

Figure 5.1: Cadastral map of Chrzanowski property

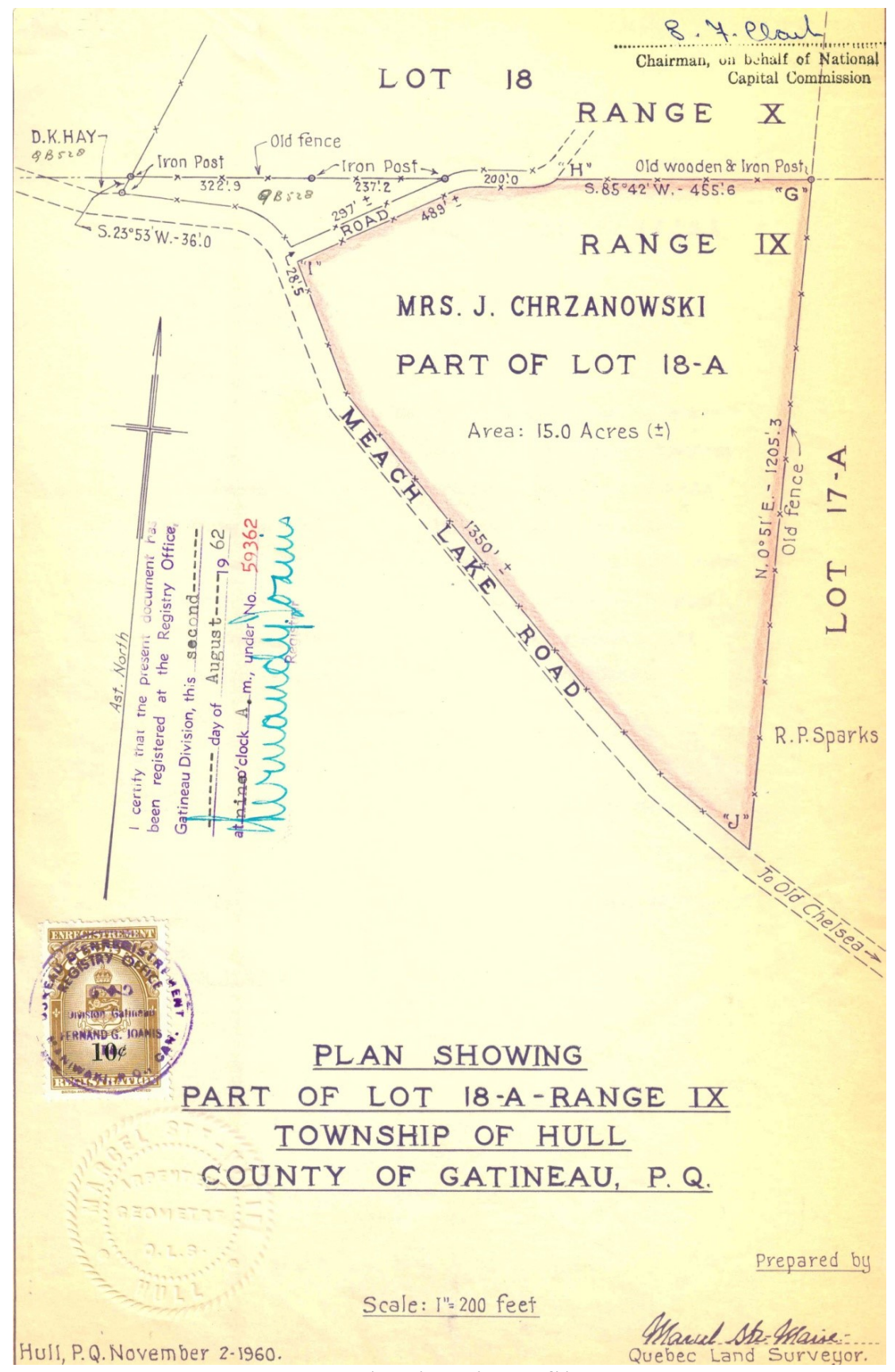

Source: NCC land registry file QB-0515 
Figure 5.2: Cadastral map of Sparks property

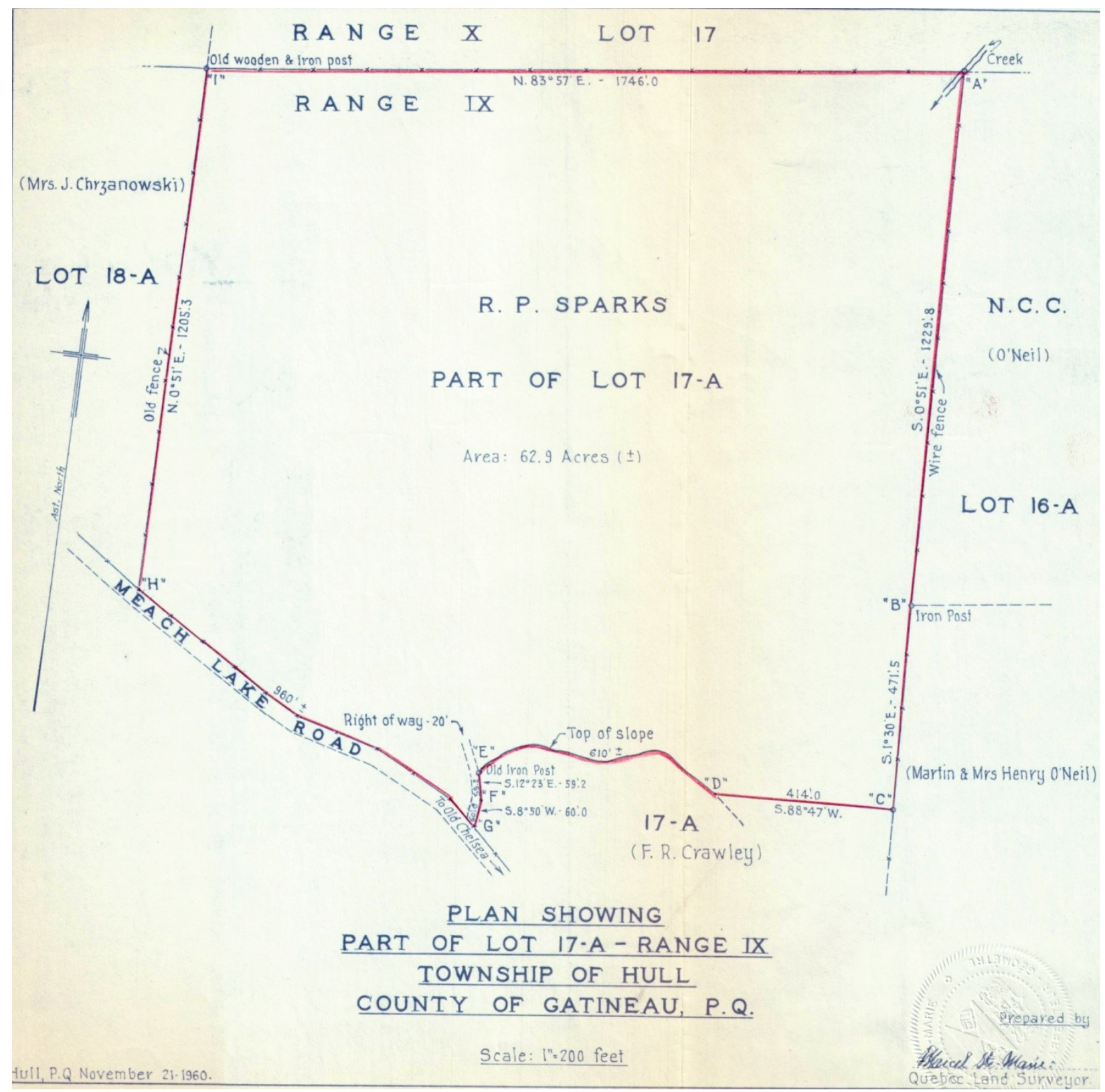

Source: Source: NCC land registry file QB-0511

In January 1962, Superintendent Edey learned that Chrzanowski had begun construction of a year-round permanent residence and that "[s]he also plans a 15 lot subdivision on one-acre lots. Lots could be sold at $\$ 2,500.00$ each. ${ }^{" 848}$ On Edey’s recommendation, the NCC sought the

\footnotetext{
${ }^{848}$ Edey, R.E. 1962, Feb. 1. Memorandum, re: Private Ownership Meech Lake Road - Chair Lift Area. RG34 P-10-
} 02. 
authority to expropriate Chrzanowski and the seven remaining private property owners along Meech Lake Road in order to "prevent development and commercial exploitation on one or two of them." ${ }^{849}$ Order-in-Council P.C. 1962-12/361 (22 March 1962) authorized the NCC to expropriate seven properties along Meech Lake Road (153 acres) at a total cost of $\$ 225,000 .{ }^{850}$ It is, of course, ironic that the children of Roderick Percy Sparks - the park's founding father and chief planner - were expropriated to protect Gatineau Park. As mentioned in the last chapter, Sparks knew that his advocacy for the public ownership of the park entailed a personal sacrifice, as the value of his property would substantially increase through construction of the Gatineau Parkway. Sure enough, only a couple years after Sparks' death, the NCC was trying to prevent the realization of Sparks' predictions. Perhaps knowing of their father's failed campaign against the park's status quo, Sparks' children fiercely resisted NCC expropriation of their lands.

And they had every reason to resist. The NCC contravened its own internal policy as it did not attempt to negotiate the purchase of the Chrzanowski property. An NCC memorandum reads:

Question 3 - Was any action taken on this authority [P.C. 1960-579] to purchase between 21 July 1960 when Mr. Edey wrote to Mrs. Chrzanowski seeking an appointment and 24 April 1961 when an appraisal was sought from Mr. Titley?

Answer 3 - Between 21 July 1960 and 24 April 1961, Mr. Edey did not discuss purchase with Mrs. Chrzanowski, since it was reported to us that she was, generally speaking, sick during most of this time. As it was reported to be a nervous disorder, brought on by alcohol, it was considered wise not to bother her. At the same time, he was in touch with F.R. Crawley, a brother-in-law, with respect to Crawley's property and was getting reports with respect to Mrs. Chrzanowski. There was nothing to indicate any urgency to purchase the property. ${ }^{851}$

\footnotetext{
${ }^{849}$ National Capital Commission. 1963, Sept. 13. Parcel QB-515 Chrzanowski: Summary of NCC Actions. RG34 1190.4.2 Vol.1, LAC ATI 201500061/MR, pg.587.

${ }^{850}$ McDonald, D.L. 1963, Sept. 11. Memorandum, re: Parcel QB-515 - Mrs. Chrzanowski. RG34 1190.4.2 Vol.1. LAC ATI 201500061/MR, pg.589.

${ }^{851}$ Ibid.
} 
Another reason for Chrzanowski to be upset was that she had begun construction of a year-round residence.

\title{
Figure 5.3: Notice of Expropriation sent to Mr. \& Mrs. J. Chrzanowski
}

\author{
NOTICE OE EXIROERIATION \\ duplicate
}

Mr. \& Mrs. J. Chrzanowski, old Chelsea,

P.Que.

Dear Sir:

NOTICE is hereby given to you that the property

formed of part of lot no. 18-A, Range IX, Registry Division

of Gatineau, has been expropriated in accordance with the

Law by the deposit of the plan and description at the

Registry office, Gatineeu Division, August 2nd, 1962, under

number 59362, and by the fact of said deposit of the plan

and description, said property becomes and remains from

then on devolved to the NATIONAL CAPITAL COMMISSION.

GIVEN at Hu11, on August 14th, 1962.

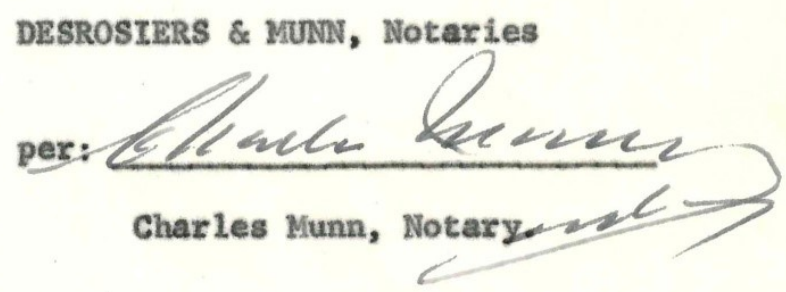

\section{REGTSTERED.}

Source: NCC land registry file QB-0515 
Upon receipt of the notice of expropriation in August 1962, Chrzanowski had to suspend construction (see Figure 5.3) ${ }^{852}$ Following this, another expropriated landowner, F.R. Crawley, negotiated on behalf of Chrzanowski, and an agreement was soon reached with the NCC: it would pay the contractor to complete the house, and would then lease the property back to Chrzanowski for $\$ 152.50$ per month. Chrzanowski would still be responsible for paying municipal and school taxes on the property. ${ }^{853}$ While the option form was signed, Chrzanowski "refused or neglected to attend at the agent's office to sign the agreement." ${ }^{\text {" } 54}$ In February 1963, when contacted by Superintendent Edey, Chrzanowski “said she had been ill since New Year's and that she would call Mr. Munn [West Hull notary agent] and arrange a meeting in the near future. ${ }^{\circ 55}$ However, the only subsequent contact from Chrzanowski concerned her request, made in April 1963, that the NCC pay $\$ 150$ for the excavation work for her home. The NCC refused the request "and this appeared not to be satisfactory to her." 856

Indeed, Chrzanowski had obtained the legal counsel of Quain and Quain. As shown in the last chapter, Redmond Quain, a Kingsmere resident, had publicly criticized the Federal District Commission for wanting to expropriate to expand Gatineau Park, even though the FDC had publicly renounced the use of expropriation for park purposes. The expropriations along Meech Lake Road provided Quain with an opportunity to go after the newly-established NCC. Quain evidently relished it, as shown in his July 1963 letter to the NCC:

May we say that we are quite surprised to find out that the NCC is starting again the old practice of expropriating in the Province of Quebec. Our recollection is that the NCC abandoned this practice, upon being told by the late Mr. Duplessis that the opinion given him by his legal advisors was that the NCC had no power

\footnotetext{
${ }^{852}$ National Capital Commission. 1963, Sept. 13. Ibid., pg.587.

${ }^{853} \mathrm{Ibid}$.

${ }^{854}$ McDonald, D.L. 1963, Sept. 4. Memorandum, re: Parcel QB-515 - Chrzanowski. RG34 1190.4.2 Vol.1 LAC ATI A201500061/MR, pg.599.

${ }^{855} \mathrm{Ibid}$.

${ }^{856}$ Ibid., pg.600.
} 
to expropriate for park lands etc., although it might expropriate for airports, railways, etc.

There must have been some specific action on the part of the Commission as a body to depart from what has been publicly declared to be its policy of nonexpropriation in the Province of Quebec and we are wondering if you feel like telling us when this change of attitude occurred ...

May we also put on record (because if the matter comes before Parliament, it is quite important) that no approach, according to our information, was made to our clients in any way, shape or form, with the object of buying the premises but a Notice of Expropriation was filed clandestinely in the Registry Office, which, if valid, operated as a conveyance to the Commission of the property. It has been repeatedly stated (and I think stated in Parliament also), that the Commission does not have recourse of expropriation unless it has exhausted all efforts to buy on a voluntary basis. ${ }^{857}$

Clearly, Quain was equating the NCC with the FDC. But the NCC had yet to publicly declare its official policy on Gatineau Park land acquisitions, even though, behind the scenes, it had adopted the same policy as its predecessor, namely, negotiated purchase with expropriation used only for parkway construction purposes.

Acting on behalf of Chrzanowski, Quain organized a campaign against the NCC expropriations. He began by enlisting the support of the Municipality of West Hull. At its September 1963 meeting, the West Hull Municipal Council passed a resolution "that Quebec Premier Lesage be petitioned to intervene and prevent the National Capital Commission from expropriating private properties in this Municipality for park purposes (Gatineau Park)." ${ }^{858}$ Upon receipt of this petition, the Quebec Premier contacted the federal Minister responsible for the NCC, Jean-Paul Deschatelets, the Minister of Public Works. Following their conversation, the

\footnotetext{
${ }^{857}$ Quain, R. 1963, July 19. Letter from Quain and Quain to National Capital Commission. Cited in McDonald, D.L. 1963, Sept. 4. Ibid., pg.600.

${ }^{858}$ Municipality of West Hull. 1963, Sept. 6. Resolution. RG34 1190.4.2 Vol.1. LAC ATI A201500061, pg.593.
} 
NCC was ordered by Minister Deschatelets "not to file any further expropriations in the Province of Quebec." $\$ 859$

This order struck a major blow to ongoing NCC operations. In addition to having six unsettled Meech Lake Road expropriations, it had another 48 unsettled expropriation cases elsewhere in Quebec. ${ }^{860}$ NCC Chairman Clark sought clarification from Minister Deschatelets, asking whether the order required the NCC:

(a) Not to seek authority to expropriate any land in the Province of Quebec from now on for any purpose whatsoever, or

(b) Not to seek authority to expropriate land from now on in the Province of Quebec for park purposes leaving the Commission free to seek authority to expropriate properties in the Province of Quebec for such things as bridge approaches and parkways. ${ }^{861}$

Despite this initial success, the Secretary-Treasurer of the Municipality of West Hull wrote the Quebec Premier again to complain about the "serious violation by the Federal Government of the rights of individual property owners of this part of the Province of Quebec." 862 Secretary-Treasurer Ryan indicated that "[t]hese people wish to live in our municipality and are being pushed out [by the NCC]." ${ }^{963}$ His letter pointed out the other implications on the municipality:

The National Capital Commission has about one half of our Municipality, and we cannot find out when they will stop. We will be left with only a small strip of land along the Gatineau River. People wish to build in this Municipality but the threat of the National Capital Commission expropriation is discouraging them; some do

\footnotetext{
${ }^{859}$ Clark, S.F. 1963, Sept. 13. Letter from S.F. Clark to D.S. Maxwell. RG34 1190.4.2 Vol.1 LAC ATI A201500061, pg.589.

${ }^{860}$ Marshall, F.S. 1963, Oct. 24. Memorandum to General Clark, re: Settlements of Expropriations - Province of Quebec for the Preceding Three Years. RG34 1190.4.2 Vol.1. LAC ATI A201500061, pg.560.

${ }^{861}$ Clark, S.F. 1963, Sept. 16. Letter from S.F. Clark to J.P. Deschatelets, re: Expropriation of the Chrzanowski property and proposed expropriation of the Shirley Ann Hope (Johnson) property and expropriations in general in the Province of Quebec. RG34 1190.4.2 Vol.1. LAC ATI A201500061,pg.585.

${ }^{862}$ Ryan, E.J. 1963, Sept. 18. Letter from E.J. Ryan to J. Lesage. RG34 1190.4.2 Vol.1. LAC ATI A201500061, pg.584.

${ }^{863}$ Ibid.
} 
start to build and their land and buildings are expropriated. This action by the

Federal Government should not be tolerated in Quebec... ${ }^{864}$

Unlike Premier Duplessis (who was a provincial "conservative" responding to expropriations by a Liberal federal government) Premier Lesage was a provincial Liberal, who had also been a federal cabinet minister, serving in Parliament from 1945-1948. Thus, Premier Lesage was far more diplomatic than his predecessor when addressing the issue of NCC expropriations in Quebec. On 26 September 1963, Lesage wrote the federal Minister of Public Works about "new protests" and asked Deschatelets to "see what could be done to remedy this situation." 865 Premier Lesage reiterated the policy of the Quebec government vis-à-vis federal expropriations: "When it is a matter of constructing harbours, canals or airports, no person will think of complaining as to the exercise of the right of expropriation but it seems to me it is altogether another matter when it is simply a question of establishing parks." ${ }^{\prime 86}$ Lesage's concern was with the welfare of the municipality of West Hull and its residents, but he must also have been worried about the political fallout from appearing weak in protecting Quebec's territorial integrity. These were Premier Lesage's concerns, not the national and public purposes of Gatineau Park.

With the expropriation powers of the NCC in question, the legal advice of the Deputy Solicitor General was requested. ${ }^{867}$ Section $13(1)$ of the National Capital Act was cited as providing the NCC with the authority to expropriate land in Quebec. It read:

The Commission may, with the approval of the Governor in Council, take or acquire lands for the purpose of this Act without the consent of the owner, and except as otherwise provided in this section, all the provisions of the Expropriation Act, with such modifications as circumstances require, are

\footnotetext{
${ }^{864}$ Ibid.

${ }^{865}$ Lesage, J. 1963, Sept. 26. Letter from J. Lesage to J.P. Deschatelets. RG34 1190.4.2 Vol.1. LAC ATI A201500061/MR, pg.582.

${ }^{866}$ Ibid.

${ }^{867}$ McDonald, D.L. 1963, Sept. 25. Letter from D.L. McDonald to Deputy Minister, Department of Justice. RG34 1190.4.2 Vol.1. LAC ATI A201500061.pg.583.
} 
applicable to and in respect of the exercise of the powers conferred by this section and the lands so taken or acquired. ${ }^{868}$

Having confirmed the legality of NCC expropriations, Minister Deschatelets lifted the ban on

NCC expropriations in Quebec. In a memorandum to Cabinet, Deschatelets recommended:

a. that Cabinet confirm that it accepts the opinion of the Deputy Solicitor General, and

b. that the National Capital Commission be permitted to continue to exercise its authority under the National Capital Act both in the Provinces of Quebec and Ontario.

Deschatelets would add that "[t]he only occasion that the National Capital Commission considered it necessary to expropriate in Gatineau Park occurred when the Commission was advised that certain properties were about to be subdivided and converted to commercial use." ${ }^{869}$ Cabinet approved both recommendations. ${ }^{870}$

Following this, Deschatelets wrote Lesage on the rationale behind ongoing NCC expropriations (e.g., for parkways, bridge approaches, consolidating land holdings) while providing the Quebec Premier with the assurance that "in all cases where the Commission is to expropriate lands located in the Province of Quebec, that a minimum of inconvenience will be caused to the Municipalities as well as to the expropriated owners and that the latter will be treated with understanding, justice and equity." ${ }^{871}$ In reply, Premier Lesage asked that the NCC prepare a plan of Gatineau Park, showing projected boundaries, existing structures, and topographical details. Lesage gave his assurance that the plan would be kept confidential. ${ }^{872}$

\footnotetext{
${ }^{868}$ Government of Canada. National Capital Act. RG34 1190.4.2 Vol.1. LAC ATI A201500061,pg.571.

${ }^{869}$ Deschatelets, J.P. 1963, Oct. 15. Memorandum for Cabinet, re: National Capital Commission Expropriations, Province of Quebec. RG34 1190.4.2 Vol.1. LAC ATI A201500061/MR, pg.565.

${ }^{870}$ Privy Council Office. 1963, Dec. 12. Record of Cabinet Decision, re: National Capital Commission expropriations, Province of Quebec. RG34 1190.4.2 Vol.1. LAC ATI A201500061/MR. pg.557.

${ }^{871}$ Deschatelets, J.P. 1963, Dec. 16. Letter from J.P. Deschatelets to J. Lesage. RG34 1190.4.2 Vol.1. LAC ATI A201500061, pg.556.

${ }^{872}$ Lesage, J. 1964, Jan. 9. Letter from J. Lesage to J.P. Deschatelets. RG34 1190.4.2 Vol.1. LAC ATI

A201500061/MR,pg.553.
} 
After providing the requested plan to Lesage, ${ }^{873}$ Minister Deschatelets removed the "administrative restrictions" placed on the NCC. Chairman S.F. Clark noted the lessons learned by the NCC from the Chrzanowski case: "[w]e should try to negotiate settlements wherever it makes sense to do so rather than expropriate. However, I realize that situations may arise where protracted negotiations could indicate the full intention of the Commission and as a result speculation in land we wish to acquire could cause a rapid increase in price." ${ }^{874}$ As shown below, this caveat proved prescient, as NCC plans for public facilities at La Pêche Lake were soon disrupted by real-estate developers.

The NCC continued to have difficulties reaching a final settlement with Chrzanowski. She did not pay the NCC rent on her property which, in December 1966 , amounted to $\$ 7,167.50$ in arrears. ${ }^{875}$ The NCC contemplated taking Mrs. Chrzanowski to the Exchequer Court, but, in February 1968 , they reached a settlement out of court. ${ }^{876}$ The land registry file does not contain the agreement; however, it does disclose that on 7 June 1971, almost a decade after her land had been expropriated, Chrzanowski finally released QB-0515 to the NCC. ${ }^{877}$

The NCC would, however, have to formally initiate court proceedings against Roderick Sparks. Notably, while the restriction on NCC expropriations was in place, Sparks wrote the NCC seeking permission to keep his home and four or five acres of land, with the NCC assuming control of the rest of the property. ${ }^{878}$ Gatineau Park Superintendent Edey rejected Sparks'

\footnotetext{
${ }^{873}$ Deschatelets, J.P. 1964, Feb. 21. Letter from J.P. Deschatelets to J. Lesage. RG34 1190.4.2 Vol.1. LAC ATI A201500061/MR, pg.553.

${ }^{874}$ Clark, S.F. 1964, Apr. 17. Memorandum, re: Expropriations in Quebec. RG34 1190.4.2 Vol.1. LAC ATI A201500061/MR,pg.541.

${ }^{875}$ National Capital Commission. 1968, Mar. 11. Resume QB-515 - Mrs. J. Chrzanowski. RG34 1190.4.2 Vol.2. LAC ATI A201500061/MR, pg.774

${ }^{876}$ Ibid.

${ }^{877}$ Mitchell, E.M. 1971, June 17. Letter to D.H. Fullerton, re: Cecily Philips Chrzanowski-QB-515. Land registry file.

${ }^{878}$ National Capital Commission. 1968, Feb. 9. Précis on Roderick Sparks. RG34 1190.4.2 Vol.2. LAC ATI A201500061/MR, pg.786.
} 
proposal, and was only prepared to assure him a "five year lease back with option to renew on yearly basis." ${ }^{879}$ As the restrictions on the NCC were lifted, the two parties resumed negotiations, and Sparks increased his price from $\$ 80,000$ to $\$ 97,000$ for the entire property. The NCC, based on the highest appraisal, was only prepared to offer $\$ 62,500$, and a lease of $\$ 1,260$ per annum; further, the NCC would assume responsibility for all taxes and property maintenance. ${ }^{880}$ Sparks rejected this counter-offer.

On 12 January 1965, another meeting to discuss compensation was held between Sparks, the NCC Chairman and the interim Minister of Public Works, Louis Joseph Lucien Cardin. Out of this meeting, the parties agreed that, since there was variance in the three appraisals $(\$ 51,300$, $\$ 52,000, \$ 63,500),{ }^{881}$ the appraisers would compare their methods of evaluation. ${ }^{882}$ In the meantime, Superintendent Edey informed Sparks that, since the NCC had not taken administrative control of the property, he was still required to pay taxes; Sparks disputed this, and became even more incensed with the NCC. ${ }^{883}$ In March 1965, Sparks complained to the NCC Chairman about inadequate compensation offers and mistreatment by NCC staff; Sparks threatened to criticize the NCC in the media. This threat prompted the NCC to modify its proposal somewhat, with park officials recommending "a last survivor lease with no sublet. Rent to be $5 \%$ of amount paid for house and four to six acres plus taxes and municipal charges. Sparks [will be] responsible for maintenance and acreage be leased to Sparks if he so wishes." 884 The newly appointed Minister of Public Works, George McIllraith, insisted that no special treatment be afforded to Sparks. Minister McIllraith maintained that, should Sparks reject

\footnotetext{
${ }^{879}$ Ibid.

${ }^{880}$ Ibid., pg. 787.

${ }^{881}$ Ibid.

882 Ibid.

${ }^{883}$ Ibid.

${ }^{884}$ Ibid.
} 
another NCC offer, the case would need to be resolved in the Exchequer Court. And, in January 1967, when Sparks refused the NCC offer of $\$ 63,500$, the Department of Justice initiated Exchequer Court proceedings. ${ }^{885}$ Although Sparks was legally required to submit a statement of defence within 15 days, he failed to comply. Finally, on 15 June 1970, Sparks submitted his statement of defence in which he asked for $\$ 87,000$ as "just and reasonable compensation for the said land and the damages resulting from its expropriation." ${ }^{886} \mathrm{He}$ claimed to have "suffered serious prejudice and damages by the action of the Plaintiff [National Capital Commission] especially since the Defendant has been deprived of his rights to exploit the said land." ${ }^{887}$ Only days before the trial was scheduled to begin, Sparks and the NCC settled the case out of court. ${ }^{888}$ Interestingly, unlike the Chrzanowski case, the offer of settlement was included in the land registry files, the NCC having paid Sparks $\$ 80,900$ compensation for his 63 acre property along Meech Lake Road.

As indicated above, the Meech Lake Road expropriations were among several unsettled Gatineau Park expropriations. By 1965, the NCC had acquired another 5,700 acres, bringing the park's overall acreage to $65,700{ }^{889}$ A total 5,210 acres of private lands remained in the park. ${ }^{890}$ As shown in the next section, NCC officials and park administrators were dealing with further subdivisions threats and land speculation, but the default policy of negotiated purchase remained firmly entrenched. There was no discussion of a blanket acquisition of remaining private lands.

\footnotetext{
885 Ibid.

${ }^{886}$ Sparks, R. 1970, June 15. "Statement of Defence.” In Federal Court of Canada, National Capital Commission v. Roderick Sparks. T-307-71.

887 Ibid.

888 Thomas, E.M. 1971, Jan. 19. Letter from E.M Thomas to J.W.N. Delorme. In Federal Court of Canada, National Capital Commission v. Roderick Sparks. T-307-71.

${ }^{889}$ National Capital Commission. 1965-1966. Annual Report. Ottawa: Queen’s Printer, pg.12.

${ }^{890}$ Davis, H.A. 1966, Nov. 2. Letter from H.A. Davis to S.F. Clark, re: Expropriation Gatineau Park Properties, Lac Lapêche area. LAC ATI A201500061/MR, pg.97.
} 
Such a decisive move would have surely been denounced by the Quebec Government, not to mention Redmond Quain.

\section{Bourque Brothers}

The federal-provincial land exchange negotiations reached a climax in the mid-1960s before trailing off. In exchange for 12,528 acres of provincial Crown lands and lake bottoms, the NCC would transfer 114 acres of parkland to the Government of Quebec which, in turn, would provide these former NCC lands to a not-for-profit organization for the purposes of an educational complex known as the "Student City." At first glance, the deal might seem to favor the NCC, which receives a great deal more territory. However, the provincial Crown lands were remote vacant lots in the middle of a wilderness, whereas the NCC parklands were immediately adjacent to the urban area of Hull. Since the land exchange involved coordination among several federal (Cabinet and NCC) and provincial bodies (Department of Agriculture and Colonization, Department of Lands and Forests), negotiations were orchestrated by Oswald Parent, the MLA for Hull.

The NCC was anxious to conclude the land exchange as soon as possible, so that it could begin developing public facilities at La Pêche Lake. The NCC wrote glowingly in its Annual Report: "[t]he sand beach on the east side of Lac Lapêche promises to be the best in the Park when fully developed by the Commission. ${ }^{" 891}$ When the NCC assumed control of the park, it immediately encountered the problems arising from mixed public-private ownership, with conflicts between park visitors and private owners over access to, and use of the area. This mixed

\footnotetext{
${ }^{891}$ National Capital Commission. 1965-1966. Ibid., pg.13.
} 
ownership prompted the NCC to prohibit "indiscriminate camping" at the lake, ${ }^{892}$ much to the consternation of many park visitors who preferred "the lack of adequate facilities" which the NCC provided as its rationale for the ban on camping. ${ }^{893}$ At the same time, the park's main public facilities at Philippe Lake, which included a restaurant, concessionaries, camping grounds, parking lots, etc., were experiencing severe overcrowding. The Gatineau Park Advisory Committee pressured the NCC to conclude the federal-provincial land negotiations since " $[\mathrm{n}] \mathrm{o}$ work in Lac Lapêche area should be started by the Commission before the exchange has been completed." 894

By 1965, the conclusion of the land exchange seemed imminent as the federal government, through Order-in-Council PC 1964-0/1694, approved the exchange. However, Student City representatives "verbally" requested an additional 189 acres (for a total of 304 acres), prompting NCC officials to review the terms of the land exchange, and complicating matters by necessitating a new Order-in-Council for the additional lands. ${ }^{895}$ And, in June 1966, with the election of Premier Daniel Johnson of the Union nationale, NCC officials sensed that the likelihood of concluding the land exchange was now even more bleak. Thus, NCC Chairman Clark lamented: "I am disappointed that we have not been able to conclude our negotiations with the Province of Quebec and I am now wondering whether the change of Government will mean a re-examination and a further delay." 896 While there were once "very happy relations" 897 between

\footnotetext{
${ }^{892}$ Clark, S.F. 1961, Nov. 15. Letter from S.F. Clark to R.K. Brown. P-10-02. LAC ATI A201500039/MR, pg.10.

${ }^{893}$ Adams, L.J. 1960, June 17. Letter from L.J. Adams to R.E. Edey. P-10-02. LAC ATI A201500039/MR, pg.41; see also MacKay, J.R. 1960, July 8. Letter from J.R. MacKay. P-10-02. LAC ATI A201500039/MR, pg.34; and Keenleyside, E.W.I. 1960, July 5. Letter from E.W.I. Keenleyside to D.J. Walker. P-10-02. LAC ATI A201500039/MR, pg.35.

${ }^{894}$ Gatineau Park Advisory Committee. 1965, Nov. 24. Minutes of Meeting. RG34 Vol.280.22(2), pg.2.

895 Thrift, E.W. 1966, Feb. 4. Letter from E.W. Thrift to S.F. Clark, re: Exchange of Lands - Province of Quebec. P10-04, LAC ATI A201500039/MR, pg.527.

${ }^{896}$ Clark, S.F. 1966, June 21. Memorandum, re: Miscellaneous Negotiations - Province of Quebec. P-10-02. LAC ATI A201500039/MR, pg.517.
} 
the NCC and Quebec government (when both were under Liberal leadership), Premier Johnson, despite initially agreeing to additional meetings, ${ }^{898}$ "stopped the sale of a territory of the Province to the National Capital Commission." ${ }^{899}$ The epigraph to this chapter indicates his reasoning: the Union nationale considered the protection of the territorial integrity of Quebec to be of paramount importance. ${ }^{900}$ As detailed in the next chapter, negotiations between the NCC and the Quebec government were resumed in May 1970, when both governments were, one again, under Liberal leadership.

While the NCC was still waiting on the completion of the exchange for provincial Crown lands, it was acquiring privately-owned lands around La Pêche Lake. Indeed, between 1954 and 1964, the NCC and its predecessor, the Federal District Commission, were the sole purchasers in the 19 property sales carried out in the La Pêche Lake area. ${ }^{901}$ However, another flaw in the policy of negotiated purchase emerged as not every property owner was a willing seller to the NCC for park purposes. George Steele, one of the largest private land owners at La Pêche Lake, "refused to sell to the NCC..."902 In the summer of 1966, George Steele sold 571 acres of La Pêche lands for $\$ 91,500$ to real-estate developers Paul and Edouard Bourque. ${ }^{903}$ Following this, Steele negotiated with the NCC for a land exchange, so that he would come to own property located immediately adjacent to the park boundaries.

\footnotetext{
${ }^{897}$ McIllraith, G. 1966, July 29. Letter from G. McIllraith to D. Johnson. RG34 1190.10.2, Vol.6, LAC ATI A201500039/MR, pg.512.

898 Johnson, D. 1966, Nov. 15. Letter from D. Johnson to G. McIlraith. RG34 1190.10.2, Vol.6, LAC ATI A201500039/MR, pg.501.

899 Johnson, D. 1967, May 10. Ibid., pg.2834-2835.

${ }^{900}$ Cited in Clark, S.F. 1967, June 19. Letter from S.F. Clark to G.J. McIllraith. RG34 1190.10.2, Vol.7, LAC ATI A201500039/MR, pg.554.

${ }^{901}$ Dumoulin, J. 1972, Dec. 10. Ibid., pg.24.

902 Ibid., pg. 15.

${ }^{903}$ Land Committee. 1966, Aug. 25. Minutes of Meeting. Ottawa: National Capital Commission. RG34 P-10-02. Vol.1, pg.5.
} 


\section{Figure 5.4: Cadastral map of Bourque Brothers La Pêche property}

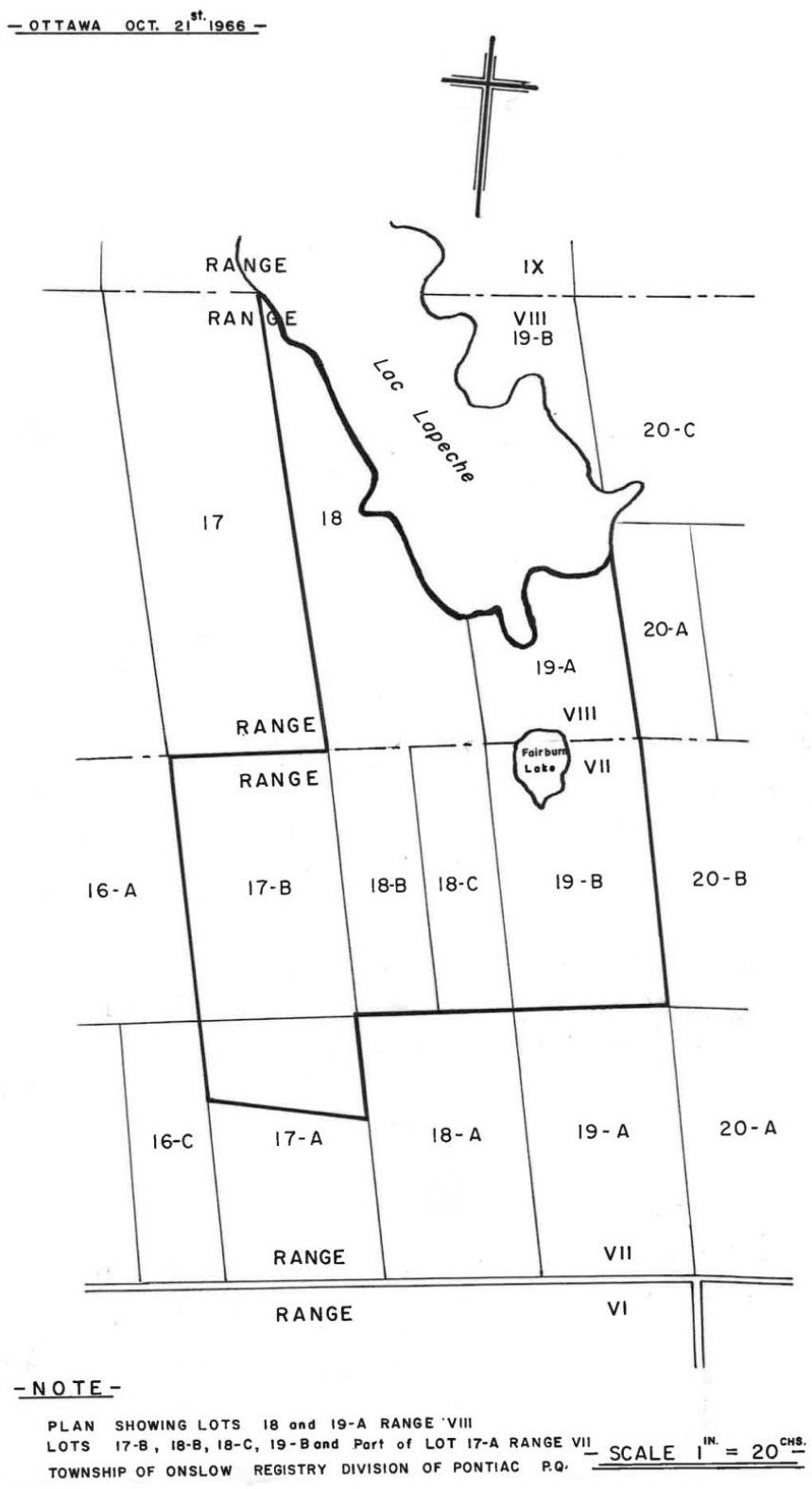

Source:

With a down payment of only $\$ 11,000$ to Steele, the Bourque Brothers, having already successfully developed cottage subdivisions at Perkins-sur-le Lac and St-Pierre des Monts, acquired their "Domaine du lac Lapêche" for a variety of purposes:

a. to develop a year-round, and (or) summer and (or) winter residential vacation area;

b. to develop a year-round recreation centre; 
c. $\quad$ to develop a commercial centre to serve the said area;

d. to carry on lumbering operations;

e. to work the two gravel pits located there. ${ }^{904}$

Shortly following their purchase, the Bourque Brothers undertook the preliminary stages of development. They hired a land surveyor to define the limits of their property. They also obtained the services of Roger Gagnon, an engineer and town planner, whose plan for the Domaine included a 60-lot cottage subdivision, hotel, and marina. ${ }^{905}$ At a cost of $\$ 20,000$, the Bourque Brothers built a 5-mile access road to La Pêche Lake, and began clearing lots and developing the beach area. ${ }^{906}$ Having done this preliminary work and received subdivision approval from the Township of Onslow, the Bourque Brothers advertised cottage lots on the radio and quickly sold twelve lakeshore lots. ${ }^{907}$ They even claimed, during the compensation trial at the Exchequer Court, to have refused 72 written applications. ${ }^{908}$

At the August 1966 meeting of the NCC Land Committee, Gatineau Park Superintendent Edey informed members about ongoing developments at La Pêche Lake. Superintendent Edey observed that "the Bourque Brothers have at least one agent working in this area with the aim of buying up more Gatineau Park land, presumably for the purposes of development or speculation..." $" 909$ To make matters worse, Edey was aware that Frank Jordan, an Ottawa lawyer, was intent on forming the Onslow Township Properties Association, which would, in Edey's view, would lead to further "speculative activities." 910 The Gatineau Park Superintendent recommended that the 571 acres owned by the Bourque Brothers "be acquired with or without

\footnotetext{
904 Ibid., pg. 1.

905 Ibid., pg. 18.

906 National Capital Commission. 1967, Oct. 24. Summary of Bourque Expropriation. RG34 1190.10.2, Vol.2, LAC ATI A201500039/MR, pg.356

${ }^{907}$ Land Committee. 1966, Aug. 25. Ibid., pg.5.

${ }^{908}$ Dumoulin, J. 1972, Dec. 10. Ibid., pg. 17.

${ }^{909}$ Land Committee. 1966, Aug. 25. Ibid., pg.5.

${ }^{910}$ Ibid.
} 
the consent of the owners." 911 The NCC Land Committee subsequently consulted the Planning Department, which replied that "[i]t is of extreme importance to the Commission to protect from private developments the total shoreline of presently undisturbed lakes within the Park."912 The Director of Planning, D.L. McDonald, added that "Lac Lapêche is the largest single water resource in the Park, and its designation for specific recreational and/or conservation purposes within the Gatineau Park Master Plan is imminent."913 In his letter to the Land Committee, McDonald noted his agreement with the recommendation in the 1953 Report of the Gatineau Parkway Subcommittee, namely, to acquire all remaining privately-owned lands. He emphasized that the 1953 Report identified the "disastrous effects ... which inevitably follow upon subdivisions and privately-owned property development." 914 The NCC was experiencing these very effects with the Bourque Brothers' "Domaine du lac Lapêche" as well as other privatelyowned lands in Gatineau Park.

Indeed, the park project was simultaneously threatened by subdivisions in its core and peripheral areas. Thus, in October 1966, the NCC sought and obtained approval for two expropriations: the Bourque Brothers at La Pêche ${ }^{915}$ and Mrs. H.J. Dunne on Kingsmere Road. ${ }^{916}$ Like the Bourque Brothers, Mrs. H.J. Dunne was intent on subdividing her property and selling individual lots. Her property was located adjacent to the Mackenzie King estate, one of the main attractions in Gatineau Park. Dunne refused to sell to the NCC, forcing it to expropriate her 73acre property, which was valued at $\$ 110,000 .{ }^{917}$ With so many unsettled expropriations

\footnotetext{
911 Ibid.

912 McDonald, D.L. 1966, Sept. 6. Letter from D.L. McDonald to F.S. Marshall, Re: Gatineau Park Property Acquisition Recommendation re Curley Lake, Lac Lapêche. RG34 P-10-02 Vol.1.

913 Ibid.

${ }^{914}$ McDonald, D.L. 1966, Sept. 6. Ibid.

915 Privy Council of Canada. 1966, Oct. 27. PC 1966-19/2013.

916 Privy Council of Canada. 1966, Oct. 27. PC 1966-18/2106.

${ }^{917}$ National Capital Commission. 1966, Oct. 17. Parcel QB-583: Authority to Acquire Land. Ottawa: Submission to Treasury Board. LAC ATIA201500061, pg.473.
} 
(including the Sparks children), the NCC did not have the necessary funds to carry out the Dunne expropriation..$^{918}$

Nevertheless, in November 1966, with the Bourque Brothers' development plans threatening to undermine the future development and use of the entire La Pêche Lake sector, the NCC announced its intention to expropriate. ${ }^{919}$ When officials met with the Bourque Brothers the following month, compensation could not be discussed since the land appraisals had still to be carried out. Nevertheless, the Bourque Brothers requested and received an advance payment of $\$ 70,000$ from the NCC. ${ }^{920}$ Another meeting was scheduled for January 1967, but one of the appraisers withdrew, and the NCC encountered difficulties obtaining a second appraisal. Prior to the next meeting, in June 1967, "many phone calls were received by the staff of the Commission from Mr. Paul Bourque. He took these opportunities to use extreme and on occasion improper language in his discussions [with NCC officials]."921

Unfortunately for the NCC, there was also "further activity by the Bourque Bros. within the boundaries of Gatineau Park." 922 First, in June 1967, the NCC erected a gate at the entrance of the access road built by the Bourque Brothers. This prevented the removal of lumber which had been cut during construction of the access road; it amounted to twelve cords and fifty-three poles. ${ }^{923}$ Upon finding the NCC gate, Paul Bourque visited the home of park warden Campbell "demanding that he be given access to the wood ..."924 He took photographs of a park warden

\footnotetext{
${ }^{918}$ O'Brien, T.W. 1966, Dec. 22. Letter from T.W. O'Brien to H.A. Davis, re: Expropriation Gatineau Park - Mrs. H.J. Dunne. LAC ATI A201500061/MR, pg.447.

${ }^{919}$ National Capital Commission. 1966, Nov. 4. Expropriation for additional land - Gatineau Park. LAC ATI A201500061/MR, pg.454.

${ }_{920}$ National Capital Commission. 1967, Oct. 24. Ibid., pg.356.

${ }^{921}$ Ibid., pg.355.

922 Clark, S.F. 1967, June 7. Letter from S.F. Clark to G.J. McIllraith. RG34 1190.4.2, Vol.1. LAC ATI A201500061/MR, pg. 433.

${ }^{923}$ Edey, R.E. 1967, June 19. Letter from R.E. Edey to F. Marshall, re: Bourque Holdings - Gatineau Park. RG34 P10-02. Vol.1.

${ }^{924}$ Ibid.
} 
behind the fence with a rifle. In a letter to Prime Minister Lester Pearson, Bourque wrote that the photos "show quite well how little respect NCC officials held towards private property. The road block was finally removed - only after a harsh exchange of words." 925 The NCC received advice from officials in the Department of Justice concerning the rights of expropriated owners; ultimately, the Bourque Brothers were allowed to remove the cut lumber under supervision, thus bringing an end to this "unfortunate situation." ${ }^{926}$ NCC problems with the Bourque Brothers went beyond this incident and their "belligerent attitude."

Since the NCC had already committed its 1967-68 funds for Gatineau Park acquisitions, they could not purchase additional lands within the park. ${ }^{927}$ While NCC officials attempted to ascertain the lands acquired by the Bourque Brothers, ${ }^{928}$ NCC Chairman Clark indicated that "[i]t is impossible to identify at this time the exact location of the area purchased and the area being negotiated."929 In a telephone conversation with Paul Bourque,

Mr. Marshall [Manager, NCC Property Division] indicated to him that he was quite surprised that after previous expropriation experience with the other lands within Gatineau Park that Mr. Bourque would acquire further lands within the Park boundaries. He [Paul Bourque] stated this was his business, he was a developer, a contractor and a wood dealer. He intended to force the hand of Government by this means. ${ }^{930}$

Having obtained the advance from the NCC, the Bourque Brothers could purchase two parcels of land, comprising 113.98 acres in the Township of Onslow. As indicated by NCC General Manager Eric Thrift, "[b]oth parcels were eventually to be purchased by the Commission and preliminary negotiations had been undertaken with the owners, but because of the location of the

\footnotetext{
925 Bourque, P.J. 1967, Oct. 6. Letter from P.J. Bourque to L.B. Pearson. RG34 1190.10.2, Vol.2. LAC ATI A201500039/MR, pg.364.

${ }^{926}$ National Capital Commission. 1967, Oct. 24. Ibid., pg.355.

${ }^{927}$ Marshall, F.S. 1967, June 19. Letter from F.S. Marshall to A. Ede, re: Bourque Brothers. RG34 P-10-02. Vol.1.

${ }^{928}$ Ibid.

${ }^{929}$ Cited in Clark, S.F. 1967, June 7. Ibid., pg.433.

${ }^{930}$ Ibid.
} 
parcels in the extreme northwest end of the Park, and because of the lack of funds no conclusive negotiations had been attempted by the Property Division to acquire." 931

On 28 August 1967, Paul Bourque sent the NCC a letter with an offer to sell the two parcels for $\$ 34,165$, which he claimed represented the total cost of acquisition, plus an additional $10 \%$ to defray his expenses. Property Division appraised the two parcels at $\$ 20,000$, and indicated that Bourque was asking $\$ 68.00$ per acre higher than market value. ${ }^{932}$ As the NCC lacked the funds to acquire the property, it deferred negotiations to the following year. Bourque responded by threatening to cancel his offer of sale, informing the NCC "that he has contracted to slash-cut the standing trees on the property. In addition, he indicated that he will be proceeding to the Exchequer Court on the property which was expropriated at Lac Lapêche."933 Clearly, ongoing negotiations with the Bourque Brothers over the expropriated 571 acres failed to reach a settlement, even though, at the meeting on 26 June 1967, “[i]t was fairly well agreed that the Bourques should receive market value of the land plus all out of pocket expenses plus something for being put back a year on their development project." 934 While the NCC was prepared to offer $\$ 150,000$, the Bourque Brothers sought compensation in the order of $\$ 350,000$ to $\$ 400,000$. Given this vast difference, the case would be referred to the Exchequer Court. ${ }^{935}$ In the meantime, the Bourque Brothers received another advance of \$35,000 from the NCC. ${ }^{936}$

In a October 1967 letter, the Bourque Brothers took their grievances directly to Prime Minister Pearson, writing that "the lands in question have been held in the Steele family for more

\footnotetext{
931 Thrift, E.W. 1967, Oct. 20. Memorandum to A.J. Frost, re: Paul J. Bourque. RG34 1190.10.2, Vol.2 LAC ATI A201500039/MR.pg.358.

932 National Capital Commission 1967, Nov. 7. Paul J. Bourque - In Trust. RG34 1190.10.2, Vol.2 LAC ATI A201500039/MR, pg.347.

933 Thrift, E.W. 1967, Oct. 20. Ibid., pg.358.

934 National Capital Commission. 1967, Oct. 24. Ibid., pg.356.

935 Ibid., pg. 357.

936 Thomas, E.M. 1968, Jan 18. Letter from E.M. Thomas to E.W. Thrift, re: N.C.C. Expropriation from Bourque Brothers, Lac Lapêche, Parcel QA-177. RG34 P-10-02 Vol.1.

${ }^{936}$ Edey, R.E. 1967, June 19. Ibid.
} 
than three generations and, although these lands have always been for sale, no representation was ever made by the Commission during the seven years which preceded our first approaches with that family."937 The Bourque Brothers then added that negotiations with the NCC and Department of Justice officials "were but a series of insults to our intelligence. This, we feel, is attributable to our racial origin [Francophone Quebec] - we may be wrong about this."938 The NCC were difficult to contact. They wrote: "[A]t certain times, it was impossible to get in touch with - even by phone - officials of the Commission who had undoubtedly chosen to ignore us." 939 Knowing that the Department of Justice does not typically get involved in expropriation proceedings (i.e., it is usually carried out between the NCC and owners directly), the Bourque Brothers questioned whether lawyers were even qualified to determine the value of compensation. They concluded their two-page letter to Pearson that, when considered overall, the NCC had treated them "like second-class citizens." The Prime Minister was even threatened with the specter of provincial intervention, the Bourque Brothers suggesting that "it would be regrettable to have the Quebec Government's influence involved in this issue."940

The NCC prepared Pearson's response letter, which offered a point-by-point rebuttal of the Bourque Brothers' original letter. It began with the statement of NCC acquisition policy:

The policy of the National Capital Commission in acquiring land in Gatineau Park is based on preserving the Park for its intended use and on protecting the interests of the people of Canada against developments which would adversely affect the Park. The history of the Steele family property is well known to the staff of the National Capital Commission, who had received assurances that in the event this property was placed on the market it would be offered to the then Federal District Commission. Officials of the Commission were surprised to find that, in spite of these assurances, arrangements had been made to sell the property to you for

\footnotetext{
${ }^{937}$ Bourque, P.J. 1967, Oct 6. Ibid., pg.364.

${ }^{938}$ Ibid.

${ }^{939}$ Ibid.

${ }^{940}$ Ibid., pg.365.
} 
developments which were not compatible with the planned use of this part of the Park. ${ }^{941}$

To be sure, later in the Exchequer Court, Paul Bourque revealed "that the Steele brothers had already refused to sell to the NCC." ${ }^{942}$ Thus, earlier assurance given to the NCC turned out to be nothing more than a delaying tactic, as the Steele's had indicated to the Bourque Brothers that the NCC "would probably expropriate the property at Lake Lapêche some day or other." 943 Evidently the Bourque Brothers did not heed this warning. As shown above and below, they profited considerably from their speculative purchases in the park.

Although the Prime Minister's letter did not offer Bourque details as to why Department of Justice officials were involved in the negotiations, NCC Chairman A.J. Frost indicated the reason for proceeding with this case through the Department of Justice as it was "a most difficult one to cope with...Because of the wide difference between the opinions expressed by the former owners, and the rather threatening attitude taken by them, the Commission on the advice of the Legal Adviser, conducted the major negotiations in the Board Room of the Department of Justice with the Director of Civic Law Section acting with and for the Commission." ${ }^{944}$ Despite this cautious approach, "[t]he threatening attitude of Mr. Bourque to all who have dealt with him, his numerous telephone calls and his resorting to profanity on occasion has made it amply clear to the Commission that this case should be dealt with at the earliest possible date by the Exchequer Court. ${ }^{9} 945$

\footnotetext{
${ }^{941}$ Emphasis added. Pearson, L.B. 1967. Letter from L.B. Pearson to P.J. Bourque. RG34 1190.10.2 Vol.2. LAC ATI A201500061/MR, pg.349.

${ }^{942}$ Bourque, P.J. cited in Dumoulin, J. 1972, Dec. 10. Reasons for Judgement. Federal Court of Canada. T-1832-72, pg. 15.

${ }^{943}$ Ibid.

${ }^{944}$ Frost, A.J. 1967, Oct. 24. Letter from A.J. Frost to G.J. McIllraith. RG34 1190.10.2 Vol.2. LAC ATI A201500039/MR, pg.352.

${ }^{945}$ Ibid.
} 
Once the trial date was finally set, the Bourque Brothers would "find it most regrettable and unjust that we should be dragged into court, at the taxpayer's expense, and forced to waste our time and the NCC's when we are prepared to negotiate a settlement in this matter." 946 In the period between the negotiations and the trial, the $\mathrm{NCC}$ would repeat its earlier offer of $\$ 150,000$ for the La Pêche lands. In response to NCC offers, the Bourque Brothers consistently raise their compensation claims. ${ }^{947}$ From an initial request of $\$ 350,000-\$ 400,000$, the Bourque Brothers later claimed $\$ 649,750 .{ }^{948}$ And, during the trial, their compensation claim was further increased to $\$ 847,350$. As Justice Dumoulin observed, there was a "gigantic difference" between the Bourque Brothers' valuation and the NCC offers. As opposed to the NCC which made its valuation on the basis of land appraisals and development costs, Paul Bourque held the view that "the law stipulates that compensations in cases of expropriation should not be based on the costs [spent on acquisition and development] but rather on the value which it represents to the owners." $" 949$ Given the residential, commercial and industrial purposes to which the 571 acre “Domaine du lac Lapêche” was intended, the Bourque Brothers justified their claim for \$847,350 on the basis of the following:

$$
\begin{aligned}
& \$ 597,600 \text { for loss of property; } \\
& \$ 174,750 \text { for loss of timber; } \\
& \text { and } \$ 75,000 \text { for loss of gravel. } .^{950}
\end{aligned}
$$

\footnotetext{
946 Bourque, E.A. 1969, Nov. 24. Letter from E.A. Bourque to D.H. Fullerton. RG34 1190.10.2 Vol.7. LAC ATI A201500061/MR, pg. 543.

${ }^{947}$ It should also be pointed out that, in the period under discussion, the Bourque Brothers would also continue to strategically purchase properties required by the NCC. These additional purchases were made outside of Gatineau Park, one in Hull and one on Sparks Street. Once again, Bourque would make compensation requests that were considerably above market value. See Frost, J.A. 1969, Jan. 24. Letter from J.A. Frost to M. Lamontagne. RG34 1190.10.2 Vol.2. LAC ATI A201500061/MR, pg.739.

948 Thomas, E.M. 1968, Aug. 14. Letter from E.M. Thomas to M. Carrière, re: NCC expropriation of Parcel QA-177 from Edouard Bourque and Paul J. Bourque. RG34 1190.10.2 Vol.2. LAC ATI A201500061/MR, pg.770.

949 Emphasis. Bourque, P.J. 1967, Oct. 6. Ibid., pg.364.

${ }^{950}$ Dumoulin, J. 1972, Dec. 10. Ibid., pg. 9.
} 
Several expert witnesses were called to the Exchequer Court to address the industrial purposes to which the Bourque Brothers' La Pêche lands could be put. The gravel pits located on the property were found to be useful only insofar as developing the adjacent property. Because much of the area had already been cut over in the $1950 \mathrm{~s},{ }^{951}$ the consensus reached by the forestry engineer and lumber dealer was that the property could not be profitably developed as a lumbering operation, since it lacked the timber supply necessary for sustained-yield forestry. ${ }^{952}$ Justice Dumoulin, in his decision on the compensation trial, "eliminated lumbering and gravel pit operations as radically incompatible with the defendants' essential objective: the opening of a year-round vacation spot, a rustic retreat on the shores of a beautiful lake in the heart of luxuriant vegetation."953 Dumoulin argued that the Bourque Brothers purchase was “manifestly a speculative venture..."954 From the beginning, it was poorly financed and hastily carried out; indeed, as the Justice pointed out, "one of the lots, number 17-B, Range VII, did not pass into the defendants' hands until April 27, 1967, nearly six months after the expropriation on November 3, 1966, somewhat like legitimation by subsequent marriage."955 Justice Dumoulin then recognized that "speculation is a normal thing, indulged in every day all the year round; there is nothing to prohibit it, except, in a case such as this, the norms of common sense and the assessment of the contingencies of a special situation, which consist in sifting truth from falsehood, moderation from lack of moderation." $" 956$

The Bourque Brothers purchased land in Gatineau Park knowing full well that the NCC intended to eventually develop La Pêche Lake for public use. But, to generate a $\$ 300,000$ profit,

\footnotetext{
951 Ibid.

952 Ibid., pg. 10.

953 Ibid., pg. 31 .

954 Ibid., pg. 15.

955 Ibid., pg. 6.

${ }^{956}$ Ibid., pg.16-17.
} 
the Bourque Brothers defied common sense as they failed to properly assess the contingencies of the situation, i.e., their inevitable expropriation by the NCC. And, as shown above, the Bourque Brothers appraisals of property values lacked moderation, for in their valuation they included land-uses which were incompatible with one another. Obviously, Dumoulin held little sympathy for the speculators, who were tormenting government officials, verbally abusing them, and going so far as to purchase parklands in advance of NCC need.

But the Bourque Brothers were only exploiting a situation that had been created for them. Through its policy of negotiated purchase, the NCC, according to Justice Dumoulin, "had left this breach open, this bait for greedy speculators, a breach in which, in the final analysis and by rebound, it found itself caught." 957 This "breach" refers to how the park territory is riddled with holes, that is, privately-owned lands that the NCC has no formal jurisdiction over. As the Bourque Brothers episode reveals, the NCC has no special status when privately-owned lands are sold in the park. As Dumoulin observed, "[t]he sovereign privilege of expropriation is all that differentiates, in law and in fact, the plaintiff from the defendants; in all other respects the plaintiff remains in the position of an ordinary purchaser dealing with an ordinary vendor."958 With so many expert witnesses, Justice Dumoulin found the 10-day trial "too long and tedious." His final decision aligned, more or less, with the NCC's offer of $\$ 150,000$. Thus, the NCC paid the Bourque Brothers \$101,500, which covered their purchase price and road costs. Additionally, the Bourque Brothers were to be compensated as per the principle of the "prudent man," 959 such that the NCC was to pay an additional \$40,000, with 5\% per annum interest from

${ }^{957}$ Ibid., pg. 17.

958 Ibid., pg. 31.

959 Justice Dumoulin refers to the decision of the Privy Council in Pastoral Finance Association, Limited v. The Minister (1914, A.C. 1083 at pg.1088): “... That which the appellants were entitled to receive was compensation not for the business profits or savings which they expected to make from the use of the land, but for the value of the land to them. No doubt the suitability of the land for the purpose of their special business affected the value of the land to them, and the prospective savings and additional profits which it could be shewn would probably attend the use of 
the date of expropriation. ${ }^{960}$ With the award of compensation in favor of the NCC, the Bourque Brothers appealed the judgment to the Supreme Court of Canada. On 15 June 1971, they finally relented and filed a notice of discontinuance. ${ }^{961}$

The Bourque Brothers took ample advantage of the vulnerabilities caused by the piecemeal approach to land acquisitions, wherein private lands are purchased by the NCC only as they became available on the market, and only if funds were available. Having been exposed to aggressive land speculators, NCC officials did not want a repeat of the Bourque Brothers episode, which could have ruined an entire sector of Gatineau Park. ${ }^{962}$ So, the month before the Bourque Brothers were expropriated, Property Division, along with the support of Gatineau Park Superintendent Edey, recommended blanket expropriations of remaining private lands in Onslow Township, and along Kingsmere Road. ${ }^{963}$ The estimated cost to acquire the remaining 1,532 acres of private lands in Onslow was $\$ 100,000$ to $\$ 200,000 .^{964}$ The influence of Major-General Howard Kennedy and Redmond Quain continued to be felt, however, as the NCC was reluctant to expropriate proactively, even though NCC officials knew that land values were increasing (in large part because of the parkway). The breaches were left wide open and, as briefly touched on in the Conclusion, subsequent real-estate developers took full advantage of them.

the land in their business furnished material for estimating what was the real value of the land to them. But that is a very different thing from saying that they were entitled to have the capitalized value of these savings and additional profits added to the market value of the land. Probably the most practical form in which the matter can be put is that they were entitled to that which a prudent man in their position would have been willing to give the land sooner than fail to obtain it. Now it is evident that no man would pay for land in addition to its market value the capitalized value of the savings and additional profits as indicating the elements of value of the land to him, and they would guide him in arriving at the price which he would be willing to pay for the land, but certainly if he were a business man that price would not be calculated by adding the capitalized savings and additional profits to the market value.

960 Ibid., pg.33.

961 O'Connor, A. 1971, June 15. Affidavit of Austin O'Connor. Federal Court of Canada. T-1832-72.

962 Davis, H.A. 1966, Nov. 2. Memorandum, re: Expropriation Gatineau Park Properties - Lac Lapêche Area. RG34 1190.10.2, Vol.2 LAC ATI A201500061/MR, pg.96.

${ }_{963}$ National Capital Commission. 1966, Sept. 12. Gatineau Park-Land Acquisition. RG34 1190.10.2 Vol.2. LAC ATI A201500061/MR, pg.181.

${ }_{964}$ Marshall, F.S. 1966, Oct. 6. Memorandum, re: Acquisition of land in Gatineau Park, Township Onslow. RG34 1190.10.2, Vol.2. LAC ATI A201500061/MR, pg.478. 


\section{Conclusion}

This discussion of Gatineau Park expropriations in the 1960s was a previously unexplored period in the scholarship and, of course, official histories. As documented above, this was a time when the NCC was still trying to consolidate ownership at La Pêche Lake, and public facilities had yet to exist at Meech Lake. Meanwhile, subdivisions were being proposed - and carried out - around Kingsmere Lake, including the Mackenzie King estate, which King had dedicated to the people of Canada as a public park. So, the areas around Kingsmere and Meech Lakes were not part of the park's territory, as the NCC could not exercise effective control over them.

In the early-1960s, the NCC proactively expropriated along Meech Lake Road and, to add insult to injury for the historical legacy of the park's founding father, Roderick Percy Sparks, his inheritors' property was among those expropriated. His children, Chrzanowski and Sparks, wanted to live in the park, and were rumored to also want to subdivide and develop their lands. As Sparks predicted, they benefitted immensely from the completion of the Old Chelsea section of the Gatineau Parkway, both in terms of improved accessibility for car travel and land values. By expropriating early, NCC officials stopped the possibility of development and probably saved tax-payers millions of dollars. But the expropriation bore its own costs, as it prompted resistance from municipal and, through Kingsmere resident Redmond Quain, provincial authorities, delaying the conclusion of the all-important federal-provincial land exchange.

Further, as Sparks predicted, the piecemeal approach to land acquisitions has cost the government through soaring land values. The NCC had difficulty setting aside the necessary funds to keep pace with the inflating costs of acquisitions. The Bourque Brothers tried to capitalize on the breaches left open by the FDC/NCC land acquisition policy, and, thanks to the reasoning of Justice Dumoulin, they only made a small profit from their La Pêche Lake lands. 
This chapter documented their aggressive attitude towards to the NCC, and revealed the Bourque Brothers to be cunning speculators, purchasing Onslow lands in advance of NCC need.

Without adequate funds, the NCC could not even pursue a passive policy of negotiated acquisition. In 1966, there were still 5,210 acres of privately-owned lands remaining in the park. Federal-provincial negotiations for the land exchange had still to be concluded. Meanwhile, public facilities at Philippe Lake had "reached the point of saturation." Park boundaries were vaguely defined in law, but the NCC was going to the extraordinary length of employing crews to cut a swath of forest to mark the boundary. There was still no formally approved long-term master plan. And the parkland acquisition program was off the rails, since the NCC lacked the funds to acquire privately-owned lands, because it had committed all allocated acquisition funds to expropriations. Thus, NCC officials had to propose shuffling budget line items and had to convince the federal government that it should be able to make requests in the Supplementary Estimates budget.

By the end of the 1960s, the NCC had not accomplished as much as it should have in terms of the "enlargement and protection of Gatineau Park." The NCC could not protect the park from development on privately-owned lands. Of course, this was not the NCC mandate; the National Capital Act does not provide it with one vis-à-vis the park. And, as Sparks predicted, privately-owned lands would wreak havoc on park administration, as entire sectors were not only threatened by development, but were actually developed upon. The NCC managed to stop the Bourque Brothers, but several subdivisions were carried out, greatly increasing land values as new residences were built. The land acquisition program remains unfinished, and the KingsmereMeech Lake privatopia remains as firmly in place as ever. Indeed, there was only one 
intervening event, that is, a single disruption to the park's otherwise continuous status-quo as a mixed-use/ownership area. 


\section{Chapter 6: Meech Lake goes public}

They wanted stories and headlines? Give it to them. It meant being provocative; it meant being frank, saying one's piece, getting the story to the people directly; above all it meant being ready to leave the job at any time if the government didn't like what you were saying. ${ }^{965}$

Douglas H. Fullerton, NCC Chairman (1969-1972)

\section{Introduction}

Maps from the federal government have always indicated that Gatineau Park encompasses Kingsmere and Meech Lakes. As shown in Chapter 3, rumors that Meech Lake would be developed for public use arose during World War II, and Meech Lake cottagers protested at the Federal District Commission headquarters in Ottawa. The issue around the lake's ownership arose a decade later during the first attempt at a Gatineau Park master plan. Chapter 4 examined the rift between those who, like the park's founding father, Roderick Percy Sparks, envisioned Gatineau Park as a national park, and those who believed that the park could and should serve public and private interests.

As the park is the essential feature of the national capital plan, so Meech Lake is the essential feature of Gatineau Park. In 1952, Sparks explained: "This is the largest lake in the park. Of the large lakes it is the closest to Ottawa. It is the most scenic and the one which if its shores were open to the public, would be the most used. It is the very heart of the whole park project and yet the Commission does not own one foot of its shoreline." 966 By 1970, this situation had changed. The NCC had purchased 32 cottages on Meech Lake, leasing many back to the former owners on short and long-term leases. And, that summer, the newly-appointed

\footnotetext{
${ }^{965}$ Fullerton, D.H. 1978. Ibid., pg. 128.

966 Sparks, R.P. 1952, May. Ibid., pg.22.
} 
NCC Chairman, Douglas Fullerton, decided to raze several NCC-owned cottages and establish public beaches.

This chapter begins with a brief biography of the "activist" NCC chairman, the only one who challenged the park's privatopia, specifically by opening Meech Lake to public use. In official histories, Fullerton's greatest achievement is opening the Rideau Canal to public skating in the winter. His multiple other contributions have been overlooked in NCC histories and the park scholarship. The second section unpacks the decision-making that culminated in opening Meech Lake to public use. The visceral reaction of park residents to Fullerton's decision is documented in section two. The third and final section describes the controversial Chairman's subsequent influence on Gatineau Park and the development of the broader Outaouais region, as Fullerton tried to impose a snowmobile ban in Gatineau Park and led the NCC through federalprovincial negotiations involving, inter alia, the land exchange agreement and a new highway construction program.

\section{Arrival of an activist Chair}

Born with a speech impediment that he eventually overcome through training, Douglas Fullerton grew up in Montreal, where he earned commerce degrees at McGill University. Fullerton established himself in the professional world as an economist and published his first of several books, The Bond Market in Canada. He served as financial consultant to Natural Resources Minister René Levesque when private utilities were expropriated to greatly expand Hydro Québec. Fullerton distinguished himself further on the Parizeau Commission, which examined Quebec's financial institutions. Before arriving at the NCC, Fullerton was Chairman of 
another crown corporation, the Cape Breton Development Corporation, in which capacity he closed two mines while attempting to promote new industry to the region.

Figure 6.1: Photo of Douglas H. Fullerton

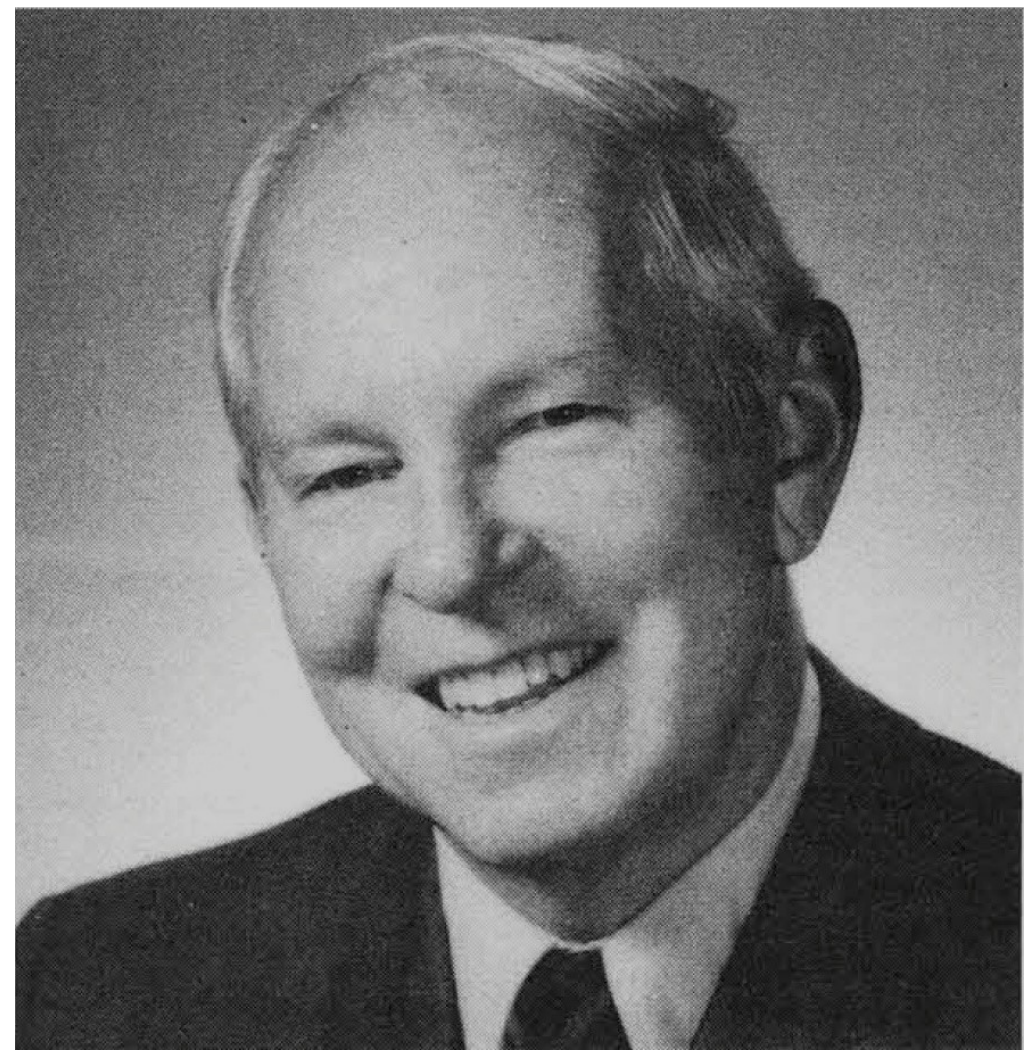

Source: Glebe Report 17 Jan. 1997

On 4 September 1969, the rising star of Fullerton reached its zenith, when Prime Minister P.E. Trudeau appointed him Chairman of the National Capital Commission. As one historian observed, "[p]rior to his appointment [in the 1960s] the National Capital Commission had attracted little attention from the press and was generally regarded as a remote planning body."967 This situation changed for the NCC through “Fullerton's frankness and his love of controversy."968 One of Fullerton’s fiercest political rivals, Lloyd Francis, characterized him as

\footnotetext{
${ }^{967}$ Woods, S. 1980. Ottawa: The Capital of Canada. Toronto: Doubleday Canada Limited, pg.312. ${ }^{968}$ Ibid.
} 
"a man not without ability, but who at times could be blunt, aggressive and impulsive."969 But, as John Learning, the lead NCC architect, also remarked of Fullerton: "behind all that impatient forthrightness, there was an idealist, an idealist who was not just satisfied with having ideals, but putting them into effect." 970

As shown below, Fullerton ambitiously pursued the ideal of transforming Gatineau Park into a public park. Fullerton wanted the public to enjoy the Park through NCC facilities. One ideal he did not want to put in practice for Gatineau Park was the conservation philosophy. He argued that the park was "simply too close to a large city to be turned completely into a wilderness area."971 An "all-out" conservation approach was impractical, Fullerton argued, because of the park's unique geography. Nevertheless, he maintained that, as Chairman, the NCC did become more conservation oriented, listing some of his early decisions:

In the fall of 1969, all plans for the building of further parkways - the parkways recommended by Gréber - were halted. We stopped power boats on Lac Philippe. In 1970 the snowmobile ban was brought in, that is, in those areas where there was some hope of policing the internal [sic] machines. The only concession we have made to recreation was to allow, finally, some modest public access to swimming at Meech Lake - surely not an improper approach after all the years during which the NCC owned about half the land around the lake! ${ }^{972}$

"Modest public access" is not the sort of achievement that wins a leader widespread recognition. But, as shown in the next section, this decision did offer a significant challenge to the park's status quo. Fullerton could have gone even further, however, and was pressured to do so by NCC officials and park planners. Thus, the month following the arrival of the new Chairman (October 1969), the General Manger of NCC Operations urged a blanket expropriation of remaining privately-owned lands in the park. GM-OPS McNiven needed only to go over

\footnotetext{
${ }^{969}$ Francis, L. 2000. Ottawa Boy. Burnstown, Ontario: General Store Publishing House, pg.103.

${ }^{970}$ Leaning, J. 1997, Jan. 17. "Douglas Fullerton-in memoriam.” Glebe Report, pg.2

${ }^{971}$ Fullerton, D.H. 1972, Feb. 29. Letter from D.H. Fullerton to W.J. Thurlow. NCC ATI A-2013-00010, pg.175.

972 Emphasis added. Ibid.
} 
Gatineau Park expropriations in the 1960s to make a compelling argument that the piecemeal approach to land acquisitions was costly and ineffective. According to McNiven, the park's remaining 9,750 acres of privately owned land could be acquired for $\$ 4,750,000 .{ }^{973}$ The existing policy, he argued, would incur substantially increased costs, such that "the balance might amount to $\$ 10,000,000$ spread over a ten year period. This is not because of accelerated development in the area but would be caused by the scarcity of this type of property close to the urban area." 974 Should the federal government provide the NCC with the authority to expropriate, McNiven recommended holding consultations with the Quebec government and demolishing "all uneconomic cottage properties."975

The planning consultants retained before Fullerton's arrival also encouraged the blanket expropriation to consolidate NCC ownership and control of the park territory. The consultants were asked to prepare a master plan based on the NCC Development Concept which partitioned Gatineau Park into three zones: an urban wedge, active recreation area, and conservation area. Kingsmere and Meech Lakes were situated in the "active recreation area," which was designated for intensive use, that is, "high density attendance and facilities." of the master plan submitted to the NCC, the consultants made the following recommendations concerning the active recreation area:

\section{Green Wedge}

5) Expropriate as soon as possible the residences south of Kingsmere Lake - i.e. between Mooreside and the Lake.

6) Expropriate or purchase all the properties around the lake.

\footnotetext{
${ }^{973}$ McNiven, J. 1969, Oct. 8. Memorandum, re: Land Acquisition in Gatineau Park. LAC ATI A201500060/MR, pg.890.

974 Ibid.

975 Ibid.

${ }^{976}$ Lambert, V., Bussiere, G., Aubry. 1970, May. Gatineau Park: Overall Development Plan. Ottawa: National Capital Commission, pg.23.
} 
7) Expropriate or purchase the properties between Kingsmere and Chelsea.

$\cdots$

\section{$\underline{\text { Intensive Recreation Sectors }}$}

1. Expropriate private residences (particularly at Meech Lake).

2. Move the Prime Minister's summer residence. ${ }^{977}$

$\cdots$

It should be noted that these recommendations are not contained in the Gatineau Park Overall Development Plan. Rather, in the master plan, the consultants recommended that, for the purposes of the active recreation area, "private residences around Meech Lake should be acquired to provide free access to the lake for general public use." 978 There is no mention of expropriation in the final master plan.

Chairman Fullerton wanted the Chain of Three Lakes to be opened to the public, but he was not prepared to expropriate remaining residences. Following the consultants' suggestion, Fullerton proposed to P.E. Trudeau that the official summer residence of the Prime Minister be relocated outside of the park boundaries, in the process opening Harrington Lake to public use. Fullerton recounted his exchange with Prime Minister Pierre Trudeau: "I wrote to him suggesting we look around for a new site, somewhere outside the park, against the day when a move might be necessary. He agreed, although he did not see any imminent need for a shift. A search was undertaken, but although several possible sites were found, none appeared to be a suitable replacement for Mousseau." 979 While Fullerton had no success opening Harrington Lake to public use (and later reversed his position), ${ }^{980}$ he would, as mentioned above, provide

\footnotetext{
${ }^{977}$ Urbatique Inc. 1970, Jan. Gatineau Park: Summary of Proposed Basic Development Policies. RG34 280.11 Vol.6.

${ }^{978}$ Lambert, V., Bussiere, G., Aubry. 1970, May. Ibid., pg.24.

${ }^{979}$ Fullerton, D.H. 1976, Sept. 29. "Protect Gatineau Park from the people." Ottawa Citizen.

${ }^{980}$ As Fullerton explained in 1976, “if I were asked again today about the need for moving the PM's summer residence, I would give a somewhat different reply than I did six years ago. I might even go so far as to recommend
} 
moderate access to swimming at Meech Lake. Further, Fullerton is to be credited with consolidating NCC control of La Pêche Lake through the conclusion of the federal-provincial land exchange, which will be discussed in the third section.

\section{Resident reaction to NCC decision}

The first steps to open Meech Lake were taken in March 1970 as the NCC declined to renew leases of its rental properties on Meech Lake. ${ }^{981}$ Following this, the NCC proceeded to demolish 27 of its 38 cottages. This move was justified in the NCC Annual Report as a means "to reduce the private use of land in Gatineau Park. $" 982$ In place of the cottages, the NCC would establish two public beaches at Meech Lake (O’Brien and Blanchet), with picnic tables, toilet facilities and a parking lot for 100 cars. As indicated in the Ottawa Citizen, "[O'Brien] beach can accommodate 500 people, and will take some of the pressure off the popular Lac Philippe." 983

Fullerton's decision was opposed by cottagers, conservationists, and even NCC staff such as Gatineau Park Superintendent Ede. Upon learning that letters had been sent to NCC tenants in February 1970, Ede wrote a 15-point letter to his superior, the General Manager of Operations, James McNiven, requesting that the beach development be delayed. The Superintendent argued that, because of the poor road conditions, park residents were in fact useful in keeping the general public out of an ecologically-sensitive area:

9. Apart from any benefit they themselves derive, the cottagers at Meech Lake perform a valuable service to the Park in that they are preventing the area from being over-run until we have facilities to take care of the visitors. The whole purpose of the studies carried out by the Planning Branch and the work being

\footnotetext{
that his enclave be enclosed by a good solid fence. We need all the barriers we can get to hold back people from damaging our natural environment." Ibid.

${ }^{981}$ No author. 1970, Mar. 2. "Cottages to go: NCC turns Meech Lake to public use." Ottawa Citizen.

982 National Capital Commission. 1970-1971. Annual Report. Ottawa: Queen's Printer, pg.12.

${ }^{983}$ No author. 1970, July 20. "Meech Beach: All it needs now is people." Ottawa Citizen.
} 
done by the Consultants is to prepare a development plan for the Park based on the carrying capacity of the resources. We will negate all the work done to date if we crash ahead now with any further unplanned development. There are already hundreds of thousands acres of ruined parkland in Canada as a result of development without planning and design. Must we add part of Gatineau Park to this sorry total. $[\mathrm{sic}]^{984}$

Although Superintendent Ede advocated public ownership in the long-term, he believed that the NCC was inadequately prepared to carry out these improvements, regulate public use, and deal with the inevitable quarrels from Meech Lake residents.

Table 6.1: Survey of Meech Lake cottages by the NCC (1970)

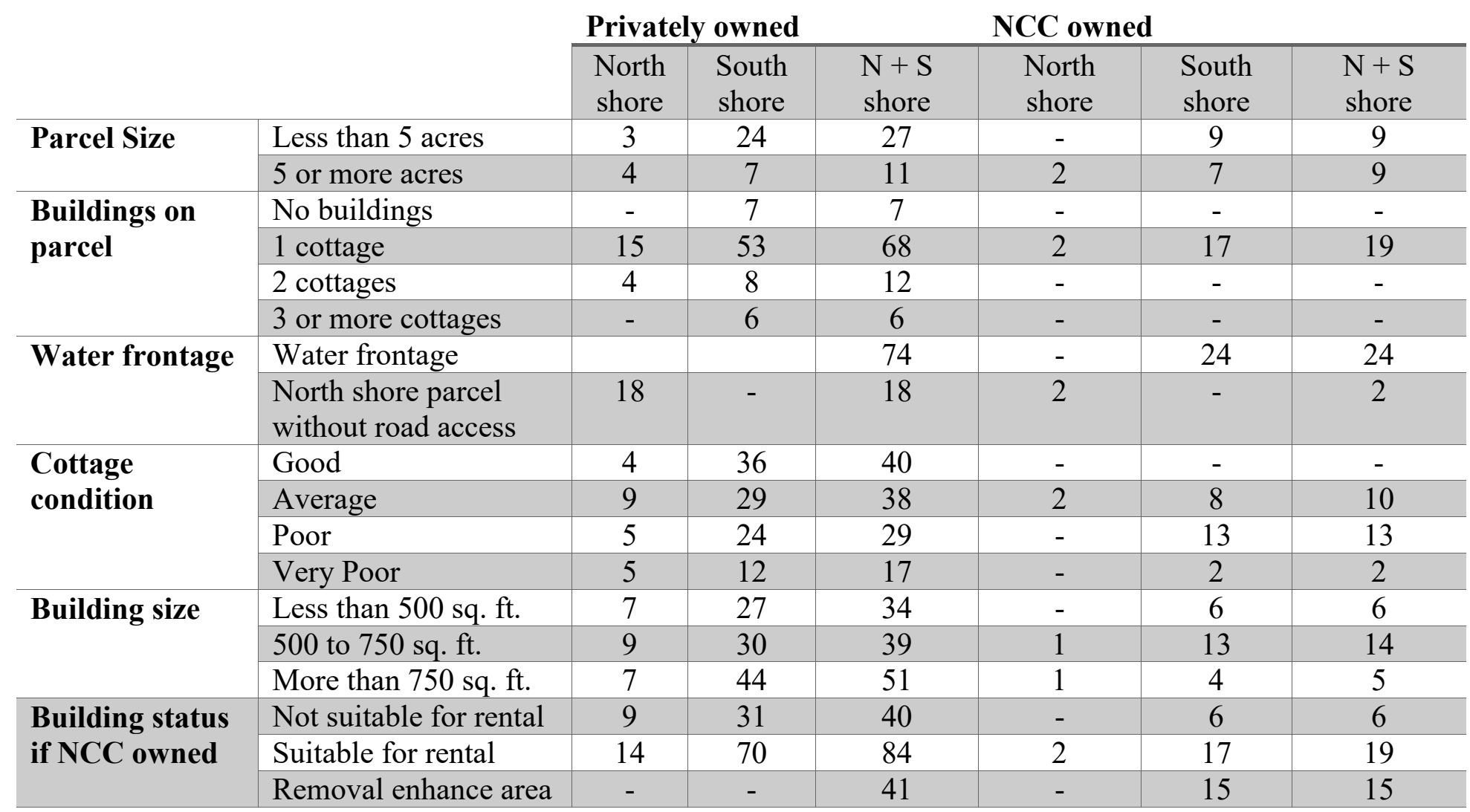

On 2 March 1970, the Ottawa Citizen announced the NCC development program for Meech Lake. It reported that NCC-tenants had already held an "informal" meeting with the

${ }^{984}$ Ede, A.R. 1970, Feb. 23. Letter from A.R. Ede to J.A. MacNiven. LAC 2014-0607 Vol.65.810-4(1). 
Meech Lake Association (MLA). The MLA President, Dr. Donald Hogarth, indicated that the MLA wanted to meet with the NCC because "we're disturbed. Nobody wants to have their properties taken out from under them." ${ }^{, 95}$ Dr. Hogarth is further quoted as saying: "While you can argue that these people [NCC tenants] don't own these cottages, they have been renting them steadily, some for as long as 17 years. The private owners are worried opening the lake as a public beach will undermine the value of their properties." 986 On the emerging conflict between park residents and the NCC, the Editors of the Ottawa Citizen endorsed Fullerton's decision in utilitarian terms: "The recreation needs of the many must take precedence over the sheltered pleasures of the few in the precious lake areas near any centre of population.. ${ }^{987}$ In response to this, former member of the Advisory Committee on Gatineau Park and 30-year Meech Lake resident, Senator John J. Connolly, voiced his opposition to the NCC decision, reiterating the argument he made earlier that Meech Lake is unsuitable for park visitors as there is "such a scarcity of real facilities for the public." 988 Senator Connolly suggested, instead, development of public facilities at La Pêche Lake.

Those directly affected (NCC tenants) regarded the decision not to renew 27 leases as "cruel" and were the first to register their protests to the NCC. ${ }^{989}$ A fourteen-year tenant of 'Silver Birch cottage' wrote GM-OPS McNiven that it was bad practice for a landlord to give less than two-months' notice. She then elaborated on the personal implications of such short notice:

\footnotetext{
985 No author. 1970, Mar. 2. Ibid.

986 Ibid.

${ }^{987}$ No author. 1970, Mar. 4. "Meech goes public." Ottawa Citizen.

988 No author 1970, Mar. 7. NCC Meech Lake Plan Doesn’t Make Sense - Senator.” Ottawa Journal.

${ }^{989}$ Ibid.
} 
Furthermore, I understand tenants are required to remove personal possessions from the premises by April 15. This, in my opinion, is unreasonable in view of having to remove such things as stoves, space heaters, fridges, built-ins like beds, kitchen units, etc. The condition of roads, locations of cottages and inconvenience of time of the year are all things that must be taken into account. Others, like ourselves, have spent years transporting things up to the lake and making improvements that will require considerable time to remove and undo.

Your decision to remove possessions so early in the season will certainly mean a financial loss to those of us who will not have adequate time to advertise and sell redundant items and yet do not have storage space in which to keep them. It will only be a few who will be fortunate enough to find other cottage accommodation on such short notice as this. ${ }^{990}$

The former owner of Silver Birch asked the NCC to reconsider the indiscriminate razing of cottages, arguing that only those useful for beach purposes should be demolished.

While long-term tenants were obviously the most directly affected by the NCC decision, park residents responded collectively. Residents wrote to former Prime Minister Diefenbaker, to see if he could "take some action to protect the rights of we property owners at Meech Lake against the National Capital Commission's latest threat."991 They also complained about the decision in the local media, arguing that opening beaches and other public facilities would "eliminate one of the few remaining spots of unspoiled beauty in the region, although such a haven is more than ever needed in this busy, greedy, noise, over-developed world.",992

Dr. Gray Merriam, who, along with Sheila Thomson and Ted Mosquin founded the Ottawa-Hull chapter of the National and Provincial Parks Association of Canada (NPPAC-OH), wrote an op-ed against the decision to open Meech Lake to public use. The letter by the NPPAC$\mathrm{OH}$ Chairman is quoted here in full:

\footnotetext{
${ }^{990}$ McWilliam, D.L. 1970, Mar. 4. Letter from D.L. McWilliam to J.A. MacNiven. LAC 2014-0607 Vol.65.810-4(1).

${ }^{991}$ Bearnman, G.M. and Noble, M.E. 1970, Mar. 11. Letter from G.M Bearman and M.E. Noble to J.D. Diefenbaker, re: Taking over Meech Lake Area by National Capital Commission FOR PUBLIC USE. LAC 2014-0607 Vol.65.810-4(2).

992 Bell. C. 1970, Mar. 18. "Save Meech.” Ottawa Citizen.
} 
The NCC plan to produce public beaches on the south shore of Meech Lake and, later to develop the north shore, carries many implications.

Once "developed," why should we expect Meech (and Harrington) to receive any better fate than Philippe did? Philippe is "overworked" so NCC proposes to open up the other two lakes and turn the half million local residents loose on all three.

What will the NCC planners develop next after these three small lakes have been overworked and any original qualities of wildness, beauty or solitude have been eroded by the human traffic?

Perhaps the public ought to ask the same question about the long-term fate of the whole Gatineau Park. Does the NCC plan to "develop" other large areas of the park and "open them up" to us? Will they too become overworked and their natural attractiveness destroyed permanently?

We would be foolish to accept such plans. In the short term they give us only inadequate playground areas which soon are too crowded to enjoy. In the long term they make us party to the permanent ruination of a beautifully wild piece of Canada which we are fortunate enough to live beside.

Neither we local residents nor the NCC have the right to destroy the natural beauty of Gatineau Park; it was set aside to preserve its wild nature for all the people of Canada, not become municipal swimming beaches for a few of us.

Restriction of public access by the cottages along the south shore of Meech Lake is appalling in an area administered as an adjunct to the National Capital for the people of Canada.

However, if given the NCC development plan as the only alternative, it might be better to leave the cottages. Has anyone considered removing the cottages and then leaving it alone? ${ }^{993}$

It should be added that the NPPAC-OH later repeated this view in its master plan, Gatineau

Park: A Proposal for its Conservation and Use, calling for the acquisition and re-naturalization of Meech Lake.

As the NCC was criticized in the media, the Meech Lake Association, knowing the full views of Chair Fullerton, held an emergency meeting. From the 20 March 1970 meeting, they petitioned the Government of Canada through the Minister responsible for the NCC, Jean

\footnotetext{
${ }^{993}$ Merriam, H.G. 1970, Mar. 18. "Preserving Meech Lake.” Ottawa Journal.
} 
Marchand, to request that the NCC delay plans for Meech Lake, "so as to afford all interests, both public and private, an opportunity to study the short and long term effects of the said plan to enable representation and to inform the public thereon and thusly assure the public interest involved in the said plans are truly and wisely protected." 994 The same day that the MLA issued its petition (see Figure 6.2), the Ottawa Journal editorialized in utilitarian terms: "The cottagers deserve sympathy for having been abruptly told to vacate buildings and land that in many cases hold long, arduous and dear associations. But the development of parks must go ahead for the good of all, and by nature this development will always work hardship on some."995

Jean Marchand was similarly unsympathetic to the interests of park residents. Since it can be taken to be representative of the view of the Trudeau government, Marchand's reply to the MLA petition is quoted here in full:

I understand that the Chair of the Commission has met with you about the Meech Lake situation and has written to you. I gather that he has indicated that a good deal of thought has gone into current Meech Lake policies, and that the Government's intention to bring the lake into the public domain has been established for many years.

Unfortunately, the long period which has been taken up in acquiring private holdings in Gatineau Park has, I believe, been misunderstood by some of those who have long benefited from the rather special circumstances enjoyed by private cottage owners in this public park. While this attitude is understandable, I can assure you that it has never been the intention that the federal holdings would indefinitely be used to maintain the status of the lake as a sanctuary for present cottage owners.

In effect, it must be recognized that the Commission's policy of gradual acquisition with a view to eventual total ownership has been somewhat selfdefeating. The Commission's ownership of Meech Lake cottages has served to limit general public use and enjoyment of one of the closest such facilities to the Capital. The NCC's presence as an ever-willing buyer has inflated acquisition costs. Its cautiousness in disturbing the status quo has encouraged new construction and expansion of existing private facilities.

\footnotetext{
${ }^{994}$ Hogarth, D.D. 1970, Mar. 23. Letter from D.D. Hogarth to J. Marchand. LAC 2014-0607 Vol.65.810-4(1).

995 No author. 1970, Mar. 23. "Why Meech Lake is Opening Up.” Ottawa Journal.
} 
[page 2] I do not question the motives nor the rights of the private owners to take legitimate advantage of this past situation. However, I agree with the Commission's present view that public access to the public lands around the lake must be expedited. ${ }^{996}$

The Minister wrote several individual property owners to reassure them that there was "no immediate (nor, I hope any proximate) danger of your property being expropriated. ${ }^{997}$

\section{Figure 6.2: Meech Lake resident petition against NCC park facilities}

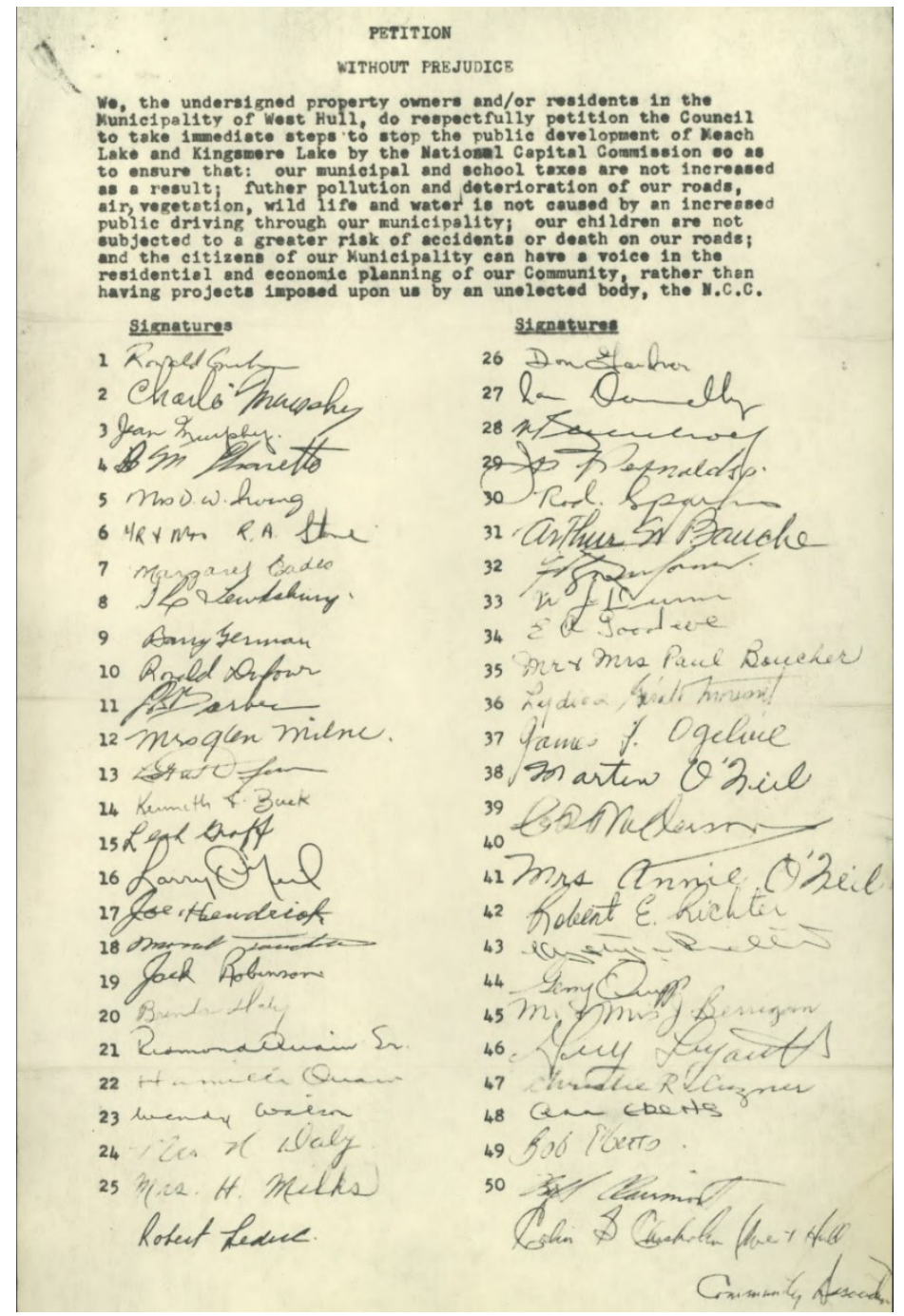

Source: Library Archives Canada ATI 2014-0607 810-4 PT.2 Vol.65

${ }^{996}$ Emphasis added. Marchand, J. 1970. Apr. 1. Letter from J. Marchand to D.D. Hogarth. LAC 2014-0607 Vol.65.810-4(1).

${ }^{997}$ Marchand, J. 1970, Apr. 8. Letter from J. Marchand to G.M. Bearman and M.E. Noble. LAC 2014-0607 Vol.65.810-4(1). See also Marchand, J. 1970, Apr. 8. Letter from J. Marchand to M. Ménard. LAC 2014-0607 Vol.65.810-4(1); and Marchand, J. 1970, Apr. 8. Letter from J. Marchand to L. Brault. LAC 2014-0607 Vol.65.8104(1). 
With only weeks before the official opening of Meech Lake, residents wrote to, and spoke with Ottawa MPs. Prime Minister Trudeau was kept apprised of the emerging situation. ${ }^{998}$ Fullerton's fiercest critic, Lloyd Francis, even had to ask for favors on their behalf. The letter from Francis to the NCC Chairman is quoted here in full:

I will be away for four weeks in London and shall not be bothering you during this period.

There is one thing, however. I had a complaint yesterday from a Meech Lake cottager that it is not possible to get everything out of the cottage by late May. Spring is late this year and there will be some restrictions on loads as the frost comes out of the ground. Some cottages have simply not been accessible because of deep snow.

Could consideration be given to extending the period before they have to vacate until the end of June. ${ }^{999}$

In response, the NCC extended the notice to vacate to three months. Despite this concession to

NCC tenants, on March 25, the "issue" of NCC expropriations for Meech Lake was brought

before the Senate. ${ }^{1000}$ The official land acquisition policy had to be reiterated, with the NCC then

offering a rather vague answer as to the work that was actually planned:

1. Is it the intention of the National Capital Commission eventually to expropriate all privately-owned cottages on Meech Lake?

It is the present policy of the Commission to expropriate property in Gatineau Park only when private developments are planned which are deemed to be prejudicial to the orderly development of the Park.

2. Is only the south shore of Meech Lake to be turned into a public beach and picnic area or are there plans to extend these services at some future date?

The pace of development of the shores along Meech Lake is dependent on continuing study of long range development plans for Gatineau Park and continuing assessment of the impact of the changes as they occur.

\footnotetext{
998 Pitfield, P.M. 1970, Mar. 24. Letter from P.M. Pitfield to D. Fullerton. LAC 2014-0607 Vol.65.810-4(1).

${ }^{999}$ Francis, L. 1970, Apr. 10. Letter from L. Francis to D.H. Fullerton. LAC 2014-0607 Vol.65.810-4(1).

${ }^{1000}$ Flynn, J. 1970, Mar. 25. "Meech Lake: Expropriations by National [Capital] Commission - Notice of Inquiry." Canada. Parliament. Senate Debates. Edited Hansard, 28th Parliament, 2nd Session, Vol.1, pgs.800-801.
} 
3. Will the public beach and picnic area on the south shore of Meech Lake result in the need to expropriate private property or are all of the cottages affected the property of the National Capital Commission?

Any current plans involve only that land owned by the NCC.

4. How many people will this new public beach accommodate?

5. What is the estimated cost of this development?

Any beach accommodation facilities are expected to be quite restricted in keeping with the topography. The major thrust of the development is designed to encourage a general appreciation of the parkland resource. No cost estimates are available.

6. What alternatives, if any, to Meech Lake were considered and why was Meech Lake chosen in preference to these alternatives.

Meech Lake was chosen because the first federal purchases of land there were made 32 years ago, initiating a long-term policy. ${ }^{1001}$

No doubt a growing desperation prompted Meech Lake residents to retain legal counsel.

The solicitor of the Meech Lake Association, the Hon. Leo Landreville, first wrote to the NCC Chairman on 13 April 1970, in response to "announcements made by the Commission."

Landreville wanted to know whether the Commission intended that: "[ $\mathrm{t}]$ his lake would become a Public Park and open to the public. The press report did not define nor explain the project of this Public Park. ..."1002 After several letters between Fullerton and Landreville, ${ }^{1003}$ Fullerton finally answered that: "[i[t is our intention to have a modest development on the south shore of Meech Lake, including a beach at the lower end, which will accent particularly the passive enjoyment of the natural setting."

${ }^{1001}$ National Capital Commission. 1970, Apr. 14. Parliamentary Returns. Question No. 9 - Honourable Senator Flynn. LAC 2014-0607 Vol.65.810-4(2).

${ }^{1002}$ Landreville, L.A. 1970, Apr. 13. Letter from L.A. Landreville to D.H. Fullerton, re: A. Amyot Estate and Meech Lake Project. LAC 2014-0607 Vol.65.810-4(2).

${ }^{1003}$ Landreville. 1970 Apr. 29. Letter from L.A. Landreville to D.H. Fullerton. LAC 2014-0607 Vol.65.810-4(2); see also Fullerton, D. 1970, May 5. Letter from D.H. Fullerton to L.A. Landreville. LAC 2014-0607 Vol.65.810$4(2)$. 
Figure 6.3: Proposed bus bays at Meech Lake (1970)

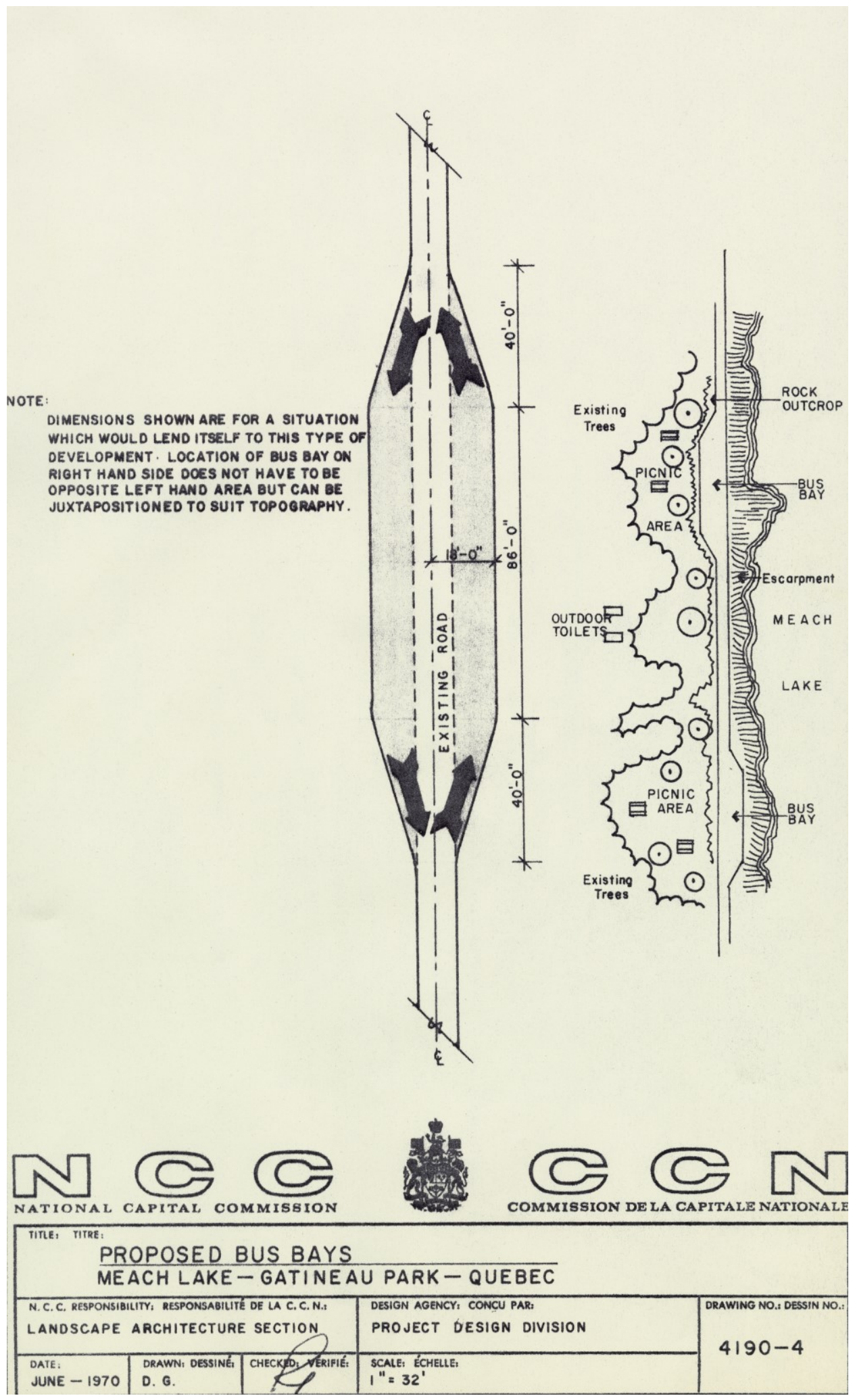

Source: Library Archives Canada ATI 2014-607 Box 65 File 810.4 PT2 
Figure 6.4: Proposed picnic area at Meech Lake (1970)

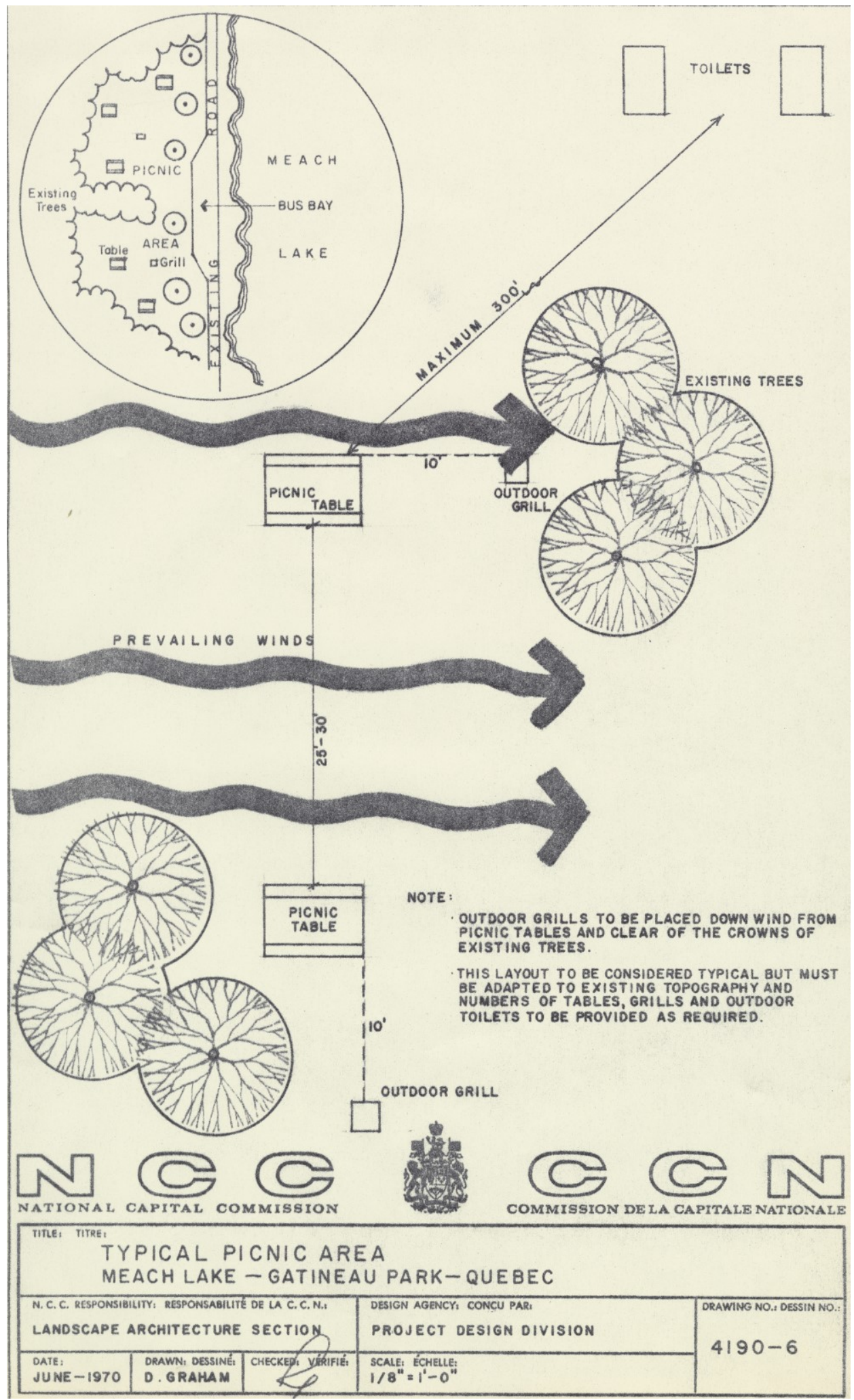

Source: Library Archives Canada ATI 2014-607 Box 65 File 810.4 PT2 
Figure 6.5: Proposed swimming raft at Meech Lake (1970)

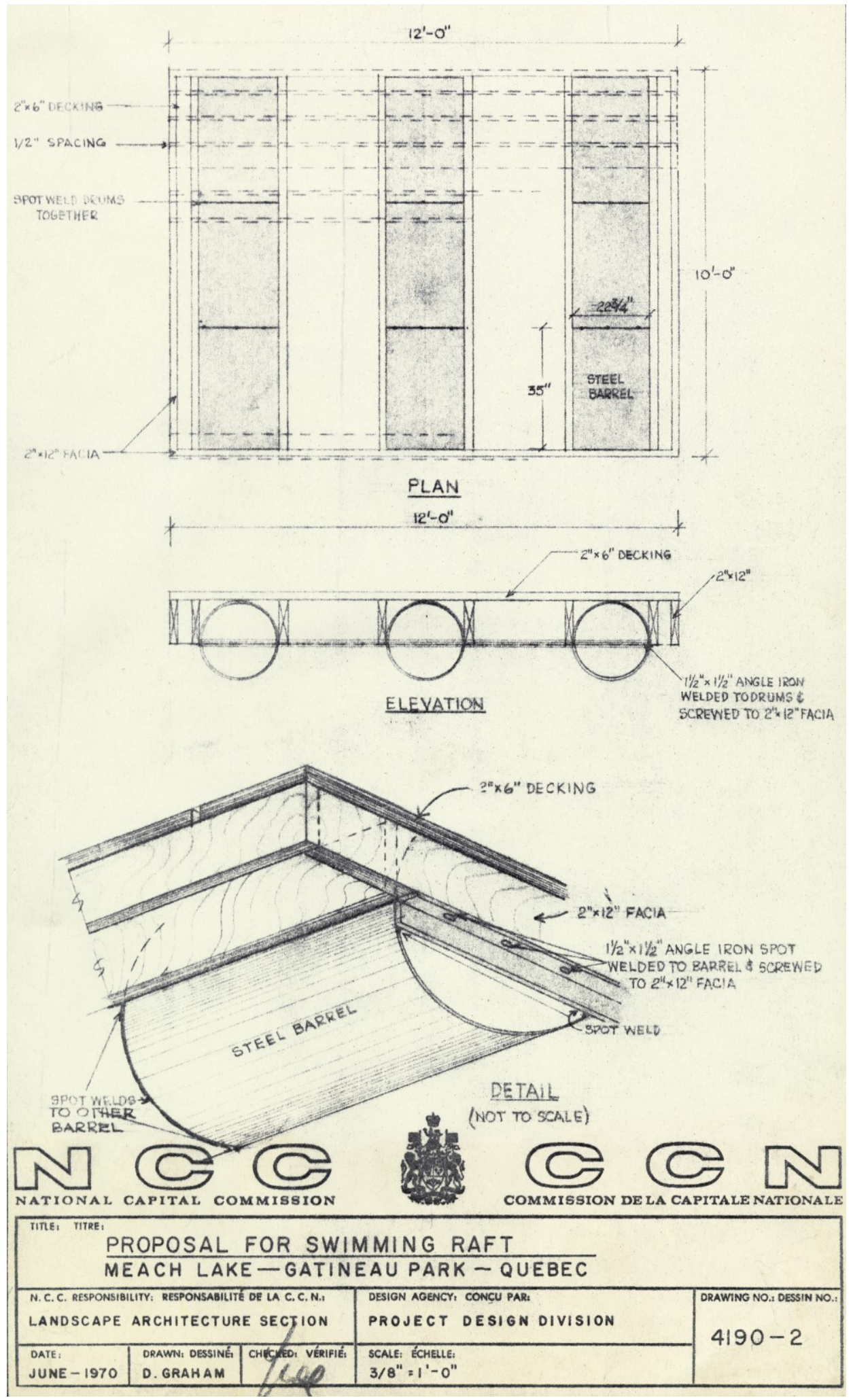

Source: Library Archives Canada ATI 2014-607 Box 65 File 810.4 PT2 
As this exchange was ongoing, the NCC began bulldozing cottages at Meech Lake. The Citizen hyperbolically claimed that NCC actions had resulted in "an influx of hundreds of motorists to the area [which] has aroused Meech Lake property owners to the boiling point."1004 The article proceeded to note the residents' position: "Charging that the National Capital Commission has prematurely opened the door to the public without first providing adequate roads and other requirements, the Meech Lake (property owners) Association will, if necessary, take to the courts to seek an injunction."1005

Thus, a month before the new beach was opened, the Meech Lake Association threatened to seek an injunction against the NCC. The Ottawa Citizen published excerpts of a letter from the MLA lawyer, Hon. Leo Landreville, detailing the "nightmare" experienced by residents because of the "auto invasion" brought to the area by new park developments. Landreville argued that Meech Lake Road, as a narrow, dirt road in poor condition, "cannot bear heavy traffic. The series of one-lane curves and rises bordering the whole length of the lake and leading to Harrington Lake makes it more hazardous for any greater traffic than that of the owners of cottages." 1006 The MLA lawyer condemned NCC Chairman Fullerton: "Your invitation to the public is an invitation to accidents, and fatalities, and the present owners of cottages, as well as taxpayers generally, take objection to your invitation to the general public to travel over a road which you neither own nor maintain." While not objecting to the "political and philanthropic policy" of the NCC in creating public parks, beaches, and picnic grounds, Meech Lake residents were not prepared to abdicate their rights "to continued peace and the absence of nuisance or noisy crowds, and they are entitled to use their motor boats and to enjoy quiet fishing." Landreville added 'the premature declaration of 'public use' will mean 'public abuse' by non-resident

\footnotetext{
${ }^{1004}$ Finn, J. 1970, June 2. "Meech Lake chaos has cottagers up in arms." Ottawa Citizen. 
motor-boat users, leading perhaps to a ban on all motor-boats on the lake." Meech Lake residents were entitled not only to unlimited access of the lake, but also to special privileges. Overall, Landreville did not believe that Gatineau Park could be "commended as a public project" until the NCC took ownership of most of the cottages. He informed the NCC: "As it now stands our clients (the association) are most apprehensive of your policy. Could it be that you are to create a 'Coney Island' occupation that they will be forced to sell at any price to the commission as the only buyer? Your announcement has already all but destroyed the sale value of properties."1007

As shown above, park residents associated the NCC beach with noise, crowds, and garbage. These were characteristics of an urban landscape, those which park residents were fleeing by way of their privatopia in Gatineau Park. This sentiment was captured in an op-ed, presumably written by a park resident:

Editor, Citizen: The Gatineau country is full of lakes much more suitable than Meech Lake topographically for recreational purposes, and probably less costly to develop.

There, those who want the portable quiet-busters of radio and record players, who know nothing of and care less for the music of the whip-poor-will, wood thrush, and white-throated sparrow, can congregate, leaving the remnants of their peculiar type of happiness in the form of cans, broken glass, paper, and discarded food, and less mentionables. They destroy the very thing that attracted them in the first place.

Meech Lake should survive under control of the residents who have kept it as it is for, I think, something like 70 or 80 years or more, a lovely haven, out of the roar, smells, and push of a day in the city. ${ }^{1008}$

Several Meech Lake residents complained in the Ottawa Journal about the effects of opening Meech Lake to public use. They all pointed out that the NCC decision had not only led to increased traffic, but also led to routine trespassing. While no one interviewed objected to public use per se, they still challenged the NCC's approach to opening the lake. A former NCC-tenant,

${ }_{1007}^{10}$ L. Landreville cited Ibid. 
Bill Zimmerman of the Social Planning Council, said: “The principle's great - but the way they're doing it's not. They need signs, better toilet facilities - and the road's so dangerous." Ivan Jelacic, a Meech Lake property owner of eight years, was also quoted as saying: "This is a big lake with room for lots of people, but it isn’t logical, particularly during an austerity period, to work on the south side when it would be cheaper on the north." The Jelacic family questioned why they should be expropriated, when their cottage on Meech Lake "literally rises up a steep rock embankment." 1009

Another area-resident, Ken Buck, echoed this in an op-ed to the Ottawa Citizen, arguing that the public interest was undermined by the creation of public beaches. Buck wrote that Fullerton's policy defeated its proposed aims:

There will be no significant increase in man-hours of enjoyment of the area because the "beaches" could scarcely accommodate the number of cottagers who use it in scattered lots around the lake.

Wilderness will not be made available to the public because concentrated crowds of picnickers and bathers will destroy that very wilderness.

The area's best protectors, the landowners and tenants, who are concerned because of many monetary and personal commitments to the area, will be removed. ${ }^{1010}$

Buck concluded with the positive suggestion that the NCC should rent out its cottages, on a firstcome first-served basis, to individual families for two to four week blocks of time. In the op-ed Buck's criticism is somewhat muted for, in a letter to Chairman Fullerton, he scathingly wrote:

...for minimal gains and with maximum expense, you are destroying the beautiful homes of 33 permanent residents and homesteads which have been built by generations of one family; you are defeating your own policy of keeping the Gatineau Park a wilderness area, and finally and most important, you are destroying this most beautiful body of pure water which is most valuable to our community as it now stands - private and protected.

\footnotetext{
${ }^{1009}$ Holland, C. 1970, June 8. 'NCC’s ‘Trial and Error' Leaves Meech Lakers Aghast.” Ottawa Journal.

${ }^{1010}$ Buck, K. 1970, June 13. "Meech policy queried." Ottawa Citizen.
} 
D.L. Tweksbury, a resident of West Hull, echoed this verdict. In an op-ed to the Ottawa Journal, he demanded that Fullerton and the NCC Commissioners responsible for approving Meech Lake plans be fired. Tweksbury argued that the NCC's "trial and error" approach occurred at the expense of Meech Lake residents, displacing families and ruining perfectly good cottages. Having condemned Fullerton and government officials, he concluded with a quote from the debates of the Senate:

Maybe its [sic] time we all listened to Senator Rheal Belisle who states in Hansard of March 3: "The record of expropriation should be studied meticulously for I have a lurking suspicion that what is being done in the so-called public interest is not benefitting the public as much as it is a number of self-seeking public figures. There is no doubt in my mind that more can be achieved by private enterprise, without the coercive force of expropriation, than can be achieved by government and all its agencies with the hoary monster of expropriation in its arsenal. The argument that what governments do with your property after they have expropriated it is invariably in the public interest is absolute tripe."1011

Incidentally, the NCC Chairman was called on to resign only a month before due to the growing controversy around his determination to build the Portage Bridge between Ottawa and Hull. ${ }^{1012}$ Despite the flurry of cottager protests and threat of legal action from the MLA lawyer, the “activist" NCC Chairman managed to weather yet another storm. Demolition crews continued work into the month of June, while legal surveys were conducted of NCC-owned lands. ${ }^{1013}$

Meanwhile, the Municipality of West Hull, citing the "influx of the public at Meech Lake in July," requested (and the NCC agreed to) funds for an additional police constable. ${ }^{1014}$ According to Mayor Jean Chapman, "[a]lready the Municipal police have experienced this [need for more policing] in many extra calls concerning vandalism, the speed rate of demolition trucks,

\footnotetext{
1011 Emphasis added. Tweksbury, D.L. 1970, June 13. "Fire Them." Ottawa Journal.

1012 Fullerton, D.H. 1978. Ibid., pg. 127.

${ }^{1013}$ Chief of Surveys. 1970, June 26. Letter from Chief of Surveys to M.M Outhet, re: Meech Lake Development Program Account 235-14-00. LAC 2014-0607 Vol.65.810-4(3).

1014 Chapman, J.M. 1970, June 22. Letter from Jean M. Chapman to D.H. Fullerton. LAC 2014-0607 Vol.65.810$4(2)$.
} 
the noise of demolition trucks, the noise of demolition crews working at night and on Sundays."

In addition to assisting with policing costs, Chairman Fullerton also agreed to assume, as per

NCC-policy, $50 \%$ of the costs of paving Notch Road, a major road which cuts across Gatineau

Park. ${ }^{1015}$ With the NCC have largely agreeing to the Municipality's terms, Mayor Chapman

thanked Fullerton for his "cooperation and assistance."1016

Given that NCC plans were going ahead regardless of their vocal protests, the Meech

Lake Association submitted a questionnaire to Fullerton, wanting him to put on record the immediate and long-term plans for Meech Lake. ${ }^{1017}$ Nowhere in Fullerton's reply letter does he mention the possibility of future expropriations along Meech Lake. Indeed, in his response letter to the MLA, Fullerton avoids any mention of his actual plans. His letter is quoted in full:

Thank you for your long questionnaire of 22 June 1970, in which you sought very detailed information from the National Capital Commission about our proposed developments at Meech Lake.

With regard to our plans for improving the Meech Lake area for use by the public this year, this has been virtually completed and the evidence is before you and your Association. We have received excellent co-operation from the Municipality of West Hull in the matters of road maintenance, traffic control and police protection and these will be under constant review during the remainder of the summer while improvements are in use.

With regard to our long-term plans for Gatineau Park and for Meech Lake in particular, we are just now receiving a revised land use plan from our consultants.

\footnotetext{
${ }^{1015}$ Fullerton, D.H. 1970, June 26. Letter from D.H. Fullerton to J.M. Chapman. LAC 2014-0607 Vol.65.810-4(3). ${ }^{1016}$ Chapman, J.M. 1970, July 15. Letter from Jean M. Chapman to J.A. MacNiven. LAC 2014-0607 Vol.65.8104(3).

1017 The questionnaire was characterized by Fullerton as lengthy, when it consisted of two questions, albeit with 7 sub-questions for the first question:

1. What are the specific plans of the NCC for opening Meech Lake to the public this year?

a. the size and location of any picnic grounds and beaches and the hours open to the public;

b. the arrangements for police protection;

c. the arrangements for fire protection;

d. the arrangements for traffic control;

e. the arrangements for road maintenance;

f. the arrangements for limiting the number of people using public facilities; and

g. the arrangements for parking.

2. What are the projected for the future development of Meech Lake over the next ten years?

Hogarth, D.H. 1970, June 22. Letter from D.D. Hogarth to D.H. Fullerton. LAC 2014-0607 Vol.65.810-4(3).
} 
I would have no objection to a presentation by the staff of the Commission to your Association after the plan has been reviewed by the Commission and the Government of Canada. You will, of course, appreciate how difficult it is for us to release plans to the general public before they are adequately considered by the Government and how impossible it is to provide a timetable for the implementation of the plan. I can say, however, that it appears from the recommendations of the consultants, and from the views of our own officers, that the major developments around Meech Lake will be on the north side.

As I indicated to you in my letter of 23 March 1979, we have attempted to make the transition from private to public as painless as possible for the cottage owners. I hope you will agree that we have managed to achieve this goal. ${ }^{1018}$

In July 1970, Fullerton's goal of opening Meech Lake had been accomplished, as the first public beach was opened. In addition to the beach accommodating 500 people, the NCC made other improvements, adding picnic tables, toilet facilities, and a parking lot for 100 cars (see Figures $6.3,6.4,6.5)$. As reported by the Ottawa Citizen, "[t]he beach ... will take some of the pressure off the popular Lac Philippe." ${ }^{1019}$ Contrary to the expectations of the Meech Lake Association, initial visitor rates were disappointingly low. As described by the Ottawa Journal, "[w]ith little fanfare, the National Capital Commission has opened a sandy beach at the south end of Meech Lake."1020 The article went on to add that "[c]omplaints from lake cottagers who opposed the NCC action, have gradually declined during the past month while NCC workmen have cleared the beach site."1021 Indeed, the Ottawa Citizen reported that "sporadic weather" meant that there were "never more than 30 people on the new Meech Lake public beach at any one time when it opened on the weekend." 1022

While Chairman Fullerton aroused the condemnation of Meech Lake residents with the new public beach, there was little in the way of other incidents involving park residents or even

\footnotetext{
1018 Fullerton, D.H. 1970, July 14. Letter from D.H. Fullerton to D.D. Hogarth. LAC 2014-0607 Vol.65.810-4(3).

1019 No author. 1970, July 20. Ibid.

${ }^{1020}$ Tost, J. 1970, July 16. "New Meech Lake Beach Now Ready for Use-NCC.” Ottawa Journal.

1021 Ibid.

${ }^{1022}$ No author. 1970, July 20. Ibid.
} 
issues with privately-owned lands in Gatineau Park during Fullerton's term of office. Without doubt, Fullerton challenged the park's status quo and disturbed the privacy of Meech Lake residents by razing cottages and establishing beaches. Still, Fullerton was clearly not intent on completely toppling the park's status quo as a mixed-use/ownership area. In a letter to an interested citizen, he wrote of the NCC approach to land acquisitions at Meech Lake, the longterm outcome of which would be the renaturalization of the shoreline and concentration of facilities on the other side of the lake:

As for Meech Lake, I should explain that Gatineau Park was formed by first establishing the boundary line and then acquiring the land within the boundary. This process has been going on for some years but there is still some freehold land remaining. Included in this freehold land are a number of cottage lots along the shores of Meech Lake. These the National Capital Commission is acquiring as they come on the market. Some two dozen or so have been acquired over the past few years and the NCC now operates three small public beaches on the lake. The road serving Meech Lake is constructed to a very low standard and was intended primarily to serve the cottage owners. It remains the responsibility of the municipality. The public beaches are marked with signs but the changes are that because of the standard of the road you were concentrating your full attention on driving and hence missed the signs. For the future, when all the freehold land along Meech Lake has been purchased by the NCC, in all probability the present road will be abandoned as the best areas for public development are on the opposite side of the lake. ${ }^{1023}$

The NCC Chairman made his views about park residents perfectly clear when, before a parliamentary committee, he referred to them as a "privileged and subsidized group." Not surprisingly, then, there continued to be "unnerving" rumors that the NCC was going to expropriate Meech Lake residents. ${ }^{1024}$ But, as Fullerton proudly recounted, "no land was expropriated by [the] NCC while I was Chairman." ${ }^{1025}$ Rather, the NCC continued its policy of negotiated purchase, albeit more aggressively, as it acquired another 24 Meech Lake cottages.

\footnotetext{
${ }^{1023}$ Fullerton, D.H. 1972, July 10. Letter from D.H. Fullerton to A. Stone. LAC 2014-0607 Vol.65.810-4(4).

${ }^{1024}$ No author. 1972, Oct. 16. "Does he mean it?" Ottawa Citizen.

${ }^{1025}$ Fullerton, D.H. 1978. Ibid., pg.130.
} 


\section{Fullerton's subsequent impact on Gatineau Park and the Outaouais}

As indicated in the epigraph, Fullerton was not averse to controversy. In addition to the resistance that his decision to open Meech Lake provoked among NCC-tenants and cottagers, Fullerton was immersed in two other controversies related to Gatineau Park. In the summer of 1970, a newly-established conservation group, the Ottawa-Hull Chapter of the National and Provincial Parks Association of Canada (NPPAC-OH), publicly condemned the ongoing planning process for Gatineau Park. This planning process was begun in 1966-1967, three years before Fullerton's arrival at the NCC. In the Development Concept, NCC planners had argued that the park's conservation mandate was no longer relevant; they believed that the park better fulfilled a recreation mandate, with conservation de-emphasized. The NCC retained consultants to prepare a comprehensive master plan based on the Development Concept. As this process was underway, the Development Concept was leaked to conservationists, who then demanded public hearings ahead of the approval of any master plan. In September 1970, with the consultants' master plan nearing completion, Fullerton met with NPPAC-OH officials to assure them that public hearings would be held. Incidentally, the NCC never approved the master plan produced by the consultants.

Another outcome of Fullerton's meeting with the NPPAC-OH was the imposition of a ban on snowmobiling on all NCC property (including Gatineau Park and Ottawa’s Greenbelt), commencing in the winter of 1970. This decision, known as the "Fullerton Ban," prompted the third Gatineau Park controversy of that year, as Quebec snowmobile clubs protested the ban. ${ }^{1026}$ Fullerton not only agreed to the snowmobile ban as a means of appeasing the NPPAC-OH, ${ }^{1027}$

\footnotetext{
${ }^{1026}$ No author. 1970, Oct. 1. "Motoneiges: Violentes protestations des clubs." Le Droit; see also No author. 1970 , Oct. 6. "Squirrels or us? Snowmobilers question Fullerton ban." Ottawa Citizen.

${ }^{1027}$ See Hart, J.S. 1970, Oct. 10. "Snowmobiles." Ottawa Journal.
} 
but also because he genuinely opposed snowmobiles, viewing them as a source of noise pollution and physical danger in a park that was intended to provide visitors with a peaceful and quiet setting. Fullerton was emphatic about banning snowmobiles: "[ $\mathrm{t}]$ hey're the greatest menace to the park yet."1028

Throughout the months of October and November 1970, there was almost daily media coverage of the snowmobilers' protest campaign, while letters in support of the ban came in at a 20:1 ratio. ${ }^{1029}$ Despite public support of the ban, ${ }^{1030}$ the snowmobilers maintained that they had a right to the park, and enlisted the support of municipal and provincial politicians. Hull Alderman Jean-Maire Seguin contested what he saw as an Anglophone exercise of territoriality:

I am afraid Mr. Fullerton, whom I admire, has bowed to pressure put on him by some bird watchers' association in Ottawa and I resent pressure coming from across the river. I wonder what Ottawa residents would say if some Hull organization decided the NCC wasn't doing the right thing with Island Park Drive or some other NCC property on the Ottawa side of the river. ${ }^{1031}$

As pressure mounted, Fullerton met with the snowmobile associations to try and find a compromise, but they could not agree on whether a snowmobile corridor should run north-south (longer route favored by the snowmobile associations) or east-west (shorter route favored by the NCC). The strongest ally recruited by the snowmobilers was Hull MLA Oswald Parent, who, as pointed out in the previous chapter, previously orchestrated the federal-provincial land exchange. Like Seguin, Parent understood the controversy as symptomatic of the violation of Quebec's territorial integrity:

It's not only a matter of snowmobiles. It goes further than that. That NCC has become a vise in which we're caught. These people are doing what they want

\footnotetext{
${ }^{1028}$ Cited in No author. 1970, Oct. 5. "Snowmobilers to battle NCC." Ottawa Citizen.

${ }^{1029}$ No author. 1970, Oct. 14. "Snowed Under." Ottawa Citizen.

${ }^{1030}$ Prime Minister Trudeau also supported the ban. He wrote Fullerton: "I congratulate you on your decision to ban the use of snowmobiles on NCC land. They are a threat to plant and animal life and a nuisance to all who value the tranquility of the woods." P.E. Trudeau cited in Fullerton, D.H. 1978. Ibid., pg.131.

${ }^{1031}$ Cited in Lemieux, C. 1970, Oct. 7. "Snowmobile Ban Protested by Hull." Ottawa Journal.
} 
with our land without consulting us. I admit that relations between the NCC and our region have improved greatly with Mr. Fullerton, but I'm wondering if this is not just an underhand [sic] way to make us swallow the idea of a federal district. Is that why there is so much federal spending for new construction in our city? ${ }^{1032}$

With the federal Minister responsible for the NCC, Robert Andras, suggesting the ban was "absolutely unacceptable," 1033 the NCC rescinded the snowmobile ban, before it could even be enforced. Parent pointed out that, technically, the NCC could not enforce the ban because snowmobile trails crossed provincial Crown lands in the La Pêche Lake sector. In the end, the public campaign launched by Quebec snowmobilers was incredibly successful, as the NCC designated the entire 30,000-acre La Pêche area for snowmobile use. ${ }^{1034}$ Far from restricting snowmobiles to a single corridor across the park, snowmobilers were surprised by the extent of their newfound "territory."

Besides these park controversies, Fullerton proved integral to plans of the P.E. Trudeau government to develop the Outaouais region (the Quebec-side of the National Capital Region). Having worked during the 1960s as an economist and financial advisor, Fullerton had a wide network of contacts within the provincial government. Under Fullerton, the NCC concluded several important cost-sharing agreements with the newly-elected provincial government of Robert Bourassa, a Liberal, for the construction of federal office complexes, an interprovincial bridge, a \$45-million sewer program, and a \$135-million road program - incidentally, the NPPAC-OH opposed the construction of Autoroute A5 which was routed along the eastern boundary of Gatineau Park and through some of the park's territory. ${ }^{1035}$ This "super-highway" -

\footnotetext{
1032 Cited in No author. 1970, Nov. 18. "Hull, Snowmobilers Allied in NCC Feud.” Ottawa Journal.

1033 Cited in Cleroux, R. 1970, Nov. 20. "Ban the ban." Ottawa Citizen.

${ }^{1034}$ Nichols, M. 1970, Nov. 27. "NCC bows to Quebec': Snowmobilers Get Use of Park Area.” Ottawa Journal; see Connolley, G. 1970, Nov. 27. "West end of Gatineau Park opened to snowmobiles by NCC." Ottawa Citizen. ${ }^{1035}$ Fullerton, D.H. 1978. Ibid., pg.136; see also Privy Council Office. 1971, Nov. 4. Record of Cabinet Decision, re: National Capital Commission Program and Fiscal Requirements to 1982. RG34 1190.10.2 Vol.8.
} 
as it was then known - further solidified the dominance of automobility; truly, this near-urban park justified road building and car dependence as much as the more distant national parks.

\section{Figure 6.5: Detail of map showing provincial Crown lands in Gatineau Park}

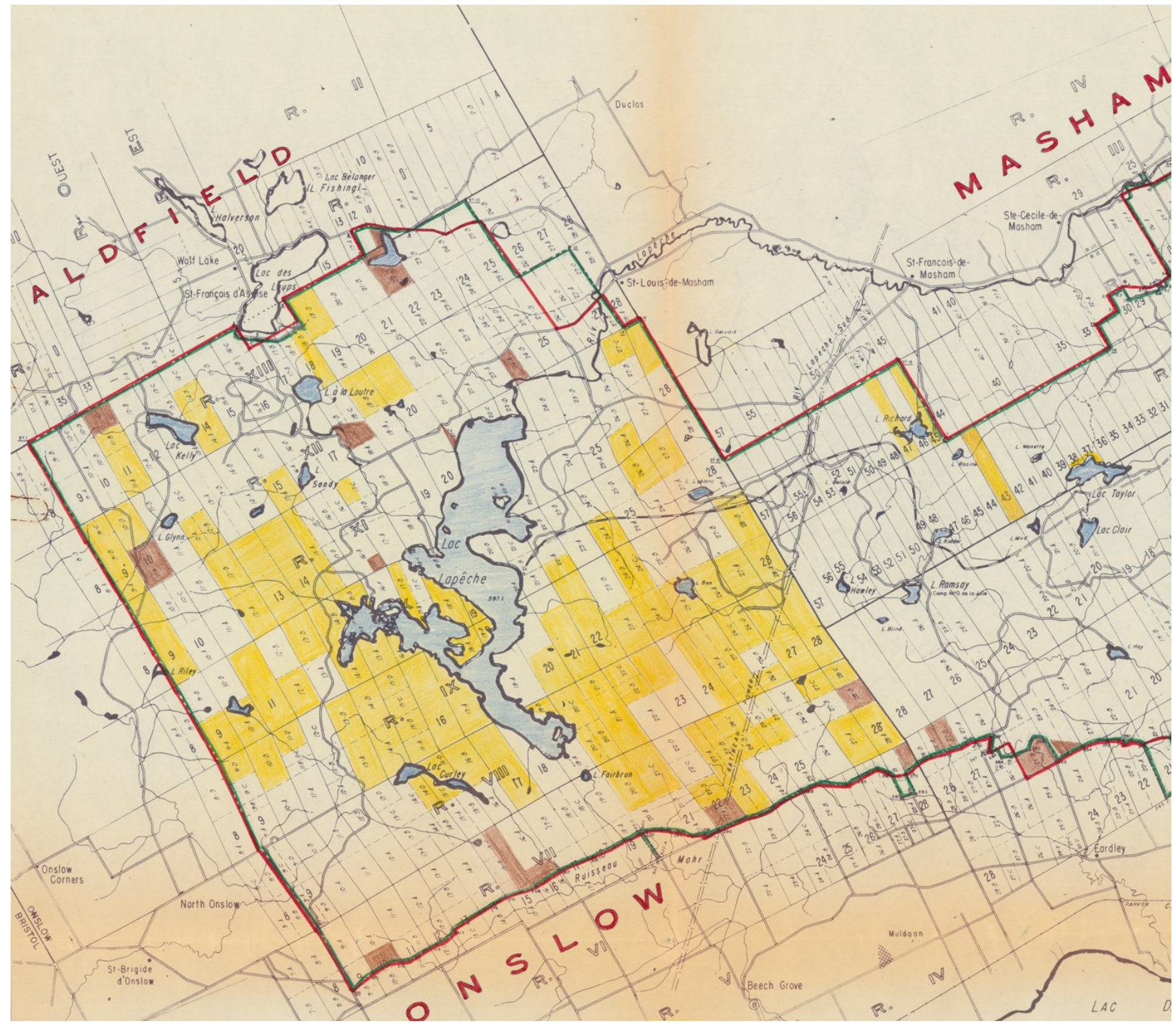

Note: Provincial Crown lands colored yellow/brown; privately owned lands colored red; uncolored parcels within red boundary are NCC-owned

Fullerton's most lasting impact on the territorialization of Gatineau Park was the conclusion of the land exchange which, as indicated in the last chapter, was initiated in the early 1960s. To be specific, the province transferred management and control of approximately 12,528 
acres $(5,070 \mathrm{ha})$ of Crown lands (see Figure 6.5). In exchange for provincial crown lands, the NCC transferred 115 acres (46ha) of parkland along Hull's Boulevard de la Cité des jeunes to the Collège d'enseignment general et professionnel (CEGEP) and other rights of way, for a total of 250 acres (101ha). ${ }^{1036}$ According to NCC briefing notes, the terms of the agreement were for control and management: "This exchange of management is similar to the other exchanges carried out by Quebec and the Federal Government for national parks or park purposes. From a practical standpoint, there is little difference between vesting title and management and control." 1037 In addition to the exchange of lands, the Quebec government also agreed, within the Gatineau Park boundaries set out by Order-in-Council, to establish a game reserve, to observe Quebec fishing laws, to no longer issue mining exploration permits, and, as if for a national park, the lakebeds were transferred to the NCC. These provincial laws applied to both privately- and publicly-owned lands.

The terms of the land exchange agreement were questioned in Quebec's legislature by the Parti Québecois, which put Fullerton's provincial counterpart, Oswald Parent, on the defensive. Quebec's Secretary of State and Hull MLA countered the media criticism: "Si on veut s'en tenir à l'écart de 12,500 acres contre 255 acres, je crois qu'en apparence ça semble un cheval, un lapin, comme l'a dit le journal Montréal-Matin. Mais si on considère la localisation des endroits, je pense qu'il y a des équivalences."1038 Despite this, a Ste.-Cecile de Masham citizen's group later condemned the provincial government for failing to protect Quebec's territorial integrity as well as the interests of Québeckers:

\footnotetext{
${ }^{1036}$ National Capital Commission. 1972, Nov. 21. Précis of proposed exchange of administration of certain lands in Gatineau Park and in Hull, Quebec, NCC - Québec Government. RG34 1190.10.2.

${ }^{1037}$ No author. No date. Brief notes, re: the Proposed Mutual Exchange of Control and Management of Lands Quebec and NCC largely affecting Gatineau Park. RG34 1190.10.2.

${ }^{1038}$ Parent, O. 1973, Mar. 15. "Capital nationale." Quebec. Legislative Assembly. Debates of the Legislative Assembly. Edited Hansard. 29 ${ }^{\text {th }}$ Legislature, $4^{\text {th }}$ Session.
} 
De quel droit nos hommes politiques peuvent-ils "échanger" comme ça des acres de terrain en laissant glisser aux mains de la Commission de la Capitale Nationale cinquante-cinq (55) fois plus de sol québecois qu'il ne reçoit. Avec vous, nous croyons que la terre appartient d'abord à ceux qui y ont travaillé, qui y ont vécu, qui ont sué pour se faire une place au soleil...non pas d'abord aux gros messieurs d'Ottawa et de la région qui aiment bien faire une petite promenade d'automobile dans un grand parc un beau dimanche près-midi par mois avec leur caniche. ${ }^{1039}$

The Francophone media was not entirely negative in its appraisal of the land exchange; one journalist astutely observed differences in the utility of the lands exchanged and praised Quebec's recent "bargaining power" with the federal government: "si l'accessibilité est presque nulle et l'utilisation rendue difficile à cause de ce morcellement; quels bienfaits pouvez-vous retirer de la possession d'un tel territoire?"1040 Given the different values and uses of the lands in question, Chairman Fullerton had no difficulty justifying the land exchange to his counterparts. When considered overall, the partnership between Fullerton and Parent was highly effective in transforming the Outaouais region in general, and Gatineau Park in particular. With his term in office set to expire in August 1973 (but it could, and probably would, have been renewed by Prime Minister Trudeau if asked), Fullerton resigned several months before. It was rumored that there was a "clash of styles" between the outspoken, confrontational, and even abrasive NCC Chairman and the new Minister of Public Works, Ron Basford, who was characterized as "a quiet, low-key, patient manipulator of situations." 1041 But Fullerton, in his autobiography, explained that he left his role as NCC Chairman because he "was fed up with the increasingly confused and tangled web of jurisdictions operating in the capital..." Or, as the Ottawa Journal put it at the time of Fullerton's resignation, "he felt he had done about as much as he could at the NCC and was getting 'bored' with the job." 1042

\footnotetext{
${ }^{1039}$ Martineau, M.G. 1973, Mar. 22. Letter from M.G. Martineau to multiple recipients. RG34 1190.10.2.

${ }^{1040}$ No author. 1973, Mar. 13. "Québec a pris une sage décision.” CJRC 1150 Ottawa-Hull. RG34 1190.10.2.

1041 Jackson, R. 1973, Jan. 30. "Fullerton quitting; clash with Basford." Ottawa Journal.

1042 Ibid.
} 
As mentioned in Chapter 1, Prime Minister Trudeau commissioned Fullerton to complete a study on the government of the National Capital Region. The main recommendation from Fullerton's report was the reconstitution of the NCC as a quasi-federal district through a new "supra-regional council" composed half of elected officials, one-quarter federal appointees, and one-quarter provincial appointees. ${ }^{1043}$ The only recommendation implemented from Fullerton's report was the creation of a joint-parliamentary committee to investigate the institutional reform of the NCC. The joint-parliamentary committee, however, shared the same fate as its progenitor; that is, no permanent or significant changes were made to the NCC, nor to the administration of Gatineau Park.

\section{Conclusion}

Up to this point, Fullerton's most noted achievement as NCC Chairman was opening the Rideau Canal to skaters. And, whenever reference is made to his achievements in Gatineau Park, official histories have rightly credited him with completing the important land exchange agreement, which saw the NCC consolidate territorial control at La Pêche Lake. Notably, the NCC misrepresents its ownership of the La Pêche sector of the park. For example, in the latest Gatineau Park Master Plan (2005), the NCC claims that the Quebec government owns these lands. It remains unclear why the NCC denies the validity of the 1973 federal-provincial land exchange.

Official histories have entirely overlooked Fullerton's most significant decision vis-à-vis Gatineau Park, opening Meech Lake to public use. This chapter documented the extensive resistance which Fullerton and the NCC encountered, not only from former NCC "tenants" but

\footnotetext{
${ }^{1043}$ Fullerton, D.H. 1978. Ibid., pg. 156.
} 
also from the Meech Lake Association. With the Kingsmere-Meech Lake privatopia threatened, park residents wrote the Prime Minister, petitioned the federal government, protested in the local media, and threatened legal action. But, even collectively, these actions were to no avail, and the NCC persisted, as Chairman Fullerton was supported, tacitly, by the Trudeau government. So, in the spring of 1970, the NCC razed 27 cottages and established the first public facilities at Meech Lake. After 32 years, the most important lake in Gatineau Park was opened to public use.

But Fullerton's job with Gatineau Park was only half finished. As this chapter has shown, Fullerton challenged the park's status quo, but he did not overturn it. Planning consultants and park officials urged him to expropriate private lands at Kingsmere and Meech Lake so as to consolidate ownership and, more importantly, control. The so-called activist Chairman was not prepared to go this far such that, by the end of Fullerton's tenure, there remained 4,000 acres of privately-owned land within the park. ${ }^{1044}$

When considered overall, the policy of negotiated purchase on a willing-seller basis continued under Fullerton, but, more than any other Chairman, he pushed the NCC towards the public ownership and use of Gatineau Park. In other words, the "breaches" in the park project, like those documented in the last chapter with the expropriation of the Bourque Brothers, remained - and still remain. Fullerton was quite fortunate in not having to contend with subdivision proposals which later plagued NCC administration of the park. These and other issue flare-ups with privately-owned lands are documented in the Conclusion, which briefly examines the ongoing implementation of the flawed land acquisition program, as well as recent efforts towards giving the park a legal status, which would, I argue, mandate the NCC with a more effective land acquisition policy.

${ }^{1044}$ National Capital Commission. 1973-1974. Annual Report. Ottawa: Queen's Printer, pg.21. 


\section{Conclusion}

The NCC believes that the need for a strong national planning and development agency, vested with responsibility to plan for the national interest in the capital region and to carry out development projects in accordance with such plans, is even greater now, greater today, than it was when the commission was virtually the only planning agent in the region. ${ }^{1045}$

Edgar Gallant, NCC Chairman (1973-1976)

Before a joint-parliamentary committee investigating the National Capital Commission on October 1975

Several developers had managed to register subdivisions and sell lots within the [Gatineau] Park. For instance, Quain at Kingsmere, Jessie Dunn at Kingsmere, Grierson at Kingsmere, Franck Lynch at Shawano and Tom Main at Brown's Lake. The only expropriation of potential development lands that I am aware of are that of Paul Bourque who started a large subdivision on the south end of Lac Lapêche, that of Hobbs who subdivided on Curly Lake near the south end of Lac Lapêche and that of Sparks who started developing land opposite the Skyline ski area on the Meech Lake Road. It seemed that practically all non-waterfront subdivisions in the Park were left alone by the NCC and not expropriated; and where expropriations occurred, owners were paid fair prices plus expenses. ${ }^{1046}$

Frank E. Macintyre, Real Estate Broker and Appraiser Affidavit on October 1986

Ultimately it is not the NCC that has failed the park. It is a long line of governments and Parliaments that have not done their duty. Parliament has not provided the statutory protection to the park that it deserves or the parliamentary oversight that is required. ${ }^{1047}$

Hon. Senator Mira Spivak

Before the Standing Senate Committee on Energy, the Environment and Natural Resources on 29 March 2007

1045 Gallant, E. 1975, Oct. 10. "Testimony." Canada. Parliament. Joint Committee of the Senate and the House of Commons on the National Capital Commission. Minutes of Proceedings and Evidence, 3, pg. 12.

1046 Macintyre, F.E. 1986, Oct. 3. Affadavit. NCC ATI A-2015-00037CS, pg.453.

1047 Spivak, M. 2007, Mar. 29. "Bill S-210, An Act to amend the National Capital Act (establishment and protection of Gatineau Park." Canada. Senate of Canada. Proceedings of the Standing Senate Committee on Energy, the Environment, and Natural Resources, 15, 39th Parliament, 1st Session, pg.15:15. 


\section{A bill park residents could not swallow}

Classification by area, geographer Sack argues, is as a key advantage of territoriality. ${ }^{1048}$ Classifying an area as a territory is more efficient for "the controller" than enumerating the various things and relations it seeks to control. Sack adds that, for territoriality to be effective, boundaries must be clearly communicated, and the rules governing conduct must be rigidly enforced. Gatineau Park is a contested and fragmented territory. Unlike Canada's national parks, Gatineau Park has a mixture of privately- and publicly-owned lands, particularly around Kingsmere and Meech Lakes, where park boundaries are often unclear. The park's governing body, the National Capital Commission (NCC), has - in principle but not in practice - the authority to zone and impose a moratorium on development on all remaining privately-owned lands. Gatineau Park is almost identical to Ottawa's Greenbelt, a project carried out by the federal government in the national interest. This study documented resort and subdivision developments that were successfully prevented by the NCC in the mid-1960s. Since that time, the NCC has since failed to enforce its so-called conservation mandate, as new subdivisions and residences have been built on private lands, especially in the Kingsmere-Meech Lake privatopia.

Gatineau Park is also an outlier of Canada's national park systems as it has no legal status. The absence of legal status was first recognized as a problem by a conservation group, which, in 1971-1972, collected 12,000 signatures from Canadians in support of Gatineau Park legislation. Now known as the Ottawa-Valley chapter of the Canadian and Parks Wilderness Society (CPAWS-OV), the group also made the case for legislation before a joint-parliamentary committee, established in 1975-1976 to review the NCC. The joint-parliamentary committee never released a final report, leaving the issue of Gatineau Park legislation in abeyance.

${ }^{1048}$ Sack, R. 1986. Ibid. pg.32. 
But the need for legislation was made apparent, once again, in 1988, when a real-estate developer, Carl McInnis, subdivided 110-acres near Pink Lake (ironically, the NCC was in the process of restoring the ecologically-sensitive lake). The Ottawa Citizen, in its "Why" column, poignantly asked: “[Why] [c]ouldn’t the National Capital Commission, which has a \$44-million capital budget and a 'masterplan' for wilderness preservation, afford to outbid a housing development of Gatineau Park land?” The NCC initially offered McInnis $\$ 650,000$ for his Pink Lake property, but the developer insisted on taking the "development potential" into account, and estimated the 73-lot subdivision to be worth around \$5-million. ${ }^{1049}$

Following protests from CPAWS-OV, the NCC expropriated McInnis as well as the twenty-one owners who had purchased individual lots from him. This "tentative victory"1050 for conservationists turned out to be a pyrrhic one for the NCC. As with the previous expropriations, McInnis and the individual property-owners contested the compensation offered by the NCC. Though the Federal Court denied McInnis' inclusion of "development potential" into the compensation amount, Justice Nadon ruled that the NCC offer was insufficient. Ultimately, McInnis was awarded \$2.4-million and the NCC, having failed to offer the real-estate developer within $10 \%$ of the property value, paid the developer's rather exorbitant costs for lawyers and expert witnesses. ${ }^{1051}$ As this compensation did not include the individual property-owners, the Ottawa Citizen estimated that the "[t] otal cost of settling the whole mess will run between $\$ 6$ million and $\$ 7$ million, including interest and penalties." ${ }^{1052}$ In conjunction with budget cuts to the NCC, the Gatineau Park expropriations prevented the NCC from purchasing any additional

\footnotetext{
1049 Ottawa-Valley chapter of the Canadian Parks and Wilderness Society. 1988, Apr. 19. Minutes of Meeting. Ottawa: CPAWS-OV; see also Yonson, D. 1989, Aug. 24. "Bid soars for Gatineau Park site." Ottawa Citizen. ${ }^{1050}$ Ibbitson, J. 1988, Dec. 30. "NCC starts move to block Gatineau Park subdivision.” Ottawa Citizen.

${ }^{1051}$ Nadon, M. 1997, May. Decision in C. \& B. Vacation Properties Inc. and Corporation Drovelle Ltée and Her Majesty the Queen. Federal Court. File number T-1160-90, pg.95.

1052 Denley, R. 1994, May 31. "NCC 'strategy' of delay hurts only the taxpayer." Ottawa Citizen.
} 
privately-owned land in the park from the 1990s into the 2000s. In 2008, under Chairperson Marie Lemay, the NCC finally resumed the Gatineau Park land acquisition program, largely in response to yet another subdivision proposal at Carman Road. ${ }^{1053}$ Following pressure from the Gatineau Park Protection Committee and CPAWS-OV, the NCC has since been acquiring privately-owned lands as they come for sale on the open market.

Immediately following the "McInnis Scare," CPAWS-OV drafted the Gatineau Park Act. The bill proposed a five-member Gatineau Park Commission (GPC). The GPC would operate independently of the NCC, and would have park preservation as its mandate. It would also be responsible for "developing a policy for land acquisition and would have sufficient funds to purchase available lands at fair market value." ${ }^{1054}$ But CPAWS-OV did not lean towards a blanket acquisition of remaining privately-owned lands in the park. Rather:

In our view, most residences and the several small communities within the park boundaries are an integral part of the park's cultural heritage, and we see no rationale for their removal provided their activities are in keeping with the general mandate of the park. On the contrary, a legal regime sensitive to both the landowner's and user's concerns about the preservation of the park is an important advantage of separate legislation. ${ }^{1055}$

Thus, the proposed legislation responded to the "[n]eed to get property owners on side." 1056 Two of the five members of the GPC would be park residents, presumably appointed by the Meech Lake Association (MLA) and/or Kingsmere Property Owners' Association (KPOA). The GPC's remaining three members would be appointed by the federal government. Surprisingly, the GPC would not have representatives from CPAWS-OV. Apart from a few meetings between CPAWSOV and NCC officials, nothing came of their draft legislation.

\footnotetext{
${ }^{1053}$ Rogers, D. 2008, Jan. 25. "NCC unaware of Gatineau Park housing plan; Owners have right to build, Chelsea mayor says." Ottawa Citizen.

${ }^{1054}$ Ottawa-Valley chapter of the Canadian Parks and Wilderness Society. 1989. Legislative Protection for Gatineau Park. Ottawa: CPAWS-OV,pg.1.

1055 Ibid., pg.9.

1056 Ottawa-Valley chapter of the Canadian Parks and Wilderness Society. 1988, May. 17. Minutes of Meeting. Ottawa: CPAWS-OV.
} 
During the mid-1990s, the NCC undertook, behind closed doors, the Gatineau Park Boundary Rationalization Exercise (BRE). NCC officials were aware that, since the park's boundaries were determined by an 1960 Order-in-Council, another Order-in-Council was needed to override the park's original boundaries. Moreover, in the late 1980s, all lands within Gatineau Park had been designated as National Interest Land Mass (NILM), which mandated the NCC to protect them in perpetuity on behalf of all Canadians. Not only did the boundary rationalization go ahead without a new Order-in-Council, it also severed NILM-designated lands from the park. Although the NCC claimed that the BRE resulted in a net addition to the park's territory through the annexation of Meech Creek Valley (but, again, the new boundaries are not legally valid), conservationists rightly condemned the NCC for its "just-trust-us approach."1057 As CPAWS-OV Executive Director, Jean Langlois, explained, "[t]hat [approach] might be fine if you have an NCC Chairman and board which see the park as a special place. But what happens when there is a Chairman and board that treats the park like it's another piece of the greenbelt, or just another tulip bed?"1058

CPAWS-OV continued to advocate for legal protection, but it struggled to get traction, i.e., the attention of parliamentarians. Finally, in 2004, the Liberal MP for Gatineau, Mark Assad, began preparing legislation. He told the local media: "This should have been done a long time ago. We take this park for granted, but I thought we should have legislation to protect it once and for all." 1059 Assad's bill, An act to establish the Gatineau Park, was modelled on the one prepared by CPAWS-OV: an independent, appointed commission would be set up to administer the newly-established park. Though Assad's bill was drafted, it was never tabled in the House of

\footnotetext{
1057 Cited in Fischer, D. 2004, May 10. "Park changes would go beyond entrance fees." Ottawa Citizen. ${ }^{1058}$ Cited in Ibid.

${ }^{1059}$ Cited in Caesar, M. 2004, May 12. "NCC fee proposal sparks Gatineau Park debate." The Low Down to Hull and Back News.
} 
Commons, since Mark Assad retired from politics when the 2004 federal election was called. Nevertheless, the campaign for park legislation had gained some traction: Ed Broadbent, the NDP MP for Ottawa Centre, and Mira Spivak, an independent Senator, both took on the park's cause. In 2005, Broadbent introduced a private member's bill into the House of Commons, and Senator Spivak did the same in the Senate.

\section{Spivak's bill, S-210: An Act to amend the National Capital Act (establishment and} protection of Gatineau Park) was referred to the Standing Senate Committee on Energy, the Environment and Natural Resources (SSCEENR). This legislation would have delimited the park boundaries, set out a process for enlarging the park, prohibited the sale of parkland, mandated the NCC to acquire all remaining privately-owned land, and provided the NCC with the right of first refusal on all property sales within the park boundaries. Right of first refusal was viewed as a compromise: on the one hand, it would not impose a blanket expropriation, leaving existing park residents undisturbed; on the other hand, it would accelerate NCC acquisition of privately-owned lands by requiring owners to offer their property to the NCC for purchase before putting it on the open market. This is not a restriction of private property rights, as right of first refusal is only activated when an owner decides to sell. ${ }^{1060}$ As the proponents of right of first refusal explained in their brief on Bill S-210, "since they [private property owners] get to maintain full control over their property until they decide to sell, we feel such an obligation to be reasonable and fair, given that its purpose is to prevent subdivisions and further urbanization of the park."1061

Whereas earlier legislation had deferred to park residents, Bill S-210 threatened the Kingsmere-Meech Lake privatopia. Thus, the property owner associations appeared before the

\footnotetext{
${ }^{1060}$ Perell, P.M. 1991. “Options, Rights of Repurchase and Rights of First Refusal as Interests in Land,” The Canadian Bar Review, 70(1): 1-28.

${ }^{1061}$ New Woodlands Preservation League. 2007, Mar. 14. "Bill S-210: A Compromise Designed to Protect Gatineau Park." Brief submitted to the Senate Standing Committee on Energy, The Environment, and Natural Resources, pg. 25 .
} 
SSCEENR in opposition to the Bill. MLA President Chris Frank argued that " $[\mathrm{t}]$ here is no reasonable justification for curtailment of property rights as contemplated by this bill. We, the private homeowners, pose no threat to the federal government's property holdings ... We seek no special status or treatment. We seek only the quiet use of our properties like millions of other Canadians across this vast country." 1062 When pressed about the fact that the bill does not contain the word "expropriation," President Frank responded: "The right of first refusal is a form of expropriation and that is why I used the term 'partial expropriation'."1063 KPOA President Hélène Couture-MacTavish supported giving Gatineau Park a legal existence and formal boundaries, but opposed right of first refusal as an "unnecessary restraint." ${ }^{1064}$ Right of first refusal was unnecessary, Couture-MacTavish explained, because: "[t]he Crown currently has the right to expropriate private property and has exercised that right in the park since its inception." ${ }^{1065}$ But the KPOA President did not explain why the NCC had expropriated private property in the first place, namely, to prevent undesirable subdivisions and increased property values. Such an admission would weaken the argument made by the property owner associations, and then reinforced by the Municipality of Chelsea. As Mayor Jean Perras told the Senate committee: "We prefer the status quo. The people who are there now have been there for generations. ... These people are genuine stewards of the park, just as much as the NCC. We want the status quo and we find the bill premature." 1066

\footnotetext{
1062 Emphasis added. Frank, C. 2007, June 7. "Bill S-210, An Act to amend the National Capital Act (establishment and protection of Gatineau Park." Canada. Senate of Canada. Proceedings of the Standing Senate Committee on Energy, the Environment, and Natural Resources, 20, 39 ${ }^{\text {th }}$ Parliament, $1^{\text {st }}$ Session, pg.20:19.

1063 Ibid., pg.20:20.

${ }^{1064}$ Couture-McTavish, H. 2007, June 7. "Bill S-210, An Act to amend the National Capital Act (establishment and protection of Gatineau Park." Canada. Senate of Canada. Proceedings of the Standing Senate Committee on Energy, the Environment, and Natural Resources, 20, $39^{\text {th }}$ Parliament, $1^{\text {st }}$ Session, pg. 20:17.

1065 Ibid., pg.20:17.

${ }^{1066}$ Perras, J. 2007, June 7. "Bill S-210, An Act to amend the National Capital Act (establishment and protection of Gatineau Park." Canada. Senate of Canada. Proceedings of the Standing Senate Committee on Energy, the Environment, and Natural Resources, 20, 39th Parliament, 1st Session, pg.20:21.
} 
And the park's status quo as a mixed-use/ownership area was maintained: Bill S-210 died on 15 September 2007, when Parliament was prorogued by Prime Minister Stephen Harper. Senator Spivak reintroduced An Act to amend the National Capita Act (establishment and protection of Gatineau Park) in subsequent parliamentary sessions. But Bills S-227 and S-204 also died on the order paper, and Spivak eventually retired in July 2009. In Canada, where there are many controversies around Senators at the moment, the Manitoba Senator was rightly celebrated as a "park savior" by the Ottawa Citizen. In the Citizen article, Spivak recounted the initial motivation behind her campaign for Gatineau Park legislation: "This is a Canadian treasure - it isn't just a local treasure. When I looked at the history [of the park] I realized that it was always intended to be a national park, but for political reasons prime ministers in the past were afraid to do that." ${ }^{1067}$ As this study has shown, the "political reasons" preventing the realization of a national park in Canada's capital were Quebec's territorial integrity and the Kingsmere-Meech Lake privatopia. Tellingly, the park's establishment involved overcoming only one of these political reasons, Quebec's concern with its territorial integrity. As the example of Bill S-210 has shown, the MLA and KPOA continue to reject any restriction of private property rights, whether real or perceived. They are entitled to the same property rights as every other Canadian, and right of first refusal, as one Kingsmere resident put it, “creates a disadvantaged class of property owner..."1068

\section{A flawed and unfinished land acquisition program}

A disadvantaged class of property owners indeed! In briefs submitted on Spivak's Bill S-210, the Meech Lake Association and Kingsmere Property Owners' Association reiterated the right of

\footnotetext{
${ }^{1067}$ Rogers, D. 2009, May 18. "Manitoba senator emerges as saviour of Gatineau Park; Mira Spivak fighting to give Crown jewel federal protection." Ottawa Citizen.

${ }^{1068}$ McAdam, S. 2007, Feb. 21-27. "Visitors, not homeowners, threaten park." Low Down to Hull \& Back News.
} 
park residents to continue living within the park as they have done for generations since the 1880s, well before the creation of Gatineau Park in 1938. But the KPOA and MLA briefs do not indicate how this rather peculiar situation - that of private enclaves surrounded by a public park - arose in the first place. I argue, first, that the park's status as a mixed-use/ownership area is a provisional achievement of the MLA (and, to a lesser extent, the KPOA, a bit player). My second argument is that Gatineau Park is a central component of the Kingsmere-Meech Lake privatopia, which was organized around the protection of property rights and property values.

These two arguments were supported through the empirical analysis in Chapters 2 through Chapter 4. To be specific, Chapter 2 examined how the 1870 s marked a "new era" in the Gatineau Hills as summer cottagers from Ottawa began purchasing property along the shorelines of Kingsmere, Meech, and Harrington (Mousseau) Lakes. The MLA and KPOA were established in the 1920s, and functioned as private forms of local governments. They exercised territoriality by trying to keep "undesirables" (and the general public) out of their cottage communities. The most famous Kingsmere cottager, Prime Minister Mackenzie King, was a KPOA member; Chapter 2 documented the anti-Semitism among cottagers of that period, including Canada's longest-serving Prime Minister, who expanded his Kingsmere estate to prevent Jews from purchasing adjacent lands. This exercise of malevolent territoriality did not have its desired effects, as there were Jewish cottagers (e.g., the Freiman family).

During the Great Depression, cottagers at Kingsmere and Meech Lakes grew increasingly alarmed by the clearcutting of the forested hillsides, which could have destroyed scenery and property values. Whereas previous scholarship on Gatineau Park has linked the Ottawa Ski Club with the establishment of the Federal Woodlands Preservation League (FWPL), this study demonstrated that the main catalyst to the League's formation was the Meech Lake Association, 
and, in retrospect, the claimed role of the OSC should have been questioned given that the FWPL leadership was drawn entirely from cottagers and residents, i.e., Presidents Harry Baldwin and Roderick Percy Sparks.

Thus, this study contributes to the existing scholarship by clarifying the chain of events that led up to the park's creation. As the NCC-commissioned study pointed out (but without mentioning either the MLA or KPOA), Gatineau Park was established by the "bourgeoisie" in co-operation with the federal government. At the behest of the FWPL, the Department of Interior surveyed the deforestation of the Gatineau Hills. The 1935 Lower Gatineau Woodlands Survey addressed cutting in the Kingsmere-Meech Lake area, finding that the League had greatly exaggerated the denudation issue. Surveyors recommended the "land purchase method" over the "national park method." This was the approach adopted by the Federal District Commission.

In the interim, the FWPL did not advocate for the establishment of a national park (cottagers were probably aware that this proposal would entail the expropriation of privatelyowned lands). However, the FWPL did promote the construction of the Gatineau Parkway to improve access to the area for summer cottagers and winter skiers, active participants in the perpetuation of automobility. Having lobbied the Bennett government to act on the Gatineau Hills denudation issue while serving as Leader of the Opposition, Mackenzie King was reticent to approve federal funds for the project when he resumed being the Prime Minister: he was concerned about the loss of privacy and earlier accusations of a conflict of interest in wanting to build a parkway to his summer estate. Thus, it took another three years of intense lobbying by the FWPL, which intensified under President Roderick Percy Sparks, to persuade King to approve funds for the Federal District Commission (FDC) to acquire, through negotiated purchase or, if necessary, expropriation, land adjacent to the Kingsmere-Meech Lake privatopia. 
The capital's wooded hillsides were saved by the Mackenzie King government (and the Prime Minister has often been credited with the park's creation), but it was really Sparks who was the driving force behind the park's establishment. This study has documented the vexed relationship between the park's founding father and the FDC "Gatineau Park" project. As Chairman of the Advisory Committee on Gatineau Park, Sparks viewed Gatineau Park to be so significant as to merit national park status, and repeatedly called it a National Park in his submission to the Appendix of the 1952 ACGP Report, which reveals the ruptures in the committee over the issue of private lands in the heart of the park.

Chapter 3 reinforced the argument that the territorialization of the newly-established "national" park was, in a sense, carried out for cottagers turned park residents. That is, FDC expropriations were carried out under the pretense of establishing a national park. In other words, if the government expropriated land, it was because it was establishing a "national park." Those families and farmers whose lands, mainly woodlots, were expropriated very much resented that Kingsmere and Meech Lake residents were left undisturbed in this "national park.” Although Gatineau Park was not a national park, the park preservation project had the effect of greatly increasing property values, not only through the protection of the forested hillsides, but also through subsequent park improvements, especially with the Gatineau Parkway in the 1950s. Chapters 3 and 4 also examined how the MLA and KPOA functioned as private forms of local governments. Notably, the MLA was instrumental in the enactment of a municipal bylaw to control development so as to prevent "slum dwellings" and, in the process, maintain class exclusivity (but the Municipality of West Hull was unable to enforce this comprehensive bylaw). The MLA also lobbied the provincial government to improve the entrance to the "Gatineau National Park," that is, Meech Lake Road. One underlying theme to emerge is the connection 
between park residents' privatopia and automobility: perhaps as much as Gatineau Park itself, the construction of Gatineau Parkway and, later, Highway A5, are evidence of the tremendous benefit incurred by this advantaged class of property owners, one with extremely close ties to the federal government.

Chapter 3 also described the initial activities of the Advisory Committee on Gatineau Park (ACGP), which was responsible for deciding on park boundaries, advising on parkland acquisitions, and preparing a long-term master plan. Notably, in 1948, the ACGP recommended the expropriation of remaining private lands at Phillipe and Kingsmere Lakes. Although the FDC carried out the expropriation of cottagers at Philippe Lake, it did not act on the recommendation to expropriate lands around Kingsmere Lake. This was a defining moment in the park's history, as the KPOA then asked the FDC to enter a partnership agreement, whereby the FDC would agree not to expropriate or establish park facilities near the lake, while the KPOA would agree to impose building standards. The FDC asked for legal advice, which shows just how seriously the KPOA request was taken. Around the same time, Quebec Premier Maurice Duplessis publicly challenged the right of the FDC to expropriate in the province for the purposes of "capital beautification." With the threat of a court challenge from provincial authorities, the expropriation of cottagers at Philippe Lake turned out to be the last one carried out by the FDC for the purposes of Gatineau Park.

Existing scholarship on this unique federal park has so far inadequately addressed the controversy which emerged over private land ownership in Gatineau Park. Chapter 4 examined the rifts within ACGP which were made visible in the Appendix to the Report on a Master Plan for Gatineau Park. Although the consensus of the Advisory Committee was that the FDC should consolidate control of the entire park territory through the elimination of privately-owned lands, 
there was disagreement as to how this should be done. Referring to Gatineau Park as a national park, the ACGP Chairman, Roderick Percy, Sparks, urged the FDC to immediately impose a timeline, with the expropriation of property owners who were unwilling to sell by the deadline. But other Advisory Committee members, like Senator John J. Connolly, who was also the MLA Secretary, and Herbert Marshall, President of the Ottawa Ski Club, rejected the view that the residential communities at Kingsmere and Meech Lakes were problematic in any way. ACGP member General E.L.M Burns took a middle of the road position: he agreed with Sparks that privately-owned lands should be eliminated, but differed from the Chairman in wanting the FDC to acquire properties only on a willing-seller basis, with park officials only expropriating in the event of undesirable developments. The FDC adopted the 1952 Report "in principle" and began purchasing Meech Lake properties on a willing-seller basis.

This move disturbed Meech Lake cottagers and residents. The MLA sought assurances from the FDC that it did not intend to expropriate cottages and residences at the lake. In a 1953 memorandum to the FDC, the MLA, in addition to pointing out that such an action would be prohibitively expensive and that Meech Lake was unsuitable for public use, requested the assistance of federal authorities in enforcing municipal bylaws. In response to the "uncertainty" the ACGP had created in the minds of park residents, the FDC issued its first public statement on Gatineau Park land acquisitions. It indicated that the FDC would acquire property on a willingseller basis only. Further, the press release claimed, falsely, that the FDC had not and would not expropriate, except for the purposes of building the Gatineau Parkway. Despite this assurance, Redmond Quain, a Kingsmere resident (who, as the second epigraph points out, subdivided his lands), condemned the FDC for wanting to expropriate remaining residents, threatening to bring the issue up with Premier Duplessis. Around the same time, Chairman Sparks was the victim of a 
smear campaign by FDC Chairman Kennedy and FDC Commissioner Caron. After this fall-out, the ACGP became dormant. Nevertheless, Sparks continued to pressure the federal government to adopt a "rational" land acquisition policy. He argued, before a joint-parliamentary committee, that the piecemeal approach to land acquisitions hardly constitutes a policy, but is, rather, an invitation to land speculation and real-estate development.

Despite the sweeping reform that the joint-parliamentary committee brought to the FDC, the administration of Gatineau Park was left unchanged. Ultimately, Sparks failed in his campaign for public ownership, and the Kingsmere-Meech Lake privatopia prevailed. Since the first public statement of official policy, the FDC and its successor, the NCC, have only provided vague assurances that all remaining privately-owned lands will be acquired on a willing-seller basis (and, as shown in Chapter 4, the FDC did not expropriate for parkway purposes when, in advance of the extension of the parkway to Philippe Lake, it encountered unwilling sellers near Meech Lake).

The third argument developed throughout this study is that the park's fragmented territory has proven disastrous for FDC/NCC park administration. Chapters 5 and 6 provided the empirical support for this argument. Chapter 5 examined NCC expropriations along Meech Lake Road in the early-1960s. Ironically, Sparks' children and five other property owners were expropriated to prevent rumored private development, but mostly to avoid increased property values from the opening of the Old Chelsea section of the Gatineau Parkway. By the mid-1960s, the NCC had carried out so many expropriations in Gatineau Park, much to the displeasure of the municipal and provincial governments, that it exhausted funds. As shown in Chapter 5, the NCC had to prioritize park expropriations in what amounted to a game of whack-a-mole, as property owners and real estate developers built subdivisions in the park and, as the second epigraph 
illustrates, the NCC managed to prevent some but not all of them. Significantly, the Bourque Brothers' "Domaine du Lac Lapêche" would have resulted not only in a cottage subdivision on the park's largest lake, but also a hotel and marina (both operating with liquor licenses). Following the expropriation, an armed park official guarded the expropriated land from the former owners. The Bourque Brothers wrote Prime Minister Pearson about the harsh treatment by the NCC and park officials, whilst simultaneously purchasing, in advance of NCC need, additional privately-owned lands within the park boundaries. The expropriation case went to the Exchequer Court which recognized the Bourque Brothers' "manifestly speculative venture" at La Pêche. The Exchequer Court judge awarded compensation in line with the NCC valuation. However, Justice Dumoulin had little sympathy for the NCC. He observed that the park's fragmented territory had left this "breach" open for speculators, as the NCC has no special status, but is the same as any buyer of private lands.

Even though NCC had prevented the "Domaine du Lac Lapêche," it had still to consolidate control of the park territory. In addition to remaining privately-owned lands, 12,000 acres were provincial Crown lands. In the 1960s, federal-provincial governments negotiated a land exchange for the La Pêche lands but this fell through with the election of Premier Daniel Johnson of the Union nationale party. Chapter 6 covered the tenure of the "activist" NCC Chairman Douglas H. Fullerton. Having worked with the Quebec government, Fullerton reactivated the federal-provincial negotiations and successfully concluded the federal-provincial land exchange. In addition to consolidating control at La Pêche Lake by successfully concluding the land exchange, Fullerton also upset the park's status quo by opening Meech Lake to public use. Thus, on Fullerton's orders, the NCC did not renew the leases of its Meech Lake tenants. Following this, it demolished several cottages, and established public beaches. Chapter 6 
described the storm of protest from park residents and the MLA. Although they recognized that NCC had the legal right, as a property owner, to demolish cottages and establish beaches, the lawyer representing the MLA, Leo Landreville, argued that the NCC should not proceed with a public project until it had complete ownership of the lake. Had this advice from the MLA lawyer been followed, the Kingsmere-Meech Lake privatopia would still be completely off-limits to the public (or, at least, access and use by park visitors at the lake would not be officially sanctioned). Even though Fullerton envisioned the renaturalization of Meech Lake and the eventual closure of Meech Lake Road, the "activist" NCC Chairman did not topple the park's status quo (and, behind the scenes, NCC officials and planning consultants were pushing for the expropriation of remaining privately-owned lands in the heart of the park). Indeed, Fullerton took pride in the fact that there were no expropriations during his tenure as NCC Chairman.

But Fullerton's successors were not so lucky, and this study could have been extended to include the Gatineau Park expropriations carried out in the 1970s, 1980s, and beyond. Similarly, this study could have been extended to include recent assertions of territoriality by the MLA and KPOA, as these property owners' associations continue to attempt to restrict public access and use by recommending the closure of public beaches (and Kingsmere Lake remains off-limits to the public). Hopefully, the problems with the park's fragmented territory have been emphasized enough by this study. That is, the NCC has not only dealt with subdivisions and property owner associations, but also with resistance from municipalities which approve subdivisions and defend the private property rights of park residents. The vertical dimensions of the park's territory have no counterpart in Canada's national parks system, where the federal government has exclusive ownership and consolidated control. In Gatineau Park, there are approximately 389-hectares of 
private-owned lands remaining, worth an estimated \$30-million. ${ }^{1069}$ Despite its NILM-status and the Supreme Court ruling that the federal government has powers of peace, order, and good government (p.o.g.g. powers) to administer the National Capital Region, the NCC continues to “work with municipalities" as it acquires privately-owned lands on a willing-seller basis. ${ }^{1070}$ It timidly exercises territoriality even though privately-owned lands mean that there might be "breaches" open to real-estate developers and land speculators. Only the NCC and its Property Branch truly know how vulnerable the park territory is to further development on private lands (there are rumors that Meech Lake is now fully developed, there being no vacant lots remaining - what activist Jean-Paul Murray refers to as a process of "subdivision-by-installment").

\section{Fixing a failed national park}

Taken together, the three arguments advanced so far serve as a diagnosis of the failings of Gatineau Park, a failed national park. The epigraphs in the Conclusion reveal that several actors are to blame for the park's precarious situation, wherein there is no legislation defining the park boundaries nor the NCC mandate when administering the park. The situation of this so-called "unique" federal park is most unfortunate given the significant role that "Gatineau National Park" could have played: the first national park east of the Rocky Mountain Parks, the first national park in Quebec, and, most importantly, the first in a planned system of near-urban

\footnotetext{
${ }^{1069}$ Gatineau Park Protection Committee. 2015, Jan. 9. "The cost of buying private lands in Gatineau Park: Another NCC swindle.” Last accessed 13 March 2017. Available at: https://www.facebook.com/gatineauparkprotection/posts/1018421931504471:0. The GPPC figure would likely be disputed by the NCC. In 2008, NCC CEO Marie Lemay estimated the cost of purchasing the then 605-hectares of remaining privately-owned land in the park at \$385-million. See Dare, P. 2008, Apr. 4. "NCC eyes private Gatineau Park property: Wants to buy up $\$ 385$ million worth to stop development." Ottawa Citizen. In March 2014, during debate of NDP MP Nycole Turmel's private members' bill, the Conservative Party of Canada estimated the remaining 377 properties inside Gatineau Park to be worth \$100-million. See Obhrai, D. 2014, Mar. 7. "National Capital Act." Canada. Parliament. House of Commons Debates. Edited Hansard. 41st Parliament, 2nd Session, pg.3689.

${ }^{1070}$ National Capital Commission. 2016. The Plan for Canada's Capital 2017 to 2067. Ottawa: NCC, pg.70.
} 
national parks. The celebrated Dominion Parks Branch Commissioner, J.B. Harkin, sought to bring Canada's national parks system to Canadian cities, but, as shown in Chapter 1, it was federally funded highways that brought Canadian cities (and automobility) to the national parks - thus Harkin's troubled association with the "autoparks." Ultimately, despite repeated attempts, the Dominion Parks Branch could not interest the Quebec government in ceding territory for a national park in the Gatineau Hills. For the Parks Branch (now Parks Canada), Gatineau Park is truly "the one that got away." This study has shown that Quebec's territorial question not only inhibited the creation of a national park in the Gatineau Hills, but it also deterred the federal government from establishing a federal district in Canada's capital. Had a federal district been created, the establishment of a national park in the Gatineau Hills would have been much easier for federal authorities who would have, in fact, a territory to govern.

Instead, I argue that the park's status quo as a mixed-use/ownership area represents a provisional achievement of the property owner associations. It is provisional, not only on restricting public access to the Kingsmere-Meech Lake privatopia (and, as this study has shown, Meech Lake could have been off-limits to the public were it not for NCC Chairman Fullerton). The park's status quo is also provisional on ensuring that Gatineau Park legislation does not get passed. It is no coincidence that the MLA and KPOA have not been pushing for park legislation, since it could (and should) entail restrictions on the so-called property rights of park residents. As in the section shown above, the MLA and KPOA argue that they should have the same rights as other Canadian property owners. But this ignores their special privilege of living within the treasured Gatineau Park. Ironically, there were expropriations for national parks elsewhere in Canada at the same time that Gatineau Park was created, but not in the national capital (not officially anyway). This study has shown how the federal government went to great lengths to 
accommodate the residents of the Kingsmere-Meech Lake privatopia, and there are intimate connections between them and the ruling Liberal Party of Canada. So, even though current Liberal MPs (Will Amos and Greg Fergus, for Pontiac and Hull-Aylmer, respectively) called for the protection of Gatineau Park in their election campaigns, the prospect of legislation seems highly unlikely in the current political climate. The park's principle problem of not having protective legislation remains. Thus, the NCC can, behind closed doors, change park policy and even park boundaries, without consulting anyone. I argue that they should, at the very least, consult Algonquin, provincial authorities, and the public interested in the park's future.

Canada's national parks are governed by the National Parks Act, which establishes the responsibilities of Parks Canada and provides mechanisms for parliamentary oversight. As Parliamentarians are aware, the National Capital Act makes no substantive reference to Gatineau Park. Rather, the park's boundaries and the land acquisition policy of negotiated purchase were set out in an 1960 Order-in-Council. Recent NCC policies are found in the 2005 Gatineau Park Master Plan, which calls for the gradual acquisition of remaining private lands. However, as GPPC and CPAWS-OV members can readily attest, there is nothing to prevent a sudden reversal in NCC policy. The removal of NILM lands from the park through the Boundary Rationalization Exercise is a case in point. Clearly, NILM designation is no substitute for legislated boundaries, which is usually the very first step in establishing a protected territory.

My analysis of this failed national park and the effects of divided control on its historical development serve to reinforce the dire need for legislation. Based on the arguments made earlier, I advance four recommendations to "sort out" the park's fragmented territory, and the competing territorialities: 
First, the park needs legislated boundaries. Senator Spivak's bills drew the boundaries from the Boundary Rationalization Exercise, which has been implemented. These more recent boundaries still need to be made the official boundaries, and the Quebec government should be consulted so that it amends the definition of the Game Reserve. Notably, Bill S-210 would have also set the conditions through which lands could be added and removed from the park territory.

Second, while park residents in the Kingsmere-Meech Lake privatopia often invoke the fact that their families predate the park, this study began by describing the dispossession of traditional Algonquin territory. Thus, a second condition ahead of any major changes to the park territory is for the federal government to properly consult the Algonquin First Nation, especially as they have recently (re)issued their land claims in Quebec and Ontario.

Third, another significant stakeholder is Quebec. This study revealed the territoriality of the provincial government, particularly with respect to presence of the federal government on the Quebec-side of the National Capital Region. As part of a 1973 federal-provincial land exchange agreement, the Quebec government designated Gatineau Park as a provincial game reserve (according to the original boundaries set by the 1960 Order-in-Council). The Government of Quebec also transferred ownership of all lake beds within the park to the NCC, and promised not to issue further mining exploration permits. These actions clearly indicated that the provincial government is supportive of the park project. Still, it is important to remember that Gatineau Park was established without the explicit consent of the Quebec government. Thus, provincial authorities should also be consulted ahead of any changes to the park's territory. The NCC failed to consult them during the 1997 Boundary Rationalization Exercise, so, if these boundaries are to be used, provincial consent is still required to approve them. 
Having documented the developments that went ahead and those that were fortunately prevented by the NCC, this phronetic case study of the park and the Kingsmere-Meech Lake privatopia illustrates the need for consolidated control over the entire park territory. The most vexing question for the future remains: how should the NCC acquire the remaining privatelyowned lands in the park? The solution proposed by the park's founding father, Roderick Percy Sparks - of imposing a time limit and expropriating residents that are unwilling to sell by the deadline - is no longer politically or financially feasible. Instead, Senator Spivak's Bill S-210 offers a more modest and reasoned approach. It would mandate the NCC to acquire all remaining privately-owned land inside the park, and also provides the NCC with the right of first refusal to ensure that it has the option of acquiring properties as they are put up for sale on the market (a present difficult for the NCC is that it does not always know when properties are put up for sale).

As shown above, right of first refusal is not seen as a compromise by residents of the Kingsmere-Meech Lake privatopia. So, proponents of right of first refusal must be prepared to face the inevitable resistance from park residents, who mistakenly regard it as a violation of property rights (when, in Canada, these rights are ill-defined). Park residents claim that they are entitled to the same property rights as other Canadians. I argue that this claim ignores their privileged status as park residents. They have benefited more than anyone else from the park. Further, I argue that Gatineau Park was made by and for cottagers turned park residents. So, it is ironic that park residents claim that right of first refusal would detrimentally affect values, because the creation of Gatineau Park had the effect of substantially increasing property values. When considered overall, I concur with the position taken by Senator Spivak, the Gatineau Park Protection Committee, and the Sierra Club of Canada, who all say that right of first refusal is a fair compromise: it allows park residents to remain in the park indefinitely, and only affects them 
should they decide to sell their property on the open market. Moreover, right of first refusal gives the NCC greater control over property acquisitions. Unless there is legislation to give the NCC right of first refusal, the park's status-quo as a mixed-use/ownership area could remain more or less undisturbed, and in perpetuity.

As Parks Canada looks to establish Canada's first near-urban national parks, Gatineau Park provides a critical and, hopefully, atypical case study of the effects of divided ownership and timid territoriality. Surely it is one not to be emulated. Gatineau Park is not, as one planning historian recently suggested, among the "great planning decisions" carried out by the federal government in the development of Canada's national capital. ${ }^{1071}$ It must be seen for what it is: a failed national park, one that benefits the privileged cottagers and residents occupying its core area, Kingsmere and Meech Lakes.

This phronetic study has sought to give practical advice as to how "we" might fix the park's fragmented territory. Park residents in the Kingsmere-Meech Lake privatopia, i.e., "they," will inevitably reject right of first refusal and any challenge to the park's status quo as a mixedownership area. Fixing the park inescapably involves power relations, and "we" are currently on the losing side as the status quo seems stronger than ever. As much as this study can offer solutions, the park still needs a political champion, one who can withstand the resistance of residents and push through legislation that the park desperately needs.

\footnotetext{
${ }^{1071}$ Gordon, D.L.E. 2015. Town and Crown: An Illustrated History of Canada's Capital. Ottawa: Ivenire Books,
} pg.323. 


\section{References}

\section{Legal cases}

National Capital Commission v Bourque, 1972, F.C. T-1832-72.

C. \& B. Vacation Properties Inc. and Corporation Drovelle Ltée v Her Majesty the Queen, 1996, F.C. T-1160-90.

Munro v National Capital Commission, 1966, S.C.R. 663.

National Capital Commission v. Roderick Sparks, 1970, F.C. T-307-71.

Pastoral Finance Association Limited v. The Minister, 1914, A.C. 1083.

\section{Legislation}

\section{Federal}

Bill 417, An Act Respecting the Development and Improvement of the National Capital Region. Bill S-210, An Act to amend the National Capital Act (establishment and protection of Gatineau Park.

British North America (Constitution) Act, 1867, 30-31 Vict., c.3.

Rocky Mountains Park Act, 1887, 50-51 Vict., c.32.

An Act Respecting the City of Ottawa, 1899, 62-63 Vict. c.10.

The National Parks Act, 1930, 20-21 George V, c.33.

Federal District Commission Act, 1928, 20-21 George V, c.28.

National Capital Act, 1985, R.S.C., c. N-4.

\section{Provincial (Quebec)}

Bill No.64, An Act to amend the Municipal Code, 1940.

\section{Orders in Council}

Privy Council of Canada. 1911, June 8. PC 1338.

Privy Council of Canada. 1939, June 29. PC 1662.

Privy Council of Canada. 1938, Sept. 8. PC 2193.

Privy Council of Canada. 1938, Oct. 4. PC 2476.

Privy Council of Canada. 1938, Oct. 4. PC 2477.

Privy Council of Canada. 1945, Aug. 16. PC 5634.

Privy Council of Canada. 1946, Apr. 18. PC 1266.

Privy Council of Canada. 1946, Dec. 5. PC 4382.

Privy Council of Canada. 1947, Mar. 25. PC 1093.

Privy Council of Canada. 1948, Jan. 5. PC 5209.

Privy Council of Canada. 1960, Apr. 29. PC 1960-579.

Privy Council of Canada. 1966, Oct. 27. PC 1966-19/2013.

Privy Council of Canada. 1966, Oct. 27. PC 1966-18/2106. 


\section{Primary sources}

Adam, M. 2012, Jan. 3. "'Timid' NCC could become irrelevant, scholar warns." Ottawa Citizen. Adams, L.J. 1960, June 17. Letter from L.J. Adams to R.E. Edey. P-10-02. LAC ATI A201500039/MR.

Adams, T. Proposal to develop Laurier National Park. Ottawa: Canadian National Parks Branch. Document obtained from Jean-Paul Murray.

Advisory Committee on Gatineau Park. 1947, May 9. Matters for consideration of Gatineau Park Committee. RG.34 Vol.272.190-G(1).

Advisory Committee on Gatineau Park. 1949, May 16. General Report. Ottawa: Federal District Commission.

Advisory Committee on Gatineau Park. 1952, May. Report on Master Plan for the Development of the Gatineau Park. Ottawa: Federal District Commission.

Alsvold, A. 1947, Aug. 8. Letter from A. Alsvold to F.E. Bronson. RG34 Vol.267.190 (13).

Baldwin, H. 1933, Sept. 16. Letter from H. Baldwin to J.R. Dickson. RG39 Vol.25.49136.

Baldwin, H. 1934, Feb. 5. Letter from H. Baldwin to J.R. Dickson. RG39 Vol.25.49136.

Baldwin, H. 1934, Aug. 17. Letter from H. Baldwin to J.R. Dickson. RG39 Vol.25.49136.

Baldwin, H. 1935, May 31. Letter from H. Baldwin to W.E. Matthews. RG34 Vol.265.190(1).

Bearnman, G.M. and Noble, M.E. 1970, Mar. 11. Letter from G.M Bearman and M.E. Noble to J.D. Diefenbaker, re: Taking over Meech Lake Area by National Capital Commission FOR PUBLIC USE. LAC 2014-0607 Vol.65.810-4(2).

Bell. C. 1970, Mar. 18. "Save Meech." Ottawa Citizen.

Bennett, R.B. 1935, May 27. "Public Works Program." Parliament. Canada. House of Commons Debates. Edited Hansard. 17th Parliament, 6th Session, Vol.3.

Blanchard, J.H. 1956, May 7. Letter from J.H. Blanchard to J.E. Handy. RG34 Vol.268.190(20).

Boissonneault, S. 2004, Apr. 26. Letter from S. Boissonneault to M. Beaudry. Available at https://www.scribd.com/doc/272305293/L-Association-des-residents-du-lac-Meechincite-la-CCN-a-fermer-la-plage-Blanchet-et-la-mise-a-1-eau-McCloskey. Last accessed 30 Dec. 2016.

Bourniot, A. 1963, Oct. 8. Some Personal Recollections and Historic Facts about Kingsmere. Ottawa: Paper presented to the Gatineau Valley Historical Society.

Bonnier, M.C. 1947, Jan. 15. Letter from M.B. Bonnier to L.J. Raymond. RG34 Vol.267.190(13).

Bonnier, M.C. 1947, Jan. 20. Letter from M.B. Bonnier to L.J. Raymond. RG34 Vol.267.190(13).

Bourque, P.J. 1967, Oct. 6. Letter from P.J. Bourque to L.B. Pearson. RG34 1190.10.2 Vol.2, LAC ATI A201500039/MR.

Bourque, E.A. 1969, Nov. 24. Letter from E.A. Bourque to D.H. Fullerton. RG34 1190.10 .2 Vol.7. LAC ATI A201500061/MR.

Bowman, C.A. 1936, June 20. "Suggested New Link in Ottawa Planning Will Extend to Beauty Area." Ottawa Citizen.

Bronson, F.E. 1935, Nov. 4. Letter from F.E. Bronson to D.K. MacTavish. RG34 Vol.265.190(1).

Bronson, F.E. 1936, Aug. 24. Letter from F.E. Bronson to A.B. Purvis, re: Proposed development of a National Parkway in the Gatineau district adjacent to Ottawa as an unemployment project. RG34 Vol.265.190(1). 
Bronson, F.E. 1937, Mar. 5. Letter from F.E. Bronson to C.A. Dunning, re: Proposed development of a National Parkway in the Gatineau Valley adjacent to Ottawa. RG34 Vol.265.190(1).

Bronson, F.E. 1937, Mar. 5. Letter from F.E. Bronson to C.A. Dunning, re: Powers of Expropriation in the Province of Quebec. RG34 Vol.265.190(1).

Bronson, F.E. 1937, Dec. 15. Letter from F.E. Bronson to C.A. Dunning. RG34 Vol.265.190(2).

Bronson, F.E. 1938, May 14. Letter from F.E. Bronson to C. Camsell, re: Gatineau Parkway Project. RG34 Vol.265.190(2).

Bronson, F.E. 1939, Jan. 9. Letter from F.E. Bronson to W.L.M King. RG34 Vol.165.190(3).

Bronson, F.E. 1940, Apr. 18. Letter from F.E. Bronson to O. Drouin. RG34 Vol.266.190(6).

Bronson, F.E. 1942, July 31. Letter from F.E. Bronson to W.C. Ronson. RG34 Vol.266.190(10).

Bronson, F.E. 1943, Aug. 18. Letter from F.E. Bronson to W.J. Turnbull. RG34 Vol.266.190(10).

Bronson, F.E. 1947, Mar 21. Letter from F.E. Bronson to R.P. Sparks. RG34 Vol.272.190-G(1).

Buchanan, W.A., 1946. Report of the Standing Committee on Tourist Traffic. Ottawa: Senate of Canada. RG34 Vol.267.190(12).

Buck, K. 1970, June 13. "Meech policy queried." Ottawa Citizen.

Burdett, S.B.1887, May 3. "Banff National Park." Canada. Parliament. House of Commons. Edited Hansard, 50-51(1), 6th Parliament, 1st session.

Burns, E.L.M. 1952, May. "Private Ownership of Property in Gatineau Park." In Advisory Committee on Gatineau Park. Report on Master Plan for the Development of Gatineau Park. Ottawa: Federal District Commission.

Caesar, M. 2004, May 12. "NCC fee proposal sparks Gatineau Park debate." The Low Down to Hull and Back News.

Cameron, D.R. 1935, May 28. Memorandum. RG39 Vol.25.49136.

Cameron, D.R. 1935, Dec. 11. Letter from D.R. Cameron to J.M. Wardle. RG39 Vol.69.49171.

Cameron, D.R. 1936, Apr. 17. Memorandum. RG34 Vol. 265.190(1).

Cauchon, N. 1922. "A federal district for Ottawa." Journal of the Town Planning Institute of Canada, 1(9): 3-6.

Carrolly, C.J.G. 1955, May 27. Letter from C.J.G. Carrolly to E.S. Richards. RG34 Vol.268.190(A1)-1.

Chamber of Commerce of Sainte-Cécile de Masham. 1956, Mar. 7. Untitled document. RG34 Vol.272.190-G(2).

Chapman, J.M. 1970, June 22. Letter from Jean M. Chapman to D.H. Fullerton. LAC 2014-0607 Vol.65.810-4(2).

Chapman, J.M. 1970, July 15. Letter from Jean M. Chapman to J.A. MacNiven. LAC 2014-0607 Vol.65.810-4(3).

Chief of Surveys. 1970, June 26. Letter from Chief of Surveys to M.M Outhet, re: Meech Lake Development Program Account 235-14-00. LAC 2014-0607 Vol.65.810-4(3).

Church, C.H. 1940, Apr. 9. Letter from C.H. Church to H.R. Cram. RG34 Vol.266.190(6).

Clark, S.F. 1961, Nov. 15. Letter from S.F. Clark to R.K. Brown. P-10-02. LAC ATI A201500039/MR.

Clark, S.F. 1963, Sept. 13. Letter from S.F. Clark to D.S. Maxwell. RG34 1190.4.2 Vol.1 LAC ATI A201500061.

Clark, S.F. 1963, Sept. 16. Letter from S.F. Clark to J.P. Deschatelets, re: Expropriation of the Chrzanowski property and proposed expropriation of the Shirley Ann Hope (Johnson) 
property and expropriations in general in the Province of Quebec. RG34 1190.4.2 Vol.1. LAC ATI A201500061.

Clark, S.F. 1964, Apr. 17. Memorandum, re: Expropriations in Quebec. RG34 1190.4.2 Vol.1. LAC ATI A201500061/MR.

Clark, S.F. 1966, June 21. Memorandum, re: Miscellaneous Negotiations - Province of Quebec. P-10-02. LAC ATI A201500039/MR.

Clark, S.F. 1967, June 7. Letter from S.F. Clark to G.J. McIllraith. RG34 1190.4.2, Vol.1, LAC ATI A201500061/MR.

Clark, S.F. 1967, June 19. Letter from S.F. Clark to G.J. McIllraith. RG34 1190.10.2, Vol.7, LAC ATI A201500039/MR.

Cleroux, R. 1970, Nov. 20. "Ban the ban." Ottawa Citizen.

Connolley, G. 1970, Nov. 27. "West end of Gatineau Park opened to snowmobiles by NCC." Ottawa Citizen.

Connolly, J.J. 1940, Mar. 5. Letter from J.J. Connolly to H.R. Cram. RG34 Vol.266.190(6).

Connolly, J.J. 1942, Jan. 18. Letter from J.J. Connolly to T.D. Bouchard. RG34 Vol.266.190(9).

Connolly, J.J. 1947, June 10. Letter from J.J. Connolly to F.E. Bronson. RG34 Vol.272.190$\mathrm{G}(1)$.

County of Gatineau. 1953, June 10. Resolution No.23 of the meeting of the Corporation of the County of Gatineau. RG34 Vol.268(17).

Couture-McTavish, H. 2007, June 7. "Bill S-210, An Act to amend the National Capital Act (establishment and protection of Gatineau Park." Canada. Senate of Canada. Proceedings of the Standing Senate Committee on Energy, the Environment, and Natural Resources, $20,39^{\text {th }}$ Parliament, $1^{\text {st }}$ Session.

Cram, H.R. 1935, July 19. Memorandum, re: Property survey of Gatineau Hills woodland adjacent to Ottawa. RG34 Vol. 265.190(1).

Cram, H.R. 1935, July 31. Letter from H.R. Cram to H. Baldwin. RG34 Vol. 265.190(1).

Cram, H.R. 1935, Aug. 1. Letter from H.R. Cram to W.L.M. King. RG34 Vol.265.190(1).

Cram, H.R. 1935, Dec. 17. Letter from H.R. Cram to T.A. Crerar. RG39 Vol.69.49171.

Cram, H.R. 1937, Mar. 16. Memorandum. RG34 Vol.265.190(1).

Cram, H.R. 1938, Feb. 23. Letter H.R. Cram to L.J. Raymond. RG34 Vol.265.190(2).

Cram, H.R. 1938, Mar. 25. Letter from Letter H.R. Cram to L.J. Raymond. RG34 Vol.265.190(2).

Cram, H.R. 1938, Oct. 21. Letter from H.R. Cram to F. Mulvihill. RG34 Vol.269.190-C(1).

Cram, H.R. 1938, Oct.29. Letter from H.R. Cram to W. Ryan. RG34 Vol.265.190(3).

Cram, H.R. 1939, Feb. 4. Letter from H.R. Cram to W.C. Ronson. RG34 Vol.270.190(D1).

Cram, H.R. 1939, June 15. Letter from H.R. Cram to W.C. Ronson. RG34 Vol.266.190(4).

Cram, H.R. 1939, Nov. 20. Memorandum to F.E. Bronson, re: Meech Lake Association Building Bylaw. RG34 Vol.266.190(5).

Cram, H.R. 1939, Nov. 27. Letter from H.R. Cram to A.J. Pelletier. RG34 Vol.266.190(5).

Cram, H.R. 1940, Mar. 8. Letter from H.R. Cram to M. Yuill. RG34 Vol.266.190(6).

Cram, H.R. 1940, Aug. 2. Letter from H.R. Cram to L.A. Richard, re: Beaver for FDC Gatineau Park. RG34 Vol.266.190(7).

Cram, H.R. 1940, Oct. 28. Letter from H.R. Cram to E. Gohier. RG34 Vol.266.190(8).

Cram, H.R. 1941, Mar. 7. Letter from H.R. Cram to J.A.C. Champion. RG34 Vol.266.190(8).

Cram, H.R. 1941, July 29. Letter from H.R. Cram to E. Gohier. RG34 Vol.266.190(9).

Cram, H.R. 1941, Aug.9. Letter from H.R. Cram to A. Bergeron. RG34 Vol.266.190(9). 
Cram, H.R. 1942, Jan. 16. Letter from H.R. Cram to W.W. Slack. RG34 Vol.266.190(10).

Cram, H.R. 1942, Feb. 12. Letter from H.R. Cram to L.A. Richard. RG34 Vol.266.190(9).

Cram, H.R. 1944, Feb. 4. Letter from H.R. Cram to E. Gohier. RG34 Vol.267.190(11).

Cram, H.R. 1944, Mar. 28. Letter from H.R. Cram to W.F. Lothian. RG34 Vol.267.190(11).

Cram, H.R. 1947, Jan. 13. Letter from H.R. Cram to A.E. Tetu. RG34 Vol.270.190-C(4).

Cram, H.R. 1947, Jan. 13. Letter from H.R. Cram to A.D.P. Heeney. RG34 Vol.267.190(13).

Cram, H.R. 1947, Feb. 18. Letter from H.R. Cram to L.J. Raymond. RG34 Vol.267.190(13).

Cram, H.R. 1948, Sept. 30. Letter from H.R. Cram to A. Macdonald. RG34 Vol.267.190(14).

Cram, H.R. 1949, July 15. Letter from H.R. Cram to R.P. Sparks. RG34 Vol.272.190-G(1).

Cram, H.R. 1952, Feb. 5. Memorandum, re: Gatineau Park. RG34 Vol.267.190(15).

Cram, H.R. 1952, Aug. 28. Letter from H.R. Cram to J. Gréber. RG34 Vol.266.190(16).

Cram, H.R. 1952, Sept. 10. Memorandum, re: Gatineau Park Land Acquisition Policy. RG34 Vol.267.190(16).

Cram, H.R. 1953, June 17. Letter from H.R. Cram to R.P. Sparks. RG34 Vol.268.190(17).

Cram, H.R. 1953, July 29. Letter from H.R. Cram to R.P. Sparks. RG34 Vol.268.190(17).

Cram, H.R. 1953, July 29. Letter from H.R. Cram to A.R. Worden. RG34 Vol.268.190(17).

Cram, H.R. 1953, Oct. 28. Letter from H.R. Cram to W. Duffet. RG34 Vol.268.190(17).

Cram, H.R. 1954, Oct. 26. Letter from H.R. Cram to R.P. Sparks. RG34 Vol.272.190-G(2).

Cram, H.R. 1957, Aug. 19. The Tale of the Beaver in Gatineau Park. RG34 Vol.268.190(A1)

Crerar, T.A. 1936, June 26. Letter from T.A. Crerar to C.E. Mortureux. RG34 Vol.265.190(1).

D’Amour, J.W. 1954, May 21. Letter from J.W. D'Amour to H.R. Cram. RG34 Vol.272-G(2).

Dare, P. 2008, Apr. 4. "NCC eyes private Gatineau Park property: Wants to buy up \$385 million worth to stop development." Ottawa Citizen.

Davis, H.A. 1966, Nov. 2. Letter from H.A. Davis to S.F. Clark, re: Expropriation Gatineau Park Properties, Lac Lapêche area. LAC ATI A201500061/MR.

Davis, H.A. 1966, Nov. 2. Memorandum, re: Expropriation Gatineau Park Properties - Lac Lapêche Area. RG34 1190.10.2, Vol.2 LAC ATI A201500061/MR.

Denley, R. 1994, May 31. "NCC 'strategy' of delay hurts only the taxpayer." Ottawa Citizen.

Deschatelets, J.P. 1963, Oct. 15. Memorandum for Cabinet, re: National Capital Commission Expropriations, Province of Quebec. RG34 1190.4.2 Vol.1. LAC ATI A201500061/MR.

Deschatelets, J.P. 1963, Dec. 16. Letter from J.P. Deschatelets to J. Lesage. RG34 1190.4.2 Vol.1. LAC ATI A201500061.

Deschatelets, J.P. 1964, Feb. 21. Letter from J.P. Deschatelets to J. Lesage. RG34 1190.4.2 Vol.1. LAC ATI A201500061/MR.

Dewar, P. 2014, Mar. 7. "National Capital Act.” Canada. Parliament. House of Commons Debates. Edited Hansard. 41st Parliament, 2nd Session.

Dickson, J.R. 1929, Dec. 4. Memorandum re: Invasion of Blister Rust in the GatineauKingsmere - Meech Lake country. RG39 Vol.25.49136.

Dickson, J.R. 1933, Sept. 14. Letter from J.R. Dickson to A. Bedard. RG39 Vol.25.49136.

Dickson, J.R. 1933, Sept. 19. Letter from J.R. Dickson to the L.A. David. RG39 Vol.25.49136.

Dickson, J.R. 1933, Sept. 27. Interim report on question of controlling the cutting of cordwood, etc., on private lands in Quebec, having in view the preservation of scenery bordering lakes and highways, in summer resort districts. RG39 Vol.25.49136.

Dodge, C.M. 1939, Aug. 18. Letter from C.M. Dodge to S. Lewis. RG34 Vol.266.190(5).

Dodge, G.B. 1941, July 14. Letter from G.B. Dodge to H.R. Cram. RG34 Vol.266.190(9).

Dominion Parks Branch. 1920-1921. Annual Report. Ottawa: Department of the Interior. 
Dorego, P. 2014, July 18. "La saga du lac Meech." Email from P. Dorego to S. McLaughlin and F. Leclerc. NCC ATIP A-2014-00053, pgs.299-300.

Dufault, S. 1914, Jan. 3. Letter from S. Dufault to J.B. Harkin. Obtained from Jean-Paul Murray. Duffett, W.E. 1957, July 8. Letter from W.E. Duffett to R.E. Edey. RG34 Vol.273.190-N4.

Dumoulin, J. 1972, Dec. 10. Reasons for Judgement. Federal Court of Canada. T-1832-72.

Ede, A.R. 1970, Feb. 23. Letter from A.R. Ede to J.A. MacNiven. LAC 2014-0607 Vol.65.810$4(1)$.

Edey, R.E. 1960, Dec. 7. Information on properties within the bounds of Gatineau Park that should be acquired at this time in order that values will not increase due to the opening of the Old Chelsea section of the Gatineau Parkway. RG34 280.22 Vol. 1.

Edey, R.E. 1962, Feb. 1. Memorandum, re: Private Ownership Meech Lake Road - Chair Lift Area. RG34 P-10-02.

Edey, R.E. 1967, June 19. Letter from R.E. Edey to F. Marshall, re: Bourque Holdings Gatineau Park. RG.34 P-10-02. Vol.1.

Edwards, J. 1927, Apr. 6. "Federal District Commission” Canada. Parliament. House of Commons Debates. Edited Hansard. 16th Parliament, 1st Session, Vol.2.

Edwards, S.W. 1937, Mar. 19. Letter from W.S. Edwards to H.R. Cram. RG34 Vol265.190(2).

Federal District Commission 1935, May 30. Meeting Re: Gatineau Woodlands. RG.34 Vol.265.190(1).

Federal District Commission. 1938, Sept. 20. Minutes of Meeting. RG34 Vol.269-A-2(1).

Federal District Commission. 1938, Oct. 21. Notice of Expropriation. RG34 Vol.265.190(3).

Federal District Commission. 1938-1939. Annual Report. Ottawa: King's Printer.

Federal District Commission. 1939-1940. Annual Report. Ottawa: King's Printer.

Federal District Commission. 1940-1941. Annual Report. Ottawa: King's Printer.

Federal District Commission. 1941-1942. Annual Report. Ottawa: King's Printer.

Federal District Commission. 1942-1943. Annual Report. Ottawa: King's Printer.

Federal District Commission. 1945-1946. Annual Report. Ottawa: King's Printer.

Federal District Commission. 1946, Oct. 11. Meeting Resolution. Ottawa. RG34 Vol.270.190$\mathrm{C}(4)$.

Federal District Commission. 1947. Annual Report. Ottawa: King's Printer.

Federal District Commission. 1947, Nov. 12. Federal District Commission Resolution. RG34 Vol.267.190(13).

Federal District Commission. 1948. Annual Report. Ottawa: King's Printer.

Federal District Commission. 1951. Annual Report. Ottawa: King's Printer.

Federal District Commission. 1952. Annual Report. Ottawa: King's Printer.

Federal District Commission. 1953, Oct. 7. Policy on land ownership within Gatineau Park (unused draft). RG34 Vol.268.190(17).

Federal District Commission. 1953, Oct. 7. Policy on land ownership within Gatineau Park. RG34 Vol.268.190(17).

Federal District Commission. 1954. Annual Report. Ottawa: Queen's Printer.

Federal District Commission. 1954, Jan. 25. Memorandum, re: Township of Masham and Gatineau Park. RG34 Vol.190.268(17).

Federal District Commission. 1955. Annual Report. Ottawa: Queen's Printer. Federal District Commission. 1955, Jan. 10. Minutes of Executive Meeting. R1181-0-2-E. 
Federal District Commission. 1956. Annual Report. Ottawa: Queen's Printer.

Federal District Commission. 1956, May 16. Minutes of Executive Meeting. R1181-0-2-E.

Federal District Commission. 1957. Annual Report. Ottawa: Queen's Printer.

Federal District Commission. 1958. Annual Report. Ottawa: Queen's Printer.

Federal District Commission. 1956, Mar. Brief. Ottawa: Submitted to the Joint Committee of the Senate and House of Commons appointed to review and report upon the progress and programs of the Federal District Commission in developing and implementing the Plan for the National Capital of Canada.

Federal Plan Commission for Ottawa and Hull. 1916. Report of the Federal Plan Commission on a General Plan for the Cities of Ottawa and Hull. Ottawa: FPC.

Federal Woodlands Preservation League. No date. Information Pamphlet. RG39 Vol.25.49136.

Federal Woodlands Preservation League. 1945, Oct. Report on the Enlargement and Development of the Gatineau Park. Ottawa: Submitted to the Federal District Commission. RG34 Vol.267.190(11).

Fielding, W.S. 1899, Aug. 2. "Grant to the City of Ottawa." Canada. Parliament. House of Commons. Edited Hansard, $8^{\text {th }}$ Parliament, $4^{\text {th }}$ Session, Vol.3.

Finn, J. 1970, June 2. "Meech Lake chaos has cottagers up in arms." Ottawa Citizen.

Fischer, D. 2004, May 10. "Park changes would go beyond entrance fees." Ottawa Citizen.

Flynn, J. 1970, Mar. 25. "Meech Lake: Expropriations by National Commission - Notice of Inquiry." Canada. Parliament. Senate Debates. Edited Hansard, $28^{\text {th }}$ Parliament, ${ }^{\text {nd }}$ Session, Vol.1.

Fontaine, J. 1927, Apr. 6. "Federal District Commission." Canada. Parliament. House of Commons. Edited Hansard, 16th Parliament, 1st Session, Vol.2.

Frank, C. 2007, June 7. "Bill S-210, An Act to amend the National Capital Act (establishment and protection of Gatineau Park." Canada. Senate of Canada. Proceedings of the Standing Senate Committee on Energy, the Environment, and Natural Resources, 20, 39 Parliament, ${ }^{\text {st }}$ Session

Frank, C. 2015, Feb. 12. Beach at Meech. Available at http://trirudy.com/region/OE/list/index.cfm?listing=3527\#5. Last accessed 30 Dec. 2016.

Frost, A.J. 1967, Oct. 24. Letter from A.J. Frost to G.J. McIllraith. RG34 1190.10.2, Vol.2. LAC ATI A201500039/MR.

Frost, J.A. 1969, Jan. 24. Letter from J.A. Frost to M. Lamontagne. RG34 1190.10.2 Vol.2. LAC ATI A201500061/MR.

Fullerton, D. 1970, May 5. Letter from D.H. Fullerton to L.A. Landreville. LAC 2014-0607 Vol.65.810-4(2).

Fullerton, D.H. 1970, June 26. Letter from D.H. Fullerton to J.M. Chapman. LAC 2014-0607 Vol.65.810-4(3).

Fullerton, D.H. 1970, July 14. Letter from D.H. Fullerton to D.D. Hogarth. LAC 2014-0607 Vol.65.810-4(3).

Fullerton, D.H. 1972, Feb. 29. Letter from D.H. Fullerton to W.J. Thurlow. NCC ATI A-201300010.

Fullerton, D.H. 1972, July 10. Letter from D.H. Fullerton to A. Stone. LAC 2014-0607 Vol.65.810-4(4).

Fullerton, D.H. 1976, Sept. 29. "Protect Gatineau Park from the people." Ottawa Citizen.

Francis, L. 1970, Apr. 10. Letter from L. Francis to D.H. Fullerton. LAC 2014-0607 Vol.65.8104(1). 
Gallant, E. 1975, Oct. 10. “ Testimony.” Canada. Parliament. Joint Committee of the Senate and the House of Commons on the National Capital Commission. Minutes of Proceedings and Evidence, 3.

Gatineau Park Advisory Committee. 1960, Dec. 7. Minutes of Meeting. RG34 Vol.280.22(1).

Gatineau Park Advisory Committee. 1960, July 8. Minutes of Meeting. RG34 280.22 Vol.1.

Gatineau Park Advisory Committee. 1961, Mar. 27. Minutes of Meeting. RG34 280.22 Vol.1.

Gatineau Park Advisory Committee. 1961, Mar. 7. Minutes of Meeting. RG34 Vol.280.22(1).

Gatineau Park Advisory Committee. 1961, May 23. Meeting with Mr. Oswald Parent, MPP, in Quebec City. RG34 Vol.280.22(1).

Gatineau Park Advisory Committee. 1965, Nov. 24. Minutes of Meeting. RG34 Vol.280.22(2).

Gatineau Park Advisory Committee. 1968, Jan. Memorandum to Executive Committee. RG34 280.22 Vol.3.

Gatineau Park Protection Committee. 2015, Jan. 9. "The cost of buying private lands in Gatineau Park: Another NCC swindle.” Last accessed 13 March 2017. Available at: https://www.facebook.com/gatineauparkprotection/posts/1018421931504471:0.

Gatineau Park Task Force. 1989, May. Acquisition Plan: Gatineau Park Private Properties. Ottawa: NCC.

Gatineau Parkway Sub-committee. 1952, Nov. 21. Minutes of Meeting. RG34 Vol.190-G-2-1(1).

Gatineau Parkway Subcommittee. 1953, Dec. General Report. Ottawa: Federal District Commission.

Geggie, H.J.G. 1948, Jan. 14. Letter from H.J.G Geggie to L. Raymond. RG34 Vol.272.190$\mathrm{G}(1)$.

Gill, A. 1936, July 14. Letter from G.A. Gill to W.E. Matthews. RG34 Vol.265.190(1).

Gohier, E. 1944, Feb. 10. Letter from E. Gohier to H.R. Cram. RG34 Vol.267.190(11).

Gordon, I. 1960. The Canadian Journal of Lady Aberdeen. Toronto: Champlain Society.

Gray, J.H. 1872. Confederation: The Political and Parliamentary History of Canada. Toronto: Copp Clark.

Gréber, J. 1952. Oct. 20. Report on Gatineau Park. Paris: Submitted to Federal District Commission.

Gréber, J. 1956, June 12. Letter from J. Gréber to H. Kennedy. RG34 Vol.281.211-D(2).

Habgood, H.M. 1953, July 27. "Beaver In Gatineau Park.” Ottawa Citizen.

Handy, J.E. 1956, May 31. Letter from J.E. Handy to Rev. Marie-Antoine. RG34 Vol.268.190(20).

Hardy, H.R. 1936, Aug.22. "Gatineau National Memorial Park Scheme Widely Approved.” Ottawa Citizen.

Hardy, A.T. 1942, Oct. 12. "Gatineau Park Trails." Ottawa Citizen.

Harkin, J.B. 1913, Dec. 3. Memorandum re: Gatineau Park. Ottawa: Dominion Parks Branch.

Harkin, J.B. 1913, Dec. 23. Letter from J.B. Harkin to C. Devlin. Obtained from Jean-Paul Murray.

Harkin, J.B. 1922, Oct. 22. Memorandum to W.W. Cory. Document obtained from Jean-Paul Murray.

Harris, G.P. 1924, Oct. 22. Letter from G.P. Harris to W.L.M. King. MG26J10 Vol.28(3). Harris, G.P. 1925, June 25. Letter from G.P. Harris to W.L.M. King. MG26J10 Vol.28(3). Harris, G.P. 1927, May 5. Letter from G.P. Harris to W.L.M. King. MG26J10 Vol.28(3). Harris, G.P. 1927, June 9. Letter from G.P. Harris to W.L.M. King. MG26J10 Vol.28(3). Hart, J.S. 1970, Oct. 10. "Snowmobiles." Ottawa Journal. 
Heggtveit, R. no date. "History of the ruins at Lac Philippe." Unpublished document obtained from Bill McGee.

Henry, H.R.L. 1936, June 18. Letter from H.R.L. Henry to C.E. Mortureux. RG34 Vol.265.190(1).

Hocken, H. 1927, Apr. 6. "Federal District Commission.” Canada. Parliament. House of Commons Debates. Edited Hansard, 16th Parliament, 1st Session, Vol.2.

Hogarth, D.D. 1970, Mar. 23. Letter from D.D. Hogarth to J. Marchand. LAC 2014-0607 Vol.65.810-4(1).

Hogarth, D.H. 1970, June 22. Letter from D.D. Hogarth to D.H. Fullerton. LAC 2014-0607 Vol.65.810-4(3).

Holland, C. 1970, June 8. "NCC's 'Trial and Error' Leaves Meech Lakers Aghast." Ottawa Journal.

Hume, J.A. 1936, June 20. "Prominent Members of House Endorse Scheme for Park in Gatineau." Ottawa Citizen.

Hurlow, W.J. 1940, Sept. 27. "This Park is Yours.” Ottawa Citizen.

Hyman, H. 1953. Letter from H. Hyman to R.P. Sparks. RG34 Vol.272.190-G2(1).

Ibbitson, J. 1988, Dec. 30. "NCC starts move to block Gatineau Park subdivision." Ottawa Citizen.

Jackson, C.W. 1937, Mar.23. Letter from C.W. Jackson to F.E. Bronson. RG34 Vol.265.190(2).

Jackson, R. 1956, Apr. 7. "Fight Over Gatineau Park Land: Cottage Owners Refuse to Sell for Scenic Drive." Ottawa Journal.

Jackson, R. 1973, Jan. 30. "Fullerton quitting; clash with Basford." Ottawa Journal.

Johnson, D. 1966, Nov. 15. Letter from D. Johnson to G. McIlraith. RG34 1190.10.2, Vol.6, LAC ATI A201500039/MR

Johnson, D. 1967, May 10. "Motion de M. Roy Fournier.” Quebec. Legislative Assembly. Debates of the Legislative Assembly. Edited Hansard. $28^{\text {th }}$ Legislature, 1st Session.

Johnstone, H. 2016, Dec. 8. "Quebec Algonquins file title claim to downtown Ottawa." CBC News. Available at http://www.cbc.ca/news/canada/ottawa/quebec-algonquins-titleclaim-ottawa-1.3888427. Last accessed 24 January 2017.

Keenleyside, E.W.I. 1960, July 5. Letter from E.W.I. Keenleyside to D.J. Walker. P-10-02. LAC ATI A201500039/MR.

Kennedy, H. 1954, Feb. 18. Letter from H. Kennedy to R.P. Sparks. RG34 Vol.272.190-G(2).

Kennedy, H. 1956, June 28. Joint Committee of the Senate and House of Commons on the Federal District Commission, Vol.19. Ottawa: Queen's Printer.

Kennedy, H. 1960, Nov. 17. Letter from H. Kennedy to J.M. Wardle. RG34 Vol.280.22(1).

King, W.L.M. 1924, Dec. 8. Letter from W.L.M. King to G.P. Harris. MG26J10 Vol.28(3).

King, W.L.M. 1926, May 23. Diary of William Lyon Mackenzie King. Item 9882. Available at: http://www.bac-lac.gc.ca/eng/discover/politics-government/prime-ministers/williamlyon-mackenzie-king/pages/item.aspx?IdNumber=9882\&. Last accessed 28 March 2016.

King, W.L.M. 1927, Apr. 6. "Federal District Commission." Canada. Parliament. House of Commons. Edited Hansard. $16^{\text {th }}$ Parliament, $1^{\text {st }}$ Session, Vol.2.

King, W.L.M. 1927, Apr. 24. "Federal District Commission." Canada. Parliament. House of Commons. Edited Hansard. $16^{\text {th }}$ Parliament, $2^{\text {nd }}$ Session, Vo.2.

King, W.L.M. 1935, May 27. "Public Works Program.” Parliament. Canada. House of Commons Debates. Edited Hansard. $17^{\text {th }}$ Parliament, $6^{\text {th }}$ Session, Vol.3. 
King, W.L.M. 1937, Dec. 20. Diary entry. Library Archives Canada, Item 18593.pg.1148. Available from http://www.bac-lac.gc.ca/eng/discover/politics-government/primeministers/william-lyon-mackenzie-king/Pages/item.aspx?IdNumber=18593\&. Last accessed 24 Jan. 2017.

King, W.L.M. 1938, Jan 19. Diary entry. Library Archives Canada, Item 18704, pg. 68. Available from http://www.bac-lac.gc.ca/eng/discover/politics-government/primeministers/william-lyon-mackenzie-king/Pages/item.aspx?IdNumber=18704\&. Last accessed 24 Jan. 2017.

King, W.L.M. 1944, Apr. 21. "City of Ottawa Agreement.” Canada. Parliament. House of Commons. Edited Hansard. $19^{\text {th }}$ Parliament, $5^{\text {th }}$ Session, Vol.3.

King, W.LM.K. 1950, Feb.28. Last will and testament of William Lyon Mackenzie King. MG26.J17(1).

King, W.L.M. No date. Memorandum, Re: Country Residence. MG26.J10 Vol.28(13).

Kingsmere Property Holders Association. 1925, Jan. 15. Memorandum. MG26J10 Vol.28(3).

Kingsmere Property Holders Association. 1925. Ideas and Schemes of the Kingsmere Property Holders Association. MG26J10 Vol.28(3).

Kingsmere Property Owners' Association. 1948. Kingsmere Building Restrictions Proposal. RG34 Vol.267.190(14).

Lambert, V., Bussiere, G., Aubry. 1970, May. Gatineau Park: Overall Development Plan. Ottawa: Submitted to National Capital Commission.

Land Committee. 1966, Aug. 25. Minutes of Meeting. Ottawa: National Capital Commission. RG34 P-10-02. Vol.1.

Landreville, L.A. 1970, Apr. 13. Letter from L.A. Landreville to D.H. Fullerton, re: A. Amyot Estate and Meech Lake Project. LAC 2014-0607 Vol.65.810-4(2).

Landreville. 1970 Apr. 29. Letter from L.A. Landreville to D.H. Fullerton. LAC 2014-0607 Vol.65.810-4(2).

Laurier, W. 1912, Jan. 10. "Ottawa Improvement Commission.” Canada. Parliament. House of Commons Debates. Edited Hansard, 103(1) 12 $2^{\text {th }}$ Parliament, ${ }^{\text {st }}$ session, pg.977.

Leaning, J. 1997, Jan. 17. "Douglas Fullerton-in memoriam." Glebe Report.

Lemieux, C. 1970, Oct. 7. "Snowmobile Ban Protested by Hull." Ottawa Journal.

Lesage, J. 1963, Sept. 26. Letter from J. Lesage to J.P. Deschatelets. RG34 1190.4.2 Vol.1. LAC ATI A201500061/MR.

Lesage, J. 1964, Jan. 9. Letter from J. Lesage to J.P. Deschatelets. RG34 1190.4.2 Vol.1. LAC ATI A201500061/MR.

Macdonald, A. 1948, Oct. 12. Letter from A. Macdonald to FDC, Re: Kingsmere. RG34 Vol.267.190(14).

MacDonald, J.A. 1887, May 3. "Banff National Park." Canada. Parliament. House of Commons Debates. Edited Hansard, 50-51(1), $6^{\text {th }}$ Parliament, $1^{\text {st }}$ Session.

MacKay, J.R. 1960, July 8. Letter from J.R. MacKay. P-10-02. LAC ATI A201500039/MR.

Macintyre, F.E. 1986, Oct. 3. Affadavit. NCC ATI A-2015-00037CS.

Macoun, J.M. 1912, Nov. 7. "National Park As Memorial." Ottawa Citizen.

Macrae, J.A. 1912, Dec. 1. "Commends National Park Idea.” Ottawa Citizen.

MacTavish, D. 1937, Mar. 6. Letter from D. MacTavish to T.A. Crerar. RG34 Vol.265.190(2).

MacTavish, D.K. 1950, May 15. Letter from D.K. MacTavish to H.R. Cram. RG34 Vol.267.190(14). 
Marchand, J. 1970. Apr. 1. Letter from J. Marchand to D.D. Hogarth. LAC 2014-0607 Vol.65.810-4(1).

Marchand, J. 1970, Apr. 8. Letter from J. Marchand to G.M. Bearman and M.E. Noble. LAC 2014-0607 Vol.65.810-4(1).

Marchand, J. 1970, Apr. 8. Letter from J. Marchand to M. Ménard. LAC 2014-0607 Vol.65.810$4(1)$.

Marchand, J. 1970, Apr. 8. Letter from J. Marchand to L. Brault. LAC 2014-0607 Vol.65.810$4(1)$.

Marshall, F.S. 1963, Oct. 24. Memorandum to General Clark, re: Settlements of Expropriations - Province of Quebec for the Preceding Three Years. RG34 1190.4.2 Vol.1. LAC ATI A201500061.

Marshall, F.S. 1967, June 19. Letter from F.S. Marshall to A. Ede, re: Bourque Brothers. RG34 P-10-02. Vol.1.

Marshall, H. 1952, May. "Private Ownership of Property in Gatineau Park." In Advisory Committee on Gatineau Park. Report on Master Plan for the Development of Gatineau Park. Ottawa: Federal District Commission.

Marshall, H. 1956, May 31. "Ottawa Ski Club." In Canada. Joint Committee of the Senate and the House of Commons on the Federal District Commission. Minutes of Proceedings and Evidence, 10.

Marshall, F.S. 1966, Oct. 6. Memorandum, re: Acquisition of land in Gatineau Park, Township Onslow. RG34 1190.10.2, Vol.2. LAC ATI A201500061/MR.

Martineau, M.G. 1973, Mar. 22. Letter from M.G. Martineau to multiple recipients. RG34 1190.10.2.

Matthews, W.E. 1935, Oct. 29. Letter from W.E. Matthews to W.L.M. King. RG34 Vol.265.190(1).

McAdam, S. 2007, Feb. 21-27. "Visitors, not homeowners, threaten park." Low Down to Hull \& Back News.

McDonald, D.L. 1963, Sept. 4. Memorandum, re: Parcel QB-515 - Chrzanowski. RG34 1190.4.2 Vol.1 LAC ATI A201500061/MR.

McDonald, D.L. 1963, Sept. 11. Memorandum, re: Parcel QB-515-Mrs. Chrzanowski. RG34 1190.4.2 Vol.1. LAC ATI 201500061/MR.

McDonald, D.L. 1963, Sept. 25. Letter from D.L. McDonald to Deputy Minister, Department of Justice. RG34 1190.4.2 Vol.1. LAC ATI A201500061.

McDonald, D.L. 1966, Sept. 6. Letter from D.L. McDonald to F.S. Marshall, Re: Gatineau Park Property Acquisition Recommendation re Curley Lake, Lac Lapêche. RG34 P-10-02 Vol.1.

McElroy, M.H. 1957, Apr. 11. Letter from M.H. McElroy to FDC RG34 Vol.268.190(A1);

McHugh, G. 1933, Dec 1. "Letter to the Editor." Ottawa Ski Club News, Vol.1. Available from: http://gvhs.ca/digital/gatineau-park/osc/1933-12-01.pdf. Last accessed 28 Mar. 2016.

McIllraith, G. 1966, July 29. Letter from G. McIllraith to D. Johnson. RG34 1190.10.2, Vol.6, LAC ATI A201500039/MR.

McLeish, J.W. 1938, May 7. Letter from J.W. McLeish to A.K. Hay. RG34 Vol.268.190(2).

McNiven, J. 1969, Oct. 8. Memorandum, re: Land Acquisition in Gatineau Park. LAC ATI A201500060/MR.

McWilliam, D.L. 1970, Mar. 4. Letter from D.L. McWilliam to J.A. MacNiven. LAC 2014-0607 Vol.65.810-4(1). 
Meech Lake Association. 1939, Aug. Draft Building By-law for the Meech Lake District. RG34 Vol.266.190(5).

Meech Lake Association. 1940, Nov. 28. Minutes of Executive Meeting. RG34 Vol.266.190(8).

Meech Lake Association. 1953, Apr. 9. Memorandum to Federal District Commission. RG34 Vol.268.190(17).

Meech Lake Association. 2003, Jan. Master Plan Review Gatineau Park. Ottawa: Brief submitted to National Capital Commission. Available at https://www.scribd.com/document/255560718/Meech-Lake-Association-Brief-2003. Last accessed 3 March 2017.

Merrell, W.J. 1947, Nov. 12. Letter from W.J. Merrell to H.R. Cram. RG34 Vol.267.190(13).

Merriam, H.G. 1970, Mar. 18. "Preserving Meech Lake." Ottawa Journal.

Metropolitan Council of Western Quebec. 1956, Mar. 14. Resolution. RG34 Vol.272.190-G(2).

Mitchell, P. 1887, Apr. 29. "Banff National Park." Canada. Parliament. House of Commons. Edited Hansard, 50-51(1), 6th Parliament, $1^{\text {st }}$ session.

Monastery of the Capuchin Fathers. 1956, May 7. Letter from the Monastery of the Capuchin Fathers to the Federal District Commission.

Morse, E.W. 1967, Dec. 6. Letter from E.W. Morse to D. Audet. RG34 280.22 Vol.3.

Mortureux, C.E. 1936, June 12. Letter from C.E. Mortureux to W.L..M King. RG34 Vol.265.190(1).

Mulvihill, R. and Leahy, M. 1938, Dec. 31. Letter from Mrs. R. Mulvihill and M. Leahy to W.L.M. King. RG34 Vol.265.190(3).

Mulvihill, R. 1939, Jan. 3. Letter from R. Mulvihill to W.L.M. King. RG34 Vol.265.190(3).

Municipality of West Hull. 1939, Jan. 3. Letter from Secretary Treasurer to F.E. Bronson. RG34 Vol.265.190(3).

Municipality of West Hull. 1940, June 3. By-Law 147. RG34 Vol.266.190(7).

Municipality of West Hull. 1942, Apr. 7. Resolution of Municipality of West Hull. RG34 Vol.266.190(9).

Municipality of West Hull. 1963, Sept. 6. Resolution. RG34 1190.4.2 Vol.1. LAC ATI A201500061.

Murphy, T.G. 1935, Apr. 26. Letter from T.G. Murphy to R.P. Sparks. RG39 Vol.379.49170.

Murphy, T.G. 1935, July 30. Letter from T.G. Murphy to W.E. Matthews. RG34 Vol.265.190(1). Nadon, M. 1997, May. Decision in C. \& B. Vacation Properties Inc. and Corporation Drovelle Ltée and Her Majesty the Queen. Federal Court. File number T-1160-90.

National Capital Commission. 1959. Annual Report. Ottawa: Queen's Printer.

National Capital Commission. 1961-1962. Annual Report. Ottawa: Queen's Printer.

National Capital Commission. 1963, Sept. 13. Parcel QB-515 Chrzanowski: Summary of NCC Actions. RG34 1190.4.2 Vol.1, LAC ATI 201500061/MR.

National Capital Commission. 1965-1966. Annual Report. Ottawa: Queen's Printer.

National Capital Commission. 1966, Sept. 12. Gatineau Park-Land Acquisition. RG34 1190.10.2 Vol.2. LAC ATI A201500061/MR.

National Capital Commission. 1966, Oct. 17. Parcel QB-583: Authority to Acquire Land. Ottawa: Submission to Treasury Board. LAC ATIA201500061.

National Capital Commission. 1966, Nov. 4. Expropriation for additional land-Gatineau Park. LAC ATI A201500061/MR.

National Capital Commission. 1967, Oct. 24. Summary of Bourque Expropriation. RG34 1190.10.2, Vol.2, LAC ATI A201500039/MR. 
National Capital Commission 1967, Nov. 7. Paul J. Bourque - In Trust. RG34 1190.10.2, Vol.2 LAC ATI A201500039/MR.

National Capital Commission. 1968, Feb. 9. Précis on Roderick Sparks. RG34 1190.4.2 Vol.2. LAC ATI A201500061/MR.

National Capital Commission. 1968, Mar. 11. Resume QB-515 - Mrs. J. Chrzanowski. RG34 1190.4.2 Vol.2. LAC ATI A201500061/MR.

National Capital Commission. 1970-1971. Annual Report. Ottawa: Queen's Printer.

National Capital Commission. 1970, Apr. 14. Parliamentary Returns. Question No. 9 Honourable Senator Flynn. LAC 2014-0607 Vol.65.810-4(2).

National Capital Commission. 1972, Nov. 21. Précis of proposed exchange of administration of certain lands in Gatineau Park and in Hull, Quebec, NCC - Québec Government. RG34 1190.10.2.

National Capital Commission. 1973-1974. Annual Report. Ottawa: Queen's Printer.

National Capital Commission. 1976. Annual Report. Ottawa: Queen's Printer.

National Capital Commission. 1980. Gatineau Park Master Plan. Ottawa: NCC.

National Capital Commission. 1985. A Very Special Mandate: The Story of the National Capital Commission. Ottawa: NCC.

National Capital Commission. 1988, Jan. Plan for Canada's Capital: A Federal Land Use Plan. Ottawa: NCC.

National Capital Commission. 1990. Gatineau Park Master Plan. Ottawa: NCC.

National Capital Commission. 2005. Master Plan for Gatineau Park. Ottawa: NCC.

National Capital Commission. 2006, Sept. About National Capital Commission Lands. Ottawa: NCC.

National Capital Commission. 2012. Cultural Heritage Plan: Public Consultation. Ottawa: NCC.

National Capital Commission. 2012-2013. Annual Report. Ottawa: NCC.

National Capital Commission. 2015, Feb. 26. Clarification Meech Lake Residents Association. Formerly available at http://www.ncc-ccn.gc.ca/places-to-visit/gatineau-park/news/201502-26/clarification-meech-lake-residents-association.

National Capital Commission. 2017. "Gatineau Park Master Plan.” Available at http://www.nccccn.gc.ca/planning/master-plans/gatineau-park-master-plan. Last accessed 24 January 2017.

National Capital Commission. 2017. “About Gatineau Park.” Ottawa: NCC. Available at http://www.ncc-ccn.gc.ca/places-to-visit/gatineau-park/about-gatineau-park. Last accessed 14 January 2017.

National Capital Commission. 2016. The Plan for Canada's Capital 2017 to 2067. Ottawa: NCC, pg.70. Available at http://www.ncc-ccn.gc.ca/sites/default/files/pubs/pfcc 201606-15-en-draft-optimized.pdf. Last accessed 14 March 2017.

National Capital Planning Committee. 1946, Mar. 19. First Report on Operations. RG34 Vol.291.211-D(1).

National Capital Planning Committee. 1947, May 15. Summary of Verbal report by Jacques Gréber Consultant City Planner to the Committee. RG34 Vol.281.211-D(1).

National Capital Planning Committee. 1950. Plan for the National Capital. Ottawa: King's Printer. 
New Woodlands Preservation League. 2007, Mar. 14. "Bill S-210: A Compromise Designed to Protect Gatineau Park." Brief submitted to the Senate Standing Committee on Energy, The Environment, and Natural Resources.

Nichols, M. 1970, Nov. 27. "NCC bows to Quebec': Snowmobilers Get Use of Park Area." Ottawa Journal.

No author. No date. Brief notes, re: the Proposed Mutual Exchange of Control and Management of Lands-Quebec and NCC largely affecting Gatineau Park. RG34 1190.10.2.

No Author. 1926, July 12. "Annual Meeting of Meech Lake Assn.” Ottawa Citizen.

No author. 1934, Dec. 15. "Form Organization With Aim of Preserving the Woodlands." Ottawa Citizen.

No author. 1934, Dec. 15. "Woodlands Around Ottawa." The Evening Citizen.

No author. 1935, Jan. 12. "The Hillsides will accuse." Ottawa Citizen.

No author. 1935, May 9. "Urge Protection Woodland Beauty in Ottawa Area." Ottawa Journal.

No author. 1935, June 13. "Liberal Leader's Proposal Scorned by Aimé Guertin." Ottawa Citizen.

No author. 1935, Aug. 16. "Murphy Sends Party of Seven to Inspect Field." Ottawa Citizen.

No author. 1935, Aug. 19. "Preserving the Gatineau." Ottawa Journal.

No author. 1935, Nov. 27. "Minister of Interior Welcomes Suggestions: Deplores Stripping of Hills in Ottawa District and Elsewhere." Ottawa Journal.

No author. 1935, Nov. 27. "Hope To Secure Co-operation In Preserving Gatineau Area." Ottawa Citizen.

No author. 1935, Nov. 28. "Gatineau Woodlands Survey." Ottawa Citizen.

No author. 1935, Dec. 17. "Ottawa May Become Winter Sports Centre of America Predicts Charles A. Bowman.” Ottawa Citizen.

No author. 1936, Apr. 25. "Federal Parkway Work." Ottawa Citizen.

No author. 1936, Aug. 22. "For National Memorial Parkway." Ottawa Citizen.

No author. 1936, Sept. 16. "For Gatineau National Parkway." Ottawa Citizen.

No author. 1936, Sept. 26. "Gatineau Highway Improvement." Ottawa Citizen.

No author. 1936, Nov. 13. "J.C. McCuaig Tells of Plans for New Gatineau Highway." Ottawa Citizen.

No author. 1936, Nov. 24. "The Woodlands North of Ottawa." Ottawa Citizen.

No author. 1936, Nov. 26. "Interest in Gatineau Parkway." Ottawa Citizen.

No author. 1936, Dec. 9. "Gatineau Park and Hull Court-house Plans Remembered." Ottawa Citizen.

No author. 1937, Jan. 7. "Work for War Veterans." Ottawa Citizen.

No author. 1937, Mar. 24. "Asks National Park In Gatineau County." Ottawa Citizen.

No author. 1937, Oct. 11. "Urge Immediate Action to Preserve Gatineau's Hillsides." Ottawa Citizen.

No author. 1937, Dec. 27. "Urging Purchase of 12,000 Acres In Gatineau." Ottawa Journal.

No author. 1937, Dec. 28. "A Good Time to Start on a Gatineau Park." Ottawa Journal.

No author. 1938, Jan. 19. "National Park In Meech Lake Area Probable. Ottawa Citizen.

No author. 1938, Feb. 4. "Provision In Estimates for Gatineau Park." Ottawa Citizen.

No author. 1938, Feb. 4. "Gatineau National Park At Last Taking Shape." Ottawa Citizen.

No author. 1938, Feb. 4. "For National Memorial Parkway." Ottawa Citizen.

No author. 1938, Feb. 4. "100-Mile Scenic Gatineau Parkway To Realize Long-Mooted Project."

Ottawa Journal. 
No author. 1938, Feb. 25. "Support Proposal of National Park." Ottawa Citizen.

No author. 1938, June 30. "House Approves Start on new Gatineau Park: Item of $\$ 100,000$

Passed." Ottawa Citizen.

No author 1938, Oct. 11. "National Parkway in Gatineau Beginning to Take Shape." Ottawa Journal.

No author. 1938, Nov. 15. "The Gatineau National Parkway." Ottawa Citizen.

No author. 1939, Jan. 3. "In the Gatineau Hills." Ottawa Citizen.

No author. 1939. Feb. 1. "Judgements Fix Price of Land for Gatineau Parkway." Ottawa Citizen.

No author. 1939, Feb. 7. "Make Progress Improving Road To Camp Fortune.” Ottawa Journal.

No author. 1939, Mar. 3. "Workmen Making Progress on New Parkland." Ottawa Journal.

No author. 1939, June 23. "Gatineau Parkway Progress." Ottawa Citizen.

No author. 1940, Feb. 1. "FDC Officials, Quebec Cabinet, Talk Park Plans." Ottawa Citizen.

No author. 1940, Feb. 1. "La province dottée d'un parc national sans qu'il lui coûte un seul sou." Quebec Evening-Journal.

No author. 1941, Feb. 26. "Creating Breach and Camp-Site Near Wakefield." Ottawa Citizen.

No author. 1941, Oct. 14. "Not Establishing Public Beach At Meech Lake." Ottawa Citizen.

No author. 1946, June 27. "Would Extend Gatineau Park To 50,000 Acres." Ottawa Journal.

No author. 1947, Feb. 5. "Choosing Sites in Development of Gatineau Park." Ottawa Journal.

No author. 1949, Apr. 8. "\$7,000,000 On Gatineau." Ottawa Citizen.

No author. 1949, Apr. 9. "Government to Spend \$7,000,000 On Gatineau Park Expropriations." Ottawa Journal.

No author. 1949, Apr. 12. "Gatineau Park: A Great Achievement." Ottawa Journal.

No author. 1949, June 11. "Gatineau National Park Will Be Extended To 60,000 Acres.” The Evening Citizen.

No author. 1949, June 11. "New Acreage Expected To Be 60,000." Ottawa Citizen.

No author. 1951, Apr. 12. "Big Step in Park Planning." Ottawa Citizen.

No author. 1951, Apr. 14. "A Great Recreation Ground." Ottawa Journal.

No author. 1953, Oct. 20. "FDC Sets Expropriation Plans for Gatineau Park." Ottawa Citizen.

No author. 1953, Oct. 20. "Council to Study FDC Request Building Permit Be Held Up." Ottawa Journal.

No author. 1953, Oct. 24. "Uneasiness Expressed Over FDC Land Grabs in Gatineau." Ottawa Citizen.

No author. 1953, Oct. 24. "Battle Shapes Up Over FDC Power.” Ottawa Journal.

No author. 1954, Jan. 29. "Oppose Federal District." Ottawa Citizen.

No author. 1954, Jan. 30. "Fraud Charge in Tremblay Study of FDC." Ottawa Citizen.

No author 1955, May 16. "Despite Policy Battle Gatineau Park Goes Ahead." Ottawa Journal.

No author. 1955, May 17. "Gatineau Park Policy Unchanged.” Ottawa Journal.

No author. 1956, Apr. 9. "Meech Lake Cottagers Resent Sparks Charges." Ottawa Citizen.

No author. 1956, Apr. 12. "Lots of Eye Appeal but Few Eyesores at Meech Lake." Ottawa Citizen.

No author. 1970, Mar. 2. "Cottages to go: NCC turns Meech Lake to public use." Ottawa Citizen.

No author. 1970, Mar. 4. "Meech goes public.” Ottawa Citizen.

No author 1970, Mar. 7. NCC Meech Lake Plan Doesn't Make Sense - Senator." Ottawa Journal.

No author. 1970, Mar. 23. "Why Meech Lake is Opening Up." Ottawa Journal. 
No author. 1970, July 20. "Meech Beach: All it needs now is people." Ottawa Citizen.

No author. 1970, Oct. 1. "Motoneiges: Violentes protestations des clubs." Le Droit.

No author. 1970, Oct. 5. "Snowmobilers to battle NCC." Ottawa Citizen.

No author. 1970, Oct. 6. "Squirrels or us? Snowmobilers question Fullerton ban." Ottawa Citizen.

No author. 1970, Oct. 14. "Snowed Under." Ottawa Citizen.

No author. 1972, Oct. 16. "Does he mean it?" Ottawa Citizen.

No author. 1970, Nov. 18. "Hull, Snowmobilers Allied in NCC Feud." Ottawa Journal.

No author. 1973, Mar. 13. "Québec a pris une sage décision.” CJRC 1150 Ottawa-Hull. RG34 1190.10.2.

O'Brien, T.W. 1966, Dec. 22. Letter from T.W. O'Brien to H.A. Davis, re: Expropriation Gatineau Park-Mrs. H.J. Dunne. LAC ATI A201500061/MR.

O'Connor, A. 1971, June 15. Affidavit of Austin O'Connor. Federal Court of Canada. T-1832-72.

Obhrai, D. 2014, Mar. 7. "National Capital Act." Canada. Parliament. House of Commons Debates. Edited Hansard. 41st Parliament, 2nd Session.

Ottawa-Valley chapter of the Canadian Parks and Wilderness Society. 1988, Apr. 19. Minutes of Meeting. Ottawa: CPAWS-OV.

Ottawa-Valley chapter of the Canadian Parks and Wilderness Society. 1988, May. 17. Minutes of Meeting. Ottawa: CPAWS-OV.

Ottawa-Valley chapter of the Canadian Parks and Wilderness Society. 1989. Legislative Protection for Gatineau Park. Ottawa: CPAWS-OV.

Ottawa Ski Club. 1929, Mar. 13. Ottawa Ski Club News. No. 10, pg.1. Available at: http://www.gvhs.ca/digital/gatineau-park/osc/1929-03-13.pdf. Last accessed 28 Mar. 2016.

Ottawa Ski Club. 1929, Dec, 3. Resolution re: Outbreak of the White Pine Blister Rust in the Gatineau - Kingsmere - Meech Lake Country. RG39 Vol.25.49136

Paquet, G. Farber, B.L., and Benoit, G. 2006, Dec. The National Capital Commission: Charting a new course. Ottawa: NCC Mandate Review.

Pearson, L.B. 1967. Letter from L.B. Pearson to P.J. Bourque. RG34 1190.10.2 Vol.2. LAC ATI A201500061/MR.

Perras, J. 2007, June 7. "Bill S-210, An Act to amend the National Capital Act (establishment and protection of Gatineau Park." Canada. Senate of Canada. Proceedings of the Standing Senate Committee on Energy, the Environment, and Natural Resources, 20, 39th Parliament, 1st Session.

Piche, G.C. 1933, Nov. 27. Letter from G.C. Piche to J.R. Dickson. RG39 Vol.25.49136.

Pitfield, P.M. 1970, Mar. 24. Letter from P.M. Pitfield to D. Fullerton. LAC 2014-0607 Vol.65.810-4(1).

Privy Council Office. 1963, Dec. 12. Record of Cabinet Decision, re: National Capital Commission expropriations, Province of Quebec. RG34 1190.4.2 Vol.1. LAC ATI A201500061/MR.

Privy Council Office. 1971, Nov. 4. Record of Cabinet Decision, re: National Capital Commission Program and Fiscal Requirements to 1982. RG34 1190.10.2 Vol.8.

Quain, R. 1954, Oct. 15. Letter from R. Quain to Federal District Commission. RG34 Vol.273.190-N.

Quain, R. 1957, June 11. Letter from Redmond Quain to H. Kennedy. RG34 Vol.273.190-N4 
Richards, E.S. 1938, June 13. Memorandum, re: Purchase of Gatineau lands for proposed park. RG34 Vol.265.190(2).

Richards, E.S. 1938, July 9. Memorandum, re: Purchase of Woodlands. RG34 Vol.265.190(2).

Richards, E.S. 1938, Aug. 2. Memorandum, re: Acquisition of Forest Lands, Lower Gatineau Region. RG34 Vol.265.190(2).

Richards, E.S. 1939, Feb. 16. Letter from E.S Richards to J.C Leslie. RG34 Vol.265.190(3).

Richards, E.S. 1939, Mar. 6. Letter from E.S. Richards to L. Depuis. RG34 Vol.266.190(5).

Richards, E.S. 1939, Sept. 16. Draft Building By-law for the Meech Lake and Kingsmere District by the Municipality of West Hull under authority of article 392A of the Municipal Code of Quebec. RG34 Vol.266.190(5).

Richards, E.S. 1940, Jan. 24. Memorandum, re: 1. Building by the Ottawa Ski Club of a ski tow part of which may be on land owned by the commission, 2. Free use by non-members of the Ottawa Ski Club trails at all times in the year. RG34 Vol.266.190(6).

Richards, E.S. 1942, Feb. 11. Memorandum, re: Visitors to Gatineau Park. RG34 Vol.266.190(9).

Richards, E.S. 1949, Feb. 14. Letter from E.S. Richards to E. Handy. RG34 Vol.267.190(14).

Richards, E.S. 1952, Sept. 10. Gatineau Options for Consideration Federal District Commission Meeting. RG34 Vol.269.190-B(2).

Richards, E.S. 1953, July 6. Memorandum dated 9th April 1953 from the Meech Lake Association. RG34 Vol.268.190(17).

Richards, E.S. 1953, Oct. 29. List of Land Expropriated and Forming Part of Gatineau Park. RG34 Vol.270-C(4).

RG34, file number 190, vols.1-20, as well as RG34 file numbers 190-A through 190-H (and 190N, 'Roads in Gatineau Parks', 2 vols.). Files RG34.190-C 'Gatineau Park - Expropriation of Lands' and RG34.190-G 'Advisory Committee on Gatineau Park'

RG39.69 files 49170 and 49171 (1935 Lower Gatineau Valley Woodlands Survey).

RG39.25 file 49136 (Federal Woodlands Preservation League).

Robertson, W.M 1935, Oct. 18. Interim Report Re: The Lower Gatineau Woodlands Survey. Ottawa: Department of Interior. RG34 Vol.265.190(1).

Rogers, D. 2008, Jan. 25. "NCC unaware of Gatineau Park housing plan; Owners have right to build, Chelsea mayor says." Ottawa Citizen.

Rogers, D. 2009, May 18. "Manitoba senator emerges as saviour of Gatineau Park; Mira Spivak fighting to give Crown jewel federal protection." Ottawa Citizen.

Ronson, W.C. 1942, July 27. Letter from W.C. Ronson to H.R. Cram. RG34 Vol.266.190(10).

Ryan, E.J. 1963, Sept. 18. Letter from E.J. Ryan to J. Lesage. RG34 1190.4.2 Vol.1. LAC ATI A201500061.

Saint-Jacques, H. 1948, Jan. 23. Letter from H. Saint-Jacques to F.E. Bronson. RG34 Vol.267.190(13).

Seton, E.T. 1912, Nov. 26. "National Park would be asset to Canada." Ottawa Citizen.

Sparks, R. 1970, June 15. "Statement of Defence." In Federal Court of Canada, National Capital Commission v. Roderick Sparks. T-307-71.

Sparks, R.P. 1935, Apr. 3. Letter from R.P. Sparks to T.G. Murphy. RG39 Vol.25.49136.

Sparks, R.P. 1937, Dec. 13. Memorandum Re: Activities of the Federal Woodlands Preservation League.

Sparks, R.P. 1938, Dec. 28. Letter from R.P. Sparks to C.A. Dunning. RG34 Vol.265.190(3).

Sparks, R.P. 1944, Feb. 16. Letter from R.P. Sparks to D.R. Cameron. RG39 Vol.25.49136. 
Sparks, R.P. 1947, July 25. Letter from R.P. Sparks to F.E. Bronson. RG34 Vol.272.190-G(1). Sparks, R.P. 1947, July 26. Letter from R.P Sparks to J.J. Connolly. RG34 Vol.272.190-G(1). Sparks, R.P. 1947, Dec. 23. Letter from R.P. Sparks to F.E. Bronson. RG34 Vol.272.190-G(1). Sparks, R.P. 1948, Jan. 29. Letter from R.P. Sparks to H.R. Cram. RG34 Vol.272.190-G(1). Sparks, R.P. 1948, May 11. Letter from R.P. Sparks to J.E. Blackburn. RG34 Vol.272.190-G(1). Sparks, R.P. 1948, May 11. Letter from R.P. Sparks to H.R. Cram. RG34 Vol.272.190-G(1). Sparks, R.P. 1949, Mar. 22. Letter from R.P. Sparks to H.R. Cram. RG34 Vol.272.190-G(1). Sparks, R.P. 1949, July 29. Letter from R.P. Sparks to H.R. Cram. RG34 Vol.272.190-G(1). Sparks, R.P. 1951, Apr. 13. Letter from R.P. Sparks to F.E. Bronson. RG34 Vol.272.190-G(2). Sparks, R.P. 1951, Apr. 17. Letter from R.P. Sparks to H. Marshall. RG34 Vol.272.190-G(2). Cram, H.R. 1952, June 11. Letter from H.R. Cram to multiple recipients. RG34 Vol.267.190(16).

Sparks, R.P. 1952, July. Memorandum to Advisory Committee on Gatineau Park. RG34 Vol.272.190-G(1).

Sparks, R.P. 1952, Sept. 10. Letter from R.P. Sparks to H.R. Cram. RG34 Vol.272.190-G(1). Sparks, R.P. 1953, Oct. 21. Letter from R.P. Sparks to H.R. Cram. RG34 Vol.272.190-G(2). Sparks, R.P. 1954, Feb. 25. Letter from R.P. Sparks to H. Kennedy. RG34 Vol.272.190-G2(1). Sparks, R.P. 1954, Sept. 14. Letter from R.P. Sparks to H. Kennedy. RG34 Vol.272.190-G(2). Sparks, R.P. 1955, May 15. Letter from R.P. Sparks to H.R. Cram. RG34 Vol.190.268(19). Sparks, R.P. 1956, June 26. "Land Policy in Gatineau Park.” Canada. Parliament. Joint Committee of the Senate and the House of Commons on the Federal District Commission. Minutes of Proceedings and Evidence, Vol.18.

Sparks, R.P. and Connolly, J.J. 1947, July 26. Letter from R.P Sparks and J.J. Connolly to Federal District Commission. RG34 Vol.272.190-G(1).

Speck, F.G. 1915. "Family Hunting Territories and Social Life of Various Algonkian Bands of the Ottawa Valley." Geological Survey Memoir, 70(8). Ottawa: Government Printing Bureau.

Spivak, M. 2007, Mar. 29. "Bill S-210, An Act to amend the National Capital Act (establishment and protection of Gatineau Park." Canada. Senate of Canada. Proceedings of the Standing Senate Committee on Energy, the Environment, and Natural Resources, 15 , 39th Parliament, 1st Session.

St. Laurent, L. 1949, Apr. 8. "National Capital Plan.” Canada. Parliament. House of Commons. Edited Hansard. $20^{\text {th }}$ Parliament, $5^{\text {th }}$ Session, Vol.3.

Ste-Marie, P. 1947, Jan. 11. Letter from P. Ste-Marie to H. Papineau. RG34 Vol.267.190(13).

Sutherland, J. 1945, Sept. 21. Letter from J. Sutherland to D.R. Cameron. RG39 Vol.25.49136.

Sykes, A.R. 1954, Jan. 29. "Say Property Owners Terrified." Ottawa Journal.

Sykes, A.R. 1955, May 12. "FDC Land Policy Assailed." Ottawa Journal.

Taschereau, L.A. 1935, Mar. 21. Letter from L.A. Taschereau to H. Baldwin. RG39 Vol.25.49136.

Taschereau, L.A. 1935, June 27. Letter from L.A. Taschereau to W.E. Matthews. RG34 Vol.265.190(1).

Task Force on Program Review. 1986. Real Property. Ottawa: Ministry of Supply and Services Canada.

Tasker, J.P. 2016, Oct. 18. "Historic land deal with Algonquin peoples signed by federal, Ontario governments." CBC News. Available at http://www.cbc.ca/newspolitics/ottawa-ontarioalgonquin-agreement-in-principle-1.3809876. Last accessed 19 October 2016. 
Tetu, A.E., Brown, H., Harris, W.R., et al. 1946, Dec. 10. Petition by cottage-owners on Brown Lake. RG34 Vol.270.190-C(4).

The Commission on the Integrity of the Territory of Québec. "A summary of the postulates and recommendations." In Fullerton, D.H. 1974. The Capital of Canada: How Should It Be Governed? Ottawa. Information Canada.

Thomas, E.M. 1968, Jan 18. Letter from E.M. Thomas to E.W. Thrift, re: N.C.C. Expropriation from Bourque Brothers, Lac Lapêche, Parcel QA-177. RG34 P-10-02 Vol.1.

Thomas, E.M. 1968, Aug. 14. Letter from E.M. Thomas to M. Carrière, re: NCC expropriation of Parcel QA-177 from Edouard Bourque and Paul J. Bourque. RG34 1190.10.2 Vol.2. LAC ATI A201500061/MR.

Thomas, E.M. 1971, Jan. 19. Letter from E.M Thomas to J.W.N. Delorme. In Federal Court of Canada, National Capital Commission v. Roderick Sparks. T-307-71.

Thrift, E.W. 1966, Feb. 4. Letter from E.W. Thrift to S.F. Clark, re: Exchange of Lands Province of Quebec. P-10-04, LAC ATI A201500039/MR.

Thrift, E.W. 1967, Oct. 20. Memorandum to A.J. Frost, re: Paul J. Bourque. RG34 1190.10.2, Vol.2 LAC ATI A201500039/MR.

Todd, F.G. 1903. Preliminary Report to the Ottawa Improvement Commission. Ottawa: Ottawa Improvement Commission.

Tost, J. 1970, July 16. "New Meech Lake Beach Now Ready for Use-NCC.” Ottawa Journal.

Turnbull, W.J. 1943, Aug. 12. Letter from W.J. Turnbull to F.E. Bronson. RG34 Vol.266.190(10).

Tweksbury, D.L. 1970, June 13. "Fire Them." Ottawa Journal.

Urbatique Inc. 1970, Jan. Gatineau Park: Summary of Proposed Basic Development Policies. RG34 280.11 Vol.6.

Yonson, D. 1989, Aug. 24. "Bid soars for Gatineau Park site." Ottawa Citizen.

Worden, A.R. 1953, Apr. 9. Letter from A.R. Worden to H.R. Cram. RG34 Vol.268.190(17).

\section{Secondary Sources}

Arnstein, S.R. 1969. “A Ladder of Citizen Participation.” JAIP, 35(4): 216-224.

Apostle, A. 1997. The View From The Hill: National Park Culture and Gatineau Park. Kingston: Queen's University (unpublished MA thesis).

Bankes, N.D. 1986. "Constitutional Problems Related to the Creation and Administration of Canada’s National Parks.” In Saunders, J.O., ed., Managing Natural Resources in a Federal State. Toronto: Carswell.

Bella, L. 1987. Parks for Profit. Montreal: Harvest House Ltd.

Binnema, T. and Niemi, M. 2006. “"'Let the Line Be Drawn Now': Wilderness, Conservation, and the Exclusion of Aboriginal People from Banff National Park in Canada." Environmental History, 11: 724-750.

Blomley, N. 2007. "Making Private Property: Enclosure, Common Right and the Work of Hedges." Rural History, 18(1): 1-21.

Brighenti, A.M. 2006. "On Territory as Relationship and Law as Territory." Canadian Journal of Law and Society, 21(2): 65-86.

Brown, R.C. 1969. "The Doctrine of Usefulness: Natural Resource and National Park Policy in Canada, 1887-1914.” In Nelson, J.G., ed., Canadian Parks in Perspective. Montreal: Harvest House Ltd. 
Carter, A.C. 2001. Planning a "Capital Worthy of the Nation": The federal district controversy and the planning of the Canadian capital. Kingston: Queen's University (unpublished MA thesis).

Cellard, A. 1997. "Kichesippi: the Great River of the Algonquins (1600-1650)." In Gaffield, C., ed., History of the Outaouais. Quebec: University of Laval Press.

Cellard, A., and Pelletier, G. 1997. "The Ottawa River: 1650-1792." In Gaffield, C., ed., History of the Outaouais. Quebec: University of Laval Press.

Cimon, J. Le Dossier Outaouais: réflexions d'un urbaniste. Quebec: Éditions du Pélican.

Creelman, J. 1978. Man and the land: A short history of Gatineau Park. Ottawa: National Capital Commission.

Cresswell, T. 2010. "Towards a politics of mobility." Environment and Planning D: Society and Space, 28: 17-31.

Culhane, D. 1998. The Pleasure of the Crown: Anthropology, Law and First Nations. Vancouver: Talon Books.

Delaney, D. 2005. Territory: A short introduction. Malden MA: Blackwell Publishing.

Dilsaver, L.M. 2004. Cumberland Island National Seashore: A History of Conservation Conflict. Charlottesville: University of Virginia Press.

Dilsaver, L.M. and Wyckoff, W. 2005. "The Political Geography of National Parks." Pacific Historical Review, 74(2): 237-266.

Dubasak, M. 1990. Wilderness Preservation: A Cross-Cultural Comparison of Canada and the United States. New York: Garland Publishing.

Eggleston, W. 1961. The Queen's Choice. Ottawa: National Capital Commission.

Elden, S. 2009. Terror and Territory: The Spatial Extent of Sovereignty. Minneapolis: University of Minnesota Press.

Elden, S. 2010. "Land, terrain, territory." Progress in Human Geography, 34(6): 799-817.

Elden, S. 2013. The Birth of Territory. Chicago: University of Chicago Press.

Elliott, B.S. 1979. "“"The Famous Township of Hull”: Image and Aspirations of a Pioneer Quebec Community." Histoire Sociale/Social History, 12(24): 339-367.

Evans, P.M.O. 1988. A Tale of Two Chelseas. Ottawa: Les Editions J. Oscar Lemieux.

Evans, P.M.O. "Cottage at Meech Lake.” Gatineau Valley Historical Society. Available at http://www.gvhs.ca/digital/lowdown/evans/display.php?row=0\&search=279. Last accessed 20 April 2016.

Fletcher, K. 2004. Historical Walks: The Gatineau Park Story, $3^{\text {rd }}$ Edition. Markham, ON: Fitzhenry \& Whiteside Limited.

Flyvbjerg, B. 2001. Making Social Science Matter: Why social inquiry fails and how it can succeed again. Cambridge: Cambridge University Press.

Flyvbjerg, B. 2004. "Phronetic Planning Research: Theoretical and Methodological Reflections." Planning Theory \& Practice, 5(3): 283-306.

Flyvbjerg, B. 2006. "Five Misunderstandings About Case-Study Research." Qualitative Inquiry, 12(2): 219-245.

Foucault, M. 1983. "The Subject and Power." In Dreyfus, H.L. and Rabinow, P., Michel Foucault: Beyond Structuralism and Hermeneutics, $2^{\text {nd }}$ edition. Chicago: University of Chicago Press.

Foster, J. 1978. Working for Wildlife: The Beginning of Preservation in Canada. Toronto: University of Toronto Press. 
Fullerton, D.H. 1978. The Dangerous Delusion: Quebec's Independence Obsession. Toronto: McClelland and Stewart.

Francis, L. 2000. Ottawa Boy. Burnstown, Ontario: General Store Publishing House.

Gagnon, S., Filion, M., and Tessier, C. 2004. The Creation and Early Development of Gatineau Park: Study on the influence of local interest groups and the sociopolitical context of the Park's creation from 1903 to 1956. Ottawa: National Capital Commission.

Gaffield, C. 1997a. "Land, Family, and the Origins of Colonization." In Gaffield, C., ed., History of the Outaouais. Quebec: University of Laval Press.

Gaffield, C. 1997b. “A Territory Transformed 1791-1886.” In Gaffield, C., ed., History of the Outaouais. Quebec: University of Laval Press.

Gibson, D. 1976. "The 'Federal Enclave' Fallacy in Canadian Constitutional Law." Alberta Law Review, 76: 167-178.

Gordon, D.L.A. 2001. "From Noblesse Oblige to Nationalism: Elite Involvement in Planning Canada's Capital." Journal of Urban History, 28(1): 3-34.

Gordon, D.L.A. 2001. "Weaving a Modern Plan for Canada's Capital: Jacques Gréber and the 1950 Plan for the National Capital Region." Urban History Review, 29(2): 43-61.

Gordon, D.L.A. 2002. "Frederick G. Todd and the Origins of the Park System in Canada's Capital." Journal of Planning History, 1(1): 29-57.

Gordon, D.L.A. 2002. "William Lyon Mackenzie King, planning advocate.” Planning Perspectives, 17: 97-122.

Gordon, D.L.A. 2008. “'Agitating people's brains': Noulan Cauchon and the City Scientific in Canada's capital." Planning Perspectives, 23: 349-379.

Gordon, D.L.E. 2015. Town and Crown: An Illustrated History of Canada's Capital. Ottawa: Ivenire Books.

Graham, S. 2009. "The Mines of Gatineau Park." The Gatineau Park Chronicle. Ottawa: NCC.

Gyton, G. 1999. A Place for Canadians: The Story of the National Capital Commission. Ottawa: National Capital Commission.

Hart, E.J. 2010. J.B. Harkin: Father of Canada's National Parks. Edmonton: University of Alberta Press.

Hemmat, S.A. 1986. "Parks, people, and private property: The National Park Service and Eminent Domain.” Environmental Law, 16: 935-961.

Henderson, G.F. 1993. "Mackenzie King's First Visit to Kingsmere.” Up the Gatineau!, 19: 811.

Hessel, P. 1993. The Algonkins of the Ottawa Valley: An Historical Outline. Arnprior, ON: Kichesippi Books.

Hindess, B. 2006. "Terrortory." Alternatives, 31: 243-257.

Hodgins, B.W. and Cannon, K.A. 1997. "The Aboriginal Presence in Ontario Parks and Other Protected Places.” In Marsh, J.S. and Hodgins, B.W., eds., Changing Parks: The history, future and cultural context of parks and heritage landscapes. Toronto: Natural Heritage.

Hughson, J.W. and Bond, C.J. 1987. Hurling Down the Pine. $3^{\text {rd }}$ edition. Chelsea, Quebec: The Historical Society of the Gatineau.

Jones, L.M. 1987. The Role and Rationale of the National Capital Commission: A Critical Analysis. Ottawa: Carleton University (unpublished Honours thesis).

Knight, D.B. 1991. Choosing Canada's Capital: Conflict Resolution in a Parliamentary System. Ottawa: Carleton University Press. 
Kopas, P. 2007. Taking the Air: Ideas and Change in Canada's National Parks. Vancouver: UBC Press.

Lait, M. 2016. "A lake with two names: The Harrington Lake (Lac Mousseau) Toponymy Controversy." Up the Gatineau!, 42: 39-52.

Lait, M. 2016. "Preserving Ottawa's metropolitan nature: How the 1970 Gatineau Park planning controversy transformed the National Capital Commission and its Conservation Park." Canadian Journal of Urban Research, 25(1): 63-79.

Lanctôt, G. 1936. Kingsmere in Chronology. Ottawa: Dominion Archives of Canada.

Lane, M.B. 2005. "Public Participation in Planning: an intellectual history." Australian Geographer, 36(4): 283-299.

Lanzon, Q. 2014. From the Ground Up: The Alpine and Cross-Country Sportscapes of Gatineau Park, 1910-1967. Ottawa: Carleton University (unpublished MA thesis).

Lloyd, S. 1979. "The Ottawa typhoid epidemics of 1911 and 1912: A case study of disease as a catalyst for urban reform." Urban History Review, 8(1): 66-89.

Lothian, W.F. 1987. A Brief History of Canada's National Parks. Ottawa: Environment Canada.

Lowry, W.R. 1998. Preserving Public Lands for the Future: The Politics of Intergenerational Goods. Washington, D.C.: Georgetown University Press.

MacEachern, A.A. 2001. Natural Selections: National Parks in Atlantic Canada, 1935-1970. Montreal: McGill-Queen's University Press.

Mahoney, E. 1999. "Summer Hotels of the Gatineau." Up the Gatineau!, Vol.25. Available at: http://www.gvhs.ca/publications/utga-summer-hotels.html. Last accessed 5 July 2016.

Marshall, H. 1973. History of the Ottawa Ski Club. Ottawa: Self-published.

Martin, J.C.G. 1999. 'In Memory Of' Chelsea 's Historic Cemeteries: Community institutions from pioneer times to the present. Ottawa: University of Ottawa (unpublished MA thesis).

McKenzie, E. 1994. Privatopia: Homeowner Associations and the Rise of Residential Private Government. New Haven and London: Yale University Press.

McNamee, K. 2002. "From Wild Places to Endangered Spaces." In Dearden, P. and Rollins, R., eds., Parks and Protected Areas in Canada, $2^{\text {nd }}$ edition. Oxford: Oxford University Press.

Messier, D. 2007. "Fresh Air Seekers." Gatineau Park Chronicles. Available at: http://www.gvhs.ca/digital/gatineau-park/chronicles/fresh.html. Last accessed 18 May 2017.

Messier, D. 2007. "Harry Baldwin.” The Gatineau Park Chronicle. Ottawa: NCC.

Messier, D. 2007. "Roderick Percy Sparks.” The Gatineau Park Chronicle. Ottawa: NCC.

Messier, D. 2009. "Gatineau Hills Forest Industry 1800 to 1938: Myth or reality?" The Gatineau Park Chronicle. Ottawa: NCC.

Mundell, D.W. 1960. "Legal Nature of Federal and Provincial Executive Governments: Some Comments on Transactions Between Them." Osgoode Hall Law Journal, 2(1): 56-75.

Murphy, A.B. 1996. "The sovereign state system as political-territorial ideal: historical and contemporary considerations." In Biersteker, T.J., and Weber, C., eds., State sovereignty as social construct. Cambridge: Cambridge University Press.

Murphy, A.B. 2012. "Entente territorial: Sack and Raffestin on territoriality." Environment and Planning D: Society and Space, 30: 159-172.

Murray, J.P. 2003. "Roderick Percy Sparks: Gatineau Park's Forgotten Founder.” Up the Gatineau!, Vol. 30: 12-16. 
Nation, R.E. 1983. "The Acquisition of National Parkland: A Challenge for the Future." Dalhousie Law Journal, 7: 260-296.

Paasi, A. 1999. "Boundaries as Social Processes: Territoriality in the World of Flows." In Newman, D., ed., Boundaries, Territory and Postmodernity. London: Frank Cass Publishers.

Painter, J. 2010. "Rethinking territory." Antipode, 42(5): 1090-1118.

Parson, H.E. 1975. "The Rise and Fall of Farming in a Marginal Area: The Gatineau Valley, Quebec." Cahiers de géographie du Québec, 19(48): 573-582.

Pasternak, S. 2014. "Jurisdiction and Settler Colonialism: Where Do Laws Meet?" Canadian Journal of Law and Society, 29(2): 145-161.

Perdue, C. and Martin-Perdue, N.J. 1980. "Appalachian Fables and Facts: A Case Study of the Shenandoah National Parks Removals.” Appalachian Journal, 7(1-2): 84-104.

Perell, P.M. 1991. "Options, Rights of Repurchase and Rights of First Refusal as Interests in Land," The Canadian Bar Review, 70(1): 1-28.

Raffestin, C. 2012. "Space, territory, and territoriality." Environment and Planning D: Society and Space, 30:121-141.

Redford, M. "The Hetherington Farm." Up the Gatineau!, 19: 31-35.

Roberts, M. 1976. “Carbide Willson - 1850-1915.” Up the Gatineau!, 2: 16-22.

Rowat, D.C. 1973. "Ottawa” in Rowat D.C., ed., The government of federal capitals. Toronto: University of Toronto Press.

Rowat, D.C. 1974. "The Proposal For a Federal Capital Territory For Canada's Capital." In Fullerton, D., Canada's Capital: How Should it be Governed? Ottawa: Information Canada.

Rudin, R. 2011. "The First French-Canadian National Parks: Kouchibouguac and Forillon in History and Memory." Journal of the Canadian Historical Association, 22(1): 161-200.

Sack, R.D. 1986. Human Territoriality: its theory and history. Cambridge: Cambridge University Press.

Sandlos, J. 2005. "Federal Spaces, Local Conflicts: National Parks and the Exclusionary Politics of the Conservation Movement in Ontario, 1900-1935." Journal of the Canadian Historical Association, 16: 293-318.

Sandlos, J. 2008. "Not Wanted in the Boundary: The Expulsion of the Keeseekoowenin Ojibway Band from Riding Mountain National Park.” The Canadian Historical Review, 89(2): 189-221.

Scace, R.C. 1969. "Banff Townsite: An historical geographical view of urban development in a Canadian national park." In Nelson, J.G., ed., Canadian Parks in Perspective. Montreal: Harvest House Ltd.

Schram, S. 2012. "Phronetic social science: an idea whose time has come." In Flyvbjerg, B., Landman, T. and Schram, S., eds., Real Social Science: Applied Phronesis. Cambridge: Cambridge University Press.

Scott, J.C. 1998. Seeing Like a State: How Certain Schemes to Improve the Human Condition Have Failed. New Haven and London: Yale University Press.

Simpson, M. 1982. "Thomas Adams in Canada, 1914-1930." Urban History Review, 11(2): 1-16.

Sheller, M. and Urry, J. 2006. "The new mobilities paradigm.” Environment and Planning A, 38: 207-226.

Sherman, P. 1998. "Review of Elusive Empires: Constructing Colonialism in the Ohio Valley, 1673-1800 by Eric Hinderaker." American Indian Quarterly, 22(4): 547-548. 
Steinberg, Philip E. 2009. "Sovereignty, Territory, and the Mapping of Mobility: A View from the Outside." Annals of the Association of American Geographers, 99(3): 467-495.

Taylor, C.J. 1990. "Legislating nature: The National Parks Act of 1930.” In Lorimer, M., M'Gonigle, M., Revéret, J., and Ross, S., eds., To see ourselves / to save ourselves: Ecology and Culture in Canada. Montreal: Association for Canadian Studies.

Taylor, J.H. 1989. "City form and capital culture: remaking Ottawa." Planning Perspectives, 4 : 79-105.

Thomson, S.C. 1965. Recollections of Early Days in the Gatineau Hills, Parts I and II. Ottawa: Unpublished document.

Urry, J. 2007. Mobilities. Cambridge, UK: Polity Press.

von Baeyer, E. 1990. Garden of Dreams: Kingsmere and Mackenzie King. Toronto and Oxford: Dundurn Press.

Valverde, M. 2009. "Jurisdiction and Scale: Legal "Technicalities" as Resources for Theory." Social and Legal Studies, 18(2): 139-157.

Vandergeest, P. and Peluso, N.L. 2001. "Territorialization and State Power in Thailand." In Blomley, N., Delaney, D. and Ford, R.T., eds., The Legal Geographies Reader: Law, Power, and Space. Oxford: Blackwell Publishers Ltd.

Waiser, B. 2011. "A Case of Special Privilege and Fancied Right": The Shack Tent Controversy in Prince Albert National Park". In Campbell, C.E., ed., A Century of Parks Canada, 1911-2011. Calgary: University of Calgary Press.

Walby, K. and Luscombe, A. 2016. "Criteria for quality in qualitative research and use of freedom of information requests in the social sciences." Qualitative Research, 1-17.

Walker, R., Jojola, T. and Natcher, D., eds., 2013. Reclaiming Indigenous Planning. Montreal \& Kingston: McGill-Queen's University Press.

Woods, S. 1980. Ottawa: The Capital of Canada. Toronto: Doubleday Canada Limited. 


\section{Appendix A: Gatineau Park land acquisitions, 1938-1978}

\begin{tabular}{|c|c|c|c|}
\hline Year & Acres added & $\begin{array}{l}\text { Total park area } \\
\text { in acres }\end{array}$ & Notes \\
\hline 1938-39 & 3,281 & 3,281 & $\$ 100,000$ authorized to FDC to acquire 12,000 acres \\
\hline 1939-40 & 8,688 & 11,969 & Outbreak of World War II \\
\hline $1940-41$ & 2,242 & 14,553 & Establishment of public facilities at Philippe Lake \\
\hline 1941-45 & 0 & $15,874.75$ & \\
\hline 1946 & $1,458.25$ & 17,333 & \\
\hline 1947 & 2,341 & 19,674 & \\
\hline 1948 & $4,760.50$ & $24,434.50$ & Acquisition of Philippe Lake \\
\hline 1949 & 957.50 & 25,392 & La Pêche Lake included in park boundaries \\
\hline 1950 & $1,506.50$ & $26,898.50$ & \\
\hline 1951 & $4,750.75$ & $31,649.25$ & Edwards-Herridge estate purchased and Mackenzie King estate donated \\
\hline 1952 & 5,417 & $37,066.25$ & Bronson estate donated \\
\hline 1953 & $6,097.25$ & $43,163.25$ & Purchases begin along Meech Lake shoreline \\
\hline 1954 & $3,124.25$ & $46,287.75$ & \\
\hline 1955 & 2,164 & $48,451.75$ & \\
\hline 1956 & & 51,000 & Annual Reports no longer provide acreage added \\
\hline 1957 & & 56,250 & \\
\hline 1958 & & 57,000 & \\
\hline 1959 & & 59,000 & \\
\hline 1960 & & 60,000 & \\
\hline 1961 & & 62,500 & \\
\hline 1962 & & 63,400 & \\
\hline 1963 & & 64,000 & \\
\hline 1964 & & 65,000 & \\
\hline 1965 & & 65,700 & \\
\hline 1966 & & 68,000 & \\
\hline 1967 & & No data & Annual Reports no longer provide total park area \\
\hline 1968 & & No data & \\
\hline 1969-? & & 68,300 & Source: MacNiven, J.A. 1969 , Oct. 8 \\
\hline 1973 & 12,500 & No data & Federal-provincial land exchange concluded \\
\hline 1978 & & 86,631 & Source: National Capital Commission. 1978, Mar. \\
\hline
\end{tabular}

Notes: Currently, the park's overall size is 88,000 acres. Arithmetic in the Annual Reports is not always accurate. Data from 1945 to 1955 are from the Federal District Commission (FDC) 1956 Brief. After 1966-1967, the NCC stopped providing data on the park area in its Annual Reports.

Sources: Data obtained from the Annual Reports of the FDC and NCC; FDC. 1956, March. Brief submitted to the Joint Committee of the Senate and House of Commons appointed to review and report upon the progress and programs of the Federal District Commission and implemting the Plan for the National Capital of Canada, pg.64; MacNiven, J.A. 1969, Oct. 8. Letter from J.A. MacNiven to D.H. Fullerton. 1070.3.6 Vol.1. Library Archives Canada ATI A2015000060/MR, pg.889; NCC. 1978, Mar. Inventaire des bâtiments, propositions d'utilisation et elaboration d'une politique et d'un programme d'acquisition des proprieties privees du Parc de la Gatineau. 1070.3.3, Vol.14. Library Archives Canada ATI A2015000060/MR, pg.603. 


\section{Appendix B: Access-to-information requests}

Agency \& ATI no.

(Date received)

National Capital
Commission (NCC)
NCC
A-2013-00010/JB
(27 May 2013)

\section{Library Archives} Canada (LAC)

LAC A-2014-00375/DJP (19 Dec. 2014)

\section{LAC A-2014-00366/CJM} (19 Dec. 2014)

\section{NCC}

A-2014-00053

(23 Jan. 2015)

\section{Documents requested}

- Correspondence between the NCC and the Ottawa-Hull Chapter of the National and Provincial Parks Association of Canada (NPPAC$\mathrm{OH})$

- Correspondence between the NCC and the Ottawa Field-Naturalists' Club (OFNC)

- Correspondence concerning the 1970 snowmobile ban in Gatineau Park

- RG34/R1181, Reg. Cont. \#2014-0607, box 8, file P-10-02 Gatineau Park - Land Purchases, Vol. 1, November 1958-May 1969. Box 2002177367

- RG34/R1181, Reg. Cont. \#2014-0607, box 8, file P-10-40-01 Gatineau Park - Regulations, Vol.1, August 1962-January 1969. Box 2002177367

- RG34/R1181, Reg. Cont. \#2014-0607, box 39, file 280.11 Committees - Advisory Committee on Planning, Vols.1-6, September 1967-July 1970. Box 2002178518

- RG34/R1181, Reg. Cont. \#2014-0607, box 39, file 280.22 Committees - Gatineau Park Advisory Committee, Vols.1-4, January 1958-October 1970. Box 2002178518

- RG34/R1181, Reg. Cont. \#2014-0607, box 47, file 290.2 Complaints - Petitions Gatineau Park, Vol.1, December 1970. Box 2002178526

- RG34/R1181, Reg. Cont. \#2014-0607, box 29, file 1190.10.2 Property and Acquisitions, Vols.1-7.

- RG34/R1181, Reg. Cont. \#2014-0608, box 20, file 1190.10 .2 Property and Acquisitions, Vol.8.

- Correspondence between the NCC and the Kingsmere Property Owners' Association since 1958

- Correspondence between the NCC and the Meech Lake Association since 1958

- Correspondence related to Gatineau Park between the NCC and the NPPAC-OH between 1980 and 1990

- Correspondence related to Gatineau Park between the NCC and the Ottawa-Valley chapter of the Canadian Parks and Wilderness Society (CPAWS-OV) since 2009

\begin{tabular}{l|ll} 
LAC & RG34/R1181 Reg. Cont. 2014-0607, box 113, 1190.10.2. Property - \\
A-2015-00039/MR & & Exchange of Land - Province of Quebec, Vols.1-7
\end{tabular}

(1 June 2015)

LAC A-2015-00058/MR (28 May 2015)

\section{LAC} A-2015-00059/MR (28 May 2015)
- RG34/R1181 Reg. Cont. 2014-0607, box 91, 1070.3.3 Parks Gatineau Master Plan, Vols.1-6

- RG34/R1181 Reg. Cont. 2014-0607, box 91, 1070.3.3 Parks Gatineau Master Plan, Vols.7-9

- RG34/R1181 Reg. Cont. 2014-0608, box 109, 1070.3.3 Parks Gatineau Master Plan, Vols.10-11
No. pgs. released (format)

181(CD-ROM)

N/A

(In-person consultations)
N/A

(In-person consultations) $n . b$. Vols.1-7 were not found. 318 (CD-ROM) Extension required for consultation with other government institutions and third parties

617 (CD-ROM) 1074 (CD-ROM) 


\section{LAC \\ A-2015-00060/MR \\ (9 June 2015)}

LAC

A-2015-00061/MR

LAC

A-2015-00062/MR

(11 June 2015)

LAC

A-2015-03319/LM

(22 July 2015)

NCC

A-2015-000363

(13 Oct. 2015)

NCC

A-2015-000373

(2 Nov. 2015)
(9 June 2015)

- RG34/R1181 Reg. Cont. 2014-0610, box 21, 1070.3.3 Parks -

Gatineau Master Plan, Vols.12-14

- RG34/R1181 Reg. Cont. 2014-0608, box 109, 1070.3.6 Parks Gatineau Public Hearing, Vols.1-2

- RG34/R1181 Reg. Cont. 2014-0607, box 106, 1140.2.12 Planning Long Range, Vols.1-2

- RG34/R1181 Reg. Cont. 2014-0607, box 110, 1190.3.2 Property Offer - Gatineau Park, Vols.1-2

- RG34/R1181 Reg. Cont. 2014-0607, box 110, Property Expropriation and Acquisition - Quebec, Vols.1-2

- RG34/R1181 Reg. Cont. 2014-0607, box 111, 1190.10.2 Property Exchange of Land - Province of Quebec, Vols.6-7

- Accession 2014-0607, box 65, file 810-4, Lakes - Meech Lake, April 1964-April 1970

- Accession 2014-0607, box 65, file 810-4, Lakes - Meech Lake, March 1970-June 1970

- Accession 2014-0607, box 65, file 810-4, Lakes - Meech Lake, June 1970-November 1970

- Accession 2014-0608, box 77, file 810-4, Lakes - Meech Lake, January 1971-October 1976

- Accession 2014-0608, box 77, file 810-4, Lakes - Kingsmere Lake, December 1960-December 1973

- Briefs, minutes of meetings, agreements, plans, proposals, and documents submitted to the National Capital Commission by the Meech Lake Association from November 1, 1976 to present

- Briefs, minutes of meetings, agreements, plans, proposals, and documents submitted to the National Capital Commission by the Kingsmere Property Owners Association from January 1, 1974 to present

- Staff memorandum, policies, discussion papers, and documents concerning or related to, the Kingsmere Property Owners Association from January 1, 1974 to present.

- Staff memorandum, policies, discussion papers, and documents concerning, or related to, Meech Lake Association from November 1, 1976 to present

- Documents, newspaper clippings, memorandum, discussion papers, plans, and policies concerning or related to the expropriation of Q0566-01-000-XXX on 1 January 1976, previous owner Brown Andrew Newton (Land ID 94873; Property 94867; Roll Number 5147-30-7545)

- Joint submission made by the Meech Lake Property Owners Association and Kingsmere Property Owners Association in March 1997 in response to NCC Discussion Paper "Enhancement Concept for Parkway Association Parkway Loop - October 1995" as referred to in A-2014-00053 on page 60

- Joint submissions submitted to the NCC by the Kingsmere Property Owners Association Meech Lake Association from 1979 to present.
1455 (CD-ROM)

802 (CD-ROM)

$136(\mathrm{CD}-\mathrm{ROM})$

N/A

(In-person

consultation)

588 (CD-ROM)

120-day extension required for consultation with other government institutions and third parties

Search fees (\$110)

552 (CD-ROM)

Extension required for consultation with other government institutions and third parties

500 (CD-ROM) Extension required 
the expropriation of part of Lot 14, Range 7, Township of Hull, Province of Quebec on 2 May 1989 (QC-0570-00-000-XX to QC5070-22-000; previous owner C\&B Vacation Properties Inc., corporation Drovelle Ltee; Land ID 347365 and 347366; Property 95018; Roll Number 5737-96-4095)

- The plan of subdivision by C\&B Vacation Properties Inc., corporation Drovelle Ltee, for part of Lot 14, Range 7, Township of Hull, Province of Quebec

- Correspondence between NCC and Carl McInnis concerning or related to the expropriation of part of Lot 14, Range 7, Township of Hull, Province of Quebec on 2 May 1989 (QC-0570-00-000-XX to QC-5070-22-000; previous owner C\&B Vacation Properties Inc., corporation Drovelle Ltee; Land ID 347365 and 347366; Property 95018; Roll Number 5737-96-4095)

- Correspondence between NCC and C\&B Vacation Properties Inc concerning the expropriation of part of Lot 14, Range 7, Township of Hull, Province of Quebec on 2 May 1989 (QC-0570-00-000-XX to QC-5070-22-000; previous owner C\&B Vacation Properties Inc., corporation Drovelle Ltee; Land ID 347365 and 347366; Property 95018; Roll Number 5737-96-4095)

- Correspondence between NCC and the Municipality of Chelsea (formerly known as the Municipality of West Hull) concerning the expropriation of part of Lot 14, Range 7, Township of Hull, Province of Quebec on 2 May 1989 (QC-0570-00-000-XX to QC-5070-22000; previous owner C\&B Vacation Properties Inc., corporation Drovelle Ltee; Land ID 347365 and 347366; Property 95018; Roll Number 5737-96-4095) for consultation with other government institutions and third parties 